Renata Lisowska

\title{
ZARZA_DZANIE ROZWOJEM MAŁYCH I ŚREDNICH PRZEDSIĘBIORSTW W OBSZARACH ZMARGINALIZOWANYCH
}


政 
Renata Lisowska

\section{ZARZĄDZANIE ROZWOJEM MAŁYCH I ŚREDNICH PRZEDSIĘBIORSTW W OBSZARACH ZMARGINALIZOWANYCH}

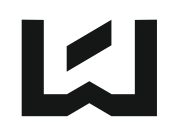

WYDAWNICTWO

UNIWERSYTETU

ŁÓDZKIEGO

ŁóDŹ 2013 
Renata Lisowska - Katedra Przedsiębiorczości i Polityki Przemysłowej, Wydział Zarządzania Uniwersytet Łódzki, 90-237 Łódź, ul. Matejki 22/26

\section{RECENZENCI}

Janusz, Kot, Bogustaw Plawgo

OPRACOWANIE REDAKCYJNE

Ewa Siwińska

SKŁAD I ŁAMANIE

Leonora Wojciechowska

OKŁADKĘ PROJEKTOWAŁA

Monika Piasecka

Wydrukowano z gotowych materiałów dostarczonych do Wydawnictwa UŁ

(C) Copyright by Uniwersytet Łódzki, Łódź 2013

Wydane przez Wydawnictwo Uniwersytetu Łódzkiego

Wydanie I. W.06315.13.0.H

ISBN 978-83-7525-953-7

e-ISBN 978-83-7969-391-7

Wydawnictwo Uniwersytetu

Łódzkiego 90-131 Łódź, ul. Lindleya 8

www.wydawnictwo.uni.lodz.pl

e-mail: ksiegarnia@uni.lodz.pl

tel. (42) 66558 63, faks (42) 6655862

Druk i oprawa: Quick Druk 


\section{Spis treści}

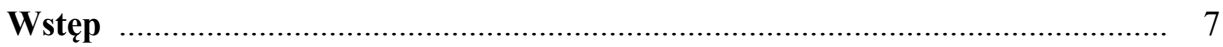

1. Obszary zmarginalizowane i ich struktura w Polsce .................................... 13

1.1. Obszary zmarginalizowane - podstawowe pojęcia i definicje ...................... 13

1.2. Dysproporcje w rozwoju regionów a obszary zmarginalizowane ................. 18

1.3. Delimitacja obszarów zmarginalizowanych ............................................. 32

2. Regionalna przestrzeń małych i średnich przedsiębiorstw .......................... 39

2.1. Małe i średnie przedsiębiorstwa w gospodarce regionu .............................. 39

2.2. Charakterystyka liczby małych i średnich przedsiębiorstw w Polsce ............ 49

2.3. Małe i średnie przedsiębiorstwa a rozwój obszarów zmarginalizowanych ..... 56

3. Determinanty rozwoju małych i średnich przedsiębiorstw w obszarach zmarginalizowanych

3.1. Teorie rozwoju małych i średnich przedsiębiorstw .................................. 67

3.2. Uwarunkowania rozwoju małych i średnich przedsiębiorstw ...................... 76

3.2.1. Klasyfikacja uwarunkowań ........................................................ 76

3.2.2. Uwarunkowania wewnętrzne ........................................................ 78

3.2.3. Uwarunkowania zewnętrzne ...................................................... 89

3.3. Stymulatory i bariery rozwoju małych i średnich przedsiębiorstw w Polsce

- wyniki dotychczasowych badań ............................................................ 99

3.4. Budowa modelu zależności pomiędzy uwarunkowaniami a rozwojem małych i średnich przedsiębiorstw w obszarach zmarginalizowanych ........... 111

4. Procesy rozwojowe małych i średnich przedsiębiorstw w obszarach rozwiniętych i zmarginalizowanych. Rezultaty badań ................................ 117

4.1. Organizacja i metodyka badań ................................................................. 117

4.2. Charakterystyka badanych przedsiębiorstw ................................................. 120

4.3. Dynamika rozwojowa badanych przedsiębiorstw ........................................ 125

4.4. Priorytety rozwojowe i stosowane przewagi konkurencyjne .......................... 130

4.5. Uwarunkowania zewnętrzne - stymulatory i bariery .................................. 141

4.6. Uwarunkowania wewnętrzne - stymulatory i bariery ............................... 157

5. Funkcjonowanie i rozwój małych i średnich przedsiębiorstw w obszarach zmarginalizowanych - implikacje dla zarządzania

5.1. Wpływ marginalizacji obszaru na rozwój małych i średnich przedsiębiorstw 167 
5.2. Instytucje otoczenia biznesu w obszarach zmarginalizowanych

5.3. Problemy zarządzania małymi i średnimi przedsiębiorstwami zlokalizowanymi w obszarach zmarginalizowanych

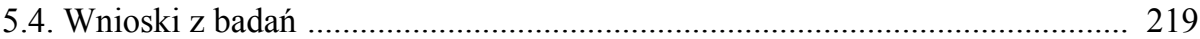

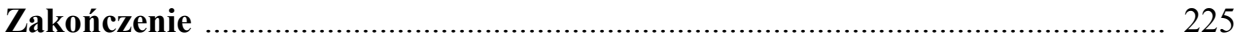

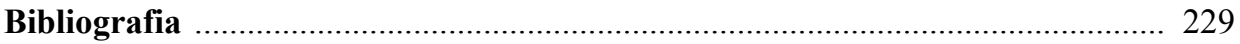

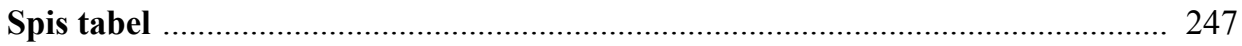

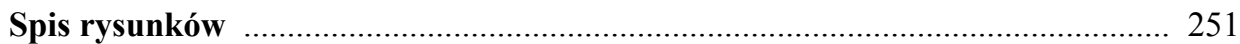

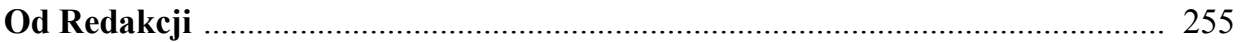




\section{Wstęp}

Zróżnicowanie poziomu rozwoju regionów jest naturalnym elementem procesów gospodarczych zachodzących zarówno w UE, jak i Polsce. Na to zjawisko w Polsce miały wpływ uwarunkowania historyczne, tzn. przynależność do trzech różnych zaborów, zniszczenia wojenne, silne ruchy migracyjne związane z wojną i zmianą granic Polski, jak również procesy transformacji gospodarki oraz integracji z UE. Ma to swój wyraz w podziale Polski na część zachodnią, która jest względnie dobrze rozwinięta, oraz na część wschodnią, która, z wyjątkiem Warszawy, charakteryzuje się bardzo niskimi wskaźnikami poziomu rozwoju społeczno-gospodarczego.

Dysproporcje w rozwoju regionów mogą powodować jego marginalizację, czego przejawem jest spadek aktywizacji biznesowej na danym terenie oraz koncentracja negatywnych zjawisk społeczno-gospodarczych, takich jak: bezrobocie, ubożenie ludności, odpływ ludności, niska produktywność, nieefektywny system edukacji, patologie społeczne (Krajowa strategia... 2009, s. 17). Marginalizacja obszaru oznacza długotrwałe wyłączenie danego obszaru $\mathrm{z}$ generowania rozwoju i partycypacji w dochodach $\mathrm{z}$ rozwoju oraz wykluczenie regionalnej społeczności z aktywnego uczestnictwa w procesach gospodarczych, co powoduje w dhugim okresie ubóstwo, niezaspokojenie podstawowych potrzeb, brak jakichkolwiek szans na znalezienie pracy (Stawasz D. 2007, Markowski 1999). Obszary te nie są w stanie jedynie w oparciu o własne, wewnętrzne siły dokonać procesu przekształceń gospodarki, gwarantujących zmianę struktury gospodarczej, wykreowanie nowych miejsc pracy i stworzenie warunków dla stabilnego rozwoju. Koszty ponownego włączenia obszarów zmarginalizowanych do współtworzenia rozwoju gospodarczego są szczególnie wysokie i charakteryzują się wydłużonym okresem zwrotu (Markowski 1999, s. 41).

W literaturze przedmiotu nie ma jednoznacznej definicji obszarów zmarginalizowanych, jedynie wymieniane są ich cechy, które mogą posłużyć do zobrazowania trudnej sytuacji tam panującej. Na potrzeby niniejszej pracy została zaproponowana lista cech obszarów zmarginalizowanych, która posłużyła do zbudowania narzędzi i modelu badawczego. Do cech tych zaliczono:

- mniejszą liczbę potencjalnych klientów,

- ograniczony dostęp do zasobów finansowych,

- brak klimatu przyjaznego dla rozwoju przedsiębiorstw, 
- ograniczony dostęp do instytucji otoczenia biznesu,

- brak wykwalifikowanej siły roboczej,

- słabą infrastrukturę - powodującą ograniczoną dostępność,

- niską innowacyjność i konkurencyjność obszaru,

- małą liczbę inwestycji,

- utrudniony dostęp do technologii,

- niewielką liczbę przedsiębiorstw - małe możliwości współpracy.

Małe i średnie przedsiębiorstwa, mające głównie lokalny charakter, odgrywają znaczącą rolę w rozwoju regionów i stanowią jeden z głównych elementów infrastruktury regionalnej, od której zależy ich konkurencyjność i przyszły rozwój. Przedsiębiorcy na ogół lokują swoją działalność gospodarczą w miejscu zamieszkania, angażując swój kapitał, wykorzystując miejscowe zasoby oraz operując na rynku lokalnym. Szczególnie dużą rolę przypisuje się tym przedsiębiorstwom w rozwoju obszarów zmarginalizowanych, w których przeważają małe i średnie przedsiębiorstwa.

Dorobek polskiej i zagranicznej literatury przedmiotu w zakresie badań małych i średnich przedsiębiorstw (MSP) jest już znaczący. Jednakże rzadko uwzględnia specyficzne ich uwarunkowania związane z lokalizacją. W niniejszej pracy podjęto próbę wypełnienia luki w zakresie identyfikacji i pomiaru czynników, wpływających na rozwój małych i średnich przedsiębiorstw w obszarach zmarginalizowanych. W ujęciach regionalnych brak jest tego typu analiz, a badanie sektora MSP sprowadza się do województwa lub kilku województw, nie uwzględniając specyfiki obszarów zmarginalizowanych w Polsce.

Podstawową przesłanką do podjęcia omawianego tematu badawczego jest znaczenie rozwoju małych i średnich przedsiębiorstw w gospodarce, ze szczególnym uwzględnieniem funkcjonowania tych podmiotów w obszarach zmarginalizowanych. Popularność zagadnień dotyczących teorii i czynników wzrostu/rozwoju MSP powoduje, że uwzględnia się coraz większą liczbę determinantów rozwoju tych przedsiębiorstw. W wyniku przeprowadzonej pogłębionej analizy literatury przedmiotu można stwierdzić, że wzrost/rozwój jest wypadkową wielu różnorodnych czynników zarówno ilościowych, jak i jakościowych. Próba identyfikacji wszystkich czynników w jednym badaniu, zaprezentowanych w rozdziale trzecim, niniejszej pracy, stanowi trudne wyzwanie badawcze.

Głównym celem pracy jest ocena kierunku i siły wpływu kluczowych czynników rozwoju MSP i określenie przesłanek na potrzeby zarządzania małymi i średnimi przedsiębiorstwami w obszarach zmarginalizowanych.

Osiągnięcie tak sformułowanego celu głównego wymagało realizacji następujących celów szczegółowych:

- zidentyfikowanie cech obszaru zmarginalizowanego,

- określenie kluczowych uwarunkowań rozwoju małych i średnich przedsiębiorstw, 
- porównanie kierunku i siły wpływu czynników wewnętrznych i zewnętrznych na rozwój małych i średnich przedsiębiorstw w obszarach rozwiniętych i zmarginalizowanych,

- określenie przesłanek na potrzeby zarządzania rozwojem małych i średnich przedsiębiorstw w obszarach zmarginalizowanych.

Aby zrealizować cel główny i cele szczegółowe, przyjęto następujące hipotezy badawcze:

$\mathrm{H}_{1}$ : Małe i średnie przedsiębiorstwa funkcjonujące $\mathrm{w}$ obszarach zmarginalizowanych charakteryzują się mniejszą dynamiką rozwojową niż funkcjonujące w obszarach rozwiniętych.

$\mathrm{H}_{2}$ : Oddziaływanie uwarunkowań rozwoju małych i średnich przedsiębiorstw pochodzących $\mathrm{z}$ makrootoczenia jest zróżnicowane $\mathrm{w}$ zależności od tego, czy firma jest zlokalizowana w obszarach rozwiniętych, czy zmarginalizowanych.

$\mathrm{H}_{3}$ : Oddziaływanie uwarunkowań rozwoju małych i średnich przedsiębiorstw pochodzących $\mathrm{z}$ mezootoczenia jest zróżnicowane w zależności od tego, czy firma jest zlokalizowana $\mathrm{w}$ obszarach rozwiniętych, czy zmarginalizowanych.

$\mathrm{H}_{4}$ : Oddziaływanie uwarunkowań rozwoju małych i średnich przedsiębiorstw pochodzących z mikrotoczenia jest zróżnicowane w zależności od tego, czy firma jest zlokalizowana w obszarach rozwiniętych, czy zmarginalizowanych.

$\mathrm{H}_{5}$ : Oddziaływanie uwarunkowań wewnętrznych rozwoju małych i średnich przedsiębiorstw związanych $\mathrm{z}$ osobą przedsiębiorcy jest zróżnicowane w zależności od tego, czy firma jest zlokalizowana w obszarach rozwiniętych, czy zmarginalizowanych.

$\mathrm{H}_{6}$ : Oddziaływanie uwarunkowań wewnętrznych rozwoju małych i średnich przedsiębiorstw związanych $\mathrm{z}$ przedsiębiorstwem jest zróżnicowane $\mathrm{w}$ zależności od tego, czy firma jest zlokalizowana w obszarach rozwiniętych, czy zmarginalizowanych.

$\mathrm{H}_{7}$ : Oddziaływanie uwarunkowań rozwoju małych i średnich przedsiębiorstw funkcjonujących $\mathrm{w}$ obszarach zmarginalizowanych jest zróżnicowane w zależności od wielkości przedsiębiorstwa.

$\mathrm{H}_{8}$ : Specyficzne cechy obszaru zmarginalizowanego wpływają w różny sposób na rozwój przedsiębiorstwa w zależności od jego wielkości.

Konstrukcja rozprawy uwarunkowana jest celem głównym oraz merytorycznym przedmiotem badań. Analiza ma charakter teoretyczno-empiryczny, a weryfikację hipotez badawczych przeprowadzono z wykorzystaniem metod statystycznych w zakresie statystyki opisowej, wnioskowania statystycznego oraz wielowymiarowej analizy statystycznej.

Praca składa się z pięciu rozdziałów. Pierwszy ma charakter teoretyczny, przybliżający problematykę obszarów zmarginalizowanych. Zawiera omówienie 
znaczenia i szczegółowe rozwinięcie zagadnienia dysproporcji w rozwoju regionów w Polsce oraz opis różnorodnych klasyfikacji, w ramach których wyodrębnia się rodzaje regionów w kontekście ich rozwoju. W rozdziale tym, na podstawie metody taksonomicznej zaproponowanej przez Z. Helwiga, wyodrębniono obszary zmarginalizowane i dokonano ich charakterystyki.

$\mathrm{W}$ rozdziale drugim zwrócono uwagę na tendencje w rozwoju małych i średnich przedsiębiorstw $w$ Polsce oraz podkreślono rolę tych podmiotów w rozwoju obszarów zmarginalizowanych. Analiza wpływu małych i średnich przedsiębiorstw na rozwój obszarów zmarginalizowanych kończy rozważania w tej części pracy.

Zadaniem trzeciego rozdziału jest dokonanie systematyzacji czynników wpływających na rozwój małych i średnich przedsiębiorstw. Rozdział ten rozpoczyna się od przeglądu teorii rozwoju MSP, na bazie których w dalszej części pracy zostały wyodrębnione czynniki wzrostu/rozwoju tych podmiotów. W dalszej części rozdziału scharakteryzowano poszczególne kategorie czynników, dzieląc je ma stymulatory i bariery rozwoju. Rozdział ten kończy się założeniami do części badawczej.

W rozdziale czwartym zaprezentowane zostały wyniki badań własnych przeprowadzone w latach 2010-2011 na 590-elementowej próbie losowej małych i średnich przedsiębiorstw w dwóch, skrajnych pod względem rozwoju społeczno-gospodarczego, obszarach. Wybór tych obszarów podyktowany był przeprowadzoną analizą komparatywną, mającą na celu wykazanie różnic w funkcjonowaniu MSP zlokalizowanych w obszarach rozwiniętych i zmarginalizowanych. Analizie poddano następujące obszary badawcze: dynamikę rozwoju badanych przedsiębiorstw w oparciu o dane ilościowe i jakościowe, priorytety rozwojowe i stosowane przewagi konkurencyjne, uwarunkowania wewnętrzne i zewnętrzne rozwoju małych i średnich przedsiębiorstw w kontekście stymulatorów i barier.

W ostatnim rozdziale pracy skoncentrowano się na implikacjach płynących z przeprowadzonych badań dla zarządzania małymi i średnimi przedsiębiorstwami w obszarach zmarginalizowanych. Rozdział ten rozpoczyna się od analizy wpływu marginalizacji obszaru na rozwój MSP. Kolejnym poruszanym zagadnieniem jest ocena efektywności działania samorządu terytorialnego i instytucji otoczenia biznesu na rzecz małych i średnich przedsiębiorstw w obszarach zmarginalizowanych. Rozdział ten kończy się sformułowaniem przesłanek na potrzeby zarządzania w MSP funkcjonujących w obszarach zmarginalizowanych.

$\mathrm{W}$ pracy wykorzystano metody przetwarzania, prezentacji i interpretacji zgromadzonych danych, $\mathrm{tj}$. metodę opisową, metodę porównawczą oraz narzędzia statystyczne. Do oceny rozwoju społeczno-gospodarczego powiatów użyto metody taksonomicznej, w przypadku oceny kondycji rozwojowej badanych 
małych i średnich przedsiębiorstw - metody skupień, przy analizie porównawczej - testy nieparametryczne i współczynnik kontyngencji C-Pearsona.

Podstawowym źródłem informacji o dysproporcjach w rozwoju regionów były dane statystyczne GUS zawarte w Banku Danych Lokalnych oraz liczne raporty krajowe, m.in. Polska 2030. Trzecia fala nowoczesności. Dlugookresowa Strategia Rozwoju Kraju. Projekt, Projekt zaktualizowanej Strategii rozwoju spoleczno-gospodarczego Polski Wschodniej do roku 2020 oraz zagraniczne, np. INTERCO Indicators of Territorial Cohesion, Draft Final Report, Investing in Europe's Future. Fifth Report on Economic, Social and Territorial Cohesion, poświęcone ocenie rozwoju regionów w Polsce. Z kolei do skonstruowania miernika syntetycznego na poziomie powiatów posłużono się publikowanymi informacjami z Banku Danych Lokalnych.

Część empiryczna pracy została przygotowana na podstawie badań własnych o charakterze ilościowym i jakościowym przeprowadzonych w latach 2011-2012 na próbie małych i średnich przedsiębiorstw z sektora prywatnego. Populację stanowily podmioty gospodarcze zlokalizowane w powiatach o najwyższym poziomie rozwoju (obszary rozwinięte, pierwsza podpopulacja) oraz o najniższym poziomie rozwoju (obszary zmarginalizowane, druga podpopulacja). Liczebność próby zrealizowanej, tj. liczba uzyskanych, kompletnie wypełnionych ankiet, wynosiła: dla podpopulacji pierwszej 319 ankiet, dla podpopulacji drugiej 271 ankiet.

Do realizacji badania jakościowego zostały przygotowane dwa scenariusze wywiadu pogłębionego (IDI) dla przedsiębiorców i przedstawicieli instytucji otoczenia biznesu. Badania te przeprowadzono w 2012 r. wśród 15 właścicieli i współwłaścicieli małych i średnich przedsiębiorstw i 10 przedstawicieli instytucji otoczenia biznesu. Dobór próby do tych badań był celowy. Wybrano przedsiębiorstwa, które brały udział w badaniu ilościowym. W przypadku instytucji były to te, które znajdowały się $\mathrm{w}$ obszarze funkcjonowania tych przedsiębiorstw.

W pracy wykorzystano również wcześniejsze badania ilościowe i jakościowe przeprowadzone w ramach projektu pt. Symptomy upadku matej firmy. Konsekwencje spoleczno-gospodarcze. Polityka przeciwdziałania, nr projektu, 1 H02D 055 30, nr umowy 0926/H03/2006/30, finansowanego przez Ministerstwo Nauki i Szkolnictwa Wyższego i przygotowanego przez zespół badawczy w składzie Bogdan Piasecki, Anna Rogut, Renata Lisowska i Jarosław Ropęga.

Prezentowane w niniejszej pracy metody badań nad czynnikami rozwoju małych i średnich przedsiębiorstw mogą, zdaniem autorki, stanowić punkt wyjścia do podobnych analiz przestrzenno-czasowych podejmowanych dla innych czynników rozwoju MSP, a rezultaty mogą zostać wykorzystane przez środowisko naukowe zajmujące się tą problematyką, jak również przez przedsiębiorców oraz instytucje odpowiedzialne za kreowanie polityki wspierającej rozwój MSP w Polsce. 
Należy zaznaczyć, iż przeprowadzone badania nie wyczerpują wszystkich kwestii, jakie można by sformułować w odniesieniu do złożonego i wielowątkowego zagadnienia uwarunkowań rozwoju MSP. Na szereg wyłaniających się pytań nie ma jednoznacznych odpowiedzi. Należy je traktować jako kwestie do dalszych rozważań i pogłębionych analiz.

Praca została opracowana w ramach habilitacyjnego projektu badawczego pt. Determinanty rozwoju malych i średnich przedsiębiorstw funkcjonujacych $w$ regionach zmarginalizowanych. Strategie rozwoju i polityka wsparcia projekt no. N N115 297738, umowa numer 2977/B/H03/2010/38, finansowanego z Ministerstwa Nauki i Szkolnictwa Wyższego.

W tym miejscu pragnę podziękować Profesorom Januszowi Kotowi i Bogusławowi Plawgo za trud zrecenzowania tej pracy oraz cenne uwagi i sugestie, które miały wpływ na ostateczny jej kształt. 


\section{Obszary zmarginalizowane i ich struktura w Polsce}

\subsection{Obszary zmarginalizowane - podstawowe pojęcia i definicje}

Zdefiniowanie obszaru zmarginalizowanego, jak również określenie jego cech wymaga analizy wielu podejść i klasyfikacji związanych z pojęciami „region” i „obszar”.

W literaturze przedmiotu pojęcie regionu nie jest jednoznaczne, a nawet brak jest powszechnie uznawanych kryteriów jego klasyfikacji. Pojęcia „region” używa się zwykle do zdefiniowania różnych obszarów o odmiennych charakterystykach. Według I. Pietrzyk region to terytorium określone historycznie lub kulturowo, przestrzeń ekonomiczna lub obszar wyodrębniony na podstawie kryteriów administracyjnych i politycznych (Pietrzyk 2000). R. Domański definiuje region, odnosząc się do gospodarki przestrzennej, jako obszar, w którym charakter części składowych i relacji przestrzennych tworzy spójną całość, wyodrębnioną z większego obszaru według specyficznych kryteriów (np. region wyodrębniony na podstawie gęstości zaludnienia) (Domański 2002, s. 110). Natomiast zdaniem S. Korenika region to teren powierzchniowo duży, jak i mały, obszar jednorodny jak również zróżnicowany (Korenik 1999). Wyróżnia się różne rodzaje regionów biorąc pod uwagę różnorodne kryteria, np. ze względu na kryterium odmienności strukturalnej wymienia się regiony jednorodne i węzłowe, według kryterium podstawowego rodzaju prowadzonej działalności można wyróżnić regiony: przemysłowe, rolnicze, przemysłoworolnicze (Kuciński 2004), wedle rozwoju społeczno-gospodarczego - regiony rozwinięte, rozwijające się i opóźnione w rozwoju itp.

Regiony, w których obserwuje się występowanie negatywnych zjawisk natury gospodarczej, społecznej i przestrzennej, najczęściej określa się jako problemowe, depresyjne, peryferyjne, zacofane, opóźnione w rozwoju lub słabo rozwinięte. W literaturze przedmiotu istnieje wiele różnorodnych definicji wyjaśniających specyfikę tych regionów. Znaleźć je można w koncepcji „rdzenia i peryferii” J. Friedmanna, w której dokonano delimitacji regionów na: regiony rdzeniowe (będące centrami przemysłowymi, finansowymi i administracyjnymi o wysokim potencjale rozwojowym), osie rozwoju (stanowiące pasma wzdłuż głównych szlaków komunikacyjnych łączących dwa lub więcej regionów rdzeniowych), regiony graniczne (mające potencjał rozwojowy, ale nie 
wykazujące zdolności do rozwoju) i depresyjne (wykazujące stagnację lub upadek gospodarczy) (Grosse 2002, Brol 2006). W koncepcji tej „rdzeń obszaru" (centrum) charakteryzuje się zdolnością do tworzenia i absorbcji innowacji, natomiast peryferia są uzależnione od centrum, ale mają zdolność do absorbcji innowacji. Peryferia posiadają tylko pojedyncze lub nieliczne, specyficzne szanse rozwoju (zasoby) (Kozak i inni 2000). Centra i peryferia tworzą zamknięty system przestrzenny, dzięki któremu innowacje rozprzestrzeniają się z centrum na peryferie (Stawasz 2000, Przygodzki 2007). Należy również dodać, że trzecią kategorią regionów w myśl tej koncepcji mógłyby się stać się regiony zmarginalizowane, które nie mają zdolności ani do tworzenia, ani do absorbcji innowacji. Dla wyjaśnienia tej relacji można przytoczyć koncepcję I.M. Wallerstreina, który dokonał klasyfikacji regionów peryferyjnych na pełne - najbardziej zależne oraz tzw. półperyferia będące pośrednikami (Wallerstein, 2007).

Natomiast w koncepcji L.H. Klassena (Bański 2011) dokonano podziału regionów według dwóch kryteriów: tempa wzrostu dochodów regionu $\mathrm{w}$ porównaniu $\mathrm{z}$ tempem wzrostu dochodu krajowego oraz poziomu dochodu $\mathrm{w}$ regionie $\mathrm{w}$ porównaniu $\mathrm{z}$ poziomem ogólnokrajowym. Pierwszy typ to obszary dostatku - wysoko rozwinięte i nadal dynamicznie rozwijające się, drugi typ to obszary niedostatku w fazie rozwoju - słabo rozwinięte, ale dysponujące dużym potencjałem rozwojowym, trzeci typ to wysoko rozwinięte charakteryzujące się tendencją spadkową i czwarty typ to obszary biedy i niedostatku bez własnego potencjału rozwojowego (Bański 2011, s. 7-8).

B. Winiarski, przyjmując za kryterium podziału ocenę stanu i tempo rozwoju, wyróżnił regiony:

- rozwinięte i rozwijające się (występujące w regionie zasoby wykorzystywane są w sposób racjonalny);

- opóźnione w rozwoju (regiony nie wykorzystujące części zasobów lub nieefektywnie i nieracjonalnie wykorzystujące te zasoby) (Winiarski red. 1992, s. 14).

Do pierwszej grupy jednostek rozwiniętych i rozwijających należą regiony rozwijające się dynamicznie i harmonijnie, dysponujące warunkami do przyspieszenia procesu wzrostu, lecz wymagające harmonizacji procesu rozwoju. Drugą grupę stanowią regiony opóźnione w rozwoju, tzn. nierozwinięte i depresyjne. Regiony nierozwinięte są traktowane jako pełne nowych możliwości, oczekujące i przygraniczne (Przygodzki 2007, Winiarski, Winiarska 2000). Natomiast regiony depresyjne są strukturalnie niedostosowane, ze względu na brak zgodności gospodarki regionu ze strukturą gospodarczą oraz nienowoczesną strukturą przestrzenną i działowo-gałęziową. Są to często regiony zurbanizowane, uprzemysłowione, z rozwiniętą infrastrukturą techniczną, wysoko wykwalifikowaną siłą roboczą i zasobami produkcyjnymi skupionymi w ramach jednej gałęzi. Nie są w stanie jedynie w oparciu o własne, wewnętrzne siły dokonać przekształceń gospodarki, gwarantujących zmianę struktury gospodarczej, 
wykreowanie nowych miejsc pracy i stworzenie warunków dla stabilnego rozwoju, dlatego też wymagają wsparcia ze strony polityki regionalnej (Stawasz D. 2000, s. 61; Winiarski, Winiarska 2000).

Inną klasyfikację zaproponowali G. Gorzelak, B. Jałowiecki (Gorzelak, Jałowiecki 1999, s. 35-36), wyodrębniając regiony:

- innowacyjne - to takie, w których pojawiły się nowe technologie, nowe produkty, nowe metody organizacji i zarządzania;

- adaptacyjne - odznaczające się potencjałem ekonomicznym, który może zapewnić samopodtrzymujący się rozwój w dłuższym okresie;

- typu „skansenowego" - to regiony zacofania ekonomicznego, technologicznego i społecznego; struktura społeczno-gospodarcza określana jest jako monofunkcyjna (rolnicza lub przemysłowa).

W dalszej części opracowania zaprezentowano istotę i liczne klasyfikacje obszaru, co umożliwiło określenie cech obszarów zmarginalizowanych. $\mathrm{W}$ literaturze przedmiotu jak również dokumentach programowych często klasyfikuje się obszary na: problemowe i peryferyjne. Obszary problemowe są przedmiotem wielu badań (np. Smętkowski 2012; Plawgo 2011; Smętkowski, Wójcik 2008; Bański 2001; Ciok 1994; Heffner red. 1990; Gorzelak 1989, Eberhardt 1989) zarówno na poziomie krajowym, jak i regionalnym. Są one często uważane za część przestrzeni geograficznej charakteryzującej się niską efektywnością struktur społeczno-gospodarczych i przestrzennych, wywołujących anomalie wewnętrzne i anormalność obszaru (Bański 2011, Ciok 1994). Obszary problemowe, tak jak w przypadku regionów, można wyodrębniać opierając się na różnych kryteriach, np. wysokim udziale bezrobocia, zjawisku wyludniania, niskim poziomie PKB na mieszkańca, jak również decyzjach politycznych i założeniach polityki regionalnej ${ }^{1}$. Jedną z klasyfikacji zaproponował J. Bański (2011, s. 10), który podzielił obszary problemowe na:

- ludnościowe (na których zachodzą niekorzystne procesy demograficzne - depopulacja, starzenie się ludności itp. $)^{2}$,

- rolnicze (charakteryzują się nagromadzeniem negatywnych zjawisk społeczno-ekonomicznych i przyrodniczych, powodujących ich upośledzenie w stosunku do innych obszarów rolniczych o cechach przeciętnych w kraju) ${ }^{3}$,

\footnotetext{
${ }^{1} \mathrm{~W}$ krajach UE w oparciu o wspólną politykę regionalną kraje członkowskie ustalają własne zasady delimitacji obszarów problemowych, np. w ramach europejskich obszarów o niekorzystnych warunkach gospodarowania wyodrębniono w Polsce obszary: (i) górskie (ponad połowa użytków rolnych jest położona powyżej wysokości 500 m n.p.m.), (ii) nizinne, (iii) ze specyficznymi utrudnieniami (spełnione są co najmniej dwa z następujących kryteriów: średnia wielkość gospodarstwa wynosi poniżej 7,5 ha, występuje zagrożenie erozją wodną; udział gospodarstw, które zaprzestały działalności rolniczej, jest na poziomie niższym niż $25 \%$ całkowitej liczby gospodarstw rolnych, udział trwałych użytków zielonych w strukturze użytków rolnych wynosi ponad 40\%). Szerzej: Czapiewski, Niewęgłowska 2006.

${ }^{2}$ Szerzej: Eberhardt 1989.

${ }^{3}$ Szerzej: Bański 2011, s. 7-18.
} 
- utrudnionej dostępności (położone są peryferyjnie w stosunku do głównych ośrodków miejskich) ${ }^{4}$,

- zjawisk ekstremalnych (np. wywołanych gwałtownymi zjawiskami pogodowymi),

- konfliktowe (są to obszary oddziaływań danej funkcji na funkcje pozostałe. Przy czym przynajmniej jedna $\mathrm{z}$ nich posiada konfliktogenny charakter utrudniający prowadzenie innych działalności (Grocholska 1986) ${ }^{5}$.

Natomiast obszary peryferyjne są definiowane według różnych podejść i kryteriów wyróżnienia.

Biorąc pod uwagę położenie geograficzne i odległość od centrów gospodarczych, obszar peryferyjny charakteryzuje się zespołem niekorzystnych cech w porównaniu z obszarami centralnymi (Leszczewska 2010, Grosse 2007, Anderson 2000), do których zalicza się (Olechnicka 2004, s. 58):

- cechy sprawcze związane z peryferyjnością, m.in. duże koszty transportu, niska jakość infrastruktury technicznej, brak korzyści, wynikających z funkcjonowania w aglomeracji;

- cechy zależne, wynikające bezpośrednio z cech sprawczych, np. słabo rozwinięty sektor $\mathrm{B}+\mathrm{R}$, niski poziom innowacyjności i przedsiębiorczości, wysokie koszty zaopatrzenia;

- cechy towarzyszące - związane z cechami sprawczymi: mała gęstość zaludnienia na skutek niskiego przyrostu naturalnego oraz odpływu ludności, słabo rozwinięta infrastruktura instytucjonalna, zależność gospodarki regionu od sektora pierwotnego najczęściej rolniczego.

Definicje obszarów peryferyjnych uwzględniają często cechy słabego rozwoju gospodarczego (Leszczewska 2010, Grosse 2007) przejawiającego się: monofunkcyjną specjalizacją rolniczą, niską innowacyjnością i przedsiębiorczością (Kumar 1995, Mason 1991,Van Horn and Harvey 1988), mało korzystnymi warunkami dla rozwoju biznesu, a w szczególności dla małych i średnich przedsiębiorstw operujących głównie na rynkach lokalnym i regionalnym (Valliere, Peterson 2009, Smallbone i inni 1993), słabym rozwojem infrastruktury komunikacyjnej (Goodal 1987) oraz niskim kapitałem intelektualnym (Mason 1991) i społecznym (Anderson 2000). Definicje peryferyjności mogą odnosić się również do odrębności kulturowej (Bocock 1993), religijnej mieszkańców tych obszarów.

Przytoczone definicje potwierdzają wieloznaczność pojęć „region” i „obszar", jak również różnorodność ich klasyfikacji. Często również używa się zamiennie obu pojęć, co stanowi zbyt duże uproszczenie, gdyż nie są one tożsame. W opracowaniu tym pojęcie „region” będzie używane dla jednostki

\footnotetext{
${ }^{4}$ Szerzej: Komornicki, Śleszyński 2009, s. 9-38.

${ }^{5}$ Szerzej: Dutkowski 1995; Kołodziejski 1982, s. 134-148.
} 
administracyjnej, jaką jest województwo, natomiast pojęcie „obszar” będzie stosowane do mniejszej jednostki administracyjnej - powiatów. Sam proces marginalizacji odnosi się raczej do obszaru $w$ ramach znacznie większej jednostki, jaką jest np. województwo, tj. w przypadku województwa mazowieckiego nie można powiedzieć o marginalizacji całego regionu, a tylko pewnego obszaru, który można zdiagnozować bardziej precyzyjnie za pomocą mniejszych jednostek administracyjnych, np. powiatów.

W opisanych typach regionów i obszarów występują różnorodne problemy w zakresie generowania rozwoju, dlatego często mówi się o nich, że ulegają procesom marginalizacji. Marginalizacja to proces i/lub stan wyłączenia społeczności, instytucji, obszarów z procesów rozwojowych (Kozak i inni 2000). W przypadku obszaru oznacza ona długotrwałe wyłączenie $\mathrm{z}$ generowania rozwoju i partycypacji $w$ dochodach $\mathrm{z}$ rozwoju oraz wykluczenie regionalnej społeczności $\mathrm{z}$ aktywnego uczestnictwa $\mathrm{w}$ procesach gospodarczych, co powoduje w długim okresie ubóstwo, niezaspokojenie podstawowych potrzeb, brak jakichkolwiek szans na znalezienie pracy (Stawasz D. 2007, Markowski 1999). Zjawisko to jest niebezpieczne, gdy ma charakter masowy, powiązany $\mathrm{z}$ redukcją miejsc pracy i często alokacją terytorialną potencjału biznesowego ${ }^{6}$. Tam, gdzie jest skorelowane $\mathrm{z}$ niskimi możliwościami restrukturyzacji i generowania stabilnego wzrostu w oparciu o dyfuzję z obszarów miejskich oraz uwarunkowaną historycznie niską jakością instytucji publicznych, istnieje realne zagrożenie pogarszania się ich pozycji konkurencyjnej, zmniejszenia udziału w procesach rozwojowych i w konsekwencji trwałej społecznej i ekonomicznej marginalizacji obszaru (Lisowska 2010a i 2011b). Obszary te nie są w stanie jedynie o własnych, wewnętrznych siłach dokonać procesu przekształceń gospodarki, gwarantujących zmianę struktury gospodarczej, wykreowanie nowych miejsc pracy i stworzenie warunków dla stabilnego rozwoju. Koszty ponownego włączenia obszarów zmarginalizowanych do współtworzenia rozwoju gospodarczego są szczególnie wysokie i charakteryzują się wydłużonym okresem zwrotu (Markowski 1999, s. 41).

Charakterystyka obszarów zmarginalizowanych w Polsce wymaga analizy przyczyn procesu marginalizacji. Niewątpliwie ich źródłem mogą stać się dysproporcje w rozwoju regionów, które są przedmiotem kolejnego podrozdziału.

${ }^{6}$ Może to oznaczać przejęcie rynku przez podmioty zewnętrzne, przejęcie pracowników przez firmy konkurencyjne, sprzedaż dotychczasowych maszyn i urządzeń. 


\subsection{Dysproporcje w rozwoju regionów a obszary zmarginalizowane}

Zróżnicowanie poziomu rozwoju regionów jest naturalnym elementem procesów gospodarczych zachodzących zarówno w UE, jak i Polsce, stanowiąc jeden z podstawowych problemów współczesnych gospodarek. Pogłębiające się zróżnicowania międzyregionalne prowadzą do powstawania regionów centralnych i regionów peryferyjnych, które często ulegają procesom marginalizacji, co nie sprzyja procesowi rozwoju społeczno-gospodarczego danego obszaru (potwierdzają to liczne opracowania, dotyczące spójności regionów UE np. INTERCO Indicators... 2011, Investing in Europe's... 2010, Growing Regions... 2007). Dysproporcje rozwojowe są głównie widoczne między miastami a obszarami wiejskimi, dużymi ośrodkami miejskimi a obszarami peryferyjnymi. Peryferyjność przejawia się głównie w niekorzystnym położeniu, niższym poziomie kapitału ludzkiego, ograniczonym dostępie do infrastruktury transportowej, teleinformatycznej i usług publicznych oraz uzależnieniu od jednego sektora zatrudnienia (monofukcyjne miasta i wsie), jak również może dotyczyć również obszarów o centralnym położeniu, ale znajdujących się poza strefą korzystnego oddziaływania ośrodków miejskich i charakteryzujących się brakiem funkcjonalnych powiązań z ośrodkami miejskimi. Czynniki te wzmocnione przez procesy demograficzne i migracyjne mogą powodować pogłębianie się dysproporcji rozwojowych między obszarami (Polska 2030... 2011; Investing in Europe's... 2010).

W Polsce na zróżnicowanie rozwoju regionów miały wpływ uwarunkowania historyczne, tzn. przynależność do trzech różnych zaborów, zniszczenia wojenne, silne ruchy migracyjne związane $\mathrm{z}$ wojną i zmianą granic Polski, jak również procesy transformacji gospodarki oraz integracji z UE. Ma to swój wyraz w podziale Polski na cześć zachodnią, która jest względnie dobrze rozwinięta, oraz na część wschodnią, która za wyjątkiem Warszawy charakteryzuje się bardzo niskimi wskaźnikami poziomu rozwoju społecznogospodarczego. W trakcie transformacji gospodarczej i po przystąpieniu Polski do Unii Europejskiej w pełni ujawniły się słabości polskiej gospodarki, okazało się bowiem, że znaczne obszary Polski są zagrożone trwałą marginalizacją i wykluczeniem dużych grup mieszkańców z życia społecznego i gospodarczego. Przyczyn tego stanu rzeczy upatruje się w szybszym rozwoju obszarów metropolitalnych niż obszarów peryferyjnych oddalonych od biegunów wzrostu gospodarczego ${ }^{7}$ (Smętkowski 2007; Markowski, Marszał, 2007; Gaczek 2010; Domański 2011). Na przewagę obszarów metropolitalnych mają wpływ zarówno uwarunkowania o charakterze egzogenicznym, jak i endogenicznym, które są

\footnotetext{
${ }^{7}$ Określenia „bieguny wzrostu” i „obszary peryferyjne” są rozumiane w kontekście rozwoju społeczno-gospodarczego i są stosowane zamiennie z pojęciami „obszary rozwinięte” oraz „obszary słabo rozwinięte” - „obszary zmarginalizowane”.
} 
źródłem odmienności gospodarczej, społecznej i kulturowej (np. zróżnicowany profil działalności gospodarczej, funkcjonowanie różnej wielkości podmiotów gospodarczych, obecność ośrodków podejmowania decyzji, bogactwa kultury, edukacji i nauki, potencjał społeczny o zróżnicowanych cechach i potrzebach). Obszary te dzięki swojemu potencjałowi gospodarczemu i dywersyfikacji działań stwarzają większe możliwości dla rozwoju różnych form działalności gospodarczej, szczególnie tych, które wymagają wysoko wykwalifikowanej kadry, np. przedsięwzięcia wykorzystujące wysoko innowacyjne rozwiązania technologiczne są w stanie przechwytywać cześć efektów mnożnikowych inwestycji lokalizowanych w innych obszarach (Domański 2009, s. 137-138).

Znaczące różnice rozwojowe pomiędzy regionami mogą wywoływać zjawisko marginalizacji danego obszaru, co powoduje spadek aktywizacji biznesowej na danym terenie oraz koncentrację negatywnych zjawisk społeczno-gospodarczych, takich jak: bezrobocie, ubożenie ludności, odpływ ludności, niska produktywność, nieefektywny system edukacji, patologie społeczne (Krajowa strategia... 2010, s. 17). Zjawisko to jest niebezpieczne, gdy ma charakter masowy, powiązany z redukcją miejsc pracy i często alokacją terytorialną potencjału biznesowego ${ }^{8}$. Tam, gdzie zjawiska te są skorelowane z niskimi możliwościami restrukturyzacji i generowania stabilnego wzrostu w oparciu o dyfuzję z obszarów miejskich oraz uwarunkowaną historycznie niską jakością instytucji publicznych, istnieje realne zagrożenie pogarszania się ich pozycji konkurencyjnej, zmniejszenia udziału w procesach rozwojowych i w konsekwencji trwałej społecznej oraz ekonomicznej marginalizacji regionu.

Szybki rozwój obszarów rozwiniętych, a tym samym pogłębianie nierówności przestrzennych, nie zawsze jest procesem niekorzystnym dla obszarów słabo rozwiniętych. $Z$ jednej strony bowiem dynamiczny rozwój biegunów wzrostu może wywoływać efekty wymywania, np. odpływ młodych aktywnych ludzi, co może hamować rozwój obszarów peryferyjnych, a z drugiej strony może być źródłem przepływów kapitału, dyfuzji innowacji oraz efektów mnożnikowych, przyczyniających się do rozprzestrzeniania się rozwoju na obszary słabo rozwinięte. Uważa się zatem, że rozwój obszarów zmarginalizowanych powinien opierać się na ich integracji z obszarami rozwiniętymi. Integracja implikuje łatwiejsze kontakty społeczne i gospodarcze, przemieszczenia ludzi, przepływ idei, dóbr i kapitału, co sprzyjać może zarówno lokalnemu rozwojowi gospodarczemu, jak i wzrostowi poziomu życia. Działania te powinny być wspierane przez władze samorządowe poprzez ograniczanie barier infrastrukturalnych, instytucjonalnych i informacyjnych, wspieranie rozwoju kapitału ludzkiego oraz lokalnych usług publicznych - bezpieczeństwa publicznego, edukacji i opieki zdrowotnej (Domański 2011, s. 63 i 67).

${ }^{8}$ Może to oznaczać przejęcie rynku przez podmioty zewnętrzne, przejęcie pracowników przez przedsiębiorstwa konkurencyjne, sprzedaż dotychczasowych maszyn i urządzeń. 
Na szeroko rozumiany rozwój społeczno-gospodarczy regionów, jak już wcześniej wspomniano, ma wpływ również standard życia ludności. W Polsce obserwuje się zróżnicowanie terytorialne warunków życia i dochodów ludności. Widoczne są bowiem różnice między regionami Polski Zachodniej i Wschodniej, jak również między aglomeracjami a pozostałymi jednostkami osadniczymi. Powoduje to występowanie obszarów problemowych, które charakteryzują się niskimi wskaźnikami społeczno-gospodarczymi oraz niskim potencjałem rozwojowym (niska dostępność i jakość usług publicznych, takich jak: administracja, zdrowie, edukacja, kultura, sport itd.), jak również ograniczonymi zasobami własnymi (Strategia rozwoju kraju 2020... 2012, s. 110). Do obszarów problemowych zalicza się również obszary: peryferyjne, wiejskie, tracące dotychczasowe funkcje społeczno-gospodarcze (np. poprzemysłowe, zdegradowane) oraz przygraniczne. Obszary te nie są w stanie, opierając się na własnych zasobach, zwiększać swoją konkurencyjność i innowacyjność, co powoduje, że nie mają szansy na udział $\mathrm{w}$ tworzeniu wzrostu gospodarczego, i sprzyja to procesom marginalizacji w wymiarze gospodarczym, społecznym i przestrzennym.

Do zbadania zróżnicowania poziomu rozwoju społeczno-gospodarczego regionów używa się na ogół wskaźników ilościowych (np. stopa bezrobocia, PKB na 1 mieszkańca, wskaźniki wykształcenia, dostęp do internetu, przeciętne dochody mieszkańców czy też wydatki na sferę B+R itp.) i jakościowych (np. wiedza, innowacyjność, jakość i sprawność administracji publicznej, zdolność instytucjonalną do zarządzania rozwojem itp.). Jednakże ze względu na ograniczoną dostępność danych statystycznych porównywalnych dla analizowanych lat oraz brak badań jakościowych w większości analiz stosuje się uproszczenia już na etapie doboru zmiennych, co nie zawsze wpływa pozytywnie na stworzenie rzetelnego obrazu poziomu rozwoju społecznogospodarczego polskich regionów.

Najczęściej stosowanym wskaźnikiem do pomiaru rozwoju społeczno-gospodarczego regionów w Polsce, jak również Unii Europejskiej, jest ich udział w tworzeniu PKB. Według danych GUS (Biuletyn statystyczny... 2013) w 2010 r. najwyższy i rosnący udział w generowaniu krajowego PKB uzyskało województwo mazowieckie z udziałem $22,3 \%$, na kolejnych miejscach znalazły się województwa: śląskie, wielkopolskie, dolnośląskie i małopolskie, które wytworzyły w 2010 r. łącznie 38,1\% ogółu krajowego PKB. Województwa te uznano za lokomotywy rozwoju gospodarczego. Jako najsłabsze okazały się województwa Polski Wschodniej i Północno-Wschodniej, tzn. świętokrzyskie, podlaskie i warmińsko-mazurskie oraz województwa lubuskie i opolskie, które mimo widocznej poprawy sytuacji społeczno-gospodarczej w ostatnich latach, nadal charakteryzują się najniższym poziomem rozwoju, starzejącym się społeczeństwem, niższym niż reszta kraju poziomem wykształcenia, zapóźnieniami infrastrukturalnymi, niskim poziomem warunków życia (w tym dostępem do dóbr i usług), niską produktywnością wszystkich sektorów gospodarki 
(Krajowa strategia... 2010, s. 30-31). W przypadku regionów Polski Wschodniej rozwój społeczno-gospodarczy nie jest jednolity, ze względu na występujące zróżnicowania wewnątrzregionalne (obszary wzrostu w postaci miast wojewódzkich i przylegających do nich obszarów zurbanizowanych, których rola społeczno-gospodarcza jest zbyt mała, aby w istotny sposób wpływać na sytuację w całym regionie), które mogą powodować problemy z wykorzystaniem własnych potencjałów w oparciu o endogeniczne zasoby (m.in. kapitał społeczny, kulturowy, innowacyjny) dla rozwoju regionów słabszych.

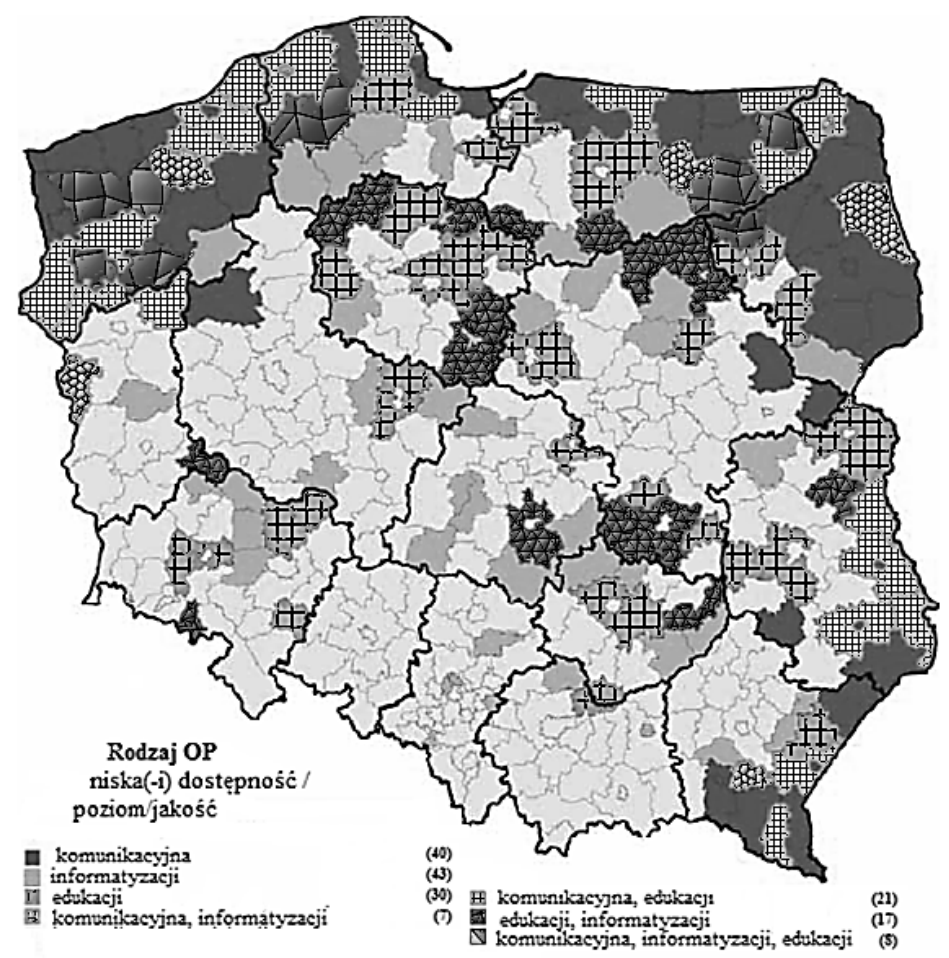

Rysunek 1. Typy obszarów problemowych (OP) ze względu na ich wyzwania rozwojowe Źródło: Identyfikacja i delimitacja..., 2009, s. 102

Oceny zróżnicowania rozwoju polskich obszarów można dokonać również na podstawie takich kryteriów ${ }^{9}$, jak $^{10}$ : dostępność infrastruktury komunikacyjnej

${ }^{9}$ Kryteria te zostały zastosowane do delimitacji obszarów problemowych na poziomie NUTS-4, będące przedmiotem działań Celu 2 KSRR.

10 Szerzej na temat metodologii i stosowanych mierników syntetycznych: Identyfikacja i delimitacja ... 2009. 
i transportowej ${ }^{11}$, rozwój społeczeństwa informacyjnego ${ }^{12}$ oraz jakość edukacji ${ }^{13}$ (Identyfikacja $i$ delimitacja... 2009, s. 98). Analiza tych trzech kryteriów pozwoliła na wyodrębnienie obszarów problemowych, do których należą peryferia Polski (zwłaszcza wschodnie i północne) oraz monofunkcyjne ośrodki lokalne i ponadlokalne (por. rysunek 1).

Natomiast w projekcie Strategii rozwoju spoteczno-gospodarczego Polski Wschodniej do roku 2020 poziom rozwoju społeczno-gospodarczego województw został oceniony metodą dekompozycji ${ }^{14} \mathrm{z}$ wykorzystaniem wskaźnika Wartość Dodana Brutto (WDB) per capita porównywanego do średniej dla kraju za pomocą następujących czynników wyjaśniających: wydajność pracy, odpływ ludności związany $\mathrm{z}$ pracą zawodową, zatrudnienie, aktywność zawodowa, struktura wiekowa ludności. Przeprowadzone analizy potwierdziły, że regionami o najniższym poziomie rozwoju są województwa Polski Wschodniej (świętokrzyskie, podlaskie, podkarpackie, lubelskie i warmińsko-mazurskie), charakteryzujące się niską wydajnością pracy oraz niedostatecznym wykorzystaniem zasobów pracy. Niska wydajność pracy może wynikać ze specjalizacji sektorowej tych regionów, tzn. wysokiego zaangażowania zasobów pracy w sektorze rolniczym o dużo niższej wydajności pracy niż pozostałe sektory gospodarki, jak również gorszego wyposażenia w regionalne aktywa: infrastrukturę, potencjał technologiczny i innowacyjny itp. Niewystarczające wykorzystanie zasobów pracy wynika $\mathrm{z}$ odpływu ludności związanego $\mathrm{z}$ pracą zawodową $\mathrm{z}$ regionów uboższych do bogatszych, a co za tym idzie uszczuplenia zasobów wykwalifikowanych pracowników oraz starzenia się społeczeństwa. Natomiast regionem o najwyższym poziomie rozwoju zgodnie $\mathrm{z}$ wcześniej przedstawionymi analizami jest województwo mazowieckie z wysoką wydajnością pracy i dobrym wykorzystaniu zasobów pracy (Projekt zaktualizowanej Strategii... 2013, s. 14-16).

Nieco innych, bardziej szczegółowych i wielopłaszczyznowych kryteriów do oceny zróżnicowania regionalnego wykorzystano w raporcie Identyfikacja i delimitacja obszarów problemowych i strategicznej interwencji w Polsce, które zostały sformułowane w sześciu osiach tematycznych:

- struktura gospodarki,

- innowacyjność,

${ }^{11}$ Wskaźnik obliczono na podstawie cechy międzygałęziowej dostępności transportowej.

${ }^{12}$ Wskaźnik obliczono na podstawie cech: liczby komputerów z dostępem do Internetu szerokopasmowego w stosunku do liczby uczniów w szkołach podstawowych i gimnazjalnych, liczby abonentów indywidualnych z dostępem do stacjonarnego Internetu szerokopasmowego w stosunku do liczby mieszkańców.

${ }^{13}$ Wskaźnik obliczono na podstawie cech: odsetek dzieci w wieku 3-6 lat objętych wychowaniem przedszkolnym, średnie wyniki egzaminu gimnazjalnego w części matematycznoprzyrodniczej, liczba imprez oświatowych w muzeach w stosunku do liczby uczniów gimnazjów.

${ }^{14}$ Metoda pozwala na wykorzystanie wielu czynników społeczno-gospodarczych do oceny ich wpływu na regionalne zróżnicowania i dynamikę rozwoju. Szerzej na temat metody i metodologii badania w Lewandowski 2011, s. 121; Projekt zaktualizowanej Strategii..., s. 1415. Analiza został wykonana w ujęciu dynamicznym dla lat 2002 i 2009. 
- środowisko naturalne,

- problemy społeczne,

- kapitał ludzki,

- dostępność ${ }^{15}$.

Dla każdego kryterium tematycznego określono grupę zmiennych, która pozwoliła na obliczenie 24 wskaźników syntetycznych, na podstawie których opracowano typologię polskich regionów na poziomie NUTS-3 w polskiej nomenklaturze podregionów, składającą się z 8 grup (Identyfikacja i delimitacja... 2009, s. 24-33). Podregiony Polski zostały podzielone na dwie kategorie: obszary rozwinięte (grupy 1-4) i peryferyjne (grupy 5-8) pod względem gospodarczym oraz przestrzennym (por. rysunek 2). Pierwsze z nich powinny rozwijać się zgodnie z założeniami koncepcji rozwoju polaryzacyjnego (wspieranie wewnętrznych przewag konkurencyjnych, które mają stać się „lokomotywami rozwojowymi"), drugie zaś w oparciu o koncepcję rozwoju dyfuzyjnego (wspieranie wewnętrznych potencjałów obszarów słabiej rozwiniętych, które mają czerpać korzyści z ośrodków gospodarczych).

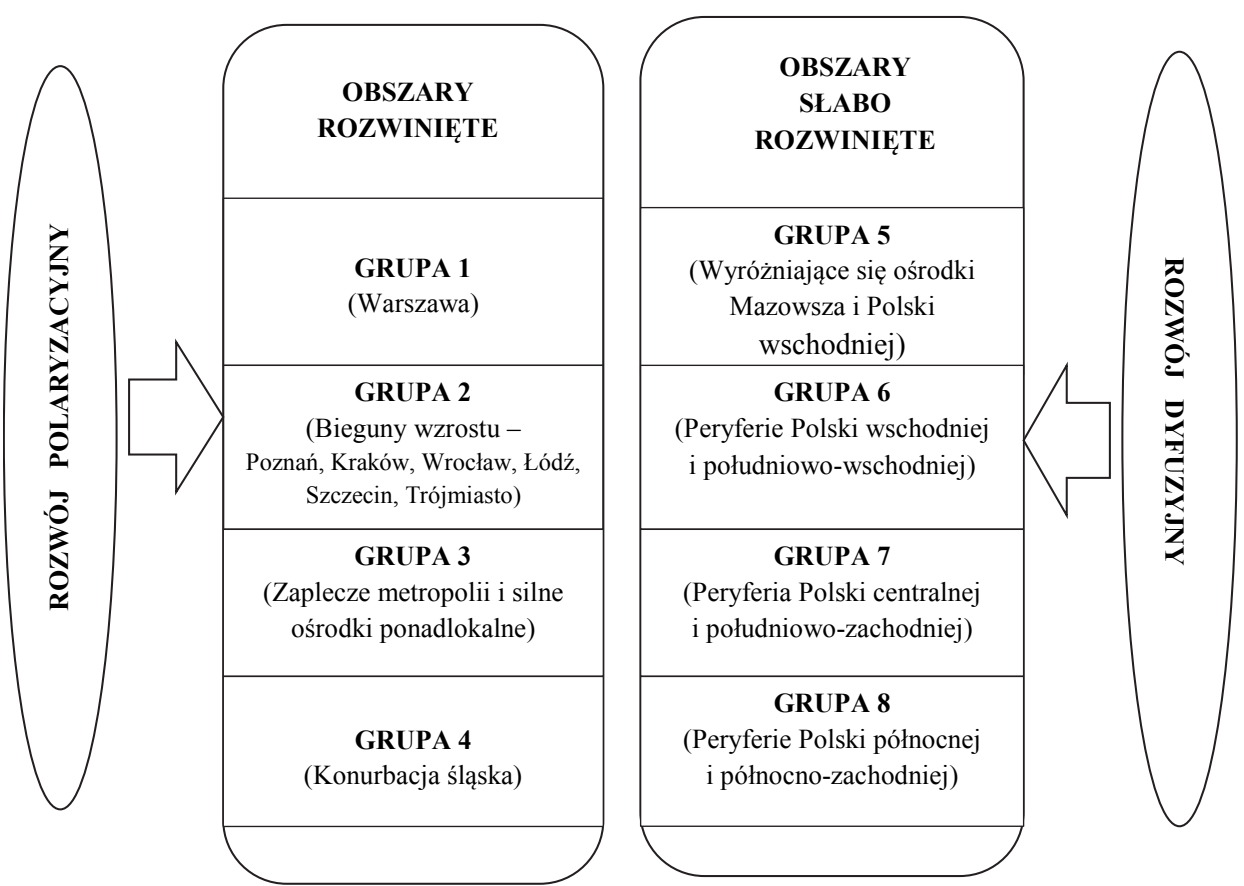

Rysunek 2. Klasyfikacja polskich podregionów według poziomu rozwoju społeczno-gospodarczego

Źródło: opracowanie własne na podstawie: Identyfikacja i delimitacja... 2009, s. 66

${ }^{15}$ Metodologia badania jak również szczegółowy wykaz czynników zawarto w raporcie Identyfikacja i delimitacja... 2009, s. 24-33. 
Podregiony Polski uznane za peryferyjne ${ }^{16}$ (grupy 5-8) (por. rysunek 3) charakteryzują się niekorzystną strukturą gospodarczą, zwykle dużo niższym poziomem innowacyjności i akumulacji kapitału ludzkiego i społecznego oraz niższym wskaźnikiem urbanizacji (Identyfikacja i delimitacja... 2009, s. 64-65). Dodatkowo każdy z tych podregionów jest wewnętrznie zróżnicowany i posiada inne problemy często uwarunkowane cechami lokalnej struktury (np. rolniczej). Niekorzystna sytuacja tych obszarów wpływa nie tylko na brak możliwości generowania rozwoju, ale również na problemy społeczne (ubóstwo, odpływ ludności w kierunku silniejszych ośrodków rozwoju, patologie itp.).

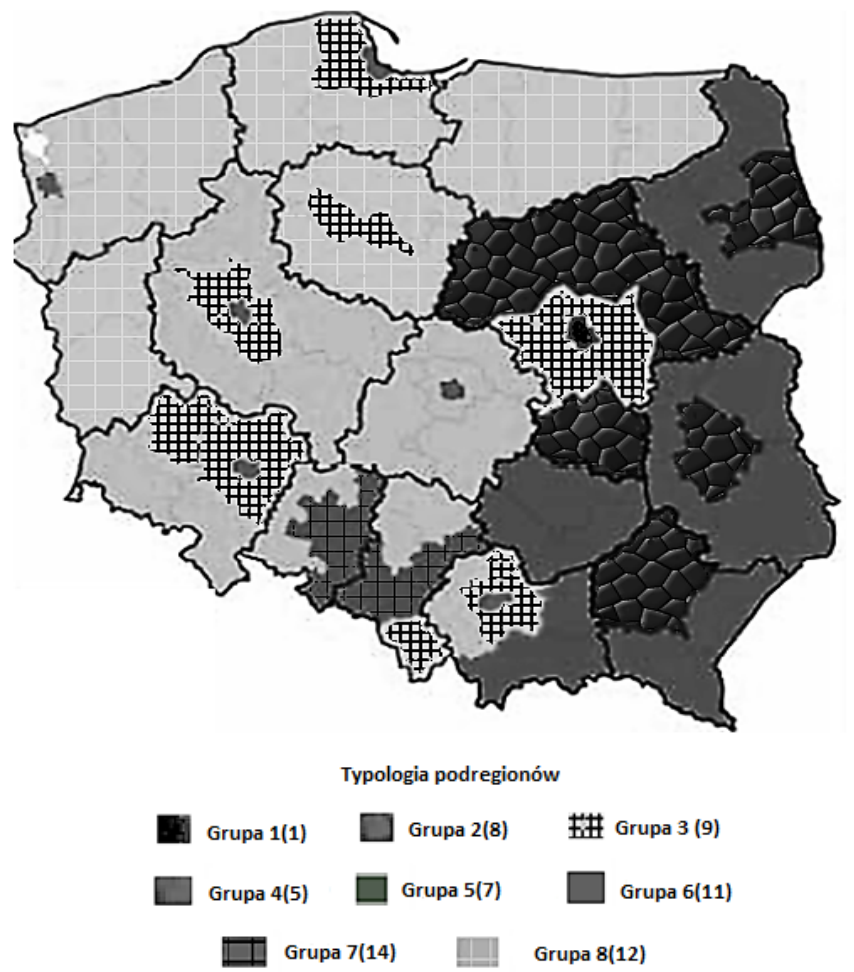

Rysunek 3. Typologia polskich podregionów Źródło: Identyfikacja i delimitacja... 2009, s. 67

Podregiony grupy 5 (wyróżniające się ośrodki Mazowsza i Polski wschodniej) charakteryzują się niskim poziomem rozwoju gospodarczego, problemami strukturalnymi rolnictwa (przeludnienie agrarne oraz niewielka towarowość

${ }^{16}$ Peryferyjność tu nie oznacza tylko geograficznego oddalenia od biegunów wzrostu, ale również niski poziom rozwoju społeczno-gospodarczego. 
rolnictwa), słabą dostępnością komunikacyjną oraz niskim poziomem innowacyjności oraz odpływem siły roboczej poszukującej lepszych możliwości zarobkowania.

W grupie 6 ( peryferie wschodniej i południowo-wschodniej Polski) znajdują się obszary o najwyższym dystansie rozwojowym wobec biegunów wzrostu, które charakteryzują się przeludnieniem agrarnym, zjawiskiem ukrytego bezrobocia, najniższą w kraju produktywnością pracy, zjawiskiem wykluczenia cyfrowego, ograniczoną dostępnością komunikacyjną oraz ubóstwem materialnym.

Grupa 7 (peryferie południowo-zachodniej i centralnej Polski) to obszary o najbardziej korzystanej sytuacji w stosunku do grup 5, 6 i 8 charakteryzujące się większą gęstością zaludnienia, wyższym poziomem urbanizacji, stosunkowo dużymi wydatkami inwestycyjnymi jednostek samorządu terytorialnego, bardzo dobrą dostępnością komunikacyjną, niskim poziomem innowacyjności, ubóstwem ekonomicznym oraz złym stanem środowiska naturalnego.

Natomiast w grupie 8 (peryferie północnej i północno-zachodniej Polski) obszary cechują się niskim poziomem urbanizacji, wysoką efektywnością i towarowością rolnictwa, dobrym stanem środowiska naturalnego, dobą dostępnością bazy turystycznej, niską innowacyjności, wykluczeniem cyfrowym oraz ubóstwem ekonomicznym ${ }^{17}$.

Przedstawione charakterystyki podkreślają znaczące zróżnicowanie problemów rozwojowych analizowanych obszarów. W najbardziej niekorzystnej sytuacji okazały się być obszary Polski Wschodniej z najsłabszymi wskaźnikami rozwoju społeczno-gospodarczego i peryferyjnym położeniem w stosunku do biegunów wzrostu. Były one również zaklasyfikowane do dodatkowego wsparcia z funduszy unijnych w latach 2007-2013 w ramach Programu Operacyjnego Rozwój Polski Wschodniej 2007-2013 ${ }^{18}$ jak również określone jako obszary problemowe w Krajowej Strategii Rozwoju Regionalnego 2010-2020: Regiony, miasta, obszary wiejskie (2010). Pozostałe obszary wymagają określenia indywidulanej trajektorii rozwoju na podstawie szczegółowej analizy barier i potencjalnych stymulatorów rozwoju; jest to możliwe dzięki licznym badaniom prowadzonym podczas przygotowania dokumentów programowych (Polska 2030... 2011, Koncepcja Przestrzennego Zagospodarowania... 2012, Projekt zaktualizowanej Strategii... 2013) związanych z nową perspektywą programowania na lata 2014-2020.

W najnowszych dokumentach strategicznych i zagospodarowania kraju, np. w Eksperckim Projekcie Koncepcji Przestrzennego Zagospodarowania Kraju do roku 2033 zostały zdefiniowane również obszary problemowe, jako wyodrębnione geograficznie lub administracyjnie terytoria, na których występuje kumulacja negatywnych zjawisk społecznych, gospodarczych i/lub przyrodniczych. Rozwiązanie których lub usunięcie wymaga interwencji ze strony władz publicznych (Korcelli i inni 2008, s. 79). Największym obszarem problemowym

\footnotetext{
${ }^{17}$ Szerzej w: Identyfikacja i delimitacja... 2009.

${ }^{18}$ Szerzej w dokumentach programowych: Program Operacyjny... 2007.
} 
o znaczeniu krajowym jest Polska Wschodnia (por. rysunek 4), która obejmuje pięć najsłabiej rozwiniętych wschodnich województw: warmińsko-mazurskie, podlaskie, lubelskie, świętokrzyskie oraz podkarpackie, a także Wschodnie Mazowsze (podregion siedlecko-ostrołęcki).

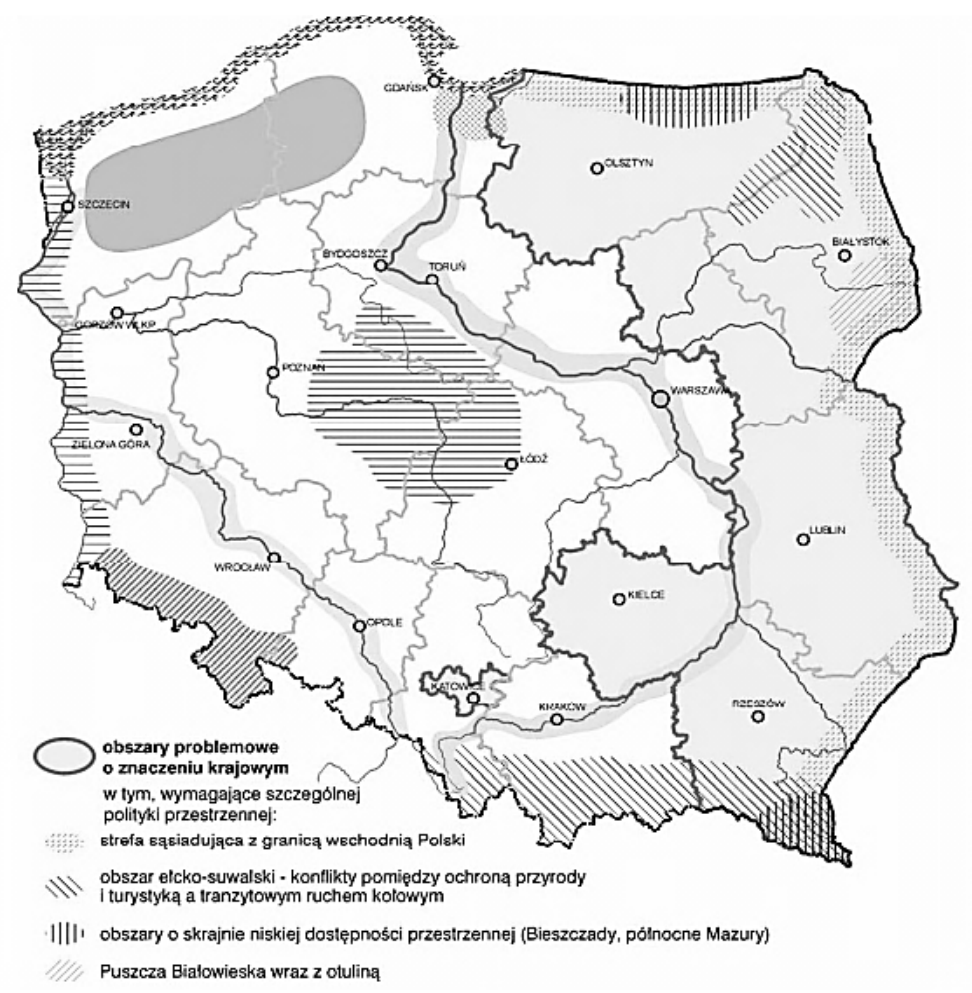

Rysunek 4. Obszary problemowe Źródło: Korcelli i inni 2008

We wschodniej Polsce, mimo znaczącej liczby problemów związanych $\mathrm{z}$ rozwojem tych obszarów, widoczne są również tzw. bieguny wzrostu w postaci funkcjonujących na terenie tego obszaru 29 klastrów (stan w 2012 r.), znajdujących się $\mathrm{w}$ fazie ustabilizowanego rozwoju o znaczeniu nie tylko krajowym, ale również europejskim i światowym (Plawgo red. 2007, Rozwój klastrów... 2012), np. Stowarzyszenie Grupy Przedsiębiorców Przemysłu Lotniczego „Dolina lotnicza”, Grono Targowe Kielce, Świętokrzysko-Podkarpacki Klaster Budowlany Innowator, Podlaski Klaster Bielizny, Wschodni Klaster Obróbki Metali, Klaster Dolina Ekologicznej Żywności.

W tym kontekście nie każdy region problemowy ulega procesom marginalizacji i wyłączony jest z generowania rozwoju, a wręcz przeciwnie - słabe strony niekiedy powinny być postrzegane jako atuty tworzące jego przewagę konku- 
rencyjną, np. peryferyjne położenie może stanowić szanse dla obszarów wykorzystujących jako przewagę konkurencyjną czynniki niematerialne, takie jak: wizerunek oraz sieć kontaktów (Borsa 2003, s. 4).

$\mathrm{W}$ ocenie stopnia rozwoju regionów uwzględnia się również poziom jego innowacyjności (Nowakowska 2009, Olechnicka 2007), który, jak wskazują liczne badania (Feltynowski 2009; Ciok, Dąbrowska-Kaniewska 2009; Gorzelak 2007), jest jednym z podstawowych czynników wpływających na rozwój gospodarczy (Koźlak 2009) i społeczny (Bućko, Sitkowska 2008), jak również wzrost atrakcyjności inwestycyjnej polskich regionów (Godlewska-Majkowska 2009).

Kluczowe znaczenie dla zapewnienia wysokiego i stabilnego poziomu innowacyjności regionów ma skutecznie prowadzona polityka na rzecz $\mathrm{B}+\mathrm{R}$ na poziomie krajowym, natomiast polityka regionalna może wpływać na stworzenie warunków w regionach do tworzenia, absorbcji i dyfuzji innowacji. Jest to niezmiernie trudne ze względu na niski poziom innowacyjności polskiej gospodarki, a tym samym regionów. Ocena zróżnicowania innowacyjności polskich regionów przy użyciu różnorodnych współczynników i metod ${ }^{19}$ to przedmiot wielu opracowań (Innovation Union... 2013; Koźlak 2009; Bućko, Siatkowska 2008).

Według raportu Innovation Union Scoreboard 2013 Polska znajduje się na końcu $\mathrm{w}$ rankingu innowacyjności, wyprzedzając tylko trzy państwa Unii Europejskiej, tzn. Bułgarię, Rumunię i Łotwę (Innovation Union... 2013, s. 10) i zaliczona została do grupy czwartej (modest innovators) innowatorów o skromnych wynikach. To potwierdzają również rezultaty badań przeprowadzone przez ESPON (Knowledge-Innovation... 2012), według których Polska jest obszarem zapóźnionym technologicznie, ze słabą skłonnością do wprowadzania innowacji w przedsiębiorstwach i niewielkim zakresem współpracy sfery nauki i biznesu. Ta sytuacja ma odzwierciedlenie w sytuacji polskich regionów, w przypadku których oprócz województwa mazowieckiego pozostałe charakteryzują się niską innowacyjnością.

Podobnych wniosków odnośnie do pozycji województwa mazowieckiego w rankingu innowacyjności dostarczyły również badania przeprowadzone przez A. Koźlak, która za pomocą miar syntetycznych dokonała oceny poziomu innowacyjności polskich regionów na tle ich poziomu rozwoju gospodarczego (por. rysunek 5). Badania te potwierdziły również w przypadku większości województw ${ }^{20}$ zależność między poziomem innowacyjności i poziomem rozwoju gospodarczego, tzn. regiony o niskim potencjale innowacyjnym charakteryzowały się niskim poziomem rozwoju gospodarczego i odwrotnie (Koźlak 2009, s. 10).

${ }^{19}$ Szerzej: Innovation Union... 2013; http://ec.europa.eu/enterprise/policies/innovation/files/ ius-2013_en.pdfKnowledge-Innovation... 2012; Feltynowski, Nowakowska 2009, Analiza porównawcza innowacyjności... 2008, s. 88.

${ }^{20}$ Oznaczone na rysunku 5 kolorem ciemniejszym. 


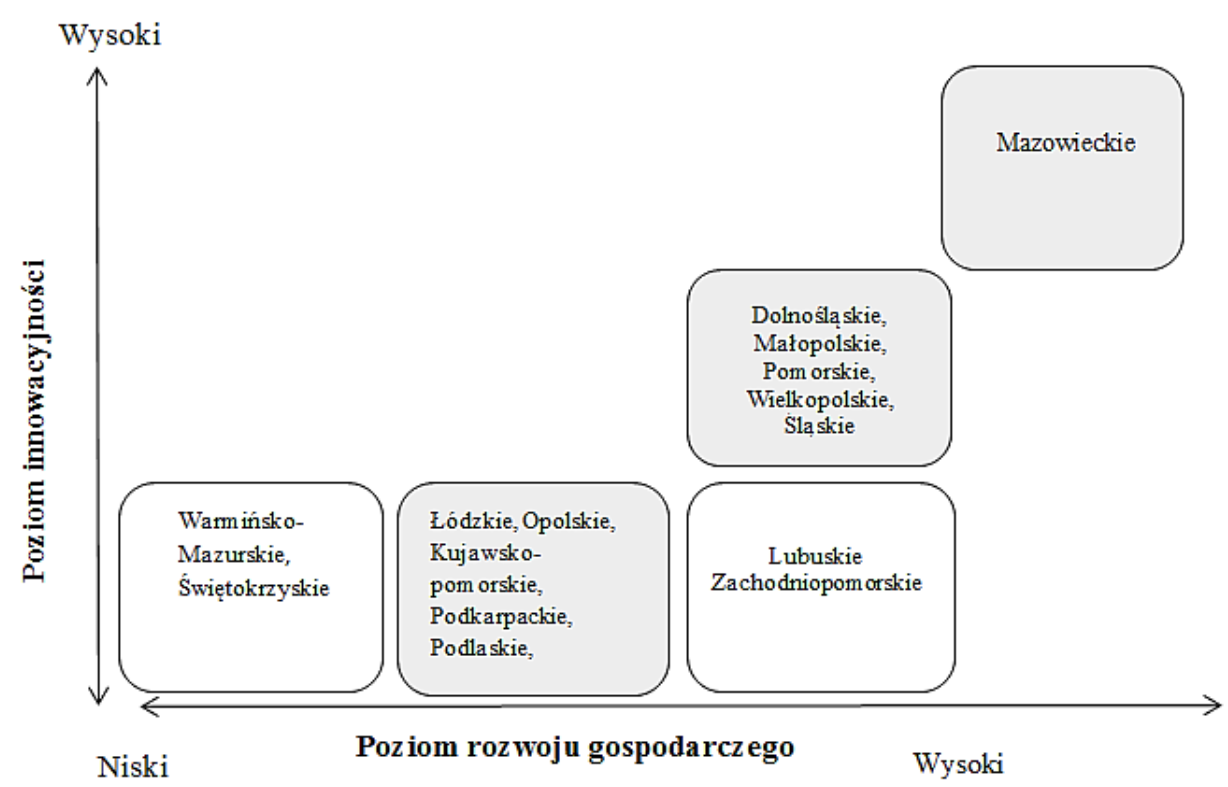

Rysunek 5. Poziom innowacyjności i rozwoju gospodarczego polskich regionów Źródło: opracowanie własne na podstawie Koźlak 2009, s. 102

Opisane wcześniej problemy rozwoju regionów w Polsce, wynikające m.in. $\mathrm{z}$ występowania dysproporcji $\mathrm{w}$ ich rozwoju, a tym samym niskiego stopnia innowacyjności i konkurencyjności, pozwalają na wskazanie obszarów szczególnie zagrożonych procesami marginalizacji.

Obszary te bowiem charakteryzują się niskim poziomem rozwoju, starzejącym się społeczeństwem, gorszym niż reszta kraju poziomem wykształcenia, zapóźnieniami infrastrukturalnymi, niskim poziomem warunków życia (w tym dostępu do dóbr i usług), słabą produktywnością wszystkich sektorów gospodarki oraz niską dostępnością transportową (Identyfikacja i delimitacja... 2009).

W Polsce za obszary szczególnie zagrożone marginalizacją uważa się pięć województw Polski Wschodniej (podkarpackie, świętokrzyskie, lubelskie, podlaskie i warmińsko-mazurskie), charakteryzujące się niskim poziomem rozwoju, starzejącym się społeczeństwem, gorszym niż reszta kraju poziomem wykształcenia, zapóźnieniami infrastrukturalnymi, niskim poziomem warunków życia (w tym dostępu do dóbr i usług), słabą produktywnością wszystkich sektorów gospodarki oraz niską dostępnością transportową (Identyfikacja i delimitacja... 2009). Szansą na rozwój u tych regionów może stać się:

- podnoszenie poziomu innowacyjności gospodarki, bazujące na ugruntowanych specjalizacjach gospodarczych i wzmacnianiu potencjału sektora nauki i badań oraz potencjału przedsiębiorstw; 
- aktywizacja zasobów pracy i poprawa jakości kapitału ludzkiego, co będzie sprzyjać większemu włączeniu społecznemu, zwłaszcza grup zmarginalizowanych;

- zbudowanie intensywnych powiązań społeczno-gospodarczych z lepiej rozwiniętym otoczeniem, dla których warunkiem niezbędnym jest zintegrowana i efektywna infrastruktura powiązań komunikacyjnych, zarówno zewnętrznych - z krajowymi biegunami wzrostu, jak i wewnętrznych, wzmacniających terytorialną spójność obszaru (Projekt zaktualizowanej Strategii... 2013, s. 10-11).

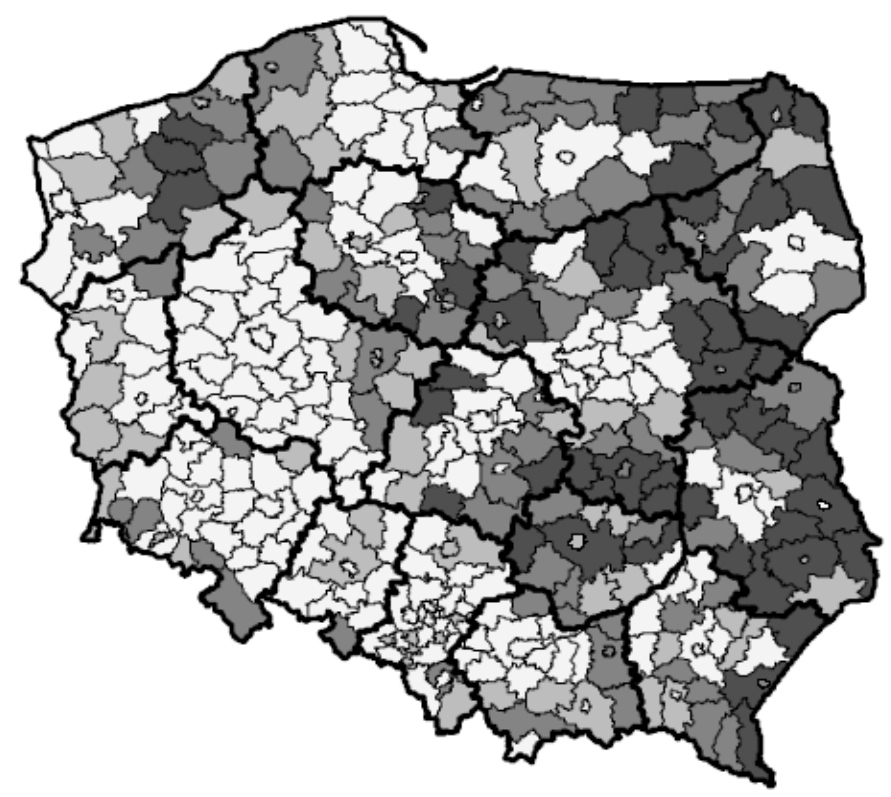

Rysunek 6. Obszary wiejskie o najgorszych wskaźnikach sytuacji społeczno-gospodarczej według powiatów

Uwaga: Najciemniejszy odcień wskazuje powiaty o najgorszych wskaźnikach sytuacji społeczno-gospodarczej, w których występuje co najmniej 6 z 11 negatywnych zjawisk spośród wymienionych poniżej: gęstość zaludnienia (średnia z lat 2006-2008) poniżej 100 osób na km², wskaźnik efektywności migracji międzypowiatowych brutto niższy od 20, wskaźnik feminizacji w grupie 20-29 lat (liczba kobiet na 100 mężczyzn) - średnia z lat 2006-2008 niższa niż 94\%, udział bezrobotnych zarejestrowanych w liczbie ludności w wieku produkcyjnym średnia w latach 2006-2008 powyżej 150\% średniej krajowej, odsetek pracujących w rolnictwie (średnia z lat 2006-2008) powyżej 50\%, odsetek zatrudnionych w usługach nierynkowych wśród zatrudnionych w usługach (średnia w latach 2006-2008) co najmniej o 50\% wyższa od średniej krajowej, liczba prywatnych spółek handlowych na 1000 osób w wieku produkcyjnym średnia w latach 2006-2008 poniżej 30\% średniej krajowej, udział gospodarstw nierynkowych w ogóle gospodarstw rolnych w 2002 r. powyżej 75\%, udział mieszkańców z wykształceniem podstawowym w grupie 13 i więcej lat w 2002 r. powyżej 120\% średniej krajowej, odległość czasowa od miasta wojewódzkiego powyżej 90 min, frekwencja w wyborach samorządowych w 2006 r. niższa niż 45\%.

Źródło: Krajowa Strategia Rozwoju... 2010, s. 33 
Kolejną grupą obszarów zagrożonych marginalizacją w Polsce są obszary wiejskie najczęściej położone peryferyjnie w stosunku do krajowych i regionalnych ośrodków aktywności społeczno-gospodarczej lub zdominowane niegdyś przez rolnictwo państwowe. Charakteryzujące się niskim wskaźnikiem rozwoju społeczno-gospodarczego (por. rysunek 6) (Krajowa Strategia... 2010), wysokim udziałem zatrudnienia $\mathrm{w}$ rolnictwie, niskim poziomem rozwoju przedsiębiorczości, dużym odsetkiem osób o niskim poziomie wykształcenia i niskich kwalifikacjach zawodowych, niskim poziomem inwestycji oraz infrastruktury technicznej. Są one skoncentrowane głównie na terenie wschodniej Polski (w tym na północy i południu województwa mazowieckiego), w województwie kujawsko-pomorskim oraz na obszarze województwa zachodniopomorskiego.

Wsparcie rozwoju w tych regionach powinno być zróżnicowane w zależności do stopnia ich rozwoju, jak również pełnionych funkcji. W przypadku obszarów wiejskich zależnych od rolnictwa istotna jest restrukturyzacja sektora rolnego, prowadząca do wzrostu konkurencyjności i modernizacji rolnictwa, natomiast w obszarach o zróżnicowanych funkcjach ważny jest ich rozwój wielofunkcyjny, umożliwiający poprawę warunków, które sprzyjają tworzeniu pozarolniczych miejsc pracy na wsi i zwiększaniu mobilności zawodowej między obszarami wiejskimi a miastami. Działania te przyczyniają się do podnoszenia poziomu i jakości życia na wsi, poczynając od zapewnienia opieki i wychowania przedszkolnego, przez poprawę dostępu do edukacji i kultury, a następnie wsparcia rozwoju przedsiębiorczości pozarolniczej i rozwoju infrastruktury oraz poprawę dostępu do usług publicznych (Strategia Rozwoju Kraju 2020... 2012, s. 126).

Za obszary zagrożone procesami marginalizacji uważa się również tereny poprzemysłowe, gdzie widoczne jest niskie tempo rozwoju, spadek nakładów inwestycyjnych oraz ubożenie ludności, jak również obszary przygraniczne związane $\mathrm{z}$ niską krajową dostępnością terytorialną, różnicami kulturowymi, społecznymi oraz zjawiskiem drenażu endogenicznych potencjałów regionalnych przez regiony zagraniczne (Strategia Rozwoju Kraju 2020 .. 2012, s. 129-130).

Aby ograniczyć postępujące procesy marginalizacji społeczno-gospodarczej, zadaniem polityki regionalnej powinno być ograniczanie pogłębiającego się zróżnicowania rozwoju obszarów poprzez wzmacnianie ich potencjału wewnętrznego oraz dbanie o rozprzestrzenianie zachodzących procesów rozwojowych w biegunach wzrostu na dalsze otoczenie, np. obszary zmarginalizowane. Bieguny wzrostu wraz z ich obszarami funkcjonalnymi mogą stymulować rozwój społeczno-gospodarczy w postaci: PKB, nowych miejsc pracy, wykwalifikowanych kadr, wiedzy i innowacji, przyczyniając się do zwiększenia konkurencyjności regionów, jak również całej gospodarki. Poprawę szans rozwojowych obszarów zagrożonych marginalizacją upatruje się w ich funkcjonalnym powiązaniu z biegunami wzrostu (ośrodkami regionalnymi, subregionalnymi i metropolami), które $\mathrm{z}$ jednej strony pozwala na wykorzystanie 
tworzonych tam innowacji, zwiększanie alternatyw zatrudnienia, poszerzanie ścieżek edukacyjnych, zwiększanie uczestnictwa w kulturze itp., z drugiej strony natomiast wymaga zbudowania własnych potencjałów rozwojowych (tworzenie warunków dla dyfuzji rozwoju, wyrównywanie szans edukacyjnych, zwiększanie dostępu do usług publicznych, transportowych i telekomunikacyjnych), pozwalających na czerpanie korzyści z liderów rozwoju.

Obszary te wymagają bardziej efektywnego wykorzystania zasobów endogenicznych, absorpcji procesów rozwojowych pochodzących z zewnątrz, wspomagania specjalizacji terytorialnej oraz zapewnienia jednolitych standardów w zakresie dostępu do podstawowych usług i dóbr publicznych (Strategia Rozwoju Kraju 2020... 2012, s. 125-128). Mogą temu służyć sieci współpracy biegunów wzrostu $\mathrm{z}$ obszarami zmarginalizowanymi, głównie w sferze nauki i badań, a także upowszechnienie sieci teleinformatycznych umożliwiających transfer wiedzy do obszarów, w których nie jest ona wytwarzana (kształcenie na odległość, unowocześnianie procesu dydaktycznego) (Gorzelak 2011, s. 79).

Procesy rozwojowe obszarów zmarginalizowanych powinny być wspierane przez działania jednostek samorządu terytorialnego, poprzez budowę i modernizację infrastruktury technicznej, wsparcie rozwoju zasobów ludzkich, tworzenie sprzyjającego klimatu dla rozwoju przedsiębiorstw oraz zapewnieniu dostępu do podstawowych usług i dóbr publicznych. Jak również poprzez politykę regionalną dostosowaną do potrzeb tych regionów oraz skierowaną na efektywne wykorzystanie środków finansowych pochodzących z UE w latach 2007-2013 z Programu Operacyjnego Rozwój Polski Wschodniej oraz Regionalnych Programów Operacyjnych, a w nowej perspektywie programowania 2014-2020 planowanego programu dla Polski Wschodniej, programu dla obszarów wiejskich i programów regionalnych.

Zaprezentowane analizy rozwoju społeczno-gospodarczego polskich regionów i ich problemów w zakresie tego rozwoju pozwoliły na dokonanie charakterystyki obszarów zmarginalizowanych w Polsce. Do specyficznych cech tych obszarów zaliczono:

- słaby potencjał gospodarczy (głównie obszary rolnicze, niska koncentracja podmiotów gospodarczych, niskie nakłady inwestycyjne w przedsiębiorstwach, słabo rozwinięty sektor usług);

- niski potencjał demograficzny (niekorzystna struktura wiekowa - starzejące się społeczeństwo, ubytek liczby ludności - ujemny przyrost naturalny, ujemne saldo migracji);

- słaba dostępność komunikacyjną (słabo rozwinięta infrastruktura drogowa, niski wskaźnik gęstości sieci wodociągowej i kanalizacyjnej);

- niską jakość kapitału intelektualnego i społecznego (niskie kwalifikacje siły roboczej, niska efektywność kształcenia);

- słaby dostęp do usług publicznych (niewystarczający dostęp do służby zdrowia, mała liczba lekarzy i przychodni, niewystarczająca infrastruktura oświatowa, np. niska liczba bibliotek, placówek oświatowych); 
- niekorzystną sytuację na rynku pracy (wysoka stopa bezrobocia, niskie kwalifikacje siły roboczej),

- problemy społeczne (wysokie natężenie ubóstwa materialnego, wysokie natężenie zjawisk patologicznych, np. alkoholizm, przemoc w rodzinie).

Identyfikacja cech obszarów zmarginalizowanych pozwoliła na dokonanie delimitacji tych obszarów w Polsce w oparciu wyodrębnione na podstawie tych cech zmienne diagnostyczne, które zostały zaprezentowane w kolejnym podrozdziale.

\subsection{Delimitacja obszarów zmarginalizowanych}

Jak już wcześniej wspomniano, nie ma jednoznacznej definicji obszarów zmarginalizowanych, są jedynie sygnały, które obszary mogą ulec procesom marginalizacji i w jakim wymiarze. Zaproponowana $\mathrm{w}$ tym podrozdziale definicja i charakterystyka obszarów zmarginalizowanych ma charakter umowny i została przygotowana na potrzeby przeprowadzonych badań wśród małych i średnich przedsiębiorstw w tych obszarach.

Zdefiniowanie i zidentyfikowanie takich obszarów w Polsce wymagało wielu analiz poziomu zróżnicowania regionów, opierając się na różnorodnych grupach czynników, które zostały przedstawione szczegółowo w pkt 1.2. Większość prowadzonych badań bowiem odnosi się głównie do poziomu NUTS-2 - województwo, rzadziej do poziomu powiatów i gmin. Tak duża ogólnikowość prowadzonych analiz nie zawsze w sposób rzetelny odzwierciedla sytuację rozwojową danego obszaru, gdyż w ramach tak dużej jednostki terytorialnej, jaką jest województwo, często widoczne jest znaczące wewnętrzne zróżnicowanie w postaci obszarów rozwiniętych i zmarginalizowanych. Dlatego dla jak najlepszego odzwierciedlenia sytuacji rozwojowej polskich regionów w tym opracowaniu przyjęto do dalszej analizy poziom NUTS-4 - powiat i miasto na prawach powiatu.

Dokonując klasyfikacji poziomu rozwoju poszczególnych obszarów dokonano założeń upraszczających. Bowiem stan i dynamikę rozwoju regionalnego trzeba traktować jako kategorie wynikowe, na które składa się wiele procesów cząstkowych podlegających tylko w ograniczonym stopniu możliwości naukowej agregacji. Należy zatem dokonywać wyboru mierników najważniejszych, poddających się kwantyfikacji i dających właściwą bazę do porównań (Plawgo 2011, s. 107-108; Klasik 2005).

W pierwszym etapie badania, biorąc to pod uwagę i ograniczoną dostępność danych statystycznych dla roku $2009^{21}$, określono zestaw cech opisujących

\footnotetext{
${ }^{21}$ Analizowane dane pochodziły z Rocznika statystycznego... 2010 oraz Banku Danych...
} 
potencjał rozwojowy powiatów i utworzono wstępny zestaw 18 zmiennych diagnostycznych poziomu rozwoju społeczno-gospodarczego powiatów (por. tabela 1).

Tabela 1. Potencjalne cechy diagnostyczne opisujące rozwój społeczno-gospodarczy powiatów w 2009 r.

\begin{tabular}{|c|l|l|}
\hline Symbol & \multicolumn{1}{|c|}{ Specyfikacja } & \multicolumn{1}{|c|}{ Charakter } \\
\hline$X_{1}$ & $\begin{array}{l}\text { Dochody budżetów powiatów i miast na prawach powiatu na } \\
\text { mieszkańca }\end{array}$ & Stymulanta \\
\hline$X_{2}$ & Przyrost naturalny na 1000 osób & Stymulanta \\
\hline$X_{3}$ & Produkcja sprzedana przemysłu ogółem i na 1 mieszkańca & Stymulanta \\
\hline$X_{4}$ & $\begin{array}{l}\text { Stopa bezrobocia rejestrowanego w \% ludności w wieku produkcyj- } \\
\text { nym }\end{array}$ & Destymulanta \\
\hline$X_{5}$ & $\begin{array}{l}\text { Udział długotrwale bezrobotnych (powyżej 1 roku) w \% liczby } \\
\text { bezrobotnych ogółem }\end{array}$ & Destymulanta \\
\hline$X_{6}$ & $\begin{array}{l}\text { Ludność w wieku nieprodukcyjnym na 100 osób w wieku produkcyj- } \\
\text { nym }\end{array}$ & $\begin{array}{l}\text { Destymulanta } \\
\text { na 10 tys. mieszkańców }\end{array}$ \\
\hline$X_{7}$ & $\begin{array}{l}\text { Podmioty gospodarki narodowej zarejestrowane w rejestrze REGON } \\
\text { mieszkańców }\end{array}$ & Stymulanta \\
\hline$X_{8}$ & Jednostki wykreślone z rejestru REGON na 10 tys. mieszkańców & Destymulanta \\
\hline$X_{9}$ & $\begin{array}{l}\text { Nakłady inwestycyjne w przedsiębiorstwach w mln zł na 1 mieszkań- } \\
\text { ca }\end{array}$ & Stymulanta \\
\hline$X_{10}$ & $\begin{array}{l}\text { Wartość brutto środków trwałych w przedsiębiorstwach w mln zł na } \\
1 \text { mieszkańca }\end{array}$ & Stymulanta \\
\hline$X_{12}$ & Przeciętne wynagrodzenie brutto & Stymulanta \\
\hline$X_{13}$ & Liczba przychodni na 10 tys. mieszkańców & Stymulanta \\
\hline$X_{14}$ & Liczba aptek na 10 tys. mieszkańców & Stymulanta \\
\hline$X_{15}$ & Liczba placówek bibliotecznych na 10 tys. mieszkańców & Stymulanta \\
\hline$X_{16}$ & Drogi gminne o nawierzchni twardej na 100 km ${ }^{2}$ & Stymulanta \\
\hline$X_{18}$ & Liczba ludności korzystająca z sieci kanalizacyjnej na 1000 osób \\
\hline
\end{tabular}

Źródło: opracowanie własne.

W drugim etapie wybrano 8 zmiennych (por. tabela 2) do dalszej analizy, redukując cechy charakteryzujące się niskim zróżnicowaniem (współczynnik zmienności mniejszy od 10\%) oraz znaczącym skorelowaniem (współczynnik korelacji większy od 0,6 ). 
Tabela 2. Cechy diagnostyczne opisujące rozwój społeczno-gospodarczy powiatów w 2009 r.

\begin{tabular}{|c|l|c|}
\hline Symbol & \multicolumn{1}{|c|}{ Specyfikacja } & \multicolumn{1}{|c|}{ Charakter } \\
\hline$X_{1}$ & $\begin{array}{l}\text { Dochody budżetów powiatów i miast na prawach powiatu na } \\
1 \text { mieszkańca }\end{array}$ & Stymulanta \\
\hline$X_{3}$ & Produkcja sprzedana przemysłu ogółem i na 1 mieszkańca & Stymulanta \\
\hline$X_{4}$ & $\begin{array}{l}\text { Stopa bezrobocia rejestrowanego w \% ludności w wieku produkcyj- } \\
\text { nym }\end{array}$ & Destymulanta \\
\hline$X_{6}$ & $\begin{array}{l}\text { Ludność w wieku nieprodukcyjnym na 100 osób w wieku produkcyj- } \\
\text { nym }\end{array}$ & Destymulanta \\
\hline$X_{7}$ & $\begin{array}{l}\text { Podmioty gospodarki narodowej zarejestrowane w rejestrze REGON } \\
\text { na 10 tys. mieszkańców }\end{array}$ & Stymulanta \\
\hline$X_{10}$ & $\begin{array}{l}\text { Nakłady inwestycyjne w przedsiębiorstwach w mln zł na 1 mieszkań- } \\
\text { ca }\end{array}$ & Stymulanta \\
\hline$X_{11}$ & $\begin{array}{l}\text { Wartość brutto środków trwałych w przedsiębiorstwach w mln zł na } \\
1 \text { mieszkańca }\end{array}$ & Stymulanta \\
\hline$X_{12}$ & Przeciętne wynagrodzenie brutto & Stymulanta \\
\hline
\end{tabular}

Źródło: opracowanie własne.

W kolejnym etapie ${ }^{22}$ obliczono miernik syntetyczny metodą taksonomiczną Z. Helwiga ${ }^{23}$. Wybrane wskaźniki miały różne miana. Aby sprowadzić je do porównywalności, dokonana została standaryzacja i określono wzorzec rozwoju wg formuły:

$$
z_{o k}=\max _{i}\left\{z_{i k}\right\}
$$

Następnie wyznaczono odległości każdego obiektu badania od tak ustalonego wzorca rozwoju o postaci:

$$
d_{i}=\left[\sum_{k=1}^{K}\left(z_{i k}-z_{o k}\right\}^{2}\right]^{\frac{1}{2}} \quad i=(1,2, \ldots, N) .
$$

W kolejnym etapie skonstruowano tzw. względny taksonomiczny miernik rozwoju zdefiniowany jako:

${ }^{22}$ Szerzej na temat metody taksonomicznej Z. Helwiga w opracowaniach: Helwig 1968, Nowak 1990, Młodak 2006.

${ }^{23}$ Do oceny rozwoju społeczno-gospodarczego powiatów w roku 2009 zastosowano koncepcję metodyczną opisaną szczegółowo w opracowaniach m.in.: Lisowska 2004, s. 89-98; 2010b, s. $57-70$. 


$$
z_{i}=1-\frac{d_{i}}{d_{0}}(i=1,2, \ldots, N)
$$

gdzie: $d_{0}=\bar{d}+3 s_{d}=17,05$,

przy czym: $\bar{d}=\frac{1}{N} \sum_{i=1}^{N} d_{i}=11,68$

oraz: $s_{d}=\left[\frac{1}{N} \sum_{i=1}^{N}\left(d_{i}-\bar{d}\right)^{2}\right]^{\frac{1}{2}}=1,79$.

Punktem wyjścia dla dokonania klasyfikacji jest uporządkowanie zbioru obiektów $O_{1} ; O_{2}, \ldots \mathrm{O}$ - według nierosnących wartości syntetycznego miernika rozwoju. Jedną z metod klasyfikacji obiektów wielocechowych na podstawie mierników taksonomicznych jest tzw. metoda trzech średnich. Zbiór badanych obiektów $O_{1} ; O_{2}, \ldots O_{N}$ jest dzielony na cztery grupy. Przy czym $\bar{z}=0,38$ jest średnią arytmetyczną miernika $z_{1} ; z_{2}, \ldots z_{\mathrm{N}}$, a $z_{i}$ to wartości miernika spełniające nierówność $z_{i} \leq 0,38$. Nierówność ta jest spełniona dla $N_{1}=197$ obiektów. Niech dalej $z_{\mathrm{i}}$ to wartości miernika spełniające nierówność $z_{i}>0,38$ to $N_{2}=182$ obiektów. Następnie wyznacza się średnie wg formuł (Lisowska 2010a, s. 64):

$$
\bar{z}_{1}=\frac{1}{N_{1}} \sum_{i=1}^{N_{1}} z_{i}=0,21 \quad \bar{z}_{2}=\frac{1}{N_{21}} \sum_{i=1}^{N_{2}} z_{i}=0,43 .
$$

Na podstawie otrzymanych wyników, w ostatnim etapie analizy, dokonano podziału powiatów na cztery grupy, odzwierciedlające poziom ich rozwoju społeczno-gospodarczego (por. rysunek 7):

- grupa 1 - powiaty o najniższym poziomie rozwoju $\left(z_{i} \leq 0,21\right)$,

- grupa 2 - powiaty słabo rozwinięte $\left(0,21<z_{i} \leq 0,38\right)$,

- grupa 3 - powiaty średnio rozwinięte $\left(0,38<z_{i} \geq 0,43\right)$,

- grupa 4 - powiaty wysoko rozwinięte $\left(z_{i} \geq 0,43\right)$.

Sporządzony ranking powiatów pozwala na wyodrębnienie grupy powiatów rozwiniętych (rozwój koncentruje się wokół największych miast i w zachodniej części kraju), które w dalszej części opracowani będą traktowane jako obszary rozwinięte, oraz grupy powiatów opóźnionych w rozwoju - zmarginalizowanych (głównie Polska Wschodnia), w dalszej części opracowania traktowane jako obszary zmarginalizowane. 


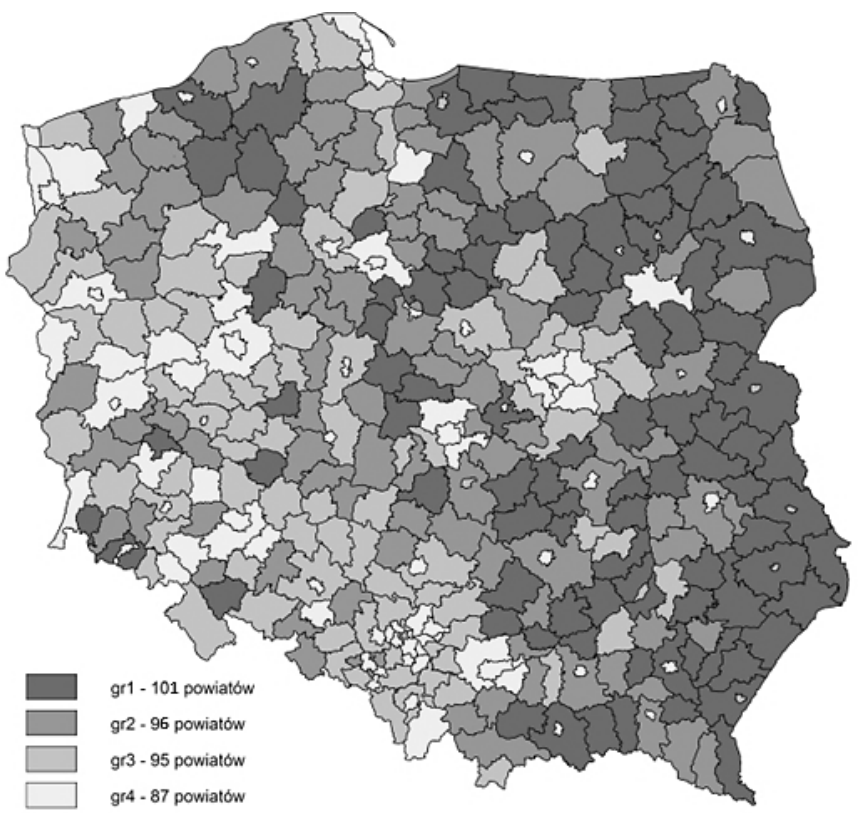

Rysunek 7. Poziom rozwoju społeczno-gospodarczego powiatów w 2009 r.

Źródło: opracowanie własne na podstawie Rocznik statystyczny... 2010, Bank Danych...

Najlepiej rozwiniętymi powiatami według rankingu są powiaty krakowski i pruszkowski oraz miasta na prawach powiatu Warszawa i Poznań, natomiast najsłabiej rozwiniętymi: aleksandrowski, głogowski, jeleniogórski i lubański, a szczegółowe dane zawiera tabela 3.

Tabela 3. Poziom rozwoju społeczno-gospodarczego powiatów w 2009 r. - podział na klasy według wskaźnika syntetycznego

\begin{tabular}{|c|c|}
\hline Powiat & Klasa \\
\hline 1 & 2 \\
\hline $\begin{array}{l}\text { M. st. Warszawa, m. Poznań, krakowski, pruszkowski, żywiecki, grodziski, } \\
\text { m. Bytom, m. Gdynia, m. Gdańsk, m. Wrocław, m. Kraków, m. Nowy Sącz, } \\
\text { m. Tarnów, m. Toruń, m. Włocławek, kwidzyński, m. Rzeszów, krapkowicki, } \\
\text { m. Opole, warszawski-zachodni, piaseczyński, policki, m. Świnoujście, } \\
\text { m. Szczecin, m. Koszalin, kołobrzeski, goleniowski, poznański, pilski, obornicki, } \\
\text { nowotomyski, m. Leszno, m. Konin, m. Kalisz, m. Olsztyn, m. Kielce, m. Żory, } \\
\text { m. Tychy, m. Sosnowiec, m. Rybnik, m. Mysłowice, m. Katowice, m. Jastrzębie- } \\
\text { Zdrój, m. Gliwice, m. Dąbrowa Górnicza, m. Częstochowa, m. Bielsko-Biała, } \\
\text { bieruńsko-lędziński, pucki, m. Sopot, m. Radom, m. Ruda Śląska, m. Siemianowice } \\
\text { Śląskie, m. Bydgoszcz, m. Jelenia Góra, m. Słupsk, m. Zabrze, ostrowski, zgierski, } \\
\text { będziński, m. Legnica, oławski, polkowicki, świdnicki, wałbrzyski, wołowski, } \\
\text { wrocławski, zgorzelecki, toruński, m. Lublin, gorzowski, m. Gorzów Wielkopolski, } \\
\text { m. Zielona Góra, słubicki, świebodziński, zielonogórski, łódzki-wschodni, m. Łódź, } \\
\text { m. Skierniewice, wielicki, grodziski, m. Ostrołęka, m. Płock, m. Siedlce, } \\
\text { m. Krosno, m. Białystok, m. Suwałki }\end{array}$ & $\begin{array}{l}\text { Wysoko } \\
\text { rozwinięte }\end{array}$ \\
\hline
\end{tabular}




\begin{tabular}{|c|c|}
\hline 1 & 2 \\
\hline $\begin{array}{l}\text { M. Biała-Podlaska, m. Chełm, m. Chorzów, m. Elbląg, m. Grudziądz, } \\
\text { m. Jaworzno, m. Łomża, olkuski, lubliniecki, m. Piekary Śląskie, m. Piotrków } \\
\text { Trybunalski, m. Przemyśl, m. Tarnobrzeg, m. Zamośc, międzychodzki, } \\
\text { nowodworski, mrągowski, myszkowski, strzeliński, rawicki, nyski, trzebnicki, } \\
\text { chrzanowski, cieszyński, wadowicki, mielecki, wałecki, bolesławiecki, } \\
\text { kluczborski, gostyński, czarnkowsko-trzcianecki, kępiński, oleśnicki, płocki, } \\
\text { brzeski, krotoszyński, legionowski, oleski, międzyrzecki, lęborski, kościański, } \\
\text { grójecki, gnieźnieński, kłodzki, gryfiński, kamieński, legnicki, częstochowski, } \\
\text { koniński, kaliski, bielski, namysłowski, lubiński, kędzierzyńsko-kozielski, } \\
\text { bydgoski, gdański, leszczyński, myśliborski, mikołowski, gliwicki, chodzieski, } \\
\text { otwocki, raciborski, mławski, jaworski, kamiennogórski, ciechanowski, } \\
\text { miński, wolsztyński, zawierciański, starachowicki, szamotulski, wodzisławski, } \\
\text { żyrardowski, tczewski, wejherowski, świecki, tarnogórski, średzki, śremski, } \\
\text { wołomiński, wrzesiński, opolski, ostrowiecki, tatrzański, wieluński, stargardz- } \\
\text { ki, sulęciński, zduńskowolski, oświęcimski, pabianicki, pszczyński, socha- } \\
\text { czewski, żarski, stalowowolski }\end{array}$ & $\begin{array}{l}\text { Średnio } \\
\text { rozwinięte }\end{array}$ \\
\hline $\begin{array}{l}\text { Dzierżoniowski, górowski, kraśnicki, żniński, mogileński, włocławski, } \\
\text { żagański, brzeziński, kutnowski, łaski, łowicki, lwówecki, średzki, świdwiński, } \\
\text { złotoryjski, brodnicki, golubsko-dobrzyński, grudziądzki, inowrocławski, } \\
\text { kościerski, malborski, nowodworski, słupski, nakielski, tucholski, wąbrzeski, } \\
\text { krośnieński, lubelski, opolski, rycki, świdnicki, nowosolski, strzelecko- } \\
\text {-drezdenecki, wschowski, pajęczański, piotrkowski, radomszczański, sieradzki, } \\
\text { tomaszowski, wieruszowski, rawski, bocheński, myślenicki, nowotarski, suski, } \\
\text { kozienicki, gostyniński, proszowicki, tarnowski, płoński, radomski, siedlecki, } \\
\text { wyszkowski, brzeski, głubczycki, prudnicki, strzelecki, dębicki, kolbuszowski, } \\
\text { krośnieński, leski, leżajski, sanocki, strzyżowski, augustowski, bielski, } \\
\text { sokólski, suwalski, zambrowski, chojnicki, kartuski, starogardzki, sztumski, } \\
\text { kielecki, kłobucki, m. Świętochłowice, rybnicki, pińczowski, włoszczowski, } \\
\text { kętrzyński, nowomiejski, olsztyński, szczycieński, ostródzki, turecki, białogar- } \\
\text { dzki, łobeski, sławieński, złotowski, ostrzeszowski, pyrzycki, choszczeński, } \\
\text { słupecki, gryficki, ostrowski, pleszewski }\end{array}$ & $\begin{array}{l}\text { Słabo } \\
\text { rozwinięte }\end{array}$ \\
\hline $\begin{array}{l}\text { Milicki, ząbkowicki, chełmiński, lipnowski, radziejowski, rypiński, sępoleński, } \\
\text { bialski, biłgorajski, chełmski, hrubieszowski, janowski, krasnostawski, } \\
\text { lubartowski, łęczycki, łęczyński, radzyński, tomaszowski, włodawski, } \\
\text { łukowski, parczewski, dąbrowski, nowosądecki, puławski, zamojski, bełcha- } \\
\text { towski, opoczyński, poddębicki, drawski, skierniewicki, gorlicki, limanowski, } \\
\text { miechowski, białobrzeski, garwoliński, lipski, łosicki, makowski, ostrołęcki, } \\
\text { przasnyski, przysuski, pułtuski, węgrowski, żuromiński, lubaczowski, } \\
\text { brzozowski, sierpecki, zwoleński, bieszczadzki, niżański, szydłowiecki, } \\
\text { ropczycko-sędziszowski, jasielski, łańcucki, przeworski, rzeszowski, tarno- } \\
\text { brzeski, sokołowski, kolneński, moniecki, siemiatycki, grajewski, białostocki, } \\
\text { łomżyński, bytowski, jarosławski, sejneński, wysokomazowiecki, przemyski, } \\
\text { braniewski, działdowski, elbląski, węgorzewski, jarociński, kolski, wągrowiec- } \\
\text { ki, koszaliński, szczecinecki, sandomierski, hajnowski, kazimierski, jędrzejow- } \\
\text { ski, człuchowski, buski, opatowski, iławski, ełcki, lidzbarski, skarżyski, olecki, } \\
\text { giżycki, gołdapski, bartoszycki, staszowski, konecki, piski, nidzicki, lubański, } \\
\text { jeleniogórski, głogowski, aleksandrowski }\end{array}$ & $\begin{array}{l}\text { Najniższy } \\
\text { poziom } \\
\text { rozwoju }\end{array}$ \\
\hline
\end{tabular}

Źródło: opracowanie własne. 
Na podstawie przyjętego podziału powiatów wylosowano próbę badawczą, (szczegółowa metodyka badań opisana została w rozdziale 4), składającą się $\mathrm{z}$ mikro, małych i średnich przedsiębiorstw zlokalizowanych $\mathrm{w}$ powiatach wysoko rozwiniętych (obszary rozwinięte) i o najniższym poziomie rozwoju (obszary zmarginalizowane). Badania zostały przeprowadzone tylko $\mathrm{w}$ dwóch skrajnych pod względem rozwoju grupach powiatów, co umożliwiło liczne porównania dynamiki rozwojowej małych i średnich przedsiębiorstw w tych obszarach i zaproponowanie nowych rozwiązań w zakresie zarządzania rozwojem tych podmiotów szczególnie w obszarach zmarginalizowanych. 


\section{Regionalna przestrzeń małych i średnich przedsiębiorstw}

\subsection{Małe i średnie przedsiębiorstwa $\mathrm{w}$ gospodarce regionu}

Małe i średnie przedsiębiorstwa ogrywają znaczącą rolę w rozwoju regionalnym ze względu na swój lokalny charakter. Podmioty te bowiem są głównie zlokalizowane $\mathrm{w}$ miejscu zamieszkania przedsiębiorcy, który inwestując swój kapitał, wykorzystując miejscowe zasoby, operuje na rynku lokalnym. Lokalny charakter małych i średnich przedsiębiorstw powoduje, że istnieje ścisła zależność, mająca charakter sprzężeń zwrotnych między ich rozwojem a rozwojem regionalnym, co potwierdziły liczne badania zarówno krajowe (np. Kokocińska 2012b; Korol, Szczuciński 2011; Ignatiuk 2011; Leszczyński 2004 i 2011; Woźniak 2006; Chmiel 1997), jak i zagraniczne (np. Acs 2010; Glaeser; Kerr 2009; Thurik, Wennekers 2004; Acs, Armington 2004). Im wyższy poziom rozwoju społeczno-gospodarczego regionu tym lepsza jego konkurencyjność, a tym samym warunki dla powstawania nowych i rozwoju już istniejących małych i średnich przedsiębiorstw. $Z$ drugiej strony rozwój tych podmiotów może przyczynić się do rozwoju regionu poprzez: kreowanie nowych miejsc pracy, stymulowanie innowacji, zaspokojenie potrzeb społeczności lokalnych, poprawę warunków życia mieszkańców, większe wpływy do budżetów lokalnych oraz poprawę ekonomiki regionu.

Według M. Strużyckiego rola małych i średnich przedsiębiorstw w rozwoju regionu zależy nie tylko od tych podmiotów, ale również od poziomu jego rozwoju. Jak wskazują wyniki badań, dzięki rozwojowi małych i średnich przedsiębiorstw regiony o wysokim rozwoju znacznie podniosły efektywność gospodarowania, w bardziej przemyślany sposób gospodarują przestrzenią ekonomiczną, wykorzystując w tym względzie politykę racjonalnej lokalizacji, uzyskują również sukcesy $\mathrm{w}$ zakresie podniesienia poziomu życia ludności w regionie (Strużycki red. 2011, s. 15). W przypadku regionów o niskim poziomie rozwoju, również obserwuje się znaczącą rolę małych i średnich przedsiębiorstw w ich rozwoju, co potwierdzają badania krajowe i zagraniczne (np. Kamińska 2011; Lisowska 2011b; Labranidis, Kalantaridis 1997; Smallbone i inni, 1993).

Małe i średnie przedsiębiorstwa uznawane są za podmioty tworzące nowe miejsca pracy, co pozytywnie wpływa na regionalny rynek pracy. Wzrost 
zatrudnienia jest najczęściej generowany przez firmy nowo powstałe, jak również młode wiekiem operujące na szerszym rynku niż rynek lokalny czy regionalny (Korol, Szczuciński 2011). Podmioty te mają również swój udział we wzroście efektywności gospodarki regionu, jak również we wzroście gospodarczym (Woźniak 2006), gdyż jako ważni aktorzy gry rynkowej przyczyniają się do pobudzenia działalności innych podmiotów gospodarczych. Pełnią również rolę społeczną, polegającą na tworzeniu szansy niezależności i zmiany statusu różnych grup społecznych i zawodowych (Korol, Szczuciński 2011; Łuczka-Bakuła, Zyskowska 2005).

Jak wskazują liczne badania empiryczne, istnieje wiele kontrowersji wobec przypisywania tak dużej roli małym i średnim przedsiębiorstwom w generowaniu zarówno wzrostu gospodarczego (Henrekson, Johansson 2009; Fritsch, Mueller 2004; Brown i inni 1990), jak i tworzeniu nowych miejsc pracy (Haltiwanger, Krizan 1999; Davis i inni 1996). Mimo to wspieranie MSP jest jednym z kluczowych priorytetów krajowych i europejskich polityk od wielu lat (np. OECD 1998, Karta Małego Przedsiębiorcy, Strategia Lizbońska, Europa 2020, Narodowa Strategia Spójności).

Relacje pomiędzy rozwojem małych i średnich przedsiębiorstw a rozwojem regionalnym obrazuje model przedsiębiorczości regionalnej (por. rysunek 8) zaproponowany przez J. Guzmana, F.J. Santosa. W modelu tym rozwój MSP jest uzależniony od przedsiębiorczej orientacji, natomiast rozwój regionalny od poziomu szeroko rozumianej przedsiębiorczej struktury.

Model wskazuje na dwie skrajne sytuacje. W pierwszej z nich można zaobserwować wysoki poziom orientacji przedsiębiorczej, z którą korespondują cechy przedsiębiorcy, takie jak: motywacja, proaktywność, innowacyjność i chęć współpracy oraz wysokiej jakości przedsiębiorcza struktura związana z wysokim rozwojem regionu. Co powoduje korzyści dla rozwoju MSP jak również regionu w postaci: dużej koncentracji firm działających w sektorach wysokich technologii, niskiej zależności produkcyjnej i funkcjonalnej oraz rozwoju zachowań przedsiębiorczych. Sprzyja to $z$ jednej strony tworzeniu i rozwijaniu przedsiębiorstw, a $z$ drugiej pozytywnie wpływa na rozwój regionu. Taka sytuacja została zaobserwowana przez autorów koncepcji w bogatych krajach UE.

Natomiast przy niskim poziomie orientacji przedsiębiorczej, wynikającej z cech przedsiębiorcy, takich jak: konformizm, reaktywność, rutyna i indywidualizm, oraz niesprzyjających uwarunkowań zewnętrznych, w postaci niskiej jakości struktury przedsiębiorczej charakteryzującej się niską koncentracją na danym obszarze podmiotów gospodarczych oraz struktury tych podmiotów - to głównie mikrofirmy i niedostępna enklawa dużych przedsiębiorstw, o wysokiej zależności produkcyjnej i funkcjonalnej. Taka sytuacja może powodować trudności z rozwojem MSP oraz regionu, co jest widoczne, jak twierdzą autorzy koncepcji, w regionach państw środkowej Europy, w tym w Polsce (Guzman, 
Santos 2008a, b). W myśl tej koncepcji uwarunkowania wewnętrzne związane z osobą przedsiębiorcy tworzą jakość przedsiębiorczej orientacji, która może mieć znaczący wpływ na charakter przedsiębiorczej struktury opisanej przez uwarunkowania zewnętrzne. Na poprawę jakości przedsiębiorczej struktury może mieć pozytywny wpływ wzrost atrakcyjności regionu dla napływu bezpośrednich inwestycji zagranicznych $\mathrm{w}$ nietradycyjnych i kreatywnych sektorach, które powinny stać się przyszłością dla rozwoju gospodarczego i podnoszenia jakości życia mieszkańców regionów o różnym stopniu rozwoju społeczno-gospodarczego.

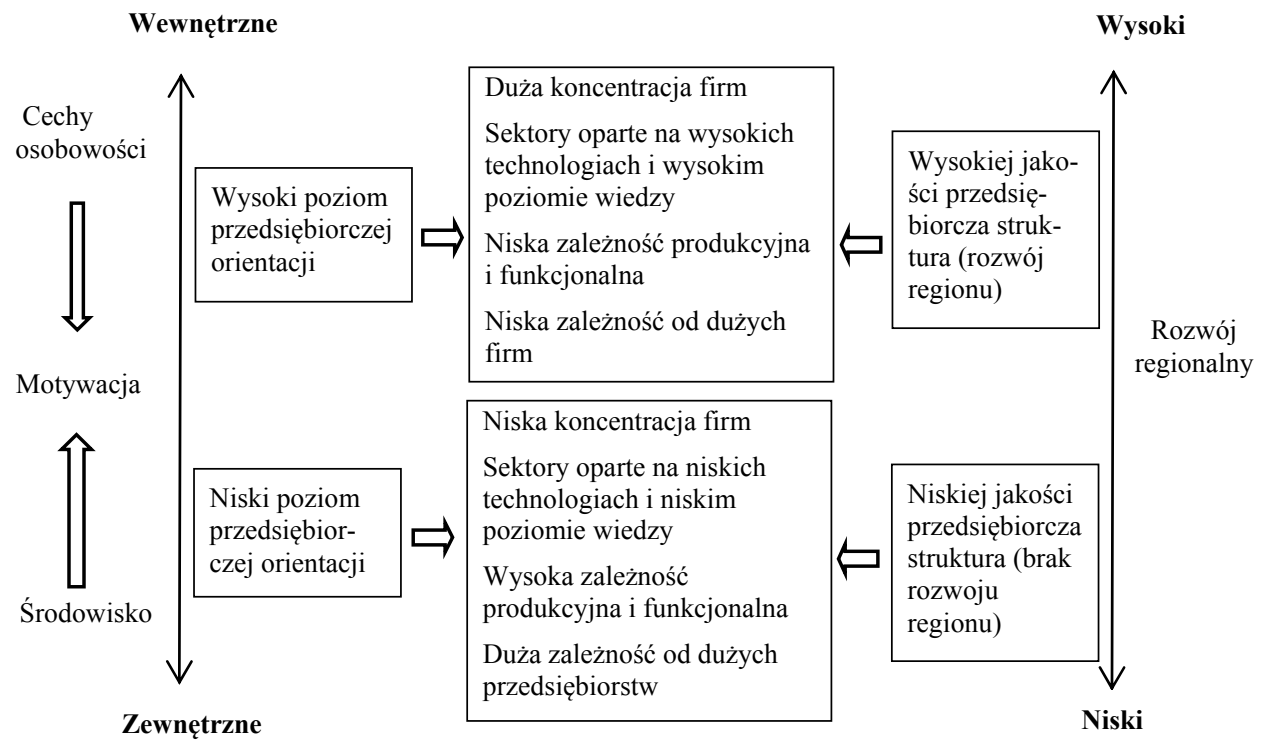

Rysunek 8. Model przedsiębiorczości regionalnej

Źródło: opracowanie własne na podstawie: Guzman, Santos 2008a, s. 65

Na rozwój małych i średnich przedsiębiorstw funkcjonujących w środowisku lokalnym ma wpływ wiele czynników nie tylko wynikających z makro i mikrootoczenia (szerzej omówione w rozdziale 3), ale także mających charakter regionalny. Do czynników regionalnych zalicza się głównie: czynniki demograficzne (np. liczbę mieszkańców, ich strukturę demograficzną), czynniki kształtujące siłę nabywczą i popyt ludności (np. wielkość i strukturę dochodów ludności), poziom edukacji społeczeństwa, posiadane umiejętności i kwalifikacje, infrastruktura społeczno-gospodarcza układu lokalnego, zasoby i walory środowiska naturalnego, potencjał gospodarczy i zasoby instytucjonalne, lokalne przepisy prawa oraz kapitał inwestycyjny (Leszczyński 2011, s. 231-232) - szerzej czynniki regionalne zostały omówione w rozdziale 3. Do czynników 
tych można również zaliczyć rynek lokalny i jego charakter. Rynek lokalny można zdefiniować jako ograniczony przestrzennie układ podmiotów sprzedających i kupujących o zróżnicowanych powiazaniach, który jest uważany za składnik rynków regionalnych i krajowych o określonych cechach charakterystycznych, pozwalających na samowystarczalność i niezależność. Rynek ten jest częścią gospodarki lokalnej będącej zbiorem instytucji i procesów wyznaczających układ warunków instytucjonalno-organizacyjnych dla podmiotów i powiązań rynkowych. Gospodarka lokalna stanowi bezpośrednie otoczenie rynku lokalnego i jest jednym z czynników mających wpływ na powstawanie, przetrwanie i rozwój podmiotów gospodarczych oraz kształtuje warunki i możliwości zaspokajania potrzeb społeczności lokalnych. Rynkowym wyznacznikiem tych potrzeb jest popyt na poszczególne kategorie dób i usług oraz podaż oferowana przez sprzedających (Leszczyński 2004, s. 237).

Podkreślając rolę MSP w rozwoju regionu zwraca się szczególnie uwagę na: ich znaczenie w tworzeniu powiązań sieciowych, a przez to udział w lokalnym systemie produkcyjnym, innowacyjne funkcje tych podmiotów oraz ich miejsce w systemie innowacyjnym regionu.

Powiązania sieciowe są jednym z głównych czynników dynamiki rozwoju regionalnego, który nie jest procesem całkowicie spontanicznym. Jest wynikiem oddziaływania różnych czynników i efektem kreacji polityki rozwoju, której skuteczność zależy od istnienia odpowiednich instytucji i organizacji. Ich ilość, struktura intensywność i jakość powiązań determinuje poziom konkurencyjności i możliwości rozwojowe regionów. Aby na danym terytorium powstały powiązana sieciowe, niezbędna jest odpowiednia liczba i różnorodność organizacji (Jewtuchowicz 1998, s. 10-12), których rozwój jest wynikiem rozwoju przedsiębiorczości i aktywności gospodarczej. Rozwój i istnienie małych i średnich przedsiębiorstw można uznać za czynnik tworzenia powiązań sieciowych i otoczenia instytucjonalnego regionu. Taka sieć powiązań przez MSP oddziałuje zarówno na tworzące ją firmy, jak i na środowisko, w którym działają (Garfoli ed. 1992). Ma to bezpośredni związek ze stymulowaniem lokalnej gospodarki, przyciąganiem nowych przedsiębiorstw i rozwojem istniejących. $\mathrm{Z}$ sieci małe i średnie przedsiębiorstwa uzyskują tzw. korzyści skali i korzyści zakresu (economies of scale and economies of scope), które pozwalają na konkurowanie z dużymi przedsiębiorstwami (Pyke 1992, s. 23). Działające w sieci małe i średnie przedsiębiorstwa mogą być konkurencyjne nie tylko indywidualnie, ale również zbiorowo i to nie tylko na rynku krajowym, ale również międzynarodowym, co może wpływać pozytywnie na rozwój regionu.

Sektor MSP ma również swój znaczący wkład w przebudowę struktury gospodarczej danego obszaru, która wyraża się m.in. przesunięciem zasobów i produktów z sektorów schyłkowych do sektorów rozwijających się. Zmiany struktury produkcyjnej $\mathrm{w}$ ostatnich latach oparte były głównie na formie industrializacji rozproszonej, małych i średnich przedsiębiorstw, wyzwalających 
się z pod kontroli dużych przedsiębiorstw przemysłowych i handlowych ${ }^{1}$. Małe i średnie przedsiębiorstwa posiadają w układzie regionalnym znaczną autonomię, która wynika z posiadanych przez nie więzów z rynkiem. Obok tych więzi coraz intensywniejsze stosowanie przez te firmy innowacji technologicznych i organizacyjnych wpływa na lepsze przystosowanie do wymagań rynku, co z kolei jest powodowane koniecznością zwiększenia elastyczności, specjalizacji produkcji oraz ciągła presją unowocześniania produkcji. W wyniku tego nastąpiło uniezależnienie efektywności od skali technicznej produkcji i zmieniły się również związki małych i średnich przedsiębiorstw z dużymi przedsiębiorstwami (Calzoni 1995, s. 83). Aktywność małych i średnich przedsiębiorstw w różnych rodzajach działalności wpływa korzystnie na przebudowę struktury społeczno-gospodarczej i funkcjonalnej danego obszaru przez (Wnorowski 2001, s. 21):

- inicjowanie i powstawanie nowych rodzajów działalności;

- tworzenie nowych miejsc pracy, a przez to ograniczenie bezrobocia;

- zapobieganie migracjom;

- wzrost dochodów ludności miejscowej;

- rozszerzenie rynków zbytu;

- pełniejsze wykorzystanie zasobów lokalnych;

- zmianę sposobów i warunków życia oraz konsumpcji ludności miejscowej;

- wzrost atrakcyjności obszarów, na których rozwijana jest działalność gospodarcza;

- stymulowanie wzrostu gospodarczego regionu i kraju;

- kreowanie postaw przedsiębiorczych i aktywizację rozwoju gospodarczego.

Kolejnym czynnikiem dynamiki rozwoju regionalnego, w którym podstawową rolę pełnią małe i średnie przedsiębiorstwa, są innowacje. Rozwój regionu i jego konkurencyjność zależy od sprawności regionalnego systemu innowacyjnego, który można zdefiniować jako zbiór instytucji wzajemnie powiązanych na wydzielonym terytorium działających na rzecz lub sprzyjającym procesom innowacji i postępowi technologicznemu w gospodarce (Hansen 1990). Jest to interakcyjny zbiór relacji między instytucjami otoczenia biznesowego oraz firmami produkcyjnymi i usługowymi. Sprawny system informacyjny jest jednym ze strategicznych elementów polityki gospodarczej w skali regionalnej, która powinna oddziaływać na sferę badawczo-rozwojową, promować innowacje, przyśpieszać dyfuzje $\mathrm{w}$ skali regionu i mobilizować zasoby kapitałowe regionu szczególnie poprzez kapitał podwyższonego ryzyka dla inwestowania $\mathrm{w}$ nowe technologie. Innowacje uznaje się za istotny czynnik budowania podstaw konkurencyjności regionów, co dokonuje się poprzez tworzenie

${ }^{1}$ Można wskazać wiele regionów w Europie, gdzie w zmianie procesu produkcyjnego uczestniczyły małe i średnie przedsiębiorstwa (systemy małych firm w Lombardii we Włoszech, obszary ze stara tradycją produkcji bazującą na małych firmach w Grecji). 
warunków do pojawienia się innowacji w określonych centrach innowacji oraz tworzenie warunków do ich dyfuzji od centrum do peryferii (Markowski 1996, s. 111). Aby zwiększyć rozwój innowacji w regionie, należy stworzyć innowacyjne środowisko przedsiębiorczości, składające się z elementów materialnych (przedsiębiorstwa, infrastruktura), niematerialnych (umiejętności, wiedza) oraz instytucji (władza lokalna, organizacje pozarządowe) (Chądzyński 2007). Małe i średnie przedsiębiorstwa są jednym $\mathrm{z}$ głównych aktorów tego środowiska często też inicjatorami procesów innowacyjnych w regionie (por. rysunek 9). Środowisko innowacyjne charakteryzuje się: ramami terytorialnymi, właściwą logiką organizacyjną (która umożliwia obieg wiedzy poprzez sieci społeczne i instytucjonalne) oraz dynamikę uczenia się (zdolność i chęci wszystkich aktorów środowiska innowacyjnego do szybkiego reagowania i dostosowywania się do zmian) (Chądzyński 2007).

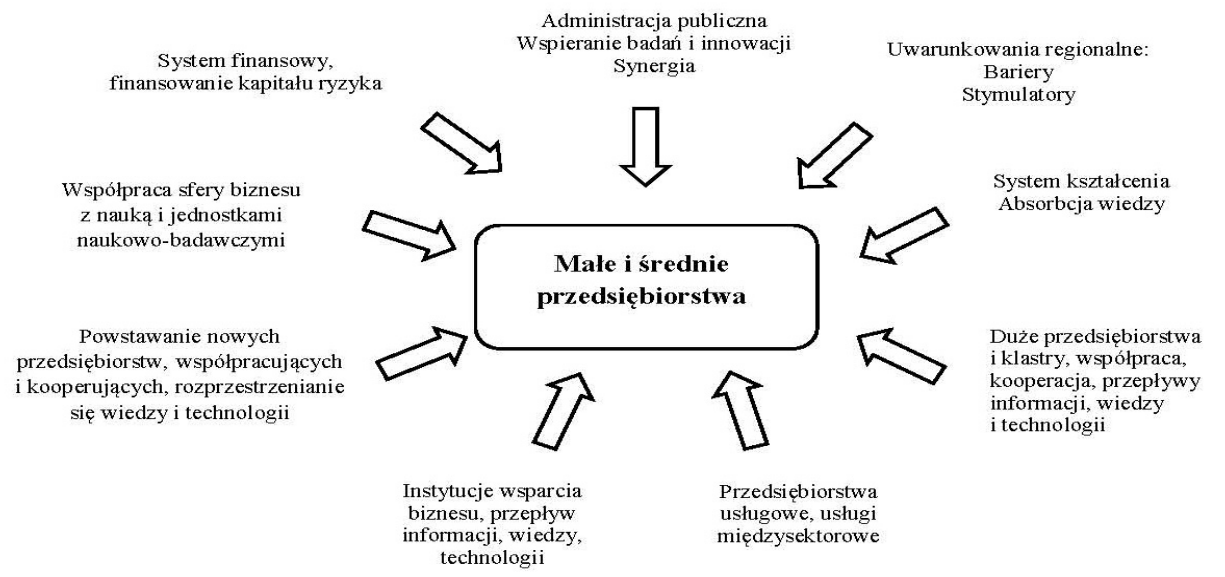

Rysunek 9. Innowacyjne środowisko przedsiębiorczości

Źródło: opracowanie własne na podstawie: Jewtuchowicz 1996

Małe i średnie przedsiębiorstwa mają również swój udział w lokalnym systemie produkcyjnym, o czym może świadczyć struktura gospodarcza z dużą liczbą małych i średnich przedsiębiorstw wyspecjalizowanych w różnych fazach produkcyjnych. Według A. Jewtuchowicz lokalny system produkcyjny powstaje, gdy (Jewtuchowicz 2000, s. 147-148):

- istnieje koncentracja małych i średnich przedsiębiorstw na określonym obszarze;

- skupienie małych i średnich przedsiębiorstw może być jednorodne (należą do tych samych sektorów) lub niejednorodne (różne branże, ale często w relacjach produkt-rynek); 
- istnieją silne i stosunkowo trwałe relacje pomiędzy firmami, np. kooperacja dużych przedsiębiorstw $\mathrm{z}$ małymi i średnimi na zasadzie partnerstwa lub podwykonawstwa, kooperacja przedsiębiorstw w zakresie działalności komplementarnych $\mathrm{w}$ celu wytwarzania produktów lub zdobywania rynków, wielostronna współpraca miedzy różnymi firmami oraz ośrodkami badawczymi w zakresie stosowania technologii itp.;

- dzięki istnieniu w systemie przedsiębiorstwo ma dostęp do różnorodnych usług;

- istnieje wspólna kultura, w tym kultura przemysłowa.

Kluczowym czynnikiem lokalnych systemów produkcyjnych jest ich elastyczność, dzięki której małe i średnie przedsiębiorstwa jako aktorzy tego systemu posiadają umiejętność szybkiej adaptacji do zmieniającej się sytuacji rynkowej. Koncentracja podmiotów w tym systemie wpływa na obniżenie kosztów logistycznych i transakcyjnych oraz poprawę sprawności komunikacji pomiędzy uczestnikami systemu.

Dla rozwoju małych i średnich przedsiębiorstw w regionach ma znaczenie również tzw. tkanka przedsiębiorczości (entreprenurial tissue) (Kokocińska 2012b, Rekowski red. 2008, Guzman, Santos 2008b), którą definiuje na podstawie 13 ilościowych i jakościowych wskaźników (por. rysunek 10), wpływających na aktywność przedsiębiorczą i jej wkład w rozwój gospodarczy regionu.

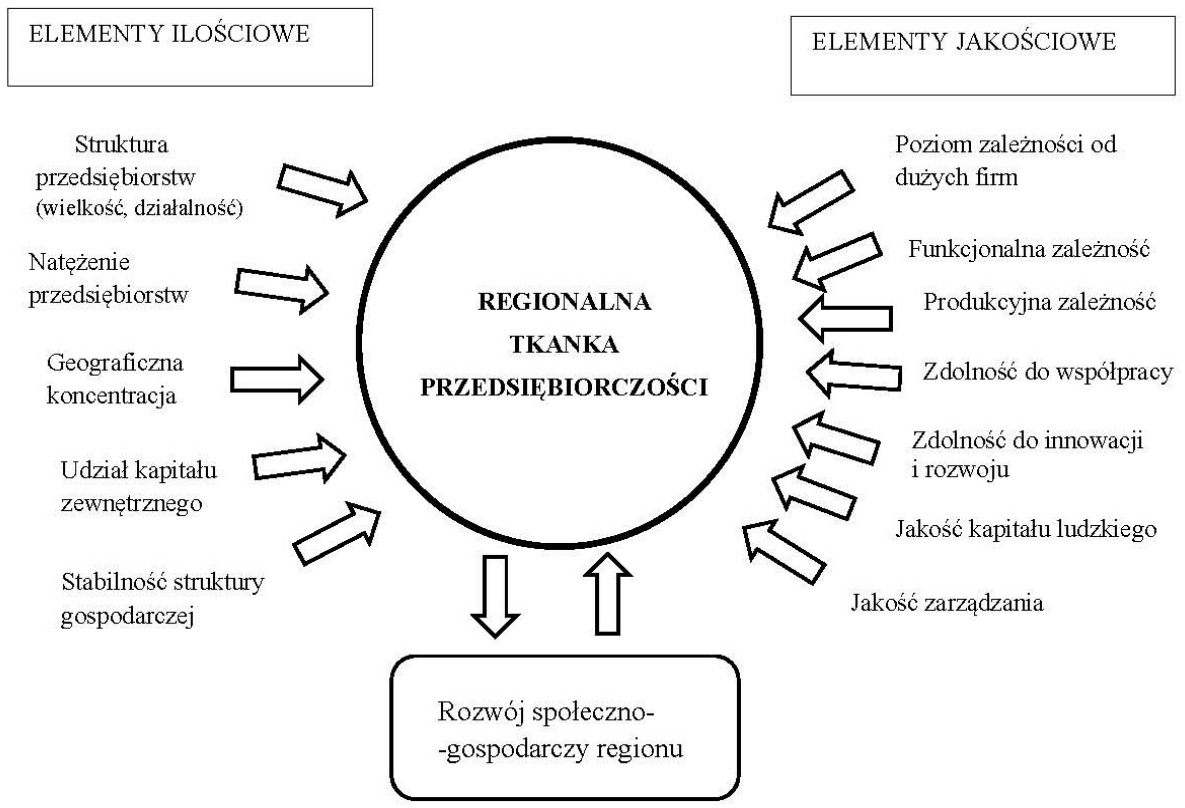

Rysunek 10. Model tkanki przedsiębiorczości

Źródło: opracowanie własne na podstawie Rekowski red. 2008, s. 71 
Wśród czynników ilościowych wymienia się: strukturę przedsiębiorstw (wielkość, rodzaj działalności), natężenie przedsiębiorstw, geograficzną koncentrację, udział kapitału zewnętrznego, stabilność struktur gospodarczych, natomiast do czynników jakościowych zaliczono: zależność od decyzji podejmowanych w dużych przedsiębiorstwach poza regionem, funkcjonalną zależność, produkcyjną zależność, skłonność do kooperacji, skłonność do innowacji i rozwoju, jakość kapitału ludzkiego i jakość zarządzania (Rekowski red. 2008, s. 72-76).

Pożądana tkanka przedsiębiorczości jest wyznaczana przez (Guzman, Santos 2008a, s. 57-63):

- średnią wielkość przedsiębiorstwa - mierzoną liczbą zatrudnionych. W rozwiniętych gospodarkach i regionach wysokiemu udziałowi dużych przedsiębiorstw towarzyszy wysoki udział małych i średnich przedsiębiorstw z zatrudnieniem powyżej 10 osób. W przypadku regionów o niskim poziomie rozwoju większość podmiotów to mikroprzedsiębiorstwa mające charakter samozatrudnienia;

- natężenie przedsiębiorstw w regionie - ważna jest w tym przypadku duża liczba przedsiębiorstw o odpowiedniej strukturze, tzn. powstających z możliwości stwarzanych przez otoczenie, a nie z konieczności wynikającej z samozatrudnienia. W regionach słabo rozwiniętych można zaobserwować duże zagęszczenie mikroprzedsiebiorstw często działających w szarej strefie, które nie przyczyniają się do rozwoju regionu;

- dominację sektora produkcyjnego - sektor ten bowiem charakteryzuje się wysokim postępem technicznym i poziomem specjalizacji, co może wpływać pozytywnie na rozwój regionu. Rozwinięte regiony charakteryzują się silną „tkanką przemysłową”, która jest wspierana przez usługi, znajdujące się na końcu łańcucha wartości;

- niebezpieczeństwo lokowania w regionie podmiotów zewnętrznych o rozdzielonej funkcji właściciela i geograficznej lokalizacji (Kokocińska 2012b, s. 48), np. filie, oddziały itp. ze względu na małą autonomiczność małych i średnich przedsiębiorstw i często zależność od zewnętrznego przedsiębiorstwa. Zmiany lokalizacji mogą bowiem negatywnie wpłynąć na dany podmiot gospodarczy jak również na rozwój danego regionu;

- funkcjonalne zależności to relacje z innymi podmiotami, w przypadku małych i średnich przedsiębiorstw są to związki z innymi przedsiębiorstwami tego sektora jak również dostawcami i klientami;

- koncentrację produkcji w regionie - zbyt wysoka może mieć negatywny wpływ na rozwój regionu, ze względu dużą liczbę małych i średnich przedsiębiorstw uzależnionych od decyzji niewielkiej liczby dużych przedsiębiorstw.

Oprócz pożądanej tkanki przedsiębiorczości na stymulowanie rozwoju małych i średnich przedsiębiorstw w regionie może mieć wpływ napływ BIZ, które zgodnie z eklektyczną teorią produkcji międzynarodowej (Dunning 1988, 
Rymarczyk 2004, Pilarska 2005) wymagają spełnienia jednocześnie warunków tzw. paradygmat OLI (Ownership, Location, Internalization), dających przedsiębiorstwu wielonarodowemu dysponowanie trzema rodzajami przewag, wynikających ze specyfiki przedsiębiorstwa (Ownership-specific Advantages), z tytułu internalizacji działalności gospodarczej (Internalization Incentive Advantages) oraz lokalizacji (Location Specific Advantages) ${ }^{2}$. Sprostanie tym warunkom wymaga zapewnienia atrakcyjności inwestycyjnej regionu, którą określają m.in.:

- chłonność rynku lokalnego (Przygodzki 2007),

- sytuacja demograficzna i jakość kapitału ludzkiego w regionie (Pakulska 2010),

- konkurencyjność regionu (Kożuch 1998),

- stopień nowoczesności gospodarki i trendy rozwojowe,

- sytuacja na rynku pracy,

- dogodne warunki finansowe,

- aktywność władz samorządowych (szczególnie marketingowa i proinwestycyjna) (Przygodzki 2007),

- warunki inwestowania,

- dostępność komunikacyjna regionu.

Siła przyciągania BIZ przez region zależy od rodzaju działalności i przyjętej strategii rozwoju. Na trwałość lokalizacji inwestycji wpływają głównie (Pakulska 2010, s. 170):

- rozwój sieci powiązań zarówno związanych z dobrami i usługami, jak również ze sferą $\mathrm{B}+\mathrm{R}$;

- poniesione nakłady, których odzyskanie nie jest możliwe, np. środki trwałe, koszty asymilacji $\mathrm{z}$ otoczeniem (kształtowanie relacji z dostawcami, odbiorcami, konsumentami);

- pozyskana wiedza o lokalnych zasobach i ich specyfice (w niewielkim stopniu do wykorzystania w nowym miejscu lokalizacji przedsiębiorstwa).

Oddziaływanie BIZ na rozwój małych i średnich przedsiębiorstw w regionie można rozważać w kontekście ich wpływu na zachowania przedsiębiorstw (np. wobec pojawiającej się konkurencji) oraz zmian w bliższym i dalszym otoczeniu (Pakulska 2010). Pojawiają się wtedy efekty zewnętrzne utożsamiane z konsekwencjami oddziaływania jednego podmiotu na inne podmioty i mogą wywierać bezpośredni lub pośredni wpływ na rozwój małych i średnich przedsiębiorstw w regionie (Witkowska 2000, Starzyńska 2012). Do efektów bezpośrednich można zaliczyć powstawanie nowych przedsiębiorstw o różnych powiązaniach z firmą pierwotną (spin-off), w przypadku efektów pośrednich o niewielkim stopniu wymierności: wielkość pozyskanego kapitału, wzrost dostępu regionu do rynków zewnętrznych, postęp technologiczny oraz wzrost PKB (Pakulska 2010,

${ }^{2}$ Szerzej na temat eklektycznej teorii produkcji międzynarodowej w opracowaniach: Dunning 1988, s. 1-32; 2000, s. 163-190; Rymarczyk 2004; Pilarska 2005. 
s. 173-176). Dla rozwoju małych i średnich przedsiębiorstw w regionie istotne jest szczególnie tworzenie sieci powiazań z firmami zagranicznymi, które mogą przyczynić się do tworzenia miejsc pracy oraz transferu technologii wiedzy i umiejętności.

W rozwoju MSP istotną rolę pełnią władze lokalne, które sterują procesami rozwoju całego układu lokalnego w celu zaspokojenia potrzeb ekonomicznych, społecznych, ekologicznych, kulturowych i innych. Tworzą one również sprzyjające warunki dla tych podmiotów, na które ma wpływ organizacja przestrzenna rynku, rozmieszczenie i efektywne gospodarowanie zasobami regionalnymi jak również rozwój innych dziedzin w regionie.

T. Markowski wprowadził pojęcie „lokalnej polityki ekonomicznej” dla określenia działań podejmowanych przez władze samorządowe na rzecz stymulowania lokalnej działalności gospodarczej i tworzenia nowych miejsc pracy. Lokalna polityka ekonomiczna to proces tworzenia instytucji, rozwijanie alternatywnych gałęzi przemysłu, wpływanie na przedsiębiorców w zakresie wytwarzania lepszych produktów, pomoc w rozpoznawaniu nowych rynków, transfer wiedzy, wspomaganie nowych firm i przedsiębiorstw itd. (Markowski 1999, s. 143). Efektem tych działań może stać się powstawanie różnorodnych dziedzin działalności małych i średnich firm. Działania i decyzje organów władzy lokalnej w regionie są uzależnione od prowadzonej w regionie polityki i kompetencji tych władz, jak również zależą od stawianych celów, środków oraz narzędzi będących do ich dyspozycji. Efektywność administracji publicznej jest wyznaczana przez adekwatność podejmowanych działań w stosunku do możliwości i oczekiwań MSP (Pakulska 2010, s. 178 i 182).

Na rozwój małych i średnich przedsiębiorstw ma również wpływ tzw. lokalność, definiowana jako cecha wyróżniająca odrębność autonomicznego sposobu działania danego układu w zbiorze podobnych układów (Chądzyński 2007). Podstawową cechą lokalności jest autonomia spraw, dziejących się na danym obszarze, niepowtarzalność zjawisk i procesów tam zachodzących. Głównymi elementami (cechami) lokalności są (Leszczyński 2004, s. 236):

- samorząd lokalny, który zajmuje się sprawami interesu miejscowego, tzn. kreuje warunki dla funkcjonowania podmiotów gospodarczych, reguluje warunki życia mieszkańców, jest siła motoryczną (animatorem) rozwoju lokalnego tworząc warunki do stabilnego, harmonijnego i dynamicznego rozwoju danej jednostki terytorialnej;

- podmiotowość społeczności lokalnej, czyli ograniczona terytorialnie przestrzeń społeczna, zamieszkana przez ludność o określonych charakterystykach powiązanych szczególnym typem interakcji i solidarnością grupową. Społeczność lokalna ma wpływ na kierunek i tempo rozwoju lokalnego, którego celem jest m.in. maksymalizacja dochodów ludności i samorządu terytorialnego, maksymalizacja spożycia dóbr materialnych, zaspokojenie potrzeb mieszkańców 
w zakresie sfery materialnej, polepszenie jakości środowiska przyrodniczego oraz zagwarantowanie ładu przestrzennego.

Reasumując dotychczasowe rozważania, małe i średnie przedsiębiorstwa są istotnym elementem przestrzeni lokalnej. Na rozwój tych podmiotów ma wpływ $\mathrm{z}$ jednej strony tzw. szeroko rozumiane środowisko regionalne, $\mathrm{z}$ drugiej zaś strony podmioty kształtujące strukturę lokalną i przyczyniające się do rozwoju regionalnego. Rozwój regionalny zatem wiąże się nie tylko ze stanem ilościowym tych podmiotów $\mathrm{w}$ danym regionie, ale również $\mathrm{z}$ ich wskaźnikiem przeżywalności. Dla potwierdzenia roli sektora MSP w rozwoju regionalnym, $\mathrm{w}$ tym $\mathrm{w}$ obszarach zmarginalizowanych, warto dokonać oceny dynamiki rozwoju tego sektora w regionie. Analiza ta została zaprezentowana w kolejnym podrozdziale.

\subsection{Charakterystyka liczby małych i średnich przedsiębiorstw w Polsce}

Powstawanie i rozwój małych i średnich przedsiębiorstw jest uwarunkowane wieloma różnorodnymi czynnikami (szczegółowe omówienie w rozdziale 3), jednak, jak wskazują badania, dla powstawania i rozwoju tych podmiotów w regionie ważny jest popyt (Edwards 2007), struktura sektorowa gospodarki (Gajewski 2011, Godlewska-Majkowska 2008), tkanka przedsiębiorczości (Guzman, Santos 2008a, b) oraz relacje przedsiębiorstw z otoczeniem regionalnym (Korol, Szczuciński 2011, s. 62), kształtowane przez dostęp do czynników produkcji oraz systemu wsparcia biznesu w danej przestrzeni (Godlewska-Majkowska 2008, s. 67).

Oceniając wpływ sektora MSP na rozwój regionalny, warto dokonać analizy stanu tego sektora (liczba przedsiębiorstw, przedsiębiorstwa nowo zarejestrowane i wyrejterowane) w układzie regionalnym, uwzględniającym strukturę gospodarki danego regionu. Przedstawione dane będą dotyczyły powiatów $\mathrm{w}$ celu bardziej szczegółowej oceny zmian w liczbie tych przedsiębiorstw i możliwości porównania $\mathrm{z}$ obszarami zmarginalizowanymi wyróżnionymi w pkt 1.3.

Jako pierwszy obszar badawczy przyjęto analizę struktury sektorowej gospodarki w Polsce w 2010 r. (por. rysunek 11), która wykazała, że w Polsce Zachodniej dominowały powiaty przemysłowe, usługowe i bez wyraźniej specjalizacji, a Polsce Środkowej rolnicze, przemysłowe oraz usługowe, natomiast w Polsce Wschodniej przeważały głównie powiaty rolnicze (dominujący sektor w strukturze zatrudnienia) oraz powiaty bez wyraźniej specjalizacji (nie wyróżniające się zatrudnieniem w konkretnym sektorze). 


\section{TYP POWIATU}
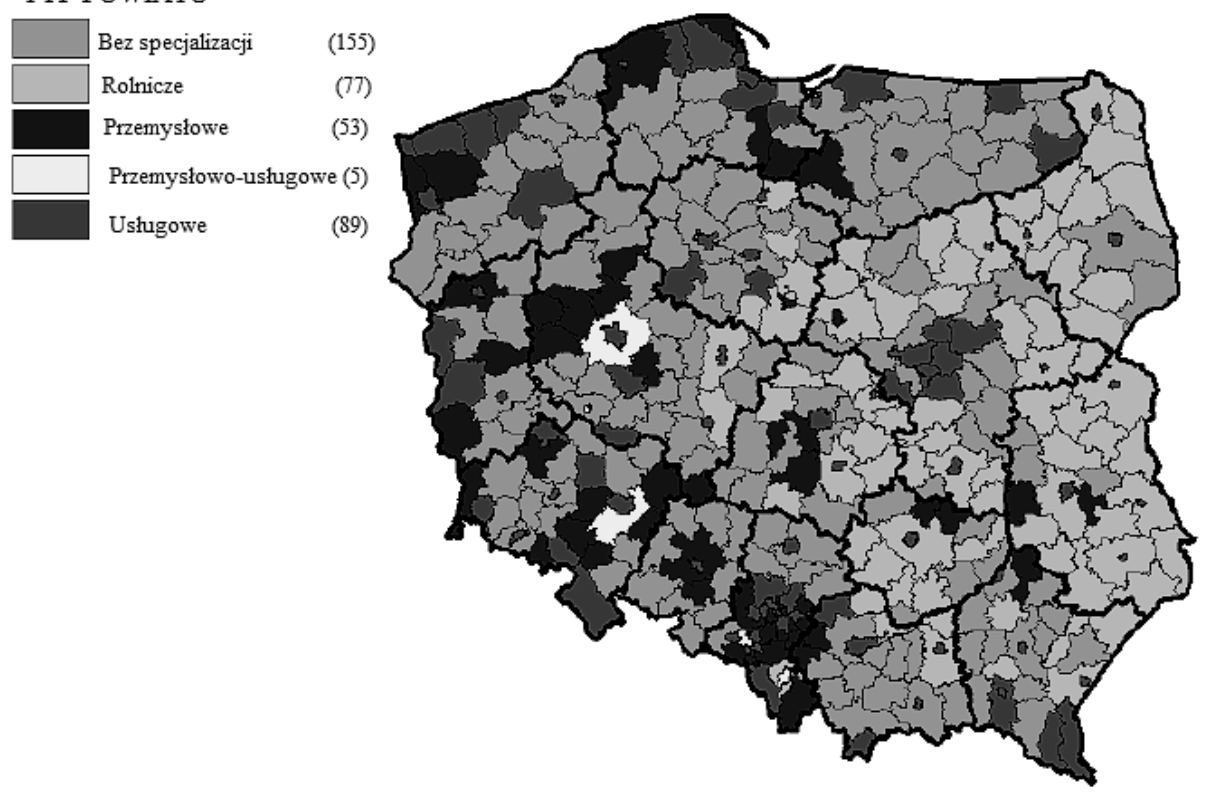

Rysunek 11. Typy powiatów według dominującego sektora w strukturze zatrudnienia w $2010 \mathrm{r}$.

Źródło: Gajewski 2011, s. 11

Taka struktura gospodarki miała swój wyraz w nasyceniu poszczególnych powiatów liczbą przedsiębiorstw na 10 tys. mieszkańców w 2010 r. Największa koncentracja małych i średnich przedsiębiorstw w stosunku do liczby mieszkańców była w miastach na prawach powiatu we wszystkich województwach oraz powiatach województwa mazowieckiego i wielkopolskiego o specjalizacji przemysłowej i usługowej, natomiast najniższa koncentracja $\mathrm{w}$ obszarach rolniczych głównie wschodniej i środkowej i północnej Polski.

Analiza zmian ${ }^{3}$ liczby małych i średnich przedsiębiorstw w latach 20052011 (por. rysunek 12) wykazała, że w większości powiatów (238) wzrosła liczba MSP, co jest zgodne, jak podają statystyki PARP, z ogólną tendencją krajową w analizowanym okresie (Raport o stanie... 2012, s. 23). W 50 powiatach odnotowano spadek, a w 91 nie zmieniła się liczba MSP. Spadek i brak zmian $\mathrm{w}$ liczebności małych i średnich przedsiębiorstw odnotowano głównie w powiatach województw łódzkiego, świętokrzyskiego, podlaskiego i lubuskiego.

\footnotetext{
${ }^{3}$ Na podstawie indeksów łańcuchowych w latach 2005-2011.
} 


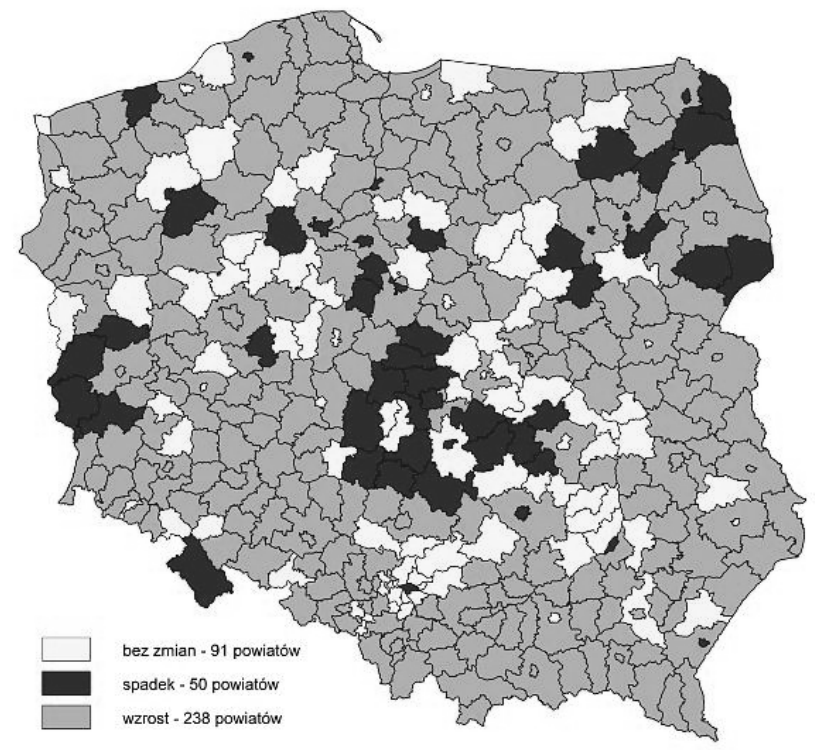

Rysunek 12. Zmiany w liczbie MSP w latach 2005-2011 (w \%)

Źródło: opracowanie własne na podstawie danych publikowanych Banku Danych Lokalnych, GUS

\section{Mikro}

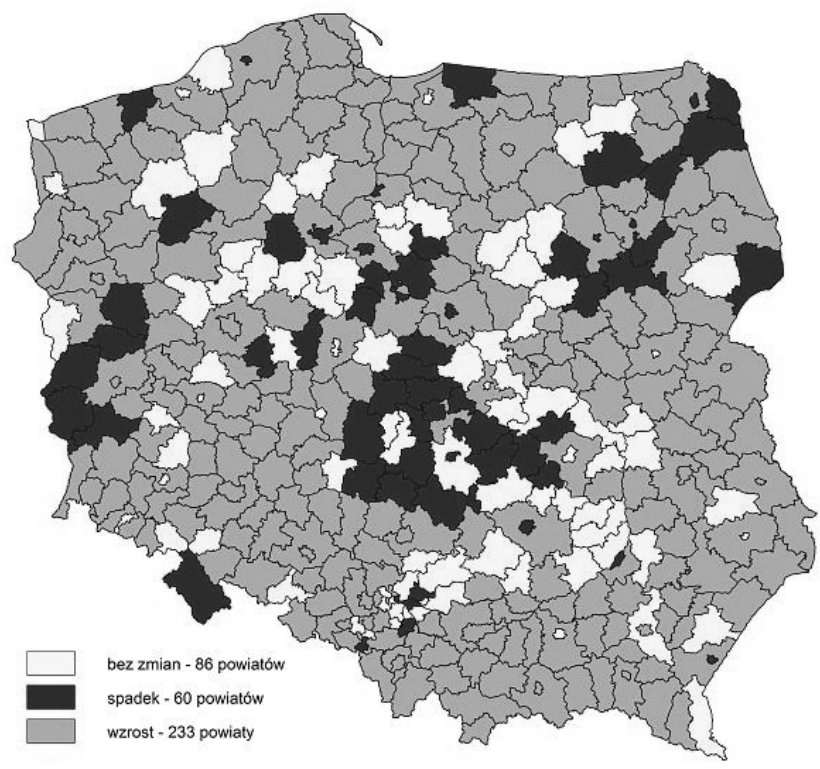


Małe

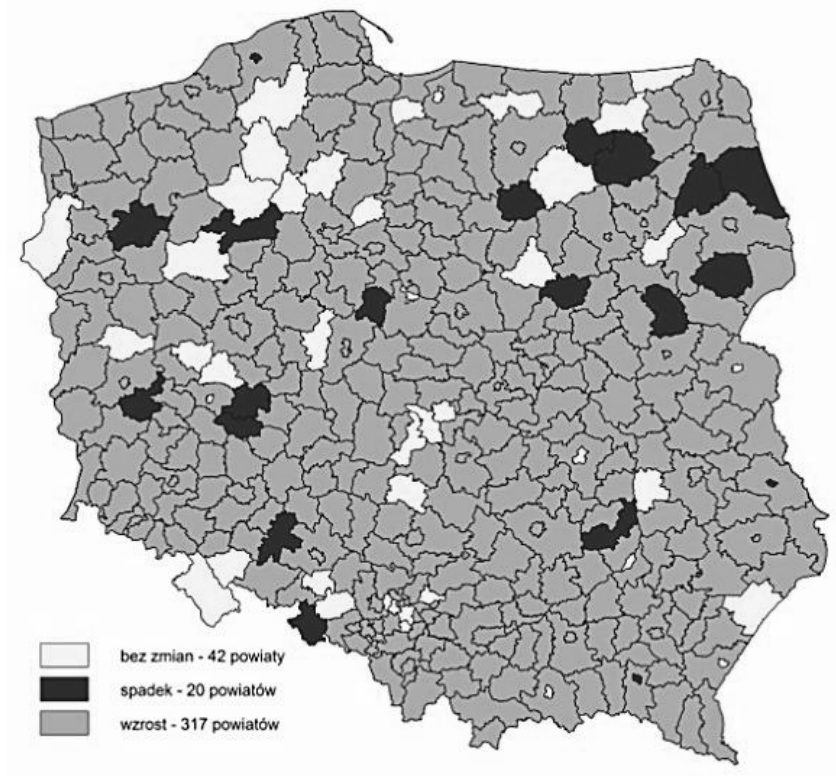

\section{Średnie}

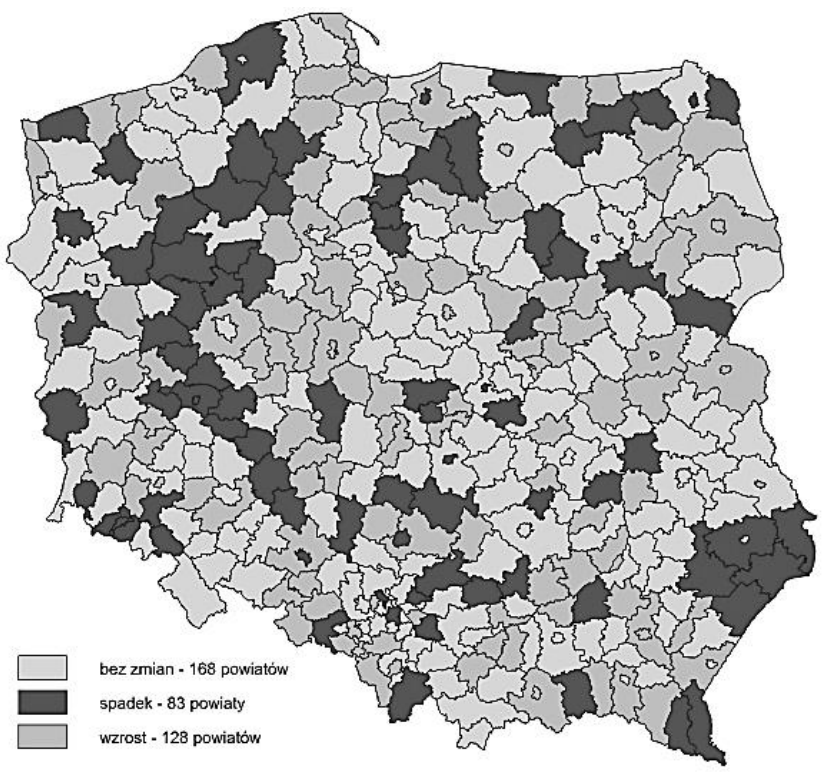

Rysunek 13. Zmiany w liczbie mikro, małych i średnich przedsiębiorstw na 10 tys. osób w latach 2005-2011 (w \%)

Źródło: opracowanie własne na podstawie danych Banku Danych Lokalnych, GUS 
Największy wzrost liczby przedsiębiorstw w latach 2005-2011 na 10 tys. osób (por. rysunek 13) był widoczny w przypadku mikro i małych przedsiębiorstw, które odnotowały swój wzrost odpowiednio w 233 i 317 powiatach. W przypadku średnich przedsiębiorstw w 168 powiatach nie odnotowano zmian liczebności przedsiębiorstw, a w przypadku 83 odnotowano spadek. Taka sytuacja może świadczyć o mniejszej dynamice wzrostu liczby średnich przedsiębiorstw obserwowanej w Polsce od 2008 r. Przyczyn takiej sytuacji można upatrywać w ogólnoświatowym kryzysie finansowym, na skutek którego często przedsiębiorstwa odnotowywały raczej spadek obrotów i zatrudnienia, w wyniku tego przedsiębiorstwa małe nie miały szansy stać się średnimi, a często średnie, redukując swoje zatrudnienie, stawały się małymi.

$\mathrm{W}$ obszarach zmarginalizowanych wyznaczonych na podstawie zaprezentowanego w podrozdziale 1.3 miernika syntetycznego liczba MSP na 10 tys. osób w latach 2005-2011 w większości powiatów wzrosła (65 powiatów), w przypadku 20 powiatów nie odnotowano zmian, natomiast tylko w 15 spadek liczby MSP (por. rysunek 14). Taka sytuacja może świadczyć z jednej strony o sprzyjających warunkach (klimacie) dla rozwoju tych przedsiębiorstw, natomiast $\mathrm{z}$ drugiej strony uruchomienie przedsiębiorstwa może być odpowiedzią na trudną sytuację na rynku pracy.

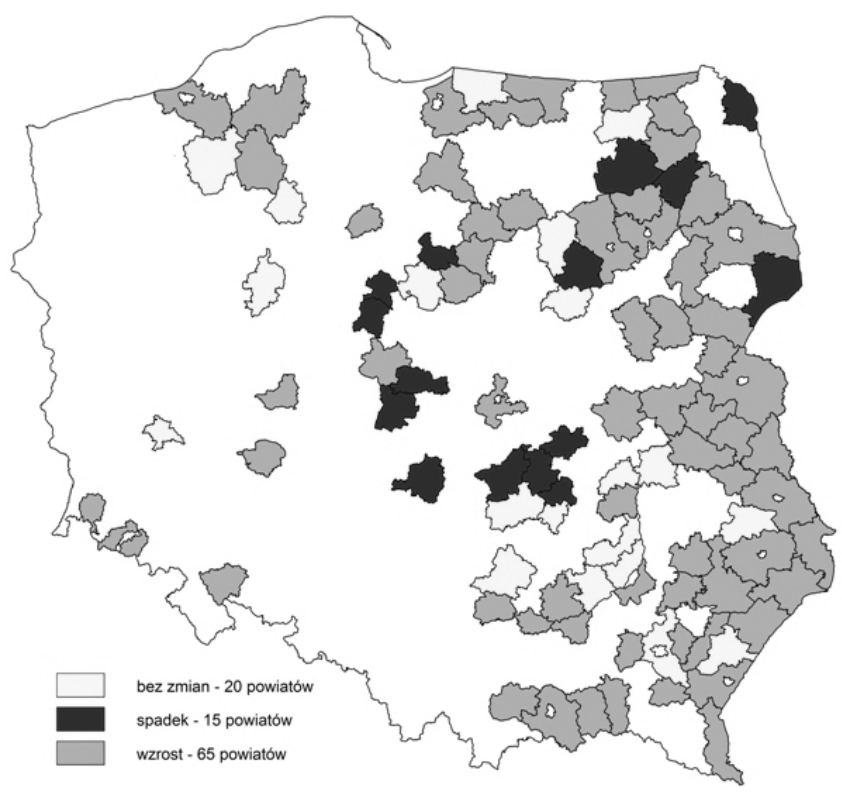

Rysunek 14. Zmiany w liczbie MSP na 10 tys. osób w latach 2005-2011

(w \%) w obszarach zmarginalizowanych

Źródło: opracowanie własne na podstawie danych publikowanych Banku Danych Lokalnych, GUS 
Analiza liczby nowo zarejestrowanych w rejestrze REGON MSP na 10 tys. osób w 2011 r. wskazuje, że najwięcej tych podmiotów powstało w powiatach najsilniejszych ośrodków miejskich, takich jak: Warszawa, Wrocław, Poznań, Gdańsk, Szczecin, natomiast najmniej w powiatach Polski Wschodniej, szczególnie w województwie podlaskim, lubelskim, świętokrzyskim oraz podkarpackim (por. rysunek 15). Przyczyn tego stanu rzeczy można upatrywać w małej atrakcyjności tych regionów uważanych głównie za obszary najsłabiej rozwinięte, o trudnym dostępie infrastruktury komunikacyjnej i telekomunikacyjnej oraz niskiej jakości kapitału intelektualnego i społecznego.

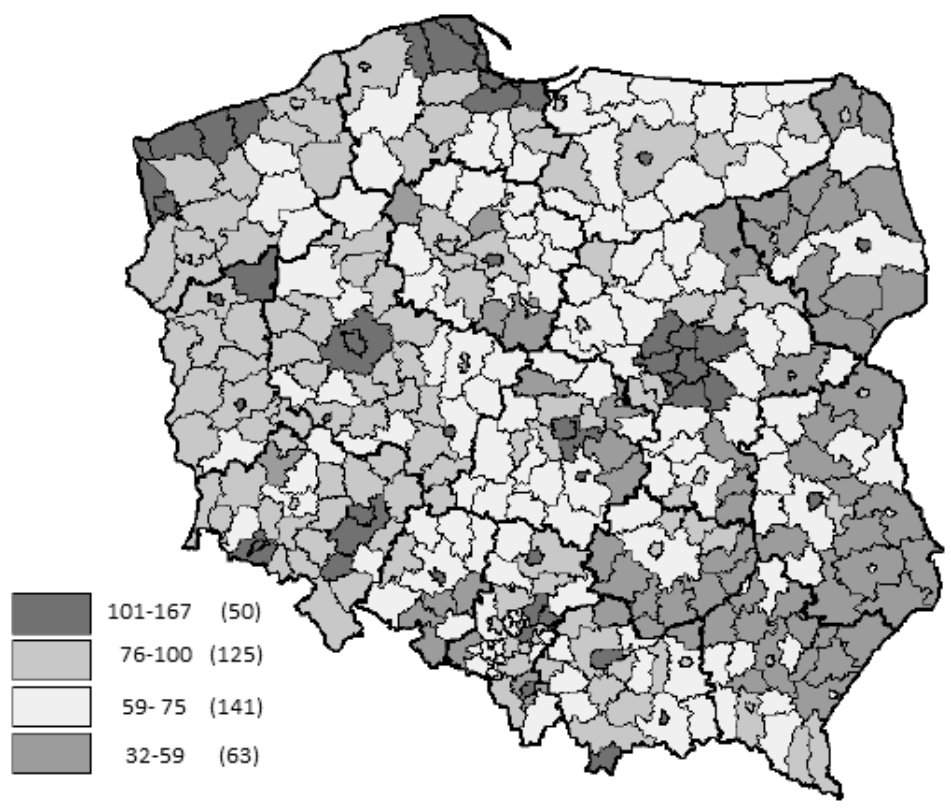

Rysunek 15. MSP nowo zarejestrowane w rejestrze REGON na 10 tys. osób w $2011 \mathrm{r}$. Źródło: opracowanie własne na podstawie danych niepublikowanych GUS

W 2011 r. najwięcej MSP wyrejestrowano z rejestru REGON głównie $\mathrm{w}$ powiatach południowo-wschodniej Polski oraz powiatach $\mathrm{z}$ terenu województw łódzkiego, podlaskiego i świętokrzyskiego, natomiast najmniej w przypadku powiatów Polski Zachodniej oraz Północnej (por. rysunek 16). Zaprezentowane dane odnośnie do MSP zarejestrowanych i wyrejestrowanych w rejestrze REGON nie dają pełnego obrazu zmian zachodzących w strukturze ilościowej tych podmiotów, dlatego ważne jest również zbadanie relacji pomiędzy tymi wielkościami. 


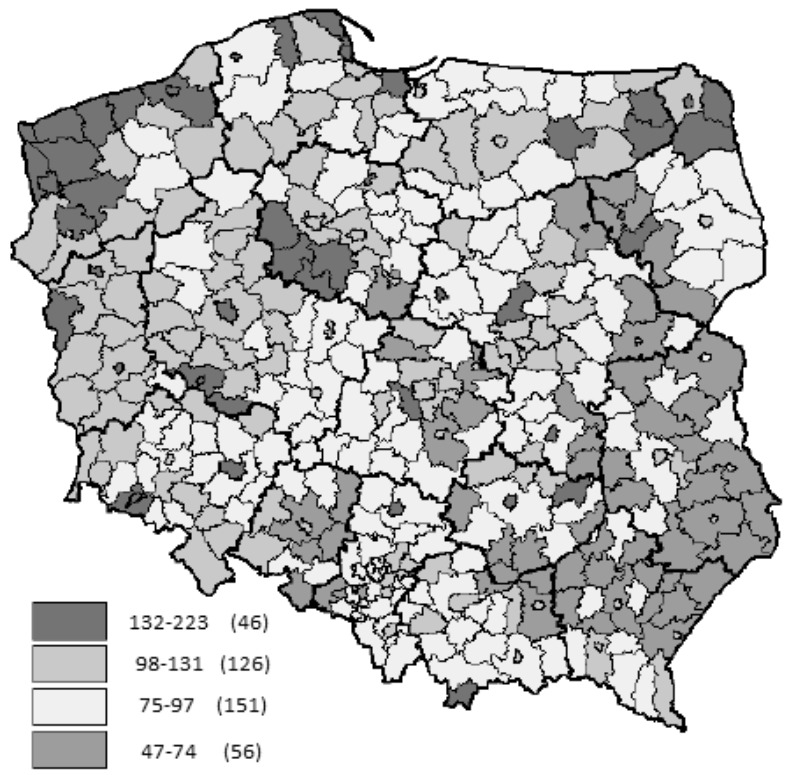

Rysunek 16. MSP wyrejestrowane z rejestru REGON na 10 tys. osób w 2011 r. Źródło: opracowanie własne na podstawie danych niepublikowanych GUS

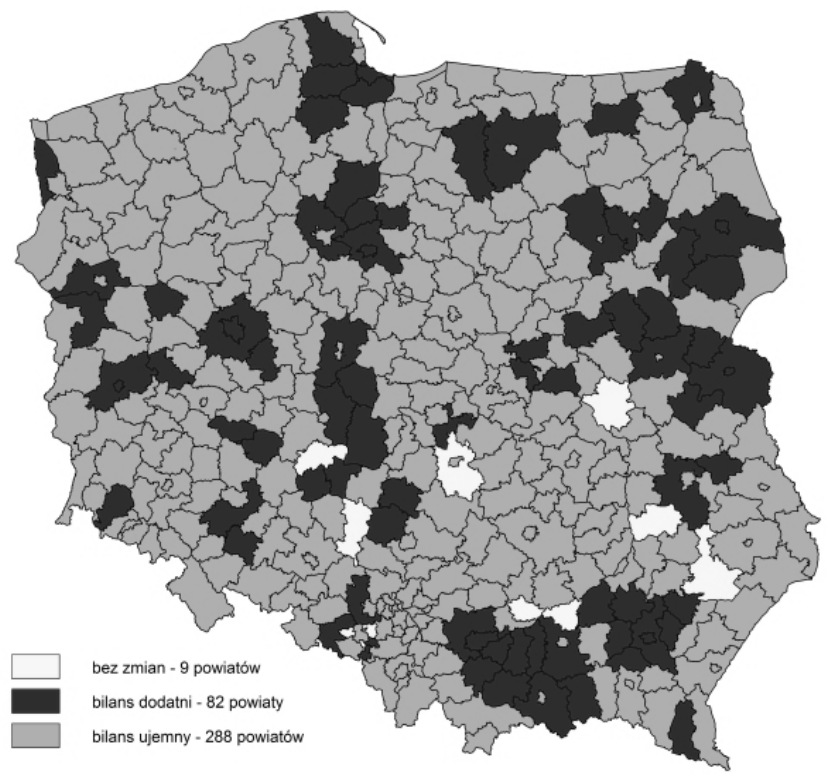

Rysunek 17. Relacja MSP nowo zarejestrowanych do wyrejestrowanych na 10 tys. osób w 2011 r. Źródło: opracowanie własne na podstawie danych niepublikowanych GUS 
Analiza relacji MSP nowo zarejestrowanych do wyrejestrowanych na 10 tys. ludności w 2011 r. (por. rysunek 17) wykazała, że w większości powiatów (288) odnotowano bilans ujemy, natomiast tylko w 82 powiatach - dodatni. Ma to niewątpliwie silny związek z wskaźnikiem przeżywalności przedsiębiorstw. Według danych GUS w 2010 r. pierwszy rok działalności przeżywały trzy na cztery przedsiębiorstwa (wskaźnik przeżywalności $77,8 \%$ ), drugi rok tylko $50 \%$ przedsiębiorstw, a piąty ok. 30\% (Raport o stanie... 2012, s. 26).

Na powstawanie nowych małych i średnich przedsiębiorstw, rozwój oraz ich przeżywalność ma wpływ wiele czynników, często wynikających $\mathrm{z}$ relacji $\mathrm{z}$ ich otoczeniem regionalnym, jak również zdolności danego obszaru do stworzenia sprzyjającego klimatu dla rozwoju biznesu, charakteryzującego się:

- dostępnością czynników produkcji o wysokiej jakości,

- pozycją i prestiżem przedsiębiorców w danym obszarze,

- korzystną sytuacją demograficzną i na rynku pracy,

- sprzyjającymi warunkami do inwestowania,

- wielkością popytu regionalnego,

- rozwojem sektorów pokrewnych i wspierających, dających możliwość tworzenia sieci współpracy i powiązań.

Przedstawiona analiza podkreśliła istotny związek pomiędzy rozwojem danego obszaru a rozwojem MSP. Im lepiej rozwinięty obszar, tam koncentracja i dynamika rozwoju małych i średnich przedsiębiorstw jest znacznie większa niż w przypadku obszarów słabo rozwiniętych - zmarginalizowanych.

\subsection{Małe i średnie przedsiębiorstwa a rozwój obszarów zmarginalizowanych}

Małe i średnie przedsiębiorstwa, jak już wcześniej podkreślono, stanowią jeden z głównych elementów infrastruktury regionalnej, od której zależy ich konkurencyjność i przyszły rozwój. Szczególnie dużą rolę przypisuje się tym przedsiębiorstwom w rozwoju obszarów zmarginalizowanych, w których przeważają firmy z sektora MSP. Obszary te ze względu na swoje problemy, m.in. takie jak: słaby rozwój społeczno-gospodarczy, niska innowacyjność i konkurencyjność, brak kapitału, niewykwalifikowana siła robocza, niska dostępność infrastruktury komunikacyjnej oraz niedostateczna skłonność do zachowań przedsiębiorczych mieszkańców, nie zawsze pozytywnie wpływają na decyzje związane $\mathrm{z}$ uruchomieniem $\mathrm{i}$ prowadzeniem biznesu. Według H. Bergmanna, A. Japsena i Ch. Tamàsy'ego warunkami sprzyjającymi urucho- 
mieniu działalności gospodarczej w regionie są następujące czynniki o charakterze regionalnym (Bergmann, Japsen i Tamàsy 2002, cyt. za Wach 2008, s. 61):

- finansowanie małych i średnich przedsiębiorstw, głównie w fazie uruchomienia;

- polityka władz regionalnych wobec małych i średnich przedsiębiorstw;

- transfer wiedzy i technologii do małych i średnich przedsiębiorstw;

- jakość wykształcenia i kształcenia ustawicznego uwzgledniającą specyficzne potrzeby potencjalnych przedsiębiorców;

- dostępność usług doradczych i biznesowych dla MSP;

- infrastruktura techniczna wykorzystywana w działalności gospodarczej;

- dostępność wysoko wykwalifikowanych pracowników na lokalnym rynku pracy;

- stosunek lokalnej społeczności do zachowań przedsiębiorczych.

W przypadku obszarów zmarginalizowanych większość tych czynników nie jest spełniona, a mimo tej niesprzyjającej sytuacji powstają nowe podmioty gospodarcze, a te już funkcjonujące poszukują różnych możliwości przetrwania i rozwoju. Czasami założenie własnej działalności na tych obszarach z jednej strony może być jedynym rozwiązaniem kwestii bezrobocia, które jest dużym problemem na lokalnym rynku pracy, a działania przedsiębiorcze są podejmowane $\mathrm{z}$ braku innych perspektyw. Z drugiej zaś strony na obszarach tych powstają przedsiębiorstwa „z wyboru”, które znalazły swoją okazję bądź niszę rynkową w specyfice obszarów zmarginalizowanych.

W przypadku przedsiębiorców funkcjonujących na obszarach zmarginalizowanych głównym motywem uruchomienia działalności gospodarczej jest reakcja na trudną sytuację na rynku pracy i są to w większości przypadków przedsiębiorstwa $\mathrm{z}$ konieczności. Często osoby uruchamiające firmy na tych terenach nie posiadają wiedzy z zakresu zarządzania firmą, bazują na własnych, zaoszczędzonych środkach lub wykorzystują środki pomocowe na przeciwdziałanie bezrobociu, a koncepcja uruchomienia biznesu zazwyczaj posiada wiele błędów, takich jak (Lisowska, Ropęga 2009, s. 211):

- rozpoczęcie działalności w dziedzinie, w której nie posiadają żadnego doświadczenia;

- inwestowanie niewystarczającej ilość kapitału lub własnego wysiłku;

- niejasno sprecyzowany wyrób lub usługa;

- błędy popełnione podczas uruchomienia biznesu, brak wiedzy z dziedziny zarządzania i prowadzenia własnej firmy oraz braki w wykształceniu.

$\mathrm{Z}$ punktu widzenia rozwoju obszarów zmarginalizowanych, jak również małych i średnich przedsiębiorstw lepszym rozwiązaniem jest powstawanie przedsiębiorstw ,z wyboru”, które mogą generować szybszy wzrost, wyższy wskaźnik przetrwania oraz lepsze wyniki finansowe (Bacławski, Koczerga, Zabierowski 2005). 
Obszary zmarginalizowane mogą być dla niektórych małych i średnich przedsiębiorstw szansą na rozwój. Szczególnie, gdy są to małe firmy, często o tradycyjnym charakterze działalności, które znajdują w lokalnym wymiarze swoją użyteczność ekonomiczną i społeczną, bardziej elastycznie dostosowują się do warunków miejscowego otoczenia, gdzie znajdują łatwiejsze warunki powstania i rozwoju (Leszczyński 2004, s. 239). Często jednak lokalny charakter prowadzonej działalności, brak możliwości rozwoju przedsiębiorstwa oraz wiedzy i doświadczenia powodują marginalizację licznej grupy przedsiębiorców i tak właśnie może się stać w przypadku obszarów zmarginalizowanych (Czaja 2011, s. 105).

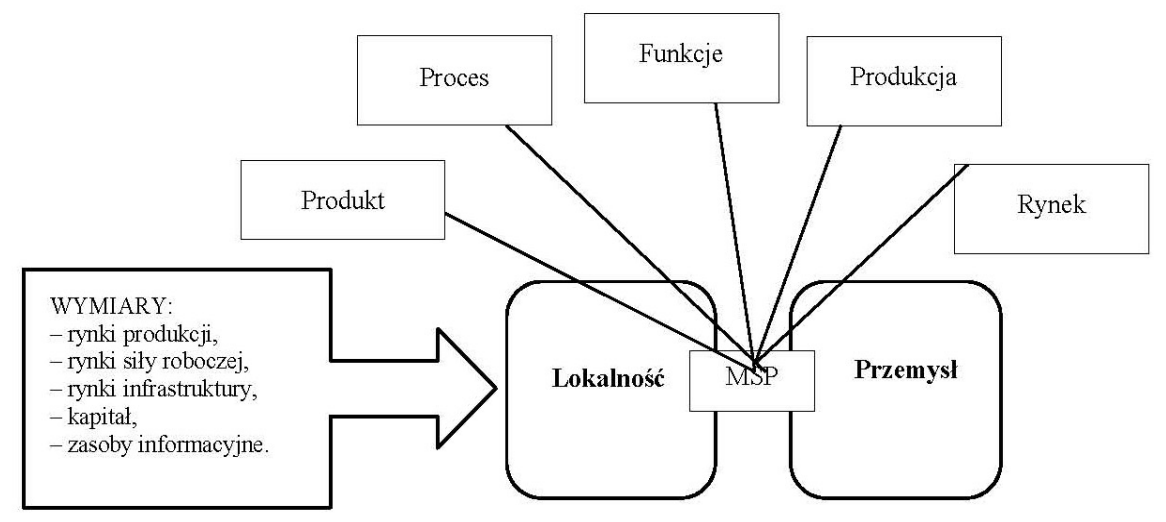

Rysunek 18. Lokalność a wzrost małych i średnich przedsiębiorstw Źródło: opracowanie własne na podstawie: Kalantaridis 2009, s. 501

Według Ch. Kalandarisa małe i średnie przedsiębiorstwa funkcjonujące $\mathrm{w}$ środowisku lokalnym/regionalnym, w tym obszarach zmarginalizowanych, wykorzystują jego specyficzne zasoby oraz otoczenie instytucjonalne. W tym kontekście na wzrost MSP ma wpływ pięć grup czynników (por. rysunek 18), do których należą: rynki produkcji, rynki siły roboczej, rynki zasobów materialnych (infrastruktura, surowce i materiały), kapitał oraz zasoby informacyjne. Istotny dla wzrostu i rozwoju MSP jest również charakter tych związków (Kalantaridis 2009, s. 501).

Małe i średnie przedsiębiorstwa działające lokalnie zajmują określoną pozycję w branży i sektorze, jednak aby ją utrzymać i osiągnąć wzrost, a później rozwój, firmy te powinny rozwijać odpowiednie strategie, umożliwiające wykorzystanie lokalnych zasobów oraz instytucjonalnego zaplecza. Strategie te są rozwijane w czterech wymiarach: produktu, procesu, produkcji (zawierającej funkcje) oraz rynku (Kalantaridis 2009, s. 502). Strategie małych i średnich przedsiębiorstw powinny być dopasowane do uwarunkowań regionalnych jak również etapu rozwoju, w jakim znajduje się przedsiębiorstwo. Szczególnie jest 
to istotne dla MSP funkcjonujących w obszarach zmarginalizowanych oddalonych od centrów rozwoju, które oprócz podstawowych problemów charakterystycznych dla wszystkich podmiotów zmagają się z zazwyczaj niekorzystnymi warunkami funkcjonowania $w$ tych obszarach. Zatem przy formułowaniu strategii należy uwzględnić również specyfikę tych obszarów, która, tak jak wcześniej wspomniano, mogą być zarówno barierą, jak również stymulatorem rozwoju dla małych i średnich przedsiębiorstw.

Wpływ małych i średnich przedsiębiorstw na rozwój danego obszaru może być bardzo zróżnicowany w zależności od fazy jego rozwoju. G. Garfoli wyróżnił pięć etapów rozwoju regionów i odziaływania małych i średnich przedsiębiorstw na gospodarkę regionu (Garfoli 1990):

- w pierwszym etapie rozwoju regionu powstają małe przedsiębiorstwa;

- kolejny etap to tworzenie sieci współpracujących w różnych obszarach ze sobą lokalnych firm, m.in. w zakresie wdrażania innowacji, którego konsekwencją może stać się wzrost wydajności pracy w przedsiębiorstwie i regionie;

- trzeci etap to utworzenie kompleksowego lokalnego systemu produkcji, stwarzającego możliwość wyjścia poza rynki lokalne i dokonywania inwestycji na potrzeby lokalnych firm;

- w czwartej fazie wzrost „eksportu” poza lokalny układ oraz rozwój usług, przy optymalnym wykorzystania zasobów regionu;

- w ostatnim etapie rozwoju lokalne przedsiębiorstwa są gotowe do ekspansji poza region, nie tylko jako sprzedawcy swoich produktów, ale jako aktywni inwestorzy czy udziałowcy.

W przypadku obszarów zmarginalizowanych trudno jest określić jednoznacznie fazę rozwoju, w której znajduje się dany obszar i odnieść ją do odziaływania na niego małych i średnich przedsiębiorstw. Przeprowadzona analiza wyników badań ilościowych i jakościowych w rozdziałach 4 i 5 wskazuje na bardzo wczesny etap rozwoju tych obszarów z punktu widzenia odziaływania małych i średnich przedsiębiorstw na gospodarkę regionu.

$\mathrm{Na}$ tworzenie i rozwój podmiotów gospodarczych w obszarach o różnym poziomie rozwoju mają wpływ również czynniki lokalizacyjne zarówno twarde, jak i miękkie (por. rysunek 19). W przypadku obszarów zmarginalizowanych istotne są szczególnie te czynniki lokalizacyjne, które wynikają ze specyfiki tych obszarów, np. poziom rozwoju społeczno-gospodarczego, dostępność komunikacyjna, wielkość rynku oraz siła nabywcza lokalnej społeczności. Poprawa konkurencyjności regionów słabiej rozwiniętych powinna zatem następować poprzez tworzenie korzystnych warunków dla rozwoju małych i średnich przedsiębiorstw. Właściwy klimat proprzedsiębiorczy sprzyja współpracy pomiędzy przedsiębiorcami, grupami interesów, dostawcami, klientami, prawnikami, analitykami finansowymi, instytucjami doradczymi, audytorami badającymi firmy i stwarza podstawy do stopniowego wyjścia z ,pętli marginalizacji” danego regionu (Krajowa Strategia..., 2010, s. 19). 


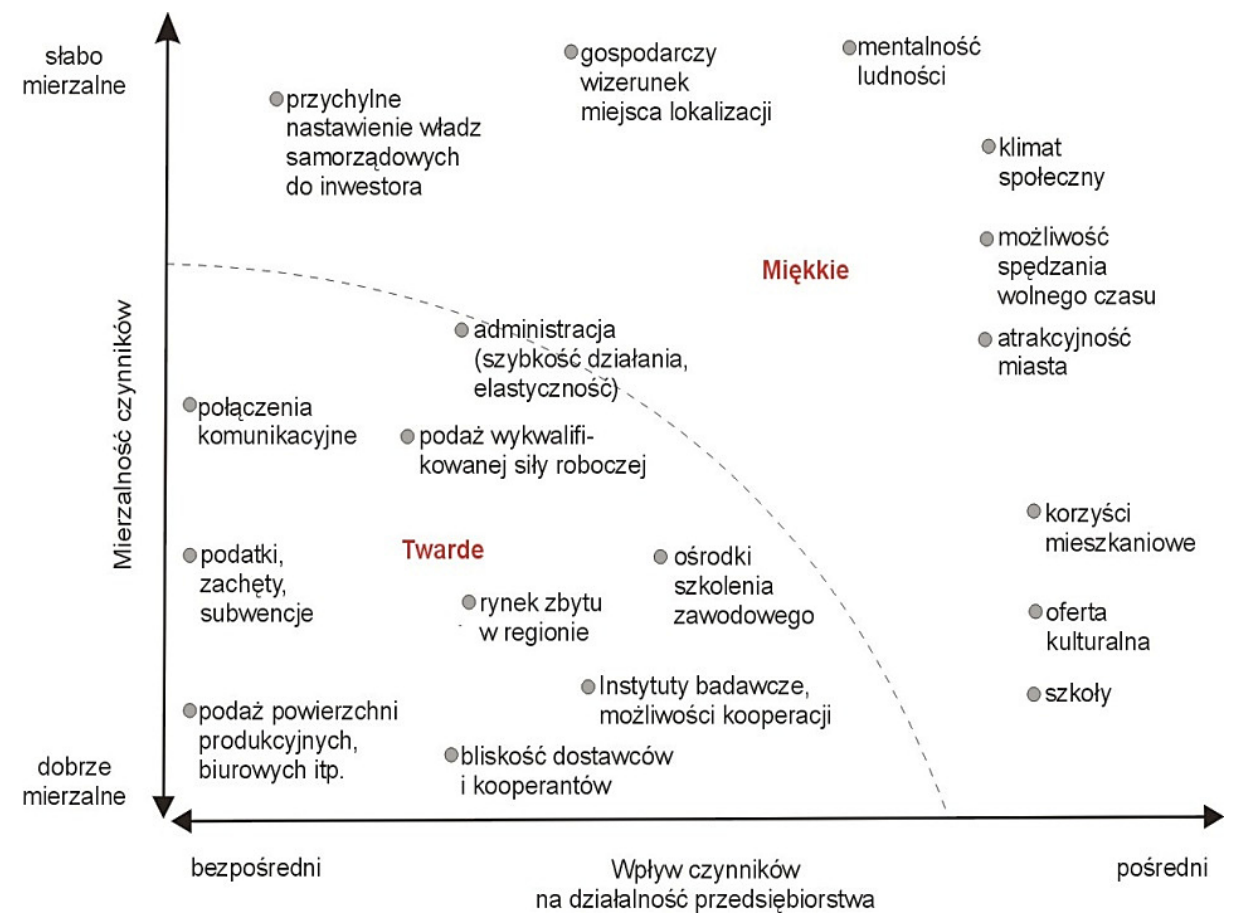

Rysunek 19. Twarde i miękkie czynniki lokalizacji

Źródło: Wieloński 2000, s. 46

Możliwości i tempo rozwoju danego regionu uzależnione są od wielu czynników, które w różny sposób wpływają na rozwój, w mniejszym lub większym zakresie go ograniczając lub stymulując. Zróżnicowanie poziomu gospodarczego regionów wyjaśniają teorie rozwoju regionalnego szeroko już opisane $\mathrm{w}$ literaturze przedmiotu ${ }^{4}$. Jednakże wiele $\mathrm{z}$ nich podkreśla rolę małych i średnich przedsiębiorstw $\mathrm{w}$ rozwoju regionalnym $\mathrm{w}$ tym $\mathrm{w}$ obszarach zmarginalizowanych, co pozwala na sformułowanie wniosków dla polityki wsparcia tych podmiotów w obszarach zmarginalizowanych (por. tabela 4).

${ }^{4}$ Przegląd niektórych teorii rozwoju regionalnego można znaleźć w pracach m.in.: Gorzelak G 1989, Szul 1991, Chmiel 1997, Kuciński red. 2010, Chądzyński J. red. i inni 2007. 
Tabela 4. Małe i średnie przedsiębiorstwa w wybranych teoriach i koncepcjach rozwoju regionalnego - wnioski dla obszarów zmarginalizowanych

\begin{tabular}{|c|c|c|}
\hline $\begin{array}{c}\text { Teoria/koncepcja } \\
\text { rozwoju } \\
\text { regionalnego }\end{array}$ & Charakterystyka & $\begin{array}{l}\text { Wnioski dla polityki } \\
\text { wsparcia MSP } \\
\text { w obszarach } \\
\text { zmarginalizowanych }\end{array}$ \\
\hline 1 & 2 & 3 \\
\hline $\begin{array}{l}\text { Teoria } \\
\text { centrum- } \\
\text { peryferie }\end{array}$ & $\begin{array}{l}\text { Teoria ta zakłada zależność rozwoju między } \\
\text { obszarami centralnymi a peryferiami, co pogłębia } \\
\text { nierówności w rozwoju. Rozwój peryferii - ob- } \\
\text { szarów niedorozwoju - jest podyktowany rozwo- } \\
\text { jem centrum i od niego zależny. Rozwój centrów } \\
\text { jest związany ze stopniem koncentracji przestrzen- } \\
\text { nej kapitału, infrastruktury i dziedzictwa kulturo- } \\
\text { wego }\end{array}$ & $\begin{array}{l}\text { Poprawa atrakcyjności } \\
\text { obszarów zmarginalizo- } \\
\text { wanych w celu zatrzy- } \\
\text { mania MSP, które mogą } \\
\text { stać się stymulatorem } \\
\text { rozwoju, zmniejszając za- } \\
\text { leżność obszarów zmar- } \\
\text { ginalizowanych od cen- } \\
\text { trów rozwoju gospodar- } \\
\text { czego }\end{array}$ \\
\hline $\begin{array}{l}\text { Neoklasyczna } \\
\text { regionalna teoria } \\
\text { wzrostu }\end{array}$ & $\begin{array}{l}\text { W myśl tej teorii zakłada się, że różnice w zakresie } \\
\text { posiadanych przez dany region czynników rozwoju } \\
\text { są likwidowane na skutek przemieszczania się. } \\
\text { Przedsiębiorcy dążą do takiej lokalizacji, w której } \\
\text { osiągną największe korzyści z zainwestowanego } \\
\text { kapitału }\end{array}$ & $\begin{array}{l}\text { Rozwój obszarów zmar- } \\
\text { ginalizowanych powi- } \\
\text { nien być wspierany w } \\
\text { celu podniesienia atrak- } \\
\text { cyjności dla lokowania } \\
\text { nowych działalności gos- } \\
\text { podarczych, w tym roz- } \\
\text { woju MSP }\end{array}$ \\
\hline $\begin{array}{l}\text { Teoria postkey- } \\
\text { nesowska }\end{array}$ & $\begin{array}{l}\text { Teoria ta eksponuje inwestycje jako najważniejszy } \\
\text { czynnik wzrostu, ze względu na powstające w ich } \\
\text { wyniku efekty mnożnikowe (inwestycje w jednej } \\
\text { dziedzinie pobudzają w innych). Inwestycje są } \\
\text { ograniczone przestrzenie i znacznie większy ich } \\
\text { poziom występuje w obszarach rozwiniętych, co } \\
\text { powoduje pogłębianie się dysproporcji rozwojo- } \\
\text { wych w regionach }\end{array}$ & $\begin{array}{l}\text { MSP powinny zostać } \\
\text { zaangażowane do reali- } \\
\text { zacji inwestycji w ob- } \\
\text { szarach zmarginalizo- } \\
\text { wanych, w tym inwe- } \\
\text { stycji publicznych }\end{array}$ \\
\hline $\begin{array}{l}\text { Teoria bazy } \\
\text { ekonomicznej }\end{array}$ & $\begin{array}{l}\text { W myśl tej teorii zakłada się, że poprawa sytuacji } \\
\text { gospodarczej w regionie zależy od eksportu } \\
\text { i popytu zewnętrznego. Rozwój produkcji i usług } \\
\text { nastawionych na zewnętrznych odbiorców skutkuje } \\
\text { tworzeniem nowych miejsc pracy i wzrostem } \\
\text { dochodów społeczności lokalnej. W gospodarce } \\
\text { regionu wyróżnia się dwa sektory: bazowy } \\
\text { (pierwotny), pełniący funkcje ponadregionalne oraz } \\
\text { niebazowy (wtórny) - zajmujący się produkcją } \\
\text { i usługami na potrzeby wewnątrzregionalne. Roz- } \\
\text { wój sektora bazowego poprzez wzrost dochodów } \\
\text { regionu z eksportu może pobudzić wzrost sektora } \\
\text { niebazowego }\end{array}$ & $\begin{array}{l}\text { Pobudzanie skłonności } \\
\text { do zachowań eksporto- } \\
\text { wych MSP, które spo- } \\
\text { wodują wzrost docho- } \\
\text { dów regionu z eksportu } \\
\text { co pozwoli na rozwój } \\
\text { innych podmiotów dzia- } \\
\text { łających na rynku lo- } \\
\text { kalnym i regionalnym }\end{array}$ \\
\hline
\end{tabular}


Tabela 4 (cd.)

\begin{tabular}{|c|c|c|}
\hline 1 & 2 & 3 \\
\hline $\begin{array}{l}\text { Teoria rozwoju } \\
\text { endogenicznego }\end{array}$ & $\begin{array}{l}\text { Teoria ta zakłada małą mobilność zasobów } \\
\text { regionalnych między regionami. Główne cele to } \\
\text { stworzenie równych szans przedsiębiorstwom } \\
\text { z regionów mniej i bardziej rozwiniętych oraz } \\
\text { zapewnienie konkurencyjności firmom z regionów } \\
\text { słabo rozwiniętym. Cele te są realizowane poprzez: } \\
\text { powstawanie nowych firm, w tym małych } \\
\text { i średnich, oraz zapoczątkowanie nowych rodzajów } \\
\text { produkcji, przedsiębiorczość i wdrażanie innowacji } \\
\text { oraz tworzenie miejsc pracy we wszystkich } \\
\text { dziedzinach gospodarki. W związku z tym polityka } \\
\text { regionalna powinna być skierowana na usuwanie } \\
\text { wewnętrznych barier wzrostu, co ma służyć jak } \\
\text { najlepszemu wykorzystywaniu posiadanych za- } \\
\text { sobów, może być to realizowane np. poprzez } \\
\text { tworzenie nowych przedsiębiorstw, nakłady na } \\
\text { B+R, kształcenie zawodowe, rozwój usług pro- } \\
\text { dukcyjnych (np. doradztwo, marketing, reklama), } \\
\text { popieranie kooperacji między firmami lokalnymi, } \\
\text { współpraca z firmami zagranicznymi oraz po- } \\
\text { między sektorem prywatnym i publicznym }\end{array}$ & $\begin{array}{l}\text { MSP, aby mogły przy- } \\
\text { czynić się do rozwoju } \\
\text { obszarów zmarginalizo- } \\
\text { wanych, powinny budo- } \\
\text { wać sieci kooperacyjne } \\
\text { oraz inicjować wspó- } \\
\text { pracę z szeroko rozu- } \\
\text { mianym otoczeniem biz- } \\
\text { nesu }\end{array}$ \\
\hline $\begin{array}{l}\text { Koncepcja cyklu } \\
\text { życia produktu }\end{array}$ & $\begin{array}{l}\text { Według tej koncepcji uzależnia się rozwój regionu } \\
\text { od innowacji generowanych przez przedsiębior- } \\
\text { stwa. Decyzje lokalizacyjne są podejmowane } \\
\text { w zależności od fazy rozwoju produktu. W fazie } \\
\text { rozwoju konieczny jest potencjał innowacyjny, } \\
\text { który znajduje się w centrum, natomiast w fazach } \\
\text { wzrostu, dojrzałości i schyłku następuje przesunie- } \\
\text { cie produkcji z centrum na peryferie }\end{array}$ & $\begin{array}{l}\text { MSP, prowadząc dzia- } \\
\text { łalność innowacyjną, } \\
\text { generują wzrost regio- } \\
\text { nu, w obszarach zmargi- } \\
\text { nalizowanych powinny } \\
\text { upowszechniać inno- } \\
\text { wacje pochodzące z cen- } \\
\text { trów przez naśladownic- } \\
\text { two }\end{array}$ \\
\hline $\begin{array}{l}\text { Koncepcje } \\
\text { biegunów } \\
\text { wzrostu }\end{array}$ & $\begin{array}{l}\text { W teoriach tych przyjmuje się, że rozwój zostaje } \\
\text { zapoczątkowany w nielicznych branżach i miej- } \\
\text { scach, a następnie na zasadzie dyfuzji obejmuje } \\
\text { swym zasięgiem pozostałą część danego teryto- } \\
\text { rium. rozwój w biegunach wzrostu następuje na } \\
\text { skutek sektora innowacji, który jest sektorem } \\
\text { napędowym i wzrasta szybciej niż reszta gospodar- } \\
\text { ki. Bieguny wzrostu przyciągają zasoby z innych } \\
\text { branż, uzależniając je od siebie i zmniejszając ich } \\
\text { możliwości rozwoju (efekty wyptukiwania). } \\
\text { Z czasem pojawiają się efekty rozprzestrzeniania } \\
\text { polegające na pobudzaniu wzrostu innych branż }\end{array}$ & $\begin{array}{l}\text { MSP funkcjonujące w } \\
\text { obszarach zmarginali- } \\
\text { zowanych będą miały } \\
\text { zaplecze dla rozwoju } \\
\text { działalności innowacyj- } \\
\text { nej (np. duże firmy, } \\
\text { inkubatory i parki tech- } \\
\text { nologiczne) w biegu- } \\
\text { nach wzrostu. Rozwój } \\
\text { obszarów zmarginalizo- } \\
\text { wanych może następo- } \\
\text { wać poprzez innowa- } \\
\text { cyjne MSP. }\end{array}$ \\
\hline
\end{tabular}




\begin{tabular}{|c|c|c|}
\hline 1 & 2 & 3 \\
\hline $\begin{array}{l}\text { Teoria kumula- } \\
\text { tywnej okrężnej } \\
\text { przyczynowości }\end{array}$ & $\begin{array}{l}\text { W myśl tej teorii w stymulowaniu rozwoju w } \\
\text { regionie duże znaczenia ma przepływ kapitału i siły } \\
\text { roboczej do miejsc o najkorzystniejszych warun- } \\
\text { kach do prowadzenia dzielności gospodarczej. } \\
\text { Występują zatem dwa równoczesne procesy, } \\
\text { pierwszy polegający na rozprzestrzenianiu się } \\
\text { aktywności ekonomicznej jak również dobrobytu } \\
\text { z miejsc najwyżej do najsłabiej rozwiniętych oraz } \\
\text { drugi, wymywający zasoby z miejsc najsłabiej do } \\
\text { najwyżej rozwiniętych. Drugi proces występuje } \\
\text { głównie w regionach słabiej rozwiniętych, jego } \\
\text { konsekwencją jest odpływ czynników produkcji } \\
\text { (kapitału, wykwalifikowane siły roboczej itp.). } \\
\text { Regiony słabiej rozwinięte wymagają interwencji } \\
\text { państwa, np. w postaci inwestycji publicznych, } \\
\text { które mogą przyciągnąć inne inwestycje np. BIZ } \\
\text { i uruchomić proces mnożnikowy inicjujący rozwój } \\
\text { danego obszaru }\end{array}$ & $\begin{array}{l}\text { Działalność MSP powi- } \\
\text { nna być wspierana przez } \\
\text { państwo w określonych } \\
\text { dziedzinach, szczegól- } \\
\text { nie tych z potencjałem } \\
\text { wzrostu. Pozwoli to na } \\
\text { uruchomienie efektu } \\
\text { mnożnikowego (wzrost } \\
\text { pobudza dalszy wzrost) }\end{array}$ \\
\hline $\begin{array}{l}\text { Rozwój oparty } \\
\text { na procesach } \\
\text { innowacyjnych }\end{array}$ & $\begin{array}{l}\text { Koncepcja ta zakłada, że o zdolności rozwoju } \\
\text { regionu decyduje jego potencjał do stałego gene- } \\
\text { rowania szeroko rozumianych innowacji. Warun- } \\
\text { kiem innowacyjnego rozwoju jest struktura oparta } \\
\text { na MSP oraz istnienie lokalnych sieci innowacji } \\
\text { (przedsiębiorstwa, władze lokalne, instytucje oto- } \\
\text { czenia biznesu, ośrodki nauki) wspierających pow- } \\
\text { stawanie i wdrażanie innowacji }\end{array}$ & $\begin{array}{l}\text { MSP są ważnymi akto- } \\
\text { rami procesów innowa- } \\
\text { cyjnych, aby zachodził } \\
\text { proces absorbcji inno- } \\
\text { wacji konieczne jest } \\
\text { budowanie lokalnych } \\
\text { sieci współpracy, które } \\
\text { z jednej strony będą } \\
\text { wspierały procesy inno- } \\
\text { wacyjne tych podmio- } \\
\text { tów, a z drugiej popra- } \\
\text { wią ich przeżywalność, } \\
\text { szczególnie w obsza- } \\
\text { rach zmarginalizowa- } \\
\text { nych }\end{array}$ \\
\hline $\begin{array}{l}\text { Koncepcja } \\
\text { terytorialnych } \\
\text { systemów } \\
\text { produkcyjnych } \\
\text { (TSP) }\end{array}$ & $\begin{array}{l}\text { W myśl tej koncepcji, zaobserwowano, że część } \\
\text { obszarów słabo rozwiniętych przekształciło się } \\
\text { w obszary wzrostu dzięki ekspansji małych } \\
\text { i średnich przedsiębiorstw. Cechą charakterystycz- } \\
\text { ną jest występowanie sieci MSP komplementar- } \\
\text { nych względem siebie, elastycznie reagujących na } \\
\text { zmiany zachodzące w otoczeniu, wykorzystujących } \\
\text { lokalną siłę roboczą. TSP to geograficzne skupisko } \\
\text { przedsiębiorstw jednego lub kilku rodzajów pro- } \\
\text { dukcji, które decyduje się na wspólną strategię } \\
\text { i koordynację środków na rzecz rozwoju z wszy- } \\
\text { stkim partnerami lokalnymi. Budowanie sieci } \\
\text { sprzyja przepływowi informacji, wymianie wiedzy. }\end{array}$ & $\begin{array}{l}\text { Tworzenie terytorialnych } \\
\text { systemów produkcyj- } \\
\text { nych w obszarach zmar- } \\
\text { ginalizowanych może } \\
\text { przyczynić się do pow- } \\
\text { stawania nowych MSP } \\
\text { opartych na innowa- } \\
\text { cjach technologicznych } \\
\text { o dużej wartości doda- } \\
\text { nej, co może pozytyw- } \\
\text { nie wpłyną na rozwój } \\
\text { społeczno-gospodarczy } \\
\text { tych regionów }\end{array}$ \\
\hline
\end{tabular}


Tabela 4 (cd.)

\begin{tabular}{|c|c|c|}
\hline 1 & 2 & 3 \\
\hline $\begin{array}{l}\text { Koncepcja } \\
\text { uczącego się } \\
\text { regionu }\end{array}$ & $\begin{array}{l}\text { Koncepcja ta zakłada, że kluczowym czynnikiem } \\
\text { rozwoju regionalnego są szeroko rozumiane } \\
\text { innowacje oraz umiejętność akceptacji do zmienia- } \\
\text { jących się uwarunkowań rynkowych. Zadaniem } \\
\text { podmiotów polityki regionalnej jest stymulowanie } \\
\text { czynników odpowiedzialnych za rozwój nauki, } \\
\text { badań i techniki oraz doskonalenie kadr poprzez } \\
\text { tworzenie sieci współpracy miedzy sferą nauki } \\
\text { i biznesu np. w postaci parków naukowo-tech- } \\
\text { nologicznych }\end{array}$ & $\begin{array}{l}\text { Budowanie sieci współ- } \\
\text { pracy sfery nauki i biz- } \\
\text { nesu z udziałem sektora } \\
\text { MSP przez władze samo- } \\
\text { rządowe w obszarach } \\
\text { zmarginalizowanych. } \\
\text { Umożliwi to rozwój } \\
\text { tych podmiotów poprzez } \\
\text { szeroko rozumianą dzia- } \\
\text { łalność innowacyjna }\end{array}$ \\
\hline $\begin{array}{l}\text { Koncepcja } \\
\text { wielkiego } \\
\text { pchnięcia }\end{array}$ & $\begin{array}{l}\text { Impulsem do rozwoju w regionach słabo rozwinię- } \\
\text { tych jest realizacja kompleksu inwestycji autono- } \\
\text { micznych (głównie infrastrukturalnych), które } \\
\text { mogą być realizowane niezależnie od rozmiarów } \\
\text { popytu i poziomu aktywności gospodarczej. } \\
\text { Inwestycje te mogą poprawić atrakcyjność in- } \\
\text { westycyjną danego regionu }\end{array}$ & $\begin{array}{l}\text { Rozwój obszarów zmar- } \\
\text { ginalizowanych powi- } \\
\text { nien opierać się na in- } \\
\text { westycjach tzw. autono- } \\
\text { micznych, które będą } \\
\text { stymulowały rozwój } \\
\text { MSP }\end{array}$ \\
\hline
\end{tabular}

Źródło: opracowanie własne na podstawie: Makieła 2008; Kuciński 2010; Chądzyński J. red. i inni 2007; Brol 2006; Stawasz 2004, s. 55-85; Stöhr 1987; Bąk i inni 2001.

Zaprezentowane wybrane koncepcje rozwoju regionalnego nie objaśniają w pełni mechanizmu rozwoju obszarów zmarginalizowanych poprzez stymulowanie rozwoju małych i średnich przedsiębiorstw. Są one jedynie przykładem poszukiwania odpowiedzi na pytania: czy małe i średnie przedsiębiorstwa mogą być siłą sprawczą rozwoju obszarów zmarginalizowanych? Co ma wpływ na rozwój MSP w tych obszarach? Jakie są możliwości poprawy dynamiki rozwoju małych i średnich przedsiębiorstw w tych obszarach?

Małe i średnie przedsiębiorstwa charakteryzują się znaczną elastycznością i skutecznością w działaniach na rynku. Są nawet zdolne konkurować z dużymi firmami ze względu na precyzyjną kontrolę kosztów, szybką dyfuzję innowacji oraz wysoką motywację do osiągnięć właściciela i pracowników (Targalski 2003, s. 14). Dla rozwoju obszarów zmarginalizowanych ważne jest, aby małe i średnie przedsiębiorstwa były zaangażowane w budowanie sieci kooperacyjnej z innymi podmiotami oraz sieci współpracy ze sferą nauki, co mogłoby się przyczynić do poprawy aktywności tych przedsiębiorstw w zakresie działalności innowacyjnej, inwestycyjnej i eksportowej. Dlatego potrzeba wsparcia sektora MSP jest zauważalna na szczeblu lokalnym przez jednostki samorządu terytorialnego, które starają się stworzyć system zachęt dla rozwoju małych i średnich przedsiębiorstw obejmujących głównie tworzenie lokalnego sytemu prawnego 
i podatkowego, prowadzenie odpowiedniej gospodarki gruntami, planowanie przestrzenne, usprawnienie pracy urzędów w celu sprawnego załatwienia wszelkich formalności związanych z prowadzeniem firmy. Jednak rola środowiska lokalnego w rozwoju sektora MSP, szczególnie na terenach zmarginalizowanych, nie powinna się ograniczać się tylko do dostarczania zasobów, ale również ważne jest, aby środowisko to tworzyło przyjazny dla przedsiębiorczości klimat, przejawiający się m.in. obecnością lokalnej „kultury przedsiębiorczości”, wsparciem lokalnych instytucji publicznych oraz kreatywnością lokalnych społeczności. 



\section{Determinanty rozwoju małych i średnich przedsiębiorstw w obszarach zmarginalizowanych}

\subsection{Teorie rozwoju małych i średnich przedsiębiorstw}

W literaturze przedmiotu używane są zamiennie pojęcia „wzrost” i „rozwój firmy", nie są to jednak synonimy, a pojęcia komplementarne. Wzrost jest traktowany jak element konieczny dla rozwoju przedsiębiorstwa. Wzrost odnosi się do zmian ilościowych (np. zwiększenie obrotów, zatrudnienia), natomiast rozwój obejmuje zmiany jakościowe (np. wprowadzenie innowacji, umiejętność dostosowania się na potrzeby klientów itp.) (Lisowska 2012a, s. 82). Istotą rozwoju firmy jest zmiana istniejącego stanu rzeczy w czasie (Machaczka 1998, Masurel i Mantfort 2006, Baruk 2009, Steffens, Davidsson, Fitzsimmonts 2009). Charakter rozwoju może być celowy lub przypadkowy, postępowy albo wsteczny, samoistny bądź wymuszony, ciągły lub skokowy (Machaczka 1998, Bławat red. 2004). Może on dotyczyć całej firmy, jak również jej obszarów, np. celów, struktury, technologii, a także odnosić się do zmian zachodzących pod wpływem otoczenia. Rozwój jest traktowany jako proces uporządkowany i przebiegający w czasie, który można analizować w kontekście osiągniętego stanu, jak również etapów jego osiągnięcia (Machaczka 1998). Według A. Kamińskiej rozwój przedsiębiorstwa to wprowadzenie zmian produktowych, procesowych, strukturalnych i technologicznych, pozwalających na dostosowanie się firmy do zachodzących zmian oraz na budowanie przewagi konkurencyjnej (Kamińska 2011, s. 21). Nieco inaczej, bo w dwojaki sposób, definiuje rozwój J. Machaczka: jako likwidację tzw. luki rozwojowej (różnica miedzy stanem potrzeb a stanem możliwości) lub jako proces doskonalenia pozycji, jaką zajmuje firma w otoczeniu (Machaczka 1998, s. 14).

W licznych opracowaniach (np. Gibb, Davies 1990; North, Smallbone 1993; Storey 1994; Davidsson, Wiklund, 2000; Fisher, Reuber, 2003) wiele miejsca poświęca się czynnikom i teoriom wzrostu, których klasyfikacji podjęła się J. Wasilczuk (2005, s. 25), wyodrębniając podejście:

- zasobowe,

- personalne,

- strategiczne,

- odwołujące się do otoczenia, 
- zintegrowane,

- oparte na cyklu życia firmy.

W pierwszym podejściu - zasobowym - większość teorii wyjaśniających wzrost firmy odnosi się do zasobów firmy, głównie do kapitału finansowego i ludzkiego. W podejściu personalnym analizuje się czynniki związane z osobą właściciela menedżera, takie jak: wiek, wykształcenie, płeć, doświadczenie, motywacja, osobowość i temperament. Kolejne z podejść - strategiczne - odnosi się do procesu formułowania strategii i sposobu zarządzania firmą jako czynników wzrostu firmy. W podejściu odwołującym się do otoczenia główny nacisk kładzie się na elementy otoczenia, które kształtują wzrost i rozwój przedsiębiorstwa. Natomiast podejście zintegrowane to szersze spojrzenie na wzrost firmy, gdyż teorie wzrostu opierają się na więcej niż jednym z wcześniej wymienionych podejść. Ostatnie skupia się na analizie cyklu życia przedsiębiorstwa, w którym teorie wzrostu odnoszą się do czynników wzrostu w poszczególnych fazach rozwoju formy (Wasilczuk 2005, s. 25-26).

Teoretycznych ram do analizy rozwoju małych i średnich przedsiębiorstw dostarczają liczne koncepcje i modele wzrostu/rozwoju opisane w literaturze przedmiotu (np. Greiner 1972; Adiezs 2004; Churchil, Lewis 1983; Scott, Bruce 1987; Quinn, Cameron 1983; Machaczka 1998; Dodge, Robbins 1992; Storey 1994), jednak większość z nich odnosi się raczej do dużych przedsiębiorstw, co nie zawsze daje możliwość ich zastosowania w małych i średnich przedsiębiorstwach.

W literaturze przedmiotu opisanych jest ponad 100 różnych modeli fazowych rozwoju firmy (Levie, Lichtenstein 2010), w których analizuje się wycinek życia przedsiębiorstwa od momentu założenia do śmierci (likwidacji) (np. Greiner 1972; Mintzberg 1979; Churchill, Lewis, 1983; Miller, Friesen 1983; Scott, Bruce 1987). Modele te różnią się liczbą analizowanych faz, np. modele trzyfazowe (Smith i inni 1985), modele czterofazowe (Quinn, Cameron 1983), pięciofazowe (Greiner 1972; Galbraith 1982; Churchill, Lewis 1983; Scott, Bruce 1987), sześciofazowe (Eggers, Leahy, Churchill 1994; Lavoie, Culbert 1978), siedmiofazowe (Flamholtz 1986) oraz jedenastofazowe (Bruce 1976). Modele te były licznie krytykowane ze względu na uproszczenie rzeczywistości i brak poparcia empirycznego, np. nie wszystkie przedsiębiorstwa przechodzą wszystkie fazy rozwoju, a w niektórych fazy mogą się powtarzać wielokrotnie (np. Storey 1994; Birley, Westhead 1990; Miller, Friesen 1983; Gibb, Davies 1990; Vinnell, Hamilton 1999).

Niektóre z tych modeli, np. L.E. Greinera, M. Scotta i B. Bruce'a, N. Churchilla i V. Lewisa są przydatne do identyfikacji kluczowych uwarunkowań rozwoju małych i średnich przedsiębiorstw.

W modelu L.E. Greinera rozwój firmy to występujące na przemian procesy ewolucji i rewolucji ${ }^{1}$, rozpatrywane ze względu na jego wiek i wielkość oraz

1 „Ewolucja” opisuje te fazy wzrostu organizacji, które cechuje stopniowy i harmonijny wzrost, ,rewolucja” to okres wstrząsów i zamieszania. 
stopę wzrostu gałęzi przemysłu w którym działa (Greiner 1972, Urbanowska-Sojkin 2003, Machaczka i Machaczka 2011). Cykl życia organizacji w modelu tym składa się z pięciu faz, a każda z nich kończy się umownie rewolucją, będąc odpowiedzią na pojawiający się kryzys. Firma wzrasta do momentu pojawienia się kryzysu, a jego przezwyciężenie pozwala na dalszy rozwój (Greiner 1972). Faza pierwsza to wzrost przez kreatywność - powstanie i wzrost organizacji są możliwe dzięki innowacyjności i kreatywności przedsiębiorcy. Faza ta kończy się wystąpieniem kryzysu przywództwa, polegającego na utracie kontroli kierownictwa nad rosnąca skalą działalności i rozmiarami organizacji (Greiner 1972, Machaczka i Machaczka 2011, Zelek 2003). Fazie drugiej, wzrost przez formalizację, podlegają obowiązki i kompetencje na poszczególnych szczeblach hierarchii organizacyjnej. Firma osiąga wzrost głównie dzięki doskonaleniu swojej struktury organizacyjnej i rozbudowywaniu systemu zarządzania. Faza ta kończy się kryzysem autonomii. Kolejna faza to wzrost przez delegację uprawnień, która charakteryzuje się przeniesieniem kompetencji i odpowiedzialności na kierowników niższych szczebli (Greiner 1972, Machaczka 1998, Wieczerzyńska 2009), a kończy się kryzysem decentralizacji; konieczne jest zatem ograniczenie autonomii niższych szczebli zarządzania. Faza czwarta, czyli wzrost przez koordynację, prowadzi do synchronizacji działań komórek organizacyjnych $\mathrm{w}$ jednym kierunku (tworzone są np. grupy ukierunkowane na produkt, przedsięwzięcia). Wzrost firmy następuje dzięki doskonaleniu polityki firmy, jak również wprowadzeniu modyfikacji w strukturze organizacyjnej. Rozrastanie się systemu może doprowadzić do kryzysu biurokratyzacji, polegającego na zmniejszeniu efektywności funkcjonowania dużych organizacji ze względu na skłonność do biurokracji. Ostatnia faza to wzrost przez współdziałanie, w której pracownicy powinni mieć współodpowiedzialność za organizację (Greiner 1972, Wieczerzyńska 2009, Machaczka i Machaczka 2011). Ma to wpływ na rozwijanie zaangażowania i skuteczność osiągania celów firmy.

Kontynuacją koncepcji L.E Greinera jest model N. Churchill i V. Lewis (Churchill i Lewis 1983) oraz M. Scotta i B. Bruce'a (Scott i Bruce 1987). Modele te różnią się tylko zakresem analizowanych obszarów. W modelu N. Churchill i V. Lewis o rozwoju firmy decydują czynniki związane z zasobami firmy (finansowe, osobowe, systemowe, biznesowe) oraz cechami właściciela (motywacja, zdolność do działania, zdolności menedżerskie oraz strategiczne) (Churchill and Lewis 1983, Machaczka 1998) (por. tabela 5).

Czynniki wpływające na przechodzenie do poszczególnych faz mają różne znaczenie w poszczególnych fazach rozwoju firmy, np. umiejętności: delegowania $i$ strategiczne nie mają znaczenia $w$ fazach początkowych, natomiast $\mathrm{w}$ momencie podjęcia decyzji o wzroście organizacji nabierają znaczenia, z kolei umiejętności operacyjne właściciela, takie jak marketing, produkcja czy dystrybucja, są istotne $\mathrm{w}$ fazie początkowej. Natomiast w przypadku czynników związanych z firmą ich rola ulega zmianie wraz z przechodzeniem do kolejnych 
faz, np. w początkowych fazach najistotniejsze są zasoby gotówkowe oraz biznesowe (relacje z klientami, udział w rynku, procesy produkcyjne, dystrybucja i technologia, reputacja). System informacyjny, planowanie i kontrola odgrywają coraz większą rolę w rosnącej organizacji, a planowanie strategiczne w fazie stabilizacji (Wasilczuk 2005, s. 61-61).

Tabela 5. Czynniki wpływające na przechodzenie do poszczególnych faz

\begin{tabular}{|c|c|}
\hline Związane z właścicielem-menedżerem & Związane z firmą \\
\hline $\begin{array}{l}\text { Umiejętność łączenia celów osobistych } \\
\text { i biznesowych }\end{array}$ & $\begin{array}{l}\text { Zasoby finansowania, m.in. gotówka i zdolności } \\
\text { kredytowe }\end{array}$ \\
\hline $\begin{array}{l}\text { Umiejętności operacyjne (marketing, pro- } \\
\text { dukcja, dystrybucja) }\end{array}$ & $\begin{array}{l}\text { Zasoby ludzkie: pracownicy, ich liczba i kwalifi- } \\
\text { kacje }\end{array}$ \\
\hline Umiejętności delegowania & Zasoby systemowe: system informacyjny, \\
\hline Umiejętności strategiczne & planowanie i kontrola \\
\hline & $\begin{array}{l}\text { Zasoby biznesowe: relacje z klientami, udział } \\
\text { w rynku, procesy produkcyjne, dystrybucja i tech- } \\
\text { nologia, reputacja }\end{array}$ \\
\hline
\end{tabular}

Źródło: Churchill, Lewis 1983, cyt. za Wasilczuk 2005, s. 61.

Natomiast w modelu M. Scotta i B. Bruce'a analizowane są na każdym etapie rozwoju: stopień rozwoju branży, kluczowe kwestie dla przedsiębiorstwa, rola przedsiębiorcy, styl zarządzania, struktura organizacyjna, systemy i mechanizmy kontroli, źródła finansowania oraz asortyment i kanały dystrybucji (Masurel i Montfort 2006; Roomi 2009). Jak już wcześniej wspomniano, modele te były krytykowane przez licznych badaczy, gdyż nie do końca są użyteczne w wyjaśnieniu procesu wzrostu i rozwoju firmy.

Według B. Hasen i R.T. Hamiltona (2011) małe przedsiębiorstwach można podzielić na dwie kategorie: rosnące i nierosnące. Klasyfikację tych firm dokonano na podstawie zmiennych $\mathrm{w}$ ramach trzech obszarów: właścicielmenedżer, przedsiębiorstwo i proces uczenia się (por. tabela 6).

Tabela 6. Przedsiębiorstwa „rosnące” i „nierosnące” - analiza porównawcza

\begin{tabular}{|c|l|l|}
\hline Wyszczególnienie & \multicolumn{1}{|c|}{ Przedsiębiorstwa „,rosnące” } & \multicolumn{1}{c|}{$\begin{array}{c}\text { Przedsiębiorstwa } \\
\text { „nierosnące” }\end{array}$} \\
\hline 1 & \multicolumn{1}{|c|}{2} & \multicolumn{1}{|c|}{3} \\
\hline Właściciel-menedżer & $\begin{array}{l}\text { Ambicja wzrostu/rozwoju } \\
\text { Pozytywny i oportunistyczny } \\
\text { światopogląd }\end{array}$ & $\begin{array}{l}\text { Styl życia } \\
\text { Wewnętrzna orientacja } \\
\text { Negatywny i deterministyczny } \\
\text { światopogląd }\end{array}$ \\
\hline
\end{tabular}




\begin{tabular}{|l|l|l|}
\hline 1 & \multicolumn{1}{|c|}{2} & \multicolumn{1}{|c|}{3} \\
\hline Przedsiębiorstwo & $\begin{array}{l}\text { Kultura innowacyjna } \\
\text { Elastyczność i nowoczesność } \\
\text { Wysokie zaangażowanie wyso- } \\
\text { kich technologii }\end{array}$ & $\begin{array}{l}\text { Kultura tradycyjna i nieelastyczna } \\
\text { Zagrożenia i ograniczenia wyni- } \\
\text { kające z zewnętrznego otoczenia } \\
\text { Niski poziom innowacyjności } \\
\text { i zaangażowania wysokich techno- } \\
\text { logii }\end{array}$ \\
\hline Proces uczenia się & $\begin{array}{l}\text { Obszerna profesjonalna sieć } \\
\text { Uczenie się głównie praktyki } \\
\text { Szkolenie i rozwój personelu }\end{array}$ & $\begin{array}{l}\text { Mało profesjonalna sieć } \\
\text { Skromny proces szkoleniowy i roz- } \\
\text { wój pracowników } \\
\text { Słaba orientacja na proces uczenia } \\
\text { się }\end{array}$ \\
\hline
\end{tabular}

Źródło: opracowanie własne na podstawie Hansen, Hamilton 2011, s. 290.

Inne podejście do wzrostu firmy o charakterze zintegrowanym przedstawił D. Storey, który poddał krytyce modele fazowe i na tej podstawie zbudował model statyczny, uwzgledniający kombinację trzech czynników: charakterystykę przedsiębiorcy (np. motywacja, wykształcenie, doświadczenie, wiek, płeć, tradycje rodzinne), charakterystykę przedsiębiorstwa (np. wiek, sektor, stan prawny, lokalizacja, wielkość i własność) oraz rodzaj strategii rozwoju (np. poziom techniczny, pozycja rynkowa, nowe produkty, konkurencyjność) (Piasecki 2001, s. 51). W modelu tym zakłada się, że przez odpowiednie zestawienie czynników z każdej grupy firma może osiągnąć szybszy wzrost (Wasilczuk 2005, s. 43). Przedsiębiorstwo ma większe szanse na przeżycie i szybki wzrost, jeśli zostało założone i jest prowadzone przez osobę (Kamińska 2011, s. 33):

- z wyższym wykształceniem,

- $\mathrm{z}$ doświadczeniem na kierowniczym stanowisku,

- w średnim wieku,

- wywodzącą się z rodziny z tradycjami biznesowymi,

- posiadające doświadczenie $\mathrm{w}$ danym sektorze.

Zachowania przedsiębiorcy są uwarunkowane cechami biograficznymi, behawioralnymi i relacyjnymi ${ }^{2}$ (Bławat 2003) oraz okazjami pojawiającymi się w otoczeniu przedsiębiorstwa, np. dostępność źródeł finansowania, sprzyjająca polityka państwa i przepisy prawne itp. Pomiędzy cechami przedsiębiorcy zachodzą interakcje, co może przyczynić się do niezależnego działania przedsiębiorcy z własnej inicjatywy oraz w perspektywie rozwoju przedsiębiorstwa (por. rysunek 20, Borowiecki, Siuta-Tokarska 2008).

\footnotetext{
${ }^{2}$ Szerzej na temat cech biograficznych, behawioralnych i relacyjnych w podpunkcie 3.2.2.
} 


\begin{tabular}{|l|}
\hline $\begin{array}{l}\text { Cechy biograficzne } \\
\text { (wiek, płeć, wykształcenie } \\
\text { doświadczenie zawodowe) }\end{array}$ \\
\hline \hline Umiejętności: \\
- rozwiazywania problemów \\
- kreatywność \\
- perswazja \\
- planowanie \\
- negocjowanie \\
- podejmowanie decyzji \\
\hline \begin{tabular}{l} 
Atrybuty: \\
- wiara w siebie \\
- autonomia \\
- orientacja na sukces \\
- dynamika \\
\hline
\end{tabular} \\
\hline $\begin{array}{l}\text { Stosunek do: } \\
\text { - zmian, } \\
\text { - konkurencji } \\
\text { - osiągnięć } \\
\text { - ryzyka } \\
\text { - autonomii }\end{array}$ \\
\hline
\end{tabular}
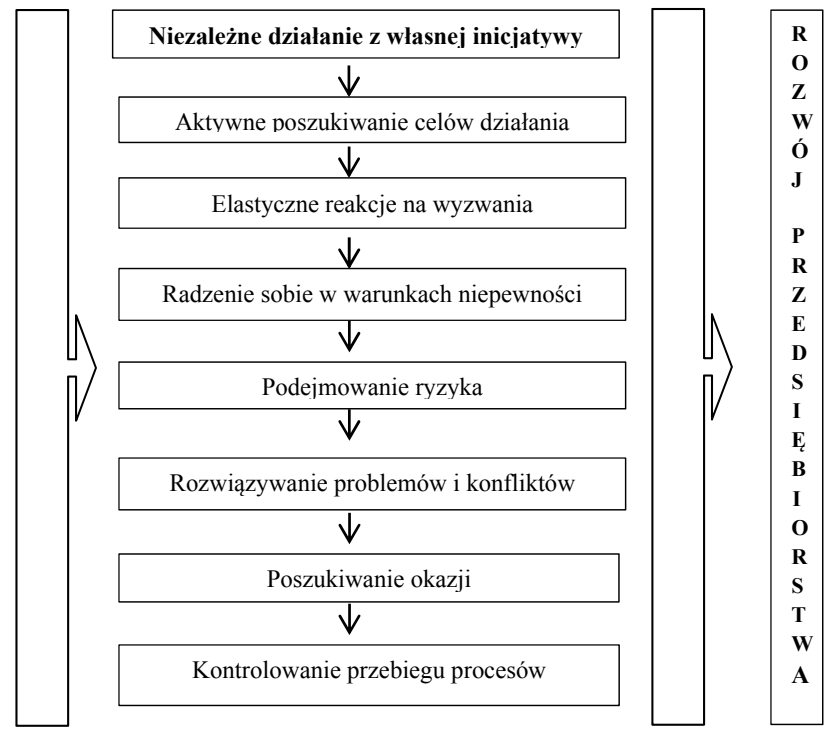

Rysunek 20. Cechy przedsiębiorcy i ich wpływ na rozwój przedsiębiorstwa Źródło: opracowanie własne na podstawie Davidson 1995, cyt. za Borowiecki, Siuta-Tokarska 2008, s. 36; Gibb 2003, cyt. za ibidem, s. 37

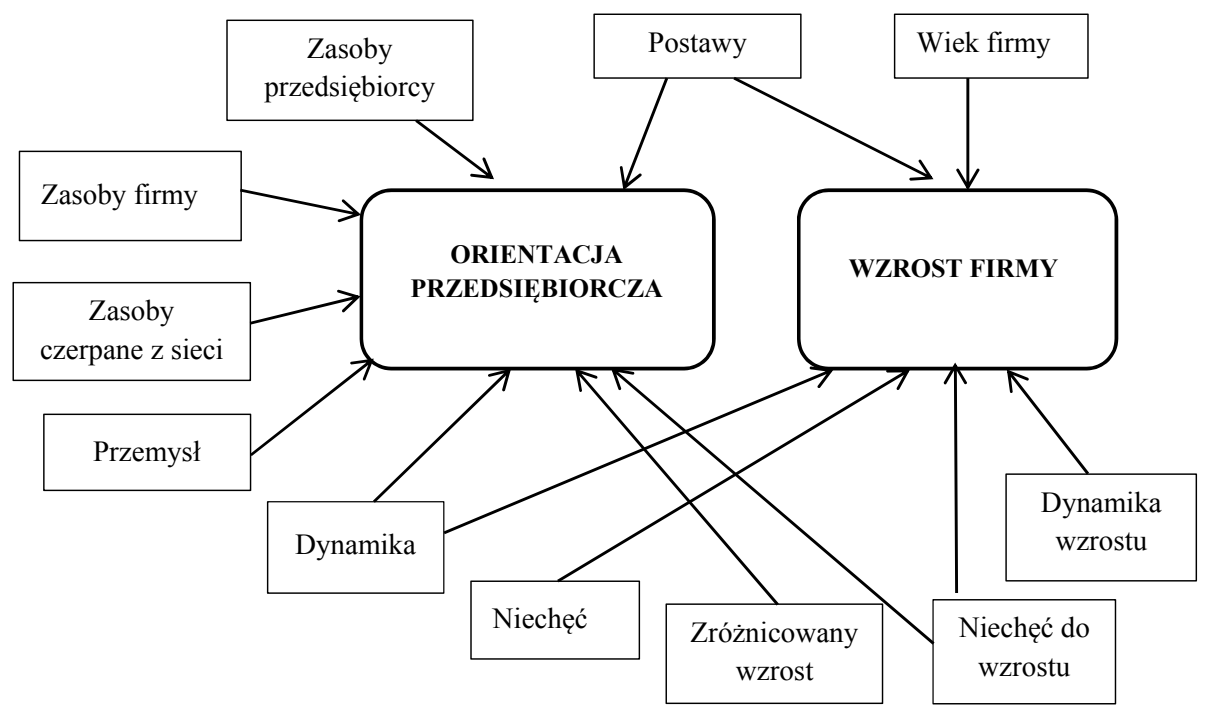

Rysunek 21. Zaktualizowany model wzrostu/rozwoju małych przedsiębiorstw Źródło: Wiklund, Patzelt, Shepherd 2009, s. 359 
Inne podejście do wzrostu firm, tzw. zintegrowane, przedstawili J. Wiklund, H. Patzelt, D. A. Shepherd, oparte na dwóch grupach zmiennych, odnoszące się do przedsiębiorczej orientacji i wzrostu firmy (por. rysunek 21). Model ten pozwala na jednoczesną analizę relacji pomiędzy orientacją przedsiębiorczą a wzrostem firmy, co pozwala na pełny obraz badanego zjawiska. Model ten wskazuje na szereg propozycji dla podjęcia badań odnośnie do czynników odpowiedzialnych za wzrost firmy.

Dynamiczny model wzrostu/rozwoju małego i średniego przedsiębiorstwa został zaproponowany przez J. Wasilczuk (2005, s. 130-132), która zaliczyła do grupy czynników mających wpływ na wzrost/rozwój przedsiębiorstwa (por. rysunek 22):

- procesy początkowe (wybór branży, formy prawnej, wielkości firmy i lokalizacji);

- zasoby firmy uzależnione od kompetencji właściciela oraz procesów początkowych;

- kompetencje właściciela-menedżera jako kluczowy element całego systemu, od kompetencji bowiem zależy sposób postrzegania możliwości rozwoju przedsiębiorstwa oraz szans i zagrożeń tkwiących $\mathrm{w}$ otoczeniu, jak również uzyskane efekty;

- możliwości wzrostowe (rzeczywiste i postrzegane przez właściciela);

- cel, strategia, zarządzanie;

- otoczenie rzeczywiste i subiektywne postrzegane przez właściciela.

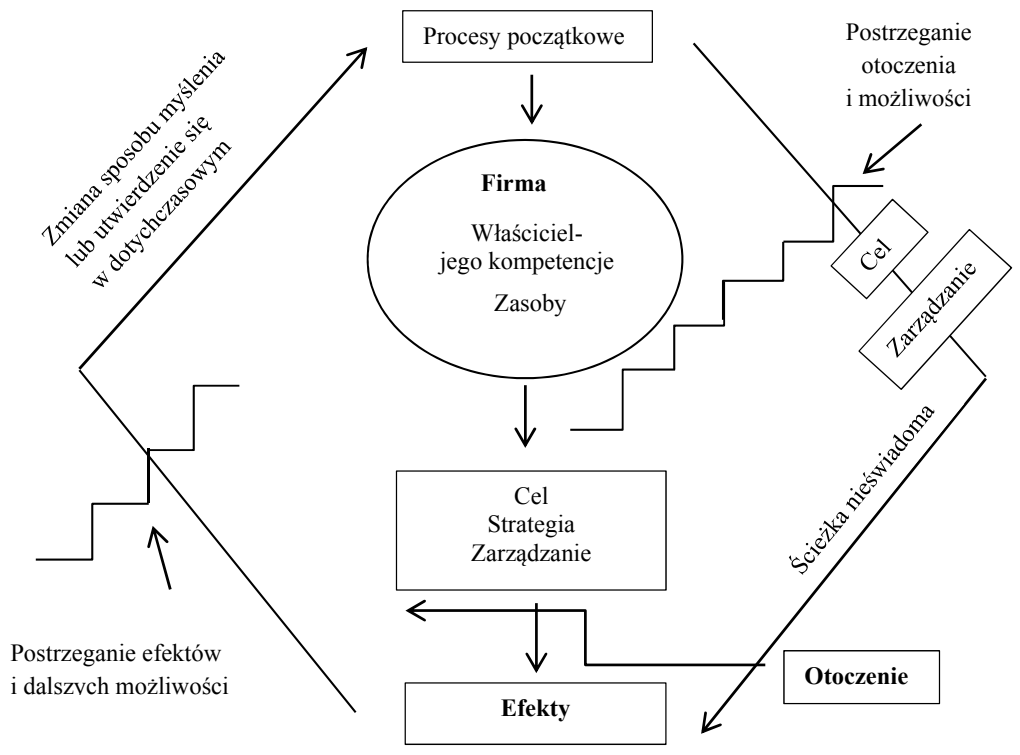

Rysunek 22. Model wzrostu małych i średnich firm Źródło: opracowanie własne na podstawie Wasilczuk 2005, s. 132 
$\mathrm{W}$ ramach nurtu wywodzącego się $\mathrm{z}$ teorii organizacji przedsiębiorstwa można wyróżnić trzy koncepcje odnoszące się do przetrwania i rozwoju przedsiębiorstw, do których należą:

- Liability of Smallness (obciążenia małych przedsiębiorstw),

- Liability of Newness (obciążenia nowych przedsiębiorstw),

- Ecological Economy (ekonomii ewolucyjna) (Poznańska 2008, s. 112).

Koncepcja Liability of Smallness jest oparta na założeniu, że małe przedsiębiorstwa maja mniejsze szanse przetrwania niż firmy o dużym stażu. Według P. Preisendorfera i T. Vossa mniejsze firmy są w wielu przypadkach niezdolne do konkurowania z dużymi firmami, które wykorzystują korzyści skali. Małe firmy mają również mniejsze szanse pozyskania wykwalifikowanych pracowników ze względu na brak możliwości zagwarantowania stabilnego zatrudnienia (Preisendorfera, Voss 1990, cyt za. Poznańska 2008, s. 112). Druga z koncepcji Liability of Newness opiera się na założeniu, że nowo powstałe przedsiębiorstwa charakteryzują się tendencją do szybkiego opuszczania rynku. Im dłużej firmy istnieją na rynku, tym wskaźnik przeżywalności firm rośnie (Hannan, Freeman 1989, cyt. za Poznańska 2008, s. 113). Natomiast według trzeciej koncepcji, Ecological Economy, na strukturę i dynamikę populacji wpływa prawdopodobieństwo powstania i przetrwania przedsiębiorstwa oraz tempo wzrostu firm pozostających na rynku (Poznańska 2008, s. 113-114).

A. Noga (2009) wyróżnił 14 teorii przedsiębiorstwa, które mogą stać się przydatne $\mathrm{w}$ analizie zachowań małego przedsiębiorstwa oraz jego uwarunkowań rozwojowych. Kryterium wyróżnienia był stopień realizacji przez przedsiębiorstwo celów powszechnych ${ }^{3}$ oraz celów autonomicznych ${ }^{4}$. Na podstawie

\footnotetext{
${ }^{3}$ Cele powszechne to: maksymalizacja zysku, zysk zadowalający, stopa zysku, zysk specjalny (nadzwyczajny), rentowność aktywów, maksymalizacja sprzedaży (przychodu), udział w rynku, wzrost aktywów przedsiębiorstwa, płynność, przetrwanie, wartość (cena) przedsiębiorstwa, dochody menedżerów, maksymalizacji wartości dodanej, samorealizacja, prestiż. Szerzej A. Noga, Teoria...

${ }^{4}$ Cele autonomiczne to nadwyżka między: efektywnością agencji (przedsiębiorstwa) a efektywnością transakcji (rynku), korzyściami skali a kosztami wzrostu, korzyściami zakresu nad kosztami złożoności, korzyściami korpuskularności nad kosztami niezwrotnymi, korzyściami praw własności nad kosztami transformacji, korzyściami dotarcia do rzadkich czynników wytwórczych nad kosztami kreowania niekontestowalności rynków, korzyściami sieci nad kosztami sieci, korzyściami kreowania wiedzy nad kosztami uczenia się, korzyściami pierwszeństwa na rynku i narzucania standardów nad kosztami przekroczenia masy krytycznej naśladownictwa, korzyściami wprowadzania innowacji nad kosztami badań B+R i kosztami ochrony praw własności, korzyściami wyspecjalizowania aktywów nad kosztami alternatywnymi, korzyściami wolności i władzy gospodarczej nad kosztami barier rozwoju przedsiębiorczości, korzyściami lewarowania kapitału nad kosztami kapitału, korzyściami z udanych przewidywań nad kosztami niepewności, korzyściami z kontroli niekompletnych kontraktów nad kosztami niekompletnych kontraktów, korzyściami dotarcia do wartości dodanych dla klienta nad kosztami zdobycia i utrzymania klienta, korzyściami wykorzystywania luk regulacyjnych nad kosztami prawnymi przedsiębiorstwa, korzyściami trafnej identyfikacji granic rynku nad kosztami przestawienia, pozytywnymi
} 
analizy tych dwóch grup celów okazało się, że cztery teorie odnoszą się tylko do małego przedsiębiorstwa (konsumpcyjna teoria przedsiębiorstwa H. Demsetza, neoklasyczna teoria przedsiębiorstwa, przedsiębiorcza teoria F. Knighta oraz innowacyjna teoria J. Schumpetera), natomiast pozostałe 10 teorii ma charakter uniwersalny i dotyczą zarówno małych, jak i dużych firm (teoria kosztów transakcji R. Coase'a, teoria kognitywna H. Simona, teoria informacyjna M. Aoki, I. Nonaki, H. Tekeuchiego, teoria konwencyjna T. Schellinga, teoria kompetencji i zasobów E. Penrose, teoria ewolucyjna R. Nelsona, S.G. Wintera, teoria praw własności A. Alchian, H. Demsetz, teoria ekologiczna T. M. Hannan, J. H. Freemana, teoria kosztów transakcji specyficznymi aktywami O. Williamsona oraz teoria kapitału intelektualnego G. Hamela, C. Prahalada). Teorie te pozwalają na wyjaśnienie, jakie czynniki są odpowiedzialne za wzrost/rozwój przedsiębiorstwa; np. teoria ekologiczna uwypukla otoczenie, w którym przedsiębiorstwo działa i ma zdolność do przeżycia, w teorii ewolucyjnej analizuje się dotychczasowy rozwój i jego wpływ na perspektywy dalszego rozwoju, w teorii kompetencji i zasobów ważna jest spójność między stroną zasobową a stroną informacyjno-regulacyjną ${ }^{5}$ (Noga 2009).

Zaprezentowane wcześniej modele wzrostu/rozwoju pomimo różnorodności posiadają pewne wspólne elementy i określają determinanty rozwoju małych i średnich przedsiębiorstw. Większość modeli zwraca uwagę na znaczenie osoby przedsiębiorcy, zasobów oraz otoczenia dla rozwoju firmy (Kamińska 2011, s. 36). Przedsiębiorstwo, aby przetrwać oraz realizować swoje cele, powinno doskonalić procesy zarządcze zorientowane na wzrost i rozwój. Procesy zmian mające skoordynowany i skuteczny charakter określa się mianem rozwoju, który jest najczęściej utożsamiany z wprowadzaniem szeroko rozumianych innowacji. Zmiany te dotyczą (Strużycki red. 2004):

- wprowadzenia nowych wartości do przedsiębiorstwa,

- poprawy jakości posiadanych zasobów i wartości,

- dostosowania strukturalne zasobów i wartości.

W literaturze przedmiotu brak jest wyczerpującej interpretacji teoretycznej przyczyn rozwoju firm. O ile możliwa jest identyfikacja kluczowych czynników rozwoju dla różnych typów firm, to jednak trudno jest sformułować spójny model rozwoju firm umożliwiający przewidywanie zdolności rozwojowej firm (Smallbone, Leigh, North 1995).

Kontynuacją rozważań dotyczących czynników, które wpływają na wzrost/rozwój małych i średnich przedsiębiorstw, jest analiza uwarunkowań rozwoju tych podmiotów zaprezentowana w kolejnym podrozdziale.

efektami zewnętrznymi a kosztami negatywnych efektów zewnętrznych, korzyściami nierównowagi $\mathrm{z}$ otoczeniem nad kosztami negatywnego wpływu otoczenia, korzyściami integracji interesów ludzkich nad kosztami harmonizowania sprzecznych interesów. Szerzej ibidem.

${ }^{5}$ Szerzej w opracowaniach Noga 2009, Teoria... 


\subsection{Uwarunkowania rozwoju małych i średnich przedsiębiorstw}

\subsubsection{Klasyfikacja uwarunkowań}

W literaturze przedmiotu przytaczane są liczne klasyfikacje uwarunkowań rozwoju ${ }^{6}$ małych i średnich przedsiębiorstw mających wpływ na charakter, dynamikę i strukturę procesów rozwojowych zachodzących w tych podmiotach (m.in. Storey 1994; Guzmán, Santos 2001; Porter 2002; Nogalski, Karpacz, Wójcik-Karpacz 2004; Steffens, Davidsson; Fitzsimmons 2009; Korol, Szczuciński 2011; Kamińska 2011; Romero, Fernandez-Serrano 2011; Lisowska 2010a; Skowronek-Mielczarek 2011b).

D. Storey do uwarunkowań rozwoju małych i średnich przedsiębiorstw zaliczył parametry demograficzne przedsiębiorcy (m.in. wiek, wykształcenie, doświadczenie w zarządzaniu) charakterystyki firmy (m.in. wiek, sektor, wielkość, własność, zasoby przedsiębiorstwa) oraz strategię (m.in. dopasowanie do rynku, koncentracja na klientach, pozycjonowanie rynku, szkolenie siły roboczej) (Storey 1994, s. 123). Zaproponowane przez D. Storeya uwarunkowania nie obejmowały szeroko rozumianego otoczenia, które zostało uwzględnione w koncepcjach P. Davidssona i J. Wiklund (Davidsson 1991, cyt. za Wasilczuk 2005; Wiklund 1996, cyt. za Wasilczuk 2005) ${ }^{7}$ oraz modelu zintegrowanym J. Wiklund, H. Patzelt., D.A. Shepherd (2009, s. 359) ${ }^{8}$.

Uwarunkowania rozwoju można analizować również w kontekście wymiarów otoczenia tzn.: makrootoczenia, mezootoczenia oraz mikrootoczenia (Skowronek-Mielczarek 2011b, s. 30; Guzmán, Santos 2001). W tym ujęciu ważne jest również określenie tzw. granic przedsiębiorstwa, tzn. dwóch silnie skorelowanych ze sobą wymiarów: wewnętrznego (opisującego sposoby wewnętrznego ukształtowania przedsiębiorstwa) i zewnętrznego (charakteryzującego relacje zawiązujące się pomiędzy przedsiębiorstwem a otoczeniem (Cyfert 2012).

W licznych opracowaniach uwarunkowania rozwoju małych i średnich przedsiębiorstw dzieli się na dwie kategorie: wewnętrzne i zewnętrzne (np. Kamińska 20011; Nogalski, Karpacz, Wójcik-Karpacz 2004; Lisowska 2012a i b). Według J.A. Korola i P. Szczucińskego (2011, s. 8-9) czynniki zewnętrzne mogą mieć charakter ogólny i do nich zalicza się np.:

- rosnący przestrzenny i przedmiotowy zasięg rynku, obejmujący nie tylko produkty, ale i kapitały;

${ }^{6}$ Jak już wcześniej wspomniano w podrozdziale 2.1, trudno jest jednoznacznie oddzielić pojęcie wzrostu od rozwoju przedsiębiorstwa. Przyjmując, że wzrost jest składową rozwoju przedsiębiorstwa, analizowane uwarunkowania będą się odnosiły do obydwu kategorii.

${ }^{7}$ Szerzej: Wasilczuk 2005, s. 45-48.

${ }^{8}$ Szerzej w podrozdziale 2.1 . 
- dokonujące się procesy globalizacji, prowadzące do całkowitej zmiany procesów produkcji, nowego podziału pracy, rozwoju badań i nauki, a także wykorzystywania w wytwórczości narzędzi IT;

- wzrost znaczenia prac badawczo-rozwojowych;

- gromadzenie, przetwarzanie i wykorzystywanie coraz większego zasobu informacji przy podejmowaniu decyzji rozwojowych przedsiębiorstwa.

Jak również charakter szczegółowy np.:

- czynniki otoczenia systemowego,

- charakter stosunków z dostawcami i odbiorcami,

- związki przedsiębiorstwa z innymi podmiotami,

- stosunki z instytucjami regionalnymi

- stosunki z otoczeniem biznesu (Korol, Szczuciński 2011, s. 8-9).

Natomiast druga grupa czynników wewnętrznych to:

- potencjał zarządzania przedsiębiorstwem - cele, strategia, know-how (Bartlett, Bukvić 2001);

- potencjał wytwarzania przedsiębiorstwa - ludzie, środki rzeczowe i finansowe (Nogalski, Karpacz, Wójcik-Karpacz 2004);

- historia przedsiębiorstwa - jego tradycja (np. w firmie rodzinnej) (Marjański 2010, Sułkowski, Marjański 2009), posiadanie znaku firmowego (Korol, Szczuciński 2011);

- kapitał intelektualny i doświadczenie (Gudkova 2008; Boyatzis 1982).

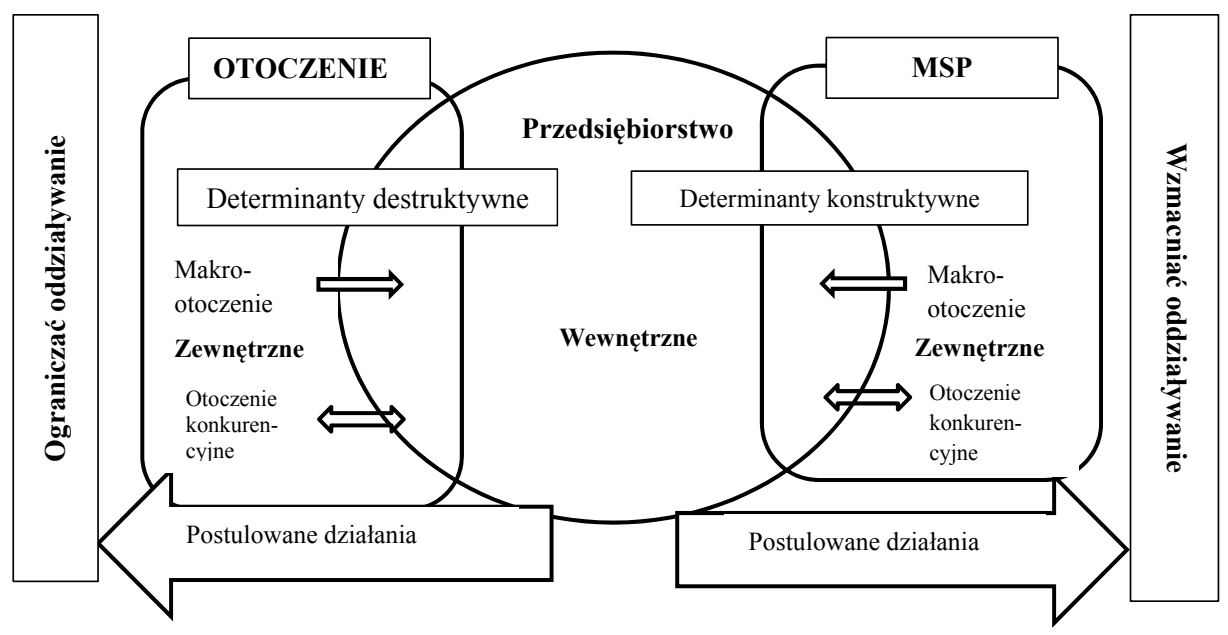

Rysunek 23. Model uwarunkowań kształtujących funkcjonowanie i rozwój małych i średnich przedsiębiorstw

Źródło: opracowanie własne na podstawie: Nogalski, Karpacz, Wójcik-Karpacz 2004, s. 39 
Według B. Nogalskiego, J. Karpacza, A. Wójcik-Karpacz na funkcjonowanie i rozwój małych i średnich przedsiębiorstw mają wpływ dwie grupy czynników: konstruktywne i destruktywne. Są one wynikiem procesów zachodzących we wnętrzu przedsiębiorstwa bądź też reakcją na warunki otoczenia. Zostały one podzielone na cztery grupy determinant ${ }^{9}$ (por. rysunek 23) (Nogalski, Karpacz, Wójcik-Karpacz 2004, s. 38):

- konstruktywnych zewnętrznych,

- konstruktywnych wewnętrznych,

- destruktywnych zewnętrznych,

- destruktywnych wewnętrznych.

Uwarunkowania rozwoju można również podzielić na stymulatory i bariery (np. Kamińska 2011, Wach 2008, Lisowska 2012a i b), analizując je w różnych układach, tzn. kontekście wymiarów otoczenia czy też jako wewnętrzne i zewnętrzne

W kolejnej części opracowania dokonano charakterystyki uwarunkowań rozwoju małych i średnich przedsiębiorstw według podziału na wewnętrzne i zewnętrzne, które mogą mieć wpływ pozytywny (stymulatory) i negatywny (bariery) (por. rysunek 24), jak również zaprezentowano bariery rozwoju małych i średnich przedsiębiorstw w Polsce w świetle dotychczasowych badań.
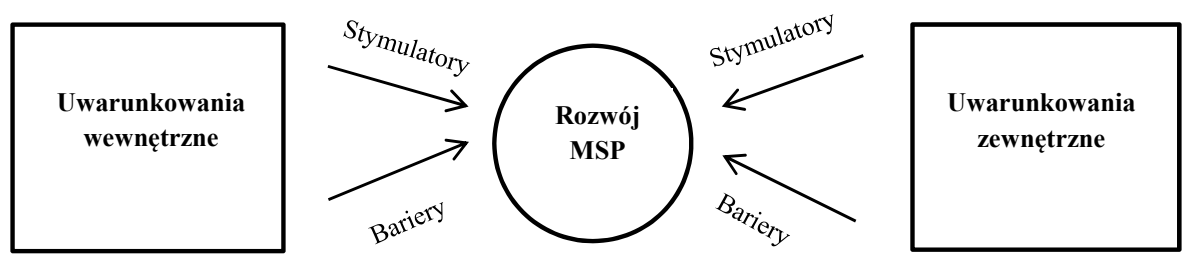

Rysunek 24. Uwarunkowania rozwoju małych i średnich przedsiębiorstw Źródło: opracowanie własne

\subsubsection{Uwarunkowania wewnętrzne}

Identyfikacja i ocena uwarunkowań wewnętrznych rozwoju małych i średnich przedsiębiorstw jest przedmiotem wielu analiz (por. tabela 7). Najczęściej klasyfikuje się je w odniesieniu do osoby przedsiębiorcy i przedsiębiorstwa (np. Wasilczuk 2004 i 2005; Romero, Fernandez-Serrano 2011; Kamińska 2011). Analiza uwarunkowań wewnętrznych związanych z osobą przedsiębiorcy sprowadza się głównie jego cech osobowych i umiejętności przedsiębiorczych, natomiast w odniesieniu do przedsiębiorstwa do mocnych i słabych jego stron.

\footnotetext{
${ }^{9}$ Szerzej w podrozdziałach 2.2.2 i 2.2.3.
} 
Tabela 7. Uwarunkowania wewnętrzne rozwoju małych i średnich przedsiębiorstw - wybrane koncepcje

\begin{tabular}{|c|c|c|}
\hline Autorzy & $\begin{array}{l}\text { Uwarunkowania wewnętrzne rozwoju małych i } \\
\text { średnich przedsiębiorstw }\end{array}$ & $\begin{array}{c}\begin{array}{c}\text { Kierunek } \\
\text { wpływu }\end{array} \\
\end{array}$ \\
\hline 1 & 2 & 3 \\
\hline $\begin{array}{l}\text { Storey (1994), Gibb, Davies } \\
\text { (1990), Churchil, Lewis (1983), } \\
\text { Gilbert, McDougall, Andretsch } \\
\text { (2006), Wiklund (1996) }\end{array}$ & $\begin{array}{l}\text { Do uwarunkowań wpływających na wzrost MSP } \\
\text { zaliczono: osobę przedsiębiorcy, strategię działa- } \\
\text { nia, zasoby (finansowe, ludzkie, rzeczowe oraz } \\
\text { infromacyjne), system organizacyjny oraz struk- } \\
\text { turę organizacyjną }\end{array}$ & $\begin{array}{l}\text { Pozytywny/ } \\
\text { negatywny }\end{array}$ \\
\hline Bławat (2003 i 2004) & $\begin{array}{l}\text { Uwarunkowania wewnętrzne związane bezpo- } \\
\text { średnio z osobą przedsiębiorcy: podejścia biogra- } \\
\text { ficzne, osobowościowe, behawioralne, relacyjne } \\
\text { i zintegrowane }\end{array}$ & $\begin{array}{l}\text { Pozytywny/ } \\
\text { negatywny }\end{array}$ \\
\hline $\begin{array}{l}\text { Romero, Fernandez-Serrano } \\
(2011), \text { Kamińska (2011), Ste- } \\
\text { ffens, Davidsson, Fitzsimmons } \\
(2009), \text { Wailczuk (2005), La- } \\
\text { zear, (2005), Blawat (2004), } \\
\text { Nogalski, Wójcik-Karpacz } \\
(2003), \quad \text { Guzmán, Santos } \\
(2001), \quad \text { Piasecki } \quad(2001), \\
\text { Storey (1994), Krueger, } \\
\text { Carsrud (1993), Ajzen (1991) }\end{array}$ & $\begin{array}{l}\text { Uwarunkowania wewnętrzne związane bezpo- } \\
\text { średnio z osobą przedsiębiorcy oraz związane } \\
\text { przedsiębiorstwem (cechy firmy, zasoby we- } \\
\text { wnętrzne oraz orientacja przedsiębiorcza). Do } \\
\text { charakterystyk przedsiębiorcy zaliczono: motywa- } \\
\text { cję (podejście do firmy), zdolność do działania } \\
\text { (umiejętność samodzielnego wykonywania zadań), } \\
\text { zdolności menedżerskie i strategiczne (myślenie } \\
\text { perspektywiczne, analizowanie sytuacji firmy). } \\
\text { Uwarunkowania dotyczące firmy obejmują pod- } \\
\text { stawowe rodzaje zasobów }\end{array}$ & $\begin{array}{l}\text { Pozytywny/ } \\
\text { negatywny }\end{array}$ \\
\hline $\begin{array}{l}\text { Romero, Fernandez-Serrano } \\
\text { (2011), Wiklund, Patzelt, She- } \\
\text { pherd (2009), Brown, Da- } \\
\text { vidsson, Wiklund (2001), } \\
\text { Pyke, Becattini, Sengenberger } \\
\text { (1991), Lumpkin, Dess (1996), } \\
\text { Stevenson, Jarillo, (1990), } \\
\text { Miller (1983) }\end{array}$ & $\begin{array}{l}\text { Orientacja przedsiębiorcza jako istotny czynnik } \\
\text { rozwoju przedsiębiorstwa. Orientację tę tworzą } \\
\text { trzy wymiary: innowacje, proaktywność oraz } \\
\text { kooperacja z innymi przedsiębiorstwami }\end{array}$ & $\begin{array}{l}\text { Pozytywny/ } \\
\text { negatywny }\end{array}$ \\
\hline $\begin{array}{l}\text { Aidis (2003), Bartlett, Bukvić } \\
\text { (2001), Daszkiewicz (2004a } \\
\text { i b), Storey (1994), }\end{array}$ & $\begin{array}{l}\text { Identyfikacja barier wewnętrznych rozwoju } \\
\text { małych firm i ich podział na: zarządzania (brak } \\
\text { kompetencji menedżerskich przedsiębiorcy wyni- } \\
\text { kających z często niewystarczających kwalifikacji } \\
\text { i wiedzy z zakresu zarządzania), finansowe } \\
\text { (zmiana struktury kapitałowej, niewystarczające } \\
\text { zasoby kapitałowe), popytu }\end{array}$ & Negatywny \\
\hline $\begin{array}{l}\text { Danielak (2010), Gudkova } \\
(2008), \text { Bird (1995), Kolb } \\
(1984), \text { Boyatzis (1982) }\end{array}$ & $\begin{array}{l}\text { Na rozwój małych przedsiębiorstw mają wpływ } \\
\text { niematerialne uwarunkowania (tzw. kapitał inte- } \\
\text { lektualny), takie jak: kompetencje przedsiębiorcze, } \\
\text { sieć osobistych powiazań oraz proces uczenia się }\end{array}$ & $\begin{array}{l}\text { Pozytywny/ } \\
\text { negatywny }\end{array}$ \\
\hline $\begin{array}{l}\text { Korol, Szczuciński (2011), } \\
\text { Marjański (2010) }\end{array}$ & $\begin{array}{l}\text { Uwarunkowania wewnętrzne (potencjał zarządza- } \\
\text { nia przedsiębiorstwem, potencjał wytwarzania } \\
\text { przedsiębiorstwa, historia przedsiębiorstwa) }\end{array}$ & $\begin{array}{l}\text { Pozytywny/ } \\
\text { negatywny }\end{array}$ \\
\hline
\end{tabular}


Tabela 7 (cd.)

\begin{tabular}{|l|l|l|}
\hline \multicolumn{1}{|c|}{ 2 } & \multicolumn{1}{|c|}{2} & \multicolumn{1}{|c|}{3} \\
\hline $\begin{array}{l}\text { Nogalski, Karpacz, Wójcik- } \\
\text { Karpacz (2004), Nogalski, } \\
\text { Wójcik-Karpacz (2003) }\end{array}$ & $\begin{array}{l}\text { Determinanty wewnętrzne konstruktywne (oso- } \\
\text { bowość przedsiębiorcy, przejrzystość struktury } \\
\text { organizacyjnej, ukierunkowanie na innowacyj- } \\
\text { ność) i destruktywne (ograniczone zasoby, sposób } \\
\text { kierowania przedsiębiorstwem, niesprecyzowane } \\
\text { plany dzielności przedsiębiorstwa) }\end{array}$ & \\
\hline
\end{tabular}

Źródło: opracowanie własne na podstawie: Boyatzis 1982; Daszkiewicz 2004a i b, s. 61-70; Daviddson, Wiklund, Delmar 2006; Gudkova 2008; Romero, Fernandez-Serrano 2011, s. 637660; Steffens, Davidsson, Fitzsimmons 2009, s. 125-148; Storey 1994; Wasilczuk 2005; Wiklund, Patzelt, Shepherd 2009, s. 351-374; Wiklund 1996; Gibb, Davies 1992, s. 3-36.

Charakterystyka wewnętrznych czynników rozwoju małych i średnich przedsiębiorstw związanych $\mathrm{z}$ osobą przedsiębiorcy odnosi się często do zaproponowanych przez F. Baławata podejść: biograficznego, osobowościowego, behawioralnego i relacyjnego (Bławat 2003, s. 49). W podejściu biograficznym za czynniki rozwoju uznaje się: wiek, płeć, wiedzę, wykształcenie zawodowe oraz doświadczenie $\mathrm{w}$ biznesie, w podejściu osobowościowym cechy osobowości, takie jak: skłonność do podejmowania ryzyka, motywację, innowacyjność, potrzebę osiągnięć, pracowitość itp. Natomiast w podejściu behawioralnym za siłę sprawczą procesów rozwojowych uważa się atrybuty przedsiębiorcy (Mitton 1989, cyt. za Bławat 2003, s. 57) według wzorców przedsiębiorczego zachowania (np. styl pracy, stosunek do okazji i zmian, skłonność do innowacji, umiejętności menedżerskie, stosunek do ryzyka). W podejściu relacyjnym jest to głównie stosunek do: ryzyka, kreatywności, przywództwa, okazji itp. (Bławat 2003, s. 60).

B. Nogalski i A. Wójcik-Karpacz analizują i zaznaczają ważność dla rozwoju małych i średnich przedsiębiorstw uwarunkowań wewnętrznych o charakterze pozafinansowym, do których, zaliczyli: system kadrowy, sposób zarządzania, rodzaj struktury organizacyjnej (Nogalski, Wójcik-Karpacz 2003a). Istotnym czynnikiem rozwoju małych i średnich przedsiębiorstw, wynikającym z zachowań przedsiębiorcy, jest motywacja, która stanowi często silę napędową do działań biznesowych (Ajzen 1991, s. 179-211; Krueger, Carsrud 1993, s. 315330), tzn. podjęcia decyzji o uruchomieniu i prowadzeniu przedsiębiorstwa. W tym kontekście ważne jest również doświadczenie zawodowe, które może pobudzać kreatywność, innowacyjność, proces uczenia się oraz rozwijać umiejętności koncepcyjne (Lazear 2005, Guzmán, Santos 2001, s. 211-228). Uwarunkowania te nabierają szczególnego znaczenia w procesie planowania i uruchomienia działalności gospodarczej, są bowiem związane ze sposobem 
zorganizowania danego przedsiębiorstwa, procesem zarządzania, realizacją celów oraz decyzją o jej przetrwaniu i rozwoju.

Determinanty związane $\mathrm{z}$ osobą przedsiębiorcy można również utożsamiać z tzw. potencjałem przedsiębiorcy, który jest związany $\mathrm{z}$ kompetencjami przedsiębiorcy i jego predyspozycjami indywidualnymi do działania i osiągania rezultatów (Karpacz 2011, s. 53-54). Na potencjał ten mają znaczący wpływ ludzie i ich zachowania organizacyjne w przedsiębiorstwie (Robbins, Judge 2011; Sikorski 1999). Potencjał przedsiębiorcy ujawnia się w procesie zarządzania, tzn. podczas podejmowania decyzji, planowania i formułowania strategii, motywowania, kontrolowania, jak również w zachowaniach przedsiębiorczych, takich jak: kreatywność innowacyjność i skłonność do ryzyka. Zachowania przedsiębiorcze są szczególnie ważne dla skutecznego zarządzania małym i średnim przedsiębiorstwem, pozwalają bowiem na przekształcenie twórczych pomysłów na konkretne działanie, zmierzające do osiągnięcia zamierzonych efektów.

Potencjał przedsiębiorcy wywiera wpływ na wzrost i rozwój małego i średniego przedsiębiorstwa w różnych fazach jego rozwoju. Niekiedy zdarza się tak, że przedsiębiorca, osiągając pewien pułap zatrudnienia, na którym kończą się jego możliwości sprawowania władzy organizacyjnej, nie jest skłonny do rozwoju przedsiębiorstwa, aby uniknąć przekazania władzy, chyba że dotyczy to sukcesji w firmach rodzinnych. Problemy związane ze sprawnością zarządzania w małych i średnich firmach, w których występuje rozczłonkowanie hierarchiczne (tzn. właściciel jest jednocześnie menedżerem), przedsiębiorcą musi podejmować równocześnie zarówno decyzje bieżące, jak również strategiczne (Piasecki 2001, Safin 2008). Często zdarza się tak, że przedsiębiorca pochłonięty bieżącymi sprawami zapomina o zarządzaniu strategicznym (Karpacz 2011). Aby uniknąć tej sytuacji, zasadne jest wytyczenie obszarów uprawnień decyzyjnych kierowników zajmujących się działalnością operacyjną w przedsiębiorstwie. Jest to możliwe $\mathrm{w}$ przypadku wielu właścicieli w małym i średnim przedsiębiorstwie, wtedy zazwyczaj istnieje $\mathrm{w}$ przedsiębiorstwie podział kierownictwa $\mathrm{w}$ układzie funkcjonalnym, natomiast w przypadku mikrofirm, gdzie właściwie władzę organizacyjną sprawuje tylko właściciel, jest to praktycznie mało prawdopodobne. Dlatego też w tym przypadku właściciel dla realizacji wytyczonych celów podejmować równolegle decyzje bieżące i strategiczne (Gudkova 2008, s. 13). Jak wskazuje praktyka gospodarcza, tempo rozwoju przedsiębiorstwa może być wyższe od rozwoju potencjału przedsiębiorcy, wtedy to tworzy się tzw. luka potencjału przedsiębiorcy (por. rysunek 25). Luka ta może wpłynąć na proces zarządzania małym i średnim przedsiębiorstwem w obszarze formułowania i realizacji strategii (Karpacz 2011, s. 59-60). Redukcja tej luki może nastąpić w wyniku procesu uczenia się, który w mikro i małej firmie następuje przez doświadczenie (Gudkova 2008, s. 29). 


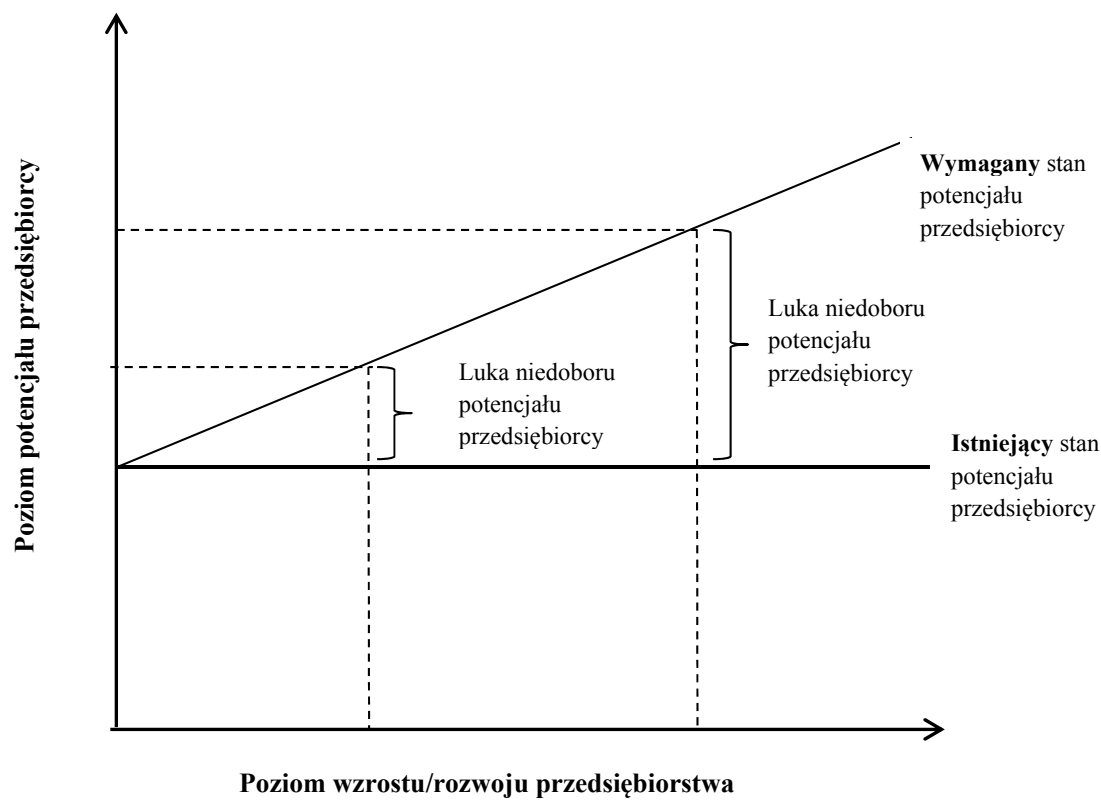

Rysunek 25. Luka potencjału przedsiębiorcy Źródło: Karpacz 2011, s. 60

Przedsiębiorca kształtuje zarówno procesy wewnętrzne (np. polityka inwestycyjna, zmiany organizacyjne, zmiany $\mathrm{w}$ metodach doboru personelu), jak również związane z rynkiem (np. polityka cenowa, polityka w zakresie działań marketingowych oraz decyzje w zakresie wyboru dostawców i odbiorców) w małym i średnim przedsiębiorstwie (Karpacz 2011, s. 61). Dlatego też wysoki jego potencjał, składający się z ogólnej i specjalistycznej wiedzy, umiejętności i oraz cech osobowości (Bratnicki 2010, cyt. za Karpacz 2011, s. 62), pozwala przedsiębiorcy na osiąganie wysokiej efektywności podejmowanych przez niego działań (Bird 1995, cyt. za Gudkova 2008, s. 17). Istotne jest jednak, aby rozwój przedsiębiorstwa nie przekraczał zdolności menedżerskich przedsiębiorcy (Bratnicki 2010, cyt. za Karpacz 2011, s. 62).

Według S. Gudkovej na rozwój małych przedsiębiorstw mają wpływ niematerialne uwarunkowania takie jak: kompetencje przedsiębiorcze, sieć osobistych powiazań oraz proces uczenia się. Kompetencje przedsiębiorcze to wiedza ogólna i specjalistyczna, motywy, cech osobowości, postrzeganie siebie, rola społeczna oraz umiejętności, które mają doprowadzić do stworzenia, przetrwania i rozwoju przedsięwzięcia (Bird 1995, cyt. za Gudkova 2008, s. 17). Kompetencje przedsiębiorcze według R.E Boyatzisa analizowane są w układzie trzech poziomów: motywy i cechy osobowości, sposób postrzegania siebie i innych oraz umiejętności (Boyatzis 1982, cyt. za Gudkova 2008, s. 16). Sieć osobistych 
kontaktów według O.E Laumanna jest definiowana jako zbiór węzłów (np. osoby, organizacje) powiązanych zbiorem specyficznego typu relacji społecznych (np. przyjaźń, transfer kapitału). Sieć ta wspomaga m.in. proces identyfikacji szans $\mathrm{w}$ otoczeniu, umożliwia dostęp do niezbędnych zasobów, w tym cennych dla prowadzenia przedsiębiorstwa informacji, motywuje przedsiębiorcę do działania, dostarcza wsparcia emocjonalnego sprzyja transferowi wiedzy, stwarza klimat dla transakcji rynkowych (Gudkova 2008, s. 44 i 62).

Proces uczenia się zachodzi w przypadku małych firm głównie w oparciu o doświadczenie. Według K. Kolba (1984) uczenie się przez doświadczenie rozpoczyna się od eksperymentowania, w ramach którego wyłaniają się pomysły, modyfikowane przez nowe doświadczenia. Przedsiębiorca, podejmując decyzje, kieruje się następującymi strategiami: wybór rozwiązania identycznego podobnego do stosowanego w przeszłości lub wkraczanie w nowe obszary, czyli niestosowanie dotychczasowych rozwiązań. Pomiędzy tymi czynnikami niematerialnymi (kompetencje przedsiębiorcze, sieć osobistych powiazań oraz proces uczenia się) zachodzą wzajemne interakcje, które występują na poziomie poszczególnych elementów składowych tych czynników (Gudkova 2008, s. 32 i 175) (por. rysunek 26).

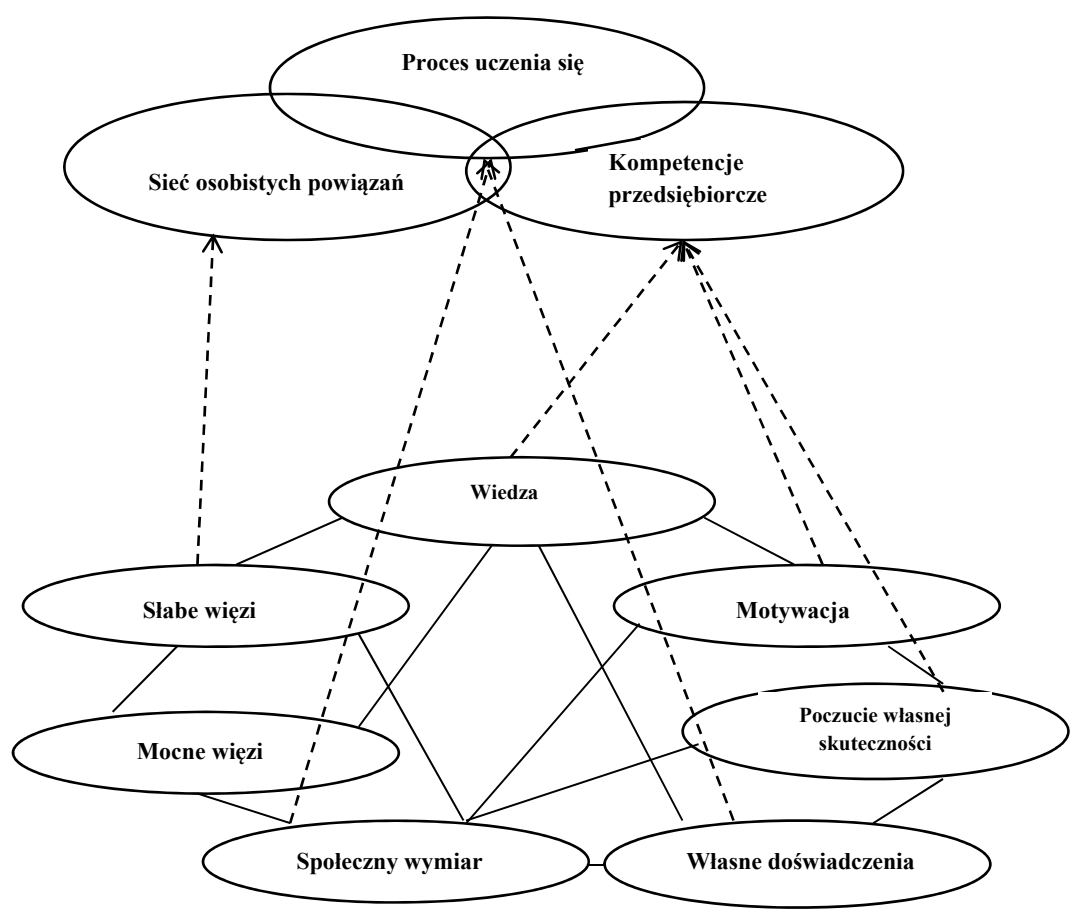

Rysunek. 26. Niematerialne uwarunkowania rozwoju małych i średnich przedsiębiorstw Źródło: opracowanie własne na podstawie Gudkova 2008, s. 175 
Uwarunkowania związane z osobą przedsiębiorcy, jego parametry demograficzne, potencjał są szczególnie ważne w przypadku procesu zarządzania małym i średnim przedsiębiorstwem $\mathrm{w}$ obszarach zmarginalizowanych, w których dodatkowo $\mathrm{w}$ procesie tym należy uwzględnić specyfikę tych obszarów. Jak wskazują wyniki badań ${ }^{10}$ przeprowadzonych w latach 2008-2009 wśród właścicieli i współwłaścicieli małych przedsiębiorstw zlokalizowanych w obszarach zmarginalizowanych, błędy w procesie zarządzania mogą stać się przyczyną upadku małych firm. Badani przedsiębiorcy wskazywali najczęściej popełniane błędy w następujących wymiarach (Lisowska 2010a, s. 203-206):

- decyzji właściciela-menedżera, polegające na braku strategii funkcjonowania firmy (20,2\% wskazań), braku wiedzy z zakresu zarządzania $(13,5 \%$ wskazań), czego skutkiem jest często niedostrzeganie znaczenia czynników odpowiedzialnych za pozycję konkurencyjną biznesu, takich jak: wprowadzanie zmian, innowacje i zarządzanie wiedzą;

- finansów przedsiębiorstwa - to zbyt niski kapitał początkowy $(31,3 \%$ wskazań), złe zarządzanie kapitałem (nieco ponad 23\% wskazań) oraz zbyt duże zadłużenie (22,8\% wskazań). Błędy te mogą wskazywać na słaba kontrolę finansową szczególnie w początkowym okresie funkcjonowania firmy;

- orientacji rynkowej - podstawowym błędem jest tutaj niedostosowanie przez przedsiębiorców oferty swoich produktów do potrzeb rynku $(21,5 \%$ wskazań), zła polityka cenowa (20,1\% wskazań) oraz złe decyzje dotyczące kierunków sprzedaży ( $20 \%$ wskazań);

- potencjału ludzkiego - nieumiejętne motywowanie pracowników $(32,6 \%$ wskazań);

- techniki i innowacji - niechęć do wprowadzenia nowych rozwiązań (35,5\% wskazań).

Przytoczone błędy mogą wynikać z niewystarczającego potencjału przedsiębiorcy, jak również $\mathrm{z}$ braku doświadczenia $\mathrm{w}$ prowadzeniu biznesu. W obszarach zmarginalizowanych często powstają tzw. przedsiębiorstwa z konieczności, będące jedyną alternatywą dla trudnej sytuacji na rynku pracy. Są one często zarządzane przez osoby przypadkowe, nieprzygotowane profesjonalnie do prowadzenia biznesu, co w specyficznych warunkach obszaru zmarginalizowanego może stać się przyczyną upadku tych podmiotów.

Druga grupa uwarunkowań wewnętrznych rozwoju MSP odnosi się bezpośrednio do przedsiębiorstwa. Jako główne czynniki wskazuje się: wiek (okres

${ }^{10}$ Badanie zostało przeprowadzone w ramach projektu pt. Symptomy upadku małej firmy. Konsekwencje społeczno-gospodarcze. Polityka przeciwdziałania, nr projektu. 1 H02D 05530 , nr umowy 0926/H03/2006/30, finansowanego przez Ministerstwo Nauki i Szkolnictwa Wyższego. Omawiane zagadnienia stanowią wycinek badań ilościowych przeprowadzonych ramach tego projektu w obszarach zmarginalizowanych w całej Polsce. W badaniu wzięły udział tylko małe firmy, próba badawcza liczyła 113 podmiotów zlokalizowanych w obszarach zmarginalizowanych. Autorka była głównym wykonawcą projektu i członkiem zespołu badawczego. 
funkcjonowania na rynku), wielkość mierzoną zazwyczaj liczbą zatrudnionych, zasięg działania, sektor i zachodzące w nim zmiany, niezależność (por. Storey 1994, Piasecki 2001, Steffens, Davidsson, Fitzsimmons 2009) oraz wewnętrzne zasoby firmy (ludzkie, rzeczowe, finansowe i niematerialne). Zasoby ludzkie jako nośnik i źródło wiedzy determinują sposoby wykorzystania pozostałych zasobów, przyczyniając się do rozwoju przedsiębiorstwa. Z kolei zasoby rzeczowe stanowią potencjał rozwojowy przedsiębiorstwa, ponieważ posiadane przez firmę zaplecze materialno-techniczne w postaci budynków, maszyn i urządzeń itp. odzwierciedla wykorzystanie postępu technicznego i wprowadzanie innowacji, co wpływa na pozycję konkurencyjną przedsiębiorstwa (Kamińska 2011, s. 58-59). Zasoby finansowe rzutują na stan i posiadanie pozostałych zasobów oraz decydują o wielkości produkcji, możliwości wejścia na nowe rynki oraz wdrożenia innowacji. W przypadku małych i średnich przedsiębiorstw niewystarczające zasoby finansowe mogą stanowić barierę rozwoju. Natomiast zasoby niematerialne stanowią tożsamość przedsiębiorstwa i decydują o jego unikalności poprzez wizerunek, markę, kulturę organizacyjną, posiadaną wiedzę i kompetencje pracowników, dlatego też zasoby te są ważnym źródłem przewagi konkurencyjnej wpływającej na rozwój przedsiębiorstwa. Niematerialne zasoby rozwoju małych i średnich przedsiębiorstw są bowiem utożsamiane z kapitałem intelektualnym obejmującym (Danielak 2010, s. 264):

- kapitał ludzki w postaci umiejętności kadry kierowniczej, wiedzy i kompetencji personelu, przedsiębiorczości i innowacyjność personelu, know-how, współpracy personelu w zakresie wykorzystania i rozwoju wiedzy na potrzeby innowacji, komplementarności wiedzy personelu wykorzystywanej w procesie innowacji, systemu motywacji sprzyjającemu wdrażaniu innowacji w organizacji, lojalności personelu względem organizacji i jego satysfakcji;

- kapitał organizacyjny, obejmujący organizację realizacji działań i strukturę procesu innowacji, organizację współpracy z partnerami w procesie innowacji, doskonalenie procesów organizacyjnych, struktury organizacyjne wykorzystywane w procesie innowacji, kompetencje, doświadczenie personelu w zakresie B+R, systemy informacji, oprogramowanie, bazy danych umożliwiające dostęp do wiedzy, jej transfer, rozwój i twórcze wykorzystanie, posiadane patenty, wnioski użytkowe, licencje, kulturę organizacji i innowacyjną, wartość wdrożonych innowacji, procedury zakupu/sprzedaży/transferu innowacji;

- kapitał relacyjny dotyczy działalności w ramach organizacji sieciowych, aliansów strategicznych z partnerami podczas realizacji procesów innowacji, dostępu do zasobów komplementarnych $\mathrm{w}$ procesie innowacji, wizerunku, renomy organizacji, pozycji firmy na rynku innowacji, posiadanych przez nią marki, ich wartości, zdolności do dzielenia się wiedzą, poziomu zaufania w stosunku do pracowników w procesie innowacji, powiązań finansowych i współpracy $\mathrm{z}$ innymi firmami-dostawcami usług, lojalności klientów 
w stosunku do organizacji, satysfakcji klientów, bazy danych o klientach, wiedzy w zakresie innowacji.

Kapitał intelektualny jest istotny dla procesu innowacyjnego małych i średnich przedsiębiorstw. Umiejętne bowiem wykorzystanie elementów tego kapitału może wpływać na powodzenie przedsięwzięć innowacyjnych, które wymagają oprócz wysokiego poziomu kapitału ludzkiego, m.in. struktury organizacyjnej dającej możliwość wdrażania innowacyjnych rozwiązań, oprogramowania, baz danych umożliwiających dostęp do wiedzy i jej transfer, kultury innowacyjnej, systemów informacyjnych, umiejętności tworzenia sieci powiazań między pomysłodawcami, wykonawcami.

W literaturze przedmiotu podkreśla się również orientację przedsiębiorczą (Miller 1983, s. 770-791; Lumpkin, Dess 1996, s. 135-172; Romero, Fernandez-Serrano 2011, s. 637-660) jako istotną determinantę rozwoju małych i średnich firm związaną z przedsiębiorstwem. Orientację tę tworzą trzy wymiary: innowacje, proaktywność (Stevenson, Jarillo 1990, s. 17-27; Brown, Davidsson, Wiklund, 2001, s. 953-968) oraz kooperacja z innymi przedsiębiorstwami (Romero, Fernandez-Serrano 2011, s. 637-660). Wprowadzanie innowacji (produktowych, procesowych, organizacyjnych i marketingowych) w różnych obszarach działalności przedsiębiorstwa jest konieczne dla tworzenia przewagi konkurencyjnej i rozwoju firmy (Stawasz E. 2008). Ważną rolę w tym procesie odgrywa proaktywność definiowana jako zdolność przedsiębiorstwa do poszukiwania, jak również wykorzystywania z wyprzedzeniem przed konkurentami okazji rynkowych i możliwości biznesowych (Stevenson, Jarillo 1990). Natomiast kooperacja z innymi przedsiębiorstwami może przybierać postać formalnej na podstawie umów współpracy lub nieformalnej na podstawie osobistych kontaktów przedsiębiorcy. Budowanie sieci współpracy, szczególnie pomiędzy lokalnymi przedsiębiorstwami, pomaga wzmocnić małym i średnim firmom swoją pozycję konkurencyjną oraz rozwijać się szybciej (Pyke, Becattini, Sengenberger 1991).

Natomiast według T. Łuczki, istotnym elementem rozwoju małych i średnich przedsiębiorstw, decydującym o jego sile ekonomicznej i konkurencyjności, jest jego gospodarka finansowa, której skuteczność wyraża się w takim zaopatrzeniu firmy w kapitał własny jak i obcy, który zapewni jej bieżącą równowagę finansową oraz trwały rozwój (Luczka 2001 i 2007). W tym kontekście ważna jest jakość zarządzania sferą finansową przedsiębiorstwa, a decyzje z nią związane powinny uwzględniać:

- pozyskiwanie kapitałów, związane z wyborem racjonalnych źródeł finansowania;

- inwestowanie kapitałów w różnego rodzaju przedsięwzięcia - procesy, projekty, działania realizowane $\mathrm{w}$ trakcie prowadzonej działalności;

- zarządzanie kapitałem pracującym, obejmujące sterowanie aktywami obrotowymi i bieżącymi zobowiązaniami oraz należnościami (Skowronek-Mielczarek 2005). 
Według Z. Mikołajczyk i K. Zimniewicza dla rozwoju małych i średnich przedsiębiorstw istotny jest wykwalifikowany personel, stanowiący zasoby strategiczne przedsiębiorstwa. Ludzie bowiem, realizując cele i zadania, czynnie uczestniczą w życiu przedsiębiorstwa, przewidując przyszłe działania i rozwój, mogą się przyczynić do tego rozwoju jak również upadku przedsiębiorstwa (Mikołajczyk, Zimniewicz 2001, s. 247). Według tych autorów, nowe metody pracy, nowoczesne maszyny i urządzenia, nowe przepisy prawne, wzrost międzynarodowej konkurencji, nowe technologie i nowe strategie motywacyjne [...] zmuszają do stałego podnoszenia umiejętności ludzi, ich zdolności adaptacji do tego, co nowe, do zmiany postaw. Nie ma ucieczki od zmian, a zatem nie ma ucieczki od rozwoju pracowników, podnoszenia ich kwalifikacji zawodowych przez doskonalenie i zdobywanie nowych umiejętności (Mikołajczyk, Zimniewicz 2001, s. 253). W przypadku małych i średnich przedsiębiorstw rozwój pracowników powinien iść $\mathrm{w}$ parze $\mathrm{z}$ rozwojem firmy, a właściciele oraz pracownicy wykazywać się skłonnością i zdolnością do podejmowania działań, co wymaga od nich pełnej akceptacji i zaangażowania.

Do stymulatorów rozwoju małych i średnich przedsiębiorstw odnoszących się do samego przedsiębiorstwa zalicza się również mocne strony tych podmiotów (Piasecki 2001, Nehring 2011, Matejun 2012):

- dużą elastyczność w działaniu umożliwiającą łatwe dostosowanie się do warunków otoczenia i możliwość szybkiej zmiany rodzaju działalności;

- prostą strukturę organizacyjną dającą możliwość bieżącej kontroli wszystkich obszarów działalności przedsiębiorstwa;

- stosunkowo niski poziom kosztów produkcji;

- zdolność do naśladownictwa produktów, usług oraz rozwiązań organizacyjnych;

- silną motywację do pracy przedsiębiorców jak również osób zatrudnionych;

- duży dynamizm i szybki rozwój;

- zdolność szybkiego uczenia się i nabywania umiejętności.

Natomiast według B. Nogalskiego, J. Karpacza, A. Wójcik-Karpacz (2004, s. 60) czynniki wpływające na funkcjonowanie i rozwój małych i średnich przedsiębiorstw mogą mieć charakter konstruktywny i destruktywny. Do stymulatorów zalicza się:

- sposób zarządzania organizacją,

- przejrzystość struktur organizacyjnych,

- strategie rozwoju nakierowane na określona niszę rynkową,

- nastawienie proinnowacyjne.

Sposób zarządzania $\mathrm{w}$ przypadku małych i średnich przedsiębiorstw jest zdominowany przez osobę właściciela/-li, w związku z tym jest uzależniony od jego cech osobowościowych, umiejętności, kompetencji i skłonności do ryzyka, jak również wnętrza przedsiębiorstwa $\mathrm{w}$ postaci struktury organizacyjnej. 
Struktura organizacyjna jest zazwyczaj prostym i przejrzystym rozwiązaniem, np. struktura prosta promienista lub struktura płaska, która daje możliwość bardziej wnikliwego monitorowania zmian zachodzących zarówno w przedsiębiorstwie, jak i jego otoczeniu. Dla sprawnego i skutecznego sposobu zarządzania ważny jest również dobór strategii, która w przypadku MSP jest najczęściej skierowana na określoną niszę rynkową. Jak również skłonność do działalności innowacyjnej nie zawsze możliwej w przypadku MSP ze względu na ograniczone zasoby nie tylko finansowe, ale również rzeczowe, ludzkie i informacyjne.

Do czynników destruktywnych (barier) można zaliczyć: (Nogalski, Karpacz, Wójcik-Karpacz 2004, s. 78):

- ograniczone zasoby, jakimi dysponują MSP;

- niewielki stopień planowania strategicznego;

- ograniczony zakres działalności marketingowej.

Niewystarczające zasoby finansowe mają negatywny wpływ na funkcjonowanie i rozwój MSP, nie tylko ze względu na problemy $\mathrm{z}$ zapewnieniem płynności finansowej, ale również na prowadzeniem działalności inwestycyjnej i finansowaniu działań marketingowych. Ograniczenia w rozwoju mogą również wynikać $\mathrm{z}$ niewielkiego zasięgu planowania, szczególnie strategicznego, a podejmowanie decyzji strategicznych tylko na podstawie intuicji właściciela nie zawsze może okazać się skuteczne w podejmowaniu decyzji strategicznych.

Jednym z głównych problemów MSP jest świadome kształtowanie swojej przyszłości w celu zapewnienia korzystnej pozycji konkurencyjnej i możliwości wzrostu i rozwoju w zmiennym otoczeniu. Przyczyn tego stanu rzeczy można upatrywać w braku jasno wytyczonej strategii działania, która powinna stać się sposobem reagowania i przystosowania tych podmiotów do warunków otoczenia. Strategia ujawnia postawę kierownictwa przedsiębiorstwa w kontaktach $\mathrm{z}$ otoczeniem oraz decyzje $\mathrm{w}$ zakresie kształtowania przyszłości przedsiębiorstwa przy wykorzystaniu szans i przezwyciężaniu zagrożeń (Bojewska 2011, s. 125).

Czynniki wewnętrzne zarówno konstruktywne, jak i destruktywne mogą być uzależnione od sposobu działania małych i średnich przedsiębiorstw w otoczeniu. Elastyczność w działaniu oraz szybkość reagowania na zmiany pochodzące $\mathrm{z}$ otoczenia wymaga potencjału wewnętrznego, będącego mocną stroną przedsiębiorstwa. Natomiast wszelkie słabości związane $\mathrm{z}$ wnętrzem firmy mogą negatywnie oddziaływać na rozwój małych i średnich przedsiębiorstw i osłabiać odpowiedź tych przedsiębiorstw na zagrożenia wynikające $\mathrm{z}$ otoczenia.

Reasumując dotychczasowe rozważania, uwarunkowania wewnętrzne mogą być zarówno stymulatorami, jak również barierami rozwoju małych i średnich przedsiębiorstw. Analiza tych uwarunkowań odnosząca się do różnych kategorii firm (mikro, małych i średnich) oraz ich lokalizacji (np. obszary rozwinięte i obszary zmarginalizowane) powinna odwoływać się do przedsiębiorcy, jego 
charakterystyki, potencjału w zakresie zarządzania przedsiębiorstwem, oraz do przedsiębiorstwa jego parametrów demograficznych, szeroko rozumianych zasobów oraz orientacji przedsiębiorczej. Propozycja zmiennych do modelu badawczego zostanie zaprezentowana w podrozdziale 3.4 .

\subsubsection{Uwarunkowania zewnętrzne}

Uwarunkowania zewnętrzne utożsamia się najczęściej z otoczeniem małych i średnich przedsiębiorstw, które jest definiowane jako środowisko zewnętrzne, stanowiące zbiór czynników wpływających na funkcjonowanie i rozwój tych przedsiębiorstw. Z perspektywy podmiotowej otoczenie to zbiór instytucji i zorganizowanych grup interesów, natomiast z perspektywy przedmiotowej to zespół procesów i zjawisk, którym poddane jest przedsiębiorstwo i na które może również oddziaływać (Kamińska 2011, s. 39). Otoczenie małych i średnich przedsiębiorstw można analizować ze względu na (Bielski 2002, Reddy 2004, cyt. za Kurowska, Matejun, Szymańska 2013):

- czas, na podstawie którego można wyróżnić otoczenie przeszłe, obecne oraz przyszłe;

- przestrzeń, która pozwala wyodrębnić otoczenie lokalne, regionalne, krajowe, międzynarodowe oraz globalne;

- złożoność, rozumiana jako stopień skomplikowania i różnorodności elementów występujących w środowisku zewnętrznym. Ze względu na to kryterium wyróżnia się otoczenie proste oraz złożone;

- zmienność analizująca szybkość i dynamikę zachodzących zmian, co stanowi podstawę do wyodrębnienia otoczenia stabilnego, zmiennego, burzliwego, a nawet migocącego, w którym szanse pojawiają się nagle i trwają przez krótki okres, co w znacznym stopniu determinuje pozycję rynkową działających w nim przedsiębiorstw;

- potencjał, który jest związany ze zdolnością otoczenia do stwarzania przedsiębiorstwu możliwości trwania, regularnego wzrostu i rozwoju. W tym ujęciu można mówić o otoczeniu o niskim bądź wysokim potencjale;

- bliskość (zasięg) oddziaływania, w ramach którego wyróżnia się otoczenie bliższe (mikrootoczenie) oraz otoczenie dalsze (makrootoczenie).

Uwarunkowania zewnętrzne najczęściej dzieli się w kontekście analizy otoczenia na makrootoczenie, mezootoczenie oraz mikrootoczenie (Skowronek-Mielczarek 2011; Romero, Fernandez Serrano 2011; Bednarczyk 1996).

Makrootoczenie to zespół ogólnych warunków funkcjonowania danego przedsiębiorstwa w danym kraju czy też regionie. Obejmuje ono pięć wymiarów, takich jak (Griffin 2010):

- ekonomiczny, czyli potencjał gospodarczy danego państwa i regionu; 
- polityczno-prawny, czyli polityka państwa, która powinna tworzyć przyjazne środowisko m.in. dla rozwoju działalności gospodarczej (m.in. łagodzenie obciążeń podatkowych, redukcja kosztów pracy, uporządkowanie przepisów uregulowań prawnych, ciągłe bowiem zmiany w otoczeniu prawno-politycznym powodują dodatkowe koszty i poczucie niepewności wśród przedsiębiorców, co hamuje postawy przedsiębiorcze, wstrzymując rozwój małych i średnich przedsiębiorstw) (Latoszek 2008; Sosnowska, Łobejko 2008; Safin red. 2008);

- technologiczny, który daje możliwość uzyskania przewagi konkurencyjnej, zmniejszenia kosztów działalności oraz poprawę efektywności działania poprzez wprowadzenie zmian $\mathrm{w}$ obszarze techniki i technologii. $\mathrm{Z}$ drugiej strony może być zagrożeniem w postaci silnej międzynarodowej konkurencji, której nie zawsze mogą sprostać małe i średnie przedsiębiorstwa;

- społeczno-kulturowy, czyli normy, wartości, przekonania, postawy i zachowania charakterystyczne dla danego społeczeństwa, które często mają znaczący wpływ na rozwój zachowań i postaw przedsiębiorczych;

- międzynarodowy wiąże się ściśle z zachodzącymi procesami globalizacji i integracji. Zjawiska te mogą pozytywnie wpływać na rozwój małych i średnich przedsiębiorstw w kierunku: poprawy jakości, możliwości kooperacji z innymi podmiotami gospodarczymi i rozwoju internacjonalizacji. Z drugiej strony dużym problemem może stać się silna międzynarodowa konkurencja, której nie zawsze mogą sprostać małe i średnie przedsiębiorstwa.

Mikrootoczenie - tzw. otoczenie konkurencyjne - składa się m.in. z klientów, dostawców, kooperantów, konkurencji oraz związków zawodowych. Podmioty te utrzymują $\mathrm{z}$ przedsiębiorstwem powiązania kooperacyjne lub konkurencyjne (Kamińska 2011, s. 42). Ważną cechą tych powiązań są sprzężenia zwrotne. Analiza tego otoczenia pomaga określić warunki funkcjonowania i rozwoju małych i średnich przedsiębiorstw w danym sektorze i na danym geograficznie rynku.

Mezootoczenie (otoczenie regionalne) - obejmuje czynniki oddziałujące na przedsiębiorstwo $\mathrm{w}$ układzie regionalnym $\mathrm{z}$ uwzględnieniem specyfiki poszczególnych regionów.

W literaturze przedmiotu istnieje wiele klasyfikacji uwarunkowań rozwoju MSP związanych z makro i mikrootoczeniem (por. tabela 8).

Według B. Nogalskiego, J. Karpacza, A. Wójcik-Karpacz (2004, s. 40). źródłem czynników zewnętrznych o charakterze konstruktywnym i destruktywnym, wpływających na funkcjonowanie i rozwój małych i średnich przedsiębiorstw, jest makrootoczenie i otoczenie konkurencyjne. 
Tabela 8. Uwarunkowania makroekonomiczne i mikroekonomiczne rozwoju małych i średnich przedsiębiorstw - wybrane koncepcje

\begin{tabular}{|c|c|c|}
\hline Autorzy & $\begin{array}{l}\text { Uwarunkowania rozwoju małych i średnich } \\
\text { przedsiębiorstw }\end{array}$ & Kierunek wpływu \\
\hline $\begin{array}{l}\text { Smallbone, Deankins, } \\
\text { Battisti, Kitching (2012), } \\
\text { Latkam (2009), Latoszek } \\
\text { (2008), Churchil, Lewis } \\
\text { (1984) }\end{array}$ & $\begin{array}{l}\text { Uwarunkowania makroekonomiczne głów- } \\
\text { nie związane z kryzysami w gospodarkach } \\
\text { światowych zarówno gospodarczych, jak } \\
\text { i finansowych }\end{array}$ & Negatywny \\
\hline $\begin{array}{l}\text { Skowronek-Mielczarek } \\
\text { (2011), Romero, Fernan- } \\
\text { dez-Serrano (2011), Ma- } \\
\text { tejun (2011), Griffin } \\
(2010), \text { Latoszek (2008), } \\
\text { Sosnowska, Lobejko } \\
(2008), \text { Safin (2008), } \\
\text { Bednarczyk (1996) }\end{array}$ & $\begin{array}{l}\text { Uwarunkowania zewnętrzne związane są } \\
\text { bezpośrednio z otoczeniem małych i śred- } \\
\text { nich przedsiębiorstw. Podział tych uwarun- } \\
\text { kowań na trzy kategorie najczęściej anali- } \\
\text { zowanego otoczenia (makrootoczenie, mezo- } \\
\text { otoczenie oraz mikrootoczenie) }\end{array}$ & Pozytywny/negatywny \\
\hline $\begin{array}{l}\text { Nogalski, Karpacz, Wój- } \\
\text { cik-Karpacz (2004), No- } \\
\text { galski, Wójcik-Karpacz } \\
(2003 b)\end{array}$ & $\begin{array}{l}\text { Determinanty zewnętrzne: konstruktywne } \\
\text { (bliskość rynku, na którym działa przedsię- } \\
\text { biorstwo, szybkośc reakcji na zmiany } \\
\text { otoczenia) i destruktywne (mocno ograni- } \\
\text { czony wpływ na rynek, brak orientacji } \\
\text { marketingowej przedsiębiorstwa) }\end{array}$ & Pozytywny/negatywny \\
\hline Korol, Szczuciński (2011) & $\begin{array}{l}\text { Uwarunkowania zewnętrzne o charakterze } \\
\text { ogólnym (rosnący przestrzenny i przedmio- } \\
\text { towy zasięg rynku, dokonujace się procesy } \\
\text { globalizacji prowadzące do całkowitej zmia- } \\
\text { ny procesów produkcji, nowego podziału } \\
\text { pracy, rozwoju badań i nauki, wzrost zna- } \\
\text { czenia prac badawczo-rozwojowych, groma- } \\
\text { dzenie, przetwarzanie i wykorzystywanie } \\
\text { informacji) i szczegółowym (czynniki oto- } \\
\text { czenia systemowego, charakter stosunków } \\
\text { z dostawcami i odbiorcami, związki przed- } \\
\text { siębiorstwa z innymi podmiotami, stosunki } \\
\text { z instytucjami regionalnymi stosunki z oto- } \\
\text { czeniem biznesu) }\end{array}$ & Pozytywny/negatywny \\
\hline $\begin{array}{l}\text { Borowiecki, } \\
\text { karska (2008), } \\
\text { nek-Mielczarek } \\
\text { Daszkiewicz (2004) }\end{array}$ & $\begin{array}{l}\text { Uwarunkowania zewnętrzne analizowane } \\
\text { głównie w kontekście barier zewnętrznych } \\
\text { związanych z etapem rozwoju przedsiębior- } \\
\text { stwa: bariery wejścia (ujawniają się podczas } \\
\text { uruchamiania firmy oraz we wczesnych } \\
\text { fazach jej rozwoju), bariery rozwoju (zwią- } \\
\text { zane z fazą wzrostu i dojrzałości firmy i to- } \\
\text { warzyszącymi tym fazom kryzysom) oraz } \\
\text { bariery wyjścia (w fazie schyłkowej i upad- } \\
\text { ku firmy) }\end{array}$ & Pozytywny/negatywny \\
\hline
\end{tabular}

Źródło: opracowanie własne na podstawie: Daszkiewicz 2004b, s. 139-147; Smallbone, Deakins, Battisti, Kitching 2012, s. 754-777; Latoszek 2008; Churchil, Lewis 1983; Nogalski, Karpacz, Wójcik-Karpacz 2004; Nogalski, Wójcik-Karpacz 2003b; Bednarczyk 1996; Safin 2008; Korol, Szczuciński 2011. 
Makrotoczenie może wywierać wpływ zarówno stymulujący, jak i hamujący rozwój małych i średnich przedsiębiorstw. Do czynników tych zalicza się: politykę państwa i władz lokalnych, otoczenie międzynarodowe, otoczenie technologiczne oraz szeroko rozumiane otoczenie biznesu. W przypadku pozytywnego wpływu na rozwój małych i średnich przedsiębiorstw polityka państwa i władz lokalnych powinna zostać skierowana na tworzenie korzystnych warunków dla prowadzenia biznesu w kraju i regionie np. poprzez tworzenie mechanizmów finansowania (środki unijne, fundusze pożyczkowe i poręczeniowe), uproszczenie systemu podatkowego, obniżenie kosztów pracy, ułatwienie dostępu do informacji, szkoleń i doradztwa, popieranie współpracy przedsiębiorstw. Polityka państwa i władz lokalnych ma również negatywny wpływ poprzez: nadmierny fiskalizm, wysokie obciążenia podatkowe, niestabilność i niejasność przepisów prawnych związanych z prowadzeniem działalności gospodarczej. Otoczenie międzynarodowe może również mieć pozytywny wpływ na rozwój MSP w postaci procesów globalizacji w gospodarce światowej i integracji z UE. Zachodzące procesy mogą spowodować napływ BIZ oraz dają możliwość kooperacji z dużymi firmami, np. w postaci podwykonawców, lub są szansą na znalezienie przez te podmioty nisz rynkowych. Negatywnego wpływu otoczenia międzynarodowego upatruje się w niekorzystnej sytuacji na rynku pracy, szczególnie UE, co może spowodować odpływ wykwalifikowanych pracowników oraz kryzys finansowy i gospodarczy.

Natomiast otoczenie technologiczne wywiera głównie pozytywny wpływ w postaci szybkiego postępu technologicznego, powodującego dezindustrializację, która jest szansą na rozwój MSP w niszach rynkowych pozostawionych przez duże podmioty gospodarcze. Stymulatorem rozwoju małych i średnich przedsiębiorstw może stać się również skutecznie i efektywnie funkcjonujące szeroko rozumiane otoczenie biznesu, np. poprzez tworzenie sieci KSU i KSI, ośrodków innowacji i przedsiębiorczości, parków technologicznych i przemysłowych, ale również może stać się barierą chociażby dla finansowania działalności gospodarczej poprzez niekorzystne warunki oferowane przez instytucje finansujące, jak również nadmierną biurokrację, która może się przyczynić do braku możliwości skorzystania ze środków unijnych.

Analizując otoczenie konkurencyjne wśród czynników konstruktywnych, wymienia się (Nogalski, Karpacz, Wójcik-Karpacz 2004, s. 54):

- bliskość i dobre kontakty z nabywcami,

- szybkość reakcji na zmiany zachodzące w tym otoczeniu,

- możliwość wykonywania jednostkowych wyrobów,

- możliwość podwykonawstwa, które daje szanse na rozwój małych i średnich przedsiębiorstw w oparciu różne formy współpracy z dużymi firmami.

Natomiast do czynników destruktywnych zalicza się (Nogalski, Karpacz, Wójcik-Karpacz 2004, s. 40):

- ekspansję rynkową dużych przedsiębiorstw, które eliminują z rynku MSP;

- rywalizację pomiędzy małymi i średnimi przedsiębiorstwami; 
- presję ze strony dostawców;

- przewagę ze strony nabywców.

Zaprezentowane czynniki zewnętrzne o charakterze konstruktywnym i destruktywnym, pochodzące $\mathrm{z}$ makrootoczenia i otoczenia konkurencyjnego, wywierają znaczący wpływ na funkcjonowanie i rozwój małych i średnich przedsiębiorstw. Przedsiębiorstwa te, aby odnieść sukces rynkowy, powinny na bieżąco monitorować otoczenie i szybko reagować na zmiany zachodzące w nim, w celu wykorzystania pojawiających się okazji stanowiących szanse na rozwój i unikania, na ile jest to możliwe, zagrożeń.

$\mathrm{W}$ odniesieniu do uwarunkowań mezoekonomicznych w literaturze przedmiotu można znaleźć wiele klasyfikacji tych uwarunkowań (por. tabela 9). Najczęściej wśród uwarunkowań mających wpływ na rozwój MSP wymienia się: jednostki administracji publicznej, instytucje finansujące, instytucje naukowo-edukacyjne oraz instytucje infrastruktury usługowej wspomagające rozwój przedsiębiorczości i prowadzenie działalności gospodarczej (Bednarczyk 1996, Wach 2008, Gancarczyk 2010).

Tabela 9. Uwarunkowania mezoekonomiczne (regionalne) rozwoju małych i średnich przedsiębiorstw - wybrane koncepcje

\begin{tabular}{|c|c|c|}
\hline Autorzy & $\begin{array}{l}\text { Uwarunkowania rozwoju małych i średnich przedsię- } \\
\text { biorstw }\end{array}$ & Kierunek wpływu \\
\hline 1 & 2 & 3 \\
\hline $\begin{array}{l}\text { Kamińska } \\
(2011), \\
\text { Strużycki } \\
(2004, \quad 2011), \\
\text { Wach (2008) }\end{array}$ & $\begin{array}{l}\text { Uwarunkowania regionalne i lokalne, np. stosowane } \\
\text { przez gminy instrumenty wspierania przedsiębiorczo- } \\
\text { ści w postaci ulg podatkowych, dbałość o rozwój } \\
\text { infrastruktury, wspieranie działalności szkoleniowej, } \\
\text { współfinansowanie ośrodków wspierania przedsię- } \\
\text { biorczości, współfinansowanie funduszy pożyczko- } \\
\text { wych i poręczeniowych, współpraca z organizacjami } \\
\text { przedsiębiorców oraz promocji walorów inwestycyj- } \\
\text { nych gminy }\end{array}$ & Pozytywny/negatywny \\
\hline Porter 2002 & $\begin{array}{l}\text { Uwarunkowania regionalne wpływające na rozwój } \\
\text { przedsiębiorstw, w tym sektora MSP, podzielił na } \\
\text { cztery grupy: uwarunkowania zasobowe, uwarunko- } \\
\text { wania popytowe, branże pokrewne i wspierające oraz } \\
\text { związane z działalnością firmy }\end{array}$ & Pozytywny/negatywny \\
\hline Porter 2002 & $\begin{array}{l}\text { Czynniki wpływające na decyzje wyboru lokalizacji } \\
\text { firmy, takie jak: potencjał gospodarczy regionu, } \\
\text { sprawnie funkcjonujące otoczenie biznesowe, stan } \\
\text { infrastruktury transportowej i technicznej, dostępność } \\
\text { kapitału i wysoko wykwalifikowanej siły roboczej, } \\
\text { atrakcyjność inwestycyjna i promocja regionu, jak } \\
\text { również standard życia lokalnej społeczności mający } \\
\text { wpływ na popyt }\end{array}$ & Pozytywny/negatywny \\
\hline
\end{tabular}


Tabela 9 (cd.)

\begin{tabular}{|c|c|c|}
\hline 1 & 2 & 3 \\
\hline \begin{tabular}{|l|} 
Markusen \\
$(2000)$ \\
Jewtuchowicz \\
$(2006)$ \\
\end{tabular} & $\begin{array}{l}\text { Uwarunkowania wpływające na rozwój to tzw. } \\
\text { czynniki specyficzne - współpraca przedsiębiorstw } \\
\text { z terytorium i miejscem lokalizacji - specjalizacja } \\
\text { regionalna }\end{array}$ & Pozytywny \\
\hline $\begin{array}{l}\text { Smallbone, } \\
\text { Welter (2001), } \\
\text { Jewtuchowicz, } \\
\text { Nowakowska, } \\
\text { Przygodzki } \\
(2006) \\
\end{array}$ & $\begin{array}{l}\text { Czynnikiem wpływającym na rozwój małych i średnich } \\
\text { przedsiębiorstw są działania administracji publicznej } \\
\text { w zakresie stwarzania klimatu dla przyciągania in- } \\
\text { westorów zagranicznych. }\end{array}$ & Pozytywny \\
\hline $\begin{array}{l}\text { Cygler (2008), } \\
\text { Klasik (2006) }\end{array}$ & $\begin{array}{l}\text { Wpływ BIZ na tworzenie sieci powiązań i wykorzysta- } \\
\text { niu dostawców lokalnych }\end{array}$ & Pozytywny \\
\hline $\begin{array}{l}\text { Bednarczyk } \\
(1996)\end{array}$ & $\begin{array}{l}\text { Podmiotowe ujęcie mezootoczenia obejmuje: jednostki } \\
\text { terenowe administracji publicznej oraz podmioty } \\
\text { infrastruktury usługowej dla prowadzenia działalności } \\
\text { gospodarczej }\end{array}$ & Pozytywny/negatywny \\
\hline Wach (2008) & $\begin{array}{l}\text { Przedmiotowe ujęcie mezootoczenia obejmuje: insty- } \\
\text { tucje finansujące, instytucje samorządowe, instytucje } \\
\text { naukowo-edukacyjne, szczególne grupy wpływów, } \\
\text { podmioty w obrębie sektora, instytucje działające na } \\
\text { rzecz rozwoju przedsiębiorczości itp. }\end{array}$ & Pozytywny/negatywny \\
\hline $\begin{array}{l}\text { Stawasz, Siko- } \\
\text { ra-Fernadez } \\
(2011), \text { Gancar- } \\
\text { czyk (2010), Ku- } \\
\text { ciński (2010), } \\
\text { Kogut-Jawor- } \\
\text { ska, Filipak, Ru- } \\
\text { szała (2009), Ma- } \\
\text { kieła (2008) } \\
\end{array}$ & $\begin{array}{l}\text { Czynnikiem wpływającym na rozwój małych i średnich } \\
\text { przedsiębiorstw są działania jednostek samorządu } \\
\text { terytorialnego, takie jak: aktywizacji społeczności } \\
\text { lokalnej poprzez stworzenie przyjaznego klimatu dla } \\
\text { rozwoju inicjatyw przedsiębiorczych, tworzenia no- } \\
\text { wych miejsc pracy, przyciągania nowych inwestorów, } \\
\text { umacniania lokalnej gospodarki poprzez tworzenie } \\
\text { sieci powiązań, podnoszenia poziomu zaawansowania } \\
\text { infrastrukturalnego obszaru }\end{array}$ & Pozytywny/negatywny \\
\hline $\begin{array}{l}\text { Markowski } \\
(1999)\end{array}$ & $\begin{array}{l}\text { Czynnikiem wpływającym na rozwój może stać się } \\
\text { „lokalna polityka ekonomiczna” określana jako } \\
\text { działania podejmowane przez władze samorządowe na } \\
\text { rzecz stymulowania lokalnej działalności gospodarczej } \\
\text { i tworzenia nowych miejsc pracy. Lokalna polityka } \\
\text { ekonomiczna to proces tworzenia instytucji, rozwijanie } \\
\text { alternatywnych gałęzi przemysłu, wpływanie na } \\
\text { przedsiębiorców w zakresie wytwarzania lepszych } \\
\text { produktów, pomoc w rozpoznawaniu nowych rynków, } \\
\text { transfer wiedzy, wspomaganie nowych firm i przed- } \\
\text { siębiorstw itd. Efektem tych działań może stać się } \\
\text { powstawanie różnorodnych dziedzin działalności } \\
\text { małych i średnich firm }\end{array}$ & Pozytywny/negatywny \\
\hline
\end{tabular}

Źródło: opracowanie własne na podstawie: Kamińska 2011; Strużycki red. 2004, 2011; Makieła 2008; Stawasz, Sikora-Fernandez 2011, s. 145-146; Gancarczyk 2010; Markowski 1999. 
M.E Porter do czynników regionalnych wpływających na rozwój przedsiębiorstw, w tym sektora MSP zaliczył: uwarunkowania zasobowe, uwarunkowania popytowe, branże pokrewne i wspierające oraz związane $\mathrm{z}$ działalnością firmy (Porter 2002, s.10-11) (por. rysunek 27).

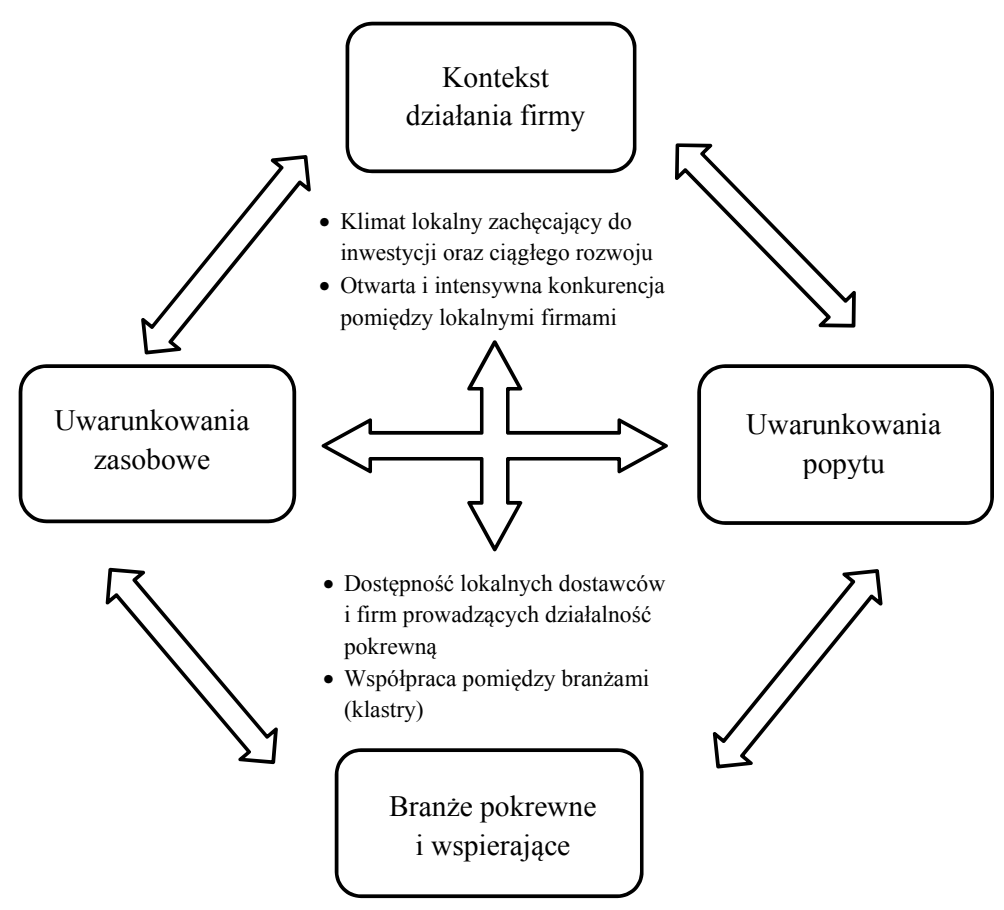

Rysunek 27. Determinanty przewagi konkurencyjnej w regionie Źródło: Porter i Monitor Group 2002, s. 10

Uwarunkowania zasobowe (zasoby ludzkie, źródła finansowania, infrastruktura techniczna, informacyjna i administracyjna, wiedza i technologie, surowce naturalne) i ich jakość przyczyniają się do konkurencyjności i innowacyjności przedsiębiorstw funkcjonujących $\mathrm{w}$ danym regionie. Uwarunkowania popytowe (wymagający klienci, lokalny popyt $\mathrm{w}$ wyspecjalizowanych segmentach) mogą wpływać na wprowadzanie zmian i innowacji, inwestycje oraz ochronę własności intelektualnej. Współpraca firm pomiędzy branżami (transfer wiedzy i innowacji), jak również klimat lokalny zachęcający do inwestycji oraz otwarta rywalizacja pomiędzy lokalnymi przedsiębiorstwami może pomóc $\mathrm{w}$ poprawie innowacyjności i zwiększeniu wydajności firm regionalnych. Pomiędzy wymienionymi grupami czynników zachodzą sprzężenia zwrotne powodujące wzajem- 
ne powiązania i zależności pobudzające zmiany w jakości otoczenia regionalnego ważne dla rozwoju małych i średnich przedsiębiorstw.

Strukturę mezootoczenia można również traktować podmiotowo (Bednarczyk 1996) i/lub przedmiotowo (Wach 2008). W podejściu podmiotowym w skład mezootoczenia wchodzą (Bednarczyk 1996, s. 46):

- jednostki administracji publicznej (np. samorząd terytorialny, urzędy skarbowe),

- podmioty infrastruktury usługowej dla prowadzenia działalności gospodarczej (np. agencje rozwoju regionalnego, izby przemysłowo-handlowe, inkubatory przedsiębiorczości, firmy szkoleniowo-doradcze).

Natomiast w ujęciu podmiotowym do mezootoczenia zalicza się (Wach 2008, s. 34-35):

- instytucje finansujące (np. banki, partnerzy finansowi, fundusze gwarancyjne, firmy leasingowe, regionalne instytucje finansowe),

- instytucje samorządowe (np. władze samorządowe, jednostki administracji lokalnej)

- instytucje samorządu gospodarczego (np. izby handlowe, izby rzemieślnicze, związki pracodawców),

- instytucje naukowo-edukacyjne (np. uczelnie wyższe, instytuty badawcze, parki naukowo-technologiczne, ośrodki informacyjne),

- instytucje aparatu państwa (np. urzędy skarbowe),

- instytucje działające na rzecz rozwoju przedsiębiorczości (np. agencje rozwoju regionalnego, inkubatory przedsiębiorczości, klastry przemysłowe, firmy doradcze, firmy konsultingowe, firmy szkoleniowe),

- podmioty w obrębie sektora (np. konkurenci, dostawcy, klienci),

- szczególne grupy wpływów (np. społeczności lokalne, lokalne grupy lobbingu).

M. Strużycki przeprowadził interesujące badania wpływu czynników regionalnych na rozwój małych i średnich przedsiębiorstw w regionie mazowieckim. Jak wynika z badań, głównymi determinantami rozwoju są: stosowane przez gminy instrumenty wspierania przedsiębiorczości w postaci ulg podatkowych, dbałość o rozwój infrastruktury, wspieranie działalności szkoleniowej, współfinansowanie ośrodków wspierania przedsiębiorczości, współfinansowanie funduszy pożyczkowych i poręczeniowych, współpraca z organizacjami przedsiębiorców oraz promocji walorów inwestycyjnych gminy (Strużycki red. 2004).

W badaniach A. Kamińskiej (2011, s. 264) przeprowadzonych w regionie lubelskim, do kluczowych czynników rozwoju małych i średnich przedsiębiorstw przedsiębiorcy zaliczyli:

- poziom życia lokalnej społeczności,

- wsparcie finansowe ze strony państwa i władz samorządowych,

- tempo podejmowania decyzji przez samorząd i administrację,

- politykę władz lokalnych i regionalnych,

- możliwości pozyskania kredytów i pożyczek. 
Czynniki te są traktowane przez przedsiębiorców zarówno jako stymulatory, jak również jako bariery rozwoju, co może świadczyć o zróżnicowanych potrzebach tych przedsiębiorstw.

Do uwarunkowań regionalnych rozwoju małych i średnich przedsiębiorstw zalicza się również czynniki wpływające na decyzje związane $\mathrm{z}$ wyborem lokalizacji firmy (Porter (2002, Strużycki red. 2004), takie jak: potencjał gospodarczy regionu, sprawnie funkcjonujące otoczenie biznesowe, stan infrastruktury transportowej i technicznej, dostępność kapitału i wysoko wykwalifikowanej siły roboczej, atrakcyjność inwestycyjna i promocja regionu, jak również standard życia lokalnej społeczności mający wpływ na popyt. Przyczyny indywidualnych decyzji o wyborze lokalizacji działalności gospodarczej wyjaśniają teorie i koncepcje lokalizacji firmy (por. Stawasz D. 2000, s. 19; Budner 2003; Przygodzki 2007; Kuciński 2010). Na przykład firmy produkcyjne mogą sobie pozwolić na peryferyjną lokalizację, gdy posiadają dostępność zasobów, natomiast firmy usługowe i handlowe są uzależnione od lokalizacji analizowanej z punktu widzenia wielkości rynku i występującego na nim popytu.

Wpływ lokalizacji firmy na rozwój małych i średnich przedsiębiorstw potwierdzają również wyniki badan ${ }^{11}$ przeprowadzonych w $2011 \mathrm{r}$. w obszarach zmarginalizowanych ${ }^{12}$ województwa łódzkiego wśród 67 małych i średnich przedsiębiorstw. Jedną z dziedzin badawczych była ocena wpływu lokalizacji przedsiębiorstwa w obszarach zmarginalizowanych na rozwój firmy. Znaczna liczba respondentów potwierdziła istnienie tego wpływu, określając go jako duży lub znaczący (73,8\% wskazań), co w dużej mierze wynika ze specyfiki tych obszarów. Właściciele badanych firm, którzy potwierdzili wpływ lokalizacji firmy $w$ regionach zmarginalizowanych na rozwój firmy, wskazali przyczyny tego wpływu. Dominowały czynniki pochodzące $\mathrm{z}$ otoczenia zewnętrznego, odnoszące się do specyfiki tych regionów, tzn. mniejszej liczby klientów (41,1\% wskazań), ograniczonego dostępu do zasobów finansowych (39,5\% wskazań), biernego wsparcia ze strony władz samorządowych $(32,3 \%$ wskazań), na dalszych miejscach umieszczono ograniczony dostęp do otoczenia biznesu i brak przyjaznego klimatu do rozwoju przedsiębiorstw (Lisowska 2012a, s. 421-422).

${ }^{11}$ Badanie zostało przeprowadzone w ramach projektu pt. Determinanty rozwoju matych $i$ średnich przedsiębiorstw funkcjonujacych $w$ regionach zmarginalizowanych. Strategie rozwoju i polityka wsparcia projekt no. N N115 297738, umowa numer 2977/B/H03/2010/38, finansowanego przez Ministerstwo Nauki i Szkolnictwa Wyższego.

12 Wybór obszarów zmarginalizowanych w województwie łódzkim według metodologii omówionej w podpunkcie 1.3. 
Dla rozwoju małych i średnich przedsiębiorstw na poziomie regionalnym istotne są również działania jednostek samorządu terytorialnego, które przyczyniają się do (Stawasz D., Sikora-Fernandez 2011, s. 42):

- aktywizacji społeczności lokalnej poprzez stworzenie przyjaznego klimatu dla rozwoju inicjatyw przedsiębiorczych w tym uruchomienia i prowadzenia biznesu;

- tworzenia nowych miejsc pracy - w wyniku korzystnych warunków dla rozwoju działalności gospodarczej firmy zwiększają zatrudnienie;

- przyciągania nowych inwestorów - na skutek podejmowanych inicjatyw władz samorządowych $\mathrm{w}$ zakresie poprawy atrakcyjności danego regionu poprawnie prowadzonej polityki inwestycyjnej;

- umacniania lokalnej gospodarki poprzez tworzenie sieci powiązań kooperacyjnych, podstawę funkcjonowania tych sieci stanowią istniejące jednostki gospodarcze wraz z firmami należącymi do inwestorów zewnętrznych;

- podnoszenia poziomu zaawansowania infrastrukturalnego obszaru, władze lokalne inwestują $\mathrm{w}$ działania związane $\mathrm{z}$ rozwojem infrastruktury technicznej i społecznej, poprawiając poziom konkurencyjności oraz warunki funkcjonowania przedsiębiorstw na danym terenie.

Jednak, jak wskazują badania (Lisowska 2011a i 2012), przedsiębiorcy oceniają zaangażowanie władz samorządowych w rozwój przedsiębiorczości jak niewystarczające. Ogranicza się bowiem do dbałości o rozwój infrastruktury (głównie drogi), działania promujące jako obszar sprzyjający inwestorom bądź atrakcyjny dla turystów, wydzielanie atrakcyjnie położonych działek pod inwestycje, wprowadzanie ułatwień $\mathrm{w}$ procedurze urzędowej oraz udzielanie inwestorom ulg podatkowych. Do najrzadziej stosowanych instrumentów badani przedsiębiorcy zaliczyli: udzielanie dotacji i pożyczek oraz inicjowanie powstawania ośrodków wspierania biznesu, których liczba jest niewystarczająca szczególnie $\mathrm{w}$ obszarach zmarginalizowanych. Wynika $\mathrm{z}$ tego, że władze samorządowe mają jeszcze wiele do zrobienia $\mathrm{w}$ zakresie stymulowanie rozwoju małych i średnich przedsiębiorstw w tych obszarach. Powinien to być proces wieloletni, składający się z: identyfikacji ważnych problemów gospodarczych i społecznych regionu, stworzenia bądź doskonalenia struktur, tworzenia klimatu dla powstawania i rozwoju podmiotów gospodarczych, współpracy z przedsiębiorcami oraz doskonalenia jakości funkcjonowania jednostek samorządu terytorialnego.

Analiza zewnętrznych uwarunkowań rozwoju małych i średnich przedsiębiorstw oprócz elementów otoczenia na poziomach: mikro, makro i mezo powinna również uwzględniać czynniki wewnętrzne związane z osobą przedsiębiorcy i przedsiębiorstwem, tzn. jego orientacją przedsiębiorczą, omówione w punkcie 3.2.2. 


\subsection{Stymulatory i bariery rozwoju małych i średnich przedsiębiorstw w Polsce - wyniki dotychczasowych badań}

Jak wynika z wcześniejszych rozważań, uwarunkowania rozwoju małych i średnich przedsiębiorstw można rozpatrywać w układzie - stymulatory i bariery rozwoju. W analizie tej warto zwrócić uwagę na subiektywizm oceny poszczególnych czynników, jak również ich zmienność w czasie. Dla niektórych bowiem małych i średnich przedsiębiorstw jedne czynniki mogą stać się barierami, a dla innych stymulatorami rozwoju. Na przykład skomplikowane procedury w pozyskaniu środków finansowych z UE stanowią dla firm poszukujących kapitału na rozwój barierę, natomiast firmy konsultingowe zajmujące się pomocą w przygotowywaniu wniosków aplikacyjnych powinny w tym czynniku upatrywać okazji rynkowej. W licznych badaniach prezentowanych w literaturze przedmiotu (np. Dominiak, Bławat red. 1993; Daszkiewicz 2004a i b; Starczewska-Krzysztoszek 2008) (szerzej tabela 8) wskazywane są głównie bariery; analiza stymulatorów rozwoju sprowadza się zwykle do analizy mocnych stron (np. Piasecki 1997 i 2001, Nehring 2011) lub polityki wsparcia MSP w różnych obszarach działalności (np. Filipiak, Ruszała 2009; Gancarczyk 2010; Skowronek-Mielczarek 2011a; Lisowska, Stanisławski 2011; Wach 2008; Kamińska 2011).

W literaturze przedmiotu istnieje wiele klasyfikacji barier rozwoju małych i średnich przedsiębiorstw ze względu różnorodne kryteria. Próbę uporządkowania barier zaproponował M. Matejun (por. tabela 10), analizując bariery $\mathrm{w}$ różnych obszarach funkcjonowania małych i średnich przedsiębiorstw (Matejun 2010, s. 245).

Tabela 10. Wybrane kryteria klasyfikacji barier rozwoju małych i średnich przedsiębiorstw

\begin{tabular}{|l|l|}
\hline \multicolumn{1}{|c|}{ Kryterium podziału } & \multicolumn{1}{c|}{ Kategorie barier } \\
\hline \multicolumn{1}{|c|}{1} & \multicolumn{1}{c|}{2} \\
\hline $\begin{array}{l}\text { Okres występowania w trakcie } \\
\text { działalności gospodarczej } \\
\text { (faza rozwoju) }\end{array}$ & $\begin{array}{l}\text { Bariery wejścia } \\
\text { bariery bieżącej działalności } \\
\text { bariery rozwoju } \\
\text { bariery wyjścia }\end{array}$ \\
\hline Obszar występowania & $\begin{array}{l}\text { Bariery zewnętrzne } \\
\text { bariery wewnętrzne }\end{array}$ \\
\hline Kontekst rynkowy & $\begin{array}{l}\text { Bariery popytowe } \\
\text { bariery podażowe }\end{array}$ \\
\hline Poziom analizy & $\begin{array}{l}\text { Bariery makroekonomiczne } \\
\text { bariery mezoekonomiczne } \\
\text { bariery mikroekonomiczne }\end{array}$ \\
\hline Dynamika & $\begin{array}{l}\text { Bariery statyczne } \\
\text { bariery dynamiczne }\end{array}$ \\
\hline
\end{tabular}


Tabela 10 (cd.)

\begin{tabular}{|l|l|}
\hline \multicolumn{1}{|c|}{1} & \multicolumn{1}{|c|}{2} \\
\hline Kryterium skuteczności & $\begin{array}{l}\text { Bariery możliwe do pokonania } \\
\text { bariery niemożliwe do pokonania }\end{array}$ \\
\hline Czas trwania & $\begin{array}{l}\text { Bariery długoterminowe (względnie trwałe) } \\
\text { bariery średnioterminowe } \\
\text { bariery krótkoterminowe }\end{array}$ \\
\hline $\begin{array}{l}\text { Kryterium podmiotowe } \\
\text { (wielkość przedsiębiorstwa) }\end{array}$ & $\begin{array}{l}\text { Bariery mikroprzedsiębiorstw } \\
\text { bariery małych firm } \\
\text { bariery średnich firm }\end{array}$ \\
\hline Kryterium rodzajowe & $\begin{array}{l}\text { Np. bariery rynkowe, bariery kadrowe, bariery finansowe, } \\
\text { bariery innowacyjności, bariery prawne, bariery technologicz- } \\
\text { ne, bariery administracyjne, bariery w obszarze zarządzania, } \\
\text { bariery związane z rozmiarami działalności, bariery informa- } \\
\text { cyjne, bariery internacjonalizacji, bariery infrastrukturalne, } \\
\text { bariery środowiska naturalnego, bariery edukacyjne, bariery } \\
\text { kompetencji i wiedzy i inne szeroko opisane w literaturze } \\
\text { przedmiotu }\end{array}$ \\
\hline
\end{tabular}

Źródło: opracowanie własne na podstawie: Matejun 2010, s. 245; Łuczka 2007.

Przyjmując za kryterium wyróżnienia etap rozwoju firmy, wyróżnia się bariery: wejścia, rozwoju (Daszkiewicz 2004a), bieżącej działalności (Matejun 2010), oraz bariery wyjścia (Borowiecki, Siuta-Tokarska 2008). Bariery wejścia pojawiają się podczas uruchamiania firmy oraz we wczesnych fazach jej rozwoju; zalicza się do nich najczęściej: niejasność i niespójność przepisów, niewystarczający popyt, problemy z pozyskaniem środków finansowych oraz niesprzyjającą koniunkturę gospodarczą itp. Natomiast bariery rozwoju odnoszą się do firm funkcjonujących już na rynku; pojawiają w punkcie krytycznym przetrwania przedsiębiorstw w poszczególnych fazach (Daszkiewicz 2004a). Biorąc za punkt odniesienia dla wskazania przykładów tych barier model rozwoju M. Scotta i B. Bruce'a, można wskazać w fazie wzrostu bariery związane z procesem zarządzania, takie jak kryzys kontroli, który jest następstwem decentralizacji, w fazie ekspansji bariera biurokracji (Scott, Bruce 1987). Natomiast bariery wyjścia odnoszą się do inwestycji, branży, rynku bądź są związane likwidacją firmy $\mathrm{w}$ postaci barier finansowych towarzyszących koniecznością poniesienia kosztów wynikające z wcześniej podjętych zobowiązań wobec dostawców, pracowników, klientów itp.

W modelu D. Felsensteina i D. Szwartza można zaobserwować pewne analogie odnoszące się do barier rozwoju małych i średnich przedsiębiorstw ze względu na fazę rozwoju (Felsenstein, Swartz, 1993, cyt. za Daszkiewicz 2004a). Pierwszy etap to budowanie koncepcji (prelaunch stage), w której przyszły przedsiębiorca określa swój pomysł na biznes i próbuje go skonkretyzować $\mathrm{w}$ postaci projektu na swoją działalność gospodarczą. Na tym etapie 
mogą pojawić się problemy z procesem planowania przyszłej działalności, jak również z podjęciem decyzji o jej uruchomieniu. Można więc powiedzieć, że są to głównie bariery związane $\mathrm{z}$ osobą przedsiębiorcy jego umiejętnościami przedsiębiorczymi i w zakresie zarządzania. W drugim etapie (stat-up stage) przedsiębiorstwo rozpoczyna swoją działalność, jak również konfrontację z rynkiem; w tym czasie pojawia się zapotrzebowanie na kapitał i związana $\mathrm{z}$ tym bariera finansowa. W kolejnym etapie (operating stage) bieżącej działalności często następuje wzrost firmy i pojawia się problem z zarządzaniem, spada jego sprawność, a tym samym konieczność wsparcia ze strony specjalistów. W ostatnim etapie ekspansji (expansion stage) rozwój przedsiębiorstw wymaga zwiększenia nakładów we wszystkich dziedzinach funkcjonowania (Daszkiewicz 2004a, s. 62).

Inną klasyfikację barier opartą na modelach cyklu życia zaproponował M. Matejun, odnosząc się do ośmiu faz życia przedsiębiorstwa. W fazie pierwszej przedzałożycielskiej głównych barier rozwoju upatruje się w niedostatecznej kulturze przedsiębiorczości, braku systemu kształcenia postaw przedsiębiorczych $\mathrm{w}$ społeczeństwie oraz skomplikowanych procedurach uruchomienia i później prowadzenia działalności gospodarczej. W fazie pojawienia się problemem może stać się mało sprawny system wsparcia MSP w kontekście finansowania, transferu technologii oraz instytucjonalnym. W kolejnej fazie przeżycia przedsiębiorstwa ujawniają się bariery zewnętrzne $\mathrm{w}$ postaci rynkowych (konkurencja, szara strefa), finansowych (utrudniony dostęp do zewnętrznych źródeł finansowania) oraz kadrowych (problemy ze znalezieniem odpowiednich pracowników). W okresie dynamicznego wzrostu najbardziej uciążliwe są bariery finansowe, które hamują rozwój, np. związany z rozszerzeniem skali działania, wprowadzeniem innowacji. W fazach oderwania i ekspansji o dalszym wzroście i rozwoju decyduje pozyskanie menedżerów najemnych, którzy wykorzystując swoje kompetencje podniosą sprawność zarządzania. Natomiast w fazach dojrzałości oraz dalszych przekształceń przedsiębiorstwo może się zmagać z barierami makroekonomicznymi, takimi jak koniunktura gospodarcza w kraju i na świecie oraz mikroekonomicznymi - konkurencja nowych dynamicznych przedsiębiorstw z nowatorskim asortymentem bazujących na elastyczności działania (Matejun 2010, s. 246-247).

Analogicznie jak uwarunkowania rozwoju bariery najczęściej dzieli się w układzie na wewnętrzne i zewnętrzne (Storey 1994; Daszkiewicz 2004a i b, Strużycki 2004). Bariery wewnętrzne odnoszą się do przedsiębiorstwa, jego właściciela i strategii działania, wynikają głównie ze słabości przedsiębiorstwa, w tym niedostatków zasobowych czy ograniczeń kompetencyjnych. Natomiast bariery zewnętrzne są uwarunkowane czynnikami zmiennego i złożonego otoczenia, a także relacji zachodzących między firma a otoczeniem (Matejun 2007). 
Do barier wewnętrznych zalicza się głównie tzw. słabości małych i średnich przedsiębiorstw, takie jak :

- niesprawność systemu zarządzania, wynikającą z niskiego poziomu wiedzy i umiejętności posiadanych przez przedsiębiorców w zakresie zarządzania firmą, brak jasno wytyczonej strategii działania, koncentrowanie się na działalności bieżącej, słabości struktur organizacyjnych (Bartlett, Bukvic 2001);

- niewystarczające zasoby - problemy finansowe wynikające $\mathrm{z}$ ograniczonego dostępu do rynku kapitałowego, niskie kwalifikacje pracowników, przestarzały park maszynowy (Piasecki 2001, Nehring 2011);

- słabości procesu produkcyjnego - niewystarczające moce produkcyjne, niska skłonność do innowacji produktowych i procesowych (Matejun 2012);

- słabości kompetencji właścicieli i pracowników - niewystarczające kompetencje przedsiębiorcze, niska skłonność uczenia się (Piasecki 2001);

- bariery związane z rozmiarem działalności - niewystarczająca baza lokalowa, oddalenie od szlaków komunikacyjnych (Matejun 2007);

- koncentracja na rynku lokalnym (Strużycki red. 2004), mała zdolność i skłonność do zachowań proeksportowych (Raport o stanie sektora... 2012);

- stosowanie przewagi konkurencyjnej w oparciu o niską cenę, a nie oferowanie produktów i usług wysokiej jakości (Matejun 2012);

- niska skłonność i poziom kooperacji pomiędzy przedsiębiorstwami, jak również szeroko rozumianym otoczeniem biznesu (instytucje otoczenia biznesu, ośrodki naukowo-badawcze, władze lokalne i samorządowe) (Lisowska 2011).

$\mathrm{Z}$ kolei do barier zewnętrznych zalicza się:

- bariery prawne, związane ze skomplikowanymi, niestabilnymi i niejasnymi przepisami prawa, brakiem skutecznej ochrony znaków towarowych oraz trudnościami w egzekwowaniu prawa (Łuczka red. 2007, Safin 2008);

- bariery ekonomiczne, przejawiające się głównie brakiem spójnej i skutecznej polityki państwa wobec małych przedsiębiorstw, kryzysem gospodarczym i finansowym, niestabilną polityką fiskalną nadmiernymi obciążeniami podatkowymi, poziomem inflacji i stóp procentowych, wysokimi kosztami pracy itp.;

- bariery rynkowe, wynikające m.in. z zawężania się rynków zbytu, niedostatecznego popytu spowodowanego zubożeniem społeczeństwa, nacisku konkurencji oraz szarej strefy;

- bariery finansowe, związane m.in. z wysokimi kosztami kredytu i procedurami udzielania kredytów, warunkami ubiegania się o zamówienia publiczne, wydłużonymi terminami płatności (Skowronek-Mielczarek 2003; Bartlett, Bukvic 2001; Łuczka red. 2007), małą dostępnością do funduszy strukturalnych, niewystarczającą informacją o pomocy publicznej, brakiem własnych środków wymaganych $\mathrm{w}$ staraniach o pomoc finansową, związane $\mathrm{z}$ procedurami ubiegania się o wsparcie finansowe; 
- bariery administracyjne, przejawiające się w niewłaściwym podejsciu jednostek publicznych do przedsiębiorców;

- bariery społeczne, znajdujące wyraz w nierównomiernej infrastrukturze przedsiębiorczości, negatywnym image'u przedsiębiorcy, braku akceptacji pracy na własny rachunek (Daszkiewicz 2004a i b, Łuczka red. 2007);

- bariery informacyjne, wynikające z mało efektywnego systemu gromadzenia informacji gospodarczych i dostępu do nich;

- bariery infrastrukturalne - trudności i koszty dostępu do infrastruktury oraz niska jej jakość.

Inny podział barier rozwoju małych firm zaproponował D. Storey (1994), dzieląc je na:

- barierę zarządzania, która jest związana z brakiem kompetencji menedżerskich przedsiębiorcy, wynikających z często niewystarczających kwalifikacji i wiedzy z zakresu zarządzania. Bariera ta ma duże znaczenie w firmach, gdzie właściciel kieruje się głównie intuicją, np. rodzinnych, funkcjonujących w sektorach tradycyjnych, natomiast słabnie w firmach, gdzie właściciel jest wykształcony, posiada wiedzę i umiejętności z zakresu zarządzania firmą, np. w małych firmach innowacyjnych funkcjonujących w obszarze wysokich technologii;

- barierę finansową, która ma szczególne znaczenie w fazie rozwoju, gdyż wraz z rozwojem firmy zmienia się struktura kapitałowa. Małe firmy w fazie startu korzystają zazwyczaj z kapitału własnego, wraz ze wzrostem firmy zwiększa się ich zapotrzebowanie na kapitał. Rozwiązaniem tego problemu byłby łatwiejszy dostęp do kapitału obcego, szczególnie w przypadku firm, które nie są $\mathrm{w}$ stanie rozwinąc się na tyle, aby stać się wiarygodnym klientem dla banku czy też instytucji oferującej kapitał;

- barierę popytu - rynek może hamować rozwój małych firm, szczególnie w okresie recesji. Intensywność wpływu tej bariery wynika z panującej koniunktury gospodarczej.

W literaturze przedmiotu opisanych jest wiele badań poświęconych identyfikacji i analizie barier rozwoju małych i średnich przedsiębiorstw (por. tabela 11). Większość odnosi się do barier zewnętrznych, które są uważane za szczególnie uciążliwe w prowadzeniu biznesu.

Tabela 11. Wybrane badania barier rozwoju MSP w Polsce

\begin{tabular}{|c|c|c|}
\hline $\begin{array}{c}\text { Autor/Instytucja } \\
\text { przeprowadzająca } \\
\text { badania }\end{array}$ & $\begin{array}{c}\text { Główny obszar badawczy, } \\
\text { badana próba i metodologia }\end{array}$ & \multicolumn{1}{|c|}{ Najważniejsze bariery } \\
\hline 1 & 2 & \multicolumn{1}{|c|}{3} \\
\hline $\begin{array}{l}\text { Polska Fundacja Promo- } \\
\text { cji i Rozwoju Małych } \\
\begin{array}{l}\text { i Srednich Przedsiębior- } \\
\text { stw (1999, 2001) }\end{array}\end{array}$ & $\begin{array}{l}\text { Celem badań była Identyfika- } \\
\text { cja brótkiej i długiej perspekty- } \\
\text { wie, w 1999 r. - próba 7072 }\end{array}$ & $\begin{array}{l}\text { Bariery krótkim w horyzoncie } \\
\text { czasowym w 1999 i 2001 r.: } \\
\text { - koszty finansowania działalności, } \\
\text { - brak kapitału obrotowego, }\end{array}$ \\
\hline
\end{tabular}


Tabela 11 (cd.)

\begin{tabular}{|c|c|c|}
\hline 1 & 2 & 3 \\
\hline & $\begin{array}{l}\text { MSP z } 15 \text { krajów UE i Polski } \\
\text { w } 2001 \text { r. - próba } 5152 \text { MSP } \\
\text { z } 15 \text { krajów UE i Polski }\end{array}$ & $\begin{array}{l}\text { - wahania kursów walut. } \\
\text { Bariery w długim horyzoncie czaso- } \\
\text { wym w } 1999 \text { i } 2001 \text { r.: } \\
\text { - koszty finansowania rozwoju, } \\
\text { - brak długoterminowego, } \\
\text { - koszty badań i rozwoju }\end{array}$ \\
\hline $\begin{array}{l}\text { Dominiak, Bławat (1993), } \\
\text { Daszkiewicz (2000) } \\
\text { Daszkiewicz (2004b) }\end{array}$ & $\begin{array}{l}\text { Analiza porównawcza w latach } \\
1992 \text { i } 1998 \text { barier zewnętrz- } \\
\text { nych i wewnętrznych zidenty- } \\
\text { fikowanych w małych i śred- } \\
\text { nich przedsiębiorstwach }\end{array}$ & $\begin{array}{l}\text { Bariery wewnętrzne i zewnętrzne } \\
\text { w roku 1992: } \\
\text { - niewystarczający popyt na pro- } \\
\text { dukty, } \\
\text { - brak środków finansowych, } \\
\text { - niewystarczająca powierzchnia } \\
\text { hal produkcyjnych. } \\
\text { Bariery wewnętrzne w roku 1998: } \\
\text { - brak środków finansowych, } \\
\text { - wysokie koszty pracy, } \\
\text { - niewystarczająca powierzchnia } \\
\text { hal produkcyjnych } \\
\text { Bariery zewnętrzne w roku 1998: } \\
\text { - niewystarczający popyt na pro- } \\
\text { dukty, } \\
\text { - niekorzystna polityka podatkowa, } \\
\text { - rosnąca konkurencja krajowa }\end{array}$ \\
\hline \begin{tabular}{|lll} 
PARP & (2003), & Łuczka \\
$(2003)$ & &
\end{tabular} & $\begin{array}{l}\text { Celem badań była identyfikacje } \\
\text { barier rozwoju MSP, badania } \\
\text { ankietowe wśród } 4842 \text { pod- } \\
\text { miotów z sektora MSP }\end{array}$ & $\begin{array}{l}\text { Bariery wskazane przez przedsię- } \\
\text { biorców: } \\
\text { - niejasne i niespójne przepisy praw- } \\
\text { ne, } \\
\text { - brak spójnej polityki wsparcia } \\
\text { skierowanej bezpośrednio do ma- } \\
\text { łych i średnich przedsiębiorstw } \\
\text { - preferowanie we wsparciu dużych } \\
\text { podmiotów }\end{array}$ \\
\hline Matejun (2007) & $\begin{array}{l}\text { Celem badań przeprowadzo- } \\
\text { nych w } 2005 \text { r. była identyfi- } \\
\text { kacja zewnętrznych barier } \\
\text { o charakterze prano-podat- } \\
\text { kowym i ZUS, zbadano 110- } \\
\text { MSP, } 37 \text { biur rachunkowych, } \\
194 \text { pracowników Urzędów } \\
\text { Skarbowych, badania w formie } \\
\text { wywiadu }\end{array}$ & $\begin{array}{l}\text { Bariery wskazane przez przedsię- } \\
\text { biorców: } \\
\text { - wysokość obciążeń ZUS, } \\
\text { - wysokość obciążeń podatkowych, } \\
\text { - zmienność przepisów prawnych. } \\
\text { Bariery wskazane przez biura ra- } \\
\text { chunkowe: } \\
\text { - zmienność przepisów podatko- } \\
\text { wych, } \\
\text { - brak jasności i czytelności po- } \\
\text { datku VAT i PIT. } \\
\text { Bariery wskazane przez pracowni- } \\
\text { ków urzędów skarbowych: } \\
\text { - brak jasności i czytelności prze- } \\
\text { pisów o podatku dochodowym, } \\
\text { - zmienność przepisów ZUS, } \\
\text { - brak jasności i czytelności prze- } \\
\text { pisów ZUS }\end{array}$ \\
\hline
\end{tabular}




\begin{tabular}{|c|c|c|}
\hline 1 & 2 & 3 \\
\hline $\begin{array}{l}\text { GUS (2007), Borowiecki, } \\
\text { Siuta-Tokarska (2008) }\end{array}$ & $\begin{array}{l}\text { Celem badań była identyfikacja } \\
\text { barier popytowych i podażo- } \\
\text { wych małych i średnich } \\
\text { przedsiębiorstw w latach } 2001- \\
2005\end{array}$ & $\begin{array}{l}\text { Bariery popytowe: } \\
\text { - konkurencja na rynku, } \\
\text { - obniżanie cen przez firmy } \\
\text { konkurencyjne, } \\
\text { - niedostateczne środki, jakim } \\
\text { dysponują klienci. } \\
\text { Bariery podażowe: } \\
\text { - niedostateczne środki finansowe, } \\
\text { - ograniczony dostęp do kredytów, } \\
\text { - trudności w ściąganiu należności }\end{array}$ \\
\hline $\begin{array}{l}\text { PKKP Lewiatan - Czarna } \\
\text { lista barier (2008-2012) } \\
\text { Starczewska-Krzyszto- } \\
\text { szek (2008) }\end{array}$ & $\begin{array}{l}\text { Celem badań była identyfikacja } \\
\text { barier rozwoju małych i śred- } \\
\text { nich przedsiębiorstw }\end{array}$ & $\begin{array}{l}\text { Bariery zewnętrzne: } \\
\text { - pozapłacowe koszty pracy, } \\
\text { - brak przejrzystości i jednoznacz- } \\
\text { ności podatków pośrednich, } \\
\text { - brak jasności systemu podatku } \\
\text { dochodowego od działalności gos- } \\
\text { podarczej i stawki tego podatku, } \\
\text { - konkurencja w branży, } \\
\text { - konkurencja ze strony szare } \\
\text { strefy, } \\
\text { - poziom infrastruktury drogowej }\end{array}$ \\
\hline Favore. pl (2008) & $\begin{array}{l}\text { Celem badań była identyfikacja } \\
\text { barier, respondenci to użyt- } \\
\text { kownicy portalu, właściciele } \\
\text { przedsiębiorstw }\end{array}$ & $\begin{array}{l}\text { Bariery zewnętrzne: } \\
\text { - wysokie podatki } \\
\text { - ograniczenia prawno-administra- } \\
\text { cyjne, } \\
\text { - brak środków pomocowych, } \\
\text { - trudności z dostępem do kredytów } \\
\text { bankowych } \\
\end{array}$ \\
\hline Kamińska (2011) & $\begin{array}{l}\text { Celem badań ankietowych była } \\
\text { identyfikacja barier, respon- } \\
\text { denci to } 103 \text { MSP z wojewódz- } \\
\text { twa lubelskiego }\end{array}$ & $\begin{array}{l}\text { Bariery rozwoju: } \\
\text { - niski poziom życia lokalnej spo- } \\
\text { łeczności i wynikająca z niego } \\
\text { chłonność rynku lokalnego, } \\
\text { - niewystarczające wsparcie finan- } \\
\text { sowe ze strony państwa i samorządu } \\
\text { terytorialnego, } \\
\text { - długi okres podejmowania decy- } \\
\text { zji przez samorząd i administrację }\end{array}$ \\
\hline NBP (2012) & $\begin{array}{l}\text { Celem badań była identyfikacja } \\
\text { barier, respondenci to } 1277 \\
\text { podmiotów niefinansowych } \\
\text { (sektor MSP i duże firmy) }\end{array}$ & $\begin{array}{l}\text { Bariery wewnętrzne i zewnętrzne: } \\
\text { - niski popyt, } \\
\text { - zatory płatnicze i problem z pły- } \\
\text { nnością finansową, } \\
\text { - rosnąca konkurencja, } \\
\text { - zła koniunktura gospodarcza, } \\
\text { - polityka władz lokalnych i regio- } \\
\text { nalnych }\end{array}$ \\
\hline
\end{tabular}


Tabela 11 (cd.)

\begin{tabular}{|c|c|c|}
\hline 1 & 2 & 3 \\
\hline $\begin{array}{l}\text { Ministerstwo Gospodarki } \\
\text { (badanie jest przeprowa- } \\
\text { dzane } 2 \text { razy w roku od } \\
1998 \text { r.) }(2012,2013)\end{array}$ & $\begin{array}{l}\text { Celem badań jest analiza } \\
\text { problemów i barier sektora } \\
\text { MSP, w II połowie } 2011 \text { r. } \\
\text { zbadano } 435 \text { firm, w II połowie } \\
2012 \text { r. zbadano ok. } 960 \text { firm }\end{array}$ & $\begin{array}{l}\text { Bariery wskazane przez mikro- } \\
\text { przedsiębiorców w } 2011 \text { (wyso- } \\
\text { kość podatków i opłat przewidzia- } \\
\text { nych prawem, małe obroty, } \\
\text { konkurencja innych MSP), w 2012 } \\
\text { (wysokość podatków i opłat prze- } \\
\text { widzianych prawem, małe obroty) } \\
\text { Bariery wskazane przez małych } \\
\text { przedsiębiorców w } 2011 \text { (wyso- } \\
\text { kość podatków i opłat przewidzia- } \\
\text { nych prawem, konkurencja dużych } \\
\text { firm, czas oczekiwania na zapłatę } \\
\text { od kontrahenta), w } 2012 \text { (wysokość } \\
\text { podatków i opłat przewidzianych } \\
\text { prawem, małe obroty, czas } \\
\text { oczekiwania na zapłatę od kontra- } \\
\text { henta) } \\
\text { Bariery wskazane przez średnich } \\
\text { przedsiębiorców w } 2011 \text { (wyso- } \\
\text { kość podatków i opłat przewidzia- } \\
\text { nych prawem, skomplikowanie } \\
\text { przepisów prawnych, konkurencja } \\
\text { innych MSP), w 2012 (wysokie } \\
\text { podatki, biurokracja, małe obroty) }\end{array}$ \\
\hline $\begin{array}{l}\text { Lisowska, Szymańska } \\
(2013)\end{array}$ & $\begin{array}{l}\text { Celem badań była identyfikacja } \\
\text { i analiza zewnętrznych czyn- } \\
\text { ników rozwoju MSP, zbadano } \\
123 \text { małe i średnie przedsię- } \\
\text { biorstwa z województwa łódz- } \\
\text { kiego w latach 2011-2012, } \\
\text { badania ankietowe }\end{array}$ & $\begin{array}{l}\text { Bariery makroekonomiczne: } \\
\text { - niesprawny i niespójny system } \\
\text { prawny i polityka fiskalna, } \\
\text { - wysokie koszty pozyskania } \\
\text { kapitału zewnętrznego, } \\
\text { - niekorzystna sytuacja makroek- } \\
\text { onomiczna w kraju i na świecie. } \\
\text { Bariery mezoekonomiczne: } \\
\text { - brak dostępu do kapitału i zew- } \\
\text { nętrznych źródeł finansowania, } \\
\text { - stan infrastruktury transporto- } \\
\text { wej, } \\
\text { - słaby rozwój społeczno-gospo- } \\
\text { darczy regionu, } \\
\text { Bariery mikroekonomiczne: } \\
- \text { silna konkurencja, } \\
- \text { wysokie koszty wprowadzenia } \\
\text { innowacji } \\
- \text { odroczone terminy płatności }\end{array}$ \\
\hline
\end{tabular}

Źródło: opracowanie własne na podstawie: Bariery rozwoju... 2008; Trendy rozwojowe... 2012; Trendy rozwojowe... 2013; Matejun 2007; Daszkiewicz 2000, 2004a, b; Czarna lista barier... 2010; Borowiecki, Siuta-Tokarska 2008; Dominiak, Bławat red. 1993; Kamińska 2011. 
W badaniach przeprowadzonych przez portal internetowy dla przedsiębiorców Favore.pl w 2008 r. największym problemem dla małych i średnich przedsiębiorstw okazały się: wysokie podatki i ograniczenia prawne Na kolejnych miejscach przedsiębiorcy wskazywali bariery finansowe, takie jak: brak środków pomocowych, trudności z dostępem do kredytów bankowych oraz bariery związane niewystarczającą infrastrukturą, niesprawnością funkcjonowania otoczenia biznesu (Bariery rozwoju... 2008). W badaniu tym dokonano również oceny wpływu kryzysu gospodarczego na funkcjonowanie badanych podmiotów, który w opinii respondentów był hamulcem rozwoju firm. $25 \%$ badanych właścicieli firm już odczuwało skutki kryzysu, 40\% liczyło się z jego konsekwencjami, a tylko $23 \%$ ankietowanych uważało, że kryzys nie będzie miał wpływu na ich firmę, pozostałe $12 \%$ nie miało wiedzy na ten temat. Podobny zestaw barier rozwoju prezentują wyniki badań przeprowadzonych przez Polską Konfederację Pracodawców Prywatnych (PKPP) „Lewiatan” (Czarna lista barier... 2010, 2011, 2012). Respondenci uważają, że najbardziej znaczące bariery rozwoju to: pozapłacowe koszty pracy, brak przejrzystości i jednoznaczności podatków pośrednich (VAT), brak jasnego systemu podatku dochodowego od działalności gospodarczej, stawki podatku dochodowego od działalności gospodarcze, konkurencja w branży, konkurencja ze strony szarej strefy. Na dalszych miejscach respondenci wymieniali: brak możliwości stosowania elastycznych form zatrudnienia, brak wykwalifikowanych pracowników, procedury administracyjne, konkurencja ze strony uprzywilejowanych przedsiębiorstw, słabo rozwiniętą infrastrukturę, niestabilną sytuację polityczną, a także trudności w dostępie do funduszy unijnych, szczególnie w kontekście bardzo dużych oczekiwań ze środków przewidzianych na lata 2007-2013 (Starczewska-Krzysztoszek 2008).

Natomiast $\mathrm{z}$ badań przeprowadzonych przez Ministerstwo Gospodarki w roku 2011 i 2012 r. wynika, że najbardziej dotkliwymi barierami rozwoju dla mikro przedsiębiorców okazała się: wysokość podatków i opłat przewidzianych prawem, małe obroty, konkurencja innych MSP, dla małych przedsiębiorców: wysokość podatków i opłat przewidzianych prawem, konkurencja dużych firm, czas oczekiwania na zapłatę od kontrahenta oraz małe obroty. W przypadku średnich przedsiębiorców wysokość podatków i opłat przewidzianych prawem, skomplikowanie przepisów prawnych, konkurencja innych MSP biurokracja, małe obroty (Trendy rozwojowe...2012 i 2013).

Znacznie inny zestaw barier rozwoju wskazywali przedsiębiorcy biorący udział w badaniu Narodowego Banku Polskiego w 2012 r., dla których głównymi barierami były: niski popyt, zatory płatnicze i problemy z płynnością finansową, zła koniunktura gospodarcza oraz polityka władz lokalnych i regionalnych (Informacja o kondycji... 2013).

$\mathrm{Z}$ zaprezentowanych badań wynika, że ważnymi przeszkodami w rozwoju małych przedsiębiorstw są niewątpliwie ograniczenia kapitałowe. Dostępność 
kapitałów zewnętrznych oraz ich koszt mają szczególnie istotne znaczenie dla rozwoju oraz ekspansji małych przedsiębiorstw, a możliwości rozwojowe przekładają się na wzrost innowacyjności i konkurencyjności tych przedsiębiorstw i umocnienia ich pozycji na rynku. Bariery ograniczające dostęp małych przedsiębiorstw do zewnętrznych źródeł finansowania to (Skowronek-Mielczarek 2003, Bartlett i Bukvić 2001, Luczka red. 2007):

- niski poziom zdolności akumulacyjnych tych przedsiębiorstw, niedający gwarancji zwrotu zainwestowanych kapitałów;

- wysokie koszty funkcjonowania firm (w tym np. koszty pracy), a co się z tym wiąże - niski poziom rentowności, niesprzyjający akumulacji środków;

- ograniczenia związane ze specyficzną gospodarką finansową przedsiębiorstw tego sektora, w której dominuje księgowość oparta na księdze przychodów i rozchodów;

- wysokie koszty pozyskiwania kapitałów z sektora bankowego;

- skomplikowane i czasochłonne procedury związane z pozyskiwaniem kapitałów z różnych źródeł;

- niewielki poziom środków publicznych przeznaczanych na wsparcie rozwoju sektora MSP $\mathrm{w}$ porównaniu $\mathrm{z}$ jego potrzebami, a także $\mathrm{z}$ potencjałem ekonomicznym, jaki ten sektor reprezentuje.

Problemy z dostępem do kapitału mogą skutkować niską skłonnością do inwestycji, a tym samym do innowacji, co stanowi kolejna barierę rozwoju małych firm. Powszechnie uważa się, że firmy te charakteryzują się niskim stopniem innowacyjności oraz słabą intensywnością wykorzystania zaawansowanych technologii. Wprowadzane innowacje zazwyczaj opierają się na jednym rodzaju produktu czy usługi, więc prawdopodobieństwo wprowadzania zmian jest tam mniejsze niż w przedsiębiorstwach o zróżnicowanej ofercie i rozbudowanych procesach jak w większości dużych firm.

Kolejna klasyfikacja barier rozwoju MSP odnosi się do funkcjonowania nowo powstałych przedsiębiorstw oraz przedsiębiorstw o długotrwałym okresie działalności. Wśród pierwszych można wyróżnić bariery podażowe (np. niedostateczna technologia, niedostateczne środki finansowe przedsiębiorstwa, trudności w ściąganiu należności, ograniczony dostęp do kredytów, brak surowców, brak wykwalifikowanej siły roboczej), które mogą ograniczać produkcję oraz bariery popytowe (np. niedostateczne środki, którymi dysponują klienci, zbyt duża konkurencja na rynku, obniżanie cen przez firmy konkurencyjne, niedostateczna znajomość firmy na rynku), hamujące sprzedaż wyprodukowanych dóbr i usług. Najczęściej zgłaszanymi barierami popytowymi przez nowych przedsiębiorców były: zbyt duża konkurencja (81\%), niewystarczające środki finansowe klientów (68\%) oraz obniżka cen przez konkurentów (58\%). Co do barier podażowych najczęściej spotykanymi były niedostateczne środki finansowe, ograniczony dostęp do kredytów oraz trudności w ściąganiu należności. Występowanie powyższych czynników hamujących rozwój nowo powsta- 
łych przedsiębiorstw było i jest uzależnione od zakresu formy prawnej podmiotu. W przedsiębiorstwach prowadzonych przez osoby fizyczne przeważają bariery popytowe zaś podażowe $\mathrm{w}$ firmach o osobowości prawnej (Borowiecki, Siuta-Tokarska 2008).

Bariery rozwoju małych i średnich przedsiębiorstw w obszarach peryferyjnych przedstawili S. Birley i P. Westhead (1990, s. 538). Jako najczęstsze bariery wzrostu respondenci wskazywali te, które są związane z makrootoczeniem, silną konkurencją, trudnościami z uzyskaniem finansowania i spadkiem popytu. Natomiast do barier wewnętrznych respondenci zaliczyli strach przed utratą autonomii, słabe umiejętności menedżerskie i marketingowe, problemy z pozyskaniem wykwalifikowanej siły roboczej, brak potencjalnych partnerów do współpracy. Wskazane bariery mają raczej charakter ogólny i właściwie nie uwzględniają specyfiki obszarów zmarginalizowanych.

Z kolei w badaniu ${ }^{13}$ przeprowadzonym w latach 2008-2009 metodą wywia$\mathrm{du}$ pogłębionego $\mathrm{z}$ właścicielami małych firm zlokalizowanych $\mathrm{w}$ obszarach zmarginalizowanych $\mathrm{w}$ całej Polsce oraz pracownikami instytucji otoczenia biznesu, jednym z obszarów badawczych było wskazanie barier rozwoju małych firm. W ocenie przedsiębiorców (wynikającej z analizy 10 wywiadów pogłębionych) do barier utrudniających rozwój małych przedsiębiorstw zaliczono (Lisowska 2011a, s. 147):

- ograniczony popyt ze względu na mniejszą silę nabywczą lokalnych społeczności,

- niewystarczająca infrastrukturę techniczną,

- brak wykwalifikowanej kadry,

- ograniczony dostęp do instytucji otoczenia biznesu, ze względu na ich brak lub niewystarczającą ich liczbę,

- brak umiejętności wykorzystania środków unijnych,

- bierne wsparcie ze strony władz samorządowych.

W opinii przedstawicieli instytucji otoczenia biznesu oprócz barier rozwoju wskazanych przez przedsiębiorców, ważnym problemem na terenach zmarginalizowanych jest niski stopień innowacyjności oraz słaba intensywność wykorzystania zaawansowanych technologii $\mathrm{w}$ małych przedsiębiorstwach. Przyczyn tego stanu rzeczy można upatrywać w niewielkiej skali działania tych podmiotów, które częściej opierają się na jednym rodzaju produktu czy usługi, więc prawdopodobieństwo wprowadzania zmian jest mniejsze niż w przedsiębior-

${ }^{13}$ Badanie zostało przeprowadzone w ramach projektu pt. Symptomy upadku matej firmy. Konsekwencje społeczno-gospodarcze. Polityka przeciwdziałania” nr projektu. 1 H02D 055 30, nr umowy 0926/H03/2006/30, finansowanego przez Ministerstwo Nauki i Szkolnictwa Wyższego. Omawiane studia przypadków (10 przedsiębiorstw i 5 instytucji otoczenia biznesu) stanowią wycinek badań jakościowych przeprowadzonych ramach tego projektu w obszarach zmarginalizowanych w całej Polsce. Autorka była głównym wykonawcą projektu i członkiem zespołu badawczego. 
stwach o zróżnicowanej ofercie i rozbudowanych procesach, jak w większości średnich i dużych firm. Wynika to również z braku środków finansowych na działalność innowacyjną, małe przedsiębiorstwa często wykorzystują na ten cel wyłącznie środki własne, które nie są wystarczające, co powoduje, że firmy te nie mogą sprostać nasilającej się konkurencji i mają duże problemy z rozwojem i przetrwaniem.

Natomiast jak stymulatory rozwoju traktuje się głównie usługi wspierające oraz politykę wsparcia małych i średnich przedsiębiorstw. Istotne jest, aby wsparcie MSP zostało dopasowane do ich potrzeb na każdym z etapów ich rozwoju (por. tabela 12) (Thematic... 1999, s. 10). W fazie uruchomienia potrzeby firm $\mathrm{w}$ zakresie wsparcia są największe, przedsiębiorstwa bowiem potrzebują usług we wszystkich dziedzinach, tzn. finansów, doradztwa, zasobów ludzkich, technologii i innowacji oraz infrastruktury. W fazie wzrostu istotne jest przetrwanie i rozwój firmy, a co z tym idzie, często przekształcenie przedsiębiorstwa $z$ mikro w małe lub średnie. W tej fazie ważne jest wsparcie finansowe związane z koniecznością dalszych inwestycji oraz szkolenia kadry zarządzającej. Natomiast $\mathrm{w}$ fazie dojrzałości wsparcie przedsiębiorstw powinno mieć charakter kompleksowy, co umożliwi im utrzymanie się na rynku.

Tabela 12. Potrzeby w zakresie wsparcia MSP w różnych fazach rozwoju

\begin{tabular}{|c|c|c|c|}
\hline \multirow{3}{*}{$\begin{array}{c}\text { Obszary } \\
\text { wsparcia } \\
\text { przedsiębiorstw }\end{array}$} & \multicolumn{2}{|l|}{ Fazy wzrostu } & \multirow{3}{*}{ Dojrzałość } \\
\hline & & \multirow{2}{*}{ Wzrost } & \\
\hline & Start-up & & \\
\hline Finanse & $\begin{array}{l}\text { - pożyczki i gran- } \\
\text { ty na uruchomie- } \\
\text { nie firmy } \\
\text { - kapitał zalążko- } \\
\text { wy }\end{array}$ & $\begin{array}{l}\text { - kapitał operacyjny } \\
\text { - zachęty inwestycyjne } \\
\text { - venture capital }\end{array}$ & $\begin{array}{l}\text { - kredyty bankowe } \\
\text { - dostęp do rynku papierów } \\
\text { wartościowych } \\
\text { - wykup menedżerski }\end{array}$ \\
\hline Doradztwo & $\begin{array}{l}\text { - w zakresie pla- } \\
\text { nowania } \\
\text { - poradniki }\end{array}$ & $\begin{array}{l}\text { - w zakresie strategii mar- } \\
\text { ketingowej } \\
\text { - w zakresie zmian orga- } \\
\text { nizacyjnych }\end{array}$ & $\begin{array}{l}\text { - strategia biznesu } \\
\text { - rozwój łańcucha dostaw } \\
\text { - sieci wiedzy }\end{array}$ \\
\hline $\begin{array}{l}\text { Zasoby } \\
\text { ludzkie }\end{array}$ & $\begin{array}{l}\text { - szkolenia z zak- } \\
\text { resu przedsiębior- } \\
\text { czości }\end{array}$ & $\begin{array}{l}\text { - umiejętności zarządzają- } \\
\text { cych } \\
\text { - rekrutacji i szkolenia per- } \\
\text { sonelu }\end{array}$ & $\begin{array}{l}\text { - szkolenia z zakresu zarzą- } \\
\text { dzania personelem } \\
\text { - specjalistyczne szkolenia } \\
\text { personelu }\end{array}$ \\
\hline $\begin{array}{l}\text { Innowacje i } \\
\text { technologia }\end{array}$ & $\begin{array}{l}\text { - doradztwo } \mathrm{B}+\mathrm{R} \\
\text { - rozwój produk- } \\
\text { tu }\end{array}$ & $\begin{array}{ll}\text { - } & \text { standardy jakości } \\
\text { - } & \text { transfer technologii } \\
\text { - } & \text { stosowanie ICT } \\
\end{array}$ & \\
\hline Infrastruktura & $\begin{array}{l}\text { - inkubatory } \\
\text { przedsiębiorczości }\end{array}$ & & \\
\hline
\end{tabular}

Źródło: opracowanie własne na podstawie Thematic... 1999. 
W badaniach K. Wacha (2008, s 132), przeprowadzonych w województwach śląskim i małopolskim wśród 109 małych i średnich przedsiębiorstw oraz w 132 gminach tych województw, badani przedsiębiorcy za stymulatory uznali: infrastrukturę telekomunikacyjną, bliskość rynków zbytu, bliskość dostawców i kooperantów, wizerunek regionu, usługi dla biznesu oraz regionalne zasobu kadrowe. Natomiast przedstawiciele gmin jako stymulatory rozwoju małych i średnich przedsiębiorstw wskazali: bliskość rynków zbytu, politykę władz lokalnych wobec MSP, wizerunek regionu, infrastrukturę telekomunikacyjną oraz zasoby kadrowe.

Inne stymulatory rozwoju małych i średnich przedsiębiorstw zostały wskazane przez przedsiębiorców w badaniach A. Kamińskiej (2011, s. 246-247) na próbie 103 MSP z województwa lubelskiego. Do najważniejszych respondenci zaliczyli: poziom życia lokalnej społeczności i wynikająca z niego chłonność rynku lokalnego, dotacje unijne, wsparcie finansowe ze strony państwa i samorządu, szybkie podejmowanie decyzji przez samorząd i administrację, polityka władz regionalnych i lokalnych.

Należy jednak podkreślić, że w przywołanych badaniach K. Wacha i A. Kamińskiej przedstawione stymulatory rozwoju małych i średnich przedsiębiorstw dla niektórych firm mogły być również barierami. Oznacza to, że ocena czynników przez przedsiębiorców była subiektywna i wynikała głównie ze zróżnicowanych potrzeb danego przedsiębiorstwa w zakresie wsparcia rozwoju.

Przedstawione uwarunkowania rozwoju małych i średnich przedsiębiorstw w kontekście barier i stymulatorów pozwoliły na opracowanie założeń do dalszych badań, które są przedmiotem kolejnego podrozdziału.

\subsection{Budowa modelu zależności pomiędzy uwarunkowaniami a rozwojem malych i średnich przedsiębiorstw $w$ obszarach zmargi- nalizowanych}

Na podstawie studiów literatury przedmiotu krajowej i zagranicznej oraz analizy wyników dotychczasowych analiz, w podejmowanych badaniach przyjmuje się, że uwarunkowania wewnętrzne jak również zewnętrzne kreują zbiór determinant, które można uznać za stymulatory i bariery rozwoju małych i średnich przedsiębiorstw. Biorąc pod uwagę główny obszar analizy, jakim są obszary zmarginalizowane, główny akcent zostanie położony na uwarunkowania wynikające z mezootoczenia uwzgledniające specyfikę tych obszarów. Według M. Bednarczyk (1996) i K. Wacha (2008, s. 32) mezootoczenie obejmuje czynniki wpływające na przedsiębiorstwa w układzie regionalnym, które uwzględniają charakterystyki poszczególnych regionów czy obszarów. 
Zamiarem autorki jest analiza związków między rozwojem małych i średnich przedsiębiorstw funkcjonujących $\mathrm{w}$ specyficznych warunkach obszaru zmarginalizowanego a uwarunkowaniami wewnętrznymi i zewnętrznymi, które mają ważny wpływ na powstawianie, rozwój i przetrwanie firm tego sektora.

Założenia do modelu badawczego przygotowano na podstawie rozwiązań przyjętych przez innych badaczy, szczegółowo opisanych w punkcie 3.2. Literatura przedmiotu eksponuje wiele uwarunkowań rozwoju małych i średnich przedsiębiorstw, które różnią się założeniami badawczymi przyjętymi przez poszczególnych autorów. Szczególną trudność stanowiła selekcja uwarunkowań, które są istotne dla wyjaśnienia problemu badawczego. Biorąc pod uwagę jako czynnik dodatkowy specyficzne cechy obszaru zmarginalizowanego do modelu badawczego, przyjęto następujący podział uwarunkowań - na wewnętrzne związane $\mathrm{z}$ osobą przedsiębiorcy oraz cechami przedsiębiorstwa i zewnętrzne tkwiące $\mathrm{w}$ otoczeniu przedsiębiorstwa, przy czym każdy $\mathrm{z}$ analizowanych czynników może być zarówno stymulatorem, jak i barierą rozwoju MSP.

Analiza uwarunkowań wewnętrznych związanych z osobą przedsiębiorcy obejmuje jego parametry demograficzne, cechy osobowości oraz potencjał przedsiębiorczy, natomiast w przypadku cech przedsiębiorstwa - jego parametry demograficzne, zasoby, orientację przedsiębiorczą oraz strategię działania (por. rysunek 28). W przypadku małych i średnich przedsiębiorstw funkcjonujących w obszarach zmarginalizowanych na przyjęte grupy czynników mają wpływ pośrednio również cechy tych obszarów. Zależność ta zostanie uwzględniona $\mathrm{w}$ przedstawionym $\mathrm{w}$ dalszej części opracowania modelu badawczym (por. rysunek 28).
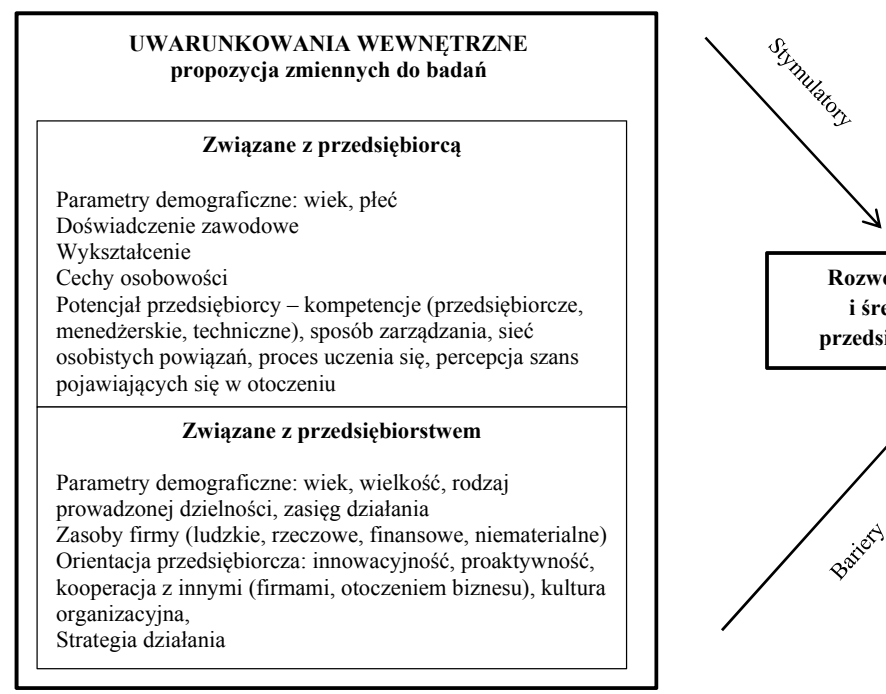

zawodowe

Wykształcenie

Potencjał przedsiębiorcy - kompetencje (przedsiębiorcze,

menedżerskie, techniczne), sposób zarządzania, sieć

osobistych powiązań, proces uczenia się, percepcja szan

Związane z przedsiębiorstwem

prowadzonej dzielności, zasięg działania

Rysunek 28. Uwarunkowania wewnętrzne rozwoju małych i średnich przedsiębiorstw Źródło: opracowanie własne 
W przypadku uwarunkowań zewnętrznych analiza odnosi się do trzech poziomów otoczenia makro, mezo i mikro. Makrootocznie jest analizowane zgodnie z propozycją R. Griffina (2010) na podstawie uwarunkowań zawartych w pięciu wymiarach: ekonomicznym, technologicznym, prawnopolitycznym, socjo-kulturowym i międzynarodowym (por. rysunek 29). Zaproponowana lista zmiennych do badań została przygotowana na podstawie dotychczasowych badań zaprezentowanych w podpunkcie 3.2, co pozwoli na poznanie ogólnych warunków funkcjonowania i rozwoju małych i średnich przedsiębiorstw.

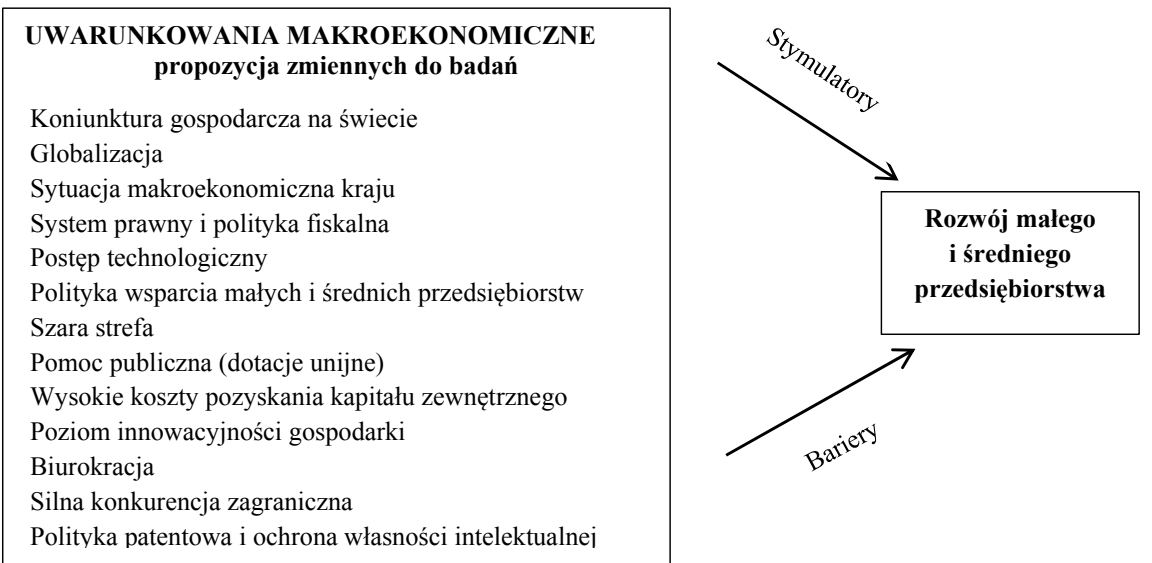

Rysunek 29. Uwarunkowania makroekonomiczne rozwoju małych i średnich przedsiębiorstw Źródło: opracowanie własne

W przypadku mezootoczenia oprócz uwarunkowań ogólnych mających charakter uniwersalny uwzględniono specyficzne cechy obszarów zmarginalizowanych (por. rysunek 30), które pozwolą na poznanie dodatkowych czynników mogących mieć wpływ pozytywny lub negatywny na funkcjonowanie małych i średnich przedsiębiorstw w tych obszarach. Jak już wcześniej wspomniano, marginalizacja obszaru wpływa raczej negatywnie na rozwój MSP, co wymaga szczegółowej analizy w celu ustalenia kierunków zmian w procesie zarządzania przedsiębiorstwem funkcjonującym $\mathrm{w}$ specyficznych warunkach obszaru zmarginalizowanego. 


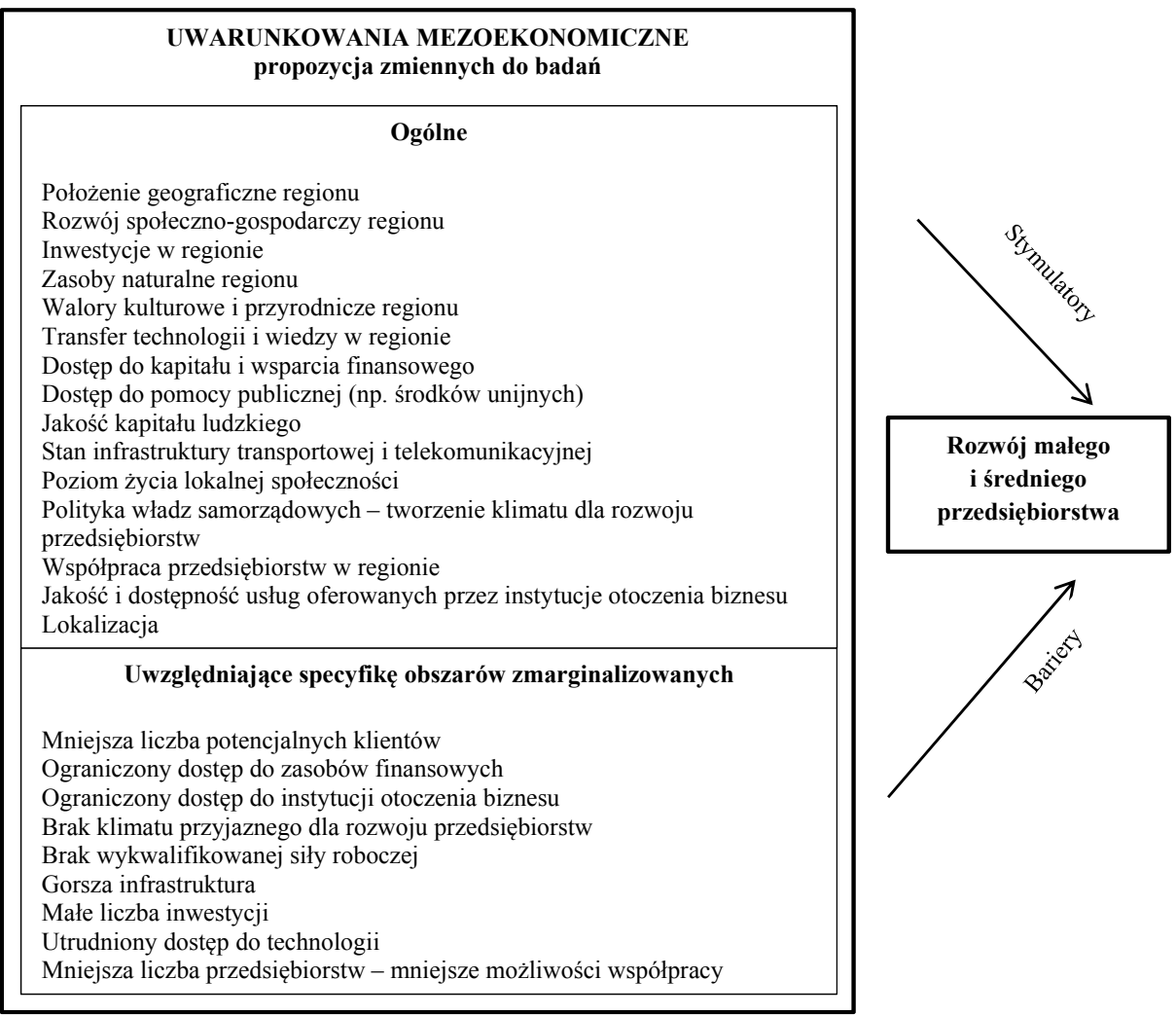

Rysunek 30. Uwarunkowania mezoekonomiczne rozwoju małych i średnich przedsiębiorstw $\mathrm{z}$ uwzględnieniem marginalizacji obszaru Źródło: opracowanie własne

Analiza uwarunkowań mikroekonomicznych obejmuje czynniki uwzględniające sytuację konkurencyjną przedsiębiorstwa w przekroju sektorowym. Doboru czynników dokonano według koncepcji W. Starbucka (1976, cyt. za Wach 2008, s. 31), odnoszącej się do dwóch ujęć: przedmiotowego (charakterystyka rynku) i podmiotowego (podmioty mające $\mathrm{z}$ przedsiębiorstwem bezpośrednie powiązania). W analizie tej, odnosząc się do małych i średnich przedsiębiorstw funkcjonujących w obszarach zmarginalizowanych, należy analogicznie jak w przypadku uwarunkowań mezoekonomicznych uwzględnić również specyfikę tych obszarów. 


\begin{tabular}{||l|}
\hline \multicolumn{1}{|c|}{$\begin{array}{c}\text { UWARUNKOWANIA MIKROEKONOMICZNE } \\
\text { propozycja zmiennych do badań }\end{array}$} \\
\hline Ogólne \\
Silna konkurencja \\
Wymagający klienci (odbiorcy) \\
Powiązania kooperacyjne z innymi firmami \\
Koszty wprowadzenia innowacji \\
Dostęp do informacji o formach wsparcia \\
Współpraca przedsiębiorstw ze sferą nauki \\
Odroczone terminy płatności \\
\hline Uwzgledniające specyfikę obszarów zmarginalizowanych \\
Zmienne jak w rys. 30 \\
\hline
\end{tabular}

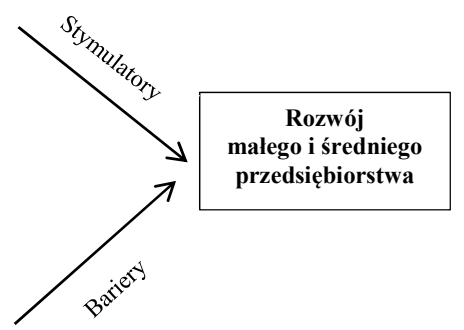

Rysunek 31. Uwarunkowania mikroekonomiczne rozwoju małych i średnich przedsiębiorstw Źródło: opracowanie własne

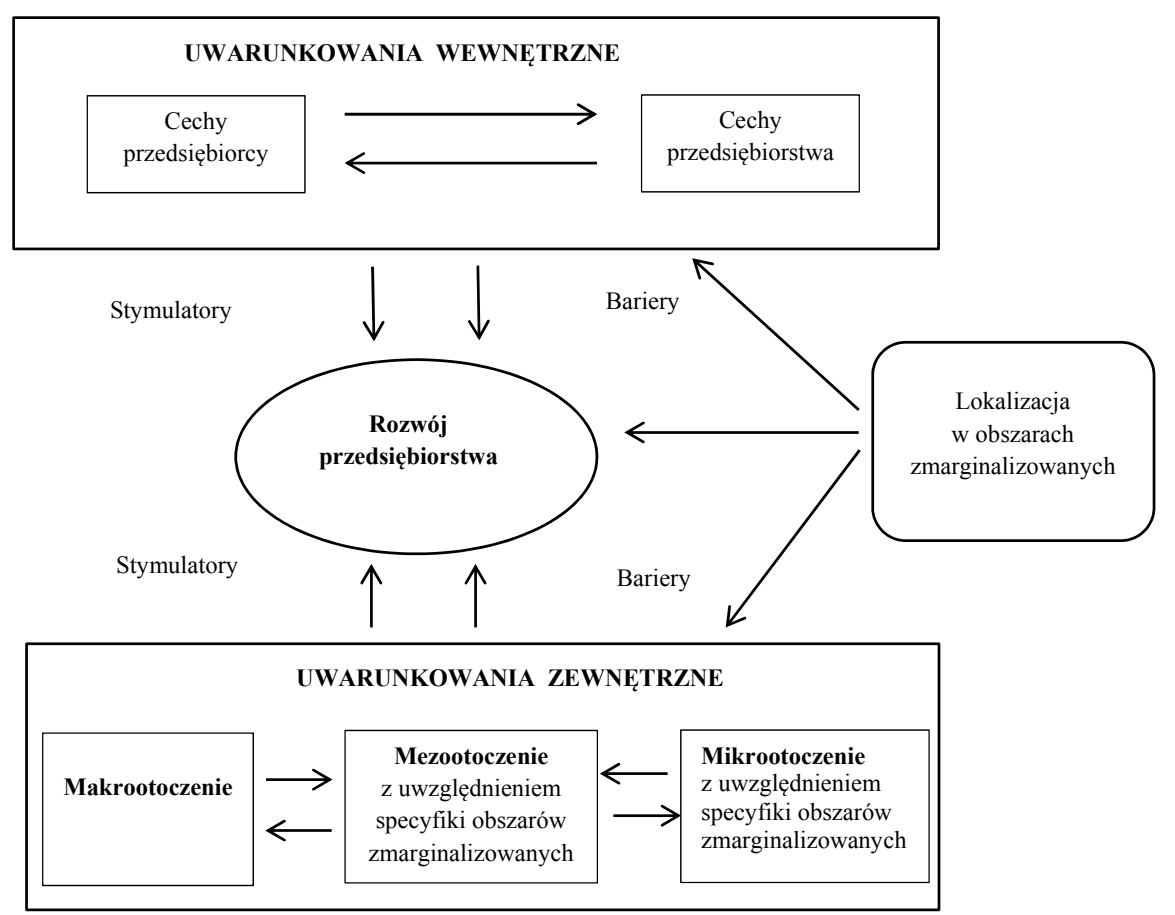

Rysunek 32. Model zależności pomiędzy uwarunkowaniami a rozwojem małych i średnich przedsiębiorstw w obszarach zmarginalizowanych Źródło: opracowanie własne 
Reasumując dotychczasowe rozważania, do dalszych badań i analiz został zaproponowany model badawczy zbudowany na podstawie wcześnie analizowanych grup uwarunkowań (por. rysunek 32). Autorka pracy zdaje sobie sprawę, że zaproponowana lista zmiennych przedstawiających uwarunkowania rozwoju małych i średnich przedsiębiorstw nie jest wyczerpująca, jednak cytowana literatura i wyniki badań innych autorów w podpunkcie 3.2 pozwala sądzić, że taki dobór czynników jest powszechnie akceptowalny i pozwoli na wyjaśnienie problemu badawczego. 


\section{Procesy rozwojowe małych i średnich przedsiębiorstw w obszarach rozwiniętych i zmarginalizowanych Rezultaty badań}

\subsection{Organizacja i metodyka badań}

Podstawową przesłanką do podjęcia przedstawionego tematu badań naukowych była chęć nawiązania do problematyki uwarunkowań rozwoju małych i średnich przedsiębiorstw, ze szczególnym uwzględnieniem funkcjonowania tych podmiotów w obszarach zmarginalizowanych. Popularność zagadnień dotyczących teorii i czynników wzrostu/rozwoju MSP powoduje, że badaniom poddaje się coraz większą liczbę czynników warunkujących rozwój tych podmiotów $\mathrm{W}$ wyniku przeprowadzonej pogłębionej analizy literatury przedmiotu można stwierdzić, że wzrost/rozwój jest wypadkową wielu różnorodnych czynników zarówno ilościowych, jak i jakościowych. Dokonanie spójnej wielowymiarowej analizy wszystkich czynników w jednym modelu, zidentyfikowanych $\mathrm{w}$ rozdziale 3 niniejszej pracy, stanowi trudne wyzwanie badawcze.

Aby osiągnąc cel badania oraz zweryfikować postawione hipotezy, wykorzystano metody analizy ilościowej i jakościowej, co pozwoliło na sprawdzenie prawdziwości założeń teoretycznych sformułowanych na podstawie studiów literaturowych zawartych $\mathrm{w}$ rozdziale 3 . Do realizacji badania ilościowego opracowano narzędzia badawcze w postaci dwóch wariantów kwestionariusza ankiety - wersja podstawowa dla przedsiębiorstw zlokalizowanych w obszarach rozwiniętych, wersja rozszerzona dla przedsiębiorstw z obszarów zmarginalizowanych $^{1}$. Aby sprawdzić zrozumiałość przygotowanych pytań i wariantów odpowiedzi, przeprowadzono w styczniu 2011 r. badania pilotażowe na próbie 67 małych i średnich przedsiębiorstw, które pozwoliły na weryfikację treści kwestionariuszy i wniesienie właściwych poprawek.

\footnotetext{
${ }^{1}$ Przygotowanie dwóch wariantów ankiety podstawowej i rozszerzonej miało na celu głębsze poznanie uwarunkowań rozwoju małych i średnich funkcjonujących w specyficznych warunkach obszaru zmarginalizowanego.
} 
Badania właściwe zostały przeprowadzone w latach 2011-2012 na próbie małych i średnich przedsiębiorstw z sektora prywatnego ${ }^{2}$. Zaprojektowano je tak, aby umożliwić porównanie warunków funkcjonowania podmiotów gospodarczych w obszarach Polski o najniższym i najwyższym poziomie rozwoju. Zastosowany algorytm doboru próby uwzględniał konieczność osiągnięcia tak postawionych celów badania.

Pierwszym elementem procedury doboru próby było ograniczenie populacji do obszarów, które stanowią przedmiot zainteresowania, zgodnie z celem badania, jak również podział populacji na podpoppulacje podlegające porównaniu. Losowanie realizowane jest odrębnie dla każdej z podpopulacji.

Podpopulacje mają charakter terytorialny i wyznaczone zostały w oparciu o analizę przeprowadzoną na poziomie powiatu. Do ich klasyfikacji zastosowano metodę taksonomiczną Z. Helwiga ${ }^{3}$, która pozwoliła na wyodrębnienie obszarów rozwiniętych (87 powiatów) oraz obszarów zmarginalizowanych (101 powiatów). Metodologia klasyfikacji obszarów została omówiona w rozdziale 1.

Populację stanowiły podmioty gospodarcze zlokalizowane w powiatach o najwyższym poziomie rozwoju (obszary rozwinięte, pierwsza podpopulacja) oraz o najniższym poziomie rozwoju (obszary zmarginalizowane, druga podpopulacja). Kategorie te stanowiły rozłączne podpopulacje, badane w sposób niezależny. Obydwie te podpopulacje (a więc cała populacja badana) nie obejmują, rzecz jasna, całego obszaru kraju, ale tylko skrajne grupy obszarów najlepiej i najsłabiej rozwiniętych.

Poza kryterium terytorialnym przy definiowaniu populacji celu uwzględniono dodatkowe kryteria. Populacja podlegająca badaniu obejmowała podmioty, które:

- powstały przed 31 grudnia 2007 r.,

- należą do sektora prywatnego (wyłączony sektor publiczny),

- należą do sektora małych i średnich przedsiębiorstw, tj. liczba pracujących nie przekracza 249 osób.

Nie została zastosowana selekcja za względu na rodzaj działalności, tj. do populacji zalicza się podmioty z wszystkich sekcji PKD pod warunkiem, że nie należą do sektora publicznego.

Operat losowania stanowił krajowy rejestr urzędowy podmiotów gospodarki narodowej REGON, prowadzony przez Główny Urząd Statystyczny. Jako jednostkę losowania (i jednostkę statystyczną w badaniu) przyjęto tzw. jednostkę prawną (odpowiadającą w przybliżeniu przedsiębiorstwu wraz ze wszystkimi

\footnotetext{
${ }^{2}$ Badanie zostało przeprowadzone w ramach projektu badawczego Determinanty rozwoju matych $i$ średnich przedsiębiorstw funkcjonujacych $w$ regionach zmarginalizowanych. Strategie rozwoju $i$ polityka wsparcia projekt, no. N N115 297738, umowa nr 2977/B/H03/2010/38, finansowanego przez Ministerstwo Nauki i Szkolnictwa Wyższego.

${ }^{3}$ Szerzej na temat metody taksonomicznej Z. Helwiga w opracowaniach: Kolenda (2006), Młodak (2006), Helwig (1968).
} 
oddziałami). Przy definiowaniu populacji oraz jej podziale na podpopulacje zastosowano przypisanie jednostek do powiatu poprzez adres siedziby.

Ponieważ założono, że wyniki badania mają pozwalać na odrębne wnioskowanie na temat każdej z dwóch podpopulacji oraz ich porównanie, optymalnym rozwiązaniem był równy podział próby pomiędzy podpoulacje. Z każdej populacji wylosowano próbę liczącą po 3000 jednostek. Liczebność próby losowanej została ustalona $\mathrm{z}$ dużym nadmiarem, biorąc pod uwagę, że przy zastosowanej technice realizacji badania możliwe będzie uzyskanie wywiadu tylko od części wylosowanych jednostek.

W każdej z podpopulacji zastosowano losowanie warstwowe. Kryteria wyodrębnienia warstw, identyczne dla obydwu podpopulacji, były następujące:

- liczba pracujących (3 grupy: mikroprzedsiębiorstwa: o liczbie pracujących 0-9; małe przedsiębiorstwa: o liczbie pracujących 10-49; średnie przedsiębiorstwa: o liczbie pracujących 50-249),

- powiat według adresu siedziby.

Zastosowany sposób warstwowania zapewnia reprezentatywność terytorialną według wielkości przedsiębiorstwa.

W każdej podpopulacji całkowita liczebność próby podzielona została między warstwy losowania proporcjonalnie do liczebności populacji generalnej. Przyjęto zasadę, że każda $\mathrm{z}$ warstw losowania, reprezentowana w populacji, powinna być również reprezentowana w próbie. Alokacja proporcjonalna próby w warstwach była rozwiązaniem optymalnym ze względu na próbę uogólnienie wniosków na na całą populację, Kwestionariusz ankiety został wysłany pocztą tradycyjną i elektroniczną, z prośbą o zwrot po wypełnieniu tą samą drogą, jednak ze względu na mały zwrot wysłanych kwestionariuszy badanie uzupełniono wywiadem bezpośrednim.

Liczebność próby zrealizowanej, tj. liczba uzyskanych, kompletnie wypełnionych ankiet, wynosi: dla podpopulacji pierwszej 319 ankiet (stopa zwrotu 10,6\%), dla podpopulacji drugiej 271 ankiet (stopa zwrotu 9,0\%). Przeprowadzone badania ilościowe z jednej strony umożliwiły dotarcie do większej liczby podmiotów gospodarczych, jak również zapewniły stopień anonimowości respondentów (często był to warunek konieczny do przeprowadzenia badań), $\mathrm{z}$ drugiej strony posiadały wiele trudności z realizacją, np. wypełnione częściowo kwestionariusze, jak również problemy $\mathrm{z}$ interpretacją treści niektórych pytań.

W celu oceny reprezentatywności próby zrealizowanej przeprowadzono porównanie jej struktury ze strukturą populacji ze względu na następujące cechy: wielkość przedsiębiorstwa (mikroprzedsiębiorstwa, małe przedsiębiorstwa, średnie przedsiębiorstwa), lokalizacja (miasto/wieś) oraz rodzaj działalności (produkcja, usługi handel), odrębnie dla obszarów rozwiniętych oraz obszarów zmarginalizowanych. Wynik porównania pozwolił uznać zbadaną próbę za 
reprezentatywną dla populacji generalnej w przypadku obydwu podpopulacji (obszarów rozwiniętych i zmarginalizowanych).

Dla realizacji badania jakościowego zostały przygotowane dwa scenariusze wywiadu pogłębionego dla przedsiębiorców i przedstawicieli instytucji otoczenia biznesu. Badania te przeprowadzono w $2012 \mathrm{r}$. za pomocą metody wywiadu bezpośredniego w obszarach zmarginalizowanych z 15 właścicielami i współwłaścicielami małych i średnich przedsiębiorstw i 10 przedstawicielami instytucji otoczenia biznesu. Dobór próby do tych badań był celowy, wybrano przedsiębiorstwa, które brały udział w badaniu ilościowym, w przypadku instytucji były to te, które znajdowały się w obszarze funkcjonowania tych przedsiębiorstw. Wyniki tych badań są przedmiotem znacznej części rozdziału 5.

\subsection{Charakterystyka badanych przedsiębiorstw}

W badanej grupie przedsiębiorstw dominowały mikrofirmy $\mathrm{z}$ udziałem $55,8 \%$, małe firmy stanowiły $26,8 \%$, zaś $17,4 \%$ to firmy średnie. Na terenach zmarginalizowanych udział mikroprzedsiębiorstw był znacznie większy $62 \%$, niż $\mathrm{w}$ przypadku przedsiębiorstw zlokalizowanych na terenach rozwiniętych $50,5 \%$ (por. rysunek 33 ).
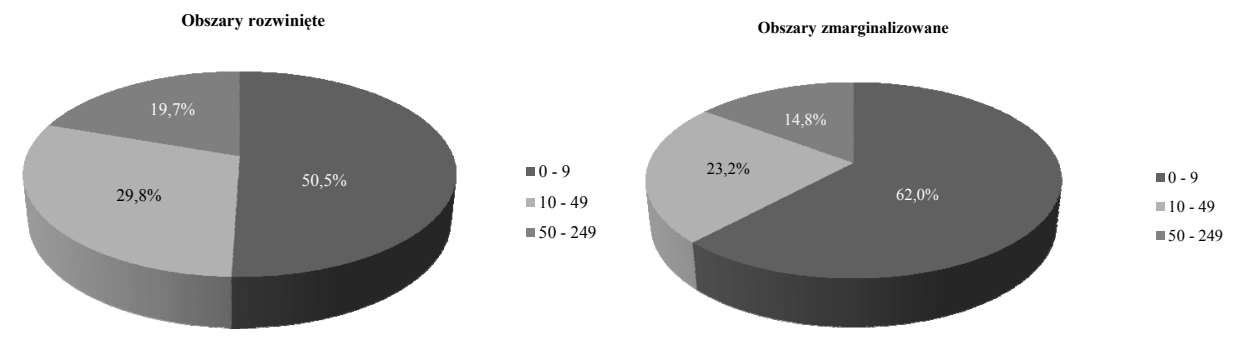

Rysunek 33. Struktura badanych przedsiębiorstw według liczby zatrudnionych (w \%)
Źródło: opracowanie własne

Średnia wielkość zatrudnienia wynosiła nieco ponad 15 osób, przy czym połowa przedsiębiorstw zatrudniała nie więcej niż 5 pracowników. Tak znaczne dysproporcje między wartością średniej i mediany wynika z przewagi podmiotów zatrudniających do 5 osób stanowiących ok. $50 \%$ badanej populacji. Tak znaczna różnica między medianą a średnią świadczy o dużej asymetrii rozkładu liczby zatrudnionych. Firmy o większej liczbie zatrudnionych (należące do grupy średnich przedsiębiorstw) występują z niewielką częstością, ale bardzo znacząco odbiegają one liczbą zatrudnionych od większości pozostałych jednostek, silnie rzutując na średnią. W obszarach rozwiniętych średnia liczba 
osób zatrudnionych była blisko dwukrotnie większa niż w regionach zmarginalizowanych - odpowiednio ok. 19 osób i ok. 9 osób. W obszarach zmarginalizowanych bowiem większość podmiotów to mikroprzedsiębiorstwa zatrudniające do 2 osób (ok. 55\% badanej populacji) jak również firmy samozatrudnieniowe, potwierdzają to również liczne badania krajowe (Strużycki red. 2011, Kamińska 2011, Makieła 2008) i zagraniczne (Romero, Fernandez-Serrano 2011, Guzman, Santos 2008b; 2007; Davidsson, Wiklund, Delmar 2006) cytowane w literaturze przedmiotu. Średnia liczba osób zatrudnionych w dużej mierze może również zależeć od sektora, który dane przedsiębiorstwo reprezentuje, ponieważ np. przedsiębiorstwa handlowe są $\mathrm{z}$ reguły znacznie mniejsze niż produkcyjne. Dlatego też bardzo ostrożnie należy wnioskować odnośnie różnic w wielkości firmy w zależności od lokalizacji $\mathrm{w}$ obszarach rozwiniętych czy zmarginalizowanych bez porównań szczegółowych w danej branży czy sektorze.

Badani respondenci to głównie mężczyźni $(79,4 \%)$, z wykształceniem średnim (41,3\%), w wieku 31-45 lat (39,5\%) oraz posiadający doświadczenie w zarządzaniu przedsiębiorstwem (67,4\%). Bardzo zbliżoną charakterystykę posiadali respondenci zarówno z obszarów rozwiniętych, jak i zmarginalizowanych.

Analiza długości istnienia badanych podmiotów ${ }^{4}$ na rynku wykazała, że ok. $70 \%$ z nich funkcjonuje już powyżej 10 lat, średni wiek wynosił 14 lat, a wiek najczęściej występujący to 11 lat. Rozkład badanych firm według ich wieku nie wykazuje istotnych różnic $\mathrm{w}$ obszarach rozwiniętych i zmarginalizowanych w porównaniu do analizy całej próby.

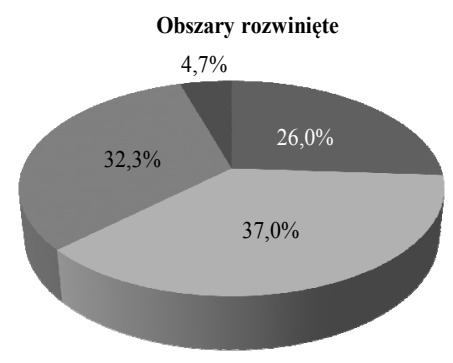

- Miasto duże (powyżej 100 tys. mieszkańców)

- Miasto średnie (od 20 -100 tys. mieszkańców)

- Miasto małe (do 20 tys. mieszkańców)

- Obszar wiejski (miejscowości nie posiadające statusu miasta)

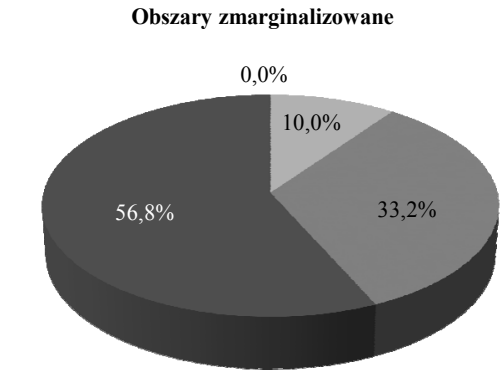

- Miasto duże (powyżej 100 tys. mieszkańców)

1- Miasto średnie (od 20 -100 tys. mieszkańców)

- Miasto małe (do 20 tys. mieszkańców)

- Obszar wiejski (miejscowości nie posiadające statusu miasta)

Rysunek 34. Lokalizacja badanych przedsiębiorstw

Źródło: opracowanie własne

\footnotetext{
${ }^{4} \mathrm{~W}$ badaniu wzięły udział podmioty powstałe przed 31 grudnia $2007 \mathrm{r}$.
} 
Badane firmy były głównie zlokalizowane na terenie małych miast i obszarów wiejskich (odpowiednio 28,6\% i 32,7\%) oraz średnich miast $(24,6 \%$ ). Rozpatrując lokalizację firm w obszarach rozwiniętych i zmarginalizowanych, widoczne jest zróżnicowanie względem całości próby (por. rysunek 34).

Najliczniej reprezentowane wśród badanych podmiotów były przedsiębiorstwa osób fizycznych (61\%) oraz spółki cywilne $(14,4 \%)$, spółki z o.o. $(10 \%)$ i spółki jawne $(8,8 \%)$, pozostałe formy organizacyjne miały niewielki udział wśród analizowanych przedsiębiorstw (od 1,5 do 2,4\%). W przypadku obszarów zmarginalizowanych udział przedsiębiorstw osób fizycznych i spółek cywilnych i jawnych to ponad $(80 \%)$ badanej populacji, natomiast w obszarach rozwiniętych znaczący udział w badaniu mają również spółki z o.o. (por. rysunek 35).

Można jednak przypuszczać, że wybór formy organizacyjno-prawnej przez badane podmioty nie wynikał głównie z lokalizacji, ale z profilu prowadzonej działalności oraz wielkości przedsiębiorstwa mierzonej liczbą osób pracujących.

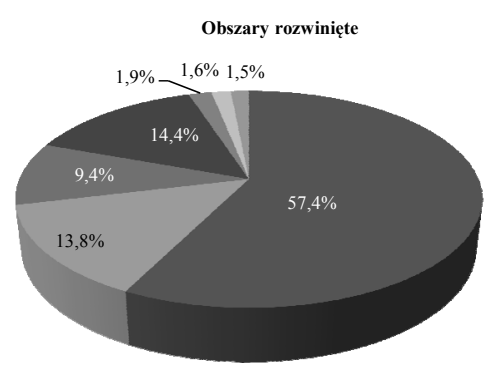

- Osoba fizyczna In Spółka cywilna — Spólka jawna - Spółka z o.o.

- Spółdzielnia \. Spółka akcyjna — Inne

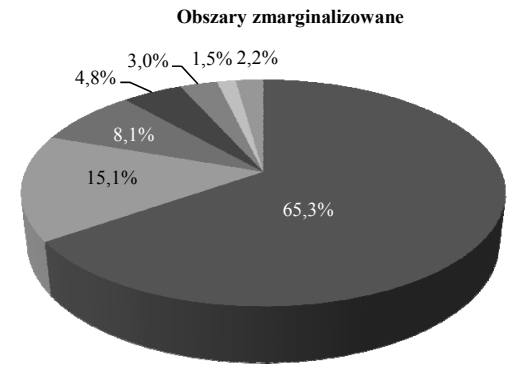

- Osoba fizyczna |- Spółka cywilna ㅌ. Spólka jawna - Spółka z o.o. - Spółdzielnia - Spółka akcyjna In Ine

Rysunek 35. Forma organizacyjno-prawna badanych przedsiębiorstw Źródło: opracowanie własne
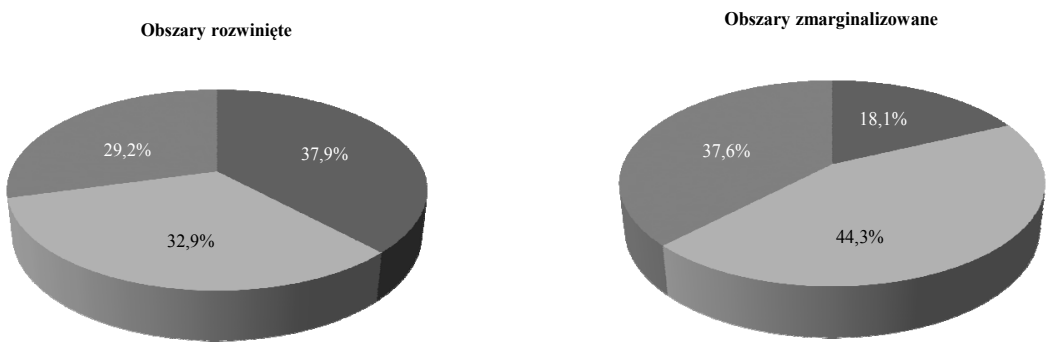
Większość badanych przedsiębiorstw zajmowała się działalnością usługową i handlową (ok. 70\%), a niecałe (30\%) produkcyjną. Widoczne jest zróżnicowanie głównego rodzaju działalności w obszarach rozwiniętych, gdzie największe znaczenie odgrywała działalność produkcyjna $(37,9 \%)$ i usługowa $(32,9 \%)$, przedsiębiorstwa $\mathrm{w}$ obszarach zmarginalizowanych miały największy udział w działalności usługowej (44,3\%) i handlowej (37,6\%) (por. rysunek 36).

Taka struktura wynika głównie ze specyfiki analizowanych obszarów, jak również struktury badanych firm według wielkości - dominująca liczba mikrofirm $\mathrm{z}$ niewielkim udziałem osób zatrudnionych szczególnie $\mathrm{w}$ obszarach zmarginalizowanych.

Badane podmioty były zróżnicowane pod względem rodzaju prowadzonej działalności według sekcji PKD, przynależąc do 15 sekcji i 47 działów. W obszarach rozwiniętych dominowały sekcje: C (Przetwórstwo przemysłowe), F (Budownictwo), G (Handel i naprawy), H (Transport i gospodarka magazynowa) i M (Działalność profesjonalna, naukowa i techniczna), natomiast w obszarach zamrginalizowanych sekcje: G (Handel i naprawy), H (Transport i gospodarka magazynowa) oraz A (Rolnictwo, leśnictwo i łowiectwo).

Operowały głównie na rynkach ${ }^{5}$ : regionalnym (52,4\% wskazań), lokalnym (52\% wskazań) i krajowym (44,6\% wskazań), tylko co 10 firma rozszerzyła swoją działalność na rynek międzynarodowy (13,2\% wskazań). Tak niski udział firm, które odnotowały obroty na rynkach zagranicznych w badanej populacji, potwierdza niską skłonność małych i średnich przedsiębiorstw w Polsce do działalności eksportowej ${ }^{6}$. Na rynkach zagranicznych operowały głównie przedsiębiorstwa prowadzące działalność produkcyjną (58,7\% całości grupy) i zlokalizowane w regionach zurbanizowanych, tzn. miastach dużych i średnich (47\%). Stosując test niezależności U Manna-Whitneya ${ }^{7}$, obserwuje się zróżnicowanie w zasięgu działania pomiędzy obszarami rozwiniętymi a obszarami zmarginalizowanymi, o czym świadczy poziom prawdopodobieństwa testowego $(p<0,05)$. W obszarach rozwiniętych przedsiębiorstwa operują głównie na rynku krajowym i regionalnym, zaś w obszarach zmarginalizowanych - przeważnie na rynku lokalnym i regionalnym (por. rysunek 37 ).

${ }^{5}$ Badane przedsiębiorstwo mogło wskazać wszystkie obszary swojego działania, czyli dowolną liczbę wariantów.

${ }^{6}$ Według danych PARP w 2011 r. niecałe 30\% małych i średnich przedsiębiorstw (wyłączając mikroprzedsiębiorstwa) prowadziło działalność eksportową. Szerzej Włodkiewicz-Donimirski 2012.

${ }^{7}$ Test U Manna-Whitneya pozwala porównywać ze sobą dwie niezależne populacje. Ma zastosowanie, gdy zmienna zależna jest ilościowa, ale nie spełnia założeń związanych z normalnością rozkładu bądź też jest wyrażona na skali porządkowej. Test ten polega na rangowaniu wyników zmiennej zależnej (od najmniejszej do największej) w badanych grupach, a następnie grupy są ze sobą porównywane. Szerzej na temat testu: Kornacki, Mielniczuk 2001, s. 460-463; Szwed 2009. 


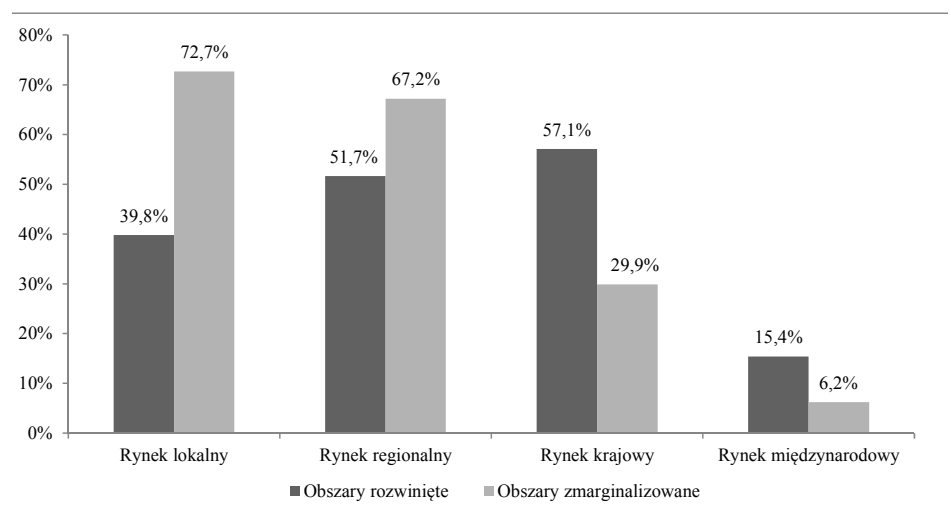

Rysunek 37. Struktura badanych przedsiębiorstw według zasięgu działania Uwaga: Respondenci mogli wskazać więcej niż jeden rynek jako obszar działania. Źródło: opracowanie własne

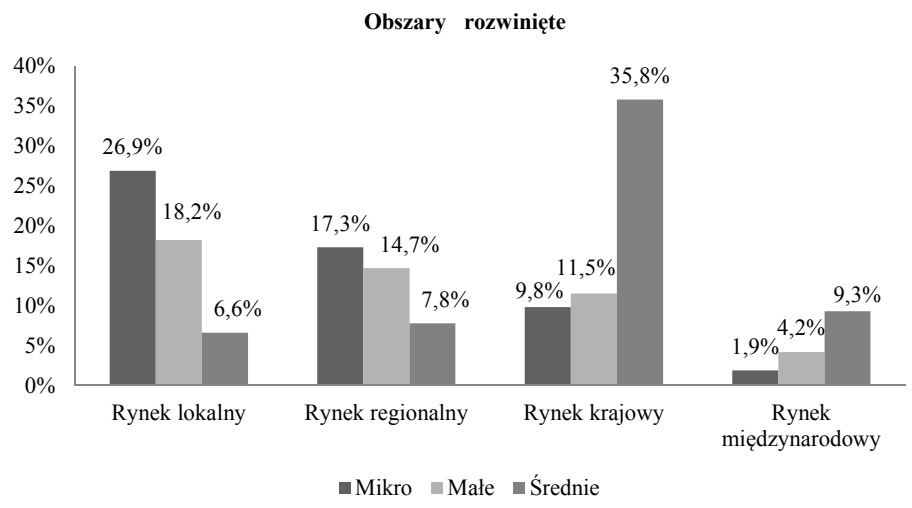

Obszary zmarginalizowane

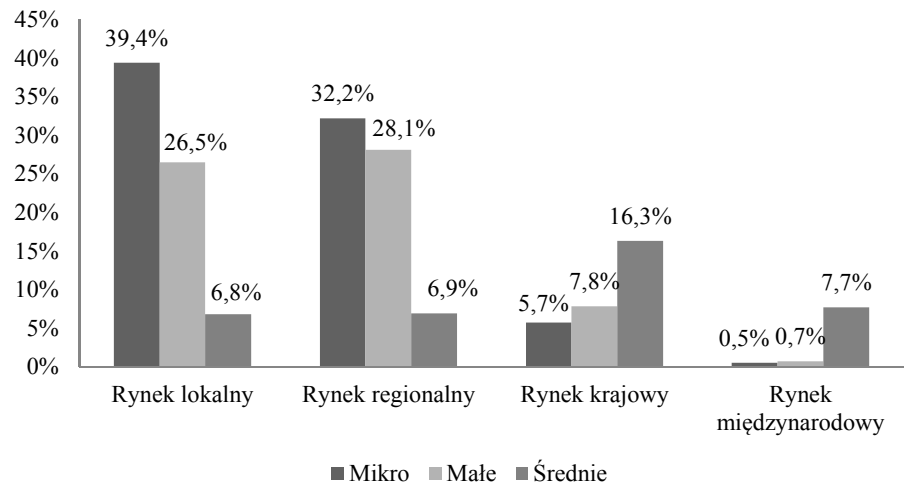

Rysunek 38. Struktura badanych przedsiębiorstw według zasięgu działania i wielkości firmy Źródło: opracowanie własne 
Podmioty z przewagą obrotów na rynku lokalnym i regionalnym to głównie mikro i małe przedsiębiorstwa zarówno w przypadku obszarów rozwiniętych, jak i zmarginalizowanych (por. rysunek 38), co podkreśla lokalny charakter tej kategorii firm, przejawiający się silnym związkiem z rynkiem lokalnym, na którym firmy te głównie operują oferując swoje produkty i usługi zaspakajając potrzeby lokalnych społeczności. Podobnie jak w przypadku mikro i małych przedsiębiorstw zasięg działania średnich przedsiębiorstw nie był zróżnicowany w zależności od lokalizacji firmy na terenach rozwiniętych i zmarginalizowanych. Podmioty te operowały głównie na rynku krajowym i międzynarodowym, co świadczy o znacznie szerszej skali działania, jak w przypadku mikro i małych przedsiębiorstw, czyli braku wpływu marginalizacji obszaru na zasięg działania średniej firmy.

\subsection{Dynamika rozwojowa badanych przedsiębiorstw}

Pierwszym obszarem badawczym była analiza dynamiki rozwojowej ${ }^{8}$ badanych przedsiębiorstw, w tym celu zostały one podzielone na trzy kategorie?: w fazie rozwoju, stagnacji i regresu w zależności od zmian wskaźników wyrażonych na skali porządkowej w latach 2009 vs 2008, 2010 vs 2009 oraz 2011 vs 2010. W pierwszym etapie dokonano wyboru wskaźników na podstawie studiów literaturowych ${ }^{10}$ (por. rysunek 39 ), a następnie posłużono się analizą skupień metodą k-średnich ${ }^{11}$ dla klasyfikacji badanych przedsiębiorstw ${ }^{12}$.

${ }^{8}$ Dynamika rozwojowa jest definiowana jako zmiany poszczególnych wskaźników w badanych okresach.

${ }^{9}$ Metodologię klasyfikacji przedsiębiorstw przyjęto za: Kamińska 2011, s. 228-230.

${ }^{10}$ Por. Wright, Stigliani 2013, s. 611-621; Hamilton 2012, s. 611-621; Kalantaridis 2009, s. 496-521; Kamińska 2011, s. 228-230; Wasilczuk 2005, s. 132-133; Wach 2008, s. 85-86.

${ }^{11}$ Analiza skupień to zbiór metod pozwalających na wyróżnienie zbiorów obserwacji (nazywanych skupieniami lub klastrami) podobnych do siebie. Analizę tę można zastosować w przypadku, gdy obiekty te są opisane przez więcej niż jedną cechę. Dla klasyfikacji przedsiębiorstw według ich kondycji rozwojowej zastosowano metodę niehierarchiczną k-średnich, w której grupowanie obiektów polega na wstępnym podzielaniu populacji na $\mathrm{z}$ góry założoną liczbę klas, a następnie wyznacza się współrzędne $k$ punktów, które zostaną uznane za środki klastrów. Obserwacja będzie należała do tego klastra, którego środek jest najbliżej niej. Poprawny podział to taki, w którym suma odległości obserwacji należących do klastra jest znacznie mniejsza od sumy odległości obserwacji pomiędzy klastrami. Szerzej na temat metody: Korzeniewski 2012, s. 7-2; Panek 2009, s. 129-151.

${ }^{12} \mathrm{Z}$ uwagi na fakt, iż celem analizy było wyróżnienie konkretnie trzech klastrów przedsiębiorstw: w fazie rozwoju, fazie stagnacji/zastoju i regresu, dlatego zrezygnowano $\mathrm{z}$ metod aglomeracyjnych - analizę przeprowadzono $\mathrm{z}$ wykorzystaniem metody k-średnich. 
Zmiany wskaźnika

Spadek bez zmian wzrost

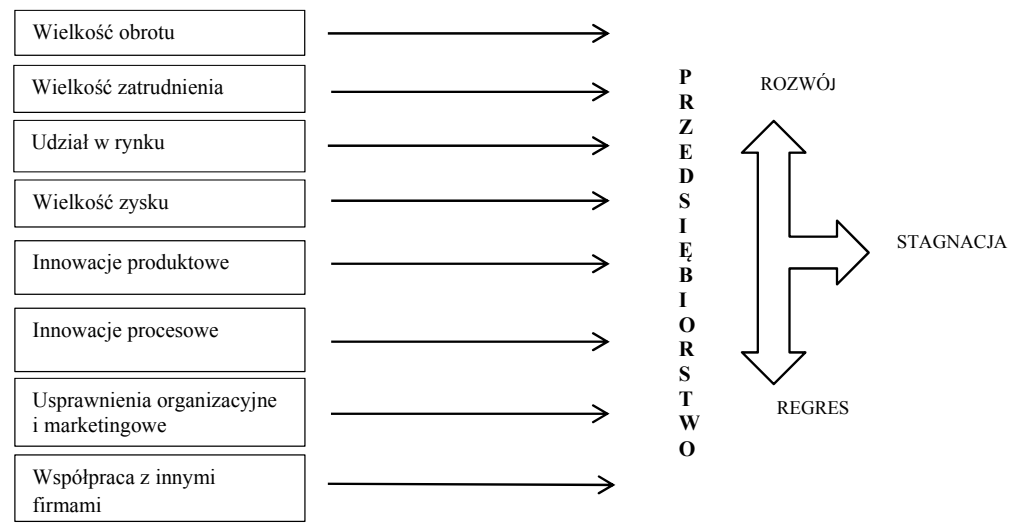

Rysunek 39. Zmienne modelu badawczego - wskaźniki wzrostu/rozwoju Źródło: opracowanie własne

Zastosowana metoda skupień zapewniła takie grupowanie przedsiębiorstw, dla których maksymalne podobieństwo charakteryzowało członków danego skupienia, a między członkami danej grupy a pozostałymi obiektami podobieństwo było minimalne. Dokonując procedury klasyfikacji, w pierwszej kolejności skwantyfikowano wytypowane cechy, mające charakter zmiennych ciągłych, jednak wyrażonych na skali porządkowej ${ }^{13}$. Kwantyfikacja polegała na przypisaniu badanym cechom określonych wartości liczbowych. W wyniku wstępnych analiz w kwestionariuszu umożliwiono wyrażenie stanu zjawiska na skali trzystopniowej. Oceny poziomu zmian danego wskaźnika $\mathrm{w}$ badanych okresach dokonywali respondenci, używając kategoryzacji: wzrost, bez zmian i spadek. Wyróżnionym stopniom przypisane zostały kolejne liczby naturalne: 3 - wzrost, 2 - bez zmian, zaś 1 - spadek danego zjawiska. Jako cechy diagnostyczne przyjęto: wielkość obrotu, wielkość zatrudnienia, udział w rynku, wielkość zysku oraz mierników jakościowych: innowacje produktowe (liczba wprowadzonych), innowacje procesowe (liczba wprowadzonych), usprawnienia organizacyjne i marketingowe (liczba wprowadzonych), współpraca z innymi przedsiębiorstwami (liczba firm).

Najwięcej badanych podmiotów znalazło się w grupie rozwój - 260 firm $(44,1 \%), 181$ firm $(30,7 \%) \mathrm{w}$ grupie stagnacja oraz 149 firm $(25,2 \%) \mathrm{w}$ grupie regres. Rozkład badanych przedsiębiorstw w podziale na te trzy kategorie wykazuje na istotne różnice w obszarach rozwiniętych i zmarginalizowanych,

${ }^{13} \mathrm{~W}$ sytuacji, gdy zmienna wyraża zjawisko mające charakter ciągły, a tak jest w przypadku proponowanych cech diagnostycznych, a pomiar dokonany został na skali słabszej - porządkowej, dopuszcza się zwykle stosowanie tradycyjnych metod statystyki wielowymiarowej, w tym analizy skupień (por. np. Kot, Słaby, Perek-Białas 2012). 
biorąc pod uwagę charakterystykę przedsiębiorstwa, tzn. jego wielkość, sektor działalności podstawowej, wiek przedsiębiorstwa i obszar działania, o czym świadczą otrzymane prawdopodobieństwa testowe dla testu Kruskala-Wallisa ${ }^{14}$ $(p<0,05)$ i $(p<0,01)$ (por. tabela 13).

Tabela 13. Charakterystyka badanego przedsiębiorstwa a jego dynamika rozwojowa

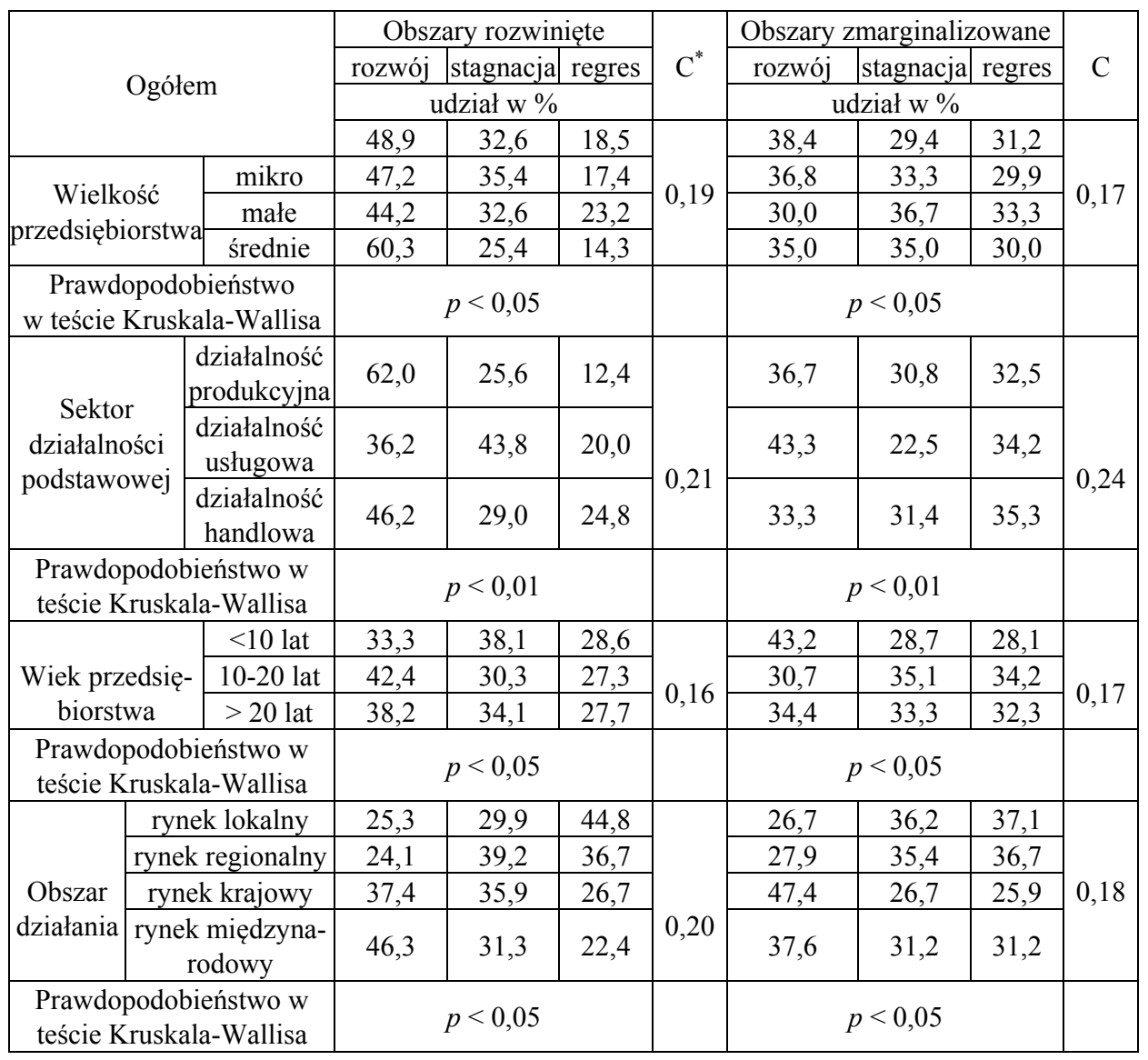

*C - współczynnik kontyngencji C-Pearsona.

Źródło: opracowanie własne.

W obszarach rozwiniętych podmioty nieleżące do grupy rozwój stanowiły 48,9\% firm, głównie z kategorii średnie, prowadzące działalność produkcyjną,

${ }^{14}$ Test Kruskala-Wallisa pozwala porównywać ze sobą więcej niż dwie niezależne populacje. Ma zastosowanie, gdy zmienna zależna jest ilościowa, ale nie spełnia założeń związanych z normalnością rozkładu bądź też jest wyrażona na skali porządkowej. Szerzej na temat testu: Kornacki, Mielniczuk 2001, s. 460-463; Szwed 2009. 
z dużym doświadczeniem na rynku (istniejące od 10 do 20 lat), operujące na rynkach krajowym i międzynarodowym. W grupie stagnacja znalazło się 32,6\% podmiotów, dominowały mikrofirmy, prowadzące działalność usługową, istniejące poniżej 10 lat na rynku, działające na rynkach krajowym i regionalnym. Z kolei do trzeciej grupy regres zaklasyfikowano $18,5 \%$ firm, głównie małych, prowadzących działalność handlową, ze stażem na rynku poniżej 10 lat, z przewagą obrotów na rynkach regionalnym i lokalnym. Dla sprawdzenia, czy istnieje współzależność pomiędzy cechami przedsiębiorstwa, takimi jak: wielkość przedsiębiorstwa, sektor działalności, wiek i obszar działania a ich stopniem rozwoju, wykorzystano test niezależności chi-kwadrat $\left(\chi^{2}\right)^{15}$.

Wyniki tego testu na poziomie istotności $\alpha=0,05$ potwierdzily istnienie zależności pomiędzy wielkością przedsiębiorstwa, sektorem działalności, wiekiem i obszarem działania, a ich dynamiką rozwoju. Następnie dla określenia siły tej zależności obliczono współczynnik kontyngencji (C-Pearsona) ${ }^{16}$ (por. tabela 14). Wartość współczynnika $C=0,19$ wskazuje na słabą zależność między wielkością przedsiębiorstwa a jego dynamiką rozwoju, zbliżone wyniki współczynnika $\mathrm{C}$ otrzymano również dla zależności: sektor działalności podstawowej a dynamika rozwoju $\mathrm{C}=0,21$, wiek przedsiębiorstwa a dynamika rozwoju $\mathrm{C}=0,16$ oraz obszar działania a stopień rozwoju $\mathrm{C}=0,20$. Wartości te wskazują na słabą zależność, choć, co należy podkreślić, statystycznie istotną.

Natomiast $\mathrm{w}$ obszarach zmarginalizowanych w pierwszej grupie rozwój znalazło się 38,4\% firm, głównie z kategorii mikro, prowadzących działalność usługową, młodych (istniejących poniżej 10 lat na rynku), operujących na rynkach krajowym i międzynarodowym. Do kategorii stagnacja i regres zaklasyfikowano ponad $60 \%$ firm, wśród których dominowały mikro i małe firmy, prowadzące działalność handlową, $\mathrm{z}$ doświadczeniem na rynku (istniejące od 10 do 20 lat), działających głównie z przewagą obrotów na rynkach lokalnym i regionalnym, tak wąski obszar działania może stanowić barierę rozwoju dla tych podmiotów, wynikającą głównie z ograniczonego popytu związanego z mniejszą liczbą potencjalnych klientów posiadających coraz mniejszą siłę nabywczą.

${ }^{15}$ Test niezależności chi-kwadrat $\left(\chi^{2}\right)$ jest stosowany w przypadku badania niezależności cech niemierzalnych (jakościowych) lub w przypadku badania niezależności cechy jakościowej $\mathrm{z}$ ilościową. Wyniki badań sklasyfikuje się $\mathrm{w}$ postaci tablicy kontyngencji wg jednej cechy $\mathrm{w} r$ wierszach i wg drugiej cechy w $k$ kolumnach. Wnętrze tablicy kontyngencji stanowią liczebności $n_{i j}$ elementów próby, które spełniają jednocześnie kryteria zawarte $\mathrm{w} i$-tym wierszu i $k$-tej kolumnie. Wyniki testu pozwalają na zbadanie zależności pomiędzy badanymi cechami. Jeżeli $p<0,05$, należy odrzucić $\mathrm{H}_{0}$ mówiącą o niezależności badanych cech na rzecz hipotezy alternatywnej $\mathrm{H}_{1} \mathrm{o}$ istnieniu takiej zależności. Szerzej na temat testu: Stanisławek 2010, s. 144-146.

${ }^{16}$ Współczynnik kontyngencji C-Pearsona bada siłę związku pomiędzy cechami niemierzalnymi, przyjmuje wartości z przedziału $(0,1)$, im wartość współczynnika jest bliższa jedności tym silniejsza zależność miedzy badanymi cechami. Wartość współczynnika nie informuje o kierunku zależności. Szerzej na temat współczynnika: Szwed 2009. 
Analogicznie jak w przypadku obszarów rozwiniętych, dla sprawdzenia, czy istnieje współzależność pomiędzy cechami przedsiębiorstwa, takimi jak: wielkość przedsiębiorstwa, sektor działalności, wiek i obszar działania, a ich stopniem rozwoju wykorzystano test niezależności chi-kwadrat $\left(\chi^{2}\right)$, którego wyniki $(p<0,05)$ wskazały na jej istnienie. Siła tego związku zbadana współczynnikiem kontyngencji (C-Pearsona) wskazywała na słabą zależność między badanymi zmiennymi (por. tabela 14), tzn. wielkością przedsiębiorstwa a jego stopniem rozwoju $\mathrm{C}=0,17$, sektorem działalności podstawowej a stopniem rozwoju $\mathrm{C}=0,24$, wiekiem przedsiębiorstwa a stopniem rozwoju $\mathrm{C}=0,17$ oraz obszarem działania a stopniem rozwoju $\mathrm{C}=0,18$. W dalszej części badania dokonano oceny relacji między cechami właściciela (wiek, wykształcenie i doświadczenie w zarządzaniu) a dynamiką rozwoju firmy (rozwój stagnacja, regres). Rozkład badanych podmiotów według ich dynamiki rozwoju nie wykazuje istotnych różnic $w$ obszarach rozwiniętych i zmarginalizowanych, biorąc pod uwagę charakterystykę przedsiębiorcy, tzn. wiek, wykształcenie i doświadczenie w zarządzaniu przedsiębiorstwem, o czym świadczą otrzymane prawdopodobieństwa testowe dla testu Kruskala-Wallisa $(p>0,05)$ (por. tabela 14).

Tabela 14. Charakterystyka właściciela a dynamika rozwoju przedsiębiorstwa

\begin{tabular}{|c|c|c|c|c|c|c|c|c|c|c|}
\hline \multirow{3}{*}{\multicolumn{3}{|c|}{ Cechy właściciela }} & \multicolumn{3}{|c|}{ Obszary rozwinięte } & \multirow{3}{*}{$\mathrm{C}^{*}$} & \multicolumn{3}{|c|}{ Obszary zmarginalizowane } & \multirow{3}{*}{$\mathrm{C}$} \\
\hline & & & rozwój & gnacj & cegres & & rozwój & agnacj & regres & \\
\hline & & & 1 & iał w & & & \multicolumn{3}{|c|}{ Udział w \% } & \\
\hline \multirow{4}{*}{$\begin{array}{c}\text { Wiek } \\
\text { właściciela }\end{array}$} & \multicolumn{2}{|c|}{ Do 30 lat } & 39,5 & 37,5 & 23,0 & \multirow{4}{*}{0,02} & 32,3 & 33,5 & 34,2 & \multirow{4}{*}{0,05} \\
\hline & \multirow{2}{*}{\multicolumn{2}{|c|}{$\frac{31-45 \text { lat }}{46-60 \text { lat }}$}} & 63,6 & 27,8 & 8,6 & & 51,6 & 31,0 & 17,4 & \\
\hline & & & 22,7 & 41,3 & 36,0 & & 25,9 & 37,8 & 36,3 & \\
\hline & \multicolumn{2}{|c|}{$>60$ lat } & 37 & 31,5 & 31,5 & & 33,5 & 34,2 & 32,3 & \\
\hline \multicolumn{3}{|c|}{$\begin{array}{l}\text { Prawdopodobieństwo w } \\
\text { teście Kruskala-Wallisa }\end{array}$} & \multicolumn{3}{|c|}{$p>0,05$} & & \multicolumn{3}{|c|}{$p>0,05$} & \\
\hline \multirow{5}{*}{$\begin{array}{l}\text { Wykształcenie } \\
\text { właściciela }\end{array}$} & \multicolumn{2}{|c|}{ podstawowe } & 30,8 & 30,8 & 38,4 & \multirow{5}{*}{0,07} & 30,5 & 35,1 & 34,4 & \multirow{5}{*}{0,03} \\
\hline & \multicolumn{2}{|c|}{ zawodowe } & 19,4 & 38,7 & 41,9 & & 21,6 & 40,2 & 38,2 & \\
\hline & \multicolumn{2}{|c|}{ średnie } & 34,7 & 40,1 & 33,2 & & 32,2 & 36,1 & 31,7 & \\
\hline & \multicolumn{2}{|c|}{$\begin{array}{c}\text { wyższe } \\
\text { zawodowe }\end{array}$} & 45,3 & 29,2 & 25,5 & & 44,9 & 27,8 & 27,3 & \\
\hline & \multicolumn{2}{|c|}{\begin{tabular}{|c|} 
wyższe \\
magisterskie
\end{tabular}} & 43,2 & 29,8 & 27,0 & & 47,8 & 25,9 & 26,3 & \\
\hline \multicolumn{3}{|c|}{$\begin{array}{c}\text { Prawdopodobieństwo } \\
\text { w teście Kruskala-Wallisa }\end{array}$} & \multicolumn{3}{|c|}{$p>0,05$} & & \multicolumn{3}{|c|}{$p>0,05$} & \\
\hline \multirow{2}{*}{\multicolumn{2}{|c|}{$\begin{array}{c}\text { Doświadczenie } \\
\text { w zarzadzaniu } \\
\text { przedsiębiorstwem }\end{array}$}} & tak & 39,8 & 30,9 & 29,3 & \multirow{2}{*}{0,06} & 41,4 & 29,6 & 29,0 & \multirow{2}{*}{0,07} \\
\hline & & nie & 25,4 & 37,0 & 37,6 & & 21,9 & 38,7 & 39,4 & \\
\hline \multicolumn{3}{|c|}{$\begin{array}{l}\text { Prawdopodobieństwo w } \\
\text { teście Kruskala-Wallisa }\end{array}$} & \multicolumn{3}{|c|}{$\mathrm{p}>0,05$} & & \multicolumn{3}{|c|}{$\mathrm{p}>0,05$} & \\
\hline
\end{tabular}

C-współczynnik kontyngencji C-Pearsona.

Źródło: opracowanie własne. 
W obszarach rozwiniętych i zmarginalizowanych (por. tabela 15) w pierwszej kategorii podmiotów $\mathrm{w}$ fazie rozwoju najliczniejszą grupę stanowili przedsiębiorcy $\mathrm{w}$ wieku 31-45 lat, $\mathrm{z}$ wykształceniem średnim oraz wyższym (zawodowym i magisterskim) posiadający doświadczenie w zarządzaniu firmą. Wśród przedsiębiorstw w fazie stagnacji i regresu dominowali przedsiębiorcy młodzi w wieku poniżej 30 lat, z wykształceniem zawodowym i średnim, nie posiadający doświadczenia w zarządzaniu firmą. Uzyskane wyniki są zgodne $\mathrm{z}$ najczęściej przywoływanymi w literaturze przedmiotu wnioskami z badań ${ }^{17}$, że przedsiębiorstwa zarządzane przez właścicieli lepiej wykształconych, w średnim wieku (Storey 1994) i z doświadczeniem w zarzadzaniu (Wasilczuk 2005) mają znacznie większe szanse rozwojowe niż przedsiębiorstwa zarządzane przez właścicieli z innymi charakterystykami.

Aby sprawdzić, czy istnieje współzależność pomiędzy cechami przedsiębiorcy (wiek, wykształcenie i doświadczenie w zarządzaniu) a dynamiką rozwoju firmy, wykorzystano test niezależności chi-kwadrat $\left(\chi^{2}\right)$, którego wyniki $(p>0,05)$ wskazały na brak zależności pomiędzy badanymi zmiennymi, a siła tego związku obliczona współczynnikiem kontyngencji (C) była nieistotna statystycznie (por. tabela 15).

Analiza otrzymanych wyników dla obszarów rozwiniętych, biorąc pod uwagę stopień rozwoju przedsiębiorstwa, sugeruje, że największe szanse rozwojowe mają firmy zajmujące się działalnością produkcyjną, firmy dojrzałe (istniejące od 10-20 lat), operujące na rynkach krajowym i międzynarodowym, których właścicielami są osoby w wieku 31-45 lat, z wykształceniem średnim i wyższym, posiadające doświadczenie w zarządzaniu firmą. Natomiast w przypadku regionów zmarginalizowanych największe szanse rozwojowe mają firmy młode (istniejące poniżej 10 lat na rynku), zajmujące się działalnością usługową, z przewagą obrotów na rynkach regionalnym i krajowym, prowadzone przez przedsiębiorców w wieku 31-45 lat, z wykształceniem zawodowym i średnim oraz doświadczeniem w zarządzaniu przedsiębiorstwem.

Reasumując dotychczasowe rozważania, można wskazać na różnice w dynamice rozwojowej małych i średnich przedsiębiorstw w obszarach rozwiniętych i zmarginalizowanych, a świadczą o tym zmiany $w$ badanych wskaźnikach wzrostu/rozwoju. W firmach zlokalizowanych w obszarach zmarginalizowanych w większości analizowanych wskaźników odnotowano spadek bądź brak zmian, co spowodowało, że ponad $60 \%$ firm znalazało się w kategoriach: regres i stagnacja, w przypadku obszarów rozwiniętych było to ok. 50\%. Uzyskane wyniki pozwalają pozytywnie zweryfikować $\mathrm{H}_{1}$, że małe i średnie przedsiębiorstwa funkcjonujące $\mathrm{w}$ warunkach obszaru zmarginalizowanego charakteryzują się mniejszą dynamiką rozwojową niż funkcjonujące w obszarach rozwiniętych.

\footnotetext{
${ }^{17}$ Wnioski dotyczą badań, w których ocena wpływu cech przedsiębiorcy na rozwój firmy nie była dokonana $\mathrm{z}$ punktu widzenia lokalizacji przedsiębiorstwa $\mathrm{w}$ regionach o różnym stopniu rozwoju społeczno-gospodarczego. Dlatego też nie potwierdzają się w przypadku regionów zmarginalizowanych.
} 


\subsection{Priorytety rozwojowe i stosowane przewagi konkurencyjne}

Kolejnym obszarem analizy były plany na przyszłość badanych podmiotów w zakresie rozwoju. Większość z nich (ok. 81,3\%) planowała rozwój w perspektywie najbliższych trzech lat, określając priorytety rozwojowe. Do najczęściej wskazywanych ${ }^{18}$ przez respondentów priorytetów rozwojowych w okresie najbliższych trzech lat zaliczono: wzrost udziału w rynku (15,5\% wskazań), wprowadzenie innowacji/ inwestycje $\mathrm{w}$ nowoczesne maszyny i urządzania (13,7\% wskazań) oraz pozyskanie nowych klientów i rynków zbytu $(12,7 \%$ wskazań), najmniej istotne priorytety rozwojowe dla badanych przedsiębiorstw to: wzrost efektywności operacyjnej (3,5\% wskazań) oraz podniesienie kwalifikacji pracowników (3,8\% wskazań).

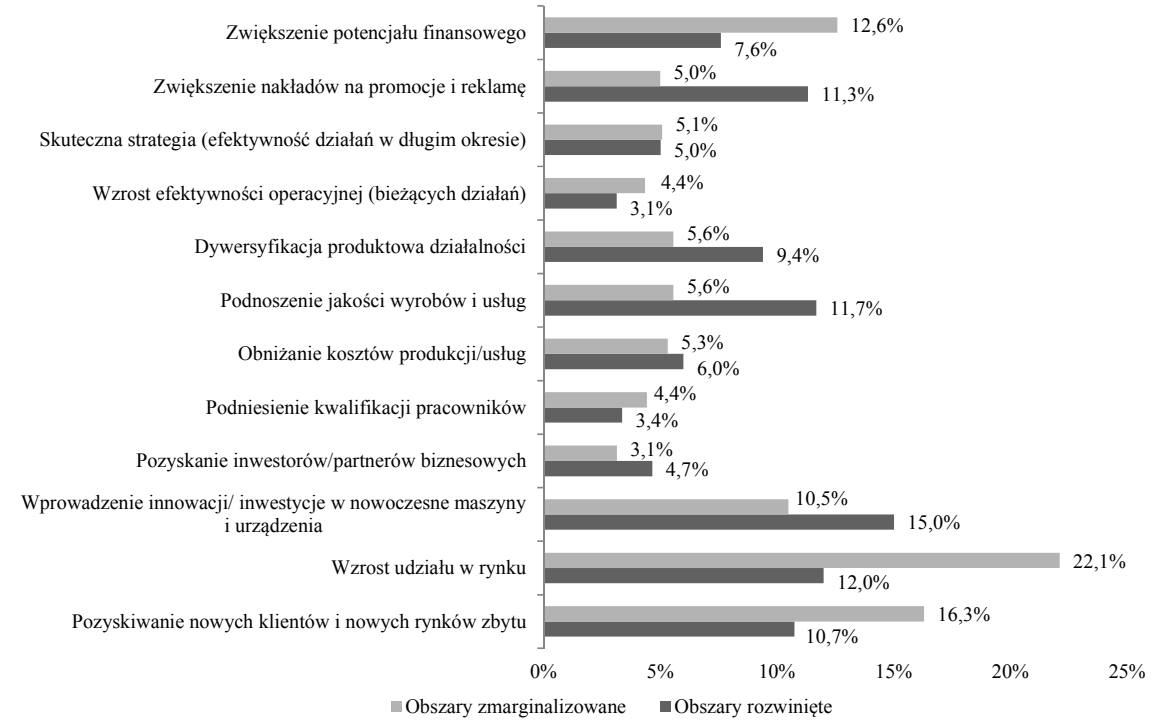

Uwaga: Respondenci wskazywali trzy odpowiedzi według ważności w skali 1-3, co oznaczało: 1 - ważna, 2 - bardzo ważna, 3 - najważniejsza.

Rysunek 40. Priorytety rozwojowe badanych przedsiębiorstw - analiza komparatywna obszary rozwinięte i zmarginalizowane Źródło: opracowanie własne

W celu sprawdzenia, czy istnieją statystycznie istotne różnice we wskazaniach respondentów odnośnie do priorytetów rozwojowych w obszarach rozwiniętych i zmarginalizowanych wykonano test U Manna-Whitneya. Jego wyniki i prawdopodobieństwo testowe $(p<0,05)$ pokazały zróżnicowanie większości badanych zmiennych (por. rysunek 40) (tj. pozyskiwanie nowych klientów i nowych rynków

${ }^{18}$ Respondenci wskazywali trzy odpowiedzi według ważności w skali 1-3, co oznaczało: 1 - ważna, 2 - bardzo ważna, 3 - najważniejsza. 
zbytu, wzrost udziału w rynku, wprowadzenie innowacji i inwestycje w nowoczesne maszyny i urządzenia, podnoszenie jakości wyrobów i usług, dywersyfikacja produktowa działalności, zwiększenie nakładów na promocje i reklamę, zwiększenie potencjału finansowego) w zależności od badanych obszarów.

W obszarach rozwiniętych jako priorytety rozwojowe najczęściej wskazywano wprowadzenie innowacji/inwestycje w nowoczesne maszyny i urządzenia, wzrost udziału w rynku, podnoszenie jakości wyrobów i usług oraz zwiększenie nakładów na promocje i reklamę. Natomiast $\mathrm{w}$ obszarach zmarginalizowanych najważniejszymi priorytetami rozwojowymi dla badanych firm były: wzrost udziału w rynku, pozyskiwanie nowych klientów i nowych rynków zbytu oraz zwiększenie potencjału finansowego. Taka struktura wypowiedzi respondentów sugeruje, że na priorytety rozwojowe małych i średnich przedsiębiorstw może mieć wpływ rozwój społecznogospodarczy obszaru, w którym zlokalizowane jest przedsiębiorstwo.

Przeprowadzona analiza priorytetów rozwojowych nie daje pełnego obrazu zachowań rozwojowych małych i średnich przedsiębiorstw $\mathrm{w}$ analizowanych obszarach, ze względu na zbyt dużą agregację danych, odnosząca się łącznie do wszystkich kategorii przedsiębiorstw. Można jednak przypuszczać, że zachowania rozwojowe $\mathrm{w}$ postaci wskazywanych priorytetów mogą być zróżnicowane dla każdej kategorii przedsiębiorstw. W celu sprawdzenia czy istnieją statystycznie istotne różnice we wskazaniach respondentów odnośnie do priorytetów rozwojowych w obszarach rozwiniętych i zmarginalizowanych wykonano test Kruskala-Wallisa. Jego wyniki i prawdopodobieństwo testowe $(p<0,05)$ pokazały zróżnicowanie większości badanych zmiennych, tj. zwiększenie potencjału finansowego, zwiększenie nakładów na promocje i reklamę, wzrost efektywności operacyjnej (bieżących działań), podnoszenie jakości wyrobów i usług, podniesienie kalifikacji pracowników, wprowadzenie innowacji/inwestycje $\mathrm{w}$ nowoczesne maszyny i urządzenia, wzrost udziału w rynku oraz pozyskiwanie nowych klientów i nowych rynków zbytu (por. tabela 15).

Tabela 15. Wartość statystyki $(H)$ według testu Kruskala-Wallisa oraz poziom prawdopodobieństwa testowego $(p)$ zmiennych określających priorytety rozwojowe badanych przedsiębiorstw w obszarach rozwiniętych w kontekście wielkości przedsiębiorstwa

\begin{tabular}{|l|c|c|}
\hline \multicolumn{1}{|c|}{ Priorytety rozwojowe } & $\begin{array}{c}\text { Wartość statystyki }(H) \\
\text { według testu } \\
\text { Kruskala-Wallisa }\end{array}$ & $\begin{array}{c}\text { Prawdopodo- } \\
\text { bieństwo } \\
\text { testowe }(p)\end{array}$ \\
\hline 1 & 2 & 3 \\
\hline Zwiększenie potencjału finansowego & 8,275 & 0,016 \\
\hline Zwiększenie nakładów na promocje i reklamę & 5,992 & 0,050 \\
\hline $\begin{array}{l}\text { Skuteczna strategia (efektywność działań w długim } \\
\text { okresie) }\end{array}$ & 4,592 & 0,101 \\
\hline $\begin{array}{l}\text { Wzrost efektywności operacyjnej (bieżących } \\
\text { działań) }\end{array}$ & 8,400 & 0,015 \\
\hline Dywersyfikacja produktowa działalności & 1,778 & 0,411 \\
\hline
\end{tabular}




\begin{tabular}{|l|c|c|}
\hline \multicolumn{1}{|c|}{1} & 2 & 3 \\
\hline Podnoszenie jakości wyrobów i usług & 15,242 & 0,000 \\
\hline Obniżanie kosztów produkcji/usług & 2,806 & 0,246 \\
\hline Podniesienie kalifikacji pracowników & 13,265 & 0,000 \\
\hline Pozyskanie inwestorów/partnerów biznesowych & 6,569 & 0,057 \\
\hline $\begin{array}{l}\text { Wprowadzenie innowacji, inwestycje w nowocze- } \\
\text { sne maszyny i urządzenia }\end{array}$ & 11,343 & 0,000 \\
\hline Wzrost udziału w rynku & 17,234 & 0,000 \\
\hline $\begin{array}{l}\text { Pozyskiwanie nowych klientów i nowych rynków } \\
\text { zbytu }\end{array}$ & 7,567 & 0,048 \\
\hline
\end{tabular}

Źródło: opracowanie własne.

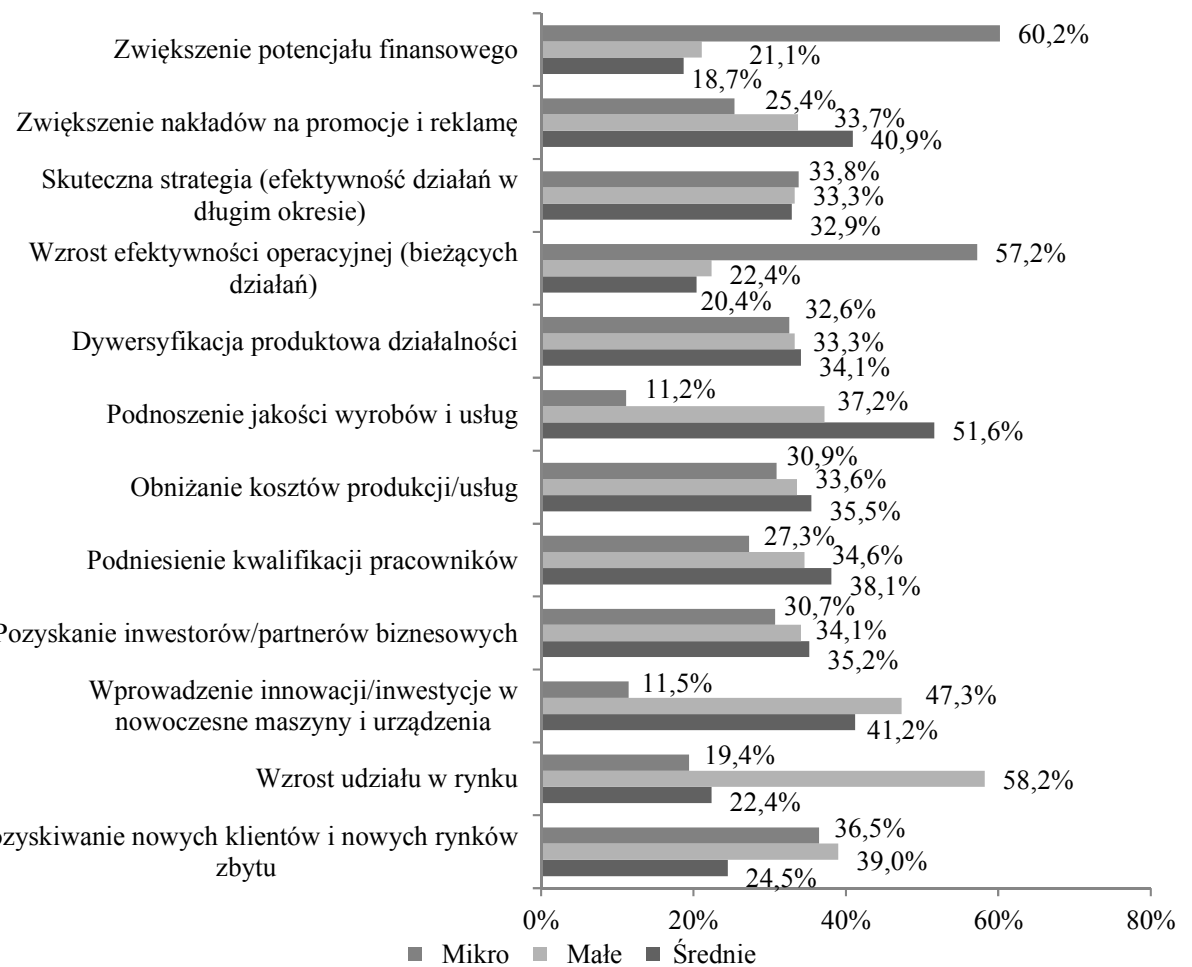

Uwaga: Respondenci wskazywali trzy odpowiedzi według ważności w skali 1-3, co oznaczało: 1 - ważna, 2 - bardzo ważna, 3 - najważniejsza.

Rysunek 41. Priorytety rozwojowe badanych przedsiębiorstw w obszarach rozwiniętych według wielkości firmy

Źródło: opracowanie własne

W obszarach rozwiniętych w perspektywie najbliższych trzech lat dla mikroprzedsiębiorstw za najważniejsze priorytety rozwojowe (por. rysunek 41) respondenci uznali zwiększenie potencjału finansowego (60,2\% wskazań) oraz 
wzrost efektywności operacyjnej (57,2\% wskazań). Świadczy to głównie o niedostatku kapitału i problemach w jego pozyskaniu w badanych firmach, co może wynikać z trudnego dostępu dla tych podmiotów do rynku kapitałowego. Problemy z efektywnością operacyjną mogą wynikać z pewnych niedostatków w procesie zarządzania, a szczególnie w obszarze planowania zarówno krótkookresowego, jak i strategicznego oraz braku innowacyjności/przestarzałej technologii.

W przypadku małych przedsiębiorstw jako najważniejsze priorytety rozwojowe respondenci wskazywali wzrost udziału w rynku (58,2\% wskazań) i wprowadzenie innowacji/inwestycje w maszyny i urządzenia (47,3\% wskazań); taki rozkład wskazań świadczy o konieczności zmiany dotychczasowej strategii na strategie penetracji przy wprowadzaniu zmian wynikających z wprowadzonych innowacji głównie produktowych i procesowych.

Właściciele średnich przedsiębiorstw upatrywali rozwoju poprzez podnoszenia jakości wyrobów i usług (51,6\% wskazań) i wprowadzenie innowacji/inwestycje w maszyny i urządzenia ( $41,2 \%$ wskazań). Taki rozkład wypowiedzi świadczy o wzroście znaczenia świadomości przedsiębiorców w zakresie doskonalenia jakości oraz zachowań innowacyjnych.

Tabela 16. Wartość statystyki $(H)$ według testu Kruskala-Wallisa oraz poziom prawdopodobieństwa testowego $(p)$ zmiennych określających priorytety rozwojowe badanych przedsiębiorstw w obszarach zmarginalizowanych w kontekście wielkości przedsiębiorstwa

\begin{tabular}{|l|c|c|}
\hline \multicolumn{1}{|c|}{ Priorytety rozwojowe } & $\begin{array}{c}\text { Wartość statystyki } \\
(H) \text { według testu } \\
\text { Kruskala-Wallisa }\end{array}$ & $\begin{array}{c}\text { Prawdopodo- } \\
\text { bieństwo } \\
\text { testowe }(p)\end{array}$ \\
\hline Zwiększenie potencjału finansowego & 7,765 & 0,021 \\
\hline Zwiększenie nakładów na promocje i reklamę & 8,226 & 0,016 \\
\hline $\begin{array}{l}\text { Skuteczna strategia (efektywność działań w długim } \\
\text { okresie) }\end{array}$ & 0,269 & 0,874 \\
\hline Wzrost efektywności operacyjnej (bieżących działań) & 5,897 & 0,043 \\
\hline Dywersyfikacja produktowa działalności & 1,886 & 0,389 \\
\hline Podnoszenie jakości wyrobów i usług & 11,986 & 0,000 \\
\hline Obniżanie kosztów produkcji/usług & 1,085 & 0,581 \\
\hline Podniesienie kalifikacji pracowników & 8,867 & 0,014 \\
\hline Pozyskanie inwestorów/partnerów biznesowych & 0,470 & 0,790 \\
\hline $\begin{array}{l}\text { Wprowadzenie innowacji, inwestycje w nowoczesne } \\
\text { maszyny i urządzenia }\end{array}$ & 6,434 & 0,036 \\
\hline Wzrost udziału w rynku & 11,395 & 0,000 \\
\hline $\begin{array}{l}\text { Pozyskiwanie nowych klientów i nowych rynków } \\
\text { zbytu }\end{array}$ & 17,345 & 0,000 \\
\hline
\end{tabular}

Źródło: opracowanie własne. 
W przypadku obszarów zmarginalizowanych również widoczne jest zróżnicowanie wskazań priorytetów rozwojowych przez badanych respondentów w zależności od wielkości przedsiębiorstwa, co potwierdził to również test Kruskala-Wallisa. Jego wyniki i prawdopodobieństwo testowe $(p<0,05)$ pokazały zróżnicowanie większości badanych zmiennych (por. tabela 16), tj. zwiększenie potencjału finansowego, zwiększenie nakładów na promocje i reklamę, wzrost efektywności operacyjnej (bieżących działań), podnoszenie jakości wyrobów i usług, podniesienie kalifikacji pracowników, wprowadzenie innowacji/inwestycje $\mathrm{w}$ nowoczesne maszyny i urządzenia, wzrost udziału w rynku oraz pozyskiwanie nowych klientów i nowych rynków zbytu.

W obszarach zmarginalizowanych $\mathrm{w}$ okresie najbliższych trzech lat dla mikroprzedsiębiorstw za najważniejsze priorytety rozwojowe (por. rysunek 42) respondenci uznali pozyskiwanie nowych klientów i nowych rynków zbytu (48,2\% wskazań) wzrost udziału w rynku (46,8\% wskazań). Świadczy to głównie o kurczeniu rynku zbytu, co może wynikać z mniejszej siły nabywczej lokalnej społeczności, jak również lokalnego charakteru tej grupy podmiotów.

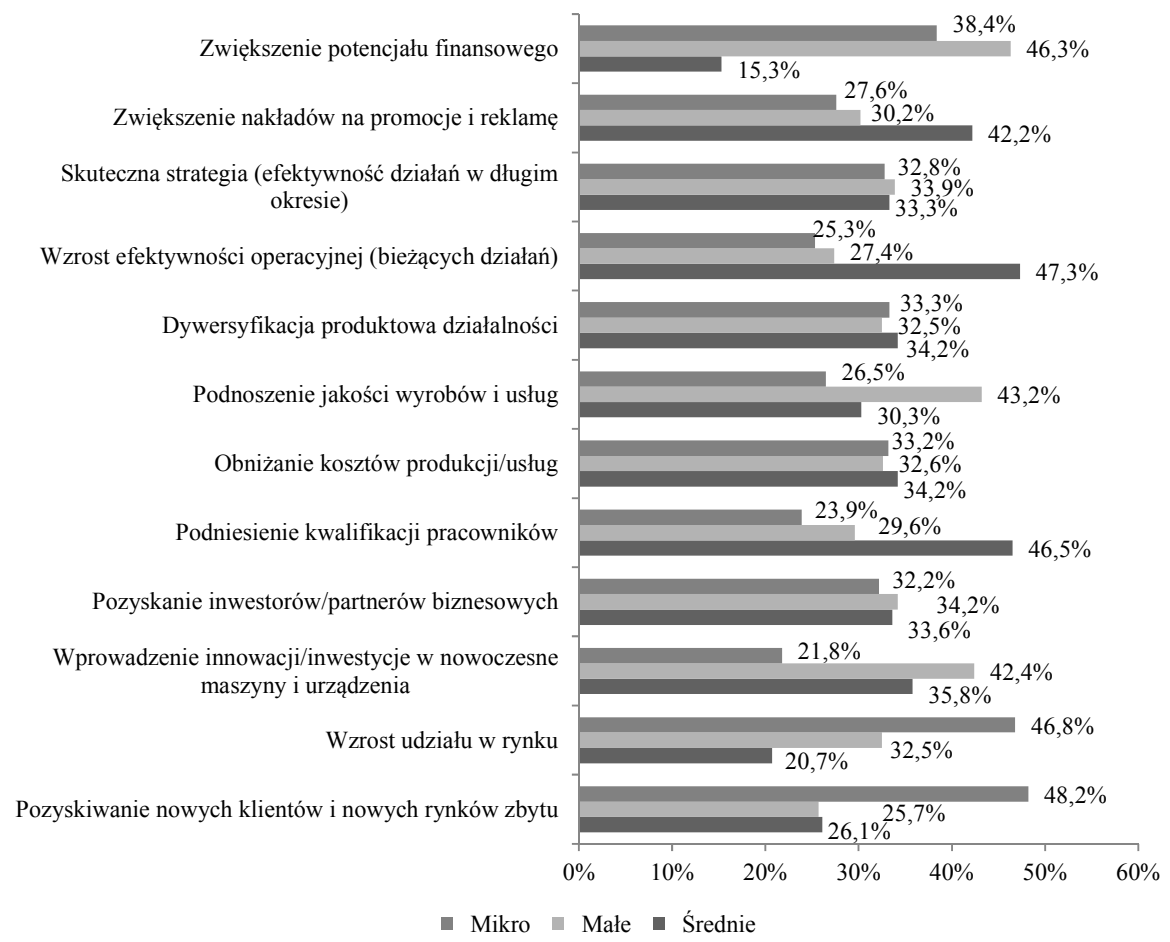

Uwaga: Respondenci wskazywali trzy odpowiedzi według ważności w skali 1-3, co oznaczało: 1 - ważna, 2 - bardzo ważna, 3 - najważniejsza.

Rysunek 42. Priorytety rozwojowe badanych przedsiębiorstw w obszarach zmarginalizowanych według wielkości firmy

Źródło: opracowanie własne 
W małych przedsiębiorstwach jako najważniejsze priorytety rozwojowe respondenci wskazywali zwiększenie potencjału finansowego (46,3\% wskazań), podnoszenie jakości wyrobów i usług (43,2\% wskazań) oraz wprowadzanie innowacji/inwestycje w nowoczesne maszyny i urządzenia (42,4\% wskazań). Taki rozkład wskazań może świadczyć o konieczności pozyskania kapitału w celu zwiększenia jakości produktów i usług oraz podniesienia poziomu innowacyjności we wszystkich obszarach przedsiębiorstwa.

Natomiast $w$ średnich przedsiębiorstwach respondenci wiązali rozwój przedsiębiorstwa ze wzrostem efektywności operacyjnej (47,3\% wskazań) podniesieniem kwalifikacji pracowników (46,5\% wskazań), jak również zwiększeniem nakładów na promocje i reklamę (42,2\% wskazań). Wyniki te mogą świadczyć o problemach wynikających z niewystarczających kwalifikacji siły roboczej oraz mało skutecznych działań marketingowych.

Priorytety rozwojowe badanych przedsiębiorstw były zróżnicowane w zależności od lokalizacji w obszarach rozwiniętych i zmarginalizowanych, jak również w różnych kategoriach firm (mikro, małych i średnich). W obszarach rozwiniętych były związane głównie $\mathrm{z}$ poprawą innowacyjności i jakości $\mathrm{w}$ przedsiębiorstwie, natomiast $\mathrm{w}$ obszarach zmarginalizowanych poprawą sytuacji na rynku oraz potencjału finansowego. Przyczyn tego stanu rzeczy można upatrywać w specyficznych warunkach obszaru zmarginalizowanego, np. mniejszego rynku (rynek regionalny lub lokalny), mniejszej liczby klientów oraz rzadszej sieci instytucji otoczenia biznesu. Co, jak już wcześniej wspominano, może mieć dla firm różne oddziaływanie - zarówno pozytywne, jak i negatywne.

Kolejnym obszarem badawczym było określenie przewag konkurencyjnych w badanych przedsiębiorstwach. Przewaga konkurencyjna to wynik zastosowania przez przedsiębiorstwo unikatowego (specyficznego jedynie dla niego) zestawu instrumentów konkurowania, co daje możliwość osiągania większej wartości dodanej niż inne przedsiębiorstwa funkcjonujące na tym samym rynku (Plawgo 2004, Adamik red. 2011, s. 18). Za źródła przewagi konkurencyjnej małych i średnich przedsiębiorstw uznaje się: elastyczność w działaniu (Piasecki 2001, s. 37), funkcjonowanie w niszy rynkowej, jakość produktów i usług, stosowaną technologię, wyrobioną markę i reputację, kompetencje menedżerskie, powiązania z dostawcami i nabywcami (Strategor 1995, s. 197). Ważnym źródłem przewagi konkurencyjnej jest unikatowość, szczególnie w kontekście unikatowego połączenia zasobów i kompetencji przedsiębiorstwa (Karpacz 2011, s. 23) Wtedy powstaje kombinacja trudna do naśladowania lub substytucji, co umożliwia osiąganie w długim czasie wyników ekonomicznych lepszych od konkurentów (Rokita 2005, s. 142). Kompetencje małych i średnich przedsiębiorstw pozostają w ścisłym związku z zasobami, jakim dysponują, gdyż od poziomu kompetencji zależy racjonalność wykorzystania posiadanych zasobów 
i odwrotnie. Każde małe i średnie przedsiębiorstwo wymaga odpowiedniego zestawienia tych czynników $\mathrm{w}$ celu podejmowania i prowadzenia działań koniecznych dla zaistnienia i funkcjonowania w łańcuchu wartości (Nogalski, Karpacz, Wójcik-Karpacz 2004, s. 28).

Przedsiębiorstwa, które planowały rozwój w ciągu najbliższych trzech lat, określiły również swoje przewagi konkurencyjne. Sposób oceny znaczenia poszczególnych rodzajów potencjalnych przewag konkurencyjnych był analogiczny jak w przypadku priorytetów rozwojowych.

Najczęściej wskazywano jako przewagi konkurencyjne następujące zmienne: jakość oferowanych usług $(19,5 \%$ wskazań), strategię cenową $(18,2 \%$ wskazań), funkcjonowanie w niszy rynkowej (13,7\% wskazań) oraz pozycję na rynku (12,8\% wskazań), natomiast za niewielkie znaczenie dla badanych przedsiębiorstw jako przewagi konkurencyjne respondenci uznali: zarządzanie wiedzą i informacją (3,1\% wskazań), patenty/unikalność produktu/usługi $(5,2 \%$ wskazań), kwalifikacje pracowników (5,3\% wskazań). Analizując przewagi konkurencyjne $\mathrm{w}$ obszarach rozwiniętych i zmarginalizowanych, widoczne jest duże zróżnicowanie większości badanych zmiennych (strategia cenowa, jakość oferowanych produktów i usług, pozycja na rynku, innowacyjność produktów i usług, renoma marki, funkcjonowanie w niszy rynkowej, szybkość i terminowość realizacji zamówień). Potwierdził to również test U Manna-Whitney|a, którego wyniki oraz prawdopodobieństwo testowe $(p<0,05)$ świadczyły o istnieniu zróżnicowania odpowiedzi dotyczących przewag konkurencyjnych badanych firm w zależności od analizowanego obszaru.

W obszarach rozwiniętych jako przewagi konkurencyjne respondenci najczęściej wskazywali (por. rysunek 43): jakość oferowanych produktów i usług, pozycję na rynku, innowacyjność produktów i usług, strategię cenowa oraz renomę marki, natomiast w obszarach zmarginalizowanych: strategię cenową, szybkość i terminowość realizacji zamówień, funkcjonowanie w niszy rynkowej oraz jakość oferowanych produktów/usług. Taki rozkład wypowiedzi respondentów pozwala przypuszczać, że na wykorzystywane przewagi konkurencyjne przez małe i średnie przedsiębiorstwa może mieć wpływ rozwój społeczno-gospodarczy obszaru, w którym zlokalizowane jest przedsiębiorstwo.

W obszarach rozwiniętych widoczne jest zróżnicowanie wskazywanych przewag konkurencyjnych przez badanie przedsiębiorstwa w zależności od jego wielkości, potwierdził to również test Kruskala-Wallisa. Jego wyniki i prawdopodobieństwo testowe $(p<0,05)$ pokazały zróżnicowanie większości badanych zmiennych (por. tabela 17, tj. strategia promocji i reklamy, funkcjonowanie w niszy rynkowej, rentowność i potencjał finansowy, renoma marki, szybkość i terminowość realizacji zamówień, pozycja na rynku, lokalizacja przedsiębiorstwa, innowacyjność produktów/usług, jakość oferowanych produktów/usług oraz strategia cenowa. 


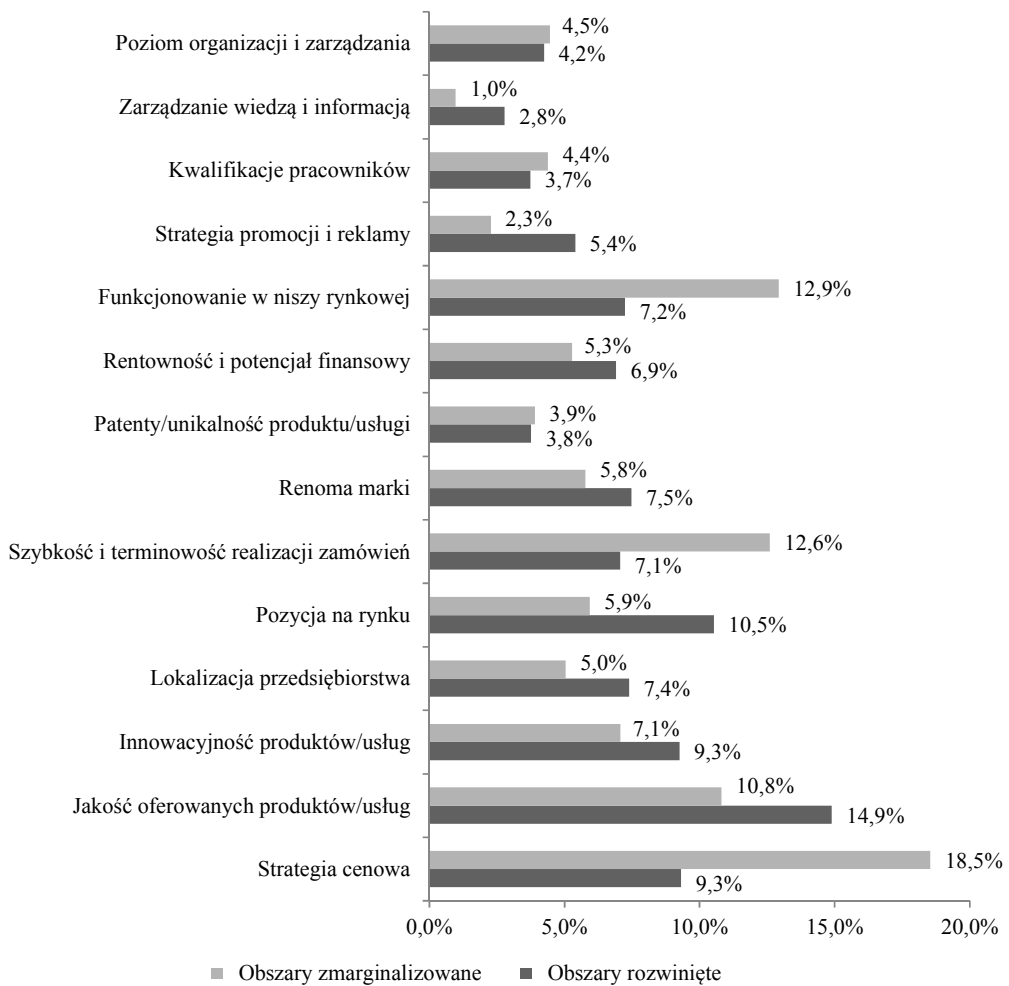

Uwaga: Respondenci wskazywali trzy odpowiedzi według ważności w skali 1-3, co oznaczało: 1 - ważna, 2 - bardzo ważna, 3 - najważniejsza.

Rysunek 43. Przewagi konkurencyjne badanych przedsiębiorstw - analiza komparatywna obszary rozwinięte i zmarginalizowane

Źródło: opracowanie własne

Tabela 17. Wartość statystyki $(H)$ według testu Kruskala-Wallisa oraz poziom prawdopodobieństwa testowego $(p)$ zmiennych określających przewagi konkurencyjne badanych przedsiębiorstw w obszarach rozwiniętych w kontekście wielkości przedsiębiorstwa

\begin{tabular}{|l|c|c|}
\hline \multicolumn{1}{|c|}{ Przewagi konkurencyjne } & $\begin{array}{c}\text { Wartość statystyki }(H) \\
\text { według testu } \\
\text { Kruskala-Wallisa }\end{array}$ & $\begin{array}{c}\text { Prawdopodo- } \\
\text { bieństwo } \\
\text { testowe }(p)\end{array}$ \\
\hline Poziom organizacji i zarządzania & 2 & 3 \\
\hline Zarządzanie wiedzą i informacją & 2,244 & 0,326 \\
\hline Kwalifikacje pracowników & 1,752 & 0,417 \\
\hline Strategia promocji i reklamy & 1,803 & 0,401 \\
\hline Funkcjonowanie w niszy rynkowej & 7,109 & 0,032 \\
\hline Rentowność i potencjał finansowy & 8,126 & 0,027 \\
\hline Patenty/unikalność produktu/usługi & 7,227 & 0,015 \\
\hline
\end{tabular}




\begin{tabular}{|l|c|c|}
\hline \multicolumn{1}{|c|}{1} & 2 & 3 \\
\hline Renoma marki & 8,236 & 0,016 \\
\hline Szybkość i terminowość realizacji zamówień & 6,238 & 0,044 \\
\hline Pozycja na rynku & 8,356 & 0,000 \\
\hline Lokalizacja przedsiębiorstwa & 7,341 & 0,012 \\
\hline Innowacyjność produktów/usług & 9,168 & 0,010 \\
\hline Jakość oferowanych produktów/usług & 9,782 & 0,000 \\
\hline Strategia cenowa & 11,925 & 0,000 \\
\hline
\end{tabular}

Źródło: opracowanie własne.

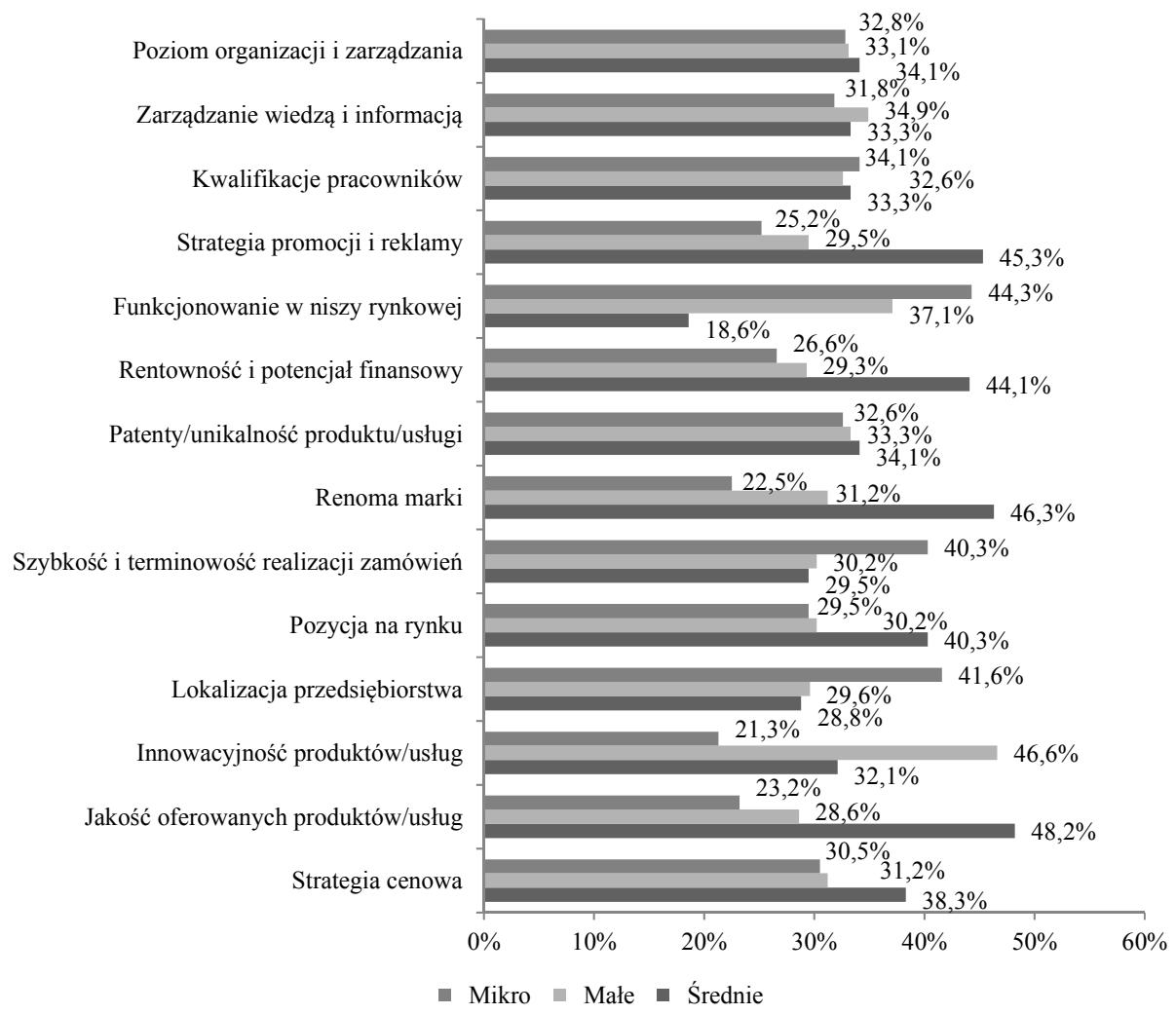

Uwaga: Respondenci wskazywali trzy odpowiedzi według ważności w skali 1-3, co oznaczało: 1 - ważna, 2 - bardzo ważna, 3 - najważniejsza.

Rysunek 44. Przewagi konkurencyjne badanych przedsiębiorstw w obszarach rozwiniętych według wielkości firmy

Źródło: opracowanie własne

W obszarach rozwiniętych jako najważniejsze przewagi konkurencyjne badanych mikroprzedsiębiorstw (por. rysunek 44) respondenci uznali funkcjonowanie w niszy rynkowej (44,3\% wskazań), lokalizację przedsiębiorstwa (41,6\% 
wskazań) oraz szybkość i terminowość realizacji zamówień (40,3\% wskazań). W przypadku małych przedsiębiorstw jako najważniejsze przewagi konkurencyjne respondenci wskazywali innowacyjność produktów i usług (46,6\% wskazań) oraz funkcjonowanie w niszy rynkowej (37,1\% wskazań). Natomiast w średnich przedsiębiorstwach badani przedsiębiorcy uznali za przewagi konkurencyjne jakość oferowanych produktów i usług (48,2\% wskazań), renomę marki (46,3\% wskazań) oraz strategię promocji i reklamy (45,3\% wskazań). Wskazane przewagi konkurencyjne są typowe dla mikroprzedsiębiorstw i małych przedsiębiorstw, które operują głównie w niszy rynkowej mając niewystarczający potencjał konkurencyjny, w średnich przedsiębiorstwach stosowane przewagi są związane z posiadanymi zasobami, które dają możliwość wyboru odpowiedniej strategii konkurowania dostosowanej do warunków otoczenia.

Natomiast w obszarach zmarginalizowanych również widoczne jest zróżnicowanie wskazywanych przewag konkurencyjnych przez badane przedsiębiorstwa $\mathrm{w}$ zależności od jego wielkości przedsiębiorstwa, potwierdził to również test Kruskala-Wallisa. Jego wyniki i prawdopodobieństwo testowe $(p<0,05)$ pokazały zróżnicowanie większości badanych zmiennych (por. tabela 18), tj. kwalifikacje pracowników, strategia promocji i reklamy, funkcjonowanie w niszy rynkowej, renoma marki, szybkość i terminowość realizacji zamówien, pozycja na rynku, lokalizacja przedsiębiorstwa, innowacyjność produktów/usług, jakość oferowanych produktów/usług oraz strategia cenowa.

Tabela 18. Wartość statystyki $(H)$ według testu Kruskala-Wallisa oraz poziom prawdopodobieństwa testowego $(p)$ zmiennych określających przewagi konkurencyjne badanych przedsiębiorstw w obszarach zmarginalizowanych w kontekście wielkości przedsiębiorstwa

\begin{tabular}{|l|c|c|}
\hline \multicolumn{1}{|c|}{ Przewagi konkurencyjne } & $\begin{array}{c}\text { Wartość statystyki }(H) \\
\text { według testu } \\
\text { Kruskala-Wallisa }\end{array}$ & $\begin{array}{c}\text { Prawdopodo- } \\
\text { bieństwo } \\
\text { testowe }(p)\end{array}$ \\
\hline Poziom organizacji i zarządzania & 3,792 & 0,150 \\
\hline Zarządzanie wiedzą i informacją & 4,470 & 0,107 \\
\hline Kwalifikacje pracowników & 18,000 & 0,000 \\
\hline Strategia promocji i reklamy & 2,064 & 0,019 \\
\hline Funkcjonowanie w niszy rynkowej & 9,462 & 0,009 \\
\hline Rentowność i potencjał finansowy & 4,231 & 0,121 \\
\hline Patenty/unikalność produktu/usługi & 0,134 & 0,935 \\
\hline Renoma marki & 6,639 & 0,000 \\
\hline Szybkość i terminowość realizacji zamówień & 8,226 & 0,016 \\
\hline Pozycja na rynku & 6934 & 0,031 \\
\hline Lokalizacja przedsiębiorstwa & 6,984 & 0,000 \\
\hline Innowacyjność produktów/usług & 7,143 & 0,028 \\
\hline Jakość oferowanych produktów/usług & 2,177 & 0,000 \\
\hline Strategia cenowa & 4,231 & 0,000 \\
\hline
\end{tabular}

Źródło: opracowanie własne. 
W obszarach zmarginalizowanych za najważniejsze przewagi konkurencyjne badanych mikroprzedsiębiorstw (por. rysunek 45) respondenci uznali funkcjonowanie w niszy rynkowej (53,2\% wskazań) oraz szybkość i terminowość realizacji zamówień (41,1\% wskazań). W przypadku małych przedsiębiorstw jako najważniejsze przewagi konkurencyjne badani wskazywali jakość oferowanych produktów i usług $(47,9 \%$ wskazań) pozycja na rynku $(46,1 \%$ wskazań) oraz strategia promocji i reklamy (38,2\% wskazań). W średnich przedsiębiorstwach badani przedsiębiorcy uznali za przewagi konkurencyjne innowacyjność produktów i usług (49,5\% wskazań), kwalifikacje pracowników (42,7\% wskazań) oraz renomę marki (38,9\% wskazań). W przypadku mikroprzedsiębiorstw wskazane przewagi konkurencyjne są typowe dla tej kategorii podmiotów, które operują głównie na rynku lokalnym, w niszy rynkowej, posiadając niewystarczający potencjał konkurencyjny, natomiast $\mathrm{w}$ małych i średnich przedsiębiorstwach stosowane przewagi są związane z potencjałem konkurencyjnym, zorientowane na poszukiwanie okazji rynkowych oraz dopasowanie do mocnych stron do pojawiających się w otoczeniu szans.

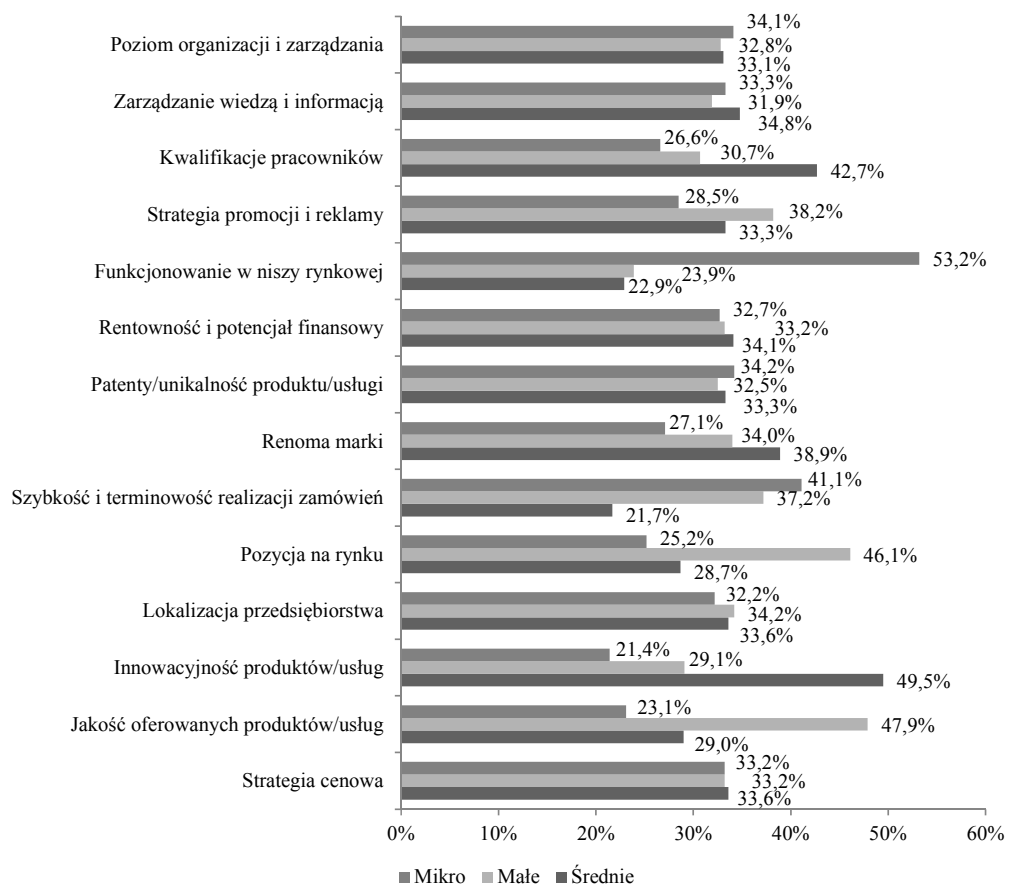

Uwaga: Respondenci wskazywali trzy odpowiedzi według ważności w skali 1-3, co oznaczało: 1 - ważna, 2 - bardzo ważna, 3 - najważniejsza.

Rysunek 45. Przewagi konkurencyjne badanych przedsiębiorstw w obszarach zmarginalizowanych według wielkości firmy

Źródło: opracowanie własne 
Przewagi konkurencyjne badanych przedsiębiorstw były zróżnicowane w zależności od lokalizacji w obszarach rozwiniętych i zmarginalizowanych, jak również $\mathrm{w}$ różnych kategoriach firm pod względem wielkości (mikro, małych i średnich). W obszarach rozwiniętych miały związek z priorytetami rozwojowymi i dotyczyły jakości, i innowacyjności, natomiast w obszarach zmarginalizowanych tak jak w przypadku analizowanych priorytetów ze specyfiką tych obszarów, tzn. funkcjonowaniem w niszy rynkowej jak również poprawą sytuacji na rynku.

\subsection{Uwarunkowania zewnętrzne - stymulatory i bariery}

Analiza uwarunkowań zewnętrznych zostanie przeprowadzona zgodnie $\mathrm{z}$ modelem badawczym zaproponowanym $\mathrm{w}$ podrozdziale 3.4 , w podziale na: makrootoczenie, mezootoczenie i mikrootoczenie. Należy jednak zaznaczyć, że utworzona lista czynników nie jest w pełni kompletna i mogłaby uwzględniać znacznie szerszy zakres badanych zmiennych, aczkolwiek wydaje się wystarczająca dla zbadania charakteru i wpływu uwarunkowań zewnętrznych na rozwój małych i średnich przedsiębiorstw w Polsce funkcjonujących w obszarach rozwiniętych i zmarginalizowanych.

Korzystając z listy zaproponowanych czynników (por. rysunki 29, 30 i 31) respondenci oceniali stopień, $w$ jakim dany czynnik pochodzący $\mathrm{z}$ danego poziomu otoczenia (makro, mezo i mikro) wywiera pozytywny (stymulator) lub negatywny (bariera) wpływ na rozwój ich przedsiębiorstwa. Oceny dokonano w skali trzystopniowej, przy czym: 1 - negatywny wpływ, 2 - brak wpływu, 3 - pozytywny wpływ.

Pierwszą grupą analizowanych czynników zewnętrznych były uwarunkowania makroekonomiczne, których większość uznawana była przez badanych przedsiębiorców za bariery rozwoju. Zdaniem największej liczy respondentów czynnikami hamującymi rozwój są: wysokie koszty pozyskania kapitału zewnętrznego (77,7\% wskazań), system prawny i polityka fiskalna $(61,8 \%$ wskazań), silna konkurencja krajowa i zagraniczna (59,1\% wskazań), sytuacja makroekonomiczna kraju (50\% wskazań), biurokracja (45,6\% wskazań) oraz szara strefa (44,7\% wskazań). Natomiast jako stymulatory respondenci uznali: pomoc publiczną (dotacje unijne) (53,3\% wskazań), politykę wsparcia małych i średnich przedsiębiorstw (47,8\% wskazań) oraz postęp technologiczny $(42,9 \%$ wskazań). W opinii badanych przedsiębiorców poziom innowacyjności gospodarki (46,6\% wskazań) oraz polityka patentowa i ochrona własności intelektualnej $(41,8 \%$ wskazań) nie miały znaczącego wpływu na rozwój analizowanych przedsiębiorstw. Oceniane czynniki często były dla jednych przedsiębiorców barierami dla innych stymulatorami lub nie miały wpływu na rozwój przedsiębiorstwa, co świadczy o indywidualnym charakterze potrzeb poszczególnych przedsiębiorstw. 
Analizując uwarunkowania makroekonomiczne w obszarach rozwiniętych i zmarginalizowanych, widoczne jest niewielkie zróżnicowanie większości badanych zmiennych (por. rysunek 46 i 47), polegające głównie na innej kolejności ustawienia $\mathrm{w}$ rankingu udzielanych przez respondentów odpowiedzi. Brak istotnego zróżnicowania ocen czynników makroekonomicznych w zależności od analizowanego obszaru potwierdził również test U Manna-Whitneya, prawdopodobieństwo testowe $(p>0,05)$.

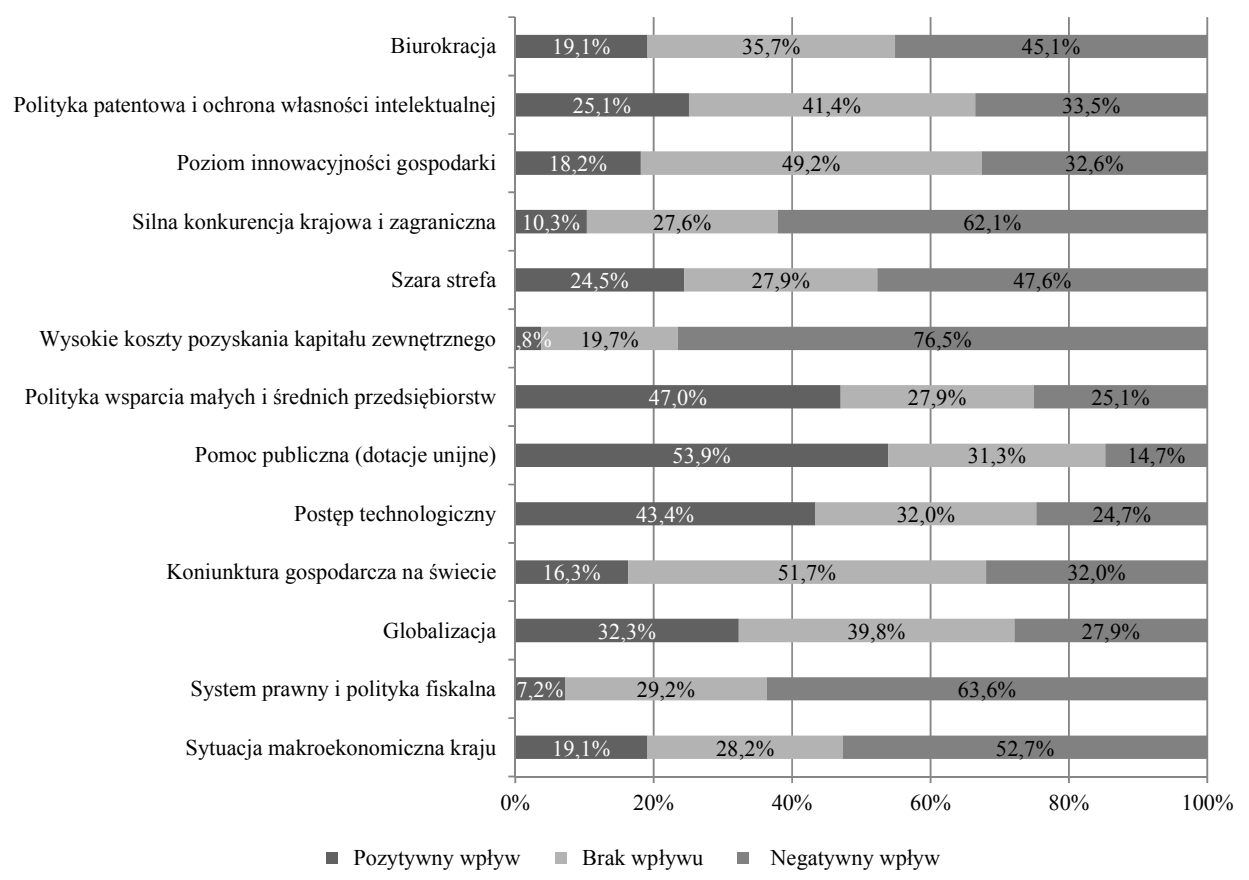

Rysunek 46. Makroekonomiczne uwarunkowania rozwoju małych i średnich przedsiębiorstw zlokalizowanych w obszarach rozwiniętych Źródło: opracowanie własne

W obszarach rozwiniętych i zmarginalizowanych (por. rysunek 46 i 47) za bariery rozwoju respondenci uznali: wysokie koszty pozyskania kapitału zewnętrznego (odpowiednio 76,5\% i 78,5\% wskazań), system prawny i politykę fiskalną (odpowiednio 63,6\% i 59,3 wskazań), silną konkurencję krajową i zagraniczną (odpowiednio 62,1\% i 55,4\% wskazań), sytuację makroekonomiczną kraju (odpowiednio 52,7\% i 48\% wskazań), szarą strefa (odpowiednio $47,6 \%$ i 42,8\% wskazań) oraz biurokrację (odpowiednio 45,1\% i 45,9\% wskazań). Jako stymulatory respondenci uznali: pomoc publiczną (dotacje unijne) (odpowiednio 53,9\% i 52,8\% wskazań), politykę wsparcia małych i średnich przedsiębiorstw (odpowiednio 47,0\% i 48,6\% wskazań) oraz postęp technologiczny (odpowiednio 43,4\% i 41,3\% wskazań). Natomiast poziom innowacyjno- 
ści gospodarki (odpowiednio 46,6\% i 43,2\% wskazań) oraz polityka patentowa i ochrona własności intelektualnej (odpowiednio 41,8\% i 42,3\% wskazań) dla badanych przedsiębiorstw nie miały znaczącego wpływu na ich rozwój.

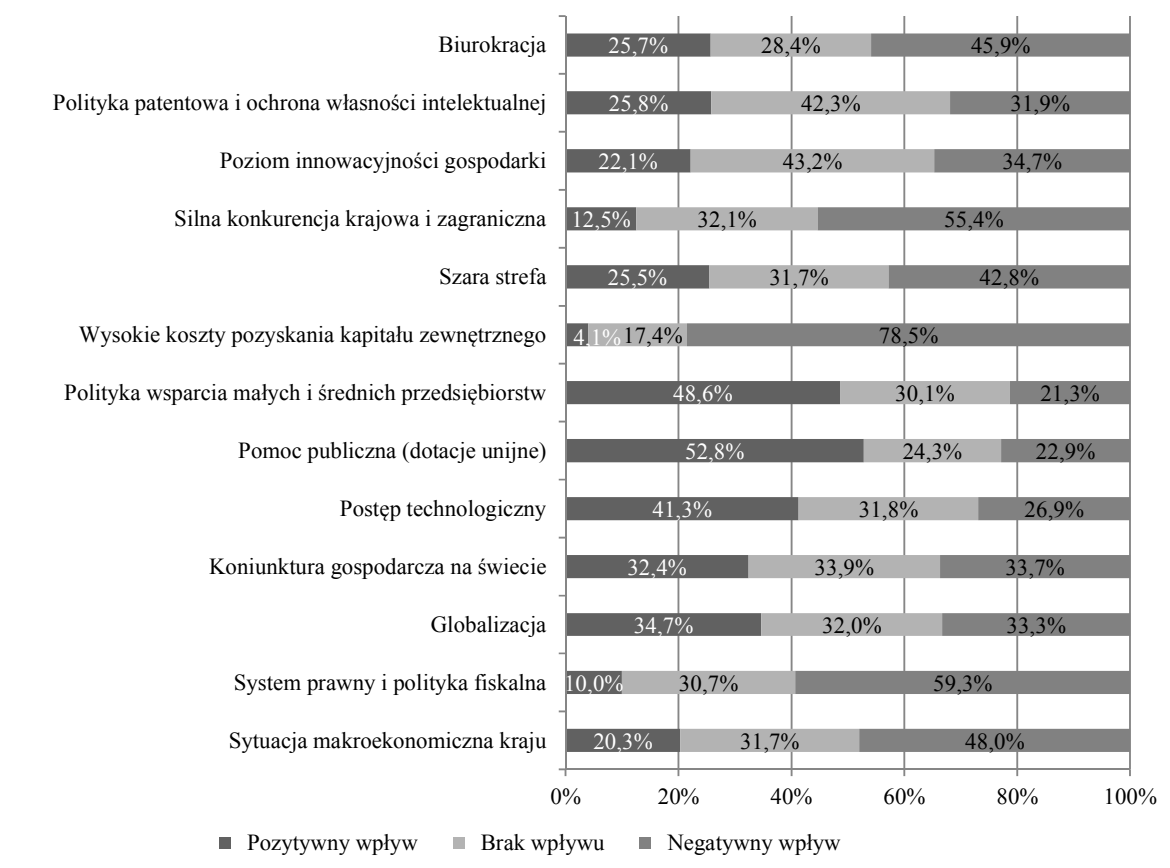

Rysunek 47. Makroekonomiczne uwarunkowania rozwoju małych i średnich przedsiębiorstw zlokalizowanych w obszarach zmarginalizowanych Źródło: opracowanie własne

Taki rozkład odpowiedzi sugeruje, że czynniki pochodzące z makrootoczenia nie są zróżnicowane wśród małych i średnich przedsiębiorstw w zależności od poziomu rozwoju społeczno-gospodarczego regionu, w którym są zlokalizowane, czyli nie uwzględniają specyfiki analizowanych obszarów, a w szczególności obszarów zmarginalizowanych. Zbadano również zróżnicowanie czynników makroekonomicznych ze względu na wielkość przedsiębiorstwa, ale otrzymane wyniki statystyki $H$ testu Kruskala-Wallisa i prawdopodobieństwa testowego $(p>0,05)$ nie potwierdziły tego zróżnicowania, co wskazuje na podobny zestaw barier i stymulatorów pochodzących z otoczenia ogólnego dla każdej kategorii analizowanych podmiotów. Uzyskane wyniki są również zgodne z rezultatami badań przytaczanych $\mathrm{w}$ bogatej literaturze przedmiotu ${ }^{19}$,

\footnotetext{
${ }^{19}$ Por. np. Matejun 2007; Daszkiewicz 2004a, b, 2000.
} 
jak również systematycznie prowadzonymi przez PKPP Lewiatan ${ }^{20}$. Pozwala to na negatywną weryfikację hipotez: $\mathrm{H}_{2}$, mówiącej, że oddziaływanie uwarunkowań rozwoju małych i średnich przedsiębiorstw pochodzących z makrootoczenia jest zróżnicowane w zależności od lokalizacji firmy w obszarach rozwiniętych i zmarginalizowanych, oraz $\mathrm{H}_{7}$ - oddziaływanie uwarunkowań rozwoju małych i średnich przedsiębiorstw funkcjonujących w obszarach zmarginalizowanych jest zróżnicowane w zależności od wielkości przedsiębiorstwa.

Kolejnym obszarem badawczym były uwarunkowania mezoekonomiczne, których analiza ujawniła kolejne stymulatory i bariery rozwoju badanych małych $\mathrm{i}$ średnich przedsiębiorstw pochodzące $\mathrm{z}$ otoczenia regionalnego. Jednak większość badanych czynników w ocenie respondentów miała charakter barier, do których zaliczono: dostęp do kapitału i wsparcia finansowego (55,3\% wskazań), stan infrastruktury transportowej i telekomunikacyjnej $(48,0 \%$ wskazań), polityka władz samorządowych- tworzenie klimatu dla rozwoju przedsiębiorstw (44,9\% wskazań) oraz jakość i dostępność usług oferowanych przez instytucje otoczenia biznesu (41,2\% wskazań). Taki rozkład wypowiedzi wskazuje na konieczność ukierunkowania polityki wsparcia małych i średnich przedsiębiorstw na poprawę finansowania tego sektora, rozwój MSP bowiem, jak wskazują liczne badania $^{21}$, jest uzależniony od możliwości pozyskania i korzystania z zewnętrznych źródeł finansowania, jak również sprawności i skuteczności funkcjonowania szeroko rozumianego otoczenia biznesu ${ }^{22}$. Znaczącą rolę powinny odegrać również władze regionalne, stwarzając korzystne warunki dla funkcjonowania biznesu w regionie.

Do grupy uwarunkowań mogących mieć pozytywny wpływ na rozwój badanych przedsiębiorstw respondenci zaliczyli: inwestycje w regionie i dostęp do pomocy publicznej (po 44,9\% wskazań), współpracę przedsiębiorstw (40,8\% wskazań) oraz transfer wiedzy i technologii w regionie (40,2\% wskazań). W opinii badanych przedsiębiorców zasoby naturalne (45,3\% wskazań) oraz położenie geograficzne regionu ( $41,8 \%$ wskazań) nie miały znaczącego wpływu na rozwój analizowanych podmiotów gospodarczych.

Analiza uwarunkowań mezoekonomicznych w obszarach rozwiniętych i zmarginalizowanych, pozwoliła na uwypuklenie zróżnicowania większości badanych zmiennych (por. rysunek 48 i 49).

\footnotetext{
${ }^{20}$ Por. raporty: Czarna lista ... 2012; Czarna lista ... 2011; Czarna lista ... 2010.

${ }^{21}$ Por. badania: Skowronek-Mielczarek 2011a, s. 149-179; Kamińska 2011.

${ }^{22}$ Por. Filipiak, Ruszała 2009, s. 62; Kamińska 2011; Stawasz, Sikora-Fernandez 2011, s. $145-146$.
} 


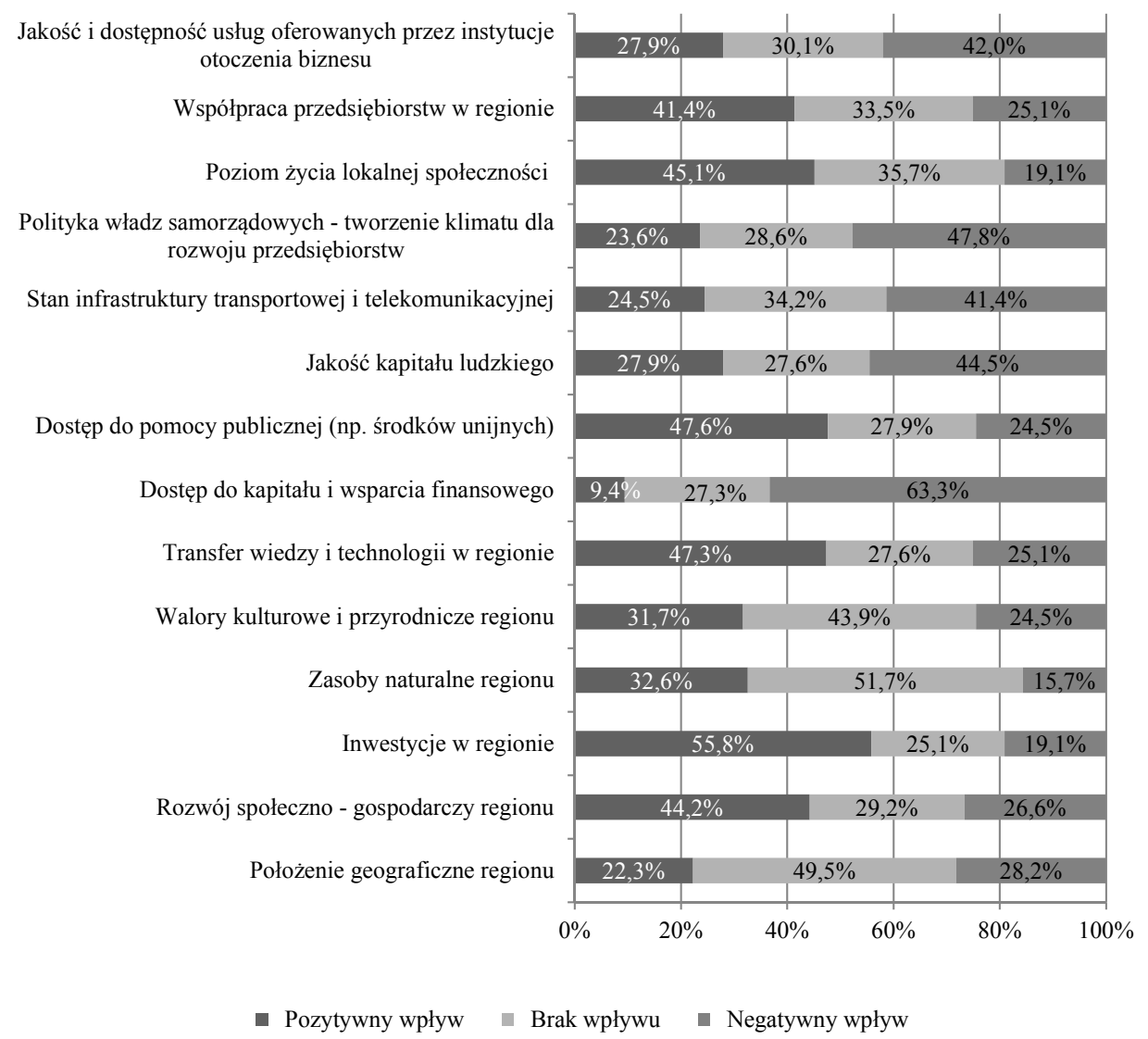

Rysunek 48. Mezoekonomiczne uwarunkowania rozwoju małych i średnich przedsiębiorstw zlokalizowanych w obszarach rozwiniętych

Źródło: opracowanie własne

Zróżnicowanie badanych czynników mezoekonomicznych w obszarach rozwiniętych i zmarginalizowanych zbadano testem U Manna-Whitneya, którego wyniki i prawdopodobieństwo testowe $(p<0,05)$ potwierdziło zróżnicowanie następujących czynników: dostęp do kapitału i wsparcia finansowego, stan infrastruktury transportowej, jakość kapitału ludzkiego, poziom życia lokalnej społeczności, rozwój społeczno-gospodarczy regionu, zasoby naturalne regionu, walory kulturowe i przyrodnicze regionu, położenie geograficzne regionu, transfer wiedzy i technologii w regionie.

W obszarach rozwiniętych jako bariery respondenci najczęściej wskazywali (por. rysunek 47): dostęp do kapitału i wsparcia finansowego, politykę władz samorządowych - tworzenie klimatu dla rozwoju przedsiębiorstw, jakość kapitału ludzkiego oraz jakość i dostępność usług oferowanych przez instytucje 
otoczenia biznesu, natomiast jako stymulatory rozwoju inwestycje w regionie, dostęp do pomocy publicznej, transfer wiedzy i technologii w regionie oraz rozwój społeczno-gospodarczy regionu.

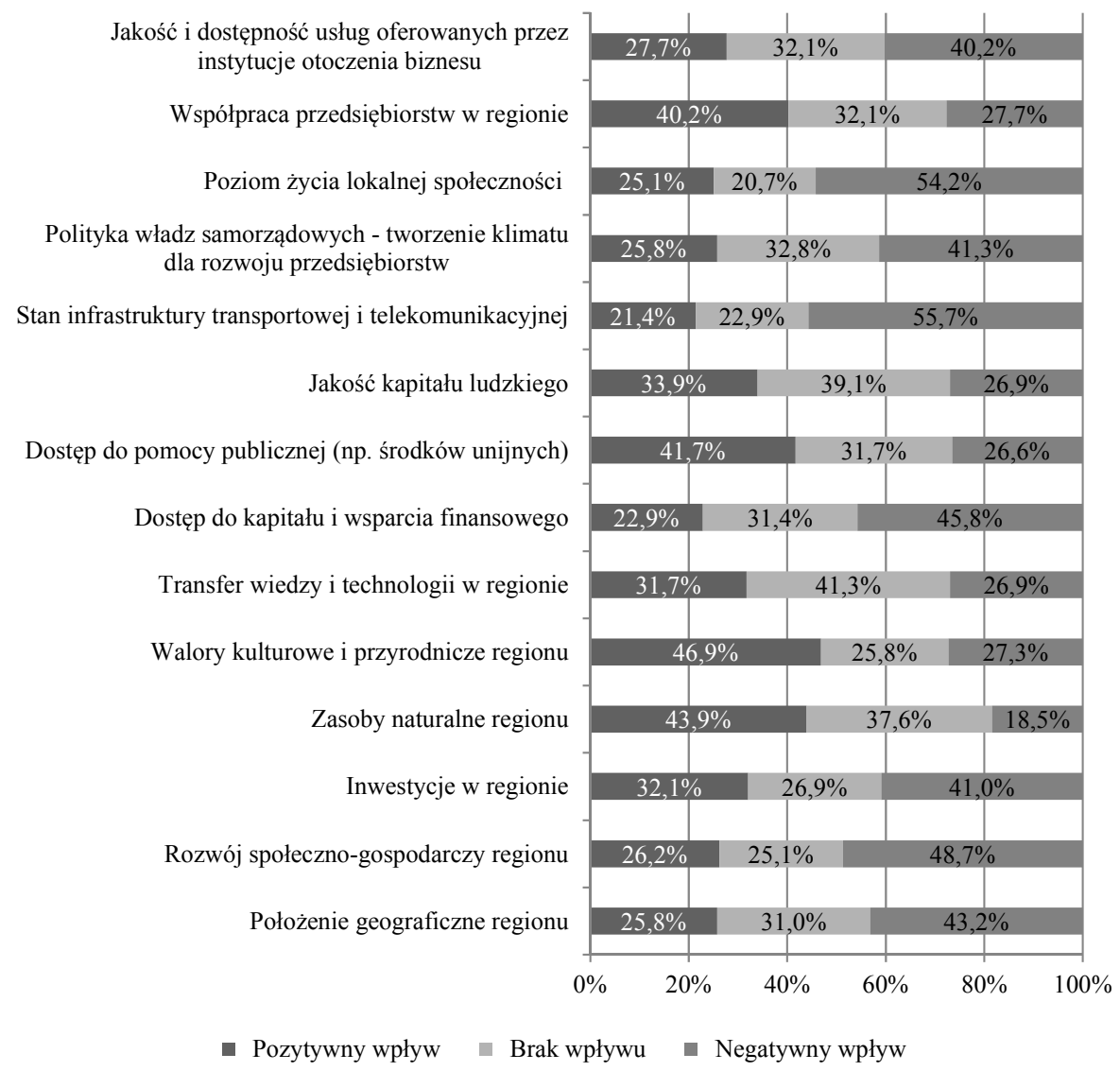

Rysunek 49. Mezoekonomiczne uwarunkowania rozwoju małych i średnich przedsiębiorstw zlokalizowanych w obszarach zmarginalizowanych Źródło: opracowanie własne

W przypadku obszarów zmarginalizowancych według wskazań respondentów przeważnie rozwój badanych firm był hamowany przez: stan infrastruktury transportowej i telekomunikacyjnej, poziom życia lokalnej społeczności, rozwój społeczno-gospodarczy regionu, dostęp do kapitału i wsparcia finansowego oraz położenie geograficzne regionu, z kolei jako czynniki rozwoju wymieniano: walory kulturowe i przyrodnicze regionu, zasoby naturalne regionu, dostęp do pomocy publicznej oraz współpracę przedsiębiorstw w regionie. 
Takie zróżnicowanie rozkładu wypowiedzi sugeruje, że rozwój małych i średnich przedsiębiorstw mogą ograniczać i stymulować zupełnie inne czynniki w zależności od poziomu rozwoju społeczno-gospodarczego regionu, w którym dany podmiot jest zlokalizowany. W przypadku obszarów rozwiniętych bariery i czynniki rozwoju są zgodne $\mathrm{z}$ dotychczasowymi wynikami badań opisanymi, jak już wcześnie wspomniano, w literaturze przedmiotu, natomiast $w$ przypadku obszarów zmarginalizowanych wynikają ze specyficznych cech tych obszarów.

Analiza uwarunkowań mezoekonomicznych w podziale na wielkość firmy będzie dotyczyła tylko obszarów zmarginalizowanych ${ }^{23}$. Rozkład wypowiedzi respondentów wskazuje na zróżnicowanie wskazywanych przez badanie przedsiębiorstwa uwarunkowań regionalnych w zależności od jego wielkości, potwierdził to również test Kruskala-Wallisa. Jego wyniki i prawdopodobieństwo testowe $(p<0,05)$ pokazały zróżnicowanie większości badanych zmiennych (por. tabela 19), tj. położenie geograficzne regionu, rozwój społecznogospodarczy regionu, zasoby naturalne regionu, transfer wiedzy i technologii w regionie, dostęp do kapitału i wsparcia finansowego, dostęp do pomocy publicznej (np. środków unijnych), jakość kapitału ludzkiego, stan infrastruktury transportowej i telekomunikacyjnej, polityka władz samorządowych - tworzenie klimatu dla rozwoju przedsiębiorstw, poziom życia lokalnej społeczności, współpraca przedsiębiorstw w regionie, jakość i dostępność usług oferowanych przez instytucje otoczenia biznesu.

Tabela 19. Wartość statystyki $(H)$ według testu Kruskala-Wallisa oraz poziom prawdopodobieństwa testowego $(p)$ zmiennych określających uwarunkowania mezoekonomiczne badanych przedsiębiorstw w obszarach zmarginalizowanych w kontekście wielkości przedsiębiorstwa

\begin{tabular}{|l|c|c|}
\hline \multicolumn{1}{|c|}{ Uwarunkowania mezoekonomiczne } & $\begin{array}{c}\text { Wartość statystyki }(H) \\
\text { według testu } \\
\text { Kruskala-Wallisa }\end{array}$ & $\begin{array}{c}\text { Prawdopodo- } \\
\text { bieństwo } \\
\text { testowe }(p)\end{array}$ \\
\hline Położenie geograficzne regionu & 2 & 3 \\
\hline Rozwój społeczno-gospodarczy regionu & 16,380 & 0,000 \\
\hline Inwestycje w regionie & 9,254 & 0,016 \\
\hline Zasoby naturalne regionu & 1,578 & 0,697 \\
\hline Walory kulturowe i przyrodnicze regionu & 7,342 & 0,011 \\
\hline Transfer wiedzy i technologii w regionie & 2,793 & 0,580 \\
\hline
\end{tabular}

${ }^{23}$ Do dalszej analizy szczegółowej w układzie mikro-, małe i średnie przedsiębiorstwa przyjęto tylko firmy zlokalizowane w obszarach zmarginalizowane ze względu wiodącą problematykę pracy odnosząca się do tych obszarów. 


\begin{tabular}{|l|c|c|}
\hline \multicolumn{1}{|c|}{1} & 2 & 3 \\
\hline Dostęp do kapitału i wsparcia finansowego & 13,752 & 0,000 \\
\hline $\begin{array}{l}\text { Dostęp do pomocy publicznej (np. środków } \\
\text { unijnych) }\end{array}$ & 6,392 & 0,031 \\
\hline Jakość kapitału ludzkiego & 4,841 & 0,041 \\
\hline $\begin{array}{l}\text { Stan infrastruktury transportowej i telekomunika- } \\
\text { cyjnej }\end{array}$ & 11,345 & 0,000 \\
\hline $\begin{array}{l}\text { Polityka władz samorządowych - tworzenie klima- } \\
\text { tu dla rozwoju przedsiębiorstw }\end{array}$ & 15,425 & 0,000 \\
\hline Poziom życia lokalnej społeczności & 9,870 & 0,021 \\
\hline Współpraca przedsiębiorstw w regionie & 10,321 & 0,000 \\
\hline $\begin{array}{l}\text { Jakość i dostępność usług oferowanych przez } \\
\text { instytucje otoczenia biznesu }\end{array}$ & 14,382 & 0,000 \\
\hline
\end{tabular}

Źródło: opracowanie własne.

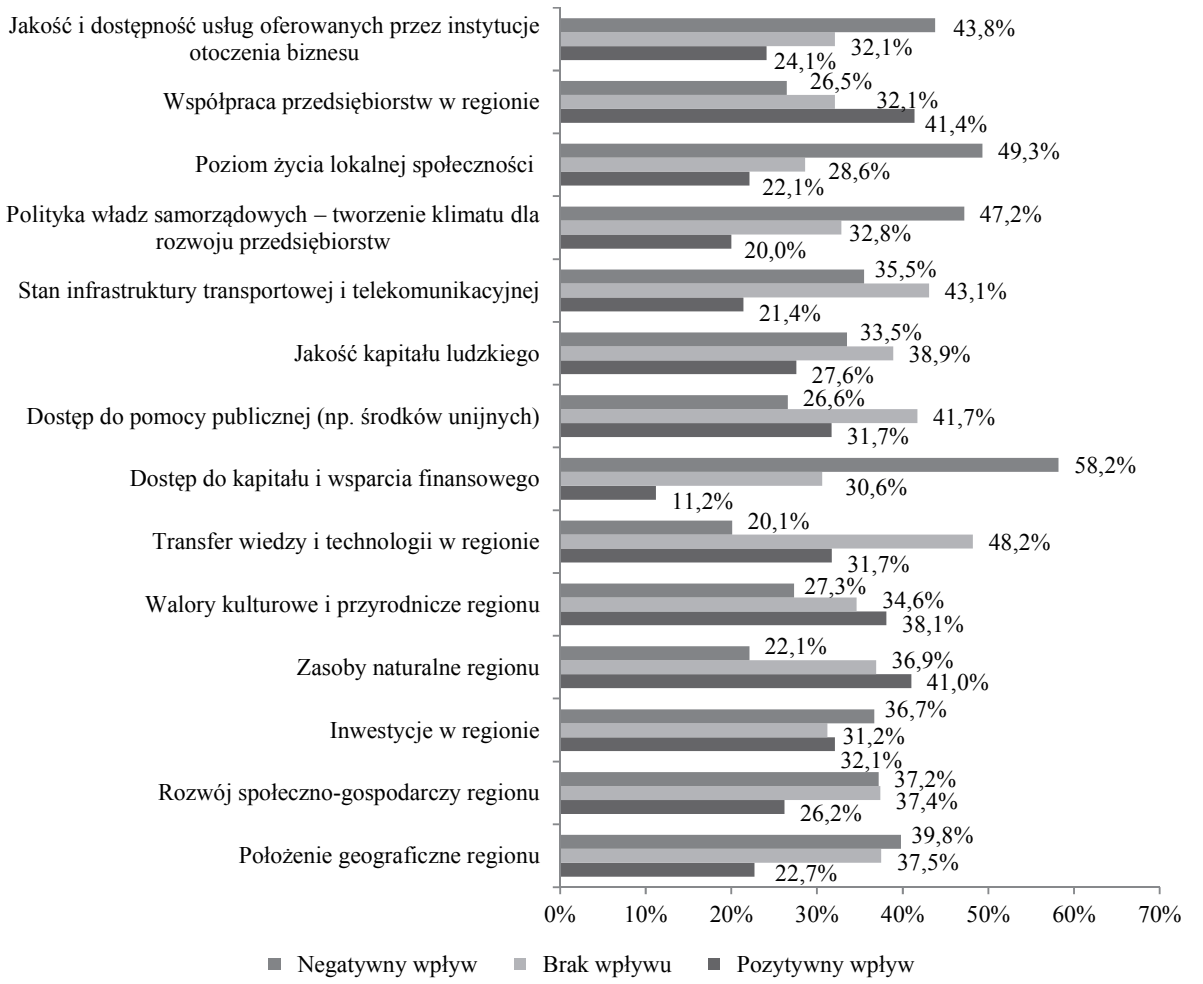

Rysunek 50. Mezoekonomiczne uwarunkowania rozwoju mikroprzedsiębiorstw zlokalizowanych w obszarach zmarginalizowanych

Źródło: opracowanie własne 
W przypadku mikroprzedsiębiorstw (por. rysunek 50) za stymulatory rozwoju respondenci uznali współpracę przedsiębiorstw w regionie $(41,4 \%$ wskazań), zasoby naturalne regionu (41,0\% wskazań), natomiast za bariery niewystarczający dostęp do kapitału i wsparcia finansowego (58,2\% wskazań), poziom życia lokalnej społeczności (49,3\% wskazań) politykę władz samorządowych w zakresie tworzenie klimatu dla rozwoju przedsiębiorstw (47,2\% wskazań). Brak wpływu na prowadzoną działalność miały takie uwarunkowania, jak transfer wiedzy i technologii $\mathrm{w}$ regionie oraz dostęp do pomocy publicznej (w tym środków unijnych).

Zaprezentowane wynik badań potwierdziły przypuszczenie, że na funkcjonowanie mikroprzedsiębiorstw w obszarach zmarginalizowanych istotny wpływ mają uwarunkowania regionalne, szczególnie te, które wynikają ze specyfiki tych obszarów.

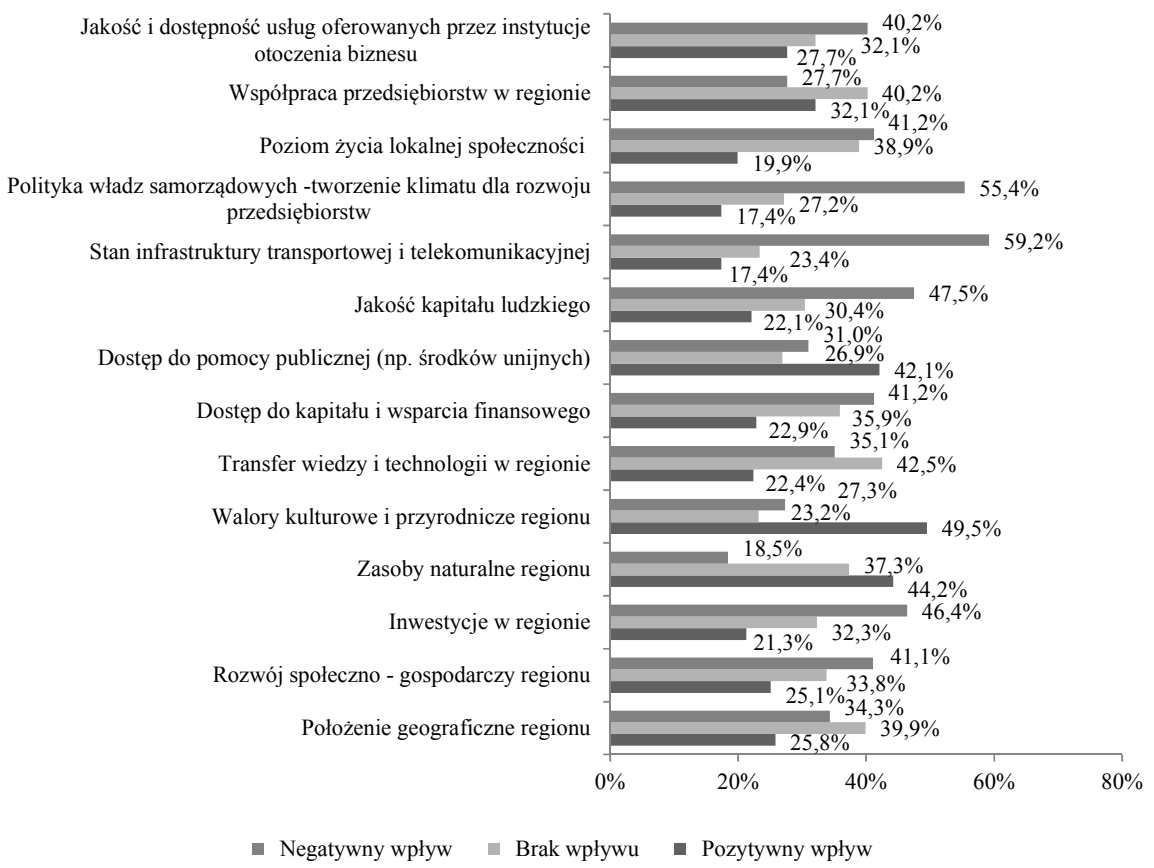

Rysunek 51. Mezoekonomiczne uwarunkowania rozwoju małych przedsiębiorstw zlokalizowanych w obszarach zmarginalizowanych

Źródło: opracowanie własne

W małych przedsiębiorstwach (por. rysunek 51) za stymulatory rozwoju respondenci uznali walory kulturowe i przyrodnicze regionu (44,8\% wskazań) oraz zasoby naturalne regionu (44,2\% wskazań), natomiast za bariery stan infrastruktury transportowej i telekomunikacyjnej (59,2\% wskazań) oraz 
politykę władz samorządowych w zakresie tworzenie klimatu dla rozwoju przedsiębiorstw (55,4\% wskazań). Brak wpływu na prowadzoną działalność miały takie uwarunkowania, jak: transfer wiedzy i technologii w regionie oraz współpraca przedsiębiorstw w regionie.

Zaprezentowane wynik badań potwierdziły przypuszczenie, że na funkcjonowanie małych przedsiębiorstw $\mathrm{w}$ obszarach zmarginalizowanych istotny wpływ mają uwarunkowania regionalne, głównie odnoszące się do charakterystyk tych obszarów.

W przypadku średnich przedsiębiorstw za stymulatory rozwoju respondenci uznali (por. rysunek 52) współpracę przedsiębiorstw w regionie $(48,9 \%$ wskazań) oraz walory kulturowe i przyrodnicze regionu (49,5\% wskazań), natomiast za bariery: stan infrastruktury transportowej i telekomunikacyjnej $(51,2 \%$ wskazań) oraz transfer wiedzy i technologii w regionie (47,3\% wskazań). Brak wpływu na prowadzoną działalność miały takie poziom życia lokalnej społeczności (54,2\% wskazań) oraz położenie geograficzne regionu (47,9\% wskazań).

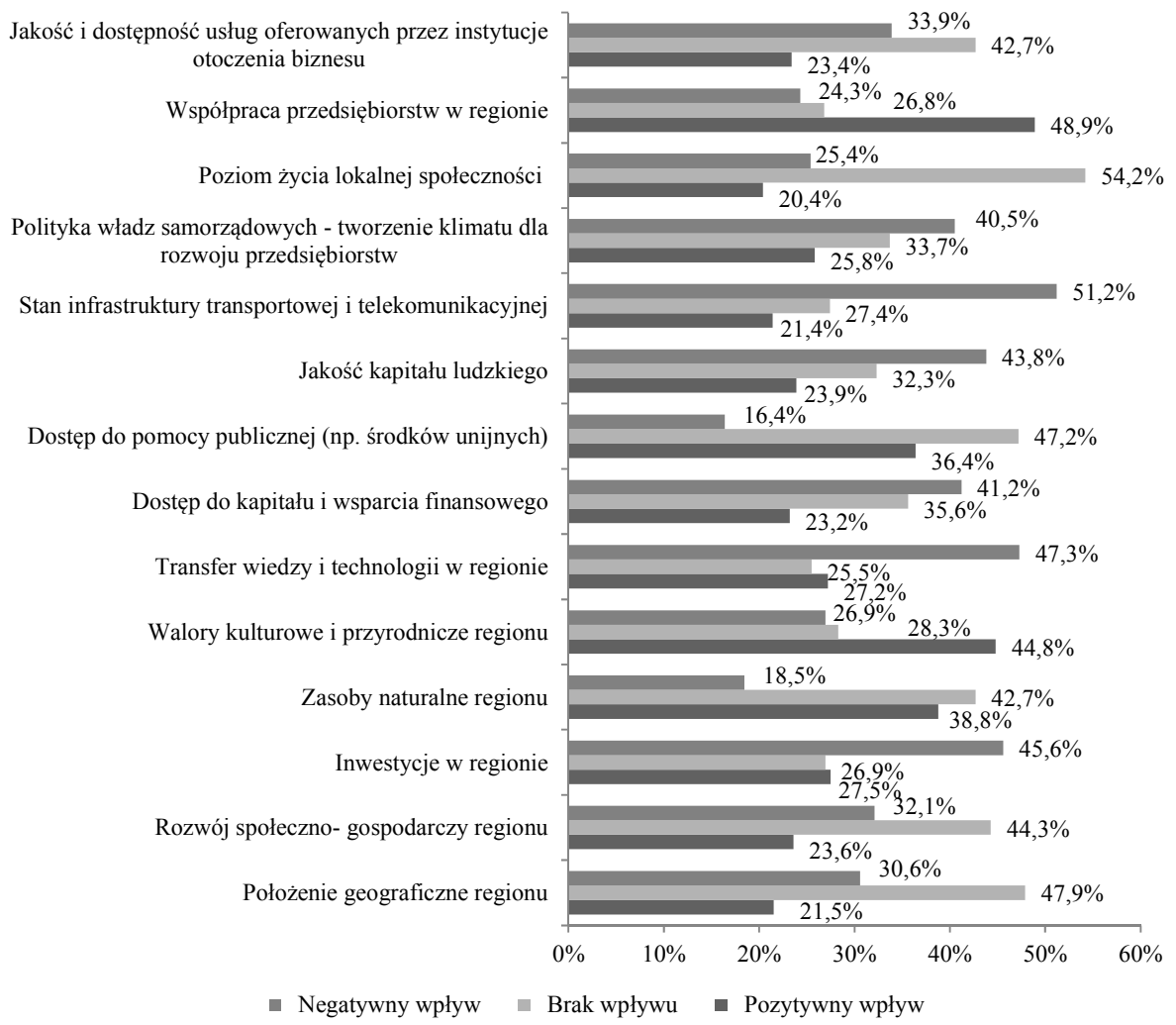

Rysunek 52. Mezoekonomiczne uwarunkowania rozwoju średnich przedsiębiorstw zlokalizowanych w obszarach zmarginalizowanych

Źródło: opracowanie własne 
Zaprezentowane wyniki badań potwierdziły przypuszczenie, że średnie przedsiębiorstwa operują częściej na rynkach krajowym i regionalnym, dlatego też uwarunkowania związane ściśle ze specyfiką regionów zmarginalizowanych nie mają decydującego wpływu na ich funkcjonowanie, jedynym problemem okazał się zły stan infrastruktury, który świadczy o braku dostępności do oferowanych przez te przedsiębiorstwa produktów czy usług.

Wpływ uwarunkowań rozwoju małych i średnich przedsiębiorstw związanych z mezootoczniem jest zróżnicowany ze względu na lokalizację firmy obszar rozwinięty i obszar zmarginalizowany, a w przypadku obszarów zmarginalizowanych również $w$ poszczególnych kategoriach firm (mikro, małych i średnich). Pozwala to pozytywnie zweryfikować hipotezy $\mathrm{H}_{3}$ : Oddziaływanie uwarunkowań rozwoju małych i średnich przedsiębiorstw pochodzących $\mathrm{z}$ otoczenia mezootoczenia jest zróżnicowane w zależności od lokalizacji firmy w obszarach rozwiniętych czy zmarginalizowanych oraz $\mathrm{H}_{7}$ : Oddziaływanie uwarunkowań rozwoju małych i średnich przedsiębiorstw funkcjonujących w obszarach zmarginalizowanych jest zróżnicowane w zależności od wielkości przedsiębiorstwa.

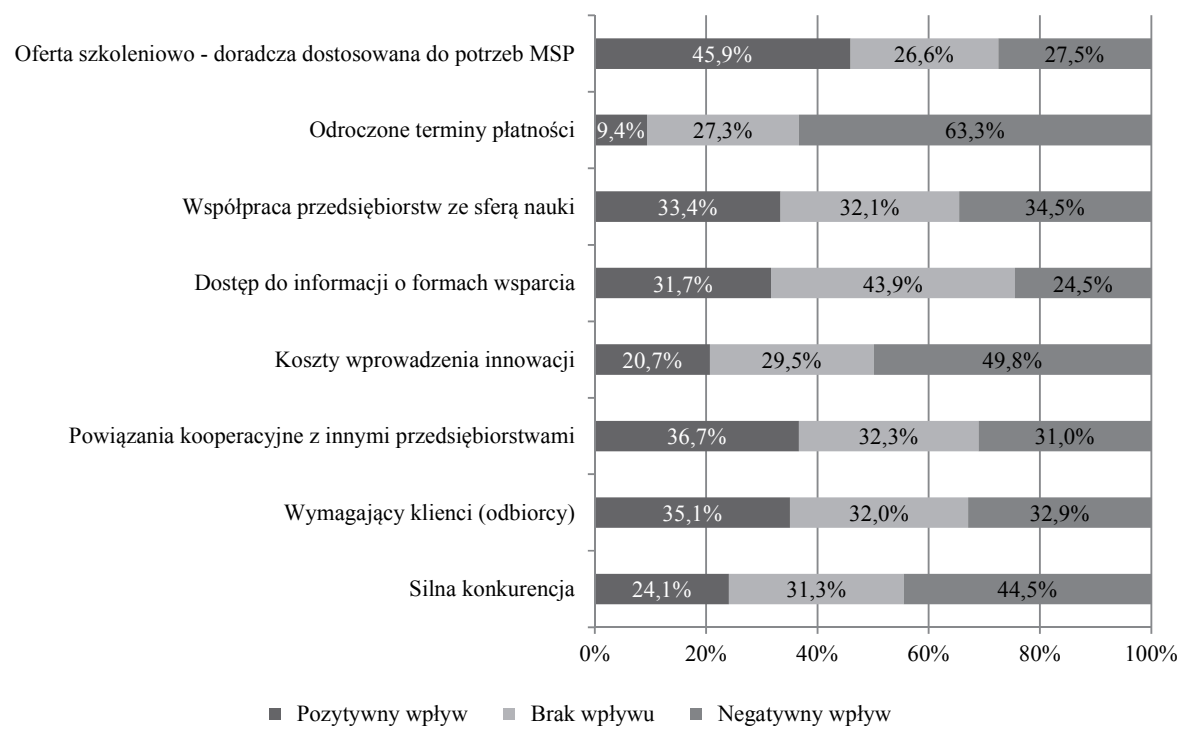

Rysunek 53. Mikroekonomiczne uwarunkowania rozwoju małych i średnich przedsiębiorstw zlokalizowanych w obszarach rozwiniętych

Źródło: pracowanie własne

Analiza uwarunkowań mikroekonomicznych w obszarach rozwiniętych i zmarginalizowanych, pozwoliła na uwypuklenie zróżnicowania większości badanych zmiennych (por. rysunek 53 i 54), potwierdził to również test 
U Manna-Whitneya, którego wyniki i prawdopodobieństwo testowe $(p<0,05)$ potwierdziło zróżnicowanie następujących czynników: silna konkurencja, powiązania kooperacyjne $\mathrm{z}$ innymi przedsiębiorstwami, dostęp do informacji o formach wsparcia, odroczone terminy płatności.

W obszarach rozwiniętych jako bariery respondenci najczęściej wskazywali (por. rysunek 53): odroczone terminy płatności, koszty wprowadzenia innowacji, silna konkurencja, natomiast jako stymulatory: oferta szkoleniowo-doradcza dostosowana do potrzeb MSP, powiązania kooperacyjne $\mathrm{z}$ innymi przedsiębiorstwami.

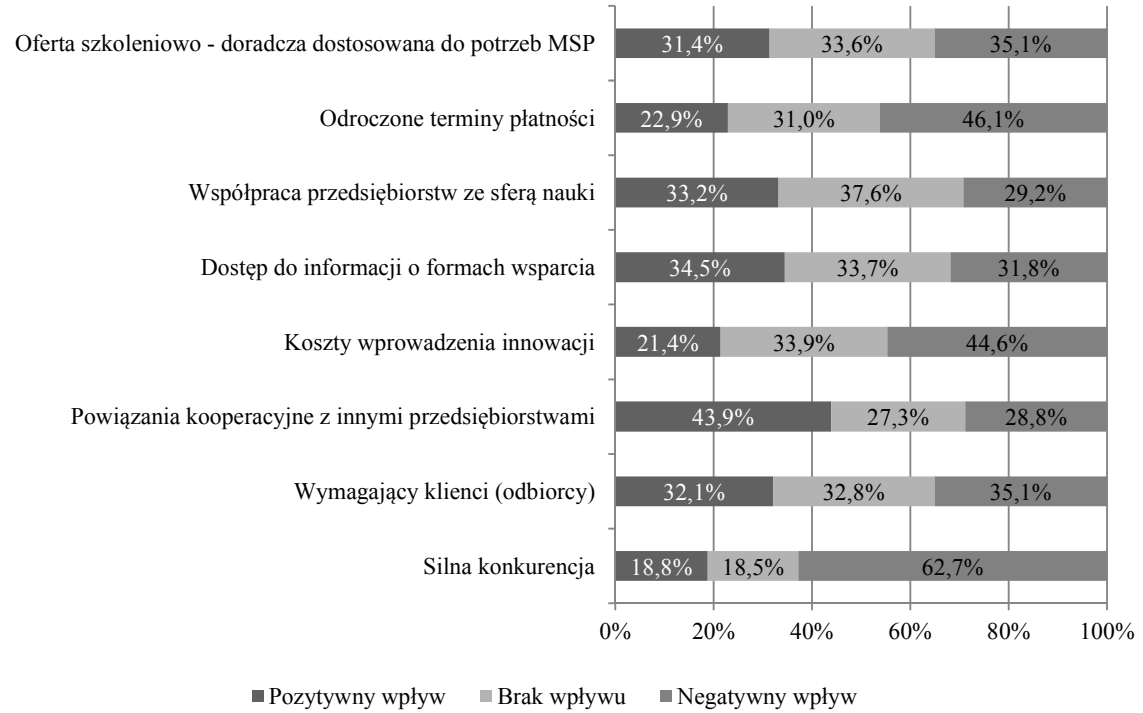

Rysunek 54. Mikroekonomiczne uwarunkowania rozwoju małych i średnich przedsiębiorstw zlokalizowanych w obszarach zmarginalizowanych Źródło: opracowanie własne

W przypadku obszarów zmarginalizowancych według wskazań respondentów przeważnie rozwój badanych firm był hamowany przez (por. rysunek 54): silną konkurencję, odroczone terminy płatności oraz koszty wprowadzenia innowacji, z kolei jako czynniki rozwoju wymieniano: powiązania kooperacyjne $z$ innymi przedsiębiorstwami oraz dostęp do informacji o formach wsparcia.

Takie zróżnicowanie rozkładu wypowiedzi sugeruje, że rozwój małych i średnich przedsiębiorstw mogą ograniczać i stymulować zupełnie inne czynniki w zależności od poziomu rozwoju społeczno-gospodarczego regionu, w którym dany podmiot jest zlokalizowany.

W dalszej części analiza będzie analogiczna jak w przypadku uwarunkowań mezoekonomicznych i będzie dotyczyła tylko obszarów zmarginalizowanych. 
Rozkład wypowiedzi respondentów wskazuje na zróżnicowanie wskazywanych przez badanie przedsiębiorstwa uwarunkowań regionalnych w zależności od jego wielkości, potwierdził to również test Kruskala-Wallisa. Jego wyniki i prawdopodobieństwo testowe $(p<0,05)$ pokazały zróżnicowanie większości badanych zmiennych (por. tabela 20): wymagający klienci (odbiorcy), powiązania kooperacyjne z innymi przedsiębiorstwami, koszty wprowadzenia innowacji, dostęp do informacji o formach wsparcia, współpracę przedsiębiorstw ze sferą nauki, odroczone terminy płatności, ofertę szkoleniowo-doradczą dostosowana do potrzeb MSP.

Tabela 20. Wartość statystyki $(H)$ według testu Kruskala-Wallisa oraz poziom prawdopodobieństwa testowego $(p)$ zmiennych określających uwarunkowania mikroekonomiczne badanych przedsiębiorstw w obszarach zmarginalizowanych w kontekście wielkości przedsiębiorstwa

\begin{tabular}{|l|c|c|}
\hline \multicolumn{1}{|c|}{ Uwarunkowania mikroekonomiczne } & $\begin{array}{c}\text { Wartość statystyki } \\
(H) \text { według testu } \\
\text { Kruskala-Wallisa }\end{array}$ & $\begin{array}{c}\text { Prawdopodobieństwo } \\
\text { testowe }(p)\end{array}$ \\
\hline Silna konkurencja & 3,730 & 0,094 \\
\hline Wymagający klienci (odbiorcy) & 7,987 & 0,022 \\
\hline $\begin{array}{l}\text { Powiązania kooperacyjne z innymi przedsiębior- } \\
\text { stwami }\end{array}$ & 5,002 & 0,039 \\
\hline Koszty wprowadzenia innowacji & 9,435 & 0,000 \\
\hline Dostęp do informacji o formach wsparcia & 17,254 & 0,000 \\
\hline Współpraca przedsiębiorstw ze sferą nauki & 11,892 & 0,000 \\
\hline Odroczone terminy płatności & 11,235 & 0,000 \\
\hline $\begin{array}{l}\text { Oferta szkoleniowo-doradcza dostosowana do } \\
\text { potrzeb MSP }\end{array}$ & 6,891 & 0,031 \\
\hline
\end{tabular}

Źródło: opracowanie własne.

Badanie wpływu uwarunkowań mikroekonomicznych na rozwój MSP w podziale na trzy kategorie firm według wielkości wykazało zróżnicowanie oddziaływania badanych czynników. W przypadku mikroprzedsiębiorstw (por. rysunek 55) za stymulatory uznano powiązania kooperacyjne z innymi przedsiębiorstwami (43,9\% wskazań) oraz ofertę szkoleniowo-doradczą dostosowaną do potrzeb MSP (40,7\% wskazań), natomiast za bariery uznano silną konkurencję (67,4\% wskazań) oraz odroczone terminy płatności (59,2\% wskazań). Brak wpływu na prowadzoną działalność miały takie uwarunkowania, jak: dostęp do informacji o formach wsparcia (45,4\% wskazań) i współpraca przedsiębiorstw ze sferą nauki (67,4\% wskazań). 


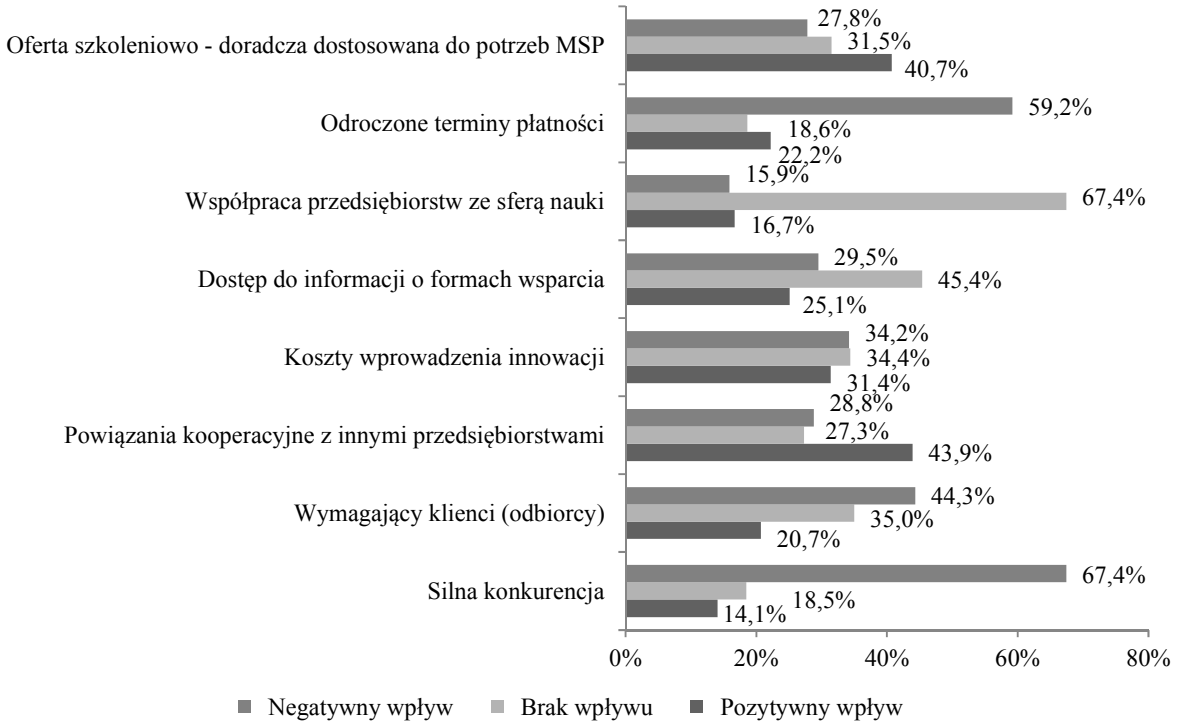

Rysunek 55. Mikroekonomiczne uwarunkowania rozwoju mikroprzedsiębiorstw zlokalizowanych w obszarach zmarginalizowanych

Źródło: opracowanie własne

W małych przedsiębiorstwach (por. rysunek 56) za stymulatory rozwoju respondenci uznali powiązania kooperacyjne $\mathrm{z}$ innymi przedsiębiorstwami (43,9\% wskazań) oraz dostęp do informacji o formach wsparcia $(42,1 \%$ wskazań), natomiast za bariery koszty wprowadzenia innowacji (59,2\% wskazań) oraz silna konkurencja (47,1\% wskazań). Brak wpływu na prowadzoną działalność miały takie uwarunkowania, jak: oferta szkoleniowo-doradcza dostosowana do potrzeb MSP (46,5\% wskazań) i współpraca przedsiębiorstw ze sferą nauki (55,4\% wskazań).

W przypadku średnich przedsiębiorstw za stymulatory rozwoju respondenci uznali (por. rysunek 57) ofertę szkoleniowo-doradczą dostosowaną do potrzeb MSP (48,1\% wskazań) oraz dostęp do informacji o formach wsparcia $(43,7 \%$ wskazań), natomiast za bariery koszty wprowadzenia innowacji (56,3\% wskazań) oraz silną konkurencję (40,7\% wskazań). Brak wpływu na prowadzoną działalność miały takie czynniki, jak: współpraca przedsiębiorstw ze sferą nauki (56,3\% wskazań) i wymagający klienci (odbiorcy) (40,7\% wskazań). 


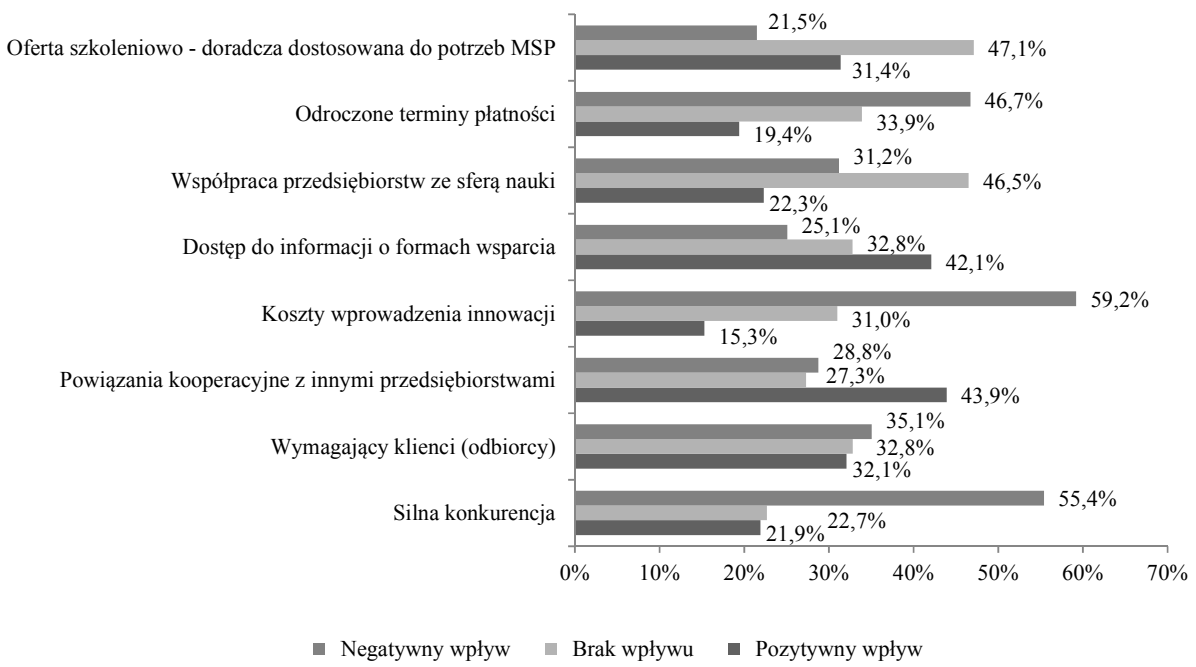

Rysunek 56. Mikroekonomiczne uwarunkowania rozwoju małych przedsiębiorstw zlokalizowanych w obszarach zmarginalizowanych

Źródło: opracowanie własne

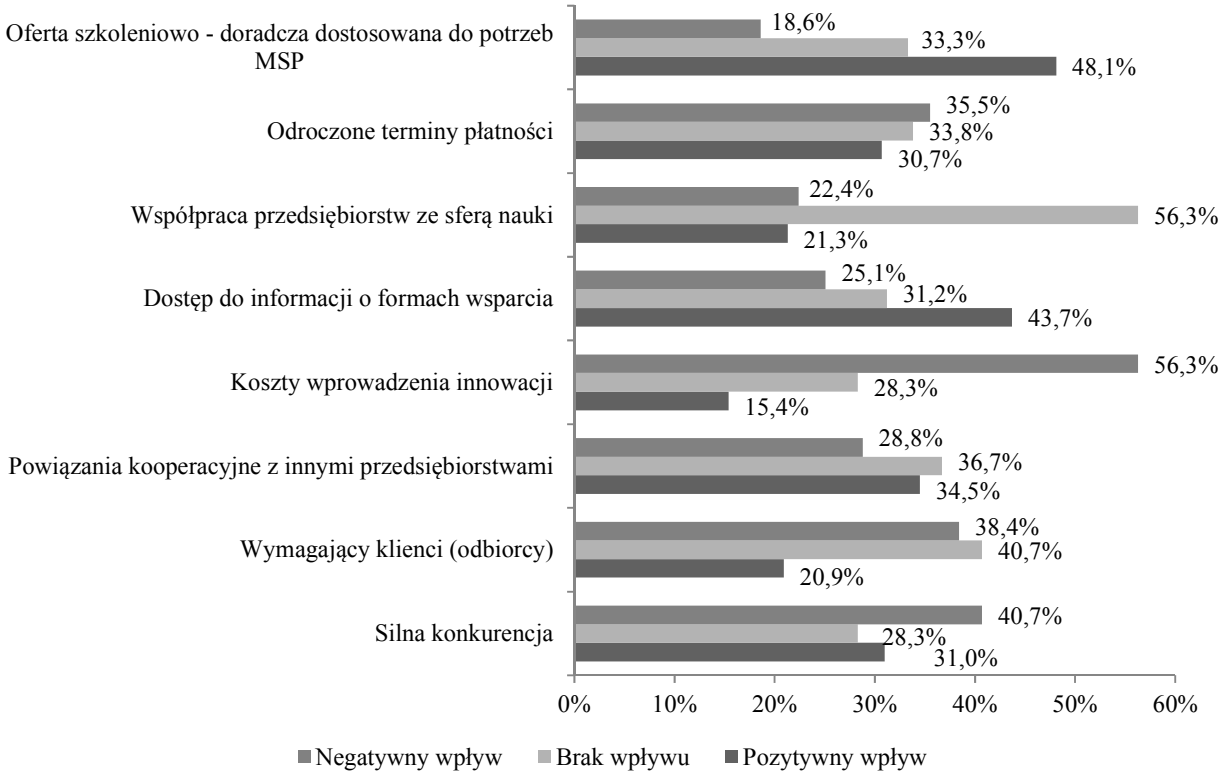

Rysunek 57. Mikroekonomiczne uwarunkowania rozwoju średnich przedsiębiorstw zlokalizowanych w obszarach zmarginalizowanych Źródło: opracowanie własne. 
Oddziaływanie uwarunkowań rozwoju małych i średnich przedsiębiorstw związanych z mikrootoczniem jest zróżnicowane ze względu na lokalizację firmy - obszar rozwinięty i obszar zmarginalizowany, a w przypadku obszarów zmarginalizowanych również $\mathrm{w}$ poszczególnych kategoriach firm (mikro, małych i średnich). Pozwala to pozytywnie zweryfikować hipotezy $\mathrm{H}_{4}$ : Oddziaływanie uwarunkowań rozwoju małych i średnich przedsiębiorstw przedsiębiorstw pochodzących $\mathrm{z}$ mikrotoczenia jest zróżnicowane $\mathrm{w}$ zależności od lokalizacji firmy w obszarach rozwiniętych czy zmarginalizowanych oraz $\mathrm{H}_{7}$ : Oddziaływanie uwarunkowań rozwoju małych i średnich przedsiębiorstw funkcjonujących w obszarach zmarginalizowanych jest zróżnicowane w zależności od wielkości przedsiębiorstwa.

\subsection{Uwarunkowania wewnętrzne - bariery i stymulatory}

Zgodnie z zaproponowaną w podrozdziale 3.4 klasyfikacją uwarunkowań wewnętrznych (podział na związane $\mathrm{z}$ przedsiębiorstwem i przedsiębiorcą) respondenci oceniali czynniki $\mathrm{w}$ ramach każdej kategorii analogiczne jak w przypadku uwarunkowań zewnętrznych jako: pozytywny wpływ, brak wpływu i negatywny wpływ. Należy jednak podkreślić, że utworzona lista czynników tak jak w przypadku uwarunkowań zewnętrznych nie jest w pełni kompletna i mogłaby uwzględniać znacznie szerszy zakres badanych zmiennych, ale wydaje się, że jest wystarczająca dla zbadania charakteru i wpływu tych uwarunkowań na rozwój MSP w Polsce zlokalizowanych w obszarach rozwiniętych i zmarginalizowanych.

Pierwszą grupą analizowanych czynników wewnętrznych były uwarunkowania związane $\mathrm{z}$ przedsiębiorstwem. Większość $\mathrm{z}$ nich uznana była przez badanych przedsiębiorców za stymulatory rozwoju, do których zaliczono: posiadaną strategię funkcjonowania i rozwoju (49,9\% wskazań), znajomość preferencji i potrzeb klientów (49,1\% wskazań), wizerunek i renoma przedsiębiorstwa (48,2 \% wskazań), elastyczność w działaniu (45,1\% wskazań), wiedza i doświadczenie kadry kierowniczej (44,4\% wskazań). Natomiast jako bariery respondenci uznali: potencjał finansowy przedsiębiorstwa (50,7\% wskazań), potencjał rzeczowy - stan parku maszynowego (46,4\% wskazań), innowacyjność (39,7\% wskazań), stosowaną technologię (38,7\% wskazań). W opinii badanych przedsiębiorców zasoby informacyjne i zarzadzanie wiedzą (44,7\% wskazań) oraz kultura organizacyjna (41\% wskazań) nie miały znaczącego wpływu na rozwój ich przedsiębiorstw. Analogicznie jak w przypadku uwarunkowań zewnętrznych oceniane czynniki często były dla jednych przedsiębiorców barierami dla innych stymulatorami lub nie miały wpływu na rozwój 
przedsiębiorstwa. Takie wyniki potwierdzają $\mathrm{z}$ jednej strony mocne strony $\mathrm{MSP}^{24}$, a $\mathrm{z}$ drugiej eksponują bariery, z którymi zmaga się ten sektor od wielu lat ${ }^{25}$, szczególnie dotkliwe są problemy finansowe, które wpływają nie tylko funkcjonowanie istniejących podmiotów oraz na powstawanie nowych, ale również na potencjał rzeczowy i ludzki przedsiębiorstwa. Niewystarczający potencjał rzeczowy np. w postaci parku maszynowego, jak również brak możliwości rozwoju pracowników ${ }^{26}$ i właściciela ${ }^{27}$, stanowią bariery dla

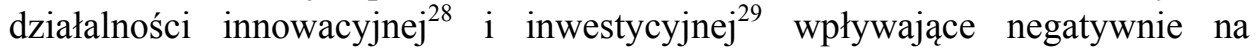
konkurencyjność MSP.

Analiza uwarunkowań wewnętrznych związanych $\mathrm{z}$ przedsiębiorstwem w obszarach rozwiniętych i zmarginalizowanych pozwoliła na uwypuklenie zróżnicowania większości badanych zmiennych (por. rysunek 57 i 58).

Zróżnicowanie badanych czynników wewnętrznych związanych z przedsiębiorstwem w obszarach rozwiniętych i zmarginalizowanych zbadano testem $\mathrm{U}$ Manna-Whitneya, którego wyniki i prawdopodobieństwo testowe $(p<0,05)$ potwierdziło zróżnicowanie następujących czynników: posiadana strategia funkcjonowania i rozwoju, innowacyjność, elastyczność w działaniu, stosowana technologia, współpraca $\mathrm{z}$ otoczeniem biznesu, powiazania $\mathrm{z}$ innymi firmami, wiedza i doświadczenie kadry zarządzającej, wiedza i kompetencje pracowników.

W obszarach rozwiniętych za najważniejsze stymulatory respondenci uważali posiadaną strategię funkcjonowania i rozwoju, znajomość potrzeb i preferencji klientów, wizerunek i renomę przedsiębiorstwa oraz wiedzę i doświadczenie kadry zarządzającej, natomiast jako bariery uznali niewystarczający potencjał finansowy i rzeczowy oraz brak współpracy $\mathrm{z}$ otoczeniem biznesu (por. rysunek 58). Taki rozkład wypowiedzi podkreśla znaczenie planowania strategicznego i analizy strategicznej ${ }^{30} \mathrm{w}$ zarządzaniu przedsiębiorstwem, jak również uwypukla rolę rozwoju kompetencji przedsiębiorcy ${ }^{31}$ ważnych zarówno w przypadku wzrostu/rozwoju przedsiębiorstwa, ale również w podejmowaniu decyzji strategicznych.

\footnotetext{
${ }^{24}$ Szerzej w publikacjach: Piasecki 2001 i 2012, Matejun 2012.

${ }^{25}$ Szerzej w publikacjach: Łuczka red. 2007, Daszkiewicz 2004 a i b.

${ }^{26}$ Szerzej: w publikacjach: Zając 2007, Sikorski 2009.

${ }^{27}$ Szerzej w publikacjach: Wasilczuk 2005, Bławat 2003, Bielawska 2010.

${ }^{28}$ Szerzej w publikacjach: Stawasz E. 2011, Stanisławski 2011.

${ }^{29}$ Szerzej w publikacji: Różański 2006.

${ }^{30}$ Szerzej Romanowska 2009; Gierszewska, Romanowska 2002; Targalski 2010.

${ }^{31}$ Szerzej Bielawska 2010, Gudkova 2008, Wasilczuk 2005.
} 


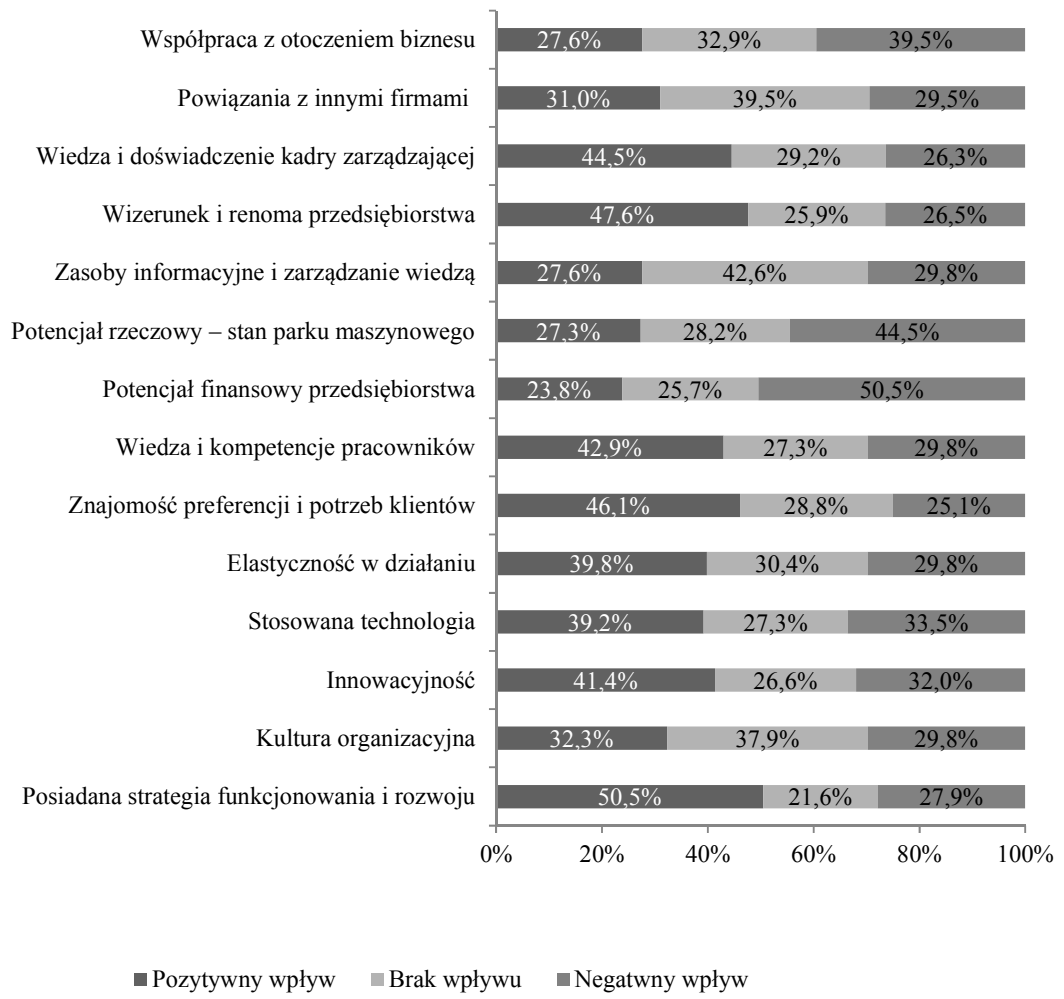

Rysunek 58. Wewnętrzne uwarunkowania rozwoju małych i średnich przedsiębiorstw zlokalizowanych w obszarach rozwiniętych związane z przedsiębiorstwem Źródło: opracowanie własne

Natomiast $\mathrm{w}$ obszarach zmarginalizowanych za stymulatory respondenci uważali znajomość potrzeb i preferencji klientów, elastyczność w działaniu, wizerunek i renomę przedsiębiorstwa oraz posiadaną strategię funkcjonowania i rozwoju, jako bariery uznali niewystarczający potencjał finansowy i rzeczowy przedsiębiorstwa, niską innowacyjność oraz stosowaną technologię (por. rysunek 59). Wyniki te wskazują na silną orientację rynkową badanych przedsiębiorstw, co ma związek ze specyfiką obszarów zmarginalizowanych, w których obserwuje się niewystarczający popyt wynikający z mniejszej liczy potencjalnych klientów i małej konkurencyjności obszaru. Składnia to przedsiębiorstwa tam funkcjonujące do poprawy swojej pozycji na rynku poprzez poprawę swojej konkurencyjności. Problemem są jednak niewystarczające środki finansowe, będące barierą $\mathrm{w}$ zakresie możliwości poprawy pozycji małych i średnich przedsiębiorstw nie tylko na rynku lokalnym, ale również krajowym i międzynarodowym. 


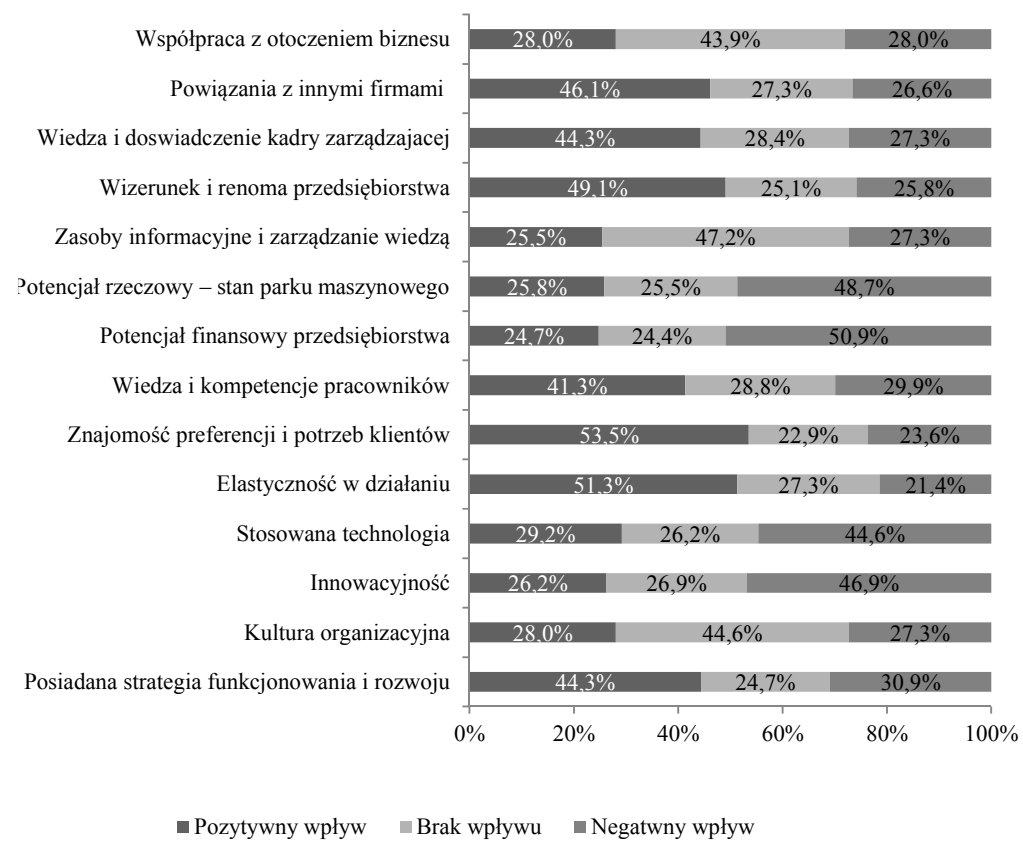

Rysunek 59. Wewnętrzne uwarunkowania rozwoju małych i średnich przedsiębiorstw zlokalizowanych w obszarach rozwiniętych związane z przedsiębiorstwem Źródło: opracowanie własne

Tabela 21. Wartość statystyki $(H)$ według testu Kruskala-Wallisa oraz poziom prawdopodobieństwa testowego $(p)$ zmiennych określających uwarunkowania wewnętrzne związane z przedsiębiorstwem w obszarach zmarginalizowanych w kontekście wielkości przedsiębiorstwa

\begin{tabular}{|l|c|c|}
\hline \multicolumn{1}{|c|}{$\begin{array}{c}\text { Uwarunkowania wewnętrzne związane } \\
\text { z przedsiębiorstwem }\end{array}$} & $\begin{array}{c}\text { Wartość statystyki } \\
(H) \text { według testu } \\
\text { Kruskala-Wallisa }\end{array}$ & $\begin{array}{c}\text { Prawdopodobieństwo } \\
\text { testowe }(p)\end{array}$ \\
\hline Posiadana strategia funkcjonowania i rozwoju & 2,730 & 0,164 \\
\hline Kultura organizacyjna & 5,984 & 0,039 \\
\hline Innowacyjność & 5,043 & 0,041 \\
\hline Stosowana technologia & 1,435 & 0,356 \\
\hline Elastyczność w działaniu & 16,231 & 0,000 \\
\hline Znajomość preferencji i potrzeb klientów & 12,192 & 0,000 \\
\hline Wiedza i kompetencje pracowników & 10,235 & 0,000 \\
\hline Potencjał finansowy przedsiębiorstwa & 2,891 & 0,438 \\
\hline Potencjał rzeczowy - stan parku maszynowego & 2,578 & 0,689 \\
\hline Zasoby informacyjne i zarządzanie wiedzą & 1,945 & 0,706 \\
\hline Wizerunek i renoma przedsiębiorstwa & 5,943 & 0,043 \\
\hline Wiedza i doświadczenie kadry zarządzającej & 2,467, & 0,654 \\
\hline Powiązania z innymi firmami & 10,987 & 0,000 \\
\hline Współpraca z otoczeniem biznesu & 4,912 & 0,046 \\
\hline
\end{tabular}

Źródło: opracowanie własne. 
W dalszej części analiza będzie analogiczna jak w przypadku uwarunkowań zewnętrznych i będzie dotyczyła tylko obszarów zmarginalizowanych. Rozkład wypowiedzi respondentów wskazuje na zróżnicowanie wskazywanych przez badane przedsiębiorstwa uwarunkowań wewnętrznych związanych z przedsiębiorstwem w zależności od jego wielkości, potwierdził to również test Kruskala-Wallisa. Jego wyniki i prawdopodobieństwo testowe $(p<0,05)$ pokazały zróżnicowanie następujących zmiennych (por. tabela 21): elastyczność w działaniu, znajomość potrzeb i preferencji klientów, powiązanie z innymi firmami, wizerunek i renoma przedsiębiorstwa, innowacyjność, kultura organizacyjna, współpraca z otoczeniem biznesu, wiedza i kompetencje pracowników.

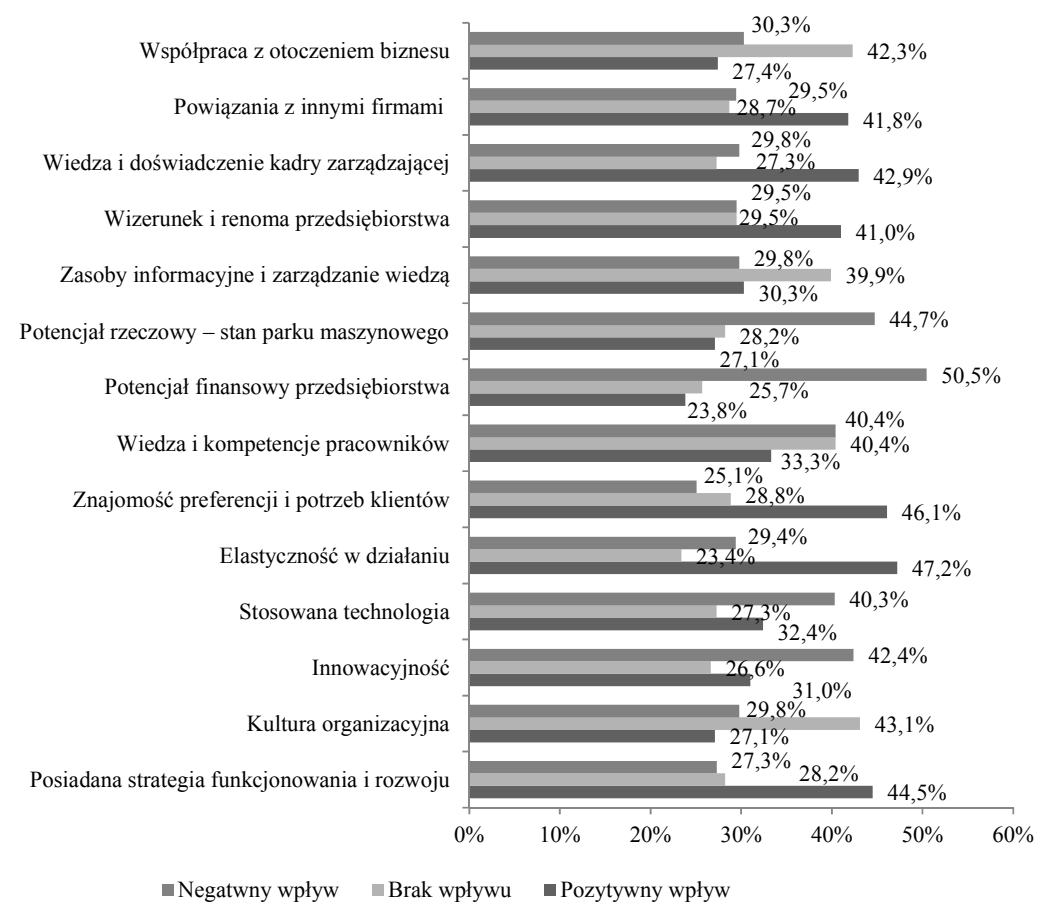

Rysunek 60. Uwarunkowania wewnętrzne (przedsiębiorstwo) rozwoju mikroprzedsiębiorstw zlokalizowanych w obszarach zmarginalizowanych

Źródło: opracowanie własne

Analiza uwarunkowań wewnętrznych związanych z przedsiębiorstwem w podziale na trzy kategorie firm według wielkości wykazała znaczne zróżnicowanie badanych czynników, dla jednych firm bowiem analizowane zmienne były stymulatorami, a dla innych barierami. W przypadku mikroprzedsiębiorstw (por. rysunek 60) za stymulatory uznano: elastyczność w działaniu (47,2\% wskazań), znajomość potrzeb i preferencji klientów (46,1\% wskazań), 
posiadana strategię funkcjonowania i rozwoju (43,9\% wskazań) oraz wiedzę i doświadczenie kadry zarządzającej (42,9\% wskazań), natomiast jako bariery wskazano: potencjał finansowy (50,5\% wskazań), potencjał rzeczowy - stan parku maszynowego (44,7\% wskazań) oraz innowacyjność (42,4\% wskazań). Brak wpływu na prowadzoną działalność miały takie uwarunkowania jak: kultura organizacyjna ( $43,1 \%$ wskazań) oraz współpraca z otoczeniem biznesu (42,3\% wskazań).

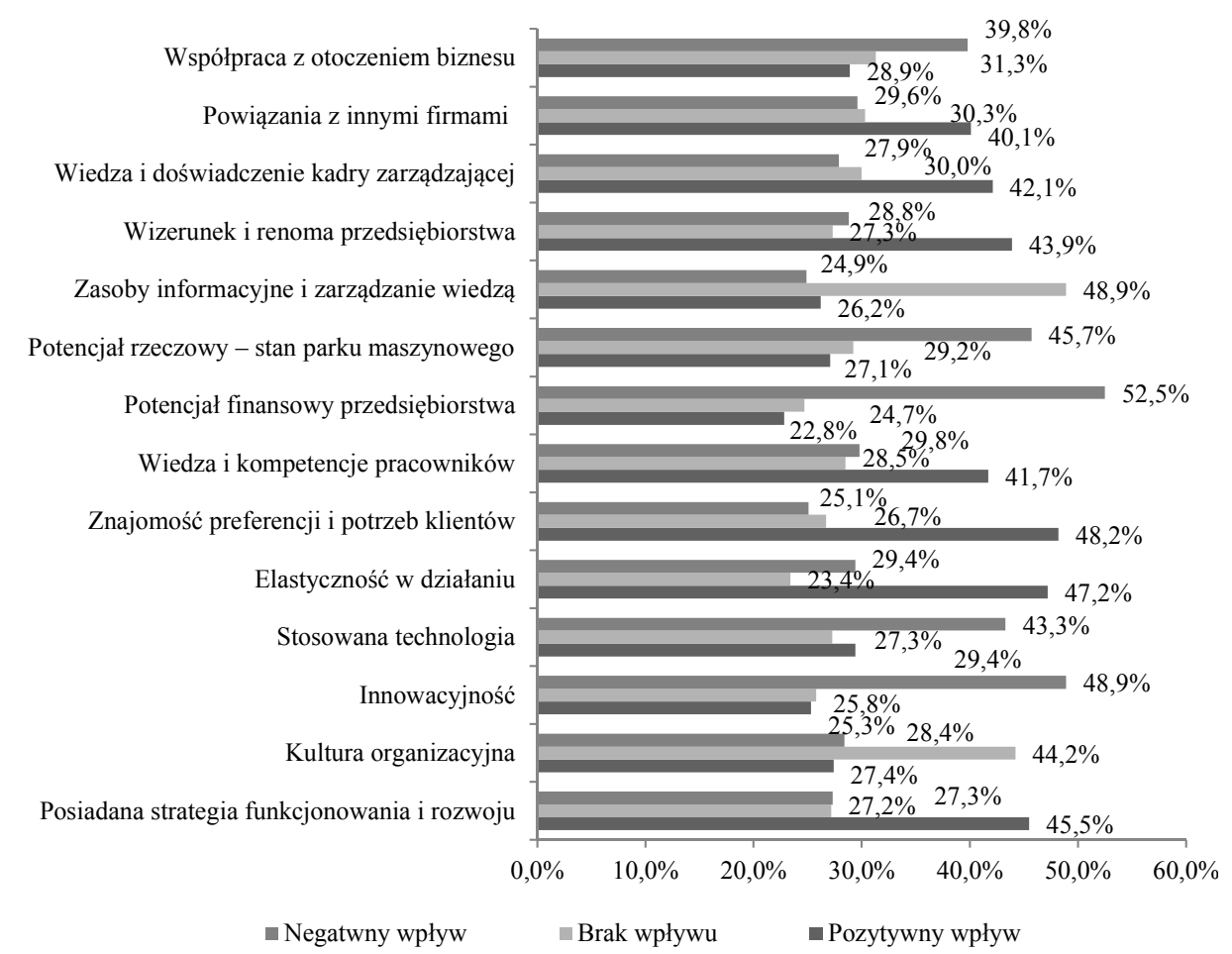

Rysunek 61. Uwarunkowania wewnętrzne (przedsiębiorstwo) rozwoju małych przedsiębiorstw zlokalizowanych w obszarach zmarginalizowanych Źródło: opracowanie własne

W przypadku małych przedsiębiorstw (por. rysunek 61) za stymulatory uznano: znajomość potrzeb i preferencji klientów (48,2\% wskazań), elastyczność w działaniu (47,2\% wskazań), posiadana strategię funkcjonowania i rozwoju (45,5\% wskazań) oraz wizerunek i renomę przedsiębiorstwa $(43,9 \%$ wskazań), natomiast jako bariery wskazano: potencjał finansowy $(52,5 \%$ wskazań), innowacyjność (48,9\% wskazań) oraz potencjał rzeczowy - stan parku maszynowego (45,7\% wskazań). Brak wpływu na prowadzoną działalność miały takie uwarunkowania jak: zasoby informacyjne i zarządzanie wiedzą (48,9\% wskazań) oraz kultura organizacyjna (44,2\% wskazań). 
Natomiast w przypadku średnich przedsiębiorstw (por. rysunek 62) za stymulatory uznano: posiadaną strategię funkcjonowania i rozwoju $(55,1 \%$ wskazań), wizerunek i renomę przedsiębiorstwa (51,3\% wskazań), wiedze i kompetencje kadry zarządzającej, (48,7\% wskazań) oraz powiązania z innymi firmami (46,9\% wskazań), natomiast jako bariery wskazano: potencjał finansowy (51,5\% wskazań), potencjał rzeczowy - stan parku maszynowego (44,7\% wskazań) oraz stosowaną technologię (43,3\% wskazań). Brak wpływu na prowadzoną działalność miały takie uwarunkowania jak: zasoby informacyjne i zarządzanie wiedzą (46,9\% wskazań) oraz współpraca z otoczeniem biznesu (46,5\% wskazań).

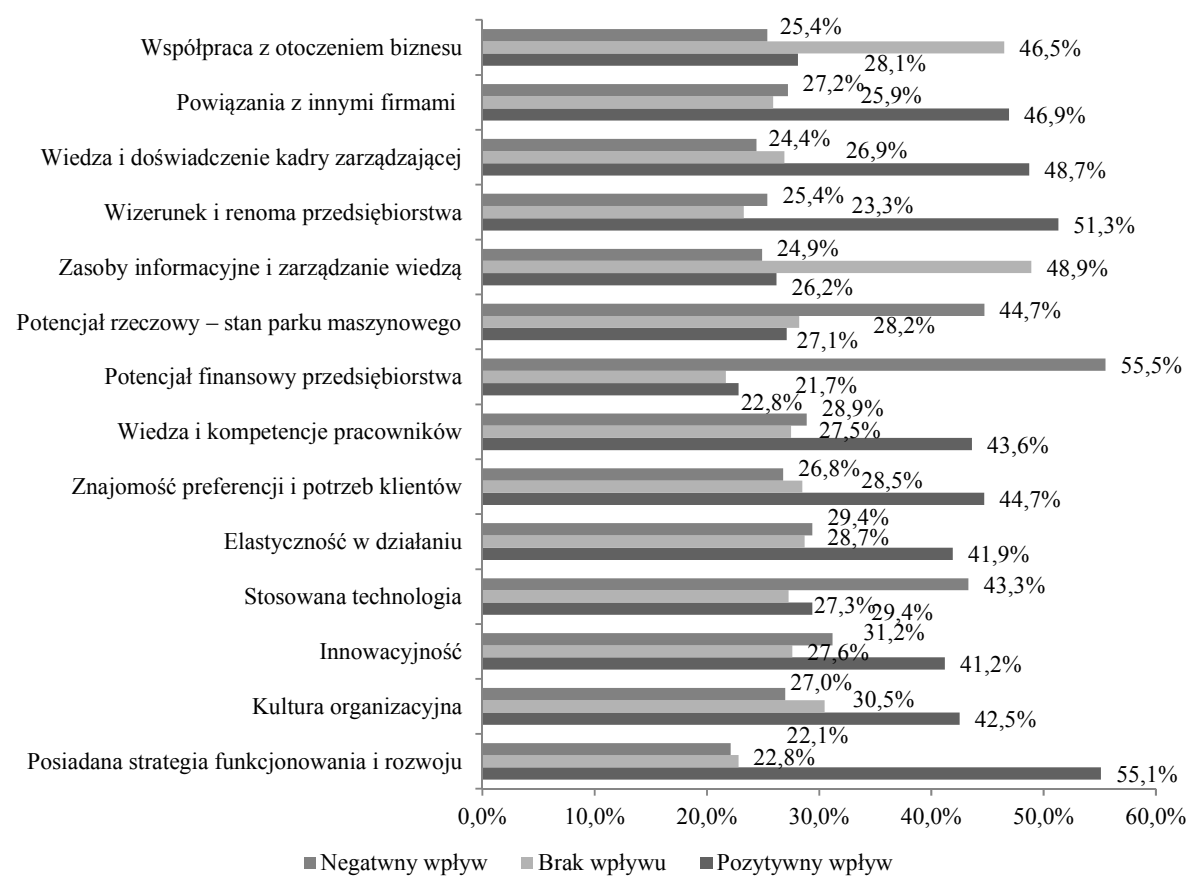

Rysunek 62. Uwarunkowania wewnętrzne (przedsiębiorstwo) rozwoju średnich przedsiębiorstw zlokalizowanych w obszarach zmarginalizowanych

Źródło: opracowanie własne

Z wypowiedzi respondentów wynika, że mikro, małe firmy wykorzystują swoje mocne strony związane $\mathrm{z}$ elastycznością działania, znajomością rynku (jest to zazwyczaj rynek lokalny), w celu znalezienia i wykorzystania okazji rynkowych, np. w postaci niszy. Takie działania wymagają konieczności zarządzania zmianami ${ }^{30} \mathrm{~W}$ przedsiębiorstwie jak również stałego monitorowania otoczenia. W przypadku średnich firm wykorzystywane są narzędzia zaradzania strategicznego, jak również kładziony jest nacisk na rozwój zasobów ludzkich

\footnotetext{
${ }^{30}$ Szerzej w publikacjach: Borowiecki, Balcerek-Wieszala 2011; Masłyk-Musiał 2003.
} 
w przedsiębiorstwie. Problemem wszystkich kategorii firm są niedostatki kapitału i niewystarczający majątek rzeczowy, co w dużej hamuje innowacyjność i konkurencyjność.

Wpływ uwarunkowań wewnętrznych rozwoju małych i średnich przedsiębiorstw związanych z przedsiębiorstwem jest zróżnicowany ze względu na lokalizację firmy - obszar rozwinięty i obszar zmarginalizowany, a w przypadku obszarów zmarginalizowanych również $\mathrm{w}$ poszczególnych kategoriach firm (mikro, małych i średnich). Pozwala to pozytywnie zweryfikować hipotezy $\mathrm{H}_{6}$ : Oddziaływanie uwarunkowań rozwoju małych i średnich przedsiębiorstw związanych z przedsiębiorstwem jest zróżnicowane w zależności od lokalizacji firmy w obszarach rozwiniętych i zmarginalizowanych oraz $\mathrm{H}_{7}$ : Oddziaływanie uwarunkowań rozwoju małych i średnich przedsiębiorstw funkcjonujących w obszarach zmarginalizowanych jest zróżnicowane w zależności od wielkości przedsiębiorstwa.

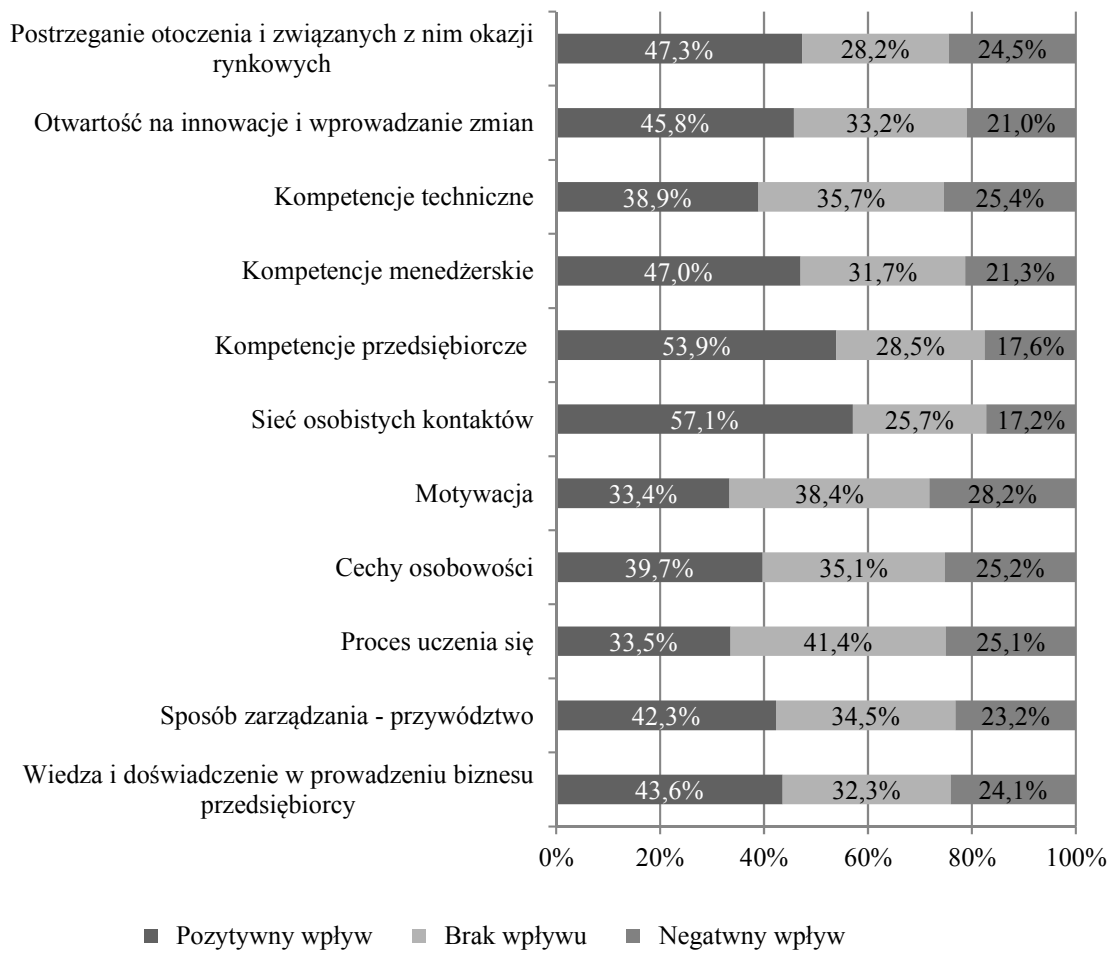

Rysunek 63. Wewnętrzne uwarunkowania rozwoju małych i średnich przedsiębiorstw zlokalizowanych w obszarach rozwiniętych związane z osobą przedsiębiorcy Źródło: opracowanie własne 


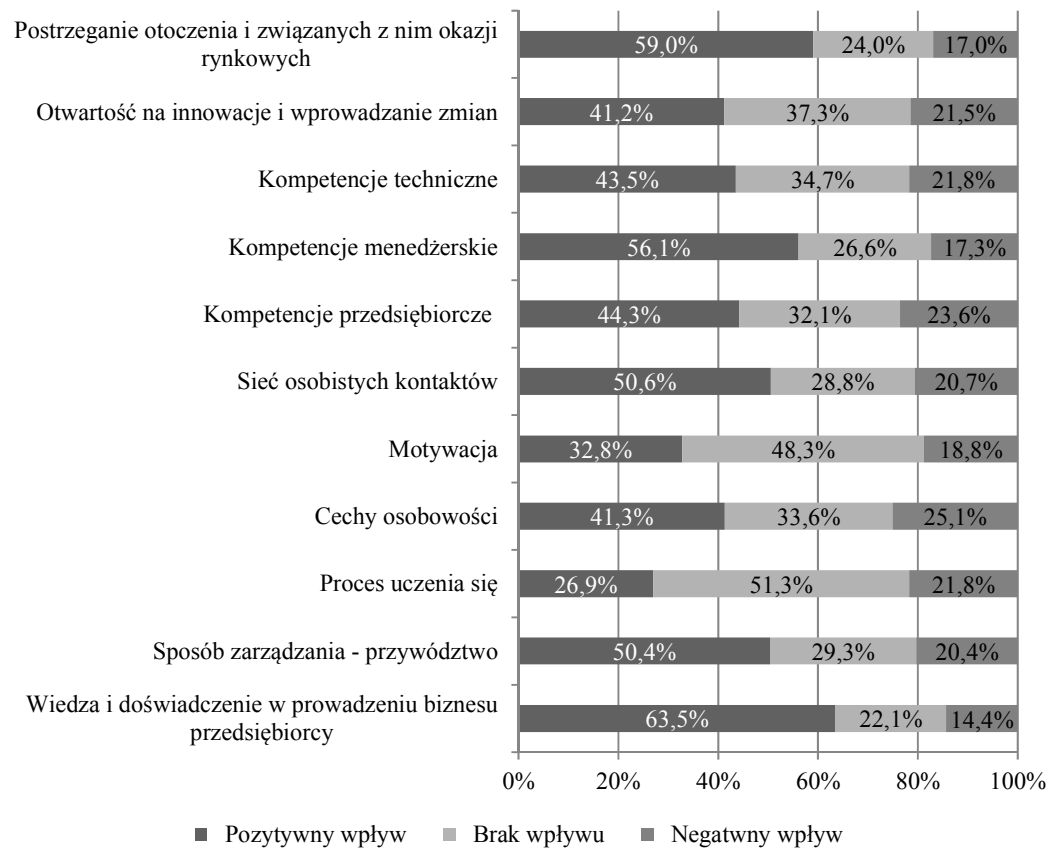

Rysunek 64. Wewnętrzne uwarunkowania rozwoju małych i średnich przedsiębiorstw zlokalizowanych w obszarach zmarginalizowanych związane z osobą przedsiębiorcy Źródło: opracowanie własne

Badanie czynników związanych bezpośrednio z osobą przedsiębiorcy zostało przeprowadzone według schematu analizy zaproponowanego w podrozdziale 3.4 (por. rysunek 29) w obszarach rozwiniętych i zmarginalizowanych. Jak wynika z wyników testów U Manna-Whitneya $(p>0,05)$ oraz Kruskala-Wallisa $(p>0,05)$ brak jest wyraźnego zróżnicowania odziaływania badanych zmiennych $\mathrm{w}$ obszarach zmarginalizowanych i rozwiniętych, jak również brak zróżnicowania badanych zmiennych $\mathrm{w}$ obszarach zmarginalizowanych $\mathrm{w}$ zależności od wielkości firmy $\mathrm{W}$ przypadku obszarów rozwiniętych jako stymulatory respondenci uważali: sieć osobistych kontaktów (57,1\% wskazań), kompetencje przedsiębiorcze $(53,9 \%$ wskazań), postrzeganie otoczenia i związanych z nim okazji rynkowych (47,3\% wskazań) kompetencje menedżerskie $(47,0 \%)$ oraz wiedza i doświadczenie w prowadzeniu biznesu (43,6\% wskazań) (por. rysunek 55).

Natomiast $\mathrm{w}$ obszarach zmarginalizowanych za stymulatory respondenci uważali: wiedzę i doświadczenie w prowadzeniu biznesu (63,5\% wskazań), postrzeganie otoczenia i związanych z nim okazji rynkowych (59\% wskazań), 
kompetencje menedżerskie (56,1\% wskazań), sieć osobistych kontaktów (50,6\% wskazań) oraz sposób zarządzania - przywództwo (50,4\% wskazań).

Badani przedsiębiorcy zarówno w przypadku obszarów rozwiniętych, jak i zmarginalizowanych ocenili badane czynniki w większości przypadków jako stymulatory rozwoju. Wydaje się zatem, że cechy badanych przedsiębiorców mogą stać się jednym z elementów potencjału rozwojowego tych podmiotów szczególnie w obszarach zmarginalizowanych. Szkoda tylko, że oceny te były mało obiektywne i nie pokazały słabości tych podmiotów, np. w sferze organizacji i zarządzania, gdzie podkreśla się dominującą rolę właściciela menedżera, niewielkie możliwości wykorzystania systemów informacyjnych oraz ograniczoną rolę sformalizowanego planowania strategicznego na rzecz intuicji.

Wpływ uwarunkowań wewnętrznych rozwoju małych i średnich przedsiębiorstw związanych z przedsiębiorcą nie jest zróżnicowany ze względu na lokalizację firmy - obszar rozwinięty i obszar zmarginalizowany, a w przypadku obszarów zmarginalizowanych również $\mathrm{w}$ poszczególnych kategoriach firm (mikro, małych i średnich). Pozwala to negatywnie zweryfikować hipotezy $\mathrm{H}_{5}$ : Oddziaływanie uwarunkowań rozwoju małych i średnich przedsiębiorstw związanych z osobą przedsiębiorcy jest zróżnicowane w zależności od tego, czy firma jest zlokalizowana $w$ obszarach rozwiniętych czy zmarginalizowanych oraz $\mathrm{H}_{7}$ : Oddziaływanie uwarunkowań rozwoju małych i średnich przedsiębiorstw funkcjonujących $\mathrm{w}$ obszarach zmarginalizowanych jest zróżnicowane w zależności od wielkości przedsiębiorstwa.

Reasumując rozważania dotyczące uwarunkowań rozwoju małych i średnich przedsiębiorstw w obszarach zmarginalizowanych i rozwiniętych, można stwierdzić, że oddziaływanie badanych czynników, z wyjątkiem uwarunkowań zewnętrznych pochodzących $\mathrm{z}$ makrootoczenia i uwarunkowań wewnętrznych związanych $\mathrm{z}$ przedsiębiorcą, różniło się $\mathrm{w}$ zależności od lokalizacji przedsiębiorstwa - obszar rozwinięty i zmarginalizowany jak również w przypadku obszarów zmarginalizowanych w zależności od wielkości firmy, co skłoniło autorkę do dalszych bardziej szczegółowych badań, które zostały przedstawione $\mathrm{w}$ rozdziale 5 . W przypadku obszarów zmarginalizowanych oddziaływanie poszczególnych uwarunkowań było ściśle związane ze cechami charakterystycznymi dla tych obszarów, natomiast $\mathrm{w}$ obszarach rozwiniętych rezultaty były zgodne $\mathrm{z}$ wynikami dotychczasowych badań autorki jak również innych autorów zawartych $\mathrm{w}$ obszernej literaturze przedmiotu zaprezentowanej w rozdziale 3 . 


\section{Funkcjonowanie i rozwój małych i średnich przedsiębiorstw w obszarach zmarginalizowanych - implikacje dla zarządzania}

\subsection{Wpływ marginalizacji regionu na rozwój małych i średnich przedsiębiorstw}

Jak już wcześniej wspomniano, obszary zmarginalizowane, z jednej strony nie są sprzyjającym terenem dla prowadzenia i rozwoju małych i średnich przedsiębiorstw. Posiadają one bowiem wiele specyficznych cech, które raczej mają negatywny wpływ na ich funkcjonowanie, np. brak dostępności komunikacyjnej, niska innowacyjność i konkurencyjność, ograniczony dostęp do otoczenia biznesu (mała liczba instytucji) itp. $Z$ drugiej zaś strony, pozycja i rozwój małych i średnich przedsiębiorstw na terenach zmarginalizowanych wynika $\mathrm{z}$ ich rozproszenia w różnorodnych układach lokalnych, przybliżając ich działalność do obszarów występowania popytu, co pozwala na:

- znaczącą redukcję kosztów transportu,

- dostosowanie wielkości produkcji do potrzeb lokalnych,

- ograniczenie kosztów przechowywania wyrobów,

- zmniejszenie kosztów ogólnych,

- indywidualizowanie kontaktów z klientami,

- kształtowanie reputacji lokalnej we wszystkich przejawach orientacji marketingowej, a także tradycji firmy, jej wielopokoleniowych kontaktów itp.,

- kształtowanie lojalności wobec marki oraz firmy (Strużycki 2002, s. 22).

Do oceny wpływu obszarów zmarginalizowanych na rozwój małych i średnich przedsiębiorstw posłuży druga część wyników badań zarówno ilościowych, jak i jakościowych ${ }^{1}$ przeprowadzonych wśród przedsiębiorstw zlokalizowanych w tych obszarach.

$\mathrm{W}$ rozszerzonym ${ }^{2}$ badaniu ankietowym jednym $\mathrm{z}$ obszarów badawczych była ocena wpływu marginalizacji obszaru na rozwój badanych przedsiębiorstw.

\footnotetext{
${ }^{1}$ Szerzej metodyka badania opisana w punkcie 4.1.

${ }^{2}$ Druga część ankiety skierowana tylko do małych i średnich przedsiębiorstw zlokalizowanych w obszarach zmarginalizowanych.
} 
Przedsiębiorcy w większości przypadków widzieli ten wpływ (ok 75\% wskazań) (por. rysunek 65). W mikroprzedsiębiorstwach wpływ ten był największy i został określony jako duży i znaczący (łącznie 52,2\% wskazań), $\mathrm{w}$ małych przedsiębiorstwach oceniono go jako umiarkowany i znaczący (łącznie 45,3\%), w przypadku średnich przedsiębiorstw jako niewielki $(22,4 \%$ wskazań) lub brak wpływu (35,3\% wskazań). Wyniki te nie są zaskakujące, gdyż mikro i małe przedsiębiorstwa funkcjonują głównie na rynkach lokalnych, natomiast średnie na rynku krajowym i międzynarodowym, gdzie wpływ ten jest niewielki.

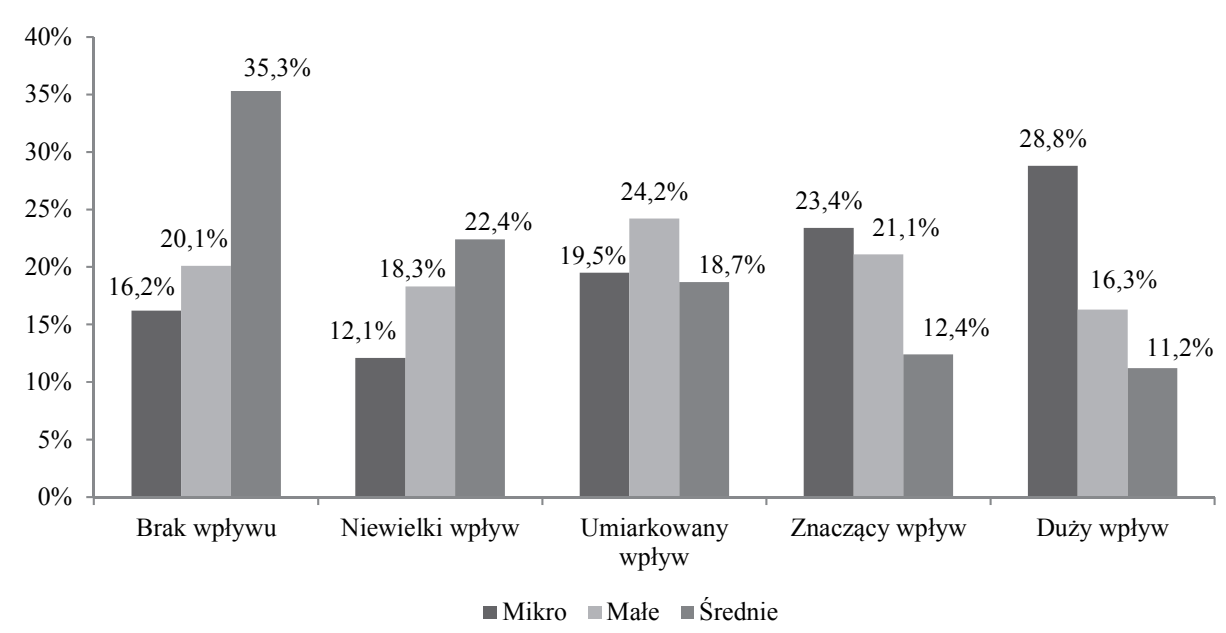

Rysunek 65. Wpływ marginalizacji obszarów na rozwój małych i średnich przedsiębiorstw Źródło: opracowanie własne

Istnienie wpływu obszarów zmarginalizowanych na rozwój badanych przedsiębiorstw potwierdziły również badania jakościowe przeprowadzone wśród 15 małych i średnich przedsiębiorstw. Ze względu na brak zgody większości respondentów na ujawnienie ich danych osobowych oraz szczegółowych informacji o firmie, rezultaty wywiadów zostały przedstawione anonimowo. Respondentami było 10 mężczyzn i 5 kobiet w wieku od 33 do 56 lat, a przedsiębiorstwa można było zaklasyfikować do trzech kategorii: mikro (7 przedsiębiorstw), małe (5 przedsiębiorstw), średnie (3 przedsiębiorstwa) założonych w latach 1969-2006 (por. tabela 22). 
Tabela 22. Charakterystyka badanych przedsiębiorstw

\begin{tabular}{|c|c|c|c|c|c|c|c|}
\hline $\begin{array}{l}\text { Przedsię- } \\
\text { biorstwo }\end{array}$ & \begin{tabular}{|c|} 
Wielkość \\
(mikro, \\
małe, \\
średnie)
\end{tabular} & \begin{tabular}{|c|} 
Forma \\
organiza- \\
cyjno- \\
prawna
\end{tabular} & $\begin{array}{l}\text { Sektor działalno- } \\
\text { ści podstawowej } \\
\text { (produkcja, } \\
\text { usługi, handel) }\end{array}$ & $\begin{array}{c}\text { Rok } \\
\text { założenia }\end{array}$ & \begin{tabular}{|c} 
Wiek \\
właściciela/ \\
współwłaściciela
\end{tabular} & $\begin{array}{c}\text { Płeć } \\
\text { właściciela }\end{array}$ & $\begin{array}{l}\text { Doświad- } \\
\text { czenie } \\
\text { w } \\
\text { zarządzaniu }\end{array}$ \\
\hline 1 & Mikro & \begin{tabular}{|l|} 
Osoba \\
fizyczna \\
\end{tabular} & \begin{tabular}{|l}
$\begin{array}{l}\text { Produkcja } \\
\text { (krawiectwo) }\end{array}$ \\
\end{tabular} & 2000 & 44 lata & $\mathrm{M}$ & Tak \\
\hline 2 & Mikro & $\begin{array}{l}\text { Osoba } \\
\text { fizyczna }\end{array}$ & $\begin{array}{l}\text { Handel } \\
\text { (sklep spożyw- } \\
\text { czy) }\end{array}$ & 1998 & 56 lat & K & Tak \\
\hline 3 & Średnie & \begin{tabular}{|l|} 
Spółka z \\
o.o.
\end{tabular} & $\begin{array}{l}\text { Produkcja } \\
\text { (piekarnia) }\end{array}$ & 1969 & 47 lat & $\mathrm{M}$ & Tak \\
\hline 4 & Mikro & \begin{tabular}{|l|} 
Osoba \\
fizyczna \\
\end{tabular} & \begin{tabular}{|l|} 
Usługi \\
(budowlane)
\end{tabular} & 1994 & 52 lata & $\mathrm{M}$ & Tak \\
\hline 5 & Mikro & $\begin{array}{l}\text { Spółka } \\
\text { cywilna }\end{array}$ & \begin{tabular}{|l}
$\begin{array}{l}\text { Produkcja } \\
\text { (przetwórstwo } \\
\text { owoców) }\end{array}$ \\
\end{tabular} & 2004 & 39 lat & $\mathrm{M}$ & Tak \\
\hline 6 & Małe & \begin{tabular}{|l|}
$\begin{array}{l}\text { Spółka } \\
\text { cywilna }\end{array}$ \\
\end{tabular} & \begin{tabular}{|l|} 
Usługi (prywat- \\
ne przedszkole)
\end{tabular} & 2006 & 34 lata & $\mathrm{M}$ & $\mathrm{Nie}$ \\
\hline 7 & Mikro & $\begin{array}{l}\text { Osoba } \\
\text { fizyczna }\end{array}$ & \begin{tabular}{|l|} 
Handel \\
(sprzedaż \\
oczyszczalni)
\end{tabular} & 2005 & 42 lata & $\mathrm{K}$ & Tak \\
\hline 8 & Średnie & $\begin{array}{l}\text { Spółka } \\
\text { jawna }\end{array}$ & \begin{tabular}{|l|} 
Produkcja \\
(produkcja \\
odzieży \\
roboczej) \\
\end{tabular} & 1981 & 54 lata & $\bar{M}$ & Tak \\
\hline 9 & Małe & \begin{tabular}{|l}
$\begin{array}{l}\text { Spółka } \\
\text { cywilna }\end{array}$ \\
\end{tabular} & $\begin{array}{l}\text { Produkcja } \\
\text { (masarnia) }\end{array}$ & 1979 & 51 lat & K & Tak \\
\hline 10 & Małe & \begin{tabular}{|l|} 
soba \\
fizyczna \\
\end{tabular} & $\begin{array}{l}\text { Usługi (wykań- } \\
\text { czanie dzianin) }\end{array}$ & 2004 & 38 lat & $\mathrm{M}$ & Tak \\
\hline 11 & Mikro & $\begin{array}{l}\text { Spółka } \\
\text { cywilna }\end{array}$ & $\begin{array}{l}\text { Handel (sklep } \\
\text { ogrodniczy) }\end{array}$ & 1999 & 45 lat & $\mathrm{M}$ & Tak \\
\hline 12 & Małe & $\begin{array}{l}\text { osoba } \\
\text { fizyczna }\end{array}$ & \begin{tabular}{|l}
$\begin{array}{l}\text { Handel } \\
\text { (hurtownia } \\
\text { alkoholi) }\end{array}$ \\
\end{tabular} & 2001 & 42 lata & K & Tak \\
\hline 13 & Średnie & \begin{tabular}{|l|} 
Spółka z \\
o.o. \\
\end{tabular} & \begin{tabular}{|l} 
Produkcja \\
(okna, drzwi)
\end{tabular} & 1991 & 53 lata & $\mathrm{M}$ & Tak \\
\hline 14 & Małe & $\begin{array}{l}\text { Spółka } \\
\text { jawna }\end{array}$ & $\begin{array}{l}\text { Produkcja (su- } \\
\text { rówki i kiszon- } \\
\text { ki) } \\
\end{array}$ & 1997 & 41 lat & $\mathrm{M}$ & Tak \\
\hline 15 & Mikro & \begin{tabular}{|l}
$\begin{array}{l}\text { Spółka } \\
\text { cywilna }\end{array}$ \\
\end{tabular} & $\begin{array}{l}\text { Usługi (biuro } \\
\text { rachunkowe) }\end{array}$ & 2005 & 33 lata & K & $\mathrm{Nie}$ \\
\hline
\end{tabular}

Źródło: opracowanie własne. 
Wpływ obszarów zmarginalizowanych na rozwój firmy potwierdziło 13 przedsiębiorców, w przypadku 2 firm z kategorii średnich nie potwierdzono tego wpływu. Za główne cechy obszarów zmarginalizowanych wpływające na rozwój przedstawiciele mikroprzedsiębiorstw uznali ograniczony popyt, wśród małych i średnich przedsiębiorstw - słabą infrastrukturę techniczną i małą liczbę klientów. Żadna z badanych firm nie wskazała zależności gospodarczej regionu od sektora pierwotnego oraz braku korzyści płynących z położenia w centrum rozwoju społeczno-gospodarczego (por. tabela 23).

Tabela 23. Wpływ specyficznych cech obszarów zmarginalizowanych na rozwój badanych przedsiębiorstw

\begin{tabular}{|c|c|c|c|c|}
\hline $\begin{array}{l}\text { Przedsię- } \\
\text { biorstwo }\end{array}$ & \begin{tabular}{|c|} 
Wpływ \\
specyfiki \\
obszaru na \\
rozwój
\end{tabular} & $\begin{array}{c}\text { Charakterystyka } \\
\text { wpływających czynników }\end{array}$ & Inne czynniki & Komentarz \\
\hline 1 & 2 & 3 & 4 & 5 \\
\hline 1 & Tak & $\begin{array}{l}\text { Ograniczony popyt } \\
\text { wynikający z niskich } \\
\text { dochodów społeczeń- } \\
\text { stwa, } \\
\text { Brak wykwalifikowanej } \\
\text { siły roboczej } \\
\end{array}$ & $\begin{array}{l}\text { Problemy z pozyska- } \\
\text { niem kapitału obcego } \\
\text { wynikające z niewy- } \\
\text { starczającej zdolności } \\
\text { kredytowej }\end{array}$ & $\begin{array}{l}\text { Problem z doborem } \\
\text { i dużą rotacją perso- } \\
\text { nelu }\end{array}$ \\
\hline 2 & Tak & $\begin{array}{l}\text { Mała liczba klientów } \\
\text { Słaba infrastruktura } \\
\text { techniczna } \\
\text { Brak klimatu dla } \\
\text { rozwoju przedsiębiorstw } \\
\text { w gminie } \\
\end{array}$ & $\begin{array}{l}\text { Niestabilne i niespójne } \\
\text { przepisy }\end{array}$ & $\begin{array}{l}\text { Problemy finansowe } \\
\text { wynikające } \mathrm{z} \text { braku } \\
\text { dotacji na moderniza- } \\
\text { cję sklepu. }\end{array}$ \\
\hline 3 & Tak & \begin{tabular}{|l|} 
Słaba infrastruktura \\
techniczna \\
Mała instytucji otoczenia \\
biznesu
\end{tabular} & $\begin{array}{l}\text { Mało sprzyjająca } \\
\text { koniunktura gospodar- } \\
\text { cza,- mniejszy popyt } \\
\text { ze względu na zmianę } \\
\text { tradycji żywieniowych }\end{array}$ & $\begin{array}{l}\text { Jest to firma rodzinna, } \\
\text { głównym problemem } \\
\text { jest proces sukcesji, } \\
\text { brak możliwości } \\
\text { pozyskania dotacji na } \\
\text { rozwój }\end{array}$ \\
\hline 4 & Tak & $\begin{array}{l}\text { Ograniczony popyt, } \\
\text { Słaba infrastruktura } \\
\text { techniczna } \\
\text { Mniejsza liczba firm } \\
\text { i wynikające z tego } \\
\text { mniejsze możliwości } \\
\text { współpracy } \\
\end{array}$ & $\begin{array}{l}\text { Problemy z pozyska- } \\
\text { niem kredytów na cele } \\
\text { mieszkaniowe }\end{array}$ & $\begin{array}{l}\text { Problemy z płynnością } \\
\text { finansową ze względu } \\
\text { na odroczone terminy } \\
\text { płatności }\end{array}$ \\
\hline 5 & Tak & $\begin{array}{l}\text { Słaby stan infrastruktury } \\
\text { technicznej, } \\
\text { Mniejsza liczba } \\
\text { klientów, } \\
\text { Niski poziom innowa- } \\
\text { cyjności }\end{array}$ & $\begin{array}{l}\text { Coraz węższy } \\
\text { wschodni rynek zbytu }\end{array}$ & $\begin{array}{l}\text { Problemy z pracowni- } \\
\text { kami, często są to oso- } \\
\text { by o niskich kwalifika- } \\
\text { cjach ulegające } \\
\text { różnym patologiom }\end{array}$ \\
\hline
\end{tabular}




\begin{tabular}{|c|c|c|c|c|}
\hline 1 & 2 & 3 & 4 & 5 \\
\hline 6 & Tak & $\begin{array}{l}\text { Niewystarczający popyt, } \\
\text { Brak klimatu dla } \\
\text { rozwoju przedsiębior- } \\
\text { czości }\end{array}$ & $\begin{array}{l}\text { Ciągłe zmiany } \\
\text { przepisów }\end{array}$ & $\begin{array}{l}\text { Mimo małej liczby } \\
\text { placówek tego typu } \\
\text { niewystarczający } \\
\text { popyt związany z siła } \\
\text { nabywczą lokalnego } \\
\text { społeczeństwa }\end{array}$ \\
\hline 7 & Tak & $\begin{array}{l}\text { Słaba współpraca władz } \\
\text { gminy z przedsiębiorca- } \\
\text { mi, } \\
\text { Brak inwestycji co } \\
\text { powoduje odpływ } \\
\text { ludności }\end{array}$ & $\begin{array}{l}\text { Utrudniony dostęp do } \\
\text { kredytów inwestycyj- } \\
\text { nych }\end{array}$ & $\begin{array}{l}\text { Skończyły się dotacje } \\
\text { w gminie na budowę } \\
\text { oczyszczalni, co spo- } \\
\text { wodowało znaczne } \\
\text { ograniczenie popytu }\end{array}$ \\
\hline 8 & Nie & nie dotyczy & $\begin{array}{l}\text { Częste zmiany } \\
\text { przepisów, wysokie } \\
\text { obciążenia podatkowe }\end{array}$ & $\begin{array}{l}\text { Przedsiębiorstwo } \\
\text { o wysokim stopniu } \\
\text { profesjonalizmu } \\
\text { zarządzania } \\
\end{array}$ \\
\hline 9 & Tak & $\begin{array}{l}\text { Niewystarczający popyt, } \\
\text { Mała konkurencyjność } \\
\text { gminy } \\
\text { Odpływ ludności }\end{array}$ & $\begin{array}{l}\text { Uciążliwe kontrole, } \\
\text { Brak wiedzy na temat } \\
\text { możliwości wsparcia } \\
\text { ze środków UE }\end{array}$ & $\begin{array}{l}\text { Problemy z pracowni- } \\
\text { kami, duża rotacja }\end{array}$ \\
\hline 10 & Tak & $\begin{array}{l}\text { Infrastruktura technicz- } \\
\text { na, } \\
\text { Mała liczba instytucji } \\
\text { biznesu } \\
\text { Brak informacji o moż- } \\
\text { liwościach finansowego } \\
\text { wsparcia }\end{array}$ & $\begin{array}{l}\text { Niesprzyjająca } \\
\text { koniunktura gospodar- } \\
\text { cza, kurczące się } \\
\text { możliwości eksporto- } \\
\text { we na wschód }\end{array}$ & $\begin{array}{l}\text { Przedsiębiorstwo } \\
\text { nastawione na rozwój, } \\
\text { rozważa zmianę } \\
\text { profilu działalności }\end{array}$ \\
\hline 11 & Tak & $\begin{array}{l}\text { Mała liczba klientów, } \\
\text { Niska konkurencyjność } \\
\text { regionu, - mało } \\
\text { informacji o formach } \\
\text { wsparcia }\end{array}$ & $\begin{array}{l}\text { Uwarunkowania } \\
\text { klimatyczne, Wysokie } \\
\text { ryzyko prowadzonej } \\
\text { działalności }\end{array}$ & \begin{tabular}{|l|} 
Mała liczba firm \\
zajmujących się \\
zakładaniem ogrodów \\
w gminie, co powodu- \\
je brak możliwości \\
współpracy
\end{tabular} \\
\hline 12 & Tak & $\begin{array}{l}\text { Słaba infrastruktura } \\
\text { techniczna, w szczegól- } \\
\text { ności stan dróg, } \\
\text { Ograniczony popyt, } \\
\text { Mała liczba instytucji } \\
\text { otoczenia biznesu }\end{array}$ & $\begin{array}{l}\text { Słaba wiedza właści- } \\
\text { ciela firmy odnośnie } \\
\text { możliwości wsparcia } \\
\text { ze środków unijnych }\end{array}$ & $\begin{array}{l}\text { Nastawienie prorozwo- } \\
\text { jowe, rozszerzenie } \\
\text { działalności. }\end{array}$ \\
\hline 13 & $\mathrm{Nie}$ & Nie dotyczy & $\begin{array}{l}\text { Ograniczony dostęp do } \\
\text { kredytów na cele } \\
\text { mieszkaniowe }\end{array}$ & $\begin{array}{l}\text { Brak płynności } \\
\text { finansowej ze względu } \\
\text { na odroczone terminy } \\
\text { płatności }\end{array}$ \\
\hline 14 & Tak & $\begin{array}{l}\text { Mała liczba klientów, } \\
\text { Mała liczba przedsię- } \\
\text { biorstw - brak możliwo- } \\
\text { ści współpracy }\end{array}$ & $\begin{array}{l}\text { Wysokie koszty } \\
\text { prowadzenia działal- } \\
\text { ności, zmiany } \\
\text { klimatyczne powodu- } \\
\text { jące duże wahani cen } \\
\text { surowców }\end{array}$ & $\begin{array}{l}\text { Brak możliwości } \\
\text { pozyskania środków } \\
\text { na działalność } \\
\text { innowacyjną, } \\
\text { Opór właściciela na } \\
\text { wszelkie zmiany } \\
\end{array}$ \\
\hline
\end{tabular}


Tabela 23 (cd.)

\begin{tabular}{|c|c|l|l|l|}
\hline 1 & 2 & \multicolumn{1}{|c|}{3} & \multicolumn{1}{c|}{4} \\
\hline 15 & Tak & $\begin{array}{l}\text { Mała liczba firm } \\
\text { będących potencjalnymi } \\
\text { klientami, } \\
\text { Brak przyjaznego } \\
\text { klimatu dla rozwoju } \\
\text { przedsiębiorczości }\end{array}$ & $\begin{array}{l}\text { Niejasne przepisy, } \\
\text { wysokie koszty } \\
\text { prowadzenia działal- } \\
\text { ności }\end{array}$ & $\begin{array}{l}\text { Przedsiębiorstwo } \\
\text { wymaga rozszerzenia } \\
\text { działalności o inne } \\
\text { usługi dla firm }\end{array}$ \\
& & & \\
\hline
\end{tabular}

Źródło: opracowanie własne.

W badaniu ilościowym przedsiębiorcy, którzy podkreśli wpływ obszarów zmarginalizowanych na rozwój MSP, wskazali również cechy tych obszarów, które miały największy wpływ na rozwój ich przedsiębiorstwa. Korzystając z listy zaproponowanych cech tych obszarów (por. rysunek 29), respondenci oceniali siłę, $\mathrm{z}$ jaką dana cecha ma wpływ na rozwój badanego przedsiębiorstwa. Oceny dokonano w skali od 0 do 5, przy czym: 0 - brak wpływu, a 5 - najsilniejszy wpływ.

Tabela 24. Wartość statystyki $(H)$ według testu Kruskala-Wallisa oraz poziom prawdopodobieństwa testowego $(p)$ zmiennych określających cechy obszarów zmarginalizowanych w kontekście wielkości przedsiębiorstwa

\begin{tabular}{|l|c|c|}
\hline \multicolumn{1}{|c|}{ Cechy obszarów zmarginalizowanych } & $\begin{array}{c}\text { Wartość statystyki }(H) \\
\text { wedhug testu } \\
\text { Kruskala-Wallisa }\end{array}$ & $\begin{array}{c}\text { Prawdopodo- } \\
\text { bieństwo } \\
\text { testowe }(p)\end{array}$ \\
\hline Mała konkurencyjność regionu & 17,360 & 0,000 \\
\hline $\begin{array}{l}\text { Zależność gospodarcza od sektora pierwotnego np. } \\
\text { rolnictwa }\end{array}$ & 16,264 & 0,000 \\
\hline $\begin{array}{l}\text { Brak korzyści związanych z funkcjonowaniem } \\
\text { w centrum rozwoju }\end{array}$ & 1,279 & 0,585 \\
\hline Niski poziom innowacyjności regionu & 9,342 & 0,009 \\
\hline Gorsza infrastruktura techniczna & 13,793 & 0,000 \\
\hline Brak wykwalifikowanej siły roboczej & 12,471 & 0,000 \\
\hline $\begin{array}{l}\text { Brak klimatu przyjaznego dla rozwoju przedsię- } \\
\text { biorstw }\end{array}$ & 13,752 & 0,000 \\
\hline Ograniczony dostęp do otoczenia biznesu & 7,382 & 0,041 \\
\hline Mniejsza liczba potencjalnych klientów & 14,543 & 0,000 \\
\hline Ograniczony dostęp do środków finansowych & 12,241 & 0,000 \\
\hline Bierne wsparcie ze strony władz samorządowych & 14,331 & 0,000 \\
\hline Ograniczony dostęp do informacji & 3,654 & 0,878 \\
\hline Brak umiejętności wykorzystania środków unijnych & 1,322 & 0,598 \\
\hline
\end{tabular}

Źródło: opracowanie własne.

Rozkład wypowiedzi respondentów wskazuje na zróżnicowanie siły wpływu specyficznych cech obszaru zmarginalizowanego w zależności od wielkości 
przedsiębiorstwa, potwierdził to również test Kruskala-Wallisa. Jego wyniki i prawdopodobieństwo testowe $(p<0,05)$ pokazały zróżnicowanie większości badanych zmiennych (por. tabela 24 ).

W mikroprzedsiębiorstwach największy wpływ miała mniejsza liczba potencjalnych klientów (51,2\% wskazań) oraz brak klimatu przyjaznego dla rozwoju przedsiębiorstw (45,9\% wskazań), w małych przedsiębiorstwach bierne wsparcie ze strony władz samorządowych (48,7\% wskazań) oraz niski poziom innowacyjności regionu (47,9\% wskazań). Natomiast średnie przedsiębiorstwa wskazały jako największy wpływ: brak wykwalifikowanej siły roboczej $(47,2 \%$ wskazań) oraz gorszą infrastrukturę techniczną (45,7\% wskazań) (por. rysunek 66). Wskazane przez respondentów cechy o największym wpływie to znaczące bariery w funkcjonowaniu MSP w obszarach zmarginalizowanych. Powinny one zostać ograniczone przez politykę wsparcia tego sektora ze strony samorządu terytorialnego oraz szeroką ofertę usług otoczenia biznesu odpowiadającą potrzebom tych podmiotów. Siła wpływu specyficznych cech obszaru zmarginalizowanego jest zróżnicowana w poszczególnych kategoriach firm (mikro, małych i średnich), co pozwala pozytywnie zweryfikować hipotezę $\mathrm{H}_{8}$ : Specyficzne cechy obszaru zmarginalizowanego wpływają w różny sposób na rozwój przedsiębiorstwa w zależności od jego wielkości.

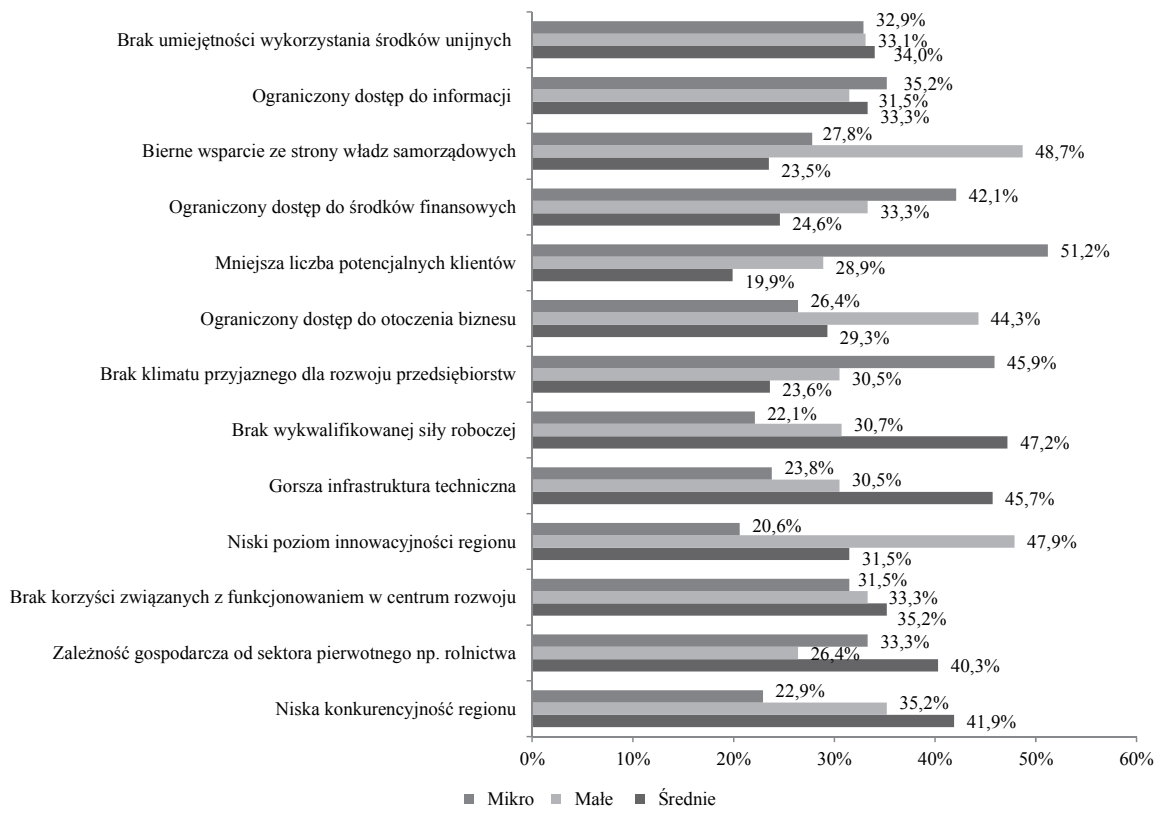

Uwaga: Respondenci mogli wybrać trzy odpowiedzi według ważności w skali 1-3, co oznaczało: 1 - ważna, 2 - bardzo ważna, 3 - najważniejsza.

Rysunek 66. Wpływ cech obszarów zmarginalizowanych na rozwój przedsiębiorstwa Źródło: opracowanie własne 
Na rozwój małych i średnich przedsiębiorstw, w tym również zlokalizowanych $\mathrm{w}$ obszarach zmarginalizowanych, ma niewątpliwie wpływ prowadzona przez te podmioty działalność innowacyjna i inwestycyjna. Przedsiębiorcy w badaniu ilościowym i jakościowym ocenili wpływ marginalizacji obszaru na wprowadzanie innowacji i realizację inwestycji. Respondenci w większości przypadków widzieli ten wpływ (70,5\% wskazań) (por. rysunek 67). W mikroprzedsiębiorstwach wpływ ten był największy i został określony jako duży i znaczący (łącznie 57,5\% wskazań), w małych i średnich przedsiębiorstwach oceniono go jako umiarkowany i znaczący (odpowiednio łącznie: 49,6\% i 44,1\% wskazań) (por. rysunek 67). Wyniki te są podobne, jak w przypadku oceny wpływu marginalizacji regionu na rozwój przedsiębiorstwa w przypadku mikro i małych przedsiębiorstw, natomiast $w$ przypadku średnich oceniona siła wpływu jest znacząco większa niż w przypadku oceny wpływu marginalizacji obszaru na rozwój przedsiębiorstwa.

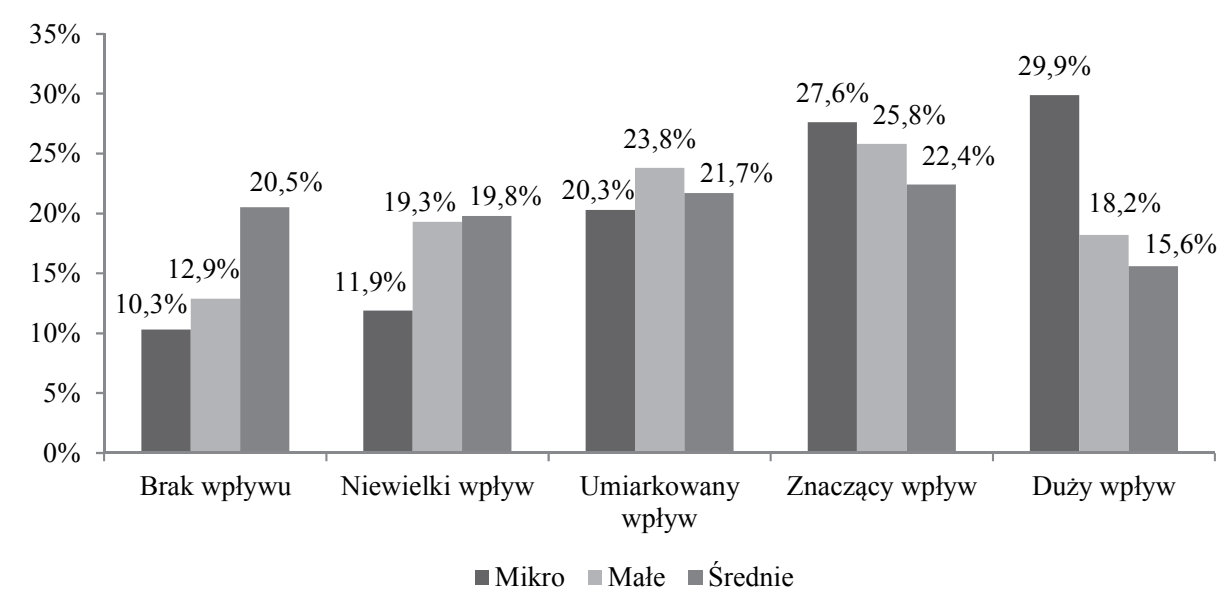

Rysunek 67. Wpływ marginalizacji obszaru na działalność innowacyjną i inwestycyjną Źródło: opracowanie własne

Poziom innowacyjność badanych przedsiębiorstw należy ocenić bardzo nisko, tylko 67 firm (niecałe 25\%) bowiem wprowadziło innowacje w 2009-2011. Najwięcej innowacji zostało wdrożonych w średnich firmach $(82,5 \%$ przedsiębiorstw), które dysponują środkami finansowymi na działalność innowacyjną, prowadząc ją we własnym zakresie lub w jednostkach $\mathrm{B}+\mathrm{R}$. W przypadku mikro i małych firm ten wynik był znacznie słabszy i wynosił odpowiednio $14,3 \%$ (przedsiębiorstw), i 28,6\% (przedsiębiorstw) (por. rysunek 68). Przyczyn tego stanu rzeczy należy upatrywać $\mathrm{w}$ wielu czynnikach mających raczej charakter barier omówionych w dalszej części opracowania. 
W badaniach jakościowych 5 przedsiębiorstw nie wprowadziło innowacji. Były to głównie przedsiębiorstwa handlowe (por. tabela 26).

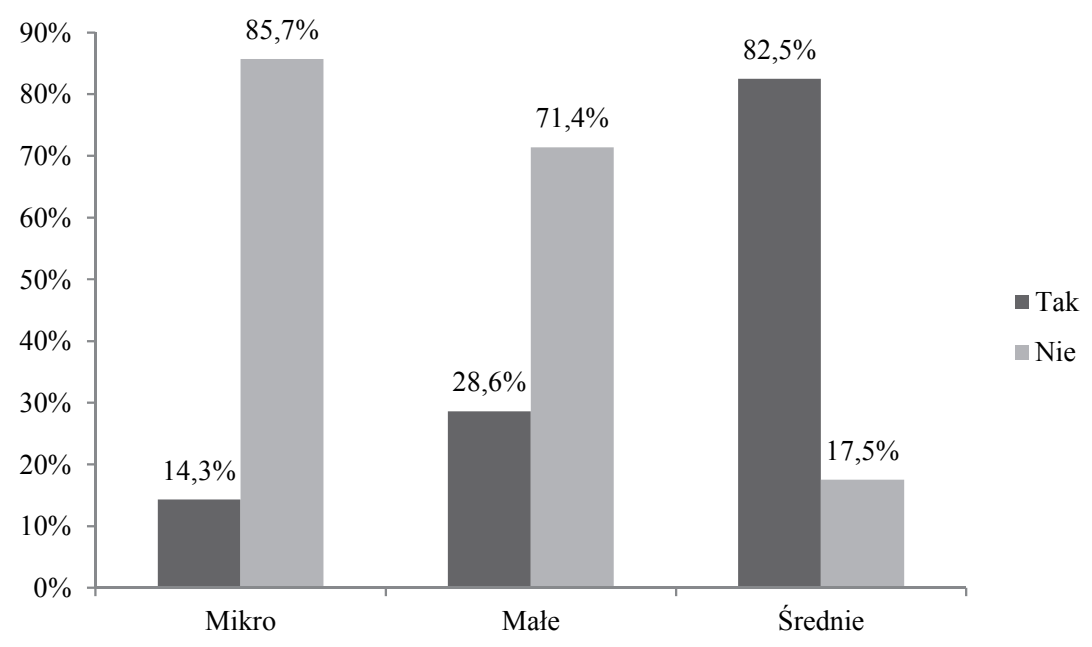

Rysunek 68. Wprowadzone innowacje w latach 2009-2011

Źródło: opracowanie własne

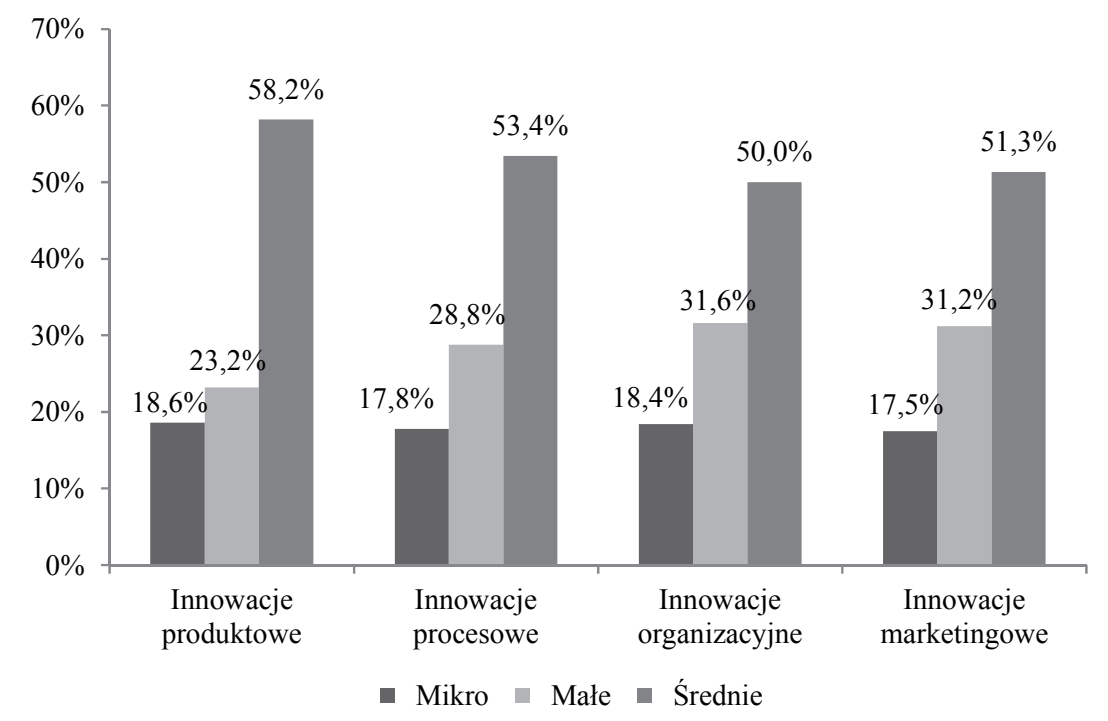

Uwaga: Respondenci mogli wskazać więcej niż jedną odpowiedź.

Rysunek 69. Rodzaje wprowadzonych innowacji

Źródło: opracowanie własne 
Najczęściej w badanych firmach wprowadzano innowacje produktowe (41,2\% wskazań) i procesowe (26\% wskazań), najmniej marketingowych (14,1\% wskazań). Jest to powszechna tendencja potwierdzona wieloma badaniami omawianymi w bogatej literaturze przedmiotu (por. np. Stawasz E. 2011; Lisowska, Stanisławski 2010; Jonasz, Kozioł 2007). Liderem w zakresie wprowadzonych innowacji były średnie przedsiębiorstwa, które dominowały w każdej kategorii innowacji (innowacje produktowe 58,2\%, procesowe 53,4\%, organizacyjne $50 \%$, marketingowe $51,3 \%$ ), świadczy to o dużym potencjale innowacyjnym tych podmiotów. W mikro i małych przedsiębiorstwach liczba wprowadzonych innowacji była znacznie mniejsza ze względu na ograniczoność zasobów finansowych, rzeczowych i ludzkich (por. rysunek 69). Podobne wyniki osiągnięto w badaniach jakościowych (por. tabela 26).

Wprowadzone rodzaje innowacji charakteryzowały się niskim stopniem nowości głównie na poziomie firmy, rzadziej na poziomie rynku lokalnego i krajowego. Taki rozkład wypowiedzi odnotowano w każdej z kategorii firm ze względu na wielkość (mikro, małe i średnie) (por. rysunek 70). Żadna z badanych firm nie mogła się pochwalić wprowadzoną innowacją na poziomie międzynarodowym, co może negatywnie wpłynąć w przyszłości na pozyskanie środków finansowych na działalność innowacyjną z funduszy unijnych.

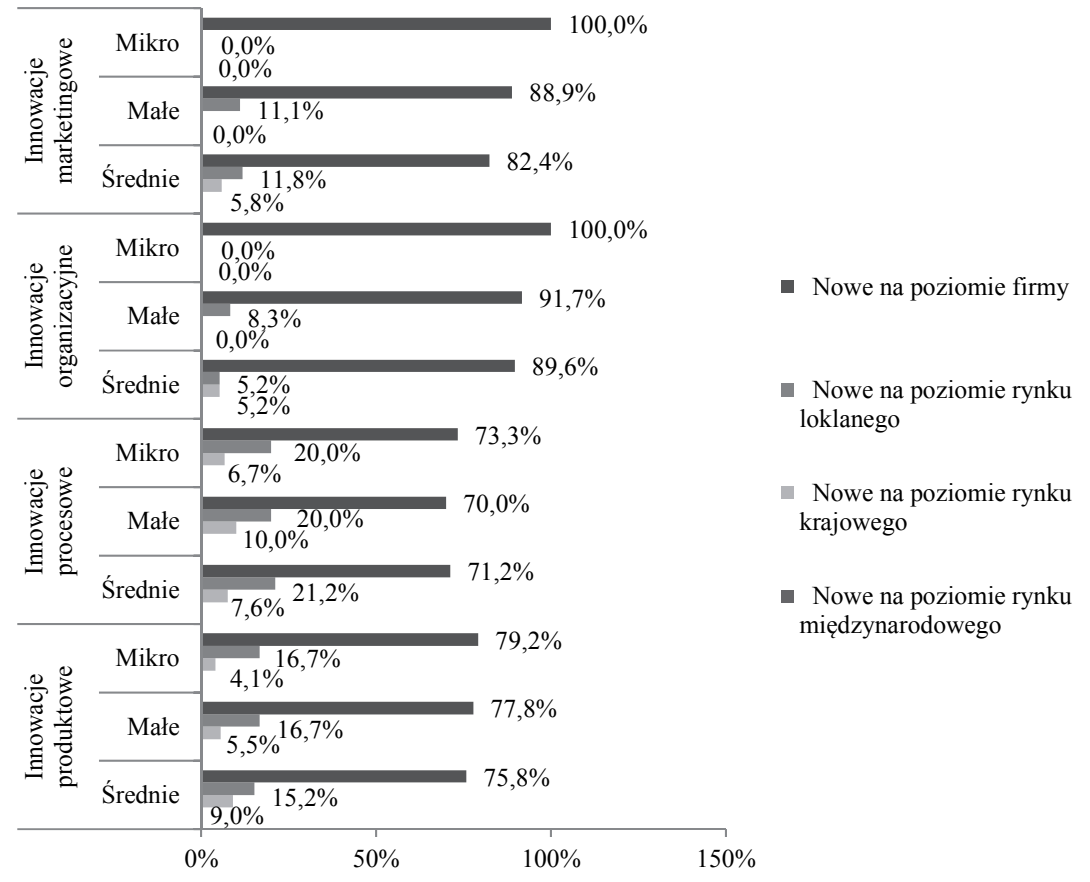

Rysunek 70. Stopień nowości zmian innowacyjnych według rodzaju innowacji Źródło: opracowanie własne 
Kolejnym obszarem badawczym było określenie przyczyn wprowadzenia innowacji. Rozkład wypowiedzi respondentów wskazuje na zróżnicowanie tych przyczyn w zależności od wielkości przedsiębiorstwa, potwierdził to również test Kruskala-Wallisa. Jego wyniki i prawdopodobieństwo testowe $(p<0,05)$ pokazały zróżnicowanie większości badanych zmiennych (por. tabela 25).

Tabela 25. Wartość statystyki $(H)$ według testu Kruskala-Wallisa oraz poziom prawdopodobieństwa testowego $(p)$ zmiennych określających przyczyny wprowadzenia innowacji w kontekście wielkości przedsiębiorstwa

\begin{tabular}{|l|c|c|}
\hline \multicolumn{1}{|c|}{ Przyczyny wprowadzenia innowacji } & $\begin{array}{c}\text { Wartość statystyki } \\
(H) \text { według testu } \\
\text { Kruskala-Wallisa }\end{array}$ & $\begin{array}{c}\text { Prawdopodo- } \\
\text { bieństwo } \\
\text { testowe }(p)\end{array}$ \\
\hline Presja konkurencji & 10,361 & 0,008 \\
\hline Chęć zwiększenia zysków & 12,264 & 0,001 \\
\hline Zwiększenie konkurencyjności firmy & 11,279 & 0,000 \\
\hline Rozwój przedsiębiorstwa & 7,342 & 0,045 \\
\hline Poprawa warunków i bezpieczeństwa pracy & 13,684 & 0,000 \\
\hline Malejące w ostatnich 3 latach koszty wdrożeń innowacji & 12,972 & 0,000 \\
\hline Potrzeby rynku & 14,751 & 0,000 \\
\hline Obniżenie kosztów działalności & 8.342 & 0,039 \\
\hline Zwiększenie jakości i wydajności pracy & 1,543 & 0,655 \\
\hline Zwiększenie sprawności i efektywności działania & 2,542 & 0,523 \\
\hline
\end{tabular}

Źródło: opracowanie własne.

W mikroprzedsiębiorstwach najczęściej wskazywano, jak przyczyny wprowadzania innowacji presję konkurencji (45,1\% wskazań), potrzeby rynku (44,7\% wskazań) oraz chęć zwiększenia zysków (41,1\% wskazań), w małych przedsiębiorstwach zwiększenie konkurencyjności firmy (47,7\% wskazań) oraz zwiększenie sprawności i efektywności działania (41,2\% wskazań), - natomiast w średnich firmach - rozwój przedsiębiorstwa (42,1\% wskazań), zwiększenie jakości i wydajności pracy (41,4\% wskazań) oraz obniżenie kosztów działalności (39,5\% wskazań) (por. rysunek 71). Wyniki te wskazują na różne potrzeby wprowadzenia innowacji, ponieważ w zależności od skali działania dla mikroprzedsiębiorstw najważniejsze są działania w celu poprawy sytuacji na rynku, w małych przedsiębiorstwach dodatkowo poprawa efektywności działania, a w przypadku średnich przedsiębiorstw rozwój firmy i poprawa sprawności i skuteczności działalności operacyjnej. 


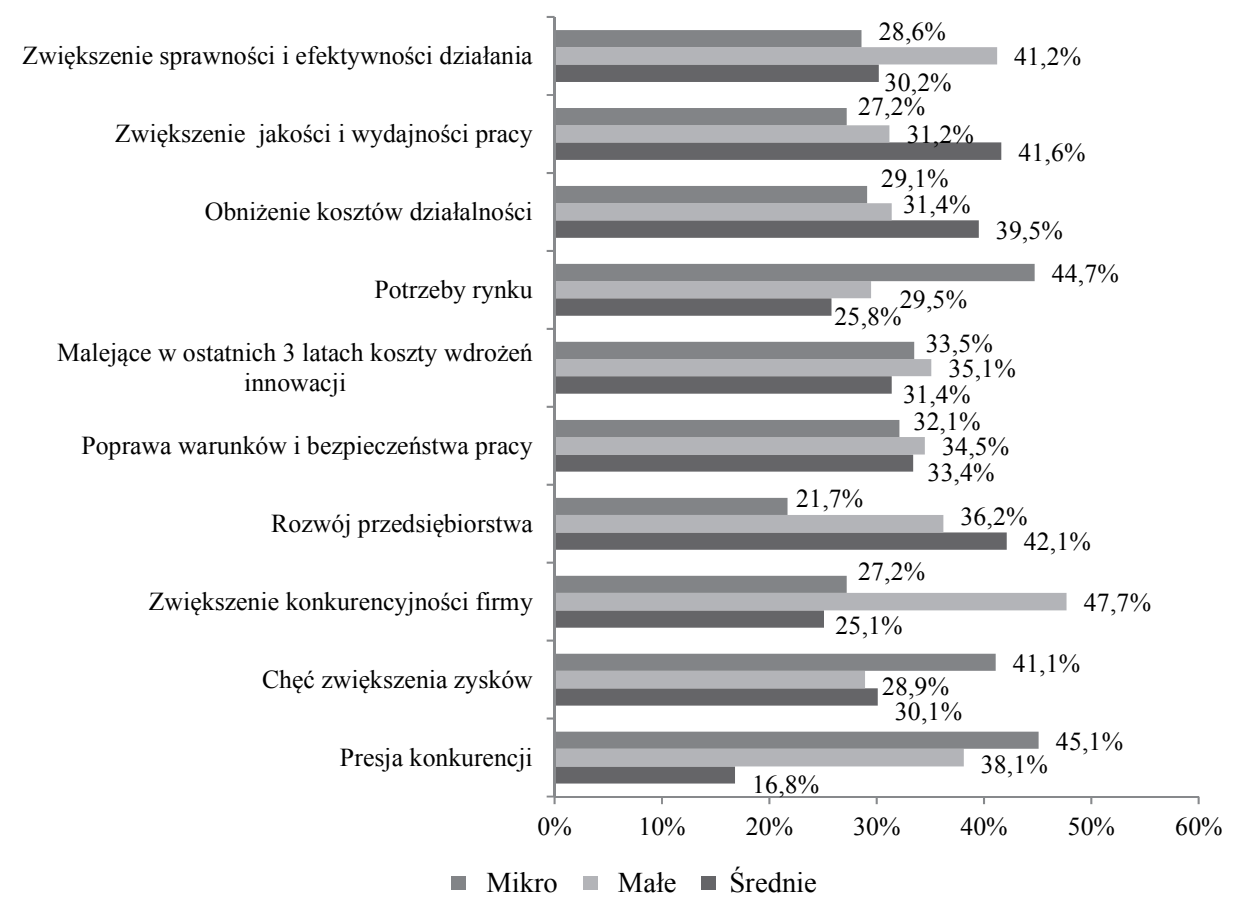

Uwaga: Respondenci mogli wskazać trzy odpowiedzi według ważności w skali 1-3, co oznaczało: 1 - ważna, 2 - bardzo ważna, 3 - najważniejsza.

Rysunek 71. Przyczyny wprowadzenia innowacji

Źródło: opracowanie własne

Potwierdziły to również badania jakościowe, w których dodatkowo część respondentów wskazała plany odnośnie do działalności innowacyjnej (por. tabela 26). Przedsiębiorcy wyrazili chęć kontynuowania lub rozpoczęcia takiej działalności w różnych obszarach funkcjonowania przedsiębiorstwa. Najczęściej wskazywano: rozpoczęcie działalności eksportowej, wprowadzeni innowacji marketingowych i organizacyjnych. Barierą jednak mogą stać się problemy finansowe (szerzej Bielawska red. 2009, Skowronek-Mielczarek 2011a i b, Piasecki red. 2012), niewystarczające zasoby kadrowe (szerzej Sikorski 2009, Zając 2007) jak również w przypadku przedsiębiorstw rodzinnych zmiany pokoleniowe (szerzej Bielawska 2011, Jeżak 2010, Marjański 2010). Biorąc pod uwagę te uwarunkowania, przedsiębiorstwa powinny budować swoją strategię innowacyjną polegającą na projektowaniu rozwiązań technicznych i zasad uczestnictwa w przedsięwzięciach innowacyjnych (Janasz red. 2009). 
Tabela 26. Marginalizacja obszaru na rozwój działalności innowacyjnej

\begin{tabular}{|c|c|c|c|c|}
\hline $\begin{array}{l}\text { Przedsiębior- } \\
\text { stwo }\end{array}$ & $\begin{array}{l}\text { Rodzaje } \\
\text { innowacji }\end{array}$ & $\begin{array}{c}\text { Przyczyny } \\
\text { wprowadzenia } \\
\text { zmian } \\
\end{array}$ & $\begin{array}{c}\text { Sposób } \\
\text { finansowania }\end{array}$ & Komentarz \\
\hline 1 & 2 & 3 & 4 & 5 \\
\hline 1 & Produktowe & $\begin{array}{|lr|}\begin{array}{l}\text { Presja } \\
\text { cji, }\end{array} & \text { konkuren- } \\
\text { Trendy } & \text { (zmiana } \\
\text { mody) } & \\
\end{array}$ & \begin{tabular}{|l|} 
Środki własne - \\
oszczędności \\
właściciela
\end{tabular} & $\begin{array}{l}\text { Przedsiębiorstwo nasta- } \\
\text { wione na rozwój dzia- } \\
\text { talności innowacyjnej } \\
\text { w obszarze marketingu, } \\
\text { barierą jest brak środków } \\
\text { finansowych oraz prob- } \\
\text { lemy kadrowe }\end{array}$ \\
\hline 2 & $\begin{array}{l}\text { Firma nie } \\
\text { wprowadziła } \\
\text { innowacji }\end{array}$ & Nie dotyczy & Nie dotyczy & $\begin{array}{l}\text { Ze względu na rodzaj } \\
\text { prowadzonej działalności } \\
\text { firma nie planuje żadnych } \\
\text { zmian w najbliższym } \\
\text { czasie }\end{array}$ \\
\hline 3 & $\begin{array}{l}\text { Procesowe, } \\
\text { produktowe }\end{array}$ & \begin{tabular}{|l|} 
Silna konkuren- \\
cja, \\
Potrzeby \\
klientów, \\
Zwiększenie \\
wydajności \\
\end{tabular} & $\begin{array}{l}\text { Leasing i kre- } \\
\text { dyt bankowy }\end{array}$ & $\begin{array}{l}\text { W przedsiębiorstwie trud- } \\
\text { no o zmiany ze względu } \\
\text { na rodzinnych charakter }\end{array}$ \\
\hline 4 & \begin{tabular}{|l|} 
Produktowe \\
organizacyjne
\end{tabular} & \begin{tabular}{|l|} 
Zwiększenie kon- \\
kurencyjności \\
firmy, \\
Poprawa \\
warunków i \\
bezpieczeństwa \\
pracy
\end{tabular} & $\begin{array}{l}\text { Środki własne, } \\
\text { leasing }\end{array}$ & $\begin{array}{l}\text { Rozwiązania innowacyjne } \\
\text { na szerszą skalę możliwe } \\
\text { po uzyskaniu dotacji unij- } \\
\text { nej }\end{array}$ \\
\hline 5 & $\begin{array}{l}\text { Produktowe, } \\
\text { procesowe } \\
\text { i organizacyjne }\end{array}$ & \begin{tabular}{|ll} 
Zwiększenie & \\
jakości & $\mathrm{i}$ \\
wydajności & \\
pracy, \\
Poprawa \\
warunków \\
bezpieczeństwa \\
pracy
\end{tabular} & $\begin{array}{l}\text { Leasing, kredyt } \\
\text { bankowy }\end{array}$ & $\begin{array}{l}\text { Przedsiębiorstwo } \\
\text { zorientowane na wysoko } \\
\text { innowacyjne rozwiązania } \\
\text { w zakresie produkcji }\end{array}$ \\
\hline 6 & \begin{tabular}{|l} 
Firma nie \\
wprowadziła \\
innowacji \\
\end{tabular} & Nie dotyczy & Nie dotyczy & $\begin{array}{l}\text { W przyszłości planowane } \\
\text { są innowacje organiza- } \\
\text { cyjne. }\end{array}$ \\
\hline 7 & $\begin{array}{l}\text { Firma nie } \\
\text { wprowadziła } \\
\text { innowacji }\end{array}$ & Nie dotyczy & Nie dotyczy & $\begin{array}{l}\text { W przyszłości planowane } \\
\text { są innowacje marketin- } \\
\text { gowe związane z podję- } \\
\text { ciem działalności ekspor- } \\
\text { towej }\end{array}$ \\
\hline 8 & $\begin{array}{l}\text { Produktowe, } \\
\text { procesowe } \\
\text { organizacyjne }\end{array}$ & \begin{tabular}{|l|} 
Silna konkuren- \\
cja, \\
Zwiększenie \\
konkurencyjności
\end{tabular} & $\begin{array}{l}\text { Dotacja unijna, } \\
\text { leasing }\end{array}$ & $\begin{array}{l}\text { Przedsiębiorstwo } \\
\text { zorientowane na wysoko } \\
\text { innowacyjne rozwiązania } \\
\text { w zakresie produkcji }\end{array}$ \\
\hline
\end{tabular}


Tabela 26 (cd.)

\begin{tabular}{|c|c|c|c|c|}
\hline 1 & 2 & 3 & 4 & 5 \\
\hline 9 & $\begin{array}{l}\text { Produktowe, } \\
\text { procesowe } \\
\text { organizacyjne i } \\
\text { marketingowe }\end{array}$ & $\begin{array}{l}\text { Potrzeby rynku, } \\
\text { Silna konkuren- } \\
\text { cja, } \\
\text { Zwiększenie } \\
\text { jakości i wydaj- } \\
\text { ności pracy }\end{array}$ & \begin{tabular}{|l|} 
Kredyt \\
bankowy, \\
leasing, zysk \\
niepodzielony
\end{tabular} & $\begin{array}{l}\text { Przedsiębiorstwo zamie- } \\
\text { rza, rozszerzyć asorty- } \\
\text { ment i w ciągu jednego } \\
\text { roku otworzenie sieci } \\
\text { sklepów, jednak proble- } \\
\text { mem mogą okazać się } \\
\text { zasoby ludzkie }\end{array}$ \\
\hline 10 & Procesowe & \begin{tabular}{|l|} 
Silna konkuren- \\
cja, \\
Zwiększenie \\
sprawności i efek- \\
tywności \\
działania \\
\end{tabular} & $\begin{array}{l}\text { Leasing, środki } \\
\text { własne }\end{array}$ & $\begin{array}{l}\text { Przedsiębiorstwo planuje } \\
\text { dalszy rozwój działalno- } \\
\text { ści innowacyjnej poprzez } \\
\text { unowocześnienie parku } \\
\text { maszynowego }\end{array}$ \\
\hline 11 & $\begin{array}{l}\text { Firma nie } \\
\text { wprowadziła } \\
\text { innowacji }\end{array}$ & Nie dotyczy & Nie dotyczy & Brak \\
\hline 12 & $\begin{array}{l}\text { Produktowe, } \\
\text { procesowe } \\
\text { organizacyjne } \\
\text { i marketingowe }\end{array}$ & $\begin{array}{l}\text { Presja konkuren- } \\
\text { cji, } \\
\text { Obniżenie kosz- } \\
\text { tów dzielności, } \\
\text { Zwiększenie } \\
\text { sprawności i efek- } \\
\text { tywności }\end{array}$ & \begin{tabular}{|lr} 
Środki własne, \\
kredyt banko- \\
wy, dotacja unij- \\
na
\end{tabular} & $\begin{array}{l}\text { Przedsiębiorstwo zamie- } \\
\text { rza rozszerzyć swoją } \\
\text { sprzedaż o półprodukty }\end{array}$ \\
\hline 13 & $\begin{array}{l}\text { Produktowe, } \\
\text { procesowe, } \\
\text { marketingowe }\end{array}$ & $\begin{array}{l}\text { Potrzeby rynku, } \\
\text { Poprawa warun- } \\
\text { ków i bezpie- } \\
\text { czeństwa pracy }\end{array}$ & $\begin{array}{l}\text { Kredyt banko- } \\
\text { wy, leasing }\end{array}$ & $\begin{array}{l}\text { Przedsiębiorstwo planuje } \\
\text { działalność eksportową }\end{array}$ \\
\hline 14 & $\begin{array}{l}\text { Produktowe, } \\
\text { procesowe, } \\
\text { organizacyjne }\end{array}$ & $\begin{array}{|lr|}\text { Silna } & \text { konkuren- } \\
\text { cja, zwiększenie } \\
\text { jakości i wydaj- } \\
\text { ności }\end{array}$ & $\begin{array}{l}\text { Leasing, środki } \\
\text { własne, dotacja } \\
\text { unijna }\end{array}$ & $\begin{array}{l}\text { Przedsiębiorstwo } \\
\text { zorientowane na rozwój } \\
\text { i wprowadzanie zmian }\end{array}$ \\
\hline 15 & $\begin{array}{l}\text { Firma nie wpro- } \\
\text { wadziła } \\
\text { innowacji }\end{array}$ & Nie dotyczy & Nie dotyczy & Brak \\
\hline
\end{tabular}

Źródło: opracowanie własne.

Przedsiębiorcy, którzy określili powody wprowadzenia innowacji, wskazali również bariery ich wdrożenia. Rozkład wypowiedzi respondentów wskazuje na zróżnicowanie tych barier w zależności od wielkości przedsiębiorstwa, potwierdził to również test Kruskala-Wallisa. Jego wyniki i prawdopodobieństwo testowe $(p<0,05)$ pokazały zróżnicowanie większości badanych zmiennych (por. tabela 27). 
Tabela 27. Wartość statystyki $(H)$ według testu Kruskala-Wallisa oraz poziom prawdopodobieństwa testowego $(p)$ zmiennych określających bariery wprowadzenia innowacji w kontekście wielkości przedsiębiorstwa

\begin{tabular}{|c|c|c|}
\hline Bariery wprowadzenia innowacji & \begin{tabular}{|c|} 
Wartość statystyki $(H)$ \\
według testu \\
Kruskala-Wallisa
\end{tabular} & $\begin{array}{l}\text { Prawdopodo- } \\
\text { bieństwo } \\
\text { testowe }(p)\end{array}$ \\
\hline $\begin{array}{lllll}\begin{array}{l}\text { Wysokie koszty } \\
\text { innowacji }\end{array} & \text { przygotowania } & \text { i } & \text { wdrożenia } \\
\end{array}$ & 12,166 & 0,000 \\
\hline Brak odpowiednio wykwalifikowanego personelu & 9,164 & 0,008 \\
\hline Zbyt duże ryzyko związane $\mathrm{z}$ wdrożeniem innowacji & 12,270 & 0,000 \\
\hline Niewystarczająca baza techniczna & 10,342 & 0,002 \\
\hline Brak informacji na temat nowości technicznych & 1,356 & 0,178 \\
\hline $\begin{array}{l}\text { Brak zainteresowania nowymi produktami/usługami } \\
\text { ze strony klientów/odbiorców }\end{array}$ & 11,979 & 0,000 \\
\hline $\begin{array}{l}\text { Brak znajomości rynku (potrzeby klientów, moż- } \\
\text { liwości sprzedaży }\end{array}$ & 2,758 & 0,098 \\
\hline $\begin{array}{l}\text { Trudny dostęp do odpowiednich specjalistów i do- } \\
\text { radców }\end{array}$ & 9.342 & 0,011 \\
\hline $\begin{array}{l}\text { Brak sektorowych kontaktów (tj. potencjalnych } \\
\text { kooperantów) }\end{array}$ & 1,543 & 0,655 \\
\hline
\end{tabular}

Źródło: opracowanie własne.

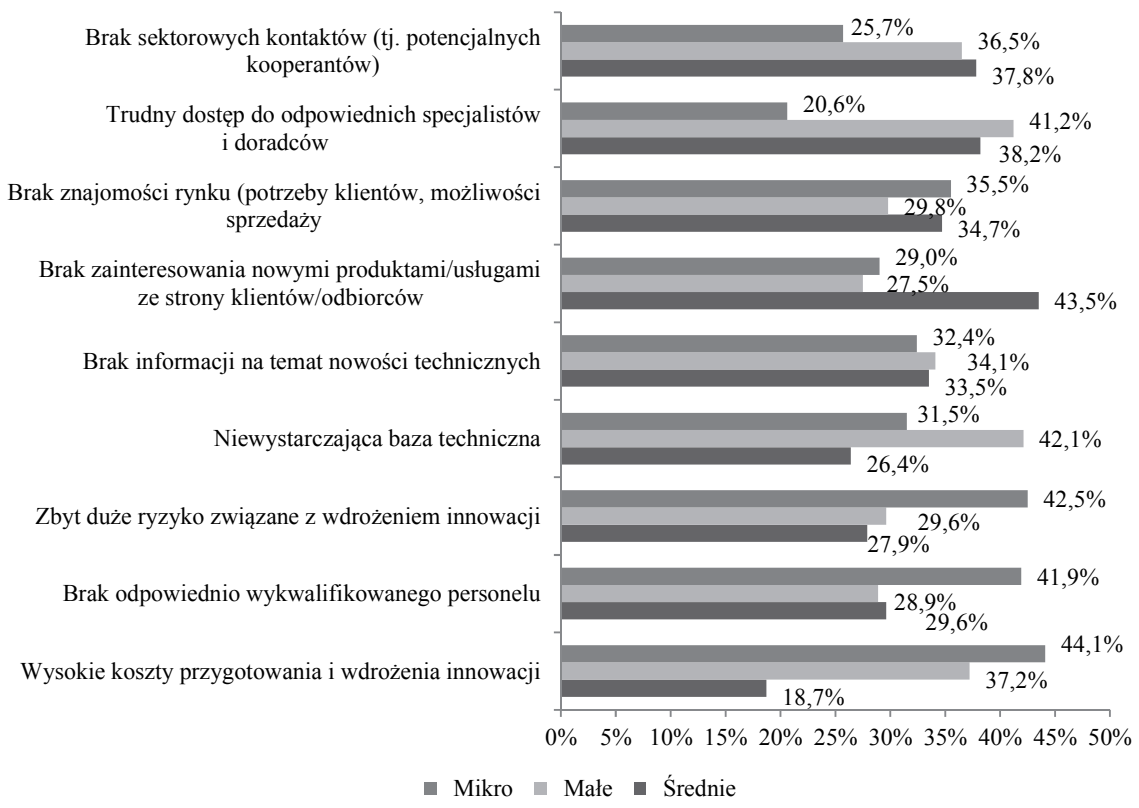

Uwaga: Respondenci mogli wybrać trzy odpowiedzi według ważności w skali 1-3, co oznaczało: 1 - ważna, 2 - bardzo ważna, 3 - najważniejsza.

Rysunek 72. Bariery wprowadzenia innowacji

Źródło: opracowanie własne 
W mikroprzedsiębiorstwach najczęściej wskazywano jako bariery wprowadzania innowacji wysokie koszty przygotowania i wdrożenia innowacji $(44,1 \%$ wskazań), zbyt duże ryzyko związane z wdrożeniem innowacji (42,5\% wskazań) oraz brak odpowiednio wykwalifikowanego personelu (41,9\% wskazań), $\mathrm{w}$ małych przedsiębiorstwach niewystarczająca baza techniczna $(42,1 \%$ wskazań) oraz trudny dostęp do odpowiednich specjalistów i doradców $(41,2 \%$ wskazań). Natomiast $\mathrm{w}$ średnich przedsiębiorstwach brak zainteresowania nowymi produktami/usługami ze strony klientów/odbiorców (43,5\% wskazań) oraz trudny dostęp do odpowiednich specjalistów i doradców (38,2\% wskazań) (por. rysunek 72). Wyniki te wskazują na różne problemy, z jakimi zmagają się przedsiębiorstwa, prowadząc działalność innowacyjną. Część tych barier wynika ze specyfiki obszarów zmarginalizowanych, np. brak sektorowych kontaktów wynikający $\mathrm{z}$ małej liczby firm $\mathrm{w}$ danym obszarze oraz brak odpowiednio wykwalifikowanego personelu.

Kolejnym obszarem badawczym było wskazanie źródeł finansowania innowacji. Na podstawie wypowiedzi respondentów można przypuszczać, że stosowne źródła są zróżnicowane w zależności od wielkości przedsiębiorstwa, potwierdził to również test Kruskala-Wallisa. Jego wyniki i prawdopodobieństwo testowe $(p<0,05)$ pokazały zróżnicowanie badanych zmiennych (por. tabela 28).

Tabela 28. Wartość statystyki $(H)$ według testu Kruskala-Wallisa oraz poziom prawdopodobieństwa testowego $(p)$ zmiennych określających źródła finansowania innowacji w kontekście wielkości przedsiębiorstwa

\begin{tabular}{|l|c|c|}
\hline \multicolumn{1}{|c|}{ Źródła finansowania innowacji } & $\begin{array}{c}\text { Wartość statystyki }(H) \\
\text { według testu } \\
\text { Kruskala-Wallisa }\end{array}$ & $\begin{array}{c}\text { Prawdopodo- } \\
\text { bieństwo } \\
\text { testowe }(p)\end{array}$ \\
\hline Emisja akcji & 3,163 & 0,118 \\
\hline Fundusze venture capital, aniołowie biznesu & 2,874 & 0,213 \\
\hline Kredyt bankowy & 12,281 & 0,000 \\
\hline Leasing & 10,342 & 0,000 \\
\hline Emisja obligacji & 5,646 & 0,479 \\
\hline Fundusze unijne & 14,274 & 0,000 \\
\hline Zysk niepodzielony & 3,372 & 0,323 \\
\hline Kapitał własny & 13.342 & 0,000 \\
\hline
\end{tabular}

Źródło: opracowanie własne.

W mikroprzedsiębiorstwach najczęściej wskazywano jak źródło finansowania innowacji, kapitał własny (47,7\% wskazań) oraz leasing (38,8\% wskazań), w małych przedsiębiorstwach również leasing (40,7\% wskazań) oraz fundusze unijne (39,8\% wskazań), natomiast w średnich firmach - kredyt bankowy (43,8\% wskazań) oraz fundusze unijne (42,1\% wskazań), zwiększenie jakości 
i wydajności pracy $(41,4 \%$ wskazań) oraz obniżenie kosztów działalności (39,5\% wskazań) (por. rysunek 73). Wyniki te wskazują na różne możliwości finansowania innowacji: najbardziej popularne typowe dla mikro i małych to kapitał własny i leasing, średnie przedsiębiorstwa ze względu lepszy dostęp do rynku kapitałowego korzystają z szerszego wachlarza możliwości finansowania w postaci kredytów i dotacji unijnych. Dostęp do środków unijnych szczególnie dla rozwoju działalności innowacyjnej jest utrudniony ze względu na niską innowacyjność i niski stopień nowości wprowadzonych innowacji w małych i średnich przedsiębiorstwach oraz niewystarczające zasoby (finansowe, rzeczowe, ludzkie i informacyjne), natomiast w obszarach zmarginalizowanych dochodzą jeszcze dodatkowo specyficzne cechy tych obszarów w postaci np. małej liczby instytucji wsparcia biznesu o charakterze informacyjnym czy doradczym oraz niskiej innowacyjności i konkurencyjności obszaru. Powoduje to, że niewielka liczba firm spełnia kryteria pozyskania środków finansowych pochodzących z programów unijnych, np. z PO IG czy Regionalnych Programów Operacyjnych.

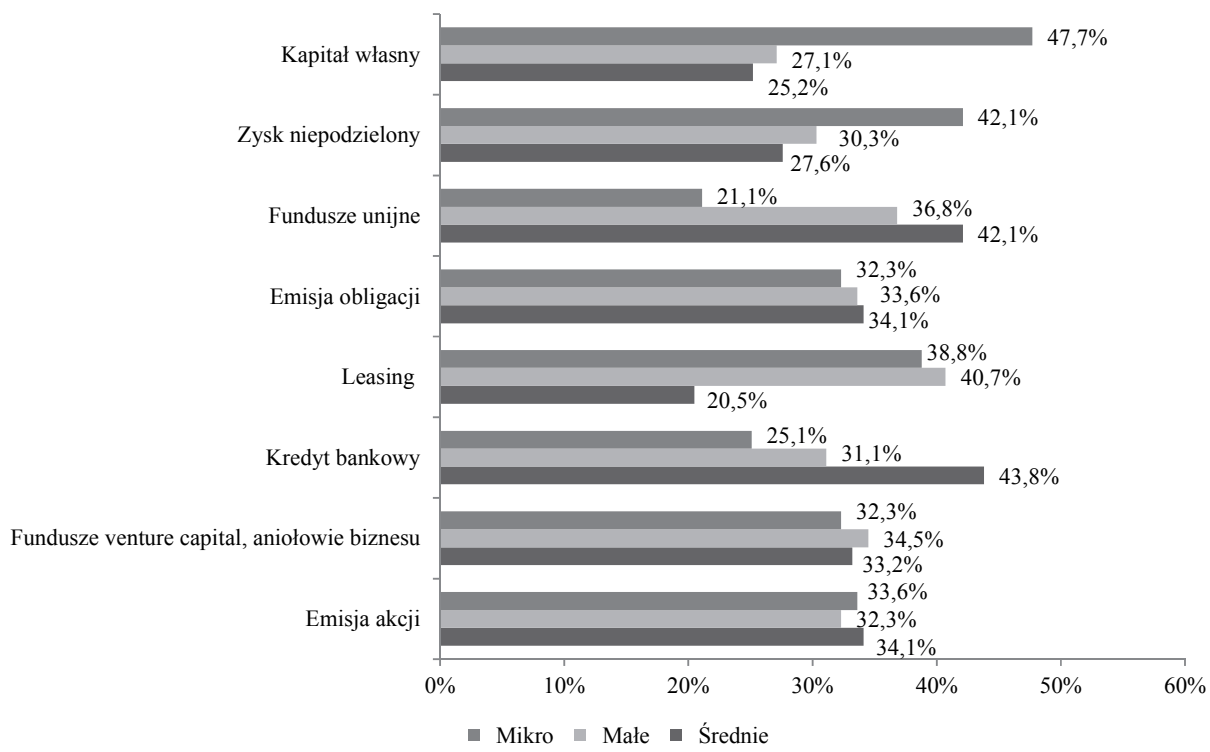

Uwaga: Respondenci mogli wybrać trzy odpowiedzi według ważności w skali 1-3, co oznaczało: 1 - ważna, 2 - bardzo ważna, 3 - najważniejsza.

Rysunek 73. Źródła finansowania innowacji

Źródło: opracowanie własne

Z działalnością innowacyjną małych i średnich przedsiębiorstw wiąże się ściśle działalność inwestycyjna tych podmiotów (Różański 2006), która była kolejnym obszarem badawczym. Działalność tę prowadziło w latach 2009-2011 
niecałe $50 \%$ badanych przedsiębiorstw, to wynik znacznie lepszy niż w przypadku działalności innowacyjnej. Były to głównie średnie firmy mające potencjał do takiej działalności (por. rysunek 74).

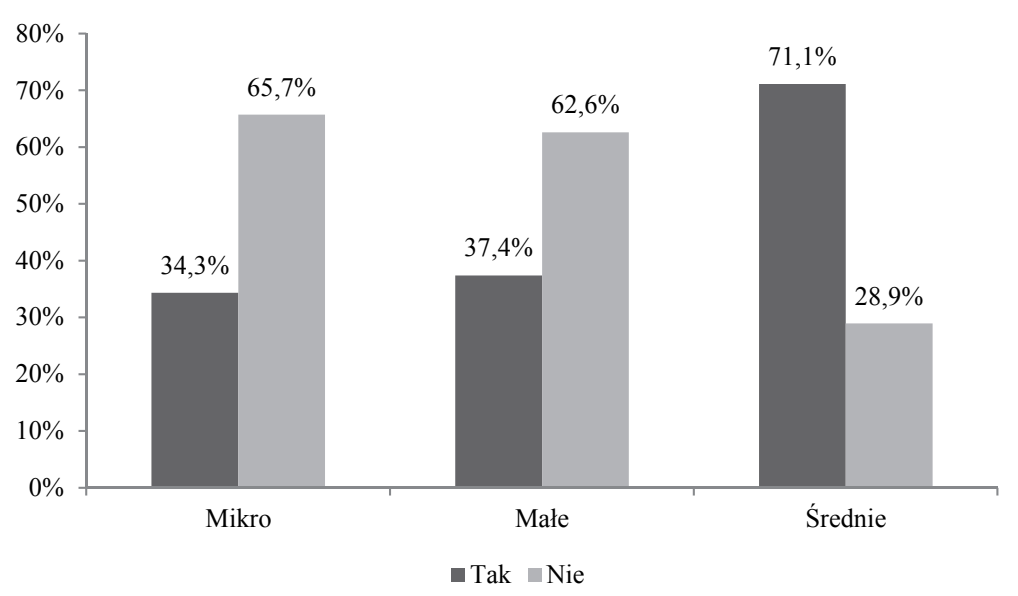

Rysunek 74. Realizowane inwestycje w latach 2009-2011

Źródło: opracowanie własne

Podejmowane przez badane przedsiębiorstwa rodzaje inwestycji były zróżnicowane $\mathrm{w}$ zależności od wielkości przedsiębiorstwa, potwierdził to również test Kruskala-Wallisa. Jego wyniki i prawdopodobieństwo testowe $(p<0,05)$ pokazały zróżnicowanie większości badanych zmiennych (por. tabela 29).

Tabela 29. Wartość statystyki $(H)$ według testu Kruskala-Wallisa oraz poziom prawdopodobieństwa testowego $(p)$ zmiennych określających rodzaje inwestycji w kontekście wielkości przedsiębiorstwa

\begin{tabular}{|l|c|c|}
\hline \multicolumn{1}{|c|}{ Rodzaje inwestycji } & $\begin{array}{c}\text { Wartość statystyki }(H) \\
\text { według testu } \\
\text { Kruskala-Wallisa }\end{array}$ & $\begin{array}{c}\text { Prawdopodo- } \\
\text { bieństwo } \\
\text { testowe }(p)\end{array}$ \\
\hline Zakup nieruchomości & 13,346 & 0,000 \\
\hline Remont, modernizacja, rozbudowa nieruchomości & 10,126 & 0,003 \\
\hline Zakup linii technologicznej, maszyn i urządzeń & 12,287 & 0,000 \\
\hline $\begin{array}{l}\text { Unowocześnienie linii technologicznej, maszyn } \\
\text { i urządzeń }\end{array}$ & 9,342 & 0,009 \\
\hline Zakup wartości niematerialnych i prawnych & 11,631 & 0,000 \\
\hline Zakup licencji & 8,775 & 0,017 \\
\hline Zakup środków transportu & 9,432 & 0,008 \\
\hline Certyfikaty jakości np. ISO & 12.947 & 0,000 \\
\hline Patenty & 2,148 & 0,527 \\
\hline
\end{tabular}

Źródło: opracowanie własne. 
W mikroprzedsiębiorstwach najczęściej działalność inwestycyjna polegała na remoncie i rozbudowie nieruchomości (44,5\% wskazań) oraz zakupie nieruchomości (42,8\% wskazań), w małych przedsiębiorstwach - zakup nieruchomości (42,8\% wskazań), unowocześnienie linii technologicznej, maszyn i urządzeń (41,3\% wskazań) oraz zakup licencji (39,1\% wskazań). Natomiast w średnich firmach zakup linii technologicznej, maszyn i urządzeń (41,9\% wskazań), zakup wartości niematerialnych i prawnych (39,8\% wskazań) oraz certyfikaty jakości, np. ISO (38,1\% wskazań) (por. rysunek 75$)$. Wyniki te wskazują na różne rodzaje prowadzonej działalności inwestycyjnej w zależności od zgłaszanych potrzeb i możliwości małych i średnich przedsiębiorstw. Specyfika obszarów zmarginalizowanych raczej utrudnia realizację inwestycji ze względu na małą ich liczbę, np. na terenie gminy czy powiatu oraz niewielkie zaangażowanie władz samorządowych $\mathrm{w}$ kreowanie klimatu dla powstawania nowych i rozwoju już funkcjonujących podmiotów gospodarczych.

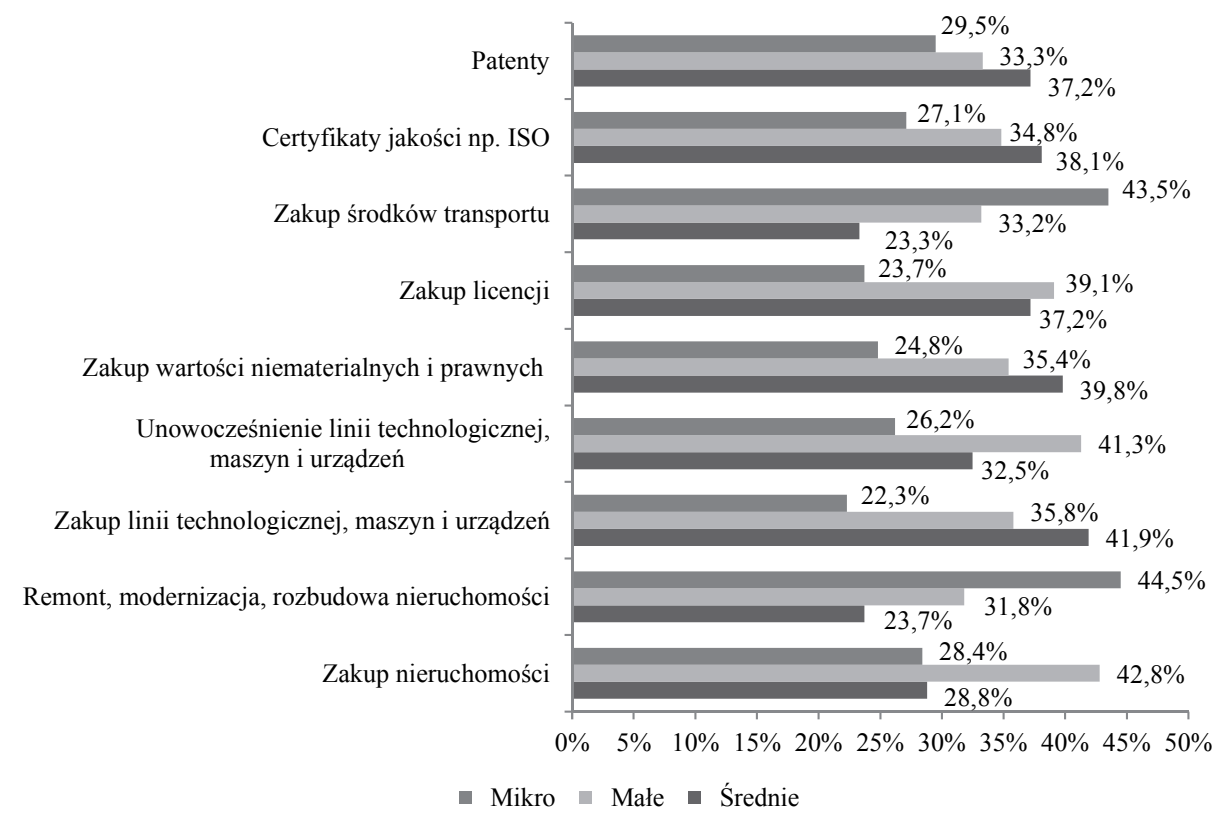

Uwaga: Respondenci mogli wybrać trzy odpowiedzi według ważności w skali $1-3$, co oznaczało: 1 - ważna, 2 - bardzo ważna, 3 - najważniejsza.

Rysunek 75. Rodzaje zrealizowanych inwestycji

Źródło: opracowanie własne

Podejmowana przez badane przedsiębiorstwa działalność inwestycyjna napotykała szereg barier, które były zróżnicowane w zależności od wielkości przedsiębiorstwa, potwierdził to również test Kruskala-Wallisa. Jego wyniki i prawdopodobieństwo testowe $(p<0,05)$ pokazały zróżnicowanie wszystkich badanych zmiennych (por. tabela 30 ). 
Tabela 30. Wartość statystyki $(H)$ według testu Kruskala-Wallisa oraz poziom prawdopodobieństwa testowego $(p)$ zmiennych określających bariery prowadzenia działalności inwestycyjnej w kontekście wielkości przedsiębiorstwa

\begin{tabular}{|l|c|c|}
\hline \multicolumn{1}{|c|}{ Bariery prowadzenia działalności innowacyjnej } & $\begin{array}{c}\text { Wartość statystyki } \\
(H) \text { według testu } \\
\text { Kruskala-Wallisa }\end{array}$ & $\begin{array}{c}\text { Prawdopodo- } \\
\text { bieństwo } \\
\text { testowe }(p)\end{array}$ \\
\hline Brak rozwiązań podatkowych stymulujących inwestycje & 10,626 & 0,001 \\
\hline Brak kapitałów własnych na inwestycje & 12,461 & 0,000 \\
\hline Wysokie koszty pozyskiwania składników majątkowych & 11,479 & 0,000 \\
\hline $\begin{array}{l}\text { Trudności w pozyskaniu zewnętrznych źródeł finansowa- } \\
\text { nia }\end{array}$ & 9,743 & 0,003 \\
\hline Długie procedury pozyskania pozwoleń inwestycyjnych & 11,451 & 0,000 \\
\hline $\begin{array}{l}\text { Problemy z pozyskaniem pomocy publicznej na działal- } \\
\text { ność inwestycyjną }\end{array}$ & 10,112 & 0,002 \\
\hline $\begin{array}{l}\text { Długi czas oczekiwania na refundację kosztów inwestycji } \\
\text { ze środków unijnych }\end{array}$ & 12,278 & 0,000 \\
\hline
\end{tabular}

Źródło: opracowanie własne.

Długi czas oczekiwania na refundację kosztów inwestycji ze środków unijnych

Problemy z pozyskaniem pomocy publicznej na działalność inwestycyjną

Długie procedury pozyskania pozwoleń inwestycyjnych

Trudności w pozyskaniu zewnętrznych źródeł finansowania

Wysokie koszty pozyskiwania składników majątkowych

Brak kapitałów własnych na inwestycje

Brak rozwiązań podatkowych stymulujących inwestycje

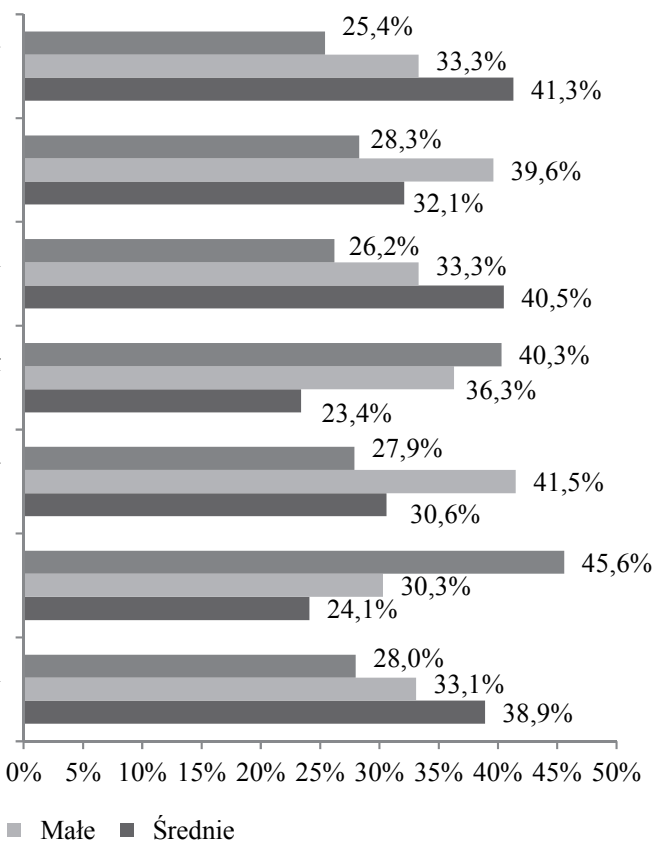

Uwaga: Respondenci mogli wybrać trzy odpowiedzi według ważności w skali 1-3, co oznaczało: 1 - ważna, 2 - bardzo ważna, 3 - najważniejsza.

Rysunek 76. Bariery utrudniające prowadzenie działalności inwestycyjnej

Źródło: opracowanie własne 
W mikroprzedsiębiorstwach najczęściej wskazywano jako bariery prowadzenia działalności inwestycyjnej brak kapitału (45,6\% wskazań) oraz trudności w pozyskaniu zewnętrznych źródeł finansowania (40,3\% wskazań), w małych przedsiębiorstwach wysokie koszty pozyskiwania składników majątkowych (41,5\% wskazań) oraz problemy z pozyskaniem pomocy publicznej na działalność inwestycyjną (39,6\% wskazań). Natomiast w średnich przedsiębiorstwach - długi czas oczekiwania na refundację kosztów inwestycji ze środków unijnych (41,3\% wskazań), długie procedury pozyskania pozwoleń inwestycyjnych (40,5\% wskazań) oraz długie procedury pozyskania pozwoleń inwestycyjnych (38,9\% wskazań) (por. rysunek 76 ). Wyniki te wskazują na duże problemy badanych przedsiębiorstw, szczególnie mikro i małych, w finansowaniu inwestycji, w przypadku średnich przedsiębiorstw bariery te związane są raczej z przepisami i procedurami realizacji inwestycji.

W kolejnym etapie badania respondenci wskazali źródła finansowania inwestycji, które były zróżnicowane w zależności od wielkości przedsiębiorstwa, potwierdził to również test Kruskala-Wallisa. Jego wyniki i prawdopodobieństwo testowe $(p<0,05)$ pokazały zróżnicowanie badanych zmiennych, które zostały wyróżnione w tabeli 31 .

Tabela 31. Wartość statystyki $(H)$ według testu Kruskala-Wallisa oraz poziom prawdopodobieństwa testowego $(p)$ zmiennych określających źródła finansowania inwestycji w kontekście wielkości przedsiębiorstwa

\begin{tabular}{|l|c|c|}
\hline \multicolumn{1}{|c|}{ Źródła finansowania inwestycji } & $\begin{array}{c}\text { Wartość statystyki }(H) \\
\text { według testu } \\
\text { Kruskala-Wallisa }\end{array}$ & $\begin{array}{c}\text { Prawdopodo- } \\
\text { bieństwo } \\
\text { testowe }(p)\end{array}$ \\
\hline Emisja akcji & 1,265 & 0,537 \\
\hline Fundusze venture capital, aniołowie biznesu & 3,471 & 0,193 \\
\hline Kredyt bankowy & 13,652 & 0,000 \\
\hline Leasing & 13,598 & 0,000 \\
\hline Emisja obligacji & 2,132 & 0,329 \\
\hline Fundusze unijne & 11,217 & 0,000 \\
\hline Zysk niepodzielony & 13,871 & 0,000 \\
\hline Kapitał własny & 11,232 & 0,000 \\
\hline
\end{tabular}

Źródło: opracowanie własne.

W mikroprzedsiębiorstwach najczęściej wskazywano jak źródło finansowania inwestycji kapitał własny (42,4\% wskazań) oraz zysk niepodzielony $(38,9 \%$ wskazań), w małych przedsiębiorstwach fundusze unijne (40,1\% wskazań) oraz leasing (38,7\% wskazań), natomiast w średnich firmach - kredyt bankowy (44,6\% wskazań) oraz fundusze unijne (38,1\% wskazań) (por. rysunek 77 ). Wyniki te są zbliżone do wskazanych źródeł finansowania działalności innowacyjnej w poszczególnych kategoriach firm. 


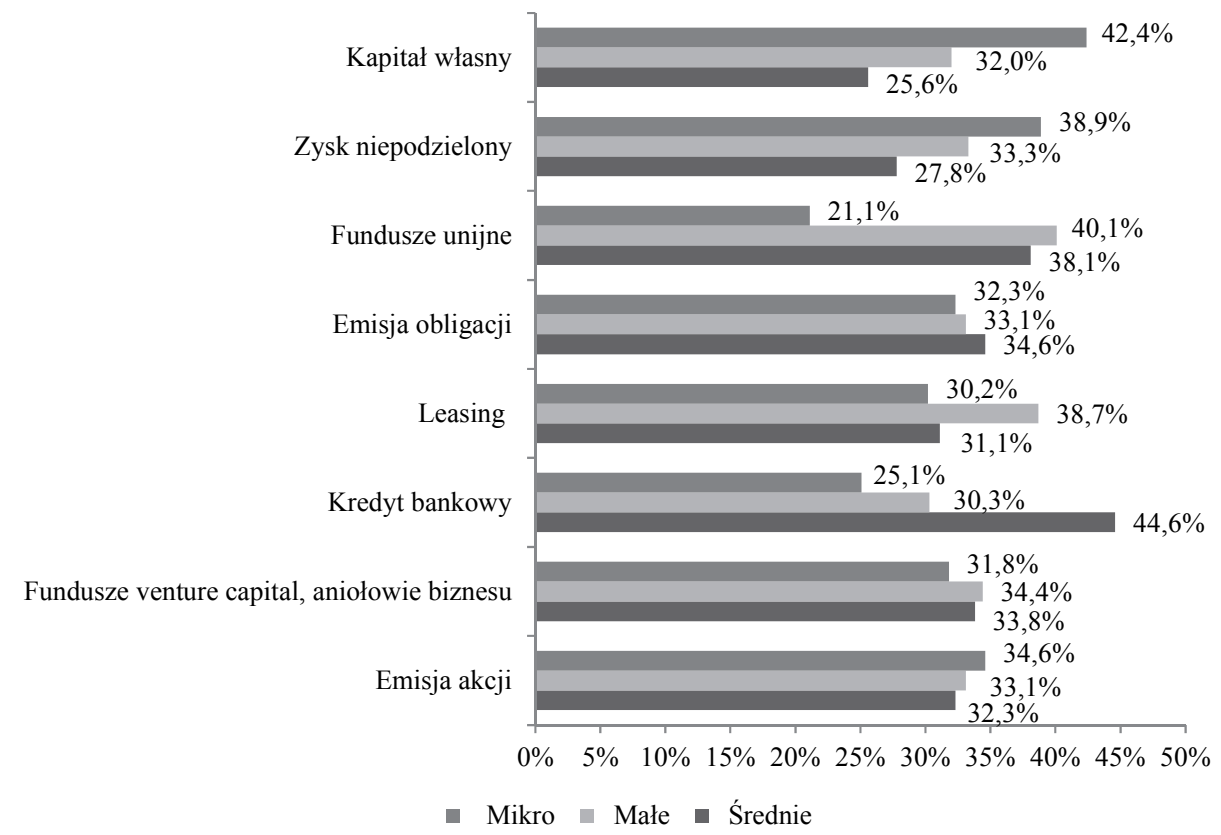

Uwaga: Respondenci mogli wybrać trzy odpowiedzi według ważności w skali 1-3, co oznaczało: 1 - ważna, 2 - bardzo ważna, 3 - najważniejsza.

Rysunek 77. Źródła finansowania działalności inwestycyjnej

Źródło: opracowanie własne

Reasumując dotychczasowe rozważania, można uznać, że marginalizacja obszaru ma znaczący wpływ na funkcjonujące tam małe i średnie przedsiębiorstwa, wiele bowiem specyficznych cech obszaru zmarginalizowanego stanowi dodatkowe bariery w rozwoju tych podmiotów. Dlatego też ważna jest prowadzona polityka wsparcia małych i średnich przedsiębiorstw w tych obszarach, która powinna być ściśle dostosowana na potrzeby MSP. W formułowaniu tej polityki mają dużą znaczenie władze samorządowe i instytucje otoczenia biznesu, których działalność jest przedmiotem kolejnego podrozdziału.

\subsection{Instytucje otoczenia biznesu w obszarach zmarginalizowanych}

Obszary zmarginalizowane charakteryzują się mniejszą liczbą instytucji otoczenia biznesu, co powoduje ograniczony dostęp do usług oferowanych dla małych i średnich przedsiębiorstw. Dla rozwoju przedsiębiorstw $\mathrm{w}$ regionie istotne są również korzystne warunki, które często tylko $\mathrm{w}$ założeniach są kreowane przez władze samorządowe. 
Władze samorządowe, tworząc klimat dla rozwoju małych i średnich przedsiębiorstw, pobudzają rozwój lokalnej przedsiębiorczości poprzez wspieranie aktywności lokalnych społeczności (Makieła 2008, s. 17). Realizacja tego celu wymaga od samorządu terytorialnego zachowań przedsiębiorczych, przejawiających się: w kreatywności i innowacyjności władz samorządowych (np. stosowanie nowoczesnych koncepcji zarządzania w celu efektywnego zarządzania rozwojem gminy (Kot 2003b, i 2004), umiejętności współpracy z przedsiębiorstwami w celu stworzenia przyjaznego klimatu dla prowadzenia działalności gospodarczej oraz umiejętności współpracy z innymi jednostkami samorządowymi i organizacjami (Makieła 2008, s. 17). Przedsiębiorcze działanie władz samorządowych zależy również od wielu uwarunkowań prawnych. Z ustawy o samorządzie gminny (ustawa z dnia 8 maja 1990 r. o samorządzie gminnym, Dz.U. 1990, nr 16, poz. 95) wynika, że gmina wykonuje zadania publiczne, m.in. takie jak: dbanie o warunki życia mieszkańców, rozwój gospodarczy, zagospodarowanie przestrzeni, jak również ochronę środowiska, w imieniu własnym i na własną odpowiedzialność. W ustawie tej brak jest konkretnych wytycznych odnośnie do wsparcia przedsiębiorczości, które zależy w dużej mierze od sposobu realizacji zadań publicznych przez władze samorządowe. $\mathrm{Z}$ ustawy o zasadach i formach wspierania rozwoju regionalnego (ustawa $\mathrm{z}$ dnia 12 maja 2000 r. o zasadach wspierania rozwoju regionalnego, Dz.U. z dnia 14 czerwca 2000 r.) wynika, że wsparcie finansowe rozwoju regionalnego ze środków budżetu państwa może być przeznaczone na:

- rozwój przedsiębiorczości, zwłaszcza małych i średnich przedsiębiorców, innowacje gospodarcze, transfer technologii;

- restrukturyzację wybranych dziedzin usług publicznych oraz gospodarki lokalnej i regionalnej opierającą się na zasadach zrównoważonego rozwoju;

- tworzenie nowych, stałych miejsc pracy;

- inwestycje w zakresie infrastruktury technicznej i transportowej poprawiające warunki realizowania inwestycji gospodarczych;

- przedsięwzięcia z zakresu edukacji, w tym edukacji dorosłych;

- przedsięwzięcia z zakresu kultury regionalnej i lokalnej będących składnikami kultury narodowej oraz ochrony i rozwoju dziedzictwa kulturowego;

- inwestycje poprawiające stan środowiska;

- rozwój instytucji działających na rzecz pobudzania aktywności i wspomagania działań samorządowych wspólnot regionalnych i lokalnych;

- studia i badania niezbędne do prowadzenia polityki rozwoju regionalnego;

- inne zadania związane ze wspieraniem rozwoju regionalnego.

W myśl tej ustawy można zgodnie z przeznaczeniem środków finansowych część działań skierować na wielokierunkowe wsparcie podmiotów gospodarczych oraz kreowanie zachowań przedsiębiorczych. Wsparcie to jest szczególnie ważne w obszarach zmarginalizowanych, które generują dodatkowe bariery 
rozwoju przedsiębiorstw wynikające ze swojej specyfiki. Działania, jakie powinny podjąć władze samorządowe w celu stymulowania rozwoju MSP, zostały one wskazane przez przedsiębiorców w badaniu ilościowym.

Wypowiedzi respondentów odnośnie do oczekiwanych działań ze strony władz samorządowych w celu stymulowania rozwoju MSP były zróżnicowane w zależności od wielkości przedsiębiorstwa (por. rysunek 78), potwierdził to również test Kruskala-Wallisa. Jego wyniki i prawdopodobieństwo testowe $(p<0,05)$. pokazały zróżnicowanie większości badanych (por. tabela 32 ).

Tabela 32. Wartość statystyki $(H)$ według testu Kruskala-Wallisa oraz poziom prawdopodobieństwa testowego $(p)$ zmiennych określających oczekiwane przez przedsiębiorców działania ze strony władz samorządowych w celu stymulowania rozwoju MSP w kontekście wielkości przedsiębiorstwa

\begin{tabular}{|l|c|c|}
\hline $\begin{array}{l}\text { Oczekiwane przez przedsiębiorców działania ze strony } \\
\text { władz samorządowych w celu stymulowania rozwoju } \\
\text { MSP }\end{array}$ & $\begin{array}{c}\text { Wartość statystyki } \\
(H) \text { według testu } \\
\text { Kruskala-Wallisa }\end{array}$ & $\begin{array}{c}\text { Prawdopodo- } \\
\text { bieństwo } \\
\text { testowe }(p)\end{array}$ \\
\hline $\begin{array}{l}\text { Kreowanie przyjaznego klimatu dla rozwoju działalno- } \\
\text { ści gospodarczej }\end{array}$ & 2 & 3 \\
\hline Poprawa infrastruktury technicznej & 14,116 & 0,011 \\
\hline Zwiększenie dostępu do otoczenia biznesu & 12,354 & 0,000 \\
\hline Pobudzanie rozwoju społeczno-gospodarczego regionu & 11,265 & 0,000 \\
\hline $\begin{array}{l}\text { Poprawa atrakcyjności terenów, na których rozwijana } \\
\text { jest działalność gospodarcza }\end{array}$ & 9,631 & 0,000 \\
\hline Promocja i przyciąganie inwestorów do regionu & 8,775 & 0,017 \\
\hline $\begin{array}{l}\text { Pomoc w nawiązywania kontaktów z kontrahentami } \\
\text { zagranicznymi }\end{array}$ & 9,432 & 0,008 \\
\hline Prowadzenie działalności informacyjnej i doradczej & 2,947 & 0,194 \\
\hline Pomoc w pozyskaniu wsparcia finansowego & 12,146 & 0,000 \\
\hline Poprawa konkurencyjności i innowacyjności regionu & 9,126 & 0,005 \\
\hline $\begin{array}{l}\text { Poprawa systemu informacji o możliwościach } \\
\text { wsparcia przedsiębiorstw }\end{array}$ & 12,385 & 0,000 \\
\hline Pomoc w uzyskaniu dotacji unijnych & 1,472 & 0,498 \\
\hline $\begin{array}{l}\text { Zachęcanie przedsiębiorców do współpracy np. } \\
\text { w formie klastrów }\end{array}$ & 1,934 & 0,323 \\
\hline
\end{tabular}

Źródło: opracowanie własne. 


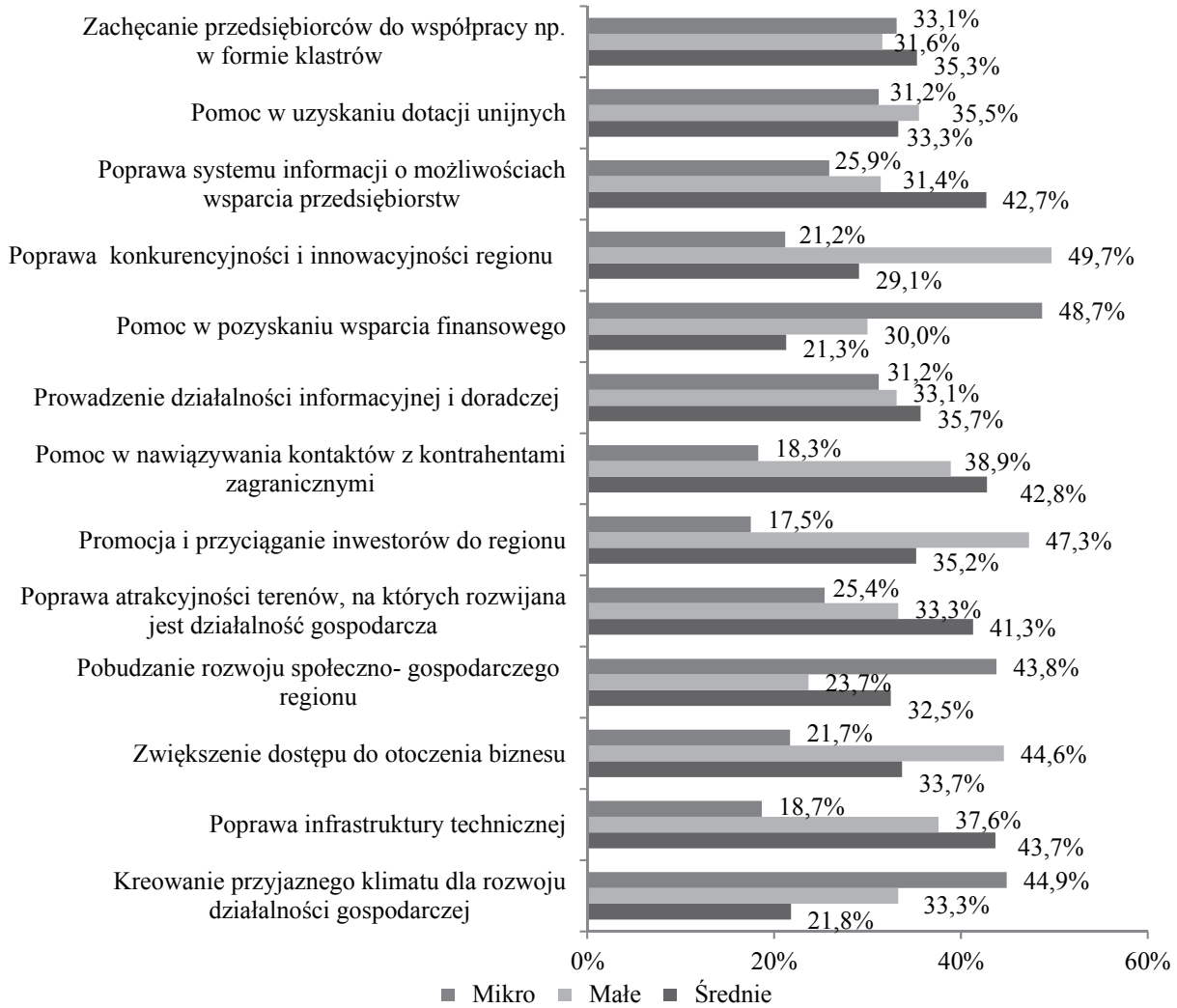

Uwaga: Respondenci mogli wybrać trzy odpowiedzi według ważności w skali 1-3, co oznaczało: 1 - ważna, 2 - bardzo ważna, 3 - najważniejsza.

Rysunek 78. Oczekiwane przez przedsiębiorców działania ze strony władz samorządowych w celu stymulowania rozwoju MSP

Źródło: opracowanie własne

W mikroprzedsiębiorstwach respondenci oczekiwali od władz samorządowych pomocy w pozyskaniu wsparcia finansowego (48,7\% wskazań), kreowania przyjaznego klimatu dla rozwoju działalności gospodarczej (44,9\% wskazań) oraz pobudzania rozwoju społeczno-gospodarczego regionu (43,8\% wskazań). Taki rozkład wypowiedzi, jak można przypuszczać, podkreśla niedostatki tych podmiotów w zakresie zasobów finansowych, jak również uwypukla problemy z niewystarczającym popytem, który może wpłynąć w dłuższym czasie na pogarszającą się kondycję tych podmiotów. Właściciele małych przedsiębiorstw oczekiwali od władz samorządowych działań w kierunku poprawy konkurencyjności i innowacyjności regionu (49,7\% wskazań), promocji i przyciągania inwestorów do regionu (47,3\% wskazań), zwiększenia dostępu do otoczenia biznesu (44,6\% wskazań). Dla średnich przedsiębiorstw najważniejsza była 
pomoc $\mathrm{w}$ nawiązywania kontaktów $\mathrm{z}$ kontrahentami zagranicznymi $(42,8 \%$ wskazań), poprawa infrastruktury technicznej (43,7\% wskazań) i systemu informacji o możliwościach wsparcia przedsiębiorstw (42,7\% wskazań) jak również poprawa atrakcyjności terenów, na których rozwijana jest działalność gospodarcza (41,3\% wskazań). Potrzeby małych i średnich przedsiębiorstw odnosiły się głównie do podnoszenia atrakcyjności regionu, w celu stworzenia jak najlepszych warunków dla prowadzenia działalności gospodarczej.

Efektywność zaproponowanych przez przedsiębiorców działań w kierunku rozwoju małych i średnich przedsiębiorstw zależy w dużej mierze od władz samorządowych, a właściwie ich umiejętności nowoczesnego i kreatywnego działania ukierunkowanego na stworzenie przyjaznego klimatu dla rozwoju podmiotów gospodarczych funkcjonujących na danym obszarze w tym w obszarach zmarginalizowanych. Oczekiwania podmiotów gospodarczych odnośnie do wsparcia ze strony władz samorządowych są coraz większe i dotyczą nie tylko zachęt finansowych, ale również dostępu do informacji, rozbudowy infrastruktury nie tylko tradycyjnej, ale również nowoczesnej informacyjnej oraz usług doradczych i szkoleniowych na wysokim poziomie.

Tabela 33. Cele wybranych instytucji wspierania przedsiebiorczości i innowacyjności

\begin{tabular}{|l|c|c|c|c|}
\hline \multirow{2}{*}{ Instytucja } & \multicolumn{4}{c|}{ Cele } \\
\cline { 2 - 5 } & $\begin{array}{c}\text { zakładanie } \\
\text { nowych firm }\end{array}$ & $\begin{array}{c}\text { przyciąganie } \\
\text { kapitału } \\
\mathrm{z} \text { zewnątrz }\end{array}$ & $\begin{array}{c}\text { wspieranie } \\
\text { rozwoju } \\
\text { istniejących } \\
\text { firm }\end{array}$ & $\begin{array}{c}\text { rozwój } \\
\text { innowacji } \\
\text { i przedsię- } \\
\text { biorczości }\end{array}$ \\
\hline Agencje rozwoju regionalnego & $\mathrm{x}$ & $\mathrm{x}$ & $\mathrm{x}$ & $\mathrm{x}$ \\
\hline Ośrodki doradcze i szkoleniowe & $\mathrm{x}$ & & $\mathrm{x}$ & \\
\hline $\begin{array}{l}\text { Fundusze pożyczkowe i fundusze } \\
\text { poręczeniowe }\end{array}$ & $\mathrm{x}$ & & $\mathrm{x}$ & \\
\hline $\begin{array}{l}\text { Centra obsługi inwestora, ośrodki } \\
\text { jednej wizyty }\end{array}$ & $\mathrm{x}$ & $\mathrm{x}$ & $\mathrm{x}$ & \\
\hline Centra wspierania biznesu & $\mathrm{x}$ & $\mathrm{x}$ & $\mathrm{x}$ & $\mathrm{x}$ \\
\hline Inkubatory przedsiębiorczości & $\mathrm{x}$ & $\mathrm{x}$ & $\mathrm{x}$ & $\mathrm{x}$ \\
\hline Parki technologiczne & $\mathrm{x}$ & $\mathrm{x}$ & $\mathrm{x}$ & \\
\hline Strefy przemysłowe & &
\end{tabular}

Źródło: Blakley 1989, s. 180, cyt. za: Filipiak, Ruszała 2009, s. 81.

Ważną rolę w stymulowaniu rozwoju małych i średnich przedsiębiorstw pełnią instytucje otoczenia biznesu, do których zalicza się ośrodki wspierania przedsiębiorczości, organizacje zrzeszające przedsiębiorców, firmy usługowe oraz instytucje finansowe. Instytucje te oferują najczęściej wsparcie w zakresie:

- poprawy zarządzania firmą oraz lepszego wykorzystania zasobów,

- nawiązywania kontaktów z kontrahentami zagranicznymi, 
- działalności informacyjnej i doradczej,

- nawiązywania kontaktów kooperacyjnych z dużymi firmami,

- udzielania lub umożliwiania pozyskania wsparcia finansowego,

- zachęcania przedsiębiorców do organizowania się w grupy producenckie, dystrybucyjne oraz tworzeniu systemu kooperacji i podwykonawstwa,

- poprawy konkurencyjności przez absorpcję i wdrażanie nowych technologii (Filipiak, Ruszała, 2009, s. 42) (por. tabela 33).

W obszarach zmarginalizowanych, tak jak wcześniej wspomniano, liczba instytucji otoczenia biznesu jest znacznie mniejsza lub ich brak, co ogranicza dostęp do wsparcia i specjalistycznych usług wspomagających prowadzenie biznesu. Oferta ośrodków wspierania biznesu obejmuje szeroki zakres usług, które są oferowane głównie na zasadach niekomercyjnych (por. tabela 34). Pomoc może dotyczyć zarówno procesu uruchomienia, jak również rozwoju przedsiębiorstwa.

Tabela 34. Charakterystyka oferty ośrodków wsparcia MSP

\begin{tabular}{|l|l|}
\hline \multicolumn{1}{|c|}{ Rodzaj ośrodka } & \multicolumn{1}{c|}{ Zakres oferty } \\
\hline \multicolumn{1}{|c|}{1} & \multicolumn{1}{c|}{2} \\
\hline $\begin{array}{l}\text { Agencja rozwoju regional- } \\
\text { nego (lokalnego) }\end{array}$ & $\begin{array}{l}\text { Usługi doradcze i szkoleniowe dotyczące uruchomienia i prowa- } \\
\text { dzenia działalności gospodarczej } \\
\text { Usługi informacyjne o możliwości pozyskania najkorzystniejszych } \\
\text { źródeł finansowania } \\
\text { Pomoc w przygotowaniu stadium wykonalności przedsięwzięcia }\end{array}$ \\
\hline $\begin{array}{l}\text { Centrum transferu } \\
\text { technologii i innowacji }\end{array}$ & $\begin{array}{l}\text { Przeprowadzenie audytów technologicznych } \\
\text { Kojarzenie partnerów } \\
\text { Prowadzenie bazy ofert technologicznych } \\
\text { Usługi doradcze i szkoleniowe z zakresu komercjalizacji zaawan- } \\
\text { sowanych technologii i wprowadzenia innowacji } \\
\text { Organizowanie targów } \\
\text { Usługi informacyjne o możliwości finansowania przedsięwzięć } \\
\text { innowacyjnych oraz prawie własności intelektualnej }\end{array}$ \\
\hline $\begin{array}{l}\text { Centrum doradztwa } \\
\text { (centrum wspierania } \\
\text { biznesu) }\end{array}$ & $\begin{array}{l}\text { Usługi szkoleniowe oraz doradcze z zakresu prawa (m.in. zawiera- } \\
\text { nie umowy, ustanowienie prokury, rejestracja nowego podmiotu } \\
\text { gospodarczego) i finansów (m.in. opodatkowanie, księgowość, } \\
\text { audyt, preferencyjne źródła finansowania) }\end{array}$ \\
\hline $\begin{array}{l}\text { Inkubator przedsiębiorczo- } \\
\text { ści }\end{array}$ & $\begin{array}{l}\text { Udostępnienie pomieszczeń dla małych i średnich przedsiębiorstw } \\
\text { (najczęściej nowo uruchamianych) na preferencyjnych warunkach } \\
\text { oraz zapewnienie doradztwa prawnego i podatkowego }\end{array}$ \\
\hline $\begin{array}{l}\text { Centrum informacji } \\
\text { europejskiej }\end{array}$ & $\begin{array}{l}\text { Usługi informacyjne z zakresu funkcjonowania Unii Europejskiej, } \\
\text { a zwłaszcza jednolitego rynku i funduszy strukturalnych, } \\
\text { Usługi szkoleniowe z zakresu prowadzenia działalności gospodar- } \\
\text { czej na rynku europejskim, wspólnotowego systemu standaryzacji } \\
\text { i certyfikacji oraz pozyskiwania dotacji unijnych }\end{array}$ \\
\hline
\end{tabular}


Tabela 34 (cd.)

\begin{tabular}{|l|l|}
\hline \multicolumn{1}{|c|}{1} & \multicolumn{1}{|c|}{2} \\
\hline Park technologiczny & $\begin{array}{l}\text { Komercjalizacja wiedzy i technologii } \\
\text { Pomoc w nawiązaniu współpracy pomiędzy jednostkami nauko- } \\
\text { wymi, a przedsiębiorstwem } \\
\text { Usługi w zakresie doradztwa w tworzeniu i rozwoju przedsię- } \\
\text { biorstw, transferu technologii oraz przekształcenia wyników badań } \\
\text { naukowych i prac rozwojowych w innowacje technologiczne } \\
\text { Stwarzanie możliwości prowadzenia działalności gospodarczej } \\
\text { przez korzystanie z nieruchomości i infrastruktury technicznej na } \\
\text { preferencyjnych zasadach }\end{array}$ \\
\hline Punkt informacyjny & $\begin{array}{l}\text { Podstawowe usługi informacyjne dotyczące zasad uruchamiania } \\
\text { i prowadzenia działalności gospodarczej }\end{array}$ \\
\hline $\begin{array}{l}\text { Strefa przemysłowa (park } \\
\text { przemysłowy) }\end{array}$ & $\begin{array}{l}\text { Stwarzanie możliwości prowadzenia działalności gospodarczej } \\
\text { przez korzystanie z nieruchomości i infrastruktury technicznej na } \\
\text { preferencyjnych zasadach }\end{array}$ \\
\hline Fundusz pożyczkowy & $\begin{array}{l}\text { Udzielanie nisko oprocentowanych (niekomercyjnych) pożyczek na } \\
\text { uruchomienie działalności gospodarczej }\end{array}$ \\
\hline $\begin{array}{l}\text { Fundusz poręczeń } \\
\text { kredytowych }\end{array}$ & $\begin{array}{l}\text { Poręczenie na rzecz małych i średnich przedsiębiorstw od 50 do } \\
80 \% \text { kwoty kredytu }\end{array}$ \\
\hline
\end{tabular}

Źródło: Wach 2008, s. 136-137.

W obszarze uruchamiania działalności gospodarczej szczególnie ważne są instrumenty finansowe, m.in. takie jak: dotacje, pożyczki, poręczenia, środki UE, venture capital, aniołowie biznesu, ulgi podatkowe oraz instrumenty informacyjne, do których zalicza się: usługi doradcze i informacyjne, szkolenia z zakresu przedsiębiorczości i zakładania firmy. Ważne również jest wsparcie instytucjonalne $\mathrm{w}$ postaci inkubatorów przedsiębiorczości, parków przemysłowych i technologicznych (Gancarczyk 2010).

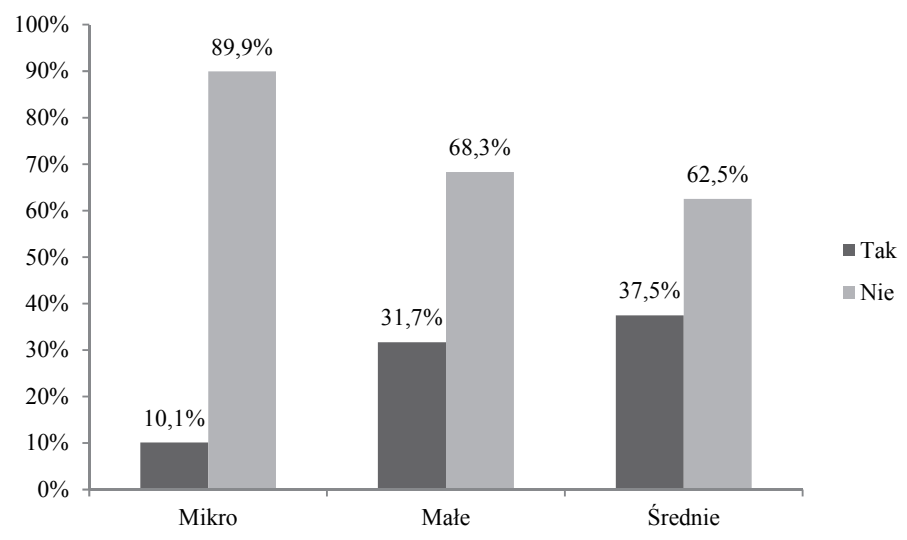

Rysunek 79. Współpraca przedsiębiorstwa z instytucjami otoczenia biznesu Źródło: opracowanie własne 
Wśród badanych MSP tylko 19,2\% współpracowała z instytucjami otoczenia biznesu, były to głównie małe i średnie przedsiębiorstwa (por. rysunek 79). Mikro przedsiębiorstwa nie wykazywały chęci do współpracy bądź tylko w niewielkim zakresie.

Przedsiębiorstwa, które współpracowały z instytucjami otoczenia biznesu, wskazały również, jakiego rodzaju były to instytucje. Wypowiedzi respondentów były zróżnicowane w zależności od wielkości przedsiębiorstwa (por. rysunek 80), potwierdził to również test Kruskala-Wallisa. Jego wyniki i prawdopodobieństwo testowe $(p<0,05)$ pokazały zróżnicowanie większości badanych zmiennych (por. tabela 35 ).

Tabela 35. Wartość statystyki $(H)$ według testu Kruskala-Wallisa oraz poziom prawdopodobieństwa testowego $(p)$ zmiennych określających rodzaj instytucji otoczenia biznesu, z którą współpracowało przedsiębiorstwo w kontekście jego wielkości

\begin{tabular}{|l|c|c|}
\hline \multicolumn{1}{|c|}{$\begin{array}{c}\text { Rodzaj instytucji otoczenia biznesu, z którą } \\
\text { współpracowało przedsiębiorstwo }\end{array}$} & $\begin{array}{c}\text { Wartość statystyki }(H) \\
\text { według testu } \\
\text { Kruskala-Wallisa }\end{array}$ & $\begin{array}{c}\text { Prawdopodo- } \\
\text { bieństwo } \\
\text { testowe }(p)\end{array}$ \\
\hline Ośrodki szkoleniowo-doradcze & 11,342 & 0,000 \\
\hline Ośrodki przedsiębiorczości & 12,166 & 0,000 \\
\hline Punkty konsultacyjne & 9,678 & 0,022 \\
\hline Inkubatory przedsiębiorczości & 1,956 & 0,000 \\
\hline Fundusze pożyczkowe & 10,931 & 0,001 \\
\hline Fundusze poręczeń kredytowych & 13,775 & 0,000 \\
\hline Sié́ Aniołów Biznesu & 1,432 & 0,348 \\
\hline Parki technologiczne & 2,773 & 0,139 \\
\hline Centra transferu technologii & 11,946 & 0,000 \\
\hline
\end{tabular}

Źródło: opracowanie własne.

W przypadku mikroprzedsiębiorstw największą popularnością cieszyły się ośrodki przedsiębiorczości (44,2\% wskazań) oraz punkty konsultacyjne $(43,1 \%$ wskazań), w małych przedsiębiorstwach ośrodki szkoleniowo-doradcze $(45,8 \%$ wskazań), fundusze pożyczkowe (35,6\% wskazań) oraz centra transferu technologii (34,5\% wskazań), a w przypadku średnich centra transferu technologii (44,3\% wskazań), fundusze pożyczkowe $(41,2 \%$ wskazań) oraz fundusze poręczeń kredytowych (40,9\% wskazań). Taki rozkład odpowiedzi świadczy $\mathrm{o}$ zróżnicowanych potrzebach $\mathrm{w}$ zakresie wsparcia, mikroprzedsiębiorstwa potrzebują zazwyczaj informacji ogólnych o prowadzeniu biznesu i możliwościach pozyskanie środków finansowych, w przypadku małych i średnich usługi te mają charakter specjalistyczny np. w zakresie poprawy innowacyjności, transferu technologii itd. 


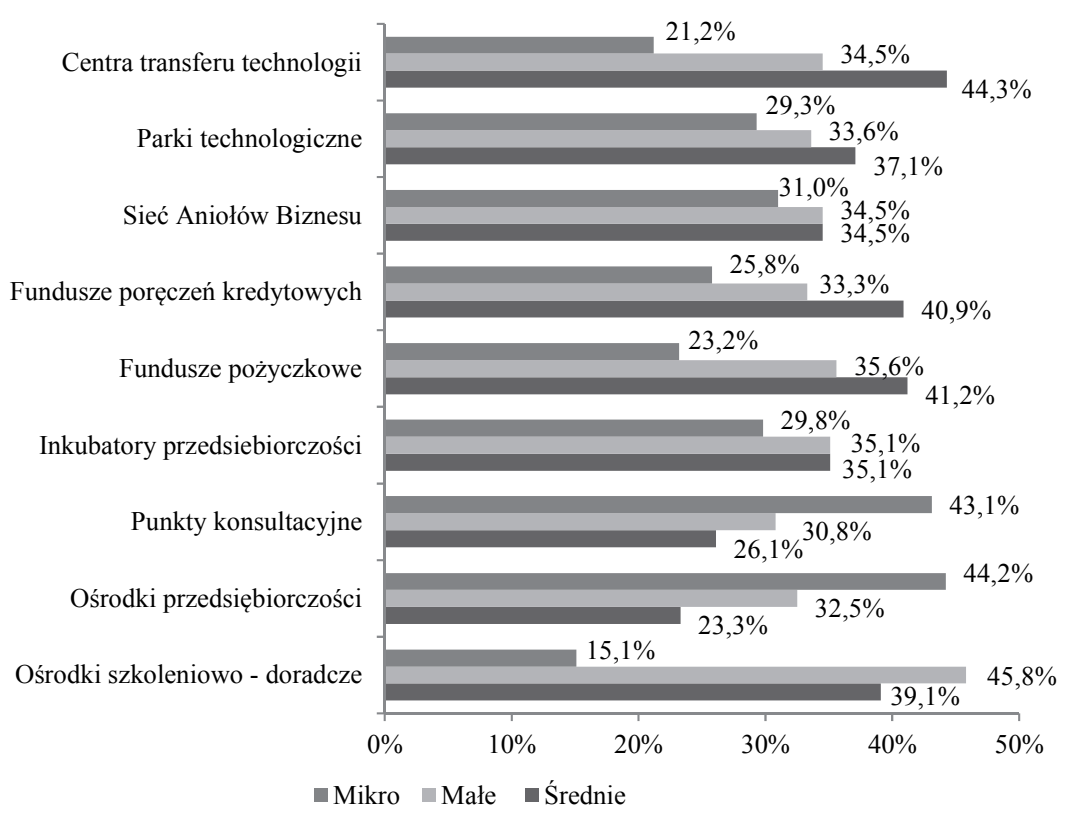

Uwaga: Respondenci mogli wybrać trzy odpowiedzi według ważności w skali 1-3, co oznaczało: 1 - ważna, 2 - bardzo ważna, 3 - najważniejsza.

Rysunek 80. Rodzaj instytucji otoczenia biznesu, z którą współpracowało przedsiębiorstwo Źródło: opracowanie własne

Przedsiębiorstwa, które współpracowały z instytucjami otoczenia biznesu, wskazały również efekty tej współpracy. Wypowiedzi respondentów były zróżnicowane w zależności od wielkości przedsiębiorstwa (por. rysunek 81), potwierdził to również test Kruskala-Wallisa. Jego wyniki i prawdopodobieństwo testowe $(p<0,05)$ pokazały zróżnicowanie większości badanych zmiennych (por. tabela 36).

Głównymi efektami tej współpracy w przypadku mikroprzedsiębiorstw było: pozyskanie środków finansowych, np. kredytu, pożyczki itd. (49,7\% wskazań), zdobycie nowych klientów i/lub rynków (47,3\% wskazań), uzyskanie pomocy w rozwiązaniu problemu (doradztwo) (43,4\% wskazań), w małych przedsiębiorstwach dostęp do wiedzy specjalistycznej (47,3\% wskazań), wykorzystanie środków z UE (43,1\% 49,7\% wskazań) oraz zakup nowych technologii (42,9\% wskazań). Natomiast w średnich możliwość wdrażania innowacyjnych rozwiązań (46,9\% wskazań) i rozwoju własnych zasobów ludzkich (45,7\% wskazań) oraz zwiększenie możliwości eksportowych $(43,8 \%$ wskazań). 
Tabela 36. Wartość statystyki $(H)$ według testu Kruskala-Wallisa oraz poziom prawdopodobieństwa testowego $(p)$ zmiennych określających efekty współpracy z instytucjami otoczenia biznesu w kontekście wielkości przedsiębiorstwa

\begin{tabular}{|l|c|c|}
\hline \multicolumn{1}{|c|}{ Efekty współpracy z instytucjami otoczenia biznesu } & $\begin{array}{c}\text { Wartość statystyki } \\
(H) \text { według testu } \\
\text { Kruskala-Wallisa }\end{array}$ & $\begin{array}{c}\text { Prawdopodo- } \\
\text { bieństwo } \\
\text { testowe }(p)\end{array}$ \\
\hline $\begin{array}{l}\text { Pozyskanie środków finansowych np. kredytu, pożyczki } \\
\text { itd.) }\end{array}$ & 9,342 & 0,011 \\
\hline Dostęp do wiedzy specjalistycznej & 13,716 & 0,000 \\
\hline Wykorzystanie środków z UE & 11,678 & 0,000 \\
\hline Możliwość wdrażania innowacyjnych rozwiązań & 1,956 & 0,489 \\
\hline Wspólne projekty i przedsięwzięcia & 11,931 & 0,000 \\
\hline Możliwość rozwoju własnych zasobów ludzkich & 10,375 & 0,001 \\
\hline Zdobycie nowych klientów i/lub rynków & 11,432 & 0,000 \\
\hline Zwiększenie możliwości eksportowych & 12,773 & 0,000 \\
\hline Zakup nowych technologii & 12,146 & 0,000 \\
\hline $\begin{array}{l}\text { Uzyskanie pomocy w rozwiązaniu problemu (doradz- } \\
\text { two) }\end{array}$ & 10,831 & 0,002 \\
\hline Nawiązanie współpracy z innymi firmami & 1,432 & 0,348 \\
\hline
\end{tabular}

Źródło: opracowanie własne.

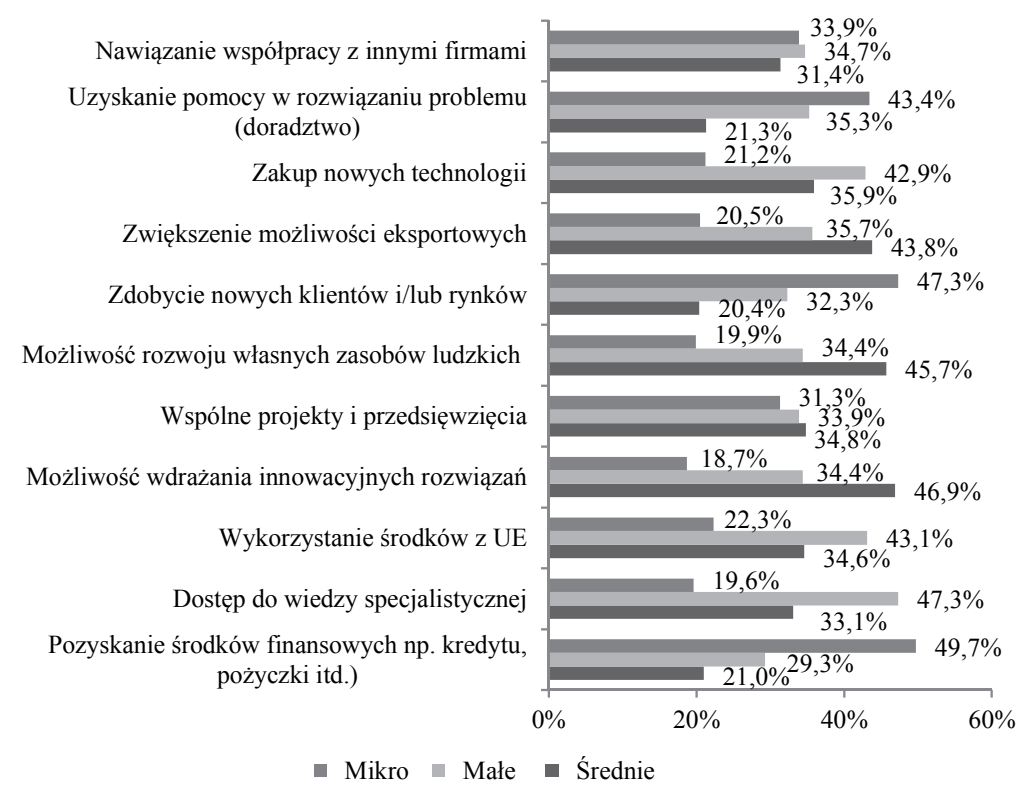

Uwaga: Respondenci mogli wybrać trzy odpowiedzi według ważności w skali 1-3, co oznaczało: 1 - ważna, 2 - bardzo ważna, 3 - najważniejsza.

Rysunek 81. Efekty współpracy przedsiębiorstwa z instytucjami otoczenia biznesu Źródło: opracowanie własne 
Przedsiębiorstwa, które nie współpracowały z instytucjami otoczenia biznesu, wskazały przyczyny jej braku. Wypowiedzi respondentów były zróżnicowane w zależności od wielkości przedsiębiorstwa (por. rysunek 82), potwierdził to również test Kruskala-Wallisa. Jego wyniki i prawdopodobieństwo testowe $(p<0,05)$ pokazały zróżnicowanie większości badanych zmiennych (por. tabela 37).

Tabela 37. Wartość statystyki $(H)$ według testu Kruskala-Wallisa oraz poziom prawdopodobieństwa testowego $(p)$ zmiennych określających przyczyny braku współpracy przedsiębiorstwa z instytucjami otoczenia biznesu w kontekście wielkości przedsiębiorstwa

\begin{tabular}{|l|c|c|}
\hline \multicolumn{1}{|c|}{$\begin{array}{c}\text { Przyczyny braku współpracy przedsiębiorstwa } \\
\text { z instytucjami otoczenia biznesu }\end{array}$} & $\begin{array}{c}\text { Wartość statystyki } \\
(H) \text { według testu } \\
\text { Kruskala-Wallisa }\end{array}$ & $\begin{array}{c}\text { Prawdopodo- } \\
\text { bieństwo } \\
\text { testowe }(p)\end{array}$ \\
\hline Niedopasowanie oferty do potrzeb przedsiębiorstwa & 11,332 & 0,000 \\
\hline Zbyt wysokie koszty współpracy & 9,719 & 0,001 \\
\hline Brak informacji o usługach instytucji otoczenia biznesu & 13,611 & 0,000 \\
\hline $\begin{array}{l}\text { Ograniczone możliwości adaptacji oferowanych } \\
\text { rozwiązań do przedsiębiorstw }\end{array}$ & 11,955 & 0,000 \\
\hline Brak potrzeby korzystania z takich usług & 10,731 & 0,000 \\
\hline Niezadawalająca jakość oferty & 12,751 & 0,000 \\
\hline Brak dostępności usług & 10,132 & 0,000 \\
\hline Zbyt mała ilość/brak tego typu instytucji w regionie & 13,753 & 0,000 \\
\hline Brak wymiernych korzyści ze współpracy & 10,646 & 0,000 \\
\hline $\begin{array}{l}\text { Zbyt trudne, długie procedury związane z rozpoczęciem } \\
\text { i prowadzeniem współpracy }\end{array}$ & 9,121 & 0,002 \\
\hline
\end{tabular}

Źródło: opracowanie własne.

W przypadku mikroprzedsiębiorstw były to następujące przyczyny: brak potrzeby korzystania $\mathrm{z}$ takich usług (52,6\% wskazań), brak wymiernych korzyści ze współpracy (51,8\% wskazań) oraz brak informacji o usługach instytucji otoczenia biznesu ( $43,7 \%$ wskazań), w małych przedsiębiorstwach niedopasowanie oferty do potrzeb przedsiębiorstwa (51,8\% wskazań), brak dostępności usług (42,6\% wskazań), ograniczone możliwości adaptacji oferowanych rozwiązań do przedsiębiorstw (41,3\% wskazań), natomiast w średnich przedsiębiorstwach niezadowalająca jakość oferty (47,9\% wskazań), zbyt mała ilość/brak tego typu instytucji w regionie (46,8\% wskazań), zbyt trudne, długie procedury związane $\mathrm{z}$ rozpoczęciem i prowadzeniem współpracy $(43,7 \%$ wskazań). Uzyskane odpowiedzi sugerują, że przedsiębiorcy oczekują innych kierunków wsparcia w zakresie prowadzenia działalności gospodarczej niż są obecnie oferowane przez te instytucje. 


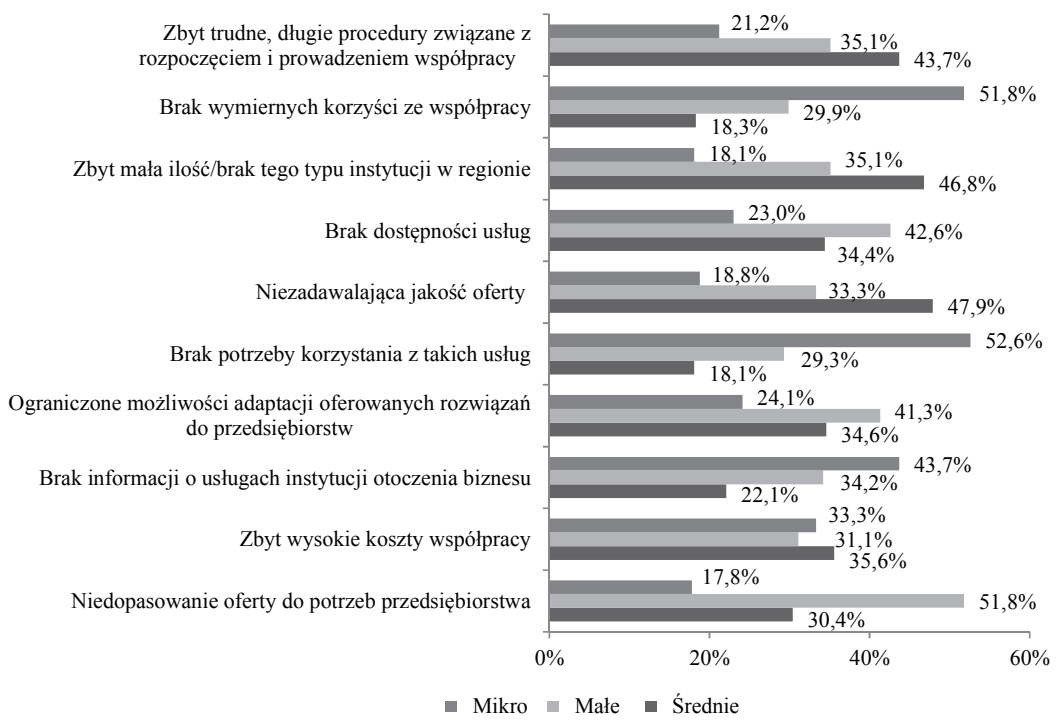

Uwaga: Respondenci mogli wybrać trzy odpowiedzi według ważności w skali 1-3, co oznaczało: 1 - ważna, 2 - bardzo ważna, 3 - najważniejsza.

Rysunek 82. Przyczyny braku współpracy przedsiębiorstwa z instytucjami otoczenia biznesu Źródło: opracowanie własne

Badane przedsiębiorstwa rzadko korzystały również z pomocy publicznej (tylko 21,4\% respondentów). Wśród tych, które korzystały najwięcej, było małych i średnich firm (por. rysunek 83). Przyczyn tego stanu rzeczy należy upatrywać $\mathrm{z}$ jednej strony $\mathrm{w}$ warunkach, które należy spełnić np. w postaci posiadanych zasobów, aby taką pomoc uzyskać, z drugiej zaś strony w brakach aktualnej informacji o oferowanych formach wsparcia.

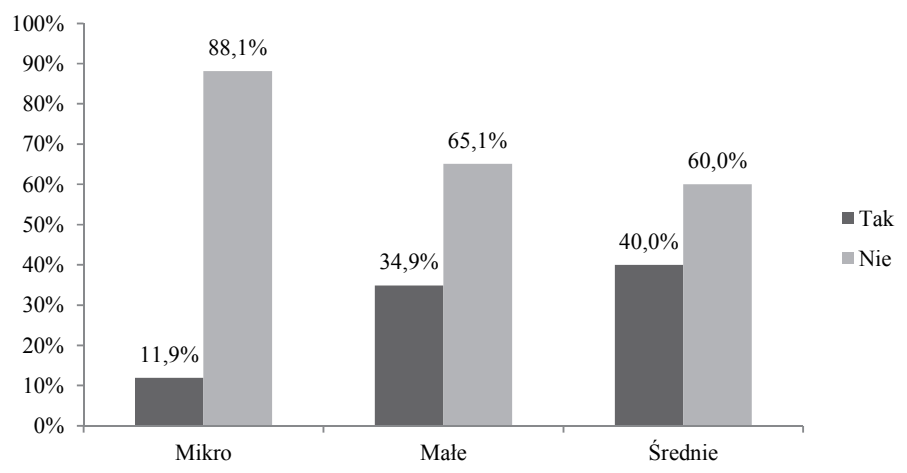

Rysunek 83. Korzystanie z pomocy publicznej

Źródło: opracowanie własne 
Przedsiębiorstwa, które korzystały z pomocy publicznej, wskazały, jakiego rodzaju była to pomoc. Wypowiedzi respondentów były zróżnicowane w zależności od wielkości przedsiębiorstwa (por. rysunek 84), potwierdził to również test Kruskala-Wallisa. Jego wyniki i prawdopodobieństwo testowe $(p<0,05)$ pokazały zróżnicowanie większości badanych zmiennych (por. tabela 38$)$.

Tabela 38. Wartość statystyki $(H)$ według testu Kruskala-Wallisa oraz poziom prawdopodobieństwa testowego $(p)$ zmiennych określających formy pomocy publicznej w kontekście wielkości przedsiębiorstwa

\begin{tabular}{|l|c|c|}
\hline \multicolumn{1}{|c|}{ Formy pomocy publicznej } & $\begin{array}{c}\text { Wartość statystyki }(H) \\
\text { według testu } \\
\text { Kruskala-Wallisa }\end{array}$ & $\begin{array}{c}\text { Prawdopodo- } \\
\text { bieństwo } \\
\text { testowe }(p)\end{array}$ \\
\hline Dotacje z funduszy unijnych & 12,132 & 0,000 \\
\hline Preferencyjne pożyczki i kredyty & 10,619 & 0,000 \\
\hline Ulgi i zwolnienia podatkowe & 8,112 & 0,002 \\
\hline Dotacje z budżetu państwa & 1,855 & 0,456 \\
\hline Obniżone opłaty (np. ZUS) & 11,791 & 0,000 \\
\hline Poręczenia i gwarancje kredytowe & 10,851 & 0,000 \\
\hline
\end{tabular}

Źródło: opracowanie własne.

W mikroprzedsiębiorstwach korzystano z preferencyjnych pożyczek i kredytów (33,1\% wskazań), obniżonych opłat (np. ZUS) (27,8\% wskazań), $\mathrm{w}$ małych $\mathrm{z}$ dotacji $\mathrm{z}$ funduszy unijnych $(45,1 \%$ wskazań), preferencyjnych pożyczek i kredytów (38,5\% wskazań) oraz obniżonych opłat (np. ZUS) $(38,0 \%$ wskazań), w przypadku średnich przedsiębiorstw z ulg i zwolnień podatkowych (47,9\% wskazań), poręczeń i gwarancji kredytowych (47,9\% wskazań).

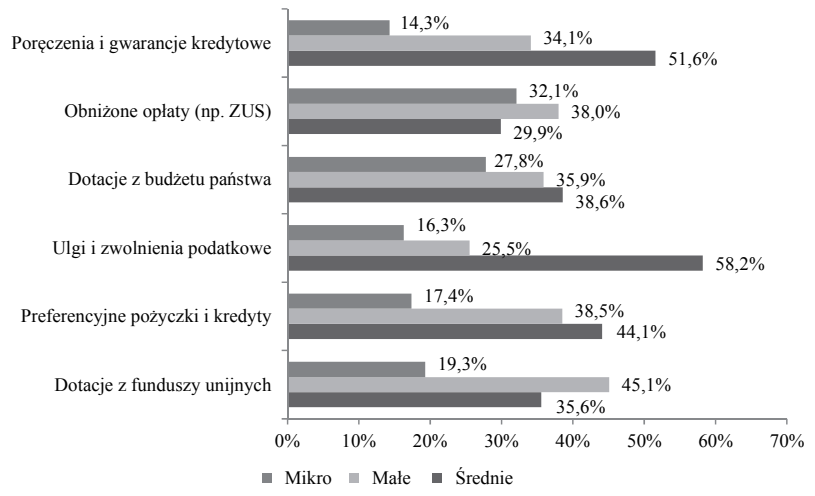

Uwaga: Respondenci mogli wybrać trzy odpowiedzi według ważności w skali 1-3, co oznaczało: 1 - ważna, 2 - bardzo ważna, 3 - najważniejsza.

Rysunek 84. Formy pomocy publicznej

Źródło: opracowanie własne 
Uzupełnieniem wiedzy na temat współpracy małych i średnich przedsiębiorstw $\mathrm{z}$ instytucjami otoczenia biznesu $\mathrm{w}$ obszarach zmarginalizowanych są opinie przedstawicieli tych instytucji na temat współpracy zebrane $\mathrm{w}$ trakcie badania jakościowego ${ }^{3}$. Badanie to zostało przeprowadzone metodą indywidualnego wywiadu pogłębionego (IDI) wśród 10 respondentów (prezesi, dyrektorzy, kierownicy) z Instytucji Otoczenia Biznesu (IOB) zlokalizowanych w obszarach zmarginalizowanych ${ }^{4}$. Pełne nazwy instytucji ze względu na anonimowość osób udzielających wywiadu nie zostały ujawnione, jedynie wskazany został rodzaj instytucji (por. tabela 38). Przedstawiciele IOB zapytani o współpracę z firmami zlokalizowanymi w obszarach zmarginalizowanych podkreślili zróżnicowaną sytuację w zakresie tej współpracy. Niewielka liczba firm jest zainteresowana i chętnie współpracuje z IOB, natomiast są przedsiębiorstwa, które nie są zainteresowane współpracą ze względu np. na brak zaufania, brak znajomości oferty jak również niedostosowaną ofertę IOB do potrzeb firmy. Respondenci podkreśli konieczność otwartości przedsiębiorstwa na współpracę oraz wskazali główne jej bariery (por. tabela 39).

Tabela 39. Bariery rozwoju współpracy z instytucjami otoczenia biznesu w obszarach zmarginalizowanych

\begin{tabular}{|c|c|c|}
\hline Przedsiębiorstwo & Rodzaj badanej instytucji & $\begin{array}{c}\text { Bariery rozwoju współpracy MSP z instytucjami } \\
\text { otoczenia biznesu w obszarach zmarginalizowanych }\end{array}$ \\
\hline 1 & 2 & 3 \\
\hline 1 & $\begin{array}{l}\text { Fundacja Rozwoju } \\
\text { Przedsiębiorczości }\end{array}$ & $\begin{array}{l}\text { "Trudna sytuacja przedsiębiorstw na rynku } \\
\text { wynikająca z niewystarczającego popytu, co } \\
\text { powoduje, ze firmy mają problemy z przetrwaniem } \\
\text { i rozwojem. Niewystarczające zasoby finansowe, } \\
\text { które uniemożliwiają korzystanie z funduszy } \\
\text { unijnych oraz brak chęci współpracy ze strony } \\
\text { przedsiębiorstw” }\end{array}$ \\
\hline 2 & $\begin{array}{l}\text { Agencja Rozwoju } \\
\text { Regionalnego }\end{array}$ & $\begin{array}{l}\text { „Brak wiedzy przedsiębiorców o możliwościach } \\
\text { współpracy, jak również potencjalnych partnerach } \\
\text { biznesowych, problemy finansowe. Brak aktyw- } \\
\text { nych działań instytucji otoczenia biznesu w celu } \\
\text { nawiązania współpracy” }\end{array}$ \\
\hline 3 & $\begin{array}{l}\text { Centrum Wspierania } \\
\text { Biznesu }\end{array}$ & $\begin{array}{l}\text { "Niska innowacyjność przedsiębiorstw w regionie, } \\
\text { szczególnie w gminach wiejskich, nie skłania do } \\
\text { współpracy z instytucjami otoczenia biznesu. Brak } \\
\text { promocji i kampanii informacyjnej o zakresie } \\
\text { oferowanych usług przez instytucje” }\end{array}$ \\
\hline 4 & $\begin{array}{l}\text { Izba przemysłowo- } \\
\text { handlowa }\end{array}$ & $\begin{array}{l}\text { „Oferta ośrodków nie jest dostosowana do potrzeb } \\
\text { przedsiębiorstw, ze względu na brak diagnozy tych } \\
\text { potrzeb. Mała liczba instytucji w regionie, niska } \\
\text { innowacyjność firm i brak skłonności inwestycyj- } \\
\text { nej. Nadmierna biurokracja ze strony instytucji } \\
\text { otoczenia biznesu” }\end{array}$ \\
\hline
\end{tabular}

\footnotetext{
${ }^{3}$ Metodyka badania została opisana w podrozdziale 4.1.

${ }^{4}$ Zgodnie $\mathrm{z}$ delimitacją zaproponowaną w podrozdziale 1.3 .
} 


\begin{tabular}{|c|c|c|}
\hline 1 & 2 & 3 \\
\hline 5 & Cech Rzemiosł Różnych & $\begin{array}{l}\text { „Brak wiedzy przedsiębiorstw odnośnie oferty } \\
\text { instytucji otoczenia biznesu, niechęć do współpra- } \\
\text { cy, brak wykwalifikowanej siły roboczej. W przed- } \\
\text { siębiorstwach rodzinnych, których jest znacząca } \\
\text { liczba na terenie powiatu problemy z wprowadza- } \\
\text { niem zmian blokowane przez starsze pokolenie” }\end{array}$ \\
\hline 6 & $\begin{array}{l}\text { Akademicki Inkubator } \\
\text { Przedsiębiorczości }\end{array}$ & $\begin{array}{l}\text { „Brak środków finansowych na uruchomienie } \\
\text { i prowadzenie biznesu, brak inwestycji w regionie } \\
\text { przyciągających firmy, słabo rozwinięta infrastruk- } \\
\text { tura B+R, słaba infrastruktura techniczna, która nie } \\
\text { sprzyja uruchomieniu biznesu” }\end{array}$ \\
\hline 7 & Park Technologiczny & $\begin{array}{l}\text { „Brak informacji o usługach instytucji biznesu, } \\
\text { długie procedury związane z nawiązaniem } \\
\text { współpracy np. szczególnie w przypadku funduszy } \\
\text { unijnych, długi czas oczekiwania na decyzje, oferta } \\
\text { nie zawsze jest dostosowana do potrzeb firmy. } \\
\text { Przedsiębiorcy nie mają zaufania do potencjalnych } \\
\text { partnerów w postaci instytucji otoczenia biznesu” }\end{array}$ \\
\hline 8 & Fundusz Pożyczkowy & $\begin{array}{l}\text { „Przedsiębiorcy nie znają oferty ośrodków otocze- } \\
\text { nia biznesu, jak również korzyści ze współpracy, } \\
\text { dlatego są niechętni do podjęcia współpracy. } \\
\text { Oferta instytucji niedopasowana do potrzeb, bark } \\
\text { specjalistycznych szkoleń np. z zakresu komercja- } \\
\text { lizacji innowacji. Trudna sytuacja w regionie } \\
\text { wysokie bezrobocie i odpływ młodych ludzi do } \\
\text { dużych ośrodków miejskich” }\end{array}$ \\
\hline 9 & $\begin{array}{l}\text { Agencja Rozwoju } \\
\text { Regionalnego }\end{array}$ & $\begin{array}{l}\text { „Przedsiębiorcy nie dostrzegają celu współpracy, } \\
\text { nadmierna biurokracja i niekiedy niekompetencja } \\
\text { pracowników tych ośrodków, zbyt mało informacji } \\
\text { na temat oferowanego wsparcia szczególnie finan- } \\
\text { sowego" }\end{array}$ \\
\hline 10 & $\begin{array}{l}\text { Stowarzyszenie Wolna } \\
\text { Przedsiębiorczość }\end{array}$ & $\begin{array}{l}\text { „Brak środków finansowych na współfinansowanie } \\
\text { projektów, nieznajomość oferty, mało instytucji } \\
\text { w regionie podejmujących kompleksowe wsparcie } \\
\text { przedsiębiorstw” }\end{array}$ \\
\hline
\end{tabular}

Źródło: opracowanie własne.

Analiza wypowiedzi przedstawicieli IOB pozwoliła wskazać na główne bariery współpracy przedsiębiorstw i IOB, które znajdowały się zarówno po stronie przedsiębiorstw:

- niska skłonność do współpracy,

- brak środków finansowych na współfinansowanie projektów,

- brak wiedzy na temat możliwości współpracy,

- niska innowacyjność i brak skłonności do wprowadzania zmian,

- niedostrzeganie celu i korzyści ze współpracy, 
- brak wykwalifikowanego personelu, jak również po stronie IOB:

- niewystarczająca informacja i działania promocyjne,

- brak dostosowania oferty na potrzeby przedsiębiorstw,

- biurokracja i długi czas oczekiwania na decyzje,

- mała liczba instytucji w regionie,

- brak specjalistycznych usług,

- niekompetencja pracowników,

- brak zaangażowania w podejmowane działania władz samorządowych w poprawę warunków prowadzenia działalności gospodarczej w danym regionie.

Respondenci, wskazując na bariery współpracy, zaproponowali działania (por. tabela 40), które należy podjąć w celu poprawy tych relacji, m.in.:

- aktualizacja informacji odnośnie do zakresu współpracy zawartych na stronachinternetowych,

- podejmowanie szerokich działań promocyjnych,

- ściślejsza współpraca z samorządem terytorialnym,

- dostosowanie oferty IOB do potrzeb przedsiębiorstw,

- rozszerzenie zakresu współpracy szczególnie o wsparcie finansowe przedsiębiorstw,

- ograniczenie biurokracji i skrócenie czasu oczekiwania na decyzje,

- zmiana polityki personalnej w celu zapewnienia profesjonalnej obsługi.

Tabela 40. Podejmowane działania przez IOB w celu nawiązywania współpracy

\begin{tabular}{|c|l|l|}
\hline Przedsiębiorstwo & Rodzaj badanej instytucji & \multicolumn{1}{|c|}{$\begin{array}{c}\text { Podejmowane działania przez IOB w celu } \\
\text { nawiązywania współpracy }\end{array}$} \\
\hline 1 & \multicolumn{1}{|c|}{3} \\
\hline 1 & $\begin{array}{l}\text { Fundacja Rozwoju } \\
\text { Przedsiębiorczości }\end{array}$ & $\begin{array}{l}\text { "Tworzenie bazy danych o przedsiębiorstwach } \\
\text { będących potencjalnymi partnerami współpracy, } \\
\text { podejmowanie działan promocyjnych, systema- } \\
\text { tyczna aktualizacja zawartych na stronie instytucji } \\
\text { informacji o możliwościach współpracy” }\end{array}$ \\
\hline 2 & $\begin{array}{l}\text { Agencja Rozwoju } \\
\text { Regionalnego }\end{array}$ & $\begin{array}{l}\text { „Spotkania z przedsiębiorcami w postaci semina- } \\
\text { riów i konferencji, utworzenie portalu zawierające- } \\
\text { go oferty współpracy, zmiana formy komunikacji } \\
\text { instytucji otoczenia biznesu z firmami poprzez } \\
\text { preferowanie bezpośrednich kontaktów” }\end{array}$ \\
\hline 3 & $\begin{array}{l}\text { „Utworzenie platformy wymiany informacji, pro- } \\
\text { mocja oferowanego wsparcia, zwiększenie liczby } \\
\text { instytucji tego typu w regionie szczególnie } \\
\text { w małych miastach, rozszerzenie oferty współpracy } \\
\text { ofinansową pomoc i poręczenia kredytowe” }\end{array}$ \\
\hline 4 & Biznesu & $\begin{array}{l}\text { „Aktualizacja strony internetowej, docieranie } \\
\text { bezpośrednie z oferta współpracy do przedsię- } \\
\text { biorstw. Ograniczenie biurokracji i procedur } \\
\text { otrzymania wsparcia do minimum” }\end{array}$ \\
\hline
\end{tabular}




\begin{tabular}{|c|c|c|}
\hline 1 & 2 & 3 \\
\hline 5 & Cech Rzemiosł Różnych & $\begin{array}{l}\text { „Ściślejsza współpraca instytucji otoczenia biznesu } \\
\text { z samorządem terytorialny, która umożliwi wspólne } \\
\text { działania w celu poprawy współpracy z przedsię- } \\
\text { biorstwami. Szerokie działania promujące ofertę } \\
\text { instytucji otoczenia biznesu” }\end{array}$ \\
\hline 6 & $\begin{array}{l}\text { Akademicki Inkubator } \\
\text { Przedsiębiorczości }\end{array}$ & $\begin{array}{l}\text { „Działania promujące instytucje zaangażowane we } \\
\text { wsparcie procesu uruchomienia firmy, zwiększenie } \\
\text { zakresu oferty o specjalistyczną wiedzę z zakresu } \\
\text { komercjalizacji wiedzy i innowacji” }\end{array}$ \\
\hline 7 & Park Technologiczny & $\begin{array}{l}\text { „Zwieszenie wsparcia finansowego przedsiębiorstw } \\
\text { - pożyczki, poręczenia kredytowe, dotacje unijne, } \\
\text { zmniejszenie biurokracji. Organizacja seminariów } \\
\text { i konferencji dla przedsiębiorców, dialog z przed- } \\
\text { siębiorstwami odnośnie potrzeb w zakresie } \\
\text { współpracy” }\end{array}$ \\
\hline 8 & Fundusz Pożyczkowy & $\begin{array}{l}\text { „Aktywny udział w działaniach promujących zakres } \\
\text { oferowanych usług: aktualizacja strony interneto- } \\
\text { wej, organizowanie seminariów i konferencji } \\
\text { z udziałem przedsiębiorców, rozszerzenie oferty } \\
\text { współpracy o usługi będące odpowiedzią na } \\
\text { potrzeby przedsiębiorców” }\end{array}$ \\
\hline 9 & $\begin{array}{l}\text { Agencja Rozwoju } \\
\text { Regionalnego }\end{array}$ & $\begin{array}{l}\text { „Zmiana polityki personalnej w kierunku rozsze- } \\
\text { rzenia kadry o specjalistów } \mathrm{z} \text { danej dziedziny } \\
\text { obejmującej wsparcie np. usługi prawne, księgowe } \\
\text { itp.” }\end{array}$ \\
\hline 10 & $\begin{array}{l}\text { Stowarzyszenie Wolna } \\
\text { Przedsiębiorczość }\end{array}$ & $\begin{array}{l}\text { „Rozbudowanie oferty wsparcia o źródła finanso- } \\
\text { wania dla przyszłych przedsiębiorców, uruchomie- } \\
\text { nie nowych ośrodków w regionie” }\end{array}$ \\
\hline
\end{tabular}

Źródło: opracowanie własne.

Wyniki badań zarówno ilościowych, jak i jakościowych wskazują na niską skłonność korzystania małych i średnich przedsiębiorstw z usług wsparcia, potwierdzają to również wyniki badań innych autorów, np. B. Piaseckiego i zespołu, K. Wacha (Piasecki 2001, Wach 2008). Jednym z głównych powodów niekorzystania $\mathrm{z}$ usług instytucji wsparcia, oprócz braku takiej potrzeby, była niewystarczająca informacja o oferowanych usługach oraz niedopasowanie do potrzeb przedsiębiorców. Aby poprawić tę sytuację, zasadna by była ściślejsza współpraca instytucji otoczenia biznesu z samorządem gospodarczym reprezentującym przedsiębiorców oraz poprawa promocji oferowanych usług głównie w środowisku lokalnych przedsiębiorców, w tym w szczególności w obszarach zmarginalizowanych. 


\subsection{Problemy zarządzania małymi i średnimi przedsiębiorstwami zlokalizowanymi w obszarach zmarginalizowanych}

Bardzo istotnym elementem prezentowanych badań jest diagnoza w zakresie zarządzania w kontekście obszaru zmarginalizowanego. Większość badanych przedsiębiorstw wskazała na problemy w zarządzaniu $(61,2 \%)$, w przypadku mikroprzedsiębiorstw było to $67,2 \%$, małych $59,8 \%$, a średnich $49,6 \%$ (por. rysunek 85). Wyniki te świadczą o świadomości przedsiębiorców o niesprawności zarządzania $\mathrm{w}$ ich przedsiębiorstwie, chociaż większość z nich deklarowała swoje wcześniejsze doświadczenie w zarządzaniu $(74,9 \%)$ (szerzej w podrozdziale 4.3).

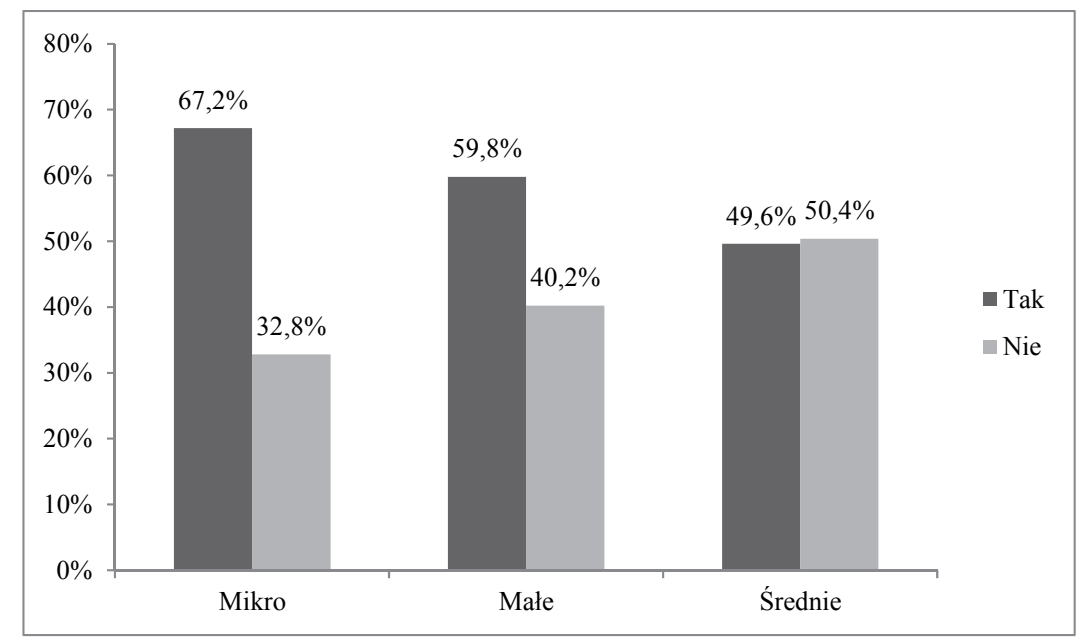

Rysunek 85. Problemy w zarządzaniu

Źródło: opracowanie własne

Przyczyn tego stanu rzeczy można upatrywać zarówno w osobie przedsiębiorcy jego wiedzy, kompetencjach i posiadanych kwalifikacjach oraz jego podejściu do efektywności tego procesu, jak również otoczeniu w kontekście specyficznych cech obszaru zmarginalizowanego. Czego potwierdzeniem mogą być wypowiedzi respondentów, którzy wskazali w większości przypadków (87,6\%) na wpływ czynników wynikających ze specyfiki obszarów zmarginalizowanych na zarządzanie małym i średnim przedsiębiorstwem, wskazując cechy tych obszarów, które miały największy wpływ na rozwój ich przedsiębiorstwa. Korzystając z listy zaproponowanych cech tych obszarów (por. rysunek 30), analogicznie jak w podrozdziale 4.1 respondenci oceniali siłę, $\mathrm{z}$ jaką dana cecha ma wpływ na rozwój badanego przedsiębiorstwa. Oceny dokonano w skali od 0 do 5, przy czym: 0 - brak wpływu, a 5 - najsilniejszy wpływ. 
Rozkład wypowiedzi respondentów wskazuje na zróżnicowanie siły wpływu specyficznych cech obszaru zmarginalizowanego na proces zarządzania przedsiębiorstwem w zależności od wielkości przedsiębiorstwa, potwierdził to również test Kruskala-Wallisa. Jego wyniki i prawdopodobieństwo testowe $(p<0,05)$ pokazały zróżnicowanie większości badanych zmiennych (por. tabela 41).

Tabela 41. Wartość statystyki $(H)$ według testu Kruskala-Wallisa oraz poziom prawdopodobieństwa testowego $(p)$ zmiennych określających wpływ cech obszarów zmarginalizowanych na zarządzanie przedsiębiorstwem w kontekście wielkości przedsiębiorstwa

\begin{tabular}{|l|c|c|}
\hline \multicolumn{1}{|c|}{$\begin{array}{c}\text { Wpływ cech obszarów zmarginalizowanych na } \\
\text { zarządzanie przedsiębiorstwem }\end{array}$} & $\begin{array}{c}\text { Wartość statystyki }(H) \\
\text { według testu } \\
\text { Kruskala-Wallisa }\end{array}$ & $\begin{array}{c}\text { Prawdopodo- } \\
\text { bieństwo } \\
\text { testowe }(p)\end{array}$ \\
\hline Niska konkurencyjność regionu & 15,602 & 0,000 \\
\hline $\begin{array}{l}\text { Zależność gospodarcza od sektora pierwotnego np. } \\
\text { rolnictwa }\end{array}$ & 3,163 & 0,498 \\
\hline $\begin{array}{l}\text { Brak korzyści związanych z funkcjonowaniem } \\
\text { w centrum rozwoju }\end{array}$ & 2,221 & 0,658 \\
\hline Niski poziom innowacyjności regionu & 17,335 & 0,000 \\
\hline Gorsza infrastruktura techniczna & 13,671 & 0,000 \\
\hline Brak wykwalifikowanej siły roboczej & 9,127 & 0,001 \\
\hline $\begin{array}{l}\text { Brak klimatu przyjaznego dla rozwoju przedsię- } \\
\text { biorstw }\end{array}$ & 1,342 & 0,812 \\
\hline Ograniczony dostęp do otoczenia biznesu & 8,382 & 0,021 \\
\hline Mniejsza liczba potencjalnych klientów & 19,958 & 0,000 \\
\hline Ograniczony dostęp do środków finansowych & 22,781 & 0,000 \\
\hline Bierne wsparcie ze strony władz samorządowych & 1,698 & 0,756 \\
\hline Ograniczony dostęp do informacji & 4,654 & 0,238 \\
\hline $\begin{array}{l}\text { Brak umiejętności wykorzystania środków } \\
\text { unijnych }\end{array}$ & 5,322 & 0,198 \\
\hline
\end{tabular}

Źródło: opracowanie własne.

W mikroprzedsiębiorstwach największy wpływ miał ograniczony dostęp do środków finansowych (48,1\% wskazań) oraz ograniczony dostęp do informacji (41,7\% wskazań), w małych przedsiębiorstwach mniejsza liczba potencjalnych klientów (51,2\% wskazań), ograniczony dostęp do otoczenia biznesu $(44,3 \%$ wskazań) oraz gorsza infrastruktura techniczna (42,1\% wskazań). Natomiast średnie przedsiębiorstwa wskazały jako największy wpływ: brak wykwalifikowanej siły roboczej (50,1\% wskazań) oraz niski poziom innowacyjności regionu (45,7\% wskazań) (por. rysunek 85$)$. Wskazane przez respondentów cechy obszarów zmarginalizowanych, mające wpływ na zarządzanie $\mathrm{w}$ badanych przedsiębiorstwach, uwypukliły konieczność uwzględniania w procesie zarządzania nie tylko uwarunkowań wewnętrznych związanych $\mathrm{z}$ przedsiębiorcą i przedsiębiorstwem, ale również charakterystyk najbliższego otoczenia, $w$ tym 
przypadku obszarów zmarginalizowanych. Siła wpływu specyficznych cech obszaru zmarginalizowanego na zarządzanie MSP jest zróżnicowana w poszczególnych kategoriach firm (mikro, małych i średnich), co pozwala precyzyjnie określić potrzeby tych firm w zakresie sprawności zarządzania.

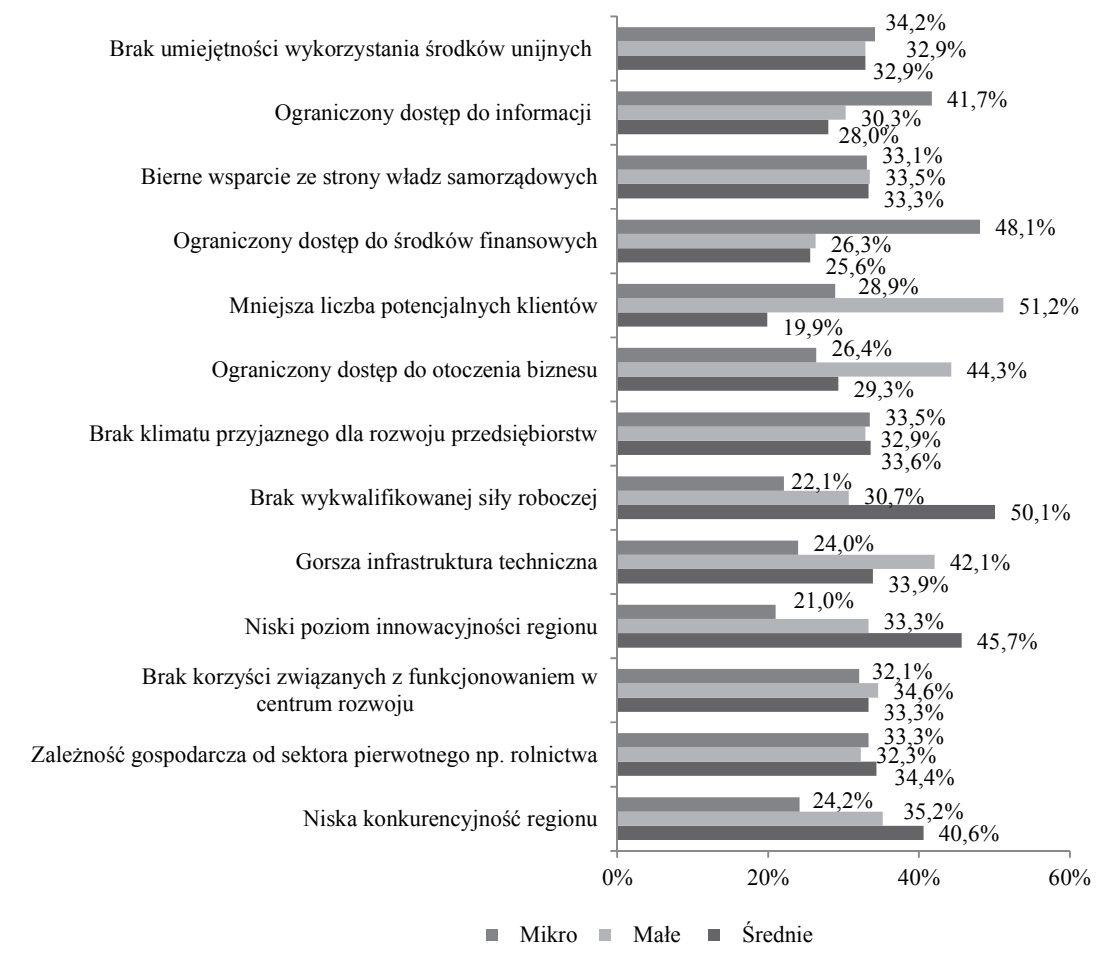

Uwaga: Respondenci mogli wybrać trzy odpowiedzi według ważności w skali 1-3, co oznaczało: 1 - ważna, 2 - bardzo ważna, 3 - najważniejsza.

Rysunek 86. Wpływ czynników wynikających ze specyfiki obszarów zmarginalizowanych na zarządzanie małym i średnim przedsiębiorstwem

Źródło: opracowanie własne

Przedsiębiorcy, którzy wskazali na problemy w zarządzaniu przedsiębiorstwem, określili również słabości tego procesu (por. rysunek 87). Rozkład wypowiedzi respondentów wskazuje na zróżnicowanie niedoskonałości tego procesu $\mathrm{w}$ zależności od wielkości przedsiębiorstwa, potwierdził to również test Kruskala-Wallisa. Jego wyniki i prawdopodobieństwo testowe $(p<0,05)$ pokazały zróżnicowanie większości badanych zmiennych (por. tabela 42). 
Tabela 42. Wartość statystyki $(H)$ według testu Kruskala-Wallisa oraz poziom prawdopodobieństwa testowego $(p)$ zmiennych określających słabości procesu zarządzania w kontekście wielkości przedsiębiorstwa

\begin{tabular}{|l|c|c|}
\hline \multicolumn{1}{|c|}{ Słabości procesu zarządzania przedsiębiorstwem } & $\begin{array}{c}\text { Wartość statystyki }(H) \\
\text { według testu } \\
\text { Kruskala-Wallisa }\end{array}$ & $\begin{array}{c}\text { Prawdopodo- } \\
\text { bieństwo } \\
\text { testowe }(p)\end{array}$ \\
\hline Brak jasno wytyczonej strategii rozwoju & 18,111 & 0,000 \\
\hline Niedostrzeganie potrzeby zarządzania wiedzą & 13,164 & 0,000 \\
\hline Brak planowania & 12,129 & 0,000 \\
\hline Niski kapitał początkowy & 14,139 & 0,000 \\
\hline Niechęć do delegowania uprawnień & 12,172 & 0,000 \\
\hline $\begin{array}{l}\text { Problemy komunikacyjne wewnątrz przedsiębior- } \\
\text { stwa }\end{array}$ & 19,127 & 0,000 \\
\hline $\begin{array}{l}\text { Brak umiejętności wykorzystywania okazji pojawia- } \\
\text { jących się w otoczeniu }\end{array}$ & 10,285 & 0,001 \\
\hline Niska skłonność do uczenia się & 1,396 & 0,921 \\
\hline Brak znajomości nowoczesnych technik zarządzania & 1,988 & 0,896 \\
\hline Niska skłonność do kreatywności i innowacyjności & 2,682 & 0,712 \\
\hline Błędy popełnione przy planowaniu i kontroli & 11,622 & 0,000 \\
\hline Brak umiejętności motywowania pracowników & 9,958 & 0,001 \\
\hline
\end{tabular}

Źródło: opracowanie własne.

W mikroprzedsiębiorstwach za największą niedoskonałość procesu zarządzania uznano brak jasno wytyczonej strategii rozwoju (51,2\% wskazań), niski kapitał początkowy (45,9\% wskazań) oraz brak umiejętności wykorzystywania okazji pojawiających się w otoczeniu (42,9\% wskazań), w małych przedsiębiorstwach - brak planowania (44,3\% wskazań), niechęć do delegowania usprawnień $(45,9 \%$ wskazań) oraz brak umiejętności motywowania pracowników (42,9\% wskazań). Natomiast średnie przedsiębiorstwa wskazały jako największe słabości w zarządzaniu przedsiębiorstwem: błędy popełnione przy planowaniu i kontroli (48,7\% wskazań), problemy komunikacyjne wewnątrz przedsiębiorstwa $(47,2 \%$ wskazań) oraz niedostrzeganie potrzeby zarządzania wiedzą (45,7\% wskazań) (por. rysunek 86). Taki rozkład wypowiedzi podkreśla głównie problemy w zarządzaniu MSP z uwzględnieniem specyficznych uwarunkowań obszaru zmarginalizowanego. W przypadku mikroprzedsiębiorstw słabością jest brak zarządzania strategicznego oraz niewystarczające zasoby finansowe, w przypadku małych przedsiębiorstw - problemy personalne oraz niewystarczające zarządzanie strategiczne, a w przypadku średnich firm - błędy zarządzania operacyjnego oraz słabości wynikające ze struktury organizacyjnej. 


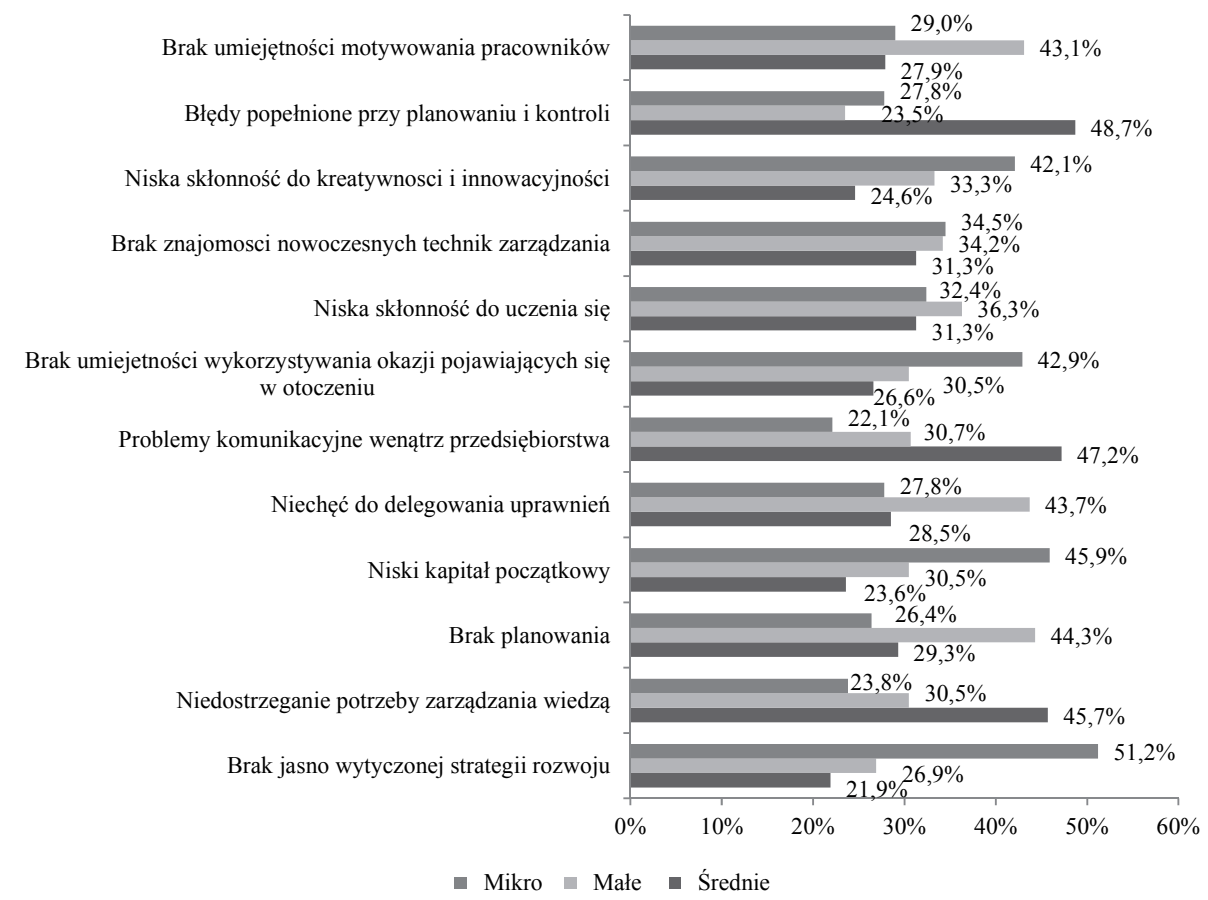

Uwaga: Respondenci mogli wybrać trzy odpowiedzi według ważności w skali 1-3, co oznaczało: 1 - ważna, 2 - bardzo ważna, 3 - najważniejsza.

Rysunek 87. Słabości w zarządzaniu

Źródło: opracowanie własne

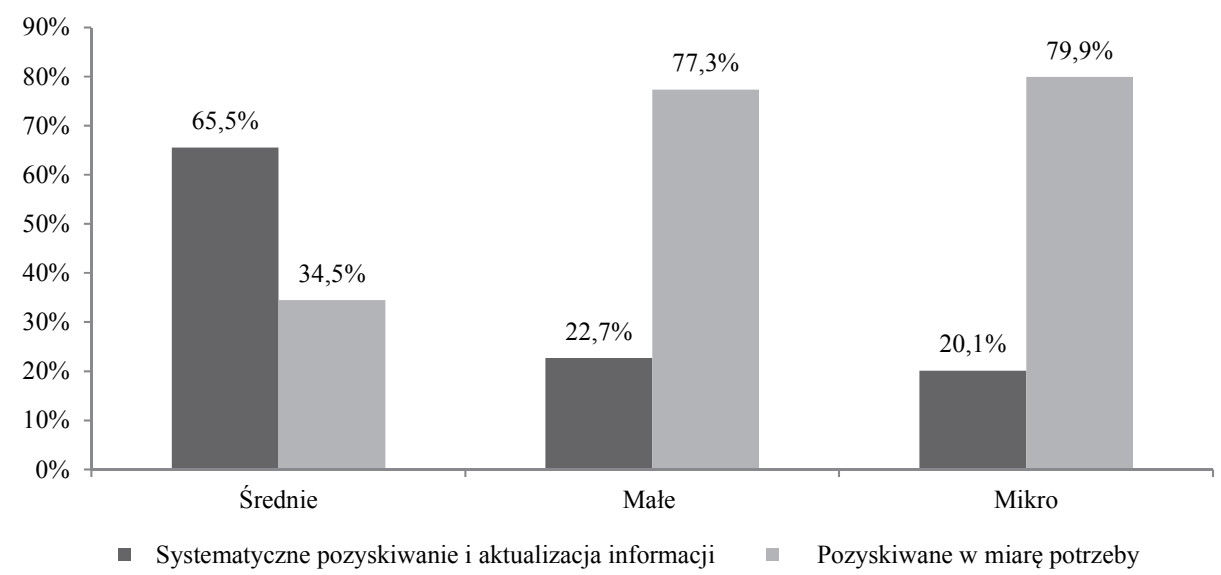

Rysunek 88. Częstotliwość pozyskiwania informacji

Źródło: opracowanie własne 
Dla sprawnego zarządzania równie istotne jest pozyskiwanie i gromadzenie informacji, które mogą mieć kluczowe znaczenie przy podejmowaniu decyzji strategicznych. W badanych przedsiębiorstwach dostrzega się duży problem z pozyskiwaniem i aktualizacją informacji (por. rysunek 88 ). Tyko $(37,8 \%$ ) przedsiębiorstw systematycznie pozyskiwała i aktualizowała informacje $\mathrm{i}$ były to głównie średnie przedsiębiorstwa $(65,5 \%)$. W przypadku mikro i małych przedsiębiorstw niedoceniona została rola informacji $\mathrm{w}$ procesie zarzadzania firmą co $\mathrm{w}$ przyszłości może powodować problemy z utrzymaniem przewagi konkurencyjnej, której źródłem może się stać sia gromadzona wiedza w postaci informacji w przedsiębiorstwie.

Respondenci w kolejnym etapie wskazali rodzaj pozyskiwanej informacji, który był zróżnicowany w zależności od wielkości przedsiębiorstwa. Potwierdziły to również wyniki testu Kruskala-Wallisa i prawdopodobieństwo testowe $(p<0,05)$ (por. tabela 43).

Tabela 43. Wartość statystyki $(H)$ według testu Kruskala-Wallisa oraz poziom prawdopodobieństwa testowego $(p)$ zmiennych określających rodzaj pozyskiwanej informacji w kontekście wielkości przedsiębiorstwa

\begin{tabular}{|l|c|c|}
\hline \multicolumn{1}{|c|}{ Rodzaj pozyskiwanej informacji } & $\begin{array}{c}\text { Wartość statystyki }(H) \\
\text { według testu } \\
\text { Kruskala-Wallisa }\end{array}$ & $\begin{array}{c}\text { Prawdopodo- } \\
\text { bieństwo } \\
\text { testowe }(p)\end{array}$ \\
\hline O nowych produktach & 13,155 & 0,000 \\
\hline Na temat sytuacji gospodarczej & 1,372 & 0,892 \\
\hline O nowych klientach & 11,328 & 0,000 \\
\hline Zmiany w prawie & 16,331 & 0,000 \\
\hline O konkurencji & 11,471 & 0,000 \\
\hline O zmianach na rynku dostawców/odbiorców & 15,141 & 0,000 \\
\hline
\end{tabular}

Źródło: opracowanie własne.

W mikroprzedsiębiorstwach najczęściej pozyskiwano informacje o nowych produktach $(51,2 \%$ wskazań) oraz zmianach $\mathrm{w}$ prawie (45,9\% wskazań), w małych przedsiębiorstwach - o nowych klientach (44,7\% wskazań) oraz konkurencji (39,5\% wskazań). Natomiast średnie przedsiębiorstwa pozyskiwały najczęściej informacje o zmianach na rynku dostawców/odbiorców $(47,2 \%$ wskazań) oraz konkurencji (38,2\% wskazań) (por. rysunek 89). Wypowiedzi respondentów wskazują, że najczęściej pozyskiwane są informacje o sytuacji rynkowej, rzadziej natomiast związane $\mathrm{z}$ dalszym otoczeniem przedsiębiorstwa. Podkreśla to wielokrotnie już eksponowany w niniejszym opracowaniu lokalny charakter szczególnie mikro i małych przedsiębiorstw i wskazuje na konieczność doceniania roli informacji w zarządzaniu przedsiębiorstwem. 


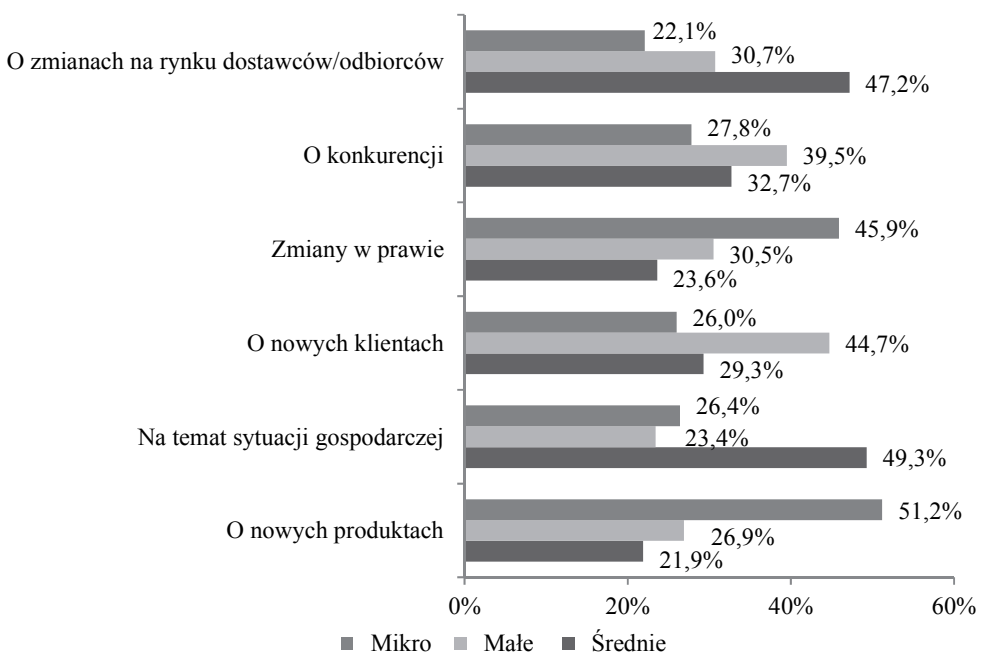

Uwaga: Respondenci mogli wybrać trzy odpowiedzi według ważności w skali 1-3, co oznaczało: 1 - ważna, 2 - bardzo ważna, 3 - najważniejsza.

Rysunek 89. Rodzaje informacji pozyskiwanych i wykorzystywanych w przedsiębiorstwie Źródło: opracowanie własne

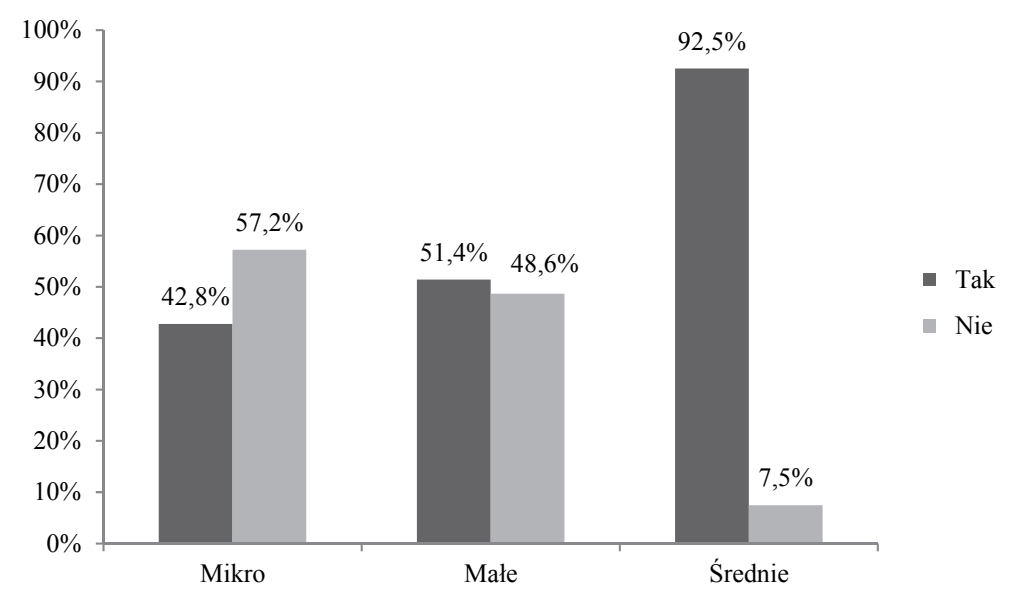

Rysunek 90. Posiadanie strategii rozwoju Źródło: opracowanie własne.

Większość badanych przedsiębiorstw zadeklarowała posiadanie strategii rozwoju $(67,2 \%)$, były to głównie średnie przedsiębiorstwa $(92,5 \%)$, znacznie gorzej sytuacja $\mathrm{z}$ posiadaniem strategii wyglądała $\mathrm{w}$ przypadku mikro i małych przedsiębiorstw (odpowiednio 42,8\% i 51,4\%) (por. rysunek 90). Forma tej strategii też była bardzo zróżnicowana; w przypadku mikro i małych przedsiębiorstw często była to 
forma ustna lub dokument o charakterze nieformalnym, w przypadku średnich to zbiór wielu dokumentów, materiałów i analiz lub formalnie jako jeden dokument przyjęty przez zarząd. Nieformalna forma strategii często nie do końca pozwala na planowanie działań, ale z drugiej strony umożliwia elastyczne działanie. To jest mocną stroną szczególnie mikro i małych przedsiębiorstw, w przypadku średnich strategia powinna być sformalizowana, co pomoże w uniknięciu błędów szczególnie związanych z procesem planowania i kontroli.

Kolejnym wątkiem badawczym związanym ze strategią była ocena wpływu specyfiki obszarów zmarginalizowanych na formułowanie strategii rozwoju. Większość respondentów $(64,4 \%)$ miała świadomość tego wpływu, najwięcej w średnich przedsiębiorstwach $(69,8 \%)$, co wydaje się być istotne szczególnie dla skorelowania działań operacyjnych z niezbędnymi zmianami strategicznymi (por. rysunek 91).

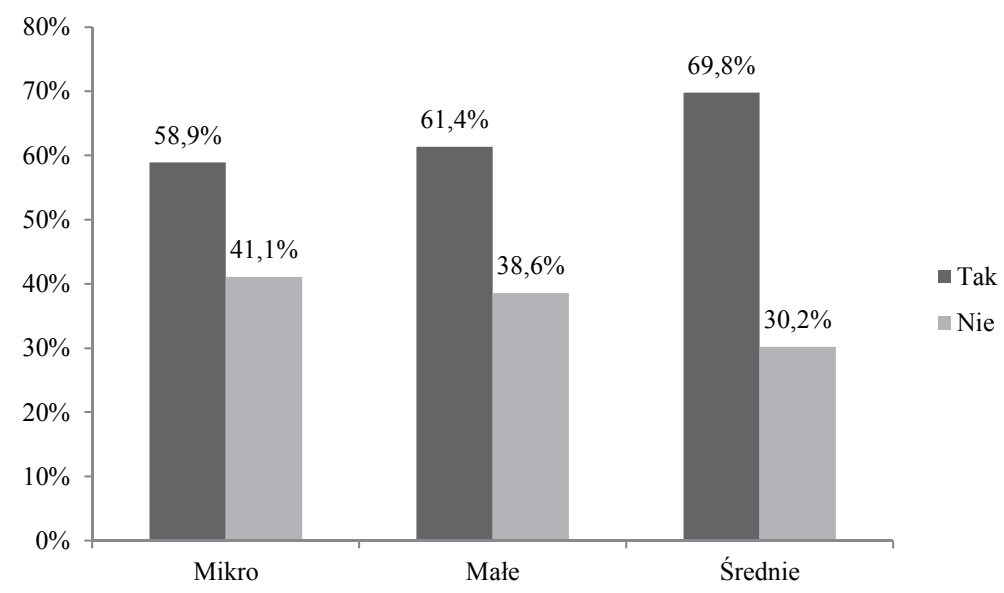

Rysunek 91. Wpływ specyfiki obszarów zmarginalizowanych na formułowanie strategii rozwoju Źródło: opracowanie własne

Przedsiębiorstwa, które potwierdziły wpływ specyfiki obszarów zmarginalizowanych na formułowanie strategii rozwoju, wskazały na czynniki mające największy wpływ na kształt tej strategii. Rozkład wypowiedzi respondentów wskazuje na zróżnicowanie siły wpływu specyficznych cech obszaru zmarginalizowanego na strategię rozwoju w zależności od wielkości przedsiębiorstwa, potwierdził to również test Kruskala-Wallisa. Jego wyniki i prawdopodobieństwo testowe $(p<0,05)$ pokazały zróżnicowanie większości badanych zmiennych (por. tabela 44). 
Tabela 44. Wartość statystyki $(H)$ według testu Kruskala-Wallisa oraz poziom prawdopodobieństwa testowego $(p)$ zmiennych określających wpływ cech obszarów zmarginalizowanych na strategię rozwoju w kontekście wielkości przedsiębiorstwa

\begin{tabular}{|l|c|c|}
\hline \multicolumn{1}{|c|}{$\begin{array}{c}\text { Wpływ cech obszarów zmarginalizowanych na } \\
\text { zarzadzanie przedsiębiorstwem }\end{array}$} & $\begin{array}{c}\text { Wartość statystyki }(H) \\
\text { według testu } \\
\text { Kruskala-Wallisa }\end{array}$ & $\begin{array}{c}\text { Prawdopodo- } \\
\text { bieństwo } \\
\text { testowe }(p)\end{array}$ \\
\hline Niska konkurencyjność regionu & 11,129 & 0,000 \\
\hline $\begin{array}{l}\text { Zależność gospodarcza od sektora pierwotnego np. } \\
\text { rolnictwa }\end{array}$ & 1,273 & 0,798 \\
\hline $\begin{array}{l}\text { Brak korzyści związanych z funkcjonowaniem } \\
\text { w centrum rozwoju }\end{array}$ & 3,745 & 0,318 \\
\hline Niski poziom innowacyjności regionu & 10,135 & 0,000 \\
\hline Gorsza infrastruktura techniczna & 9,691 & 0,001 \\
\hline Brak wykwalifikowanej siły roboczej & 13,187 & 0,000 \\
\hline $\begin{array}{l}\text { Brak klimatu przyjaznego dla rozwoju przedsię- } \\
\text { biorstw }\end{array}$ & 11,198 & 0,000 \\
\hline Ograniczony dostęp do otoczenia biznesu & 12,818 & 0,000 \\
\hline Mniejsza liczba potencjalnych klientów & 19,958 & 0,000 \\
\hline Ograniczony dostęp do środków finansowych & 16,911 & 0,000 \\
\hline Bierne wsparcie ze strony władz samorządowych & 2,616 & 0,651 \\
\hline Ograniczony dostęp do informacji & 14,394 & 0,000 \\
\hline $\begin{array}{l}\text { Brak umiejętności wykorzystania środków unij- } \\
\text { nych }\end{array}$ & 4,383 & 0,298 \\
\hline
\end{tabular}

Źródło: opracowanie własne.

W mikroprzedsiębiorstwach największy wpływ na kształt strategii rozwoju miała mniejsza liczba potencjalnych klientów (54,6\% wskazań), ograniczony dostęp do środków finansowych $(45,9 \%$ wskazań) oraz ograniczony dostęp do informacji (39,2\% wskazań), w małych przedsiębiorstwach - gorsza infrastruktura techniczna (45,7\% wskazań), niska konkurencyjność regionu (42,0\% wskazań) oraz brak klimatu przyjaznego dla rozwoju przedsiębiorstw (40,9\% wskazań). Natomiast średnie przedsiębiorstwa wskazały jako największy wpływ: brak wykwalifikowanej siły roboczej (47,2\% wskazań) oraz ograniczony dostęp do otoczenia biznesu (44,3\% wskazań) (por. rysunek 92). Wskazane przez respondentów cechy obszarów zmarginalizowanych mające wpływ na kształt strategii rozwoju są bardzo zróżnicowane w każdej z omawianych kategorii firm, ich identyfikacja może przyczynić się do trafnie sformułowanej strategii wynikającej z szczegółowej diagnozy najbliższego otoczenia firmy. 


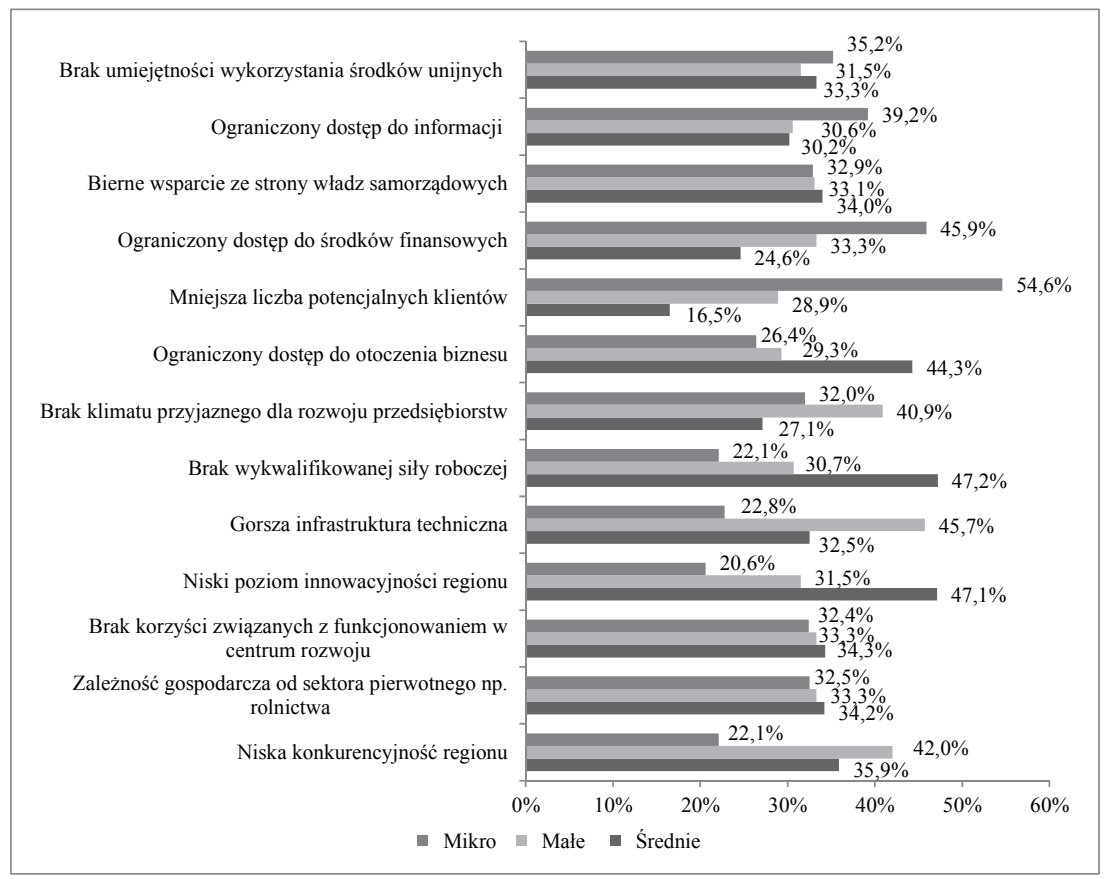

Uwaga: Respondenci mogli wybrać trzy odpowiedzi według ważności w skali 1-3, co oznaczało: 1 - ważna, 2 - bardzo ważna, 3 - najważniejsza.

Rysunek 92. Wpływ czynników wynikających ze specyfiki obszarów zmarginalizowanych na strategię rozwoju w małym i średnim przedsiębiorstwie Źródło: opracowanie własne

Tabela 45. Marginalizacja obszaru a proces zarządzania*

\begin{tabular}{|c|c|c|}
\hline $\begin{array}{l}\text { Przedsię- } \\
\text { biorstwo }\end{array}$ & $\begin{array}{l}\text { Wpływ marginalizacja obszaru na } \\
\text { zarzadzanie przedsiębiorstwem }\end{array}$ & Komentarz \\
\hline 1 & 2 & 3 \\
\hline 1 & $\begin{array}{l}\text { „Właściciel przedsiębiorstwa stara się } \\
\text { dostosować strategię działania i sposób } \\
\text { zarządzania do warunków lokalnych. } \\
\text { Prowadzenie firmy jest trudne ze wzglę- } \\
\text { du na małą liczbę klientów, co przekłada } \\
\text { się na wielkość produkcji. Problemem } \\
\text { jest również duża rotacją personelu, być } \\
\text { może wynikająca z nieumiejętnego mo- } \\
\text { tywowania, jak również niskich wyna- } \\
\text { grodzeń. Przedsiębiorstwo próbuje wejść } \\
\text { na rynek zagraniczny, jednak ograniczo- } \\
\text { ne środki finansowe, jak również brak } \\
\text { innowacyjności stanowią barierę rozwoju } \\
\text { tej działalności. Firma wcześniej zaj- } \\
\text { mowała się przerobem uszlachetniają- } \\
\text { cym, co właściwie nie pozwoliło na pier- } \\
\text { wszym etapie działalności na wykreowa- } \\
\text { nie własnej marki” }\end{array}$ & $\begin{array}{l}\text { Głównym problemem w badanym } \\
\text { przedsiębiorstwie jest brak środków } \\
\text { finansowych na dalszy rozwój jak } \\
\text { również brak elastyczności w działaniu, } \\
\text { które powinno zostać dostosowane do } \\
\text { uwarunkowań zewnętrznych firmy, } \\
\text { pochodzących z najbliższego otoczenia }\end{array}$ \\
\hline
\end{tabular}




\begin{tabular}{|c|c|c|}
\hline 1 & 2 & 3 \\
\hline 2 & $\begin{array}{l}\text { „Największym problemem jest brak } \\
\text { środków finansowych na rozwój i mała } \\
\text { liczba klientów, wynikająca z jednej } \\
\text { strony z niskiej siły nabywczej lokalnego } \\
\text { społeczeństwa, z drugiej zaś strony } \\
\text { lokalizacji przedsiębiorstwa w obszarach } \\
\text { wiejskich. Właściciel firmy nie monito- } \\
\text { ruje na bieżąco lokalnego otoczenia, co } \\
\text { w wielu przypadkach mogło już do- } \\
\text { prowadzić do upadku firmy, np. w nie- } \\
\text { dalekiej okolicy powstał kolejny sklep, } \\
\text { który stanowił poważną konkurencję dla } \\
\text { badanej firmy, jedynie szybka reakcja } \\
\text { i możliwość wykorzystania strategii ce- } \\
\text { nowej pozwoliła na utrzymanie jej na } \\
\text { rynku” }\end{array}$ & $\begin{array}{l}\text { Głównym problemem firmy jest loka- } \\
\text { lizacja firmy i brak reakcji właściciela } \\
\text { na zmieniającą się sytuacje rynkową }\end{array}$ \\
\hline 3 & $\begin{array}{l}\text { „Właściciel firmy ma największy prob- } \\
\text { lem z przekazaniem firmy młodszemu } \\
\text { pokoleniu, brak innowacyjności firmy } \\
\text { może stanowić zagrożenie, mimo wielo- } \\
\text { krotnych starań nie udało się pozyskać } \\
\text { środków z funduszy unijnych, coraz } \\
\text { mniejsza liczba klientów związana } \\
\text { z lokalizacją (obszar wiejski) oraz zmia- } \\
\text { na nawyków żywieniowych” }\end{array}$ & $\begin{array}{l}\text { Delegowanie uprawnień } \mathrm{i} \text { sukcesja } \\
\mathrm{w} \text { firmie to główny problem oraz } \\
\text { kłopoty finansowe powodują brak roz- } \\
\text { woju firmy }\end{array}$ \\
\hline 4 & $\begin{array}{l}\text { „Sytuacja firmy jest zagrożona i ma to } \\
\text { związek z brakiem inwestycji w regionie, } \\
\text { właściciel stara się wykorzystać strategię } \\
\text { niszy rynkowej, która pozwoli utrzymać } \\
\text { się na rynku. Największym problemem } \\
\text { są jednak pracownicy i nieumiejętny } \\
\text { sposób zarządzania nimi, jak również } \\
\text { poszukiwanie i wykorzystywanie okazji } \\
\text { rynkowych. Brak skłonności właściciela } \\
\text { do zmian powoduje, że firma znajduje } \\
\text { się w słabej kondycji szczególnie finan- } \\
\text { sowej” }\end{array}$ & $\begin{array}{l}\text { Głównym problemem jest brak ot- } \\
\text { wartości właściciela na zmiany i zwią- } \\
\text { zany z tym brak rozwoju }\end{array}$ \\
\hline 5 & $\begin{array}{l}\text { „Największym problemem jest niewy- } \\
\text { starczający stan infrastruktury technicz- } \\
\text { nej, który ma wpływ na liczbę potencjal- } \\
\text { nych klientów oraz słaba orientacja } \\
\text { właściciela we wprowadzaniu innowacji } \\
\text { i zmian. Słabością jest również brak } \\
\text { wiedzy i kwalifikacji z zakresu sprzeda- } \\
\text { ży i marketingu oraz brak kontroli } \\
\text { wewnętrznej” }\end{array}$ & $\begin{array}{l}\text { Przedsiębiorstwo zarządzane mało pro- } \\
\text { fesjonalnie, szczególnie w obszarze } \\
\text { planowania, kontroli i zarządzania } \\
\text { logistycznego }\end{array}$ \\
\hline
\end{tabular}


Tabela 45 (cd.)

\begin{tabular}{|c|c|c|}
\hline 1 & 2 & 3 \\
\hline 6 & $\begin{array}{l}\text { „Przedszkole ma trudności z rozwojem ze } \\
\text { względu na swoją lokalizację oraz siłę } \\
\text { nabywczą lokalnego społeczeństwa. Jest to } \\
\text { już kolejna działalność właściciela, wcześ- } \\
\text { niej prowadził firmę krawiecką, ze względu } \\
\text { na brak zamówien zmienił profil działalno- } \\
\text { ści, błędem niewątpliwie jest słaba analiza } \\
\text { lokalnego rynku jak również brak strategii } \\
\text { na dalszy rozwój. Specyfika obszarów } \\
\text { zmarginalizowanych wpłynęła na zmianę } \\
\text { profilu działalności, ale nie była to dobra } \\
\text { decyzja, a właściwie pogrążyła firmę } \\
\text { w problemach finansowych. Właściciel } \\
\text { popełnił wiele poważnych błędów, nie } \\
\text { biorąc pod uwagę specyfiki obszarów } \\
\text { zmarginalizowanych, w szczególności } \\
\text { nieznajomość rynku i brak długookresowej } \\
\text { strategii rozwoju” }\end{array}$ & $\begin{array}{l}\text { Przedsiębiorstwo, aby utrzymać się na } \\
\text { rynku, powinno być bardziej profesjo- } \\
\text { nalnie zarządzane, może warto nawet } \\
\text { zatrudnić osobę z większymi kompe- } \\
\text { tencjami w zakresie zarzadząnia }\end{array}$ \\
\hline 7 & $\begin{array}{l}\text { „Firma bardzo dobrze się rozwijała się } \\
\text { szczególnie podczas dobrej koniunktury } \\
\text { polegającej na dopłatach do przydomo- } \\
\text { wych oczyszczalni przez gminę, po } \\
\text { zakończeniu możliwości finansowania } \\
\text { budowy oczyszczalni przez mieszkań- } \\
\text { ców obroty firmy spadły o } 2 / 3 \text {, co spo- } \\
\text { wodowało znaczące kłopoty finansowe } \\
\text { firmy, największy błędem był brak } \\
\text { strategii i brak rozwoju, a wykorzysty- } \\
\text { wanie tylko sprzyjających warunków } \\
\text { doprowadziło firmę do trudnej sytuacji” }\end{array}$ & $\begin{array}{l}\text { Firma potrzebuje rozwoju w postaci } \\
\text { dywersyfikacji oraz większego profes- } \\
\text { jonalizmu w zarządzaniu }\end{array}$ \\
\hline 8 & $\begin{array}{l}\text { „Przedsiębiorstwo jest znaczącym praco- } \\
\text { dawcą w powiecie, rozwija się prężnie, } \\
\text { operując na rynku krajowym i zagranicz- } \\
\text { nym. Prowadzi znaczącą działalność } \\
\text { innowacyjną i inwestycyjną. Lokalizacja } \\
\text { firmy w obszarach zmarginalizowanych } \\
\text { nie ma wpływu na jej funkcjonowanie } \\
\text { i proces zarządzania” }\end{array}$ & $\begin{array}{l}\text { Przedsiębiorstwo zorientowane na } \\
\text { rozwój, profesjonalnie zarządzane, właś- } \\
\text { ciciel posiada odpowiednie kompetencje } \\
\text { w tym zakresie }\end{array}$ \\
\hline 9 & $\begin{array}{l}\text { „Jest to typowa firma rodzinna w fazie } \\
\text { delegowania uprawnien na młodsze } \\
\text { pokolenie. Największym problemem jest } \\
\text { brak formalnej strategii dostosowanej do } \\
\text { warunków lokalnych. Przedsiębiorstwo } \\
\text { wymaga zmian innowacyjnych, co umoż- } \\
\text { liwi konkurowanie na rynku krajowym. } \\
\text { Problemem w zarządzaniu jest duża liczba } \\
\text { osób zatrudnionych z rodziny, co w pew- } \\
\text { nym sensie powoduje problemy komunika- } \\
\text { cyjne w firmie jak również ciągłe konflikty } \\
\text { pomiędzy pracownikami” }\end{array}$ & $\begin{array}{l}\text { Przedsiębiorstwo wymaga zmian orga- } \\
\text { nizacyjnych, a przede wszystkim uda- } \\
\text { nego procesu sukcesji }\end{array}$ \\
\hline
\end{tabular}




\begin{tabular}{|c|c|c|}
\hline 1 & 2 & 3 \\
\hline 10 & $\begin{array}{l}\text { „Największym problemem związanym } \\
\text { z lokalizacją w obszarach zmarginalizo- } \\
\text { wanych jest mała liczba instytucji oto- } \\
\text { czenia biznesu, które mogłyby stać się } \\
\text { wparciem dla firm w obszarze zarządza- } \\
\text { nia, finansów, marketingu itp., jak } \\
\text { również niewystarczająca infrastruktura } \\
\text { techniczna zmniejszająca dostępność do } \\
\text { firmy” }\end{array}$ & $\begin{array}{l}\text { Przedsiębiorstwo potrzebuje odpowied- } \\
\text { niego doradztwa w celu poprawy jako- } \\
\text { ści zarządzania i pozyskania środków } \\
\text { unijnych }\end{array}$ \\
\hline 11 & $\begin{array}{l}\text { „Problemem firmy jest sezonowość } \\
\text { sprzedaży, co może stanowić barierę } \\
\text { problem w utrzymaniu się na rynku. } \\
\text { Dzięki analizie rynku firma rozszerzyła } \\
\text { swoją działalność o dodatkowe usługi } \\
\text { związane z zakładaniem ogrodów, jed- } \\
\text { nak działalność ta również ma charakter } \\
\text { sezonowy. Dużym problemem jest rów- } \\
\text { nież rotacja pracowników wynikająca } \\
\text { z nieumiejętnego zarządzania zasobami } \\
\text { ludzkimi i sezonowym charakterem } \\
\text { działalności” }\end{array}$ & $\begin{array}{l}\text { Przedsiębiorstwo potrzebuje dywersyfi- } \\
\text { kacji działalności, aby nie borykać się } \\
\text { z problemami związanymi z sezonowo- } \\
\text { ścią }\end{array}$ \\
\hline 12 & $\begin{array}{l}\text { „Przedsiębiorstwo planuje rozwój poprzez } \\
\text { wprowadzenie innowacji. Głównym } \\
\text { celem wprowadzonych zmian jest roz- } \\
\text { szerzenie działalności o proces produk- } \\
\text { cji. Jednak wymaga to wysokokapitało- } \\
\text { wych inwestycji. Przedsiębiorstwo będzie } \\
\text { starało się pozyskać środki z UE na } \\
\text { dalsze działania prorozwojowe” }\end{array}$ & $\begin{array}{l}\text { Właściciel firmy nastawiony na szybki } \\
\text { rozwój firmy i dywersyfikacje działno- } \\
\text { ści }\end{array}$ \\
\hline 13 & $\begin{array}{l}\text { „Na sposób zarządzania nie ma wpływu } \\
\text { lokalizacja firmy, ale raczej odroczone } \\
\text { terminy płatności, które pogrążają firmę } \\
\text { finansowo, przedsiębiorstwo sprzedaje } \\
\text { głównie na rynku krajowym. W firmie } \\
\text { sformalizowano strategię działania i uzu- } \\
\text { pełniono ją wieloma analizami głównie } \\
\text { rynku” }\end{array}$ & $\begin{array}{l}\text { Firma o nieznanej marce, ale prężnie } \\
\text { rozwijająca się dzięki profesjonalizmo- } \\
\text { wi zarządzania, które jest zorientowane } \\
\text { na elastyczność }\end{array}$ \\
\hline 14 & $\begin{array}{l}\text { „Dużym problemem jest brak profesjo- } \\
\text { nalnego zarządzania oraz brak rozwoju, } \\
\text { przedsiębiorstwo jest obecnie w fazie } \\
\text { stagnacji. Właściciel nie wykazuje skłon- } \\
\text { ności do zmian szczególnie o charakterze } \\
\text { innowacyjnym, obecny stan parku ma- } \\
\text { szynowego może sprawić, że oferowane } \\
\text { produkty nie będą konkurencyjne na } \\
\text { rynku” }\end{array}$ & $\begin{array}{l}\text { Większa otwartość właściciela na zmia- } \\
\text { ny oraz konieczność pozyskania środ- } \\
\text { ków finansowych na wprowadzenie } \\
\text { innowacji szczególnie produktowych } \\
\text { i procesowych }\end{array}$ \\
\hline
\end{tabular}


Tabela 45 (cd.)

\begin{tabular}{|c|l|l|}
\hline 1 & \multicolumn{1}{|c|}{2} & \multicolumn{1}{|c|}{3} \\
\hline 15 & $\begin{array}{l}\text { „Lokalizacja firmy ma bardzo duży } \\
\text { wpływ na sposób zarządzania, właści- } \\
\text { cielka stara się dostosować swoją ofertę } \\
\text { do potrzeb lokalnych firm, szczególnie } \\
\text { poprzez rozszerzenie swoich usług” }\end{array}$ & $\begin{array}{l}\text { Firma prężnie rozwijająca się poprzez } \\
\text { dostosowanie oferty do potrzeb okoli- } \\
\text { cznych przedsiębiorstw }\end{array}$ \\
\hline
\end{tabular}

*W tabeli umieszczono najciekawsze fragmenty wypowiedzi respondentów.

Źródło: opracowanie własne.

Uzupełnieniem rozważań odnośnie do sposobu zarządzania w specyficznych warunkach obszaru zmarginalizowanego są badania jakościowe. W przypadku dwóch firm średnich nie potwierdzono wpływu marginalizacji obszaru na zarządzanie firmą. Przyczyną może być szeroki obszar działania tych firm jest to rynek krajowy i międzynarodowy. W przypadku pozostałych firm potwierdzono wpływ specyfiki tych obszarów na zarządzanie przedsiębiorstwem (por. tabela 45).

Efektywne zarządzanie w obszarach zmarginalizowanych polega głównie na bieżącym monitorowaniu najbliższego otoczenia przedsiębiorstwa i wykorzystywaniu pojawiąących się okazji oraz przeciwdziałaniu zagrożeniom. Strategia rozwoju firmy powinna być budowana w oparciu o specyficzne cechy tych obszarów. Mniejsza liczba klientów, czyli dostosowanie wielkości produkcji do potrzeb lokalnego rynku bądź poszukiwanie innych rynków zbytu, gorsza infrastruktura jak również brak wykwalifikowanej siły roboczej mogą wpływać na wybór takiego rodzaju działalności, gdzie te czynnik nie będą miały wpływu. Niski poziom innowacyjności i konkurencyjności nie będzie sprzyjał wysoko innowacyjnym przedsięwzięciom, które wymagają odpowiedniego zaplecza w postaci jednostek naukowo-badawczych, a ograniczony dostęp do instytucji otoczenia biznesu i środków finansowych może oznaczać dla firmy brak wsparcia zarówno w obszarach zarządzania, takich jak: sprzedaż i marketing, komunikacja wewnętrzna, zarządzanie wiedzą itp., jak również trudnościom w pozyskaniu środków finansowych. Przedsiębiorcy w procesie zarządzania i formułowania strategii nie biorą pod uwagę działalności władz samorządowych, których wsparcie określane jest jako bierne.

Reasumując dotychczasowe rozważania, można stwierdzić, że zarządzanie rozwojem w małych i średnich przedsiębiorstwach w obszarach zmarginalizowanych wymaga sprawnego i skutecznego zarządzania. Proces ten powinien uwzględniać cechy tych obszarów jak również wykorzystywać narzędzia zarządzania strategicznego, które pozwoli na zdobycie informacji o firmie i jej otoczeniu. Szanse bowiem na rynku mają te przedsiębiorstwa, które dysponują aktualną informacją i wiedzą, którą potrafią wykorzystać w celu utrzymania 
przewagi konkurencyjnej. Małe i średnie przedsiębiorstwa nie mają jasno wytyczonej strategii, co powoduje, że nie zawsze podejmowane zgodnie $\mathrm{z}$ intuicją działania są efektywne. Podmioty te są często zarządzane przez właścicieli, którzy są traktowani jako założyciele. W miarę wzrostu i rozwoju firmy widoczny jest brak elastyczności zarządzania, osoba będąca założycielem często nie jest skłonna do delegowania uprawnień decyzyjnych, co powoduje niesprawność procesu zarządzania. Dlatego wydaje się konieczna w miarę wzrostu firmy profesjonalizacja zarządzania.

\subsection{Wnioski z badań}

Na podstawie wyników badań ilościowych i jakościowych sformułowano uogólnienia i wnioski dotyczące oceny wpływu marginalizacji obszaru na zarządzanie rozwojem małych i średnich przedsiębiorstw. Wnioski odnoszą się do trzech kategorii badań: analizy komparatywnej funkcjonowania małych i średnich przedsiębiorstw $\mathrm{w}$ obszarach rozwiniętych i zmarginalizowanych, oceny wpływu marginalizacji obszarów na rozwój MSP oraz analizy przypadków firm i instytucji otoczenia biznesu.

1. Dynamika rozwoju małych i średnich przedsiębiorstw w obszarach rozwiniętych i zmarginalizowanych jest zróżnicowana. Podmioty te znacznie prężniej rozwijają się w obszarach rozwiniętych, o czym świadczy wzrost wartosci analizowanych zmiennych (m.in. wielkość obrotu, wielkość zatrudnienia, udział w rynku, wielkość zysku, itd.) w latach 2008-2011. W przypadku obszarów zmarginalizowanych odnotowano natomiast spadek lub brak zmian wartości tych zmiennych. Wyniki te wskazują zatem na wpływ lokalizacji w obszarach zmarginalizowanych na dynamikę rozwoju małych i średnich przedsiębiorstw.

2. Na podstawie analizy priorytetów rozwojowych małych i średnich przedsiębiorstw $\mathrm{w}$ obszarach rozwiniętych i zmarginalizowanych można wyciągnąć wniosek o występowaniu zróżnicowanych potrzeb w zakresie rozwoju. W obszarach rozwiniętych były związane głównie z poprawą innowacyjności i jakości $w$ przedsiębiorstwie, natomiast $w$ obszarach zmarginalizowanych poprawą sytuacji na rynku oraz potencjału finansowego. W obszarach zmarginalizowanych widoczny jest zatem wpływ specyfiki tych obszarów np. w postaci mniejszego popytu spowodowanego mniejszą liczbą klientów i niską ich siła nabywczą na podejmowane wyzwania rozwojowe. Dlatego też w strategii rozwoju przedsiębiorstwa należy uwzględnić specyficzne uwarunkowania pochodzące $\mathrm{z}$ najbliższego otoczenia.

3. Przewagi konkurencyjne badanych przedsiębiorstw były zróżnicowane w zależności od lokalizacji w obszarach rozwiniętych i zmarginalizowanych, jak również w różnych kategoriach firm (mikro, małych i średnich). W obszarach 
rozwiniętych miały związek z priorytetami rozwojowymi, były bowiem związane jakością i innowacyjnością, natomiast w obszarach zmarginalizowanych tak jak w przypadku analizowanych priorytetów ze specyfiką tych obszarów, tzn. funkcjonowaniem w niszy rynkowej jak również poprawą sytuacji na rynku.

4. Analiza uwarunkowań zewnętrznych rozwoju małych i średnich przedsiębiorstw pochodzących z makrootoczenia nie potwierdziła ich zróżnicowania wśród małych i średnich przedsiębiorstw w zależności od poziomu rozwoju społeczno-gospodarczego regionu, w którym są zlokalizowane.

$\mathrm{W}$ obszarach rozwiniętych i zmarginalizowanych za bariery rozwoju respondenci uznali: wysokie koszty pozyskania kapitału zewnętrznego, system prawny i politykę fiskalną, silną konkurencję krajową i zagraniczną, sytuację makroekonomiczną kraju, szarą strefa oraz biurokrację. Są to wiec typowe bariery wskazywane $\mathrm{w}$ wielu badaniach zagranicznych i krajowych omówionych szczegółowo w podpunkcie 3.3. Natomiast jako stymulatory respondenci uznali: pomoc publiczną (dotacje unijne), politykę wsparcia małych i średnich przedsiębiorstw oraz postęp technologiczny.

5. Wpływ uwarunkowań zewnętrznych rozwoju małych i średnich przedsiębiorstw pochodzących $\mathrm{z}$ mezootoczenia był zróżnicowany $\mathrm{w}$ zależności od lokalizacji firmy. W obszarach rozwiniętych jako bariery respondenci najczęściej wskazywali: dostęp do kapitału i wsparcia finansowego, politykę władz samorządowych - tworzenie klimatu dla rozwoju przedsiębiorstw, jakość kapitału ludzkiego oraz jakość i dostępność usług oferowanych przez instytucje otoczenia biznesu, natomiast jako stymulatory rozwoju inwestycje w regionie, dostęp do pomocy publicznej, transfer wiedzy i technologii $\mathrm{w}$ regionie oraz rozwój społeczno-gospodarczy regionu. Natomiast w obszarach zmarginalizowanych: stan infrastruktury transportowej i telekomunikacyjnej, poziom życia lokalnej społeczności, rozwój społeczno-gospodarczy regionu, dostęp do kapitału i wsparcia finansowego oraz położenie geograficzne regionu, z kolei jako czynniki rozwoju wymieniano: walory kulturowe i przyrodnicze regionu, zasoby naturalne regionu, dostęp do pomocy publicznej oraz współpracę przedsiębiorstw $\mathrm{w}$ regionie. Zróżnicowanie wypowiedzi respondentów pozwala wnioskować, że w przypadku obszarów rozwiniętych bariery i czynniki rozwoju są zgodne z dotychczasowymi wynikami badań opisanymi jak już wcześniej wspomniano $\mathrm{w}$ podpunkcie 3.3, natomiast $\mathrm{w}$ przypadku obszarów zmarginalizowanych wynikają z charakterystyki tych obszarów.

6. Analiza uwarunkowań mikroekonomicznych rozwoju małych i średnich przedsiębiorstw potwierdziła ich zróżnicowanie w obszarach rozwiniętych i zmarginalizowanych. W obszarach rozwiniętych jako bariery respondenci najczęściej wskazywali: odroczone terminy płatności, koszty wprowadzenia innowacji, silną konkurencję, natomiast jako stymulatory: ofertę szkoleniowodoradczą dostosowaną do potrzeb MSP oraz powiązania kooperacyjne z innymi przedsiębiorstwami. Natomiast w obszarach zmarginalizowanych rozwój badanych firm był hamowany przez: silną konkurencję, odroczone terminy płatności 
oraz koszty wprowadzenia innowacji, natomiast jako czynniki rozwoju wymieniano: powiązania kooperacyjne $\mathrm{z}$ innymi przedsiębiorstwami oraz dostęp do informacji o formach wsparcia. Uzyskane wyniki potwierdzają konieczność uwzględnienia wpływu tych czynników przy budowaniu strategii i w procesie zarządzania rozwojem małych i średnich przedsiębiorstw.

7. Uwarunkowania zewnętrzne rozwoju małych i średnich przedsiębiorstw wynikające $\mathrm{z}$ makro-, mezo- i mikrootoczenia są również zróżnicowane w zależności od wielkości przedsiębiorstwa. Zależność ta została zbadana ze względu na główny wątek opracowania tylko w firmach zlokalizowanych w obszarach zmarginalizowanych. Tak szczegółowa analiza pozwoliła precyzyjne określenie wpływu poszczególnych grup czynników na rozwój poszczególnych kategorii przedsiębiorstw.

8. Analiza uwarunkowań wewnętrznych rozwoju małych i średnich przedsiębiorstw związanych z przedsiębiorstwem potwierdziła ich zróżnicowanie w obszarach rozwiniętych i zmarginalizowanych. W obszarach rozwiniętych za najważniejsze stymulatory respondenci uważali posiadaną strategię funkcjonowania i rozwoju, znajomość potrzeb i preferencji klientów, wizerunek i renomę przedsiębiorstwa oraz wiedzę i doświadczenie kadry zarządzającej, natomiast jako bariery uznali niewystarczający potencjał finansowy i rzeczowy oraz brak współpracy z otoczeniem biznesu. Respondenci zatem docenili rolę planowania i zarządzania strategicznego $\mathrm{w}$ zarządzaniu przedsiębiorstwem. Natomiast w obszarach zmarginalizowanych za stymulatory respondenci uważali znajomość potrzeb i preferencji klientów, elastyczność w działaniu, wizerunek i renomę przedsiębiorstwa oraz posiadaną strategię funkcjonowania i rozwoju, za bariery natomiast uznali niewystarczający potencjał finansowy i rzeczowy przedsiębiorstwa, niską innowacyjność oraz stosowaną technologię. Wyniki te wskazują na silną orientację rynkową badanych przedsiębiorstw, co ma związek ze specyfiką obszarów zmarginalizowanych, w których obserwuje się niewystarczający popyt wynikający z mniejszej liczy potencjalnych klientów i małej konkurencyjności obszaru.

9. Wpływ uwarunkowań wewnętrznych rozwoju małych i średnich przedsiębiorstw związanych $\mathrm{z}$ osobą przedsiębiorcy był $\mathrm{w}$ niewielkim stopniu zróżnicowany w obszarach rozwiniętych i zmarginalizowanych. Respondenci wskazywali głównie stymulatory rozwoju, do których w przypadku obszarów rozwiniętych zaliczono: sieć osobistych kontaktów, kompetencje przedsiębiorcze, postrzeganie otoczenia i związanych z nim okazji rynkowych, kompetencje menedżerskie oraz wiedza i doświadczenie w prowadzeniu biznesu. Natomiast $\mathrm{w}$ obszarach zmarginalizowanych: wiedza i doświadczenie $\mathrm{w}$ prowadzeniu biznesu, postrzeganie otoczenia i związanych z nim okazji rynkowych, kompetencje menedżerskie, sieć osobistych kontaktów oraz sposób zarządzania - przywództwo. Wyniki te sugerują, że badani przedsiębiorcy posiadają duży potencjał w zakresie zarządzania ze względu na posiadane kompetencje, wiedzę 
i kwalifikacje. Co nie potwierdza się w dalszej części badań, z których wynikają braki szczególnie kompetencyjne w zarządzaniu firmą.

10. Respondenci zarówno w badaniach ilościowych, jak i jakościowych potwierdzili wpływ marginalizacji obszaru na rozwój małych i średnich przedsiębiorstw, określając go jako znaczący i umiarkowany. W mikroprzedsiębiorstwach wpływ ten był największy i został określony jako duży i znaczący, w małych przedsiębiorstwach oceniono go jako umiarkowany i znaczący, w przypadku średnich przedsiębiorstw jako niewielki lub brak wpływu. Wyniki te nie są zaskakujące, gdyż mikro i małe przedsiębiorstwa funkcjonują głównie na rynkach lokalnych, natomiast średnie na rynku krajowym i międzynarodowym, gdzie wpływ ten jest niewielki. Do cech mających największy wpływ badani przedsiębiorcy zaliczyli następujące cechy obszarów zmarginalizowanych, w przypadku mikroprzedsiębiorstw: mniejsza liczba potencjalnych klientów oraz brak klimatu przyjaznego dla rozwoju przedsiębiorstw, w małych przedsiębiorstwach bierne wsparcie ze strony władz samorządowych oraz niski poziom innowacyjności regionu, natomiast $\mathrm{w}$ średnich: brak wykwalifikowanej siły roboczej oraz gorszą infrastrukturę techniczną. Wyniki potwierdzają świadomość przedsiębiorców odnośnie do specyficznych uwarunkowań, w których prowadzą i rozwijają swoją działalność gospodarczą. Konieczne jest zatem bieżące monitorowanie najbliższego otoczenia przedsiębiorstwa $\mathrm{w}$ celu dostosowania działalności na potrzeby lokalnych i opracowania strategii rozwoju uwzględniającej cechy obszaru zmarginalizowanego.

11. Poziom innowacyjność badanych przedsiębiorstw zlokalizowanych w obszarach zmarginalizowanych, należy ocenić bardzo nisko, bowiem niecałe 25\% wprowadziło innowacje w latach 2009-2011, których największa liczba została wdrożona w średnich firmach $(82,5 \%)$ dysponujących środkami finansowymi na działalność innowacyjną, prowadząc ją we własnym zakresie lub $\mathrm{w}$ jednostkach $\mathrm{B}+\mathrm{R}$. W przypadku mikro i małych przedsiębiorstw wynik ten był znacznie słabszy i wynosił odpowiednio 14,3\% i 28,6\%. Najczęściej w badanych firmach wprowadzano innowacje produktowe ze względu na ograniczone zasoby. Były to głównie innowacje na skalę firmy lub na poziomie rynku lokalnego, co świadczy to niskiej ich nowości. Przyczyną tak niskiej skłonności wprowadzania zmian są niewystarczające środki finansowe i trudność ich pozyskania, jak również niewykwalifikowany personel. Podsumowując, małe i średnie przedsiębiorstwa charakteryzują się niską innowacyjnością, co staje się problemem, gdy nie mogą sprostać silnej konkurencji. Na zachowania innowacyjne firm sektora MSP mają znaczący wpływ również czynniki wewnętrzne związane m.in. $\mathrm{z}$ procesem zarządzania, strukturą organizacyjną i osobą przedsiębiorcy, takie jak: kreatywność, otwartość na innowacje, zdolności organizacyjne, wytrwałość, chęć podjęcia ryzyka, gdyż pomagają one w podejmowaniu ważnych decyzji dotyczących profilu działalności, wyboru portfela produktowego, poziomu technicznego, wyboru kierunków ekspansji rynkowej itd. Inną grupę czynników wewnętrznych kształtującą innowacyjność 
firmy jest kultura organizacyjna i kwalifikacje pracowników oraz poziom ich zaangażowania $\mathrm{w}$ prace na rozwojem innowacji. Umiejętność współpracy kierownictwa (właścicieli) firmy z pracownikami polegająca na włączaniu ich $\mathrm{w}$ proces podejmowania decyzji, współpracy $\mathrm{z}$ klientami oraz zapewnieniu wynagrodzenia, które umożliwi pełne zaangażowanie pracownika w działalność firmy (Sosnowska, Łobejko 2008). Na działalność innowacyjną MSP mają również wpływ uwarunkowania rynkowe, gdzie ważnym problemem jest ograniczony popyt ze względu na małą siłę nabywczą społeczeństwa wynikającą z niskiego poziomu dochodów Ważną barierą innowacyjności są również czynniki ekonomiczne, takie jak: ryzyko powodzenia, koszty wprowadzenia innowacyjności, dostępność źródeł finansowania.

12. Działalność inwestycyjna przedsiębiorstw zlokalizowanych w obszarach zmarginalizowanych, była prowadzona $\mathrm{w}$ ok. $50 \% \mathrm{w}$ badanych przedsiębiorstwach, lecz sprowadzała się ona głównie do modernizacji i rozbudowy nieruchomości. Do głównych barier działalności inwestycyjnej respondenci zaliczyli:

- w mikroprzedsiębiorstwach najczęściej - brak kapitału oraz trudności w pozyskaniu zewnętrznych źródeł finansowania,

- w małych przedsiębiorstwach - wysokie koszty pozyskiwania składników majątkowych oraz problemy z uzyskaniem pomocy publicznej na działalność inwestycyjną,

- w średnich przedsiębiorstwach - długi czas oczekiwania na refundację kosztów inwestycji ze środków unijnych oraz długie procedury pozyskania pozwoleń inwestycyjnych.

Wyniki te wskazują na duże problemy badanych przedsiębiorstw, szczególnie mikro i małych, w finansowaniu inwestycji, w przypadku średnich przedsiębiorstw bariery te związane są raczej z przepisami i procedurami ich realizacji. Działalność innowacyjna i inwestycyjna małych i średnich przedsiębiorstw wymaga wsparcia szczególnie $\mathrm{w}$ dziedzinie finansów, jak również zasobów ludzkich.

13. Władze samorządowe mają tworzyć klimat dla rozwoju przedsiębiorczości $\mathrm{w}$ regionie, $\mathrm{w}$ tym również $\mathrm{w}$ obszarach zmarginalizowanych, jak również stymulować rozwój małych i średnich przedsiębiorstw. Oczekiwania badanych przedsiębiorców wobec władz samorządowych były zróżnicowane w zależności od wielkości przedsiębiorstwa. W mikroprzedsiębiorstwach respondenci głównie oczekiwali od władz samorządowych pomocy w pozyskaniu wsparcia finansowego, w małych przedsiębiorstwach działań w kierunku poprawy konkurencyjności i innowacyjności regionu, a dla średnich przedsiębiorstw najważniejsza była pomoc w nawiązywania kontaktów z kontrahentami zagranicznymi i poprawa infrastruktury technicznej. Potrzeby mikroprzedsiębiorstw dotyczyły wsparcia finansowego, małych i średnich przedsiębiorstw odnosiły się głównie do podnoszenia atrakcyjności regionu, w celu stworzenia jak najlepszych warunków dla prowadzenia działalności gospodarczej. 
14. Współpraca przedsiębiorców z instytucjami otoczenia biznesu w obszarach zmarginalizowanych jest nisko ocenia przez przedsiębiorców, niecałe $20 \%$ współpracowało z takimi instytucjami i były to głównie małe i średnie przedsiębiorstwa. W przypadku mikroprzedsiębiorstw największą popularnością cieszyły się ośrodki przedsiębiorczości oraz punkty konsultacyjne, w małych przedsiębiorstwach ośrodki szkoleniowo-doradcze, fundusze pożyczkowe oraz centra transferu technologii, a w przypadku średnich centra transferu technologii, fundusze pożyczkowe oraz fundusze poręczeniowe. Wypowiedzi respondentów świadczą o zróżnicowanych potrzebach w zakresie wsparcia ze strony instytucji otoczenia biznesu, przedsiębiorstwa małe potrzebują zazwyczaj informacji ogólnych o prowadzeniu biznesu i możliwościach pozyskanie środków finansowych, w przypadku małych i średnich usługi te mają charakter specjalistyczny, np. w zakresie poprawy innowacyjności, transferu technologii itd. Głównymi efektami tej współpracy według respondentów powinno być pozyskanie środków finansowych w przypadku mikroprzedsiębiorstw, w małych dostęp do wiedzy specjalistycznej, a w średnich zakup nowych technologii. Przedsiębiorstwa, które nie współpracowały z IOB, wskazały na przyczyny braku współpracy, takie jak: brak potrzeby korzystania z usług tych instytucji, brak wymiernych korzyści ze współpracy, jak również brak informacji o usługach instytucji otoczenia biznesu, niedopasowanie oferty do potrzeb przedsiębiorstwa ora brak dostępności usług. Uzyskane odpowiedzi sugerują, że przedsiębiorcy oczekują innych kierunków wsparcia w zakresie prowadzenia działalności gospodarczej niż są obecnie oferowane przez te instytucje. Oferta wsparcia wymaga modyfikacji po uprzednim poznaniu potrzeb przedsiębiorców w tym zakresie.

15. Większość badanych przedsiębiorstw zlokalizowanych w obszarach zmarginalizowanych wskazało na problemy $\mathrm{w}$ zarządzaniu, co świadczy o świadomości przedsiębiorców o niesprawnym zarządzaniu w ich przedsiębiorstwie.

W mikroprzedsiębiorstwach za największą niedoskonałość procesu zarządzania uznano brak jasno wytyczonej strategii rozwoju oraz brak umiejętności wykorzystywania okazji pojawiających się w otoczeniu, w małych przedsiębiorstwach - brak planowania, niechęć do delegowania usprawnień oraz brak umiejętności motywowania pracowników. Natomiast średnie przedsiębiorstwa wskazały jako największe słabości w zarządzaniu przedsiębiorstwem: błędy popełnione przy planowaniu i kontroli, problemy komunikacyjne wewnątrz przedsiębiorstwa oraz niedostrzeganie potrzeby zarządzania wiedzą. Przedsiębiorcy potwierdzili również wpływ specyficznych cech obszarów zmarginalizowanych na sposób zarządzania jak również formułowanie strategii. Uwzględnienie tych cech pozwoli na unikniecie błędów w zarządzaniu, co pozwoli małym i średnim przedsiębiorstwom zlokalizowanym w obszarach zmarginalizowanych na poprawę dynamiki rozwoju. 


\section{Zakończenie}

Głównym celem pracy była ocena kierunku i siły wpływu kluczowych czynników rozwoju MSP oraz określenie przesłanek na potrzeby zarządzania rozwojem małych i średnich przedsiębiorstw w obszarach zmarginalizowanych.

$\mathrm{Na}$ podstawie przeprowadzonych studiów literaturowych dokonano identyfikacji cech obszaru zmarginalizowanego jak również klasyfikacji czynników rozwoju małych i średnich przedsiębiorstw z uwzględnieniem specyfiki tego obszaru. Zidentyfikowano dwie grupy czynników - wewnętrzne i zewnętrzne o charakterze pozytywnym (stymulatory) oraz negatywnym (bariery).

W kolejnym etapie dokonano delimitacji obszarów w Polsce ze względu na ich poziom rozwoju społeczno-gospodarczego metodą taksonomiczną Z. Helwiga. Klasyfikacja obszarów posłużyła do wyodrębnienia obszarów rozwiniętych i zmarginalizowanych, w których przeprowadzono badania zarówno ilościowe, jak i jakościowe.

Badania własne ilościowe umożliwiły rozważenie kierunku i siły wpływu czynników wewnętrznych i zewnętrznych na rozwój małych i średnich przedsiębiorstw w obszarach rozwiniętych i zmarginalizowanych oraz dokonanie analizy komparatywnej dla tych obszarów. Wyniki badań jakościowych i druga część badań ilościowych pozwoliły na sformułowanie implikacji na potrzeby zarządzania małymi i średnimi przedsiębiorstwami w obszarach zmarginalizowanych, w kontekście wpływu cech obszaru zmarginalizowanego na rozwój MSP, oceny efektywności wsparcia instytucji otoczenia biznesu w obszarach zmarginalizowanych oraz problemów zarządzania wynikających w marginalizacji obszaru.

W pracy zrealizowano cel główny i cele szczegółowe, a także na podstawie badań empirycznych zweryfikowano osiem hipotez badawczych:

Podczas weryfikacji hipotezy $\mathrm{H}_{1}$ udowodniono, że małe i średnie przedsiębiorstwa funkcjonujące $\mathrm{w}$ obszarach zmarginalizowanych charakteryzują się mniejszą dynamiką rozwojową niż funkcjonujące w obszarach rozwiniętych. Weryfikacja hipotezy jest pozytywna, potwierdzona licznymi metodami statystycznymi, takimi jak metoda skupień, testy nieparametryczne, współczynnik kontyngencji, które wskazały w większości przypadków na zróżnicowanie analizowanych czynników ze względu na miejsce lokalizacji jak również wielkość przedsiębiorstwa. Stworzyło to pełen obraz analizowanych zmiennych w poszczególnych kategoriach firm i dowiodło, że traktowanie całego sektora MSP łącznie nie do końca przyczynia się do formułowania rzetelnych wnio- 
sków, a jak wskazują liczne badania zachowania i problemy tych podmiotów, są bardzo zróżnicowane.

Na podstawie przeprowadzonych badań można wskazać na różnice w dynamice rozwojowej małych i średnich przedsiębiorstw zlokalizowanych w obszarach rozwiniętych i zmarginalizowanych, a świadczą o tym zmiany w badanych wskaźnikach wzrostu/rozwoju.

Nie udało się udowodnić $\mathrm{H}_{2}$ za pomocą testu nieparametrycznego U MannaWhitneya, mówiącej o zróżnicowanym oddziaływaniu uwarunkowań pochodzących z makrootoczenia na rozwój małych i średnich przedsiębiorstw w obszarach rozwiniętych i zmarginalizowanych

Odnośnie do weryfikacji hipotezy $\mathrm{H}_{3}$, to udowodniono na podstawie przeprowadzonych badań oraz wyników testu U Manna-Whitneya, że oddziaływanie uwarunkowań rozwoju małych i średnich przedsiębiorstw pochodzących z mezootoczenia jest zróżnicowane w zależności od lokalizacji firmy w obszarach rozwiniętych i zmarginalizowanych.

Na podstawie przeprowadzonych badań zweryfikowano pozytywnie hipotezę $\mathrm{H}_{4}$, że oddziaływanie uwarunkowań rozwoju małych i średnich przedsiębiorstw pochodzących z mikrotoczenia jest zróżnicowane w zależności od tego, gdzie zlokalizowana jest firma w obszarach rozwiniętych czy zmarginalizowanych. Weryfikacja hipotezy została potwierdzona testem nieparametrycznym U Manna-Whitneya.

Odnośnie do weryfikacji hipotezy $\mathrm{H}_{5}$, to nie udało się udowodnić, że oddziaływanie uwarunkowań rozwoju małych i średnich przedsiębiorstw związanych z osobą przedsiębiorcy zależy od lokalizacji firmy w obszarach rozwiniętych i zmarginalizowanych. Weryfikacja hipotezy jest negatywna, potwierdzona testem nieparametrycznym U Manna-Whitneya. Na podstawie przeprowadzonych badań nie wykryto zróżnicowania wpływu uwarunkowań wewnętrznych związanych z osobą przedsiębiorcy na rozwój MSP zlokalizowanych w obszarach rozwiniętych i zmarginalizowanych.

Na podstawie przeprowadzonych badań zweryfikowano pozytywnie hipotezę $\mathrm{H}_{6}$. Wykryto zróżnicowanie oddziaływania uwarunkowań wewnętrznych związanych z przedsiębiorstwem na rozwój małych i średnich przedsiębiorstw w obszarach rozwiniętych i zmarginalizowanych. Weryfikacja hipotezy została potwierdzona testem nieparametrycznym U Manna-Whitneya.

Udowodniono hipotezę $\mathrm{H}_{7}$, na podstawie przeprowadzonych badań. Wykryto zróżnicowanie odziaływania uwarunkowań rozwoju małych i średnich przedsiębiorstw funkcjonujących $\mathrm{w}$ obszarach zmarginalizowanych $\mathrm{w}$ zależności od wielkości przedsiębiorstwa. Weryfikacja hipotezy została potwierdzona testem nieparametrycznym Kruskala-Wallisa.

Odnośnie do weryfikacji $\mathrm{H}_{8}$, to udowodniono, że specyficzne cechy obszaru zmarginalizowanego wpływają $\mathrm{w}$ różny sposób na rozwój przedsiębiorstwa 
w zależności od jego wielkości. Weryfikacja hipotezy została potwierdzona testem nieparametrycznym Kruskala-Wallisa.

Przeprowadzone badania i sformułowane wnioski stanowią przyczynek do dalszych prac w tym zakresie, wzbogacając prezentowaną w polskiej literaturze przedmiotu wiedzę o uwarunkowaniach rozwoju małych i średnich przedsiębiorstw w obszarach zmarginalizowanych Polsce. 



\section{Bibliografia}

Achtenhagen L., Naldi L., Melin L. (2010), “Business Growth” - do practitioners and scholars really talk about the same thing?, ,Entrepreneurship Theory and Practice”, Baylor University, vol. 34, Issue 2, s. 289-316.

Acs Z. (2010), Entrepreneurship and Regional Development, Northampton MA: Edward Elgar.

Acs Z., Armington C. (2004), The impact og geographic differences in human capital on service firm formation rates, ,Journal of Urban Economies”, vol. 56(2), s. 244-278.

Adamik A. (red.) (2011), Ksztaltowanie konkurencyjności i przewagi konkurencyjnej małych $i$ średnich przedsiębiorstw, Wydawnictwo C.H.Beck, Warszawa.

Adizes I. (2004), Managing Corporate Lifecycles, Adizes Institute Publications, Santa Barbara.

Ajzen I. (1991), The theory of planned behavior, „Organizational Behavior and Human Decision Processes", vol. 50(2), s. 179-211.

Analiza porównawcza innowacyjności regionów $w$ Polsce $w$ oparciu o metodologię European Innovation Scoreboard, Instytut Technologii Eksploatacji Państwowy Instytut Badawczy, Radom 2008, s. 88 http://www.mg.gov.pl/NR/rdonlyres/3B2E3AC5-CBDE-47D4-AF6A 3ED270D74965/52556/Ekspertyza.pdf (dostęp 18.05.2011).

Anderson A.R. (2000), Paradox in periphery: entrepreneurial reconstruction?, „Entrepreneurship \& Regional Development”, no. 12, s. 91-109.

Bacławski K., Koczerga M., Zabierowski P. (2005), Polacy - przedsiębiorczym społeczeństwem?, „Global Entreprenurship Monitor Polska 2004”, Fundacja Edukacyjna Bachalski, Warszawa-Poznań-Katowice.

Bank Danych Lokalnych, http://www.stat.gov.pl/bdl_n/app/strona.indeks.

Bański J. (2001), Stan i perspektywy rolnictwa na obszarach problemowych $w$ Polsce, PAN IGiPZ, „Dokumentacja Geograficzna”, nr 22.

Bański J. (2011), Obszar problemowy - koncepcje i kryteria identyfikacji, [w:] Budowanie spójności terytorialnej i przeciwdziałanie marginalizacji obszarów problemowych. Wybór referatów konferencyjnych, Ministerstwo Rozwoju Regionalnego, Warszawa, s. 7-18.

Bański J. (red.) (2009), Analiza zróżnicowania i perspektyw rozwoju obszarów wiejskich w Polsce do 2015 roku, „Studia Obszarów Wiejskich”, nr 16, IGiPZ PAN, PTG.

Bariery rozwoju sektora MSP (2008), portal internetowy Favore.pl, Wrocław, http://file.favore.pl/ store/ctx/docs/reports/Bariery_rozwoju_sektora_MSP.pdf (dostęp 10.04.2010).

Barlett W., Bukovic B. (2001), Barriers of SME growth in Slovenia, „Economic Policy in Transition Economies", vol. 11(2), s. 177-195.

Baruk, J. (2009), Zarzadzanie wiedza i innowacjami, Wydawnictwo Adam Marszałek, Toruń.

Bąk i inni (2001), Mate i średnie przedsiębiorstwa a rozwój regionalny, PARP, Warszawa.

Bednarczyk M. (1996), Otoczenie i przedsiębiorczość w zarzązaniu strategicznym organizacja gospodarcza, „Zeszyty Naukowe AE w Krakowie”.

Bergmann H., Japsen A., Tamàsy Ch. (2002), Regional Entrepreneurship Monitor (REM), University in Köln, University in Lüneburg, Köln-Lüneburg.

Bibu N., Sala D.C. (2011), Investigating fast-growing companies from Romania, „Managerial Challenges of the Contemporary Society", Issue 2, s. 16-23. 
Bielawska A. (2010), Kategorie czynników determinujących sukces nowo założonego przedsiębiorstwa, [w:] A. Bielawska, A. Szopa (red.), Strategie zarzadzania mikro i matymi przedsiębiorstwami. Mikrofirma 2010, „Zeszyty Naukowe Uniwersytetu Szczecińskiego”, nr 585, Ekonomiczne Problemy Usług nr 50, s. 53-60.

Bielawska A. (2011), Zmiany pokoleniowe $w$ przedsiębiorstwach, [w:] A. Bielawska (red.), Uwarunkowania rynkowe rozwoju mikro, matych i średnich przedsiębiorstw. Mikrofirma 2011. Tworzenie i zarzadzanie. „Zeszyty Naukowe Uniwersytetu Szczecińskiego”, nr 638, Ekonomiczne Problemy Usług nr 63, Szczecin, s. 32-39.

Bielawska A. (red.) (2009), Nowoczesne zarządzanie finansami przedsiębiorstwa, Wydawnictwo C.H. Beck, Warszawa.

Bielski M. (2002), Podstawy teorii organizacji i zarządzania, Wydawnictwo C.H. Beck, Warszawa.

Bird B.J. (1995), Toward a theory of entrepreneurial competency, [w:] J.A. Katz, R.H. Brockhaus (eds), Advances in Entrepreneurship. Firm Emergence and Growth, vol. 2, JAI Pres.

Birley S., Stockley S. (2000), Entrepreneurial teams and venture growth, [w:] D. Sexton \& H. Landström (eds), Handbook of Entrepreneurship, Blackwell, Oxford, s. 287-307.

Birley S., Westhead P. (1990), Growth and performance contrasts between 'types' of small firms, „Strategic Management Journal”, vol. 11, s. 535-557.

„Biuletyn Statystyczny” (2013), nr 3, GUS, Warszawa.

Blackburn R.A., Smallbone D. (2008), Researching small firms and entrepreneurship in the U.K.: Developments and distinctiveness, „Entrepreneurship Theory and Practice”, Baylor University, vol. 32, Issue 2, s. 267-288.

Blakley E.J. (1989) Planing Local Economic Development. Theory and Prctice, SAGE Library of Social Research, London.

Bławat F. (2003), Przedsiębiorca $w$ teorii przedsiębiorczości i praktyce małych firm, Gdańskie Towarzystwo Naukowe, Gdańsk.

Bławat F.red. (2004), Przetrwanie i rozwój małych i średnich przedsiębiorstw, SPG, Gdańsk.

Bocock R. (1993), Consumption, Routledge, London.

Bojewska B. (2011), Tworzenie nowych wartości w przedsiębiorstwie z nastawieniem na wzrost $i$ rozwój, [w:] M. Strużycki (red.), Małe i średnie przedsiębiorstwa $w$ gospodarce regionu, SGH, Warszawa, s. 111-149.

Bończak E., Kucharczyk K., Herbst K. Chmura (1998), Jak władze lokalne moga wspierać przedsiębiorczość, Polska Fundacja Promocji i Rozwoju Małych i Średnich Przedsiębiorstw, Warszawa.

Borowiecki R., Balcerek-Wieszala A. (2011), Restrukturyzacja a zarządzanie zmiana - próba uporządkowania pojęć, [w:] R. Borowiecki, A. Jaki (red.), Dylematy wspótczesnych przedsiębiorstw w procesie restrukturyzacji dywersyfikacja - integracja - rozwój, Wyd. Fundacja Uniwersytetu Ekonomicznego w Krakowie, Kraków, s. 15-32.

Borowiecki R., Siuta-Tokarska B. (2008), Problemy funkcjonowania i rozwoju, małych i średnich przedsiębiorstw w Polsce, Difin, Warszawa.

Borsa M. (2003), Obszary zagrożone marginalizacja $i$ wykluczeniem społecznym. Kryteria i identyfikacja, Ministerstwo Gospodarki, Pracy i Polityki Społecznej, Warszawa.

Boyatzis R.E. (1982), The Competent Manager. A Model for Effective Performance, John Wiley\&Sons.

Bratnicki M. (2010), Przedsiębiorcze zdolności dynamiczne jako źródto trwałej, wysokiej efektywności przedsiębiorstwa, [w:] H. Jagoda, J. Lichtarski (red.), Kierunki i dylematy rozwoju nauki i praktyki zarzadzania przedsiębiorstwem, Wydawnictwo UE, Wrocław, s. 37-44.

Brol R. (2006), Rozwój regionalny jako kategoria ekonomiczna, [w:] D. Strahl (red.), Metody oceny rozwoju regionalnego, Wydawnictwo AE, Wrocław, s. 13-37. 
Brown C., Hamilton J., Medoff J. (1990), Employers Large and Small, Harvard University Press, Cambridge, MA.

Brown T., Davidsson P. \& Wiklund J. (2001), An operationalization of Stevenson's conceptualization of entrepreneurship as opportunity-based firm behavior, „Strategic Management Journal", vol. 2, s. 953-968.

Bruce R. (1976), The Entrepreneurs: Strategies, Motivations, Successes, and Failures, U.K Libertarian Books, Bedford.

Bućko J., Sitkowska R. (2008), Analiza porównawcza innowacyjności polskich regionów w 2006 r. (wg metodologii EIS), „Problemy Eksploatacji”, nr 3, s. 113-121.

Budner W. (2003), Lokalizacja przedsiębiorstw. Aspekty ekonomiczno-przestrzenne i środowiskowe, Wydawnictwo Akademii Ekonomicznej w Poznaniu, Poznań.

Bukowski M., Spor A., Śniegocki A. (2012), Potencjat i bariery polskiej innowacyjności, Instytut Badań Strukturalnych, Warszawa.

Calzoni G. (1995), Aspekty teoretyczne i praktyczne wzmocnienia systemów mniejszych przedsiębiorstw, [w:] B. Winiarski (red.), Polityka ekonomiczna, Akademia Ekonomiczna we Wrocławiu, Wrocław, s. 76-97.

Chądzyński J. (2007), Istota rozwoju lokalnego, [w:] J. Chądzyński i inni (red.), Region i jego rozwój w warunkach globalizacji, CeDeWu, Warszawa, s. 69-80.

Chądzyński J. i inni (red.) ( 2007), Region i jego rozwój $w$ warunkach globalizacji, CeDeWu, Warszawa.

Chmiel J. (1997), Małe i średnie przedsiębiorstwa a rozwój regionów, Zakład Badań StatystycznoEkonomicznych Głównego Urzędu Statystycznego i Polskiej Akademii Nauk, Warszawa.

Chojnacki Z. (1996), Region w ujęciu geograficzno-systemowym, [w:] T. Czyż (red.), Podstawy regionalizacji geograficznej, Bogucki Wydawnictwo Naukowe, Poznań.

Churchil N., Lewis V. (1983), The five stages of small business growth, „Harvard Business Review", vol. 29, no. 1, s. 33-51.

Ciok S. (1994), Wybrane obszary problemowe Polski Południowo-Zachodniej, „Acta Universitatis Wratislaviensis", 1631, Studia Geogr., 62.

Ciok S., Dobrowolska-Kaniewska H. (2009), Polityka innowacyjna państwa a regionalny potencjat innowacyjny. Przyklad Dolnego Ślaska, Rozprawy Naukowe Instytutu Geografii i Rozwoju Regionalnego, t. 7, Wrocław.

Czaja I. (2011), Przedsiębiorcze strategie rynkowe $w$ cyklu rozwoju drobnych przedsiębiorstw, [w:] J. Targalski, K. Zieliński (red.), Strategie rozwoju małych i średnich przedsiębiorstw. Ujęcie teoretyczne i empiryczne, Fundacja Uniwersytetu Ekonomicznego w Krakowie, Kraków, s. 105-120.

Czapiewski K., Niewęgłowska G. (2006), Przestrzenne zróżnicowanie dopłat wyrównawczych w Polsce w 2004 r., IERiGŻ PIB, Warszawa.

Czarna lista barier dla rozwoju przedsiębiorczości 2010, PKPP Lewiatan, kwiecień 2010, http://pkpplewiatan.pl/wydawnictwa/_files/publikacje/CLB2010.pdf (dostęp 4.12.2011).

Czarna lista barier dla rozwoju przedsiębiorczości 2011, PKPP Lewiatan, kwiecień 2011 http://pkpplewiatan.pl/wydawnictwa/_files/publikacje/clb2011_prev_.pdf (dostęp 12.01.2013).

Czarna lista barier dla rozwoju przedsiębiorczości 2012, PKPP Lewiatan, kwiecień 2012, http://pkpplewiatan.pl/wydawnictwa/_files/publikacje/clb_2012_14.pdf (dostęp 14.02.2013).

Cyfert Sz. (2012), Granice organizacji, Wydawnictwo UE, Poznań.

Danielak W. (2010), Elementy kapitatu relacyjnego oddziałujące na konkurencyjność matych $i$ średnich przedsiębiorstw, [w:] Matejun M. (red.), Wyzwania i perspektywy zarzadzania w małych i średnich przedsiębiorstwach, Wydawnictwo C.H. Beck, Warszawa 2010, s. 253-265. 
Daszkiewicz N. (2000), Bariery rozwoju matych $i$ średnich przedsiębiorstw $w$ teorii $i$ świetle badań empirycznych, „Gospodarka w Praktyce i Teorii”, Katedra Ekonomii Uniwersytetu Łódzkiego, nr 2 (7), s. 87-95.

Daszkiewicz N. (2004a), Bariery wzrostu małych i średnich przedsiębiorstw [w:] F. Bławat (red.), Przetrwanie i rozwój matych i średnich przedsiębiorstw, SPG, Gdańsk, s. 61-70.

Daszkiewicz N. (2004b), Bariery wzrostu matych i średnich przedsiębiorstw $w$ świetle badań empirycznych, [w:] F. Bławat (red.), Przetrwanie i rozwój małych i średnich przedsiębiorstw, SPG, Gdańsk, s. 139-147

Daviddson P., Wiklund J., Delmar F. (2006), Entrepreneurship and the growth of firms, Edwar Elgar, London.

Davidsson, P., Wiklund J. (2000), Conceptual and empirical challenges in the study of firm growth, [w:] D. Sexton \& H. Landström (eds), Handbook of entrepreneurship, Blackwell, Oxford, s. 26-44.

Davis S.J., Haltiwanger J., Schuh S. (1996), Small business and job creation: Dissecting the myth and reassesing the facts, „Small Business Economics”, vol. 8(4), s. 297-315.

Dodge H.R., Robbibs J.E (1992), An empirical investigation of the organizational life cycle model for small business development and survival, „Journal of Small Business Management”, vol. 30(1), s. 27-37.

Doern R. (2009), Investigating barriers to SME growth and development in transition environments: A critique and suggestions for developing the methodology, „International Small Business Journal”, vol. 27(3), s. 275-305.

Dolata M. (2006), Małe i średnie przedsiębiorstwa $w$ gospodarce województwa lubuskiego, Bogucki Wydawnictwo Naukowe, Poznań.

Domański R., (1989), Podstawy planowania przestrzennego, PWN, Poznań-Warszawa.

Domański R. (2002), Gospodarka przestrzenna, Wydawnictwo Naukowe PWN, Warszawa.

Domański B. (2009), Rozwój polskich metropolii a regiony peryferyjne. Bezpowrotna separacja czy wspótzależność rozwoju?, [w:] Marszał T. (red.), Rola polskich aglomeracji wobec wyzwań Strategii Lizbońskiej, Studia KPZK PAN, t. 120, Warszawa, s. 135-143.

Domański B. (2011), Czy regiony słabo rozwinięte potrzebuja wyrównywania nierówności regionalnych?, [w:] Budowanie spójności terytorialnej i przeciwdziałanie marginalizacji obszarów problemowych. Wybór referatów konferencyjnych, Ministerstwo Rozwoju Regionalnego, Warszawa, s. 62-70.

Dominiak P., Bławat F. (red.) (1993), Small and Medium Size Enterprises and the Role Private Industry in Poland, Wydział Zarządzania i Ekonomii, Politechnika Gdańska, Gdańsk.

Dunning H. (1988), The eclectic paradigm of international production: a restatement and some possible extensions, ,Journal of International Business Studies”, no. 1, s. 1-32.

Dunning H. (2000), The eclectic paradigm as an envelope for economic and business theories of MNE activity, „International Business Review”, no. 9, s. 163-190.

Dutkowski M. (1995), Konflikty w gospodarowaniu dobrami środowiskowymi, Rozprawy i Monografie Uniwersytetu Gdańskiego nr 215, Gdańsk;

Eberhardt P. (1989), Regiony wyludniajace się w Polsce, Prace Geograficzne, 148, IGiPZ PAN, Warszawa.

Edwards M. (2007), Regional and Urban Economics Development: Theory and Methods. Boca Raton, Auerbach Publications, New York.

Eggers J.H, Leahy K.T, Churchill N.C. (1994), Stages of small businessgrowth revisited: Insights into growth path and leadership management skills in low-andhogh-growth campanies, [w:] W.D. Bygrave, S. Birley, N.C. Churchill, E. Gatewood, , F. Hoy, R.H. Keeley, W.E. Wetzel (eds), Frontiers of entrepreneurship research 1994, Babson College, Babson Park, Massachusetts, s. 131-144. 
Ekspercki projekt koncepcji przestrzennego zagospodarowania kraju do roku 2033, Ministerstwo Rozwoju Regionalnego, Warszawa.

http://www.mrr.gov.pl/MINISTERSTWO/ZAMOWIENIA_PUBLICZNE/AKTUALNE_ZAMO WIENIA/Documents/KPZK_106_KS_17gru.pdf (dostęp 15.02.2013).

Europejska Karta Małych Przedsiębiorstw (2000), Komisja Europejska.

Europejski sondaż matych i średnich przedsiębiorstw (1999), Polska Fundacja Promocji i Rozwoju Małych i Średnich Przedsiębiorstw, Warszawa.

Europejski sondaż matych i średnich przedsiębiorstw (2001), Polska Fundacja Promocji i Rozwoju Małych i Średnich Przedsiębiorstw, Warszawa.

Felsenstein D., Swartz D. (1993), Constrains to Small Bussines Development Across the Life Cycle Model. Some Evidence from Peripheral Areas in Israel, Hebrew University of Jerusalem.

Feltynowski M. (2009), Ranking potencjału innowacyjnego polskich regionów z wykorzystaniem miar syntetycznych, [w:] Nowakowska A. (red.), Zdolności innowacyjne polskich regionów, Wydawnictwo UŁ, Łódź, s. 25-40.

Feltynowski M., Nowakowska A. (2009) Metoda oceny potencjału innowacyjnego regionów, [w:] Nowakowska A. (red.), Zdolności innowacyjne polskich regionów, Wydawnictwo UŁ, Łódź, s. $11-24$.

Filipiak B., Ruszała J. (2009), Instytucje otoczenia biznesu. Rozwój, wsparcie i instrumenty, Difin, Warszawa 2009.

Fisher, E. \& R. Reuber (2003), Support for rapid-growth firms: a comparison of the views of founders, government policymakers, and private sector resource providers, „Journal of Small Business Management", vol. 41(4), s. 346-365.

Flamholtz, E. (1986), Managing the Transition from an Entrepreneurship to a Professionally Managed Firm, Jossey-Bass, San Francisco.

Fritsch M., Mueller P. (2004), Effects of new business formation on regional development over time, ,Regional Studies”, vol. 38(3), s. 961-975.

Gaczek W.M. (2010), Metropolia jako źródto przewagi konkurencyjnej gospodarki regionu, [w:] Słupińska M. (red), Innowacyjna metropolia, konkurencyjny region, „Acta Universitatis Lodziensis", Folia Oeconomica 246, s. 5-21.

Gajewski P. (2011), Poziom i dynamika rozwoju małej i średniej przedsiębiorczości w Polsce Wschodniej, Ekspertyza wykonana na zlecenie Ministerstwa Rozwoju Regionalnego na potrzeby aktualizacji Strategii rozwoju społeczno-gospodarczego Polski Wschodniej do roku 2020, Ministerstwo Rozwoju Regionalnego, Warszawa.

Galbraith J.R. (1982), The stages of growth, „Journal of Business Strategy”, no. 3, s. 70-79.

Gancarczyk M. (2010), Wsparcie publiczne dla MSP. Podstawy teoretyczne a praktyka gospodar$c z a$, Wydawnictwo C.H.Beck, Warszawa.

Garfoli G. (1990), Local development: patterns and policy implications, [w:] N. Konsolas (ed.), Local Development, Regional Development Institute and Hellenic Agency for Local Development, Athens, s. 87-98.

Garfoli G. (ed.) (1992), Endogenous Development in Southern Europe, Aldershot, Avebury.

Gazda J., Puziak M. (2012), Źródta wzrostu gospodarczego w regionach, [w:] Kokocińska M. (red.), Etapy konwergencji w rozwiniętych krajach Unii Europejskiej, Wydawnictwo Uniwersytetu Ekonomicznego w Poznaniu, Poznań, s. 130-112.

Gibb A., Davies L. (1990), In pursuit of frameworks for the development of growth models of the small business', ,International Small Business Journal”, vol. 9, no. 1, s. 15-31.

Gibb A., Davies L. (1992), Methodological problems in the development of a growth model of business enterprise, ,Journal of Entrepreneurship”, no. 1 (1), s. 3-36.

Gierszewska G., Romanowska M. (2002), Analiza strategiczna przedsiębiorstwa, PWE, Warszawa. 
Gilbert, Brett A., Patricia P. McDougall, Audretsch D. B. (2006), New Venture Growth: A Review and Extension, ,Journal of Management”, vol. 32, s. 926-950.

Glaeser E., Kerr W. (2009), Local industrial conditions and entrepreneurship: How much of the spatial distribution can we explain?, „Journal of Economics and Management Strategy”, vol. 18(3), s. 623-663.

Godlewska-Majkowska H. (2008), Regionalne uwarunkowania wzrostu konkurencyjności przedsiębiorstw, [w:] Sosnowska A., Łobejko S. (red.), Drogi do sukcesu polskich matych $i$ średnich przedsiębiorstw, SGH, Warszawa, s. 65-75.

Godlewska-Majkowska H. (2009) (red.), Atrakcyjność inwestycyjna regionów Polski a ksztattowanie lokalnych $i$ regionalnych specjalizacji gospodarczych, Studia i Analizy Instytutu Przedsiębiorstwa, Oficyna Wydawnicza SGH, Warszawa.

Goodall B. (1987), The Dictionary of Human of Human Geography, Penguin, London.

Gorzelak G. (1989), Rozwój regionalny Polski w warunkach kryzysu i reformy. Rozwój regionalny - rozwój lokalny - samorząd terytorialny, Instytut Gospodarki Przestrzennej WGiSR, z. 14, UW, Warszawa.

Gorzelak G. (2011), Obszary problemowe jako adresat polityki regionalnej - doświadczenia polskie i międzynarodowe, [w:] Budowanie spójności terytorialnej i przeciwdziałanie marginalizacji obszarów problemowych. Wybór referatów konferencyjnych, Ministerstwo Rozwoju Regionalnego, Warszawa, s. 71-81.

Gorzelak G., Jałowiecki B. (1999), Strategie polskich regionów w procesie integracji europejskiej, „Samorząd Terytorialny”, nr 1-2, s. 32-62.

Gorzelak G. (2007), Rozwój - region - polityka, [w:] G. Gorzelak, A. Tucholska (red.), Rozwój, region, przestrzeń, Ministerstwo Rozwoju Regionalnego, EUROREG, Warszawa, s. 179214.

Gray C. (2004), Management development in european small and medium enterprises, „Advances in Developing Human Resources", vol. 6, no. 6, s. 451-469.

Greiner L. (1972), Evolution and revolution as organizations grow, „Harvard Business Review”, July-August, vol. 50, no. 4, s. 37-46.

Griffin R.W. (2010), Podstawy zarządzania organizacjami, Wydawnictwo Naukowe PWN, Warszawa.

Grocholska J., (1986), Konflikty $w$ planowaniu przestrzennym i próby ich rozwiązania (na przyktadzie wybranych obszarów aglomeracji warszawskiej), [w:] Studia nad funkcjonalnym makroregionem Warszawy (III), „Biuletyn Informacyjny”, t. 53, IGiPZ PAN, s. 205-222.

Grosse T.G, (2002), Przegląd koncepcji teoretycznych rozwoju regionalnego, „Studia Regionalne i Lokalne", nr 1(8), s. 26-48.

Grosse T.G, (2007), Wybrane koncepcje teoretyczne $i$ doświadczenia praktyczne dotyczące regionów peryferyjnych, „Studia Regionalne i Lokalne”, nr 1, s. 27-49.

Growing Regions, Growing Europe. Fourth Report on Economic and Social Cohesion, European Union 2007, http://ec.europa.eu/regional_policy/sources/.../reports/cohesion4/.../4cr_en.pdf (dostęp 12.12.2012).

Gudkova S. (2008), Rozwój matych przedsiębiorstw. Wiedza, sieci osobistych powiązań, proces uczenia się, Wydawnictwa Akademickie i Profesjonalne, Warszawa.

Guzman J., Santos F.J. (2008a), Entrepreneurial orientation, entrepreneurial structure and the economic growth of regions, [w:] Rekowski M. (ed.) Entrepreneurial Tissue and Regional Economy. Case Studies of Selected Polish and Spanish Regions, Akademia Ekonomiczna w Poznaniu, Poznań, s. 49-70.

Guzman J., Santos F.J. (2008b), Entrepreneurial Structure from a Regional Perspective, [w:] M-E. Gaindo, J. Guzman, D. Ribeiro (eds), Entrepreneurship and Business. A Regional Perspective, Springer, Heidelberg, s. 51-73. 
Guzmán J. \& Santos F.J. (2001), The booster function and the entrepreneurial quality: An application to the province of Seville, „Entrepreneurship and Regional Development”, vol. 13, s. 211-228.

Haltiwanger J., Krizan C.J. (1999), Small business and job creation in the united states: the role of new and young businesses, [w:] Z.J. Acs, (ed.), Are Small Firms Important? Their Role and Impact, Kluwer Academic Publishers, Boston and Dordrecht, s. 79-97.

Hamilton R.T. (2012), How firms grow and the influence of size and age, „International Small Business Journal", vol. 30(6), s. 611-621.

Hannan M.T., Freeman J.H. (1989), Organizational Ecology, Harvard University Press, Cambridge.

Hansen N. (1990), Innovative regional milieu, small firms, and regional development: evidence from Mediterranean France, ,Annals of Regional Science”, vol. 24, s. 107-123.

Hansen B., Hamilton R.T. (2011), Factors distinguishing small firm growers and non-growers, „International Small Business Journal”, no. 29(3), s. 278-294.

Heffner K. (red.) (1990), Procesy wyludniania się wsi w regione opolskim, Instytut Śląski, Opole.

Helwig Z. (1968), Zastosowanie metody taksonomicznej do typologicznego podziatu krajów ze względu na poziom ich rozwoju oraz zasoby i strukturę wykwalifikowanych kadr, „Przegląd Statystyczny", z. 4, s. 307-326.

Henrekson M., Johansson D. (2009), Competencies and institutions fostering high-growth firms. Foundations and Trends in Entrepreneurship, 5(1), s. 1-80.

Identyfikacja i delimitacja obszarów problemowych i strategicznej interwencji w Polsce. Wnioski $z$ analiz (2009), Ministerstwo Rozwoju Regionalnego, Warszawa.

Ignatiuk S. (2011), Wptyw przedsiębiorstw z sektora MSP ba rozwój gospodarczy pótnocnowschodniego regionu kraju, „Ekonomia i Zarządzanie”, t. 3, nr 2, s. 7-20.

Informacja o kondycji sektora przedsiębiorstw ze szczególnym uwzględnieniem stanu koniunktury w IV kw. 2012 oraz prognoz koniunktury na I kw. 2013 roku, NBP, Instytut ekonomiczny http://www.nbp.pl/publikacje/koniunktura/raport_1_kw_2013.pdf (dostęp10.04.2013).

Innovation Union Scoreboard 2013. Komisja Europejska. Bruksela (2013), http://ec.europa.eu/ enterprise/policies/innovation/files/ius-2013_en.pdf (dostę 12.04.2013).

INTERCO Indicators of territorial cohesion, Draft Final Report, ESPON\&University of Geneva, $2011 \mathrm{http}: / /$ espon.eu/export/sites/default/.../Interco/INTERCO_DFR_Annexes.pdf (dostęp 10.02.2013).

Investing in Europe's future. Fifth report on economic, social and territorial cohesion. European Union 2010.

Janasz W. (red.) (2009), Innowacje w strategii rozwoju organizacji w Unii Europejskiej, Difin, Warszawa.

Janasz W., Kozioł W. (2007), Determinanty działalności innowacyjnej przedsiębiorstw, PWE, Warszawa.

Jewtuchowicz A. (1998), Innowacje technologiczne w rozwoju lokalnym i regionalnym. Materiały konferencyjne, Łódź.

Jewtuchowicz A. (2000), Terytorialne systemy produkcyjne - nowy model rozwoju lokalnego i regionalnego, [w:] A. Jewtuchowicz (red.), Strategiczne problemy rozwoju miast i regionów, Wydawnictwo UŁ, Łódź.

Jeżak J. (2010), Przedsiębiorczość rodzinna - nowy obszar badań w zarzadzaniu strategicznym, [w:] H. Jagoda, L. Lichtarski (red.), Kierunki i dylematy rozwoju nauki i praktyki zarzadzania przedsiębiorstwem, Wydawnictwo Uniwersytetu Ekonomicznego we Wrocławiu, Wrocław, s. 51-63.

Kalantaridis Ch. (2009), SME strategy, embeddedness and performance in East Cleveland, North East England, „International Small Business Journal”, vol. 27(4), s. 496-521. 
Kamińska A. (2011), Regionalne determinanty rozwoju małych i średnich przedsiębiorstw, Difin, Warszawa.

Karpacz J. (2011), Determinanty odnowy strategicznej potencjału matych i średnich przedsiębiorstw. Aspekty teoretyczne i wyniki badań empirycznych, Oficyna Wydawnicza SGH, Warszawa.

Klasik A.(2005), Przedsiębiorczość i konkurencyjność a rozwój regionalny. Kluczowe pojęcia i metodologia, [w:] A. Klasik (red.), Przedsiębiorczy i konkurencyjny region w teorii i praktyce rozwoju regionalnego, PAN KPZK, nr 218, Warszawa.

Klimek J. (2011), Instytucje otoczenia biznesu a rozwój przedsiębiorczości w Polsce, [w:] I. Lichniak (red.), Determinanty rozwoju przedsiębiorczości w Polsce, Oficyna Wydawnicza SGH, Warszawa, s. 134-183.

Knoben J., Pondsb R., van Oortc F. (2011), Employment from new firm formation in the Netherlands:Agglomeration economies and the Knowledge Spillover. Theory of Entrepreneurship, „Entrepreneurship \& Regional Development”, vol. 23, no. 3-4, s. 135-157.

Knowledge-Innovation-Territory, ESPON, EU 2012, http://www.espon.eu/export/sites/default/ Documents/Projects/AppliedResearch/KIT/FinalReport/KIT_Final-Report_final.pdf (dostęp 12.04.2013).

Kobus P., Zrobek J. (2011), Mate i średnie przedsiębiorstwa na terenach stabo rozwiniętych, [w:] Matejun M. (red.), Wspomaganie i finansowanie rozwoju matych $i$ średnich przedsiębiorstw, Difin, Warszawa 2011, s. 44-58.

Kogut-Jaworska M. (2008), Instrumenty interwencjonizmu lokalnego w stymulowaniu rozwoju gospodarczego, CeDeWu, Warszawa 2008.

Kokocińska M. (2012a), Konwergencja gospodarcza na poziomie mezoekonomicznym, [w:] Kokocińska M. (red.), Etapy konwergencji w rozwiniętych krajach Unii Europejskiej, Wydawnictwo UE, Poznań, s. 9-39.

Kokocińska M. (2012b), Małe i średnie przedsiębiorstwa w gospodarkach europejskich. Metody badawcze. Dekompozycja sektorowa. Profile krajów, Wydawnictwo UE, Poznań.

Kokocińska M. (red.) (2012), Etapy konwergencji w rozwiniętych krajach Unii Europejskiej, Wydawnictwo UE, Poznań.

Kolb D.A (1984), Experiential Learning. Experience as a Source of Learning and Development, Prentice Hall.

Kolenda M. (2006), Taksonomia numeryczna. Klasyfikacja, porzadkowanie i analiza obiektów wielocechowych, Wydawnictwo Akademii Ekonomicznej we Wrocławiu, Wrocław.

Kołodziejski J. (1982), Geneza, funkcjonowanie oraz ocena sytuacji konfliktowych w gospodarce przestrzennej Polski, [w:] Diagnoza stanu gospodarki przestrzennej Polski, Biuletyn KPZK PAN, z. 123, Warszawa, s. 134-148.

KOM (2010), Europa 2020. Strategia na rzecz inteligentnego $i$ zrównoważonego rozwoju sprzyjajacego właczeniu społecznemu, Bruksela.

Komornicki T., Śleszyński P. (2009), Typologia obszarów wiejskich pod względem powiazań funkcjonalnych i relacji miasto-wieś, [w:] Bański J. (red.), Analiza zróżnicowania i perspektyw rozwoju obszarów wiejskich w Polsce do 2015 roku, Studia Obszarów Wiejskich, nr 16, IGiPZ PAN, PTG, Warszawa, s. 9-38.

Koncepcja Przestrzennego Zagospodarowania Kraju 2030 (2012), „Monitor Polski. Dziennik Urzędowy Rzeczypospolitej Polskiej) 27 kwietnia 2012, poz. 252, uchwała 239, Warszawa.

Korcelli P., Degorski M., Drzazga D., Komornicki T., Markowski T., Szlachta J., Węcławowicz G., Zaleski J., Zaucha J. (2008), Ekspercki projekt koncepcji przestrzennego zagospodarowania kraju do roku 2033, Ministerstwo Rozwoju Regionalnego, Warszawa. http://www.mrr.gov.p1/MINISTERSTWO/ZAMOWIENIA_PUBLICZNE/AKTUALNE_ZA MOWIENIA/Documents/KPZK_106_KS_17gru.pdf (dostęp 12.11.2011). 
Kornacki J., Mielniczuk J. (2001), Statystyka dla studentów kierunków technicznych i przyrodniczych, WNT, Warszawa.

Korenik S. (1999), Rozwój ekonomiczny na przykładzie Dolnego Ślaska, Prace Naukowe AE we Wrocławiu. Monografie i opracowania nr 131, Wydawnictwo AE, Wrocław.

Korenik S. (2003), Dysproporcje w rozwoju regionów Polski: wybrane aspekty. Prace Naukowe AE we Wrocławiu nr1033, Wydawnictwo AE, Wrocław.

Korol J.A, Szczuciński P. (2011), Sektor małych i średnich przedsiębiorstw w przestrzeni regionalnej Polski. Studium z zakresu ekonometrii regionalnej, Wydawnictwo Adam Marszałek, Torun.

Korzeniewski J. (2012), Metody selekcji zmiennych $w$ analizie skupień. Nowe procedury, Wydawnictwo Uniwersytetu Łódzkiego, Łódź.

Kot J. (2001), Planowanie strategiczne w jednostkach terytorialnych, [w:] T. Markowski, D. Stawasz (red.), Ekonomiczne i środowiskowe aspekty zarzadzania rozwojem miast i regionów, Wydawnictwo Uniwersytetu Łódzkiego, Łódź.

Kot J. (2003), Zarządzanie rozwojem gmin a praktyka planowania strategicznego, Wydawnictwo UŁ, Łódź.

Kot J. (2004), Zarzadzanie i planowanie w jednostkach terytorialnych, [w:] D. Stawasz (red.), Ekonomiczno-organizacyjne uwarunkowania regionu - teoria i praktyka, Wydawnictwo Uniwersytetu Łódzkiego, Łódź, s. 86-100.

Kot S. M., Słaby T., Perek-Białas J. (2012), wystąpienia w trakcie konferencji Quality of Life and Sustainable Development, Wydawnictwo UE, Wrocław.

Kornacki J., Mielniczuk J. (2001), Statystyka dla studentów kierunków technicznych i przyrodniczych, WNT, Warszawa.

Kozak M., Paszkowski A, Szewczyk R. (2000), Stownik rozwoju regionalnego w Polsce, Agencja Rozwoju Regionalnego, Warszawa.

Koźlak A. (2009), Ocena zróżnicowania innowacyjności regionów w Polsce i jego wplyw na poziom rozwoju gospodarczego, [w:] R. Brol, Gospodarka lokalna i regionalna $w$ teorii i praktyce, Prace Naukowe Uniwersytetu Ekonomicznego we Wrocławiu nr 46, Wydawnictwo Uniwersytetu Ekonomicznego we Wrocławiu, Wrocław, s. 93-104.

Kożuch B. (1998), Inwestycje zagraniczne a wzrost konkurencyjności regionu, [w:] Z. Oleśnicki, Bezpośrednie inwestycje zagraniczne w Polsce, PWE, Warszawa, s. 191-213.

Krajowa Strategia Rozwoju Regionalnego 2010-2020: Regiony, miasta, obszary wiejskie, Ministerstwo Rozwoju Regionalnego, Warszawa 2010.

Krasniqi B.A. (2007), Barriers to entrepreneurship and SME growth in transition: the case of Kosova, „Journal of Developmental Entrepreneurship”, vol. 12, no. 1, s. 71-94.

Krueger, N. \& Carsrud, A. (1993), Entrepreneurial intentions: Applying the theory of planned behavior, „Entrepreneurship and Regional Development”, vol. 5(1), s. 315-330.

Kuciński K. (2004), Geografia ekonomiczna. Zarys teoretyczny, SGH, Warszawa.

Kuciński K. (red.) (2010), Przedsiębiorczość a rozwój regionalny w Polsce, Difin, Warszawa, s. $153-209$.

Kumar K. (1995), From Post-Industrial to Post Modern Society, Blackwell, Oxford.

Kurowska M., Matejun M., Szymańska K. (2013), Zewnętrzne uwarunkowania rozwoju przedsiębiorczości technologicznej, [w:] Lachiewicz S., Matejun M., Walecka A. (red.), Przedsiębiorczość technologiczna $w$ matych i średnich firmach, Wydawnictwo WTN, Warszawa, s. 49-77 [w druku].

Labranidis L., Kalantaridis Ch. (1997), Globalization and local industrial development in the european periphery: Enterprise strategies in Eastern Macedonia and Thrace, „European Planning Studies", vol. 5, no. 4, s. 477-494. 
Latoszek E. (2008), Finansowanie MSP w Polsce ze środków finansowych UE jako czynnik wptywajacy na konkurencyjność przedsiębiorstw, SGH, Warszawa.

Lavoie D, Culbert S.A. (1978), Stages of organization and development, „Human Relation”, vol. 31(5), s. 417-438.

Lazear, E. P. (2005), Entrepreneurship, ,Journal of Labour Economics”, vol. 23(4), s. 649-680.

Leitch C., Hill F., Neergaard H., Entrepreneurial and business growth and the quest for a "comprehensive theory”: Tilting at windmills?, „Entrepreneurship Theory and Practice, Baylor University”, vol. 34, Issue 2, s. 249-260.

Leszczewska K. (2010), Aktywność ekonomiczna regionów peryferyjnych, [w:] M.G. Woźniak (red.), Nierówności spoleczne a wzrost gospodarczy. Spójność-społeczno-ekonomiczna a modernizacja gospodarki, Uniwersytet Rzeszowski, nr 17, Rzeszów, s. 215-225.

Leszczyński Z. (2004), Małe i średnie przedsiębiorstwa w przekrojach sektorowym i regionalnym, [w:] M. Strużycki (red.), Małe i średnie przedsiębiorstwa w gospodarce regionu, SGH, Warszawa, s. 235-270.

Leszczyński Z. (2011), Przedsiębiorstwa w rozwoju regionalnym, [w:] M. Strużycki (red.), Przedsiębiorstwo. Region. Rozwój, Difin, Warszawa, s. 228-260.

Levie J., Lichtenstein B. B. (2010), A Terminal Assessment of Stages Theory: Introducing a Dynamic States Approach to Entrepreneurship, „Entrepreneurship Theory and Practice”, Baylor University, vol. 34, Issue 2, s. 317-350.

Lewandowski M. (2011), Identyfikacje determinant rozwoju gospodarczego Polski Wschodniej przy zastosowaniu metody dekompozycji PKB. Ekspertyza dla Ministerstwa Rozwoju Regionalnego, MRR, Warszawa.

Lichniak I. (red.) (2011), Determinanty rozwoju przedsiębiorczości w Polsce, Oficyna Wydawnicza SGH, Warszawa.

Lisowska R. (2004), Zastosowanie metody taksonomicznej Z. Helwiga do klasyfikacji powiatów ze względu na poziom ich gospodarczego rozwoju, [w:] C. Gradowicz (red.), Metody ilościowe $w$ praktyce gospodarczej, „Zeszyty Naukowe Wyższej Szkoły HumanistycznoEkonomicznej w Łodzi”, nr 1(42), s. 89-98.

Lisowska R. (2010a), Analiza warunków ograniczajacych rozwój matych i średnich przedsiębiorstw funkcjonujacych $w$ regionach zmarginalizowanych, [w:] M. Matejun (red.), Wyzwania i perspektywy zarzadzania w matych i średnich przedsiębiorstwach, Wydawnictwo C.H. Beck, Warszawa 2010, s. 198-199.

Lisowska R. (2010b), Kreowanie postaw przedsiębiorczych $w$ regionach zmarginalizowanych przez władze samorzadowe, [w:] P. Niedzielski, J. Guliński, K.B. Matusiak (red.), Kreatywność-innowacje-przedsiębiorczość. SOOIPP ANNUAL 2009, „Zeszyty Naukowe Uniwersytetu Szczecińskiego", nr 579, Ekonomiczne Problemy Usług nr 47, Szczecin, s. 57-70.

Lisowska R. (2011a), Warunki funkcjonowania matych firm $w$ regionach zmarginalizowanych [w:] A. Bielawska (red.), Uwarunkowania rynkowe rozwoju mikro, matych i średnich przedsiębiorstw, „Zeszyty Naukowe Uniwersytetu Szczecińskiego”, nr 638, Ekonomiczne Problemy Usług nr 63, Szczecin, s. 141-149.

Lisowska R. (2011b), Wpływ małych i średnich przedsiębiorstw na rozwój regionów zmarginalizowanych, [w:] R. Brol, A. Raszkowski (red.), Problemy rozwoju regionalnego, Prace Naukowe Uniwersytetu Ekonomicznego we Wrocławiu nr 180, Wydawnictwo UE, Wrocław, s. $255-264$.

Lisowska R. (2012a), Bariery i progi rozwojowe matych przedsiębiorstw w Polsce, [w:] Piasecki B. (red.), Upadek matych firm. Symptomy i strategie wczesnego ostrzegania, Wydawnictwo UŁ, Łódź, s. 81-112.

Lisowska R. (2012b), Uwarunkowania rozwoju matych i średnich przedsiębiorstw $w$ regionach zmarginalizowanych na przykładzie województwa łódzkiego, [w:] E. Sobczak, A. Raszkow- 
ski (red.), Problemy rozwoju regionalnego, Prace Naukowe Uniwersytetu Ekonomicznego we Wrocławiu nr 244, Wrocław, s. 416-424.

Lisowska R. (2013), Regional determinants of the development of small and medium enterprises, [w:] E. Stawasz (red.), New trends and challenges in innovative entrepreneurship, ,Acta Universitatis Lodzenias", Folia Oeconomica 277, s. 61-70 [w druku].

Lisowska R., Ropęga J. (2009), Przyczyny upadku małych firm na terenach zmarginalizowanych, [w:] Sokołowski J. (red.), Problemy ekonomii, polityki ekonomicznej i finansów publicznych, t. 1, Prace Naukowe Uniwersytetu Ekonomicznego we Wrocławiu nr 39, Wydawnictwo UE, Wrocław.

Lisowska R., Stanisławski R. (2011), Obszary i instrument wsparcia matych i średnich przedsiębiorstw $w$ świetle badań na przykładzie województwa tódzkiego, [w:] M. Matejun (red.), Wspomaganie i finansowanie rozwoju małych $i$ średnich przedsiębiorstw, Difin, Warszawa.

Lisowska R, Szymańska K. (2013), Determinanty rozwoju przedsiębiorczego matych i średnich przedsiębiorstw w województwie tódzkim, Monografia Politechniki Łódzkiej, Łódź [w dru$\mathrm{ku}$.

Lobo C. A., da Silva Costa J. (2003), New Firm Formation: An Empirical Study for Portugal, www.regional-studies-assoc.ac.uk/events/pisa03/lobo.pdf (dostęp 10.08.2010).

Lumpkin, G. T. \& Dess, G.G. (1996), Clarifying the entrepreneurial orientation construct and linking it to performance, „Academy of Management Journal”, vol. 21(1), s. 135-172.

Łuczka T. (2001), Kapitat obcy w małym i średnim przedsiębiorstwie. Wybrane aspekty mikroi makroekonomiczne, Wydawnictwo Naukowe PWN, Poznań.

Łuczka T. (red.) (2007), Mate i średnie Przedsiębiorstwa, szkice o współczesnej przedsiębiorczości, Wydawnictwo Politechniki Poznańskiej, Poznań.

Łuczka-Bukała W., Zyskowska I. (2005), Czynniki rozwoju matych i średnich przedsiębiorstw. Wybrane aspekty, Akademia Rolnicza w Poznaniu, Poznań.

Machaczka J., Machaczka K. (2011), Wykorzystanie modelu Greinera-Lepparda $w$ diagnostyce rozwoju przedsiębiorstwa, [w:] S. Lachiewicz, M. Matejun, Zarzadzanie rozwojem matych i średnich przedsiębiorstw, Oficyna, Warszawa, s. 159-180.

Machaczka J. (1998), Zarządzanie rozwojem organizacji. Czynniki, modele, strategia i diagnoza. PWN, Warszawa-Kraków.

Makieła Z. (2008), Przedsiębiorczość regionalna, Difin, Warszawa.

Malinowska W., Misiąg, A. Niedzielski, J. Pancewicz (1999), Zakres sektora publicznego w Polsce, Instytut Badań nad Gospodarką Rynkową, Warszawa.

Marjański A. (2010), Badania matych $i$ średnich przedsiębiorstw rodzinnych $w$ Polsce, [w:] M. Matejun (red.), Wyzwania i perspektywy zarzadzania $w$ matych i średnich przedsiębiorstwach, Wydawnictwo C.H. Beck, Warszawa, s. 30-47.

Markowski T. (1996), Wspieranie wzrostu konkurencyjności w polityce rozwoju regionalnego, w: Strategiczne wyzwania dla polityki rozwoju regionalnego Polski, Fundacja im. F. Eberta, Kraków.

Markowski T. (1999), Zarzadzanie rozwojem miast, Wydawnictwo Naukowe PWN, Warszawa.

Markowski T., Marszał T. (2007), Metropolitan Areas of Poland - Challenges and Policy Recommendations, [w:] T. Marszał, W. Zmitrowicz (red.) Metropolises and Metropolitan Areas - Structures, Functions and Role, „Studia Regionalia”, vol. 20, s. 9-22.

Masłyk-Musiał (2003), Organizacje w ruchu. Strategia zarzadzania zmianami, Oficyna Ekonomiczna, Grupa Wolters Kluwer, Kraków.

Mason C. (1991), Spatial Variations in enterprise: the geography of new firmfoundation, [w:] R. Barrows (ed.), Deciphering the Enterprise Culture, Routledge, London, s. 74-106.

Masurel, E., Mantfort, K. (2006), Life cycle characteristics of small professional service firms, „Journal of Small Business Management”, vol. 44 (3), s. 461-473. 
Matejun M. (2007), Analiza zewnętrznych, prawno-podatkowych barier rozwoju firm sektora MSP, „Zeszyty Naukowe Politechniki Łódzkiej”, Seria Organizacja i Zarządzanie, z. 43, s. $107-121$.

Matejun M. (2010), Zewnętrzne bariery rozwoju w cyklu życia matych i średnich przedsiębiorstw, [w:] A. Kaleta, A. Moszkowicz (red.), Zarzadzanie strategiczne w praktyce $i$ teorii, Prace Naukowe Uniwersytetu we Wrocławiu, nr 116, Wrocław 2010, s. 243-254.

Matejun M. (2012), Specyfika zarządzania małymi $i$ średnimi przedsiębiorstwami, [w:] M. Matejun (red.), Zarzadzanie mała i średnia firma w teorii i ćwiczeniach, Difin, Warszawa, s. 13-45.

McKelvie A., Wiklund J. (2010), Advancing firm growth research: A focus on growth mode instead of growth rate, „Entrepreneurship Theory and Practice”, Baylor University, vol. 34, Issue 2, s. 261-288.

Mikołajczyk Z., Zimniewicz K. (2001), Zarzadzania małym i średnim przedsiębiorstwem, [w:] B. Piasecki (red.), Ekonomika i zarzadzanie mała firma, Wydawnictwo Naukowe PWN, Warszawa, s. 177-262.

Miller D. (1983), The correlates of entrepreneurship in three types of firms, „Management Sciences", vol. 29, s. 770-791.

Miller N.J., Besser T., Malshe A. (2007), Strategic networking among small businesses in small US Communities, „International Small Business Journal”, vol. 25(6), s. 631-665.

Miller, D. \& P. Friesen (1983), Successful and unsuccessful phases of the corporate life cycle, „Organization Studies”, vol. 4(4), s. 339-356.

Mintzberg, H. (1979), The Structuring of Organizations, Englewood Cliffs, Prentice-Hall, New York.

Mitton D.G. (1989), The complete entrepreneur, „Entrepreneurship Theory and Practice”, vol. 13(3).

Młodak A. (2006), Analiza taksonomiczna w statystyce regionalnej, Difin, Warszawa.

Mutalemwa D. K. (2009), Barriers to SMEs development in the manufacturing sector: Evidence from Tanzania, „African Journal of Business and Economic Research”, vol. 4, no. 2 \& 3, s. 93-111.

Narodowe strategiczne ramy odniesienia 2007-2013 wspierajace wzrost gospodarczy i zatrudnienie. Narodowa Strategia Spójności (2007), Ministerstwo Rozwoju Regionalnego, Warszawa.

Nehring A. (2011), Stan i rozwój sektora MSP w Polsce, [w:] M. Matejun (red.), Wspomaganie finansowe rozwoju matych $i$ średnich przedsiębiorstw, Difin, Warszawa, s. 13-27.

Noga A., Teoria małego przedsiębiorstwa, http://www.adam-noga.pl/publikacje/item/17-teoriamałego-przedsiębiorstwa-adam-noga.html (dostęp 05.02.2013).

Noga A. (2009), Teorie przedsiębiorstw, PWE, Warszawa,

Nogalski B., Karpacz J., Wójcik-Karpacz A. (2004), Funkcjonowanie i rozwój małych i średnich przedsiębiorstw. Od czego zależy?, Wydawnictwo AJG, Bydgoszcz.

Nogalski B., Wójcik-Karpacz A. (2003a), Pozafinansowe uwarunkowania wewnętrzne rozwoju małych przedsiębiorstw, [w:] J. Stankiewicz (red.), Zarządzanie kapitatem i informacja, Uniwersytet Zielonogórski, Zielona Góra, s. 15-22.

Nogalski B., Wójcik-Karpacz A. (2003b), Warunki rozwoju małej i średniej przedsiębiorczości w regionie świętokrzyskim, [w:] K. Jeremczuk (red.), Uwarunkowania rozwoju przedsiębiorczości-szanse i zagrożenia, PWSZ w Tarnobrzegu, Tarnobrzeg, s. 365-379.

North, D. \& D. Smallbone (1993), Employment generation and small business growth in different geographical environments, The $16^{\text {th }}$ National Small Firms Policy and Research Conference. Nottingham, England, November 17-19.

Nowak E. (1990), Metody taksonomiczne w klasyfikacji obiektów społeczno-gospodarczych, PWE, Warszawa. 
Nowakowska A. (2009) (red.), Zdolności innowacyjne polskich regionów, Wydawnictwo UŁ, Łódź.

OECD (1998), Fostering entrepreneurship, Paris.

Okpara J.O., Kabongo J. D. (2009), An empirical evaluation of barriers hindering the growth of small and medium sized enterprises (SMEs) in a developing economy, „African Journal of Business and Economic Research", vol. 4, no. 1, s. 7-21.

Olechnicka A. (2004), Regiony peryferyjne w gospodarce informacyjnej, Wydawnictwo Naukowe Scholar, Warszawa.

Olechnicka A. (2007), Innowacyjność polskich regionów, [w:] Gorzelak G. (red.), Polska regionalna i lokalna $w$ świetle badań EUROREG- $u$, Wydawnictwo Naukowe Scholar, Warszawa.

Quin R., Cameron K. (1983), Organizational life cycles aad shifting criteria of effectiveness: Some preliminary evidence, „Management Science”, no. 29, s. 33-51.

Pakulska T. (2010), Bezpośrednie inwestycje zagraniczne $w$ rozwoju przedsiębiorczości w regionie, [w:] K. Kuciński (red.), Przedsiębiorczość a rozwój regionalny w Polsce, Difin, Warszawa, s. 153-209.

Panek T. (2009), Statystyczne metody wielowymiarowej analizy porównawczej, Wydawnictwo SGH, Warszawa, s. 129-151.

Piasecki B. (1997), Przedsiebiorczość i mała firma. Teoria i praktyka, Wydawnictwo UŁ, Łódź.

Piasecki B. (2001), Ekonomika i zarządzanie mała firma, Wydawnictwo Naukowe PWN, Warszawa.

Piasecki B. (red.) (2012), Upadek matych firm, Symptomy i strategie wczesnego ostrzegania, Wydawnictwo UŁ, Łódź.

Pietrzyk I. (2000), Polityka regionalna Unii Europejskiej i regiony w państwach członkowskich, Wydawnictwo Naukowe PWN, Warszawa.

Pilarska C. (2005), Bezpośrednie inwestycje zagraniczne w teorii ekonomii, Wydawnictwo AE w Krakowie, Kraków.

Platonoff A. L., Sysko-Romańczuk S. (2003), Dynamiczne modelowanie funkcjonowania przedsiebiorstwa, „Organizacja i Kierowanie”, nr 2, s. 19-34.

Plawgo B. (2004), Zachowania małych i średnich przedsiębiorstw w procesie internacjonalizacji, Instytut Organizacji i Zarządzania ORGMASZ, Warszawa.

Plawgo B. (2011), Determinanty rozwoju lokalnego na obszarze problemowym Polski Wschodniej, [w:] Budowanie spójności terytorialnej i przeciwdziałanie marginalizacji obszarów problemowych. Wybór referatów konferencyjnych, Ministerstwo Rozwoju Regionalnego, Warszawa, s. 106-123.

Plawgo B. (red.) (2007), Rozwój struktur klastrowych w Polsce Wschodniej, Ministerstwo Rozwoju Regionalnego, Warszawa.

Polska 2030. Trzecia fala nowoczesności. Dtugookresowa Strategia Rozwoju Kraju. Projekt (2011), Kancelaria Prezesa Rady Ministrów, Warszawa.

Porter M.E., (2002), Harvard University Monitor Group, Research Triangle. Clusters of innovation initiative. Council on Competitiveness, Washington.

Porter M.E. i Monitor Group (2001), Research Triangle. Clusters of Innovation Initiative. Council on Competitiveness, Washington.

Poznańska K. (2008), Cykle życia przedsiębiorstw a instytucjonalna infrastruktura ich funkcjonowania, [w:] E. Mączyńska (red.), Bankructwa przedsiębiorstw. Wybrane aspekty instytucjonalne, Wydawnictwo SGH w Warszawie, Warszawa, s. 111-120.

Preisendorfera P., Voss T. (1990), Organizational morality of small firms: The effects of entrepreneurial age and human capital, „Organizational Studies”, no. 19, s. 107-129. 
Program Operacyjny Rozwój Polski Wschodniej 2007-2013 (2007), Ministerstwo Rozwoju Regionalnego, Warszawa http://www.polskawschodnia.gov.p1/Dokumenty/Lists/Dokumenty \%20programowe/Attachments/87/PORPW_280612rejzm.pdf_(dostęp 11.10.2012).

Projekt zaktualizowanej Strategii rozwoju społeczno-gospodarczego Polski Wschodniej do roku 2020 (2013), http://www.mrr.gov.pl/rozwoj_regionalny/Polityka_regionalna/Strategia_rozwoju _polski_wschodniej_do_2020/Dokumenty/Documents/SPW_www_9_04_13.pdf (dostęp 11.04.2013).

Przygodzki Z. (1997), Zewnętrzne uwarunkowania konkurencyjności regionów, [w:] J. Chądzyński, A. Nowakowska, Z. Przygodzki, Region i jego rozwój $w$ warunkach globalizacji, CeDeWu, Warszawa 2007.

Przygodzki Z. (2007), Konkurencyjność regionów, [w:] J. Chądzyński i inni (red.), Region i jego rozwój w warunkach globalizacji, CeDeWu, Warszawa, s. 69-80.

Pyke F. (1992), Industrial Development Throght Small - Firm Cooperation, International Labour Office, Geneva.

Pyke R., Becattini G., \& Sengenberger W. (1991), Industrial Districts and Inter-firm. Cooperation in Italy, ILO, Geneva.

Raport o stanie matych i średnich przedsiębiorstw w latach 2001-2002, (2003), PARP, Warszawa. Raport o stanie sektora matych i średnich przedsiębiorstw w Polsce w latach 2010-2011, (2012), A. Tarnawa, P. Zadura-Lichota (red.), PARP, Warszawa.

Reddy R.J. (2004), Business Environment, APH Publishing, New Delhi.

Rekowski M. (red.) (2008), Entrepreneurial Tissue and Regional Economy. Case Studies of Selected Polish and Spanish Regions, Akademia Ekonomiczna w Poznaniu, Poznań.

Richert-Kaźmierska A. (2010), Władze samorzadowe w procesie kreowania przedsiębiorczości, „Studia i Materiały, Miscellanea Oeconomicae”, nr 1, s. 269-278.

Robbins S.P, Judge T.A (2011), Zachowania w organizacji, PWE, Warszawa.

Rocznik Statystyczny Województw 2010, GUS, Warszawa 2010.

Rokita J. (2005), Zarzadzanie strategiczne. Tworzenie i utrzymywanie przewagi konkurencyjnej, PWE, Warszawa.

Romanowska M. (2009), Planowanie strategiczne w przedsiębiorstwie, PWE, Warszawa.

Romero I., Fernandez-Serrano J. (2011), Analysing the composition of the SME sector in high-and low-income regions: Some research hypotheses, „Entrepreneurship \& Regional Development", vol. (23), Issue 7-8, s. 637-660.

Roomi M. (2009), Impact of social capital development and use in the growth process of womenowned firms, ,Journal of Enterprising Culture”, vol. 17, no. 4, s. 473-395.

Rozwój klastrów w Polsce Wschodniej, PARP, Warszawa 2012.

Różański J. (red.) (2006), Inwestycje rzeczowe i kapitałowe, Difin, Warszawa.

Rymarczyk J. (2004), Internacjonalizacja i globalizacja przedsiębiorstwa, PWE, Warszawa.

Sadowska-Snarska C. (2000), Zmiany strukturalne w zatrudnieniu jako czynnik rozwoju regionalnego (na przykładzie regionu pótnocno-wschodniej Polski), Wydawnictwo Wyższej Szkoły Ekonomicznej w Białymstoku, Białystok.

Safin. K, (2008), Zarządzanie małym i średnim przedsiębiorstwem, Wydawnictwo AE, Wrocław.

Scott B.R. (1973), Stages of corporate development, „Harvard Business Review”, March-April, s. $133-148$.

Scott, M., Bruce R. (1987), Five stages of growth in small business, „Long Range Planning”, vol. 20, s. 45-52.

Sikorski Cz. (1999), Zachowanie ludzi w organizacji, Wydawnictwo Naukowe PWN, Warszawa.

Sikorski Cz. (2009), Nauka o zarządzaniu, Wydawnictwo AHE, Łódź.

Skowronek-Mielczarek A. (2003), Małe i średnie przedsiębiorstwa. Źródła finansowania, Wydawnictwo C.H. Beck, Warszawa. 
Skowronek-Mielczarek A. (2005), Mate i średnie przedsiębiorstwa. Źródła finansowania, Wydawnictwo C.H. Beck, Warszawa.

Skowronek-Mielczarek A. (2011a), Finansowe formy wspierania rozwoju przedsiębiorstw w regionie, [w:] M. Strużycki (red.), Przedsiębiorstwo. Region. Rozwój, Difin, Warszawa, s. $149-179$.

Skowronek-Mielczarek A. (2011b), Regionalne uwarunkowania rozwoju matych i średnich przedsiębiorstw, [w:] M. Matejun (red.), Wspomaganie i finansowanie rozwoju matych i średnich przedsiębiorstw, Difin, Warszawa.

Smallbone D., Deakins D., Battisti M. and Kitching J. (2012), Small business responses to a major economic downturn: Empirical perspectives from New Zealand and the United Kingdom, „International Small Business Journal”, vol. 30(7), s. 754-777.

Smallbone, D., Leig, R., North, D. (1995), The characteristics and strategies of high growth $S M E s$, ,International Journal of Entrepreneurial Behaviour \& Research”, vol. 1(3), s. 44-62.

Smallbone D., North D., Leigh R. (1993), The growth and survival of mature manufacturing SMEs in the1989s:an urban-urban comparison, [w:] J. Curran, D. Storey (eds.), Small firms in Urban and Rural Locations, Routledge, London, s. 79-130.

Smallbone D., Welter F. (2001), The role of government in SME development in transition economies, „International Small Business Journal”, no. 19, s. 63-77.

Smętkowski M., (2007), Nowe relacje metropolia-region $w$ gospodarce informacyjnej na przykładzie Warszawy i Mazowsza, [w:] G. Gorzelak (red.), Polska regionalna i lokalna w świetle badań EUROREG, Wydawnictwo Naukowe Scholar, Warszawa, s. 163-187.

Smętkowski M., (2012), Wschodnie obszary problemowe i ich trajektorie rozwojowe na przyktadzie Polski i Niemiec, „Studia Regionalne i Lokalne”, nr 4 (50), s. 29-53.

Smętkowski M., Wójcik P. (2008), Regiony w Europie Środkowo-Wschodniej: tendencje i czynniki rozwojowe, Centrum Europejskich Studiów Regionalnych i Lokalnych, Uniwersytet Warszawski, Warszawa.

Smith, K., Mitchell T., Summer C. (1985), Top level management priorities in different stages of the organization life cycle, „Academy of Management Journal”, vol. 28 (4), s. 799-820.

Sosnowska A., Łobejko S. (2008), Drogi do sukcesu polskich malych i średnich przedsiębiorstw, SGH, Warszawa.

Stanisławek J. (2010), Podstawy statystyki. Opis statystyczny, korelacja, rozkłady zmiennej losowej, wnioskowanie statystyczne, Politechnika Warszawska, Warszawa.

Stanisławski R. (2011), Instrumenty polityki innowacyjnej skierowane do MSP, [w:] P. Niedzielski, R. Stanisławski, E. Stawasz (red.), Polityka innowacyjna wobec sektora małych i średnich przedsiębiorstw $w$ Polsce-analiza uwarunkowań i ocena realizacji, „Zeszyty Naukowe Uniwersytetu Szczecińskiego", nr 654, Ekonomiczne Problemy Usług nr 70, Szczecin, s. $77-$ 122.

Starczewska-Krzysztoszek M. (2008), Bariery rozwoju małych $i$ średnich przedsiębiorstw $w$ Polsce, Infos nr 4(28), Biuro Analiz Sejmowych (BAS) Warszawa http://orka.sejm.gov.pl/ WydBAS.nsf/0/C5322ED5A2F2D077C12573F400399B54/\$file/infos_028.pdf (dostęp 10.07.2011).

Starzyńska D. (2012), Bezpośrednie inwestycje zagraniczne a konkurencyjność przedsiębiorstw przemystowych $w$ Polsce, Wydawnictwo UŁ, Łódź.

Stawasz D. (2000), Wspótczesne uwarunkowania rozwoju polskich regionów, Wydawnictwo UŁ, Łódź.

Stawasz D. (2004), Wybrane aspekty gospodarki regionalnej, [w:] D. Stawasz (red.), Ekonomiczno-organizacyjne uwarunkowania regionu-teoria i praktyka, Wydawnictwo UŁ, Łódź, s. $55-85$. 
Stawasz D. (2007), Rozwój regionalny ujęcie teoretyczne, [w:] H. Skłodowski, E. Stawasz (red.), Psychologiczne wyznaczniki efektywności poszukiwania pracy $i$ samozatrudnienia $w$ regionach zmarginalizowanych, Wydawnictwo UŁ, Łódź, s. 43-53.

Stawasz D., Sikora-Fernandez D. (2011), Polityka miejska a rozwój sektora MŚP, [w:] S. Lachiewicz, M. Matejun (red.), Zarządzanie rozwojem matych i średnich przedsiębiorstw, Oficyna Wolters Kluwer Business, Warszawa 2011, s. 128-148.

Stawasz E. (2008), Wybrane problemy funkcjonowania i zarzadzania wzrostem przedsiębiorstw z sektora MSP, [w:] E. Stawasz (red.), Zarzadzanie wzrostem matych i średnich przedsiębiorstw w kontekście szarej strefy, Wydawnictwo UŁ, Łódź, s. 65-89.

Stawasz E. (2011), Innowacyjność polskiego sektora MSP $w$ świetle badań własnych, [w:] P. Niedzielski, R. Stanisławski, E. Stawasz (red.), Polityka innowacyjna wobec sektora matych $i$ średnich przedsiębiorstw $w$ Polsce-analiza uwarunkowań $i$ ocena realizacji, „Zeszyty Naukowe Uniwersytetu Szczecińskiego", nr 654, Ekonomiczne Problemy Usług nr 70, Szczecin, s. 241-290.

Steffens P., Davidsson P, Fitzsimmons J. (2009), Performance Configurations Over Time: Implications for Growth-and Profit-Oriented Strategies, „Entrepreneurship Theory and Practice", Baylor University, vol. 33, Issue 1, s. 125-148.

Stevenson, H., Jarillo, J. (1990), A Paradigm of Entrepreneurship: Entrepreneurial Management, „Strategic Management Journal”, vol. 11, s.17-27.

Stöhr W. (1987), Regional Economic Development and the World Economic Crisis, „International Social Science Journal", vol. 39, s. 187-199.

Storey D.J. (1994), Understanding the Small Business Sector, Routledge, London.

Strategia rozwoju kraju 2020. Aktywne społeczeństwo, konkurencyjna gospodarka, sprawne państwo (2012), Ministerstwo Rozwoju Regionalnego, Warszawa.

Strategor (1995), Zarządzanie firma, strategie, struktury, tożsamość, PWE, Warszawa.

Strużycki M. (2002), Zarządzania małym i średnim przedsiębiorstwem. Uwarunkowania europejskie, Difin, Warszawa.

Strużycki M. (red.) (2004), Małe i średnie przedsiębiorstwa w gospodarce regionu, Wydawnictwo SGH, Warszawa.

Strużycki M. (red.) (2011), Przedsiębiorstwo. Region. Rozwój, Difin, Warszawa.

Sułkowski Ł., Marjański A. (2009), Firmy rodzinne - jak osiagnać suckes w sztafecie pokoleń, Poltext, Warszawa.

Szul R. (1991), Przestrzeń, gospodarka, państwo, Europejski Instytut Rozwoju Lokalnego i Regionalnego, Warszawa

Szwed R. (2009), Metody statystyczne w naukach społecznych. Elementy teorii i zadania, Wydawnictwo KUL, Lublin.

Targalski J.(2003), Przedsiębiorczość i zarządzanie, C.H.Beck, Warszawa.

Targalski J. (2010), Strategia jako narzędzie zarządzania rozwojem małych i średnich przedsiębiorstw, [w:] J. Targalski, K. Zieliński, Strategie rozwoju matych i średnich przedsiębiorstw. Ujęcie teoretyczne i empiryczne, Wyd. Fundacja Uniwersytetu Ekonomicznego w Krakowie, Kraków, s. 9-18.

Targalski J., Zieliński K. (red.) (2011), Strategie rozwoju małych i średnich przedsiębiorstw. Ujęcie teoretyczne i empiryczne, Fundacja Uniwersytetu Ekonomicznego w Krakowie, Kraków.

Thematic Evaluation of Structural Found Impacts on SMEs. Synthesis Report, (1999), European Commision, Brussels, http://ec.europa.eu/regional_policy/sources/docgener/evaluation/ pdf/eval_sme.pdf(dostęp 17.03.2012).

Thornton P. H., Ribeiro-Soriano D., Urbano D. (2011), Socio-cultural factors and entrepreneurial activity: An overview, ,International Small Business Journal”, vol. 29(2), s. 105-118. 
Thurik R., Wennekers S.(2004), Entrepreneurship, small business and economic growth, „Journal of Small Business Enterprise Development", vol. 11(1), s. 140-149.

Trendy rozwojowe sektora MSP w ocenie przedsiębiorców w drugiej polowie 2011 roku (2012), Ministerstwo Gospodarki Departament Analiz i Prognoz Warszawa, (nr 1/2012), http://www.mg.gov.pl/files/upload/8438/MSP.1.2012.pdf (dostęp 10.05.2012).

Trendy rozwojowe sektora MSP $w$ ocenie przedsiębiorców $w$ drugiej połowie 2012 roku (2013), Ministerstwo Gospodarki Departament Analiz i Prognoz, Warszawa, (nr 1/2013), http://www.mg.gov.pl/files/upload/8438/MSP.1.2013.pdf (dostęp 04.03.2013).

Urbanowska-Sojkin E. (2003), Zarządzanie przedsiębiorstwem. Od kryzysu do sukcesu, Wydawnictwo Akademii Ekonomicznej w Poznaniu, Poznań.

Urbanowska-Sojkin (red.) (2011), Podstawy wyborów strategicznych w przedsiębiorstwach, PWE, Warszawa.

Ustawa z dnia 12 maja 2000 r. o zasadach wspierania rozwoju regionalnego (Dz.U. z dnia 14 czerwca 2000 r.).

Ustawa z dnia 8 maja 1990 r. o samorządzie gminnym, Dz.U. 1990, nr 16 poz. 95.

Valliere D., Peterson R. (2009), Entrepreneurship and economic growth: Evidence from emerging and developed countries, „Entrepreneurship \& Regional Development”, vol. 21, no. 5-6, s. $459-480$.

Van Horn R.L, Harvey M.G. (1988), The rural entrepreneurial venture: creating the virtual firm, „Journal of Business Venturing”, no. 13, s. 257-274.

Van Stel A., Suddle K. (2008), The impact of new firm formation on regional development in the Netherlands, ,Small Business Economics”, vol. 30, s. 31-47.

Vinnell, R. \& R. Hamilton (1999), A historical perspective on small firm development, „Entrepreneurship Theory \& Practice”, vol. 23(4), s. 5-18.

Wach K. (2008a), Regionalne otoczenie małych $i$ średnich przedsiębiorstw, Wydawnictwo Uniwersytetu Ekonomicznego w Krakowie, Kraków 2008.

Wach K. (2008a) Skutki akcesji do Unii Europejskiej dla polskich przedsiębiorstw, Wydawnictwo Uniwersytetu Ekonomicznego w Krakowie, Kraków.

Wallerstein I.M. (2007), Analiza systemów-światów. Wprowadzenie, Wydawnictwo Akademickie Dialog, Warszawa.

Wasilczuk J. (2004a), Bariery wzrostu matych i średnich przedsiębiorstw $w$ świetle badań empirycznych, [w:] F. Bławat (red.), Przetrwanie i rozwój matych i średnich przedsiębiorstw, SPG, Gdańsk, s. 139-148.

Wasilczuk J. (2004b), Determinanty wzrostu matych i średnich przedsiębiorstw, [w:] F. Bławat (red.), Przetrwanie i rozwój matych i średnich przedsiębiorstw, SPG, Gdańsk, s. 23-44.

Wasilczuk J. (2005), Wzrost matych i średnich przedsiębiorstw aspekty teoretyczne i praktyczne. Wydawnictwo PG, Gdańsk.

Wieczerzyńska B. (2009), Kryzys w przedsiębiorstwie, Wydawnictwo CeDeWu, Warszawa.

Wieloński A. (2000), Geografia przemystu, Wydawnictwo Naukowe PWN, Warszawa.

Wiklund J. (1996), Theoretical perspectives in research on firm growth, [w:] Materiaty konferencyjne, RENT X, Brussels.

Wiklund J., Davidsson P., Audretsch David B., Karlsson Ch. (2011), The Future of Entrepreneurship Research Entrepreneurship Theory and Practice, Baylor University, s. 1-9.

Wiklund J., Patzelt H., Shepherd D.A (2009), Building an integrative model of small business growth, ,Small Business Economics”, no. 32, Springer, s. 351-374.

Winiarski B. (red.) (1992), Polityka regionalna $w$ warunkach gospodarki rynkowej, Ossolineum, Wrocław. 
Winiarski B., Winiarska F., (2000), Polityka regionalna, [w:] B. Winiarski (red.), Polityka gospodarcza, Wydawnictwo Naukowe PWN, Warszawa, s. 278-307.

Witkowska J. (2000), Bezpośrednie inwestycje zagraniczne a rynek pracy w kraju przyjmującym aspekty teoretyczne, „Ekonomista”, nr 5, s. 647-668.

Włodkiewicz-Donimirski Z., (2012), Małe i średnie przedsiębiorstwa w eksporcie Polski w latach 2007-2011, [w:] A. Tarnawa, P. Zadura-Lichota (red.), Raport o stanie sektora matych i średnich przedsiębiorstw w Polsce w latach 2010-2011, PARP, Warszawa, s. 48-62.

Wnorowski H. (2001), Małe $i$ średnie przedsiębiorstwa - ich rola $w$ gospodarce oraz czynniki rozwoju, [w:] Wnorowski H. Letkiewicz A. (red.), Praktyczne problemy przedsiębiorczości, Wydawnictwo Uniwersytetu w Białymstoku, Białystok.

Woźniak M.G. (2006), Rozwój sektora matych i średnich przedsiębiorstw w Polsce a wzrost gospodarczy, Wydawnictwo AE w Krakowie, Kraków.

Wright M., Marlow S. (2012), Entrepreneurial activity in the venture creation and development process, „International Small Business Journal”, vol. 30(2), s. 107-114.

Wright M., Stigliani I. (2013), Entrepreneurship and growth, „International Small Business Journal", vol. 31(1), s. 611-621.

Zając Cz. (2007), Zarządzanie zasobami ludzkimi, Wyd. Wyższa Szkoła Bankowa w Poznaniu, Poznań.

Zelek A. (2003), Zarządzanie kryzysem w przedsiębiorstwie-perspektywa strategiczna, Instytut Organizacji i Zarządzania w Przemyśle, ORGMASZ, Warszawa. 


\section{Spis tabel}

Tabela 1. Potencjalne cechy diagnostyczne opisujące rozwój społeczno-gospodarczy powiatów w $2009 \mathrm{r}$.

Tabela 2. Cechy diagnostyczne opisujące rozwój społeczno-gospodarczy powiatów w 2009 r. . 34

Tabela 3. Poziom rozwoju społeczno-gospodarczego powiatów w 2009 r. - podział na klasy według wskaźnika syntetycznego

Tabela 4. Małe i średnie przedsiębiorstwa w wybranych teoriach i koncepcjach rozwoju regionalnego - wnioski dla obszarów zmarginalizowanych

Tabela 5. Czynniki wpływające na przechodzenie do poszczególnych faz ………................... 70

Tabela 6. Przedsiębiorstwa „rosnące” i „nierosnące” - analiza porównawcza ......................... 70

Tabela 7. Uwarunkowania wewnętrzne rozwoju małych i średnich przedsiębiorstw - wybrane koncepcje

Tabela 8. Uwarunkowania makroekonomiczne i mikroekonomiczne rozwoju małych i średnich przedsiębiorstw - wybrane koncepcje.

Tabela 9. Uwarunkowania mezoekonomiczne (regionalne) rozwoju małych i średnich przedsiębiorstw - wybrane koncepcje

Tabela 10. Wybrane kryteria klasyfikacji barier rozwoju małych i średnich przedsiębiorstw .

Tabela 11. Wybrane badania barier rozwoju MSP w Polsce

Tabela 12. Potrzeby w zakresie wsparcia MSP w różnych fazach rozwoju ............................

Tabela 13. Charakterystyka badanego przedsiębiorstwa a jego dynamika rozwojowa ............

Tabela 14. Charakterystyka właściciela a dynamika rozwoju przedsiębiorstwa

Tabela 15. Wartość statystyki $(H)$ według testu Kruskala-Wallisa oraz poziom prawdopodobieństwa testowego $(p)$ zmiennych określających priorytety rozwojowe badanych przedsiębiorstw w obszarach rozwiniętych $\mathrm{w}$ kontekście wielkości przedsiębiorstwa ...

Tabela 16. Wartość statystyki $(H)$ według testu Kruskala-Wallisa oraz poziom prawdopodobieństwa testowego $(p)$ zmiennych określających priorytety rozwojowe badanych przedsiębiorstw $\mathrm{w}$ obszarach zmarginalizowanych w kontekście wielkości przedsiębiorstwa

Tabela 17. Wartość statystyki $(H)$ według testu Kruskala-Wallisa oraz poziom prawdopodobieństwa testowego $(p)$ zmiennych określających przewagi konkurencyjne badanych przedsiębiorstw w obszarach rozwiniętych w kontekście wielkości przedsiębiorstwa ...

Tabela 18. Wartość statystyki $(H)$ według testu Kruskala-Wallisa oraz poziom prawdopodobieństwa testowego $(p)$ zmiennych określających przewagi konkurencyjne badanych przedsiębiorstw $\mathrm{w}$ obszarach zmarginalizowanych w kontekście wielkości przedsiębiorstwa

Tabela 19. Wartość statystyki $(H)$ według testu Kruskala-Wallisa oraz poziom prawdopodobieństwa testowego $(p)$ zmiennych określających uwarunkowania mezoekonomiczne badanych przedsiębiorstw $\mathrm{w}$ obszarach zmarginalizowanych w kontekście wielkości przedsiębiorstwa

Tabela 20. Wartość statystyki $(H)$ według testu Kruskala-Wallisa oraz poziom prawdopodobieństwa testowego $(p)$ zmiennych określających uwarunkowania mikroekonomiczne 
badanych przedsiębiorstw w obszarach zmarginalizowanych w kontekście wielkości przedsiębiorstwa

Tabela 21. Wartość statystyki $(H)$ według testu Kruskala-Wallisa oraz poziom prawdopodobieństwatestowego $(p)$ zmiennych określających uwarunkowania wewnętrzne związane $\mathrm{z}$ przedsiębiorstwem $\mathrm{w}$ obszarach zmarginalizowanych $\mathrm{w}$ kontekście wielkości przedsiębiorstwa

Tabela 22. Charakterystyka badanych przedsiębiorstw .....

Tabela 23. Wpływ specyficznych cech obszarów zmarginalizowanych na rozwój badanych przedsiębiorstw

Tabela 24. Wartość statystyki $(H)$ według testu Kruskala-Wallisa oraz poziom prawdopodobieństwa testowego $(p)$ zmiennych określających cechy obszarów zmarginalizowanych w kontekście wielkości przedsiębiorstwa

Tabela 25. Wartość statystyki $(H)$ według testu Kruskala-Wallisa oraz poziom prawdopodobieństwa testowego $(p)$ zmiennych określających przyczyny wprowadzenia innowacji w kontekście wielkości przedsiębiorstwa

Tabela 26. Marginalizacja obszaru na rozwój działalności innowacyjnej

Tabela 27. Wartość statystyki $(H)$ według testu Kruskala-Wallisa oraz poziom prawdopodobieństwa testowego $(p)$ zmiennych określających bariery wprowadzenia innowacji w kontekście wielkości przedsiębiorstwa

Tabela 28. Wartość statystyki $(H)$ według testu Kruskala-Wallisa oraz poziom prawdopodobieństwa testowego $(p)$ zmiennych określających źródła finansowania innowacji w kontekście wielkości przedsiębiorstwa

Tabela 29. Wartość statystyki $(H)$ według testu Kruskala-Wallisa oraz poziom prawdopodobieństwa testowego $(p)$ zmiennych określających rodzaje inwestycji w kontekście wielkości przedsiębiorstwa

Tabela 30. Wartość statystyki $(H)$ według testu Kruskala-Wallisa oraz poziom prawdopodobieństwa testowego $(p)$ zmiennych określających bariery prowadzenia działalności inwestycyjnej w kontekście wielkości przedsiębiorstwa

Tabela 31. Wartość statystyki $(H)$ według testu Kruskala-Wallisa oraz poziom prawdopodobieństwa testowego $(p)$ zmiennych określających źródła finansowania inwestycji w kontekście wielkości przedsiębiorstwa

Tabela 32. Wartość statystyki $(H)$ według testu Kruskala-Wallisa oraz poziom prawdopodobieństwa testowego $(p)$ zmiennych określających oczekiwane przez przedsiębiorców działania ze strony władz samorządowych w celu stymulowania rozwoju MSP w kontekście wielkości przedsiębiorstwa

Tabela 33. Cele wybranych instytucji wspierania przedsiebiorczości i innowacyjności ..........

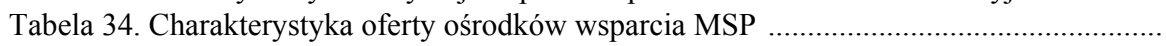

Tabela 35. Wartość statystyki $(H)$ według testu Kruskala-Wallisa oraz poziom prawdopodobieństwa testowego $(p)$ zmiennych określających rodzaj instytucji otoczenia biznesu, z którą współpracowało przedsiębiorstwo w kontekście jego wielkości

Tabela 36. Wartość statystyki $(H)$ według testu Kruskala-Wallisa oraz poziom prawdopodobieństwa testowego $(p)$ zmiennych określających efekty współpracy z instytucjami otoczenia biznesu w kontekście wielkości przedsiębiorstwa

Tabela 37. Wartość statystyki $(H)$ według testu Kruskala-Wallisa oraz poziom prawdopodobieństwa testowego $(p)$ zmiennych określających przyczyny braku współpracy przedsiębiorstwa z instytucjami otoczenia biznesu w kontekście wielkości przedsiębiorstwa.

Tabela 38. Wartość statystyki $(H)$ według testu Kruskala-Wallisa oraz poziom prawdopodobieństwa testowego $(p)$ zmiennych określających formy pomocy publicznej w kontekście wielkości przedsiębiorstwa 
Tabela 39. Bariery rozwoju współpracy z instytucjami otoczenia biznesu w obszarach zmarginalizowanych

Tabela 40. Podejmowane działania przez IOB w celu nawiązywania współpracy ................. 203

Tabela 41. Wartość statystyki $(H)$ według testu Kruskala-Wallisa oraz poziom prawdopodobieństwa testowego $(p)$ zmiennych określających wpływ cech obszarów zmarginalizowanych na zarządzanie przedsiębiorstwem w kontekście wielkości przedsiębiorstwa

Tabela 42. Wartość statystyki $(H)$ według testu Kruskala-Wallisa oraz poziom prawdopodobieństwa testowego $(p)$ zmiennych określających słabości procesu zarządzania w kontekście wielkości przedsiębiorstwa

Tabela 43. Wartość statystyki $(H)$ według testu Kruskala-Wallisa oraz poziom prawdopodobieństwa testowego $(p)$ zmiennych określających rodzaj pozyskiwanej informacji w kontekście wielkości przedsiębiorstwa

Tabela 44. Wartość statystyki $(H)$ według testu Kruskala-Wallisa oraz poziom prawdopodobieństwa testowego $(p)$ zmiennych określających wpływ cech obszarów zmarginalizowanych na strategię rozwoju w kontekście wielkości przedsiębiorstwa

Tabela 45. Marginalizacja obszaru a proces zarządzania 



\section{Spis rysunków}

Rysunek 1. Typy obszarów problemowych (OP) ze względu na ich wyzwania rozwojowe ... Rysunek 2. Klasyfikacja polskich podregionów według poziomu rozwoju społeczno-gospodarczego

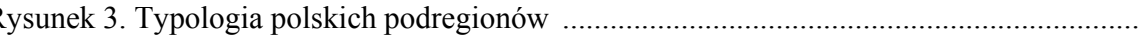

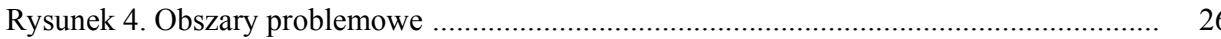

Rysunek 5. Poziom innowacyjności i rozwoju gospodarczego polskich regionów ................. 28

Rysunek 6. Obszary wiejskie o najgorszych wskaźnikach sytuacji społeczno-gospodarczej według powiatów

Rysunek 7. Poziom rozwoju społeczno-gospodarczego powiatów w 2009 r. ........................ 36

Rysunek 8. Model przedsiębiorczości regionalnej ................................................................. 41

Rysunek 9. Innowacyjne środowisko przedsiębiorczości ...................................................... 44

Rysunek 10. Model tkanki przedsiębiorczości .................................................................... 45

Rysunek 11. Typy powiatów według dominującego sektora w strukturze zatrudnienia w $2010 \mathrm{r}$

Rysunek 12. Zmiany w liczbie MSP w latach 2005-2011 (w \%) ........................................ 51

Rysunek 13. Zmiany w liczbie mikro, małych i średnich przedsiębiorstw na 10 tys. osób w latach 2005-2011 (w \%)

Rysunek 14. Zmiany w liczbie MSP na 10 tys. osób w latach 2005-2011 (w \%) w obszarach zmarginalizowanych

Rysunek 15. MSP nowo zarejestrowane w rejestrze REGON na 10 tys. osób w 2011 r. ........ 54

Rysunek 16. MSP wyrejestrowane z rejestru REGON na 10 tys. osób w 2011 r. .................. 55

Rysunek 17. Relacja MSP nowo zarejestrowanych do wyrejestrowanych na 10 tys. osób w $2011 \mathrm{r}$.

Rysunek 18. Lokalność a wzrost małych i średnich przedsiębiorstw .................................. 58

Rysunek 19. Twarde i miękkie czynniki lokalizacji ................................................................. $\quad 60$

Rysunek 20. Cechy przedsiębiorcy i ich wpływ na rozwój przedsiębiorstwa ......................... 72

Rysunek 21. Zaktualizowany model wzrostu/rozwoju małych przedsiębiorstw ..................... 72

Rysunek 22. Model wzrostu małych i średnich firm ..................................................... 73

Rysunek 23. Model uwarunkowań kształtujących funkcjonowanie i rozwój małych i średnich przedsiębiorstw .................................................................................... $\quad 77$

Rysunek 24. Uwarunkowania rozwoju małych i średnich przedsiębiorstw .......................... 78

Rysunek 25. Luka potencjału przedsiębiorcy ................................................................ 82

Rysunek 26. Niematerialne uwarunkowania rozwoju małych i średnich przedsiębiorstw ...... 83

Rysunek 27. Determinanty przewagi konkurencyjnej w regionie ........................................ 95

Rysunek 28. Uwarunkowania wewnętrzne rozwoju małych i średnich przedsiębiorstw ......... 112

Rysunek 29. Uwarunkowania makroekonomiczne rozwoju małych i średnich przedsiębiorstw

Rysunek 30. Uwarunkowania mezoekonomiczne rozwoju małych i średnich przedsiębiorstw z uwzględnieniem marginalizacji obszaru 
Rysunek 31 Uwarunkowania mikroekonomiczne rozwoju małych i średnich przedsiębiorstw

Rysunek 32. Model zależności pomiędzy uwarunkowaniami a rozwojem małych i średnich przedsiębiorstw w obszarach zmarginalizowanych

Rysunek 33. Struktura badanych przedsiębiorstw według liczby zatrudnionych (w \%) ..........

Rysunek 34. Lokalizacja badanych przedsiębiorstw

Rysunek 35. Forma organizacyjno-prawna badanych przedsiębiorstw ....

Rysunek 36. Sektor podstawowej działalności badanych przedsiębiorstw

Rysunek 37. Struktura badanych przedsiębiorstw według zasięgu działania ..........................

Rysunek 38. Struktura badanych przedsiębiorstw według zasięgu działania i wielkości firmy ...

Rysunek 39. Zmienne modelu badawczego - wskaźniki wzrostu/rozwoju

Rysunek 40. Priorytety rozwojowe badanych przedsiębiorstw - analiza komparatywna, obszary rozwinięte i zmarginalizowane

Rysunek 41. Priorytety rozwojowe badanych przedsiębiorstw w obszarach rozwiniętych według wielkości firmy

Rysunek 42. Priorytety rozwojowe badanych przedsiębiorstw w obszarach zmarginalizowanych według wielkości firmy

Rysunek 43. Przewagi konkurencyjne badanych przedsiębiorstw - analiza komparatywna, obszary rozwinięte i zmarginalizowane

Rysunek 44. Przewagi konkurencyjne badanych przedsiębiorstw w obszarach rozwiniętych według wielkości firmy

Rysunek 45. Przewagi konkurencyjne badanych przedsiębiorstw w obszarach zmarginalizowanych według wielkości firmy

Rysunek 46. Makroekonomiczne uwarunkowania rozwoju małych i średnich przedsiębiorstw zlokalizowanych w obszarach rozwiniętych ...

Rysunek 47. Makroekonomiczne uwarunkowania rozwoju małych i średnich przedsiębiorstw zlokalizowanych w obszarach zmarginalizowanych ....

Rysunek 48. Mezoekonomiczne uwarunkowania rozwoju małych i średnich przedsiębiorstw zlokalizowanych w obszarach rozwiniętych

Rysunek 49. Mezoekonomiczne uwarunkowania rozwoju małych i średnich przedsiębiorstw zlokalizowanych w obszarach zmarginalizowanych

Rysunek 50. Mezoekonomiczne uwarunkowania rozwoju mikroprzedsiębiorstw zlokalizowanych w obszarach zmarginalizowanych ....

Rysunek 51. Mezoekonomiczne uwarunkowania rozwoju małych przedsiębiorstw zlokalizowanych w obszarach zmarginalizowanych

Rysunek 52. Mezoekonomiczne uwarunkowania rozwoju średnich przedsiębiorstw zlokalizowanych w obszarach zmarginalizowanych

Rysunek 53. Mikroekonomiczne uwarunkowania rozwoju małych i średnich przedsiębiorstw zlokalizowanych w obszarach rozwiniętych .....

unek 54. Mikroekonomiczne uwarunkowania rozwoju małych i średnich przedsiębiorstw zlokalizowanych w obszarach zmarginalizowanych

Rysunek 55. Mikroekonomiczne uwarunkowania rozwoju mikroprzedsiębiorstw zlokalizowanych w obszarach zmarginalizowanych

Rysunek 56. Mikroekonomiczne uwarunkowania rozwoju małych przedsiębiorstw zlokalizowanych w obszarach zmarginalizowanych

Rysunek 57. Mikroekonomiczne uwarunkowania rozwoju średnich przedsiębiorstw zlokalizowanych w obszarach zmarginalizowanych

Rysunek 58. Wewnętrzne uwarunkowania rozwoju małych i średnich przedsiębiorstw zlokalizowanych w obszarach rozwiniętych związane z przedsiębiorstwem 
Rysunek 59. Wewnętrzne uwarunkowania rozwoju małych i średnich przedsiębiorstw zlokalizowanych $\mathrm{w}$ obszarach zmarginalizowanych związane $\mathrm{z}$ przedsiębiorstwem ......

Rysunek 60. Uwarunkowania wewnętrzne (przedsiębiorstwo) rozwoju mikroprzedsiębiorstw zlokalizowanych w obszarach zmarginalizowanych

Rysunek 61. Uwarunkowania wewnętrzne (przedsiębiorstwo) rozwoju małych przedsiębiorstw zlokalizowanych w obszarach zmarginalizowanych

Rysunek 62. Uwarunkowania wewnętrzne (przedsiębiorstwo) rozwoju średnich przedsiębiorstw zlokalizowanych w obszarach zmarginalizowanych

Rysunek 63. Wewnętrzne uwarunkowania rozwoju małych i średnich przedsiębiorstw zlokalizowanych w obszarach rozwiniętych związane z osobą przedsiębiorcy

Rysunek 64. Wewnętrzne uwarunkowania rozwoju małych i średnich przedsiębiorstw zlokalizowanych w obszarach zmarginalizowanych związane z osobą przedsiębiorcy ..

Rysunek 65. Wpływ marginalizacji obszarów na rozwój małych i średnich przedsiębiorstw.. Rysunek 66. Wpływ cech obszarów zmarginalizowanych na rozwój przedsiębiorstwa .......... Rysunek 67. Wpływ marginalizacji obszaru na działalność innowacyjną i inwestycyjną ........ Rysunek 68. Wprowadzone innowacje w latach 2009-2011 .............................................. 17

Rysunek 69. Rodzaje wprowadzonych innowacji ........................................................ 175

Rysunek 70. Stopień nowości zmian innowacyjnych według rodzaju innowacji ................... 176

Rysunek 71. Przyczyny wprowadzenia innowacji .......................................................... 178

Rysunek 72. Bariery wprowadzenia innowacji .......................................................... 181

Rysunek 73. Źródła finansowania innowacji ................................................................... 183

Rysunek 74. Realizowane inwestycje w latach 2009-2011 _........................................... 184

Rysunek 75. Rodzaje zrealizowanych inwestycji ......................................................... 185

Rysunek 76. Bariery utrudniające prowadzenie działalności inwestycyjnej .......................... 186

Rysunek 77. Źródła finansowania działalności inwestycyjnej ............................................ 188

Rysunek 78. Oczekiwane przez przedsiębiorców działania ze strony władz samorządowych w celu stymulowania rozwoju MSP ................................................................... 191

Rysunek 79. Współpraca przedsiębiorstwa $\mathrm{z}$ instytucjami otoczenia biznesu ......................... 194

Rysunek 80. Rodzaj instytucji otoczenia biznesu, z którą współpracowało przedsiębiorstwo. 196

Rysunek 81. Efekty współpracy przedsiębiorstwa z instytucjami otoczenia biznesu .............. 197

Rysunek 82. Przyczyny braku współpracy przedsiębiorstwa z instytucjami otoczenia biznesu .. 199

Rysunek 83. Korzystanie z pomocy publicznej .............................................................. 199

Rysunek 84. Formy pomocy publicznej ..................................................................... 200

Rysunek 85. Problemy w zarządzaniu ............................................................................... 205

Rysunek 86. Wpływ czynników wynikających ze specyfiki obszarów zmarginalizowanych na zarządzanie małym i średnim przedsiębiorstwem ………...................................... 207

Rysunek 87. Słabości w zarządzaniu .......................................................................... 209

Rysunek 88. Częstotliwość pozyskiwania informacji ....................................................... 209

Rysunek 89. Rodzaje informacji pozyskiwanych i wykorzystywanych w przedsiębiorstwie .. 211

Rysunek 90. Posiadanie strategii rozwoju ................................................................... 211

Rysunek 91. Wpływ specyfiki obszarów zmarginalizowanych na formułowanie strategii rozwoju

Rysunek 92. Wpływ czynników wynikających ze specyfiki obszarów zmarginalizowanych na strategię rozwoju w małym i średnim przedsiębiorstwie 



\section{Od Redakcji}

Doktor Renata Lisowska ukończyła w 1995 studia magisterskie na Wydziale Ekonomiczno-Socjologicznym Uniwersytetu Łódzkiego na kierunku Ekonomika i Organizacja Przemysłu ze specjalnością Ekonomika i Organizacja Przedsiębiorstw Przemysłowych. Od 1 października 2003 r. jest zatrudniona w Katedrze Przedsiębiorczości i Polityki Przemysłowej, początkowo na stanowisku asystenta, a od grudnia 2003 r. na stanowisku adiunkta.

Stopień doktora nauk ekonomicznych w zakresie nauk o zarządzaniu uzyskała w 2003 r. po obronie pracy doktorskiej pt. Rola sektora matych i średnich przedsiębiorstw $w$ tworzeniu miejsc pracy na terenach zmarginalizowanych, napisanej pod kierunkiem prof. zw. dr. hab. Bogdana Piaseckiego.

$\mathrm{W}$ polu zainteresowań naukowych autorki znajdują się zagadnienia związane z przedsiębiorczością i zarządzaniem w małych i średnich przedsiębiorstwach w kontekście specyficznych uwarunkowań obszaru zmarginalizowanego, barierami i czynnikami rozwoju przedsiębiorstwa, pozyskiwaniem środków finansowych z Unii Europejskiej, współpracą małych i średnich przedsiębiorstw $\mathrm{z}$ otoczeniem biznesu oraz działalnością innowacyjną przedsiębiorstw.

Autorka brała i obecnie bierze udział w wielu projektach międzynarodowych (m.in. CASE Confidence of Ageing Workers for Competitiveness and Success in Enterprises, WBLQUAL - An Approach to Qualifications through Negotiated Work Based Learning for the EU), krajowych: finansowanych przez Ministerstwo Nauki i Szkolnictwa Wyższego (m.in. projekt własny Symptomy upadku matej firmy. Konsekwencje społeczno-gospodarcze. Polityka przeciwdziałania, grant habilitacyjny Determinanty rozwoju matych i średnich przedsiębiorstw funkcjonujacych $w$ regionach zmarginalizowanych. Strategie rozwoju i polityka wsparcia oraz projekt własny Koncepcja ,open innovation” w matych $i$ średnich przedsiębiorstwach - modele, trendy $i$ uwarunkowania rozwoju oraz finansowanych z PO KL (Wyrównanie szans na rynku pracy dla osób 50+, Wspótpraca nauki i biznesu jako czynnik wzmacniający innowacyjność regionu łódzkiego), na stanowisku kierownika jak również członka zespołu.

Aktywnie uczestniczy w konferencjach naukowych zarówno krajowych, jak i zagranicznych, prezentując wyniki swoich badań m.in.: 75th International Atlantic Economic Conference (2013) w Wiedniu, 74th International Atlantic Economic Conference (2012) w Montrealu, TIIM 2012 - Technology Innovation and Industrial Management (2012) w Lublinie, 21st International Conferen- 
ce on Metallurgy and Materials (2012) w Brnie, 72th International Atlantic Economic Conference (2011) w Waszyngtonie oraz 70th International Atlantic Economic Conference (2010) w Charlston.

Doktor Renata Lisowska jest autorem i współautorem ponad 60 opublikowanych arykułów naukowych $\mathrm{w}$ monografiach i czasopismach naukowych (w tym 1 książka i 3 artykuły zagraniczne). Najwięcej publikacji poświęciła tematyce uwarunkowań rozwoju małych i średnich przedsiębiorstw w obszarach zmarginalizowanych. Jest również autorem i współautorem 7 podręczników oraz 4 opracowań dla praktyki gospodarczej.

Praca naukowa autorki pozostaje $\mathrm{w}$ ścisłym związku z dydaktyką i praktyką zarządzania. Prowadzi ona zajęcia z przedmiotów: przedsiębiorczość, fundusze unijne, integracja europejska, programy wsparcia MSP, instytucje otoczenia biznesu, przygotowanie biznes planu, warsztaty z przygotowania wniosków unijnych oraz zarządzanie projektami unijnymi.

Pod jej kierunkiem powstało ponad 100 dyplomowych i magisterskich. Angażując się w życie akademickie, pełniła wiele funkcji, m.in: opiekuna specjalności i modułów, opiekuna grup studenckich, członka i sekretarza Wydziałowych Komisji Rekrutacyjnych, opiekuna studenckiego koła naukowego SKN Globalni. Obecnie kieruje Stowarzyszeniem Innowatorów Zarządzania działającym przy Wydziale Zarządzania.

Autorka jest członkiem International Atlantic Economic Society oraz Polskiego Towarzystwa Ekonomicznego. 